\title{
CONVERGENCIAS: CARLOS EDMUNDO DE ORY Y LA POESÍA DE LA MARGINALIDAD EN LAS POÉTICAS DE POSGUERRA Y EN LOS DISCURSOS DE LA POSMODERNIDAD
}

D. José Rafael Mesado Gimeno

DNI: 18940346

Director: Dr. Santiago Fortuño Llorens 


\section{PRELIMINARES}

I. PRESENTACIÓN .......................................................... 13

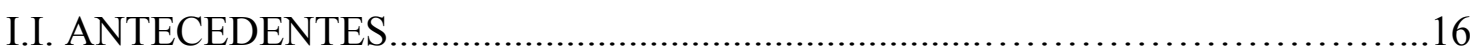

\section{PRIMERA PARTE. SOBRE EL POSTISMO}

I. DELIMITACIÓN DEL POSTISMO EN LA TERRITORIALIDAD POÉTICA DE

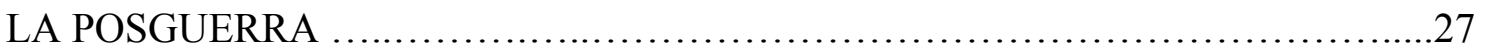

1. Demarcación de la poesía de la marginalidad $\quad \ldots \ldots \ldots \ldots \ldots \ldots \ldots \ldots . \ldots . \ldots . \ldots 28$

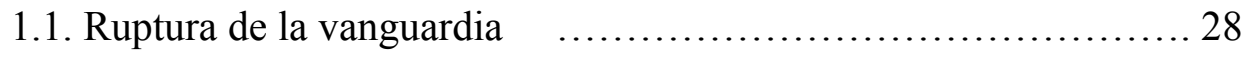

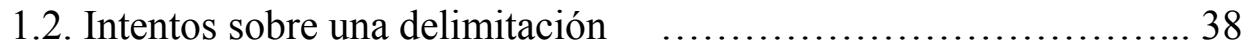

1.2.1. Posguerra inmediata $\quad \ldots . \ldots \ldots \ldots \ldots \ldots \ldots \ldots \ldots . . . \ldots . \ldots 1$

1.2.2. Segunda etapa poética de posguerra $\quad \ldots \ldots \ldots \ldots . . . .42$

1.2.3. Etapa social …............................... 43

1.2.4. Poesía de la sinceridad, última posguerra......................44

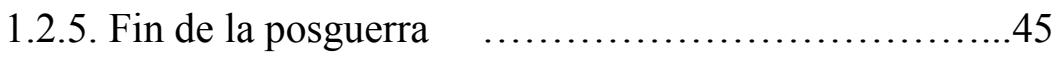

1.3. Los poetas de la guerra $\quad$.................................. 49

1.3.1. Poesía exiliada $\quad$................................. 50

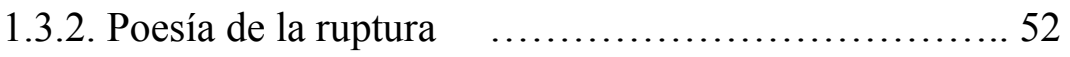

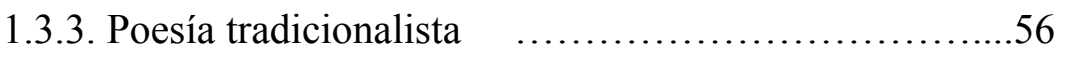

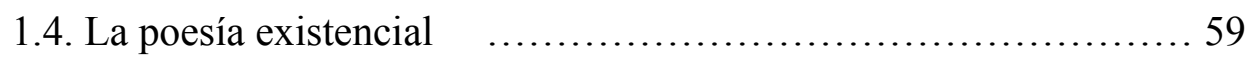

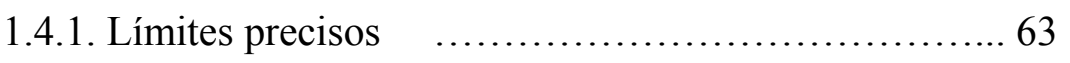

1.4.2. Poéticas existenciales $\quad \ldots \ldots \ldots \ldots \ldots \ldots \ldots \ldots \ldots \ldots . \ldots 6$

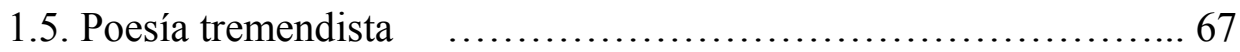

1.6. Poesía social …........................................... 69

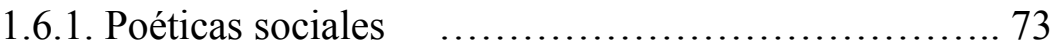

1.6.2. Poesía histórica aleixandrina $\quad \ldots \ldots \ldots \ldots \ldots \ldots \ldots . . . \ldots 74$

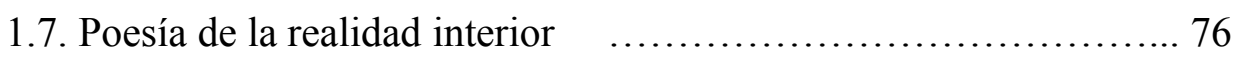

1.7.1. Propuestas poéticas $\quad$................................ 77 
1.8. Poesía esteticista $\quad$........................................ 79

1.9. Poesía de la marginalidad $\quad$.................................. 81

1.9.1. El Postismo $\quad$....................................... 82

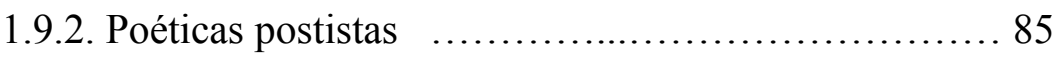

1.9.3. Poesía surreal $\quad \ldots \ldots \ldots \ldots \ldots \ldots \ldots \ldots \ldots \ldots \ldots \ldots . \ldots . \ldots \ldots$

1.9.4. Poesía experimental $\ldots \ldots \ldots \ldots \ldots \ldots \ldots \ldots \ldots \ldots \ldots . \ldots . \ldots . \ldots . \ldots 2$

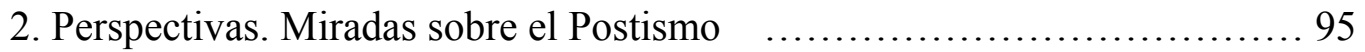

2.1. Una mirada de rechazo f..................................... 95

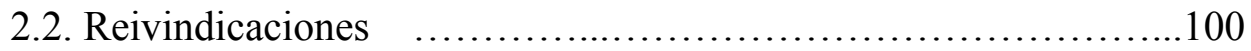

2.2.1. Desde la generación del underground ................100

2.2.2. El grupo Marejada de Cádiz $\quad$....................107

2.2.2.1. La Orygénesis ......................111

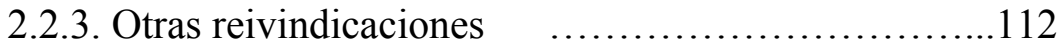

3. Trascendencia de Postismo........................................................................ 114

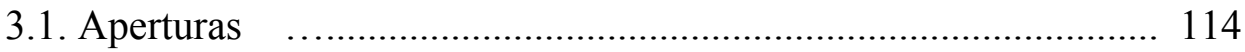

3.2. Convergencias con la Beat generation .......................................115

II. LA GEOGRAFÍA ACCIDENTADA DEL POSTISMO..........................................119

1. Entre la poética y el manifiesto..................................................................120

1.1. Inicio de las poéticas tras el desastre................................................120

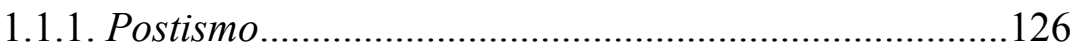

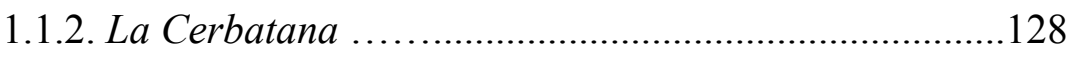

1.2. Génesis de la poesía de la marginalidad........................................137

1.2.1. Mil duros, irrupción del Postismo como subversión....137

1.2.2. El Postismo en serio.....................................................142

1.2.3. Otros ensayos tras el Postismo.................................... 145

1.2.3.1.. El introrrealismo íntegro.....................145

1.2.3.2. El Atelier de Poésie Ouverte................148

1.3. Los manifiestos y otras proclamas............................................. 152

1.3.1. Los manifiestos del Postismo....................................152 


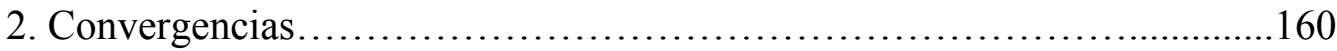

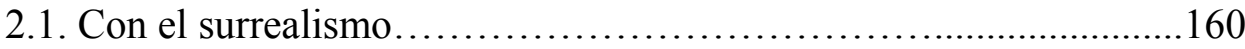

2.1.1. La realidad oculta ..........................................161

2.1.2. Una lógica paradójica...........................................163

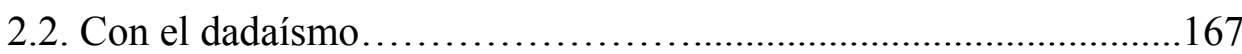

2.2.1. Provocación y ruptura........................................167

2.2.2. La subversión poética...........................................170

2.2.3. Lo naïf ....................................................172

2.2.4. Budismo zen.................................................175

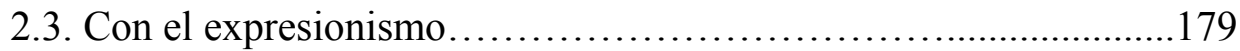

2.3.1. El lenguaje de la atrocidad.....................................180

2.3.2. Representaciones de la realidad interior........................182

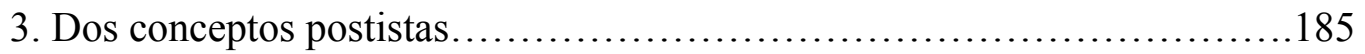

3.1. La euritmia .................................................. 185

3.2. El enderezamieno .....................................................195

SEGUNDA PARTE. SOBRE LA POESÍA DE CARLOS EDMUNDO DE ORY

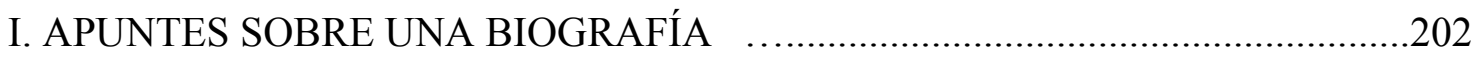

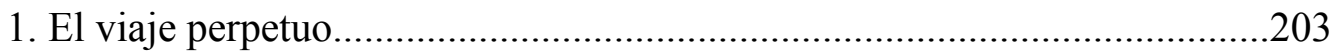

1.1. Cádiz, entre el mar y la luz..........................................203

1.2. Madrid, ciudad de algarabía, bohemia y rebelión...........................205

1.3. París, el horizonte abierto del desierto........................................209

1.4. Amiens, la ciudad y la cabaña.....................................................211

1.5. Thézy-Glimont, refugio entre los árboles y el agua..................... 215

2. Epílogo........................................................217 
1. Una poesía cíclica...................................................222

1.1. Poesía crepuscular..........................................224

1.2. Poesía postista..........................................226

1.3. Poesía nómada.............................................227

1.4. El ciclo de los sonetos...................................229

1.5. Poesía del recuerdo.................................................232

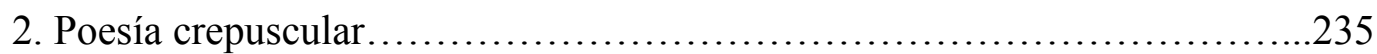

2.1. Estética simbolista.........................................237

2.1.1. Herencia modernista.............................238

2.1.2. Impresionismo poético..........................241

2.1.3. Poesía visionaria.................................249

2.1.4. Estética de la enfermedad.........................254

2.2. Contactos con la vanguardia................................259

2.2.1. Raigambre popular...........................260

2.2.2. Estética cubista..................................264

2.2.3. Un tímido surrealismo...........................270

2.3. Poesía rizomática..........................................274

2.4. Poesía y silencio...........................................281

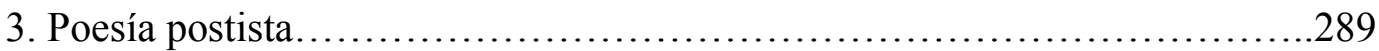

3.1. Una poesía libre y surreal..................................290

3.1.1. Acercamientos al surrealismo francés...............291

3.1.2. El juego, de lo barroco a la vanguardia...............301

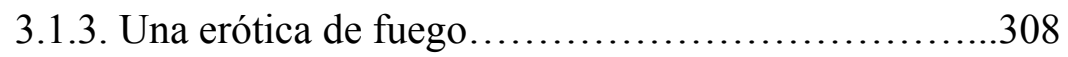

3.1.4. La caída, una poesía existencial.....................316

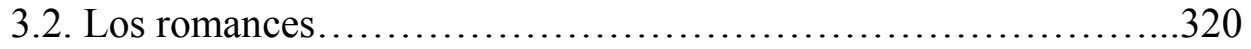

3.2.1. Práctica de la parodia y de la contrafactura...........321

3.2.2. Presencia de una estética expresionista...............328

3.2.3. Una poesía lúdica...................................336 


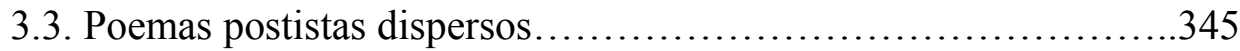

3.3.1. Surrealismo y provocación.............................346

3.3.2. Sueños eróticos........................................353

3.3.3. Hacia un lenguaje experimental....................................361

3.3.4. Una poesía metafísica..................................365

3.3.5. Una poesía metapoética.................................373

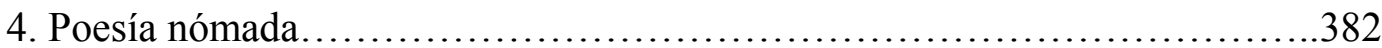

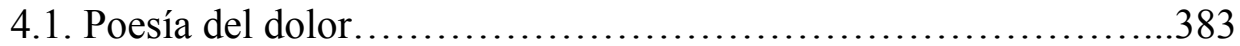

4.1.1. Acercamientos al expresionismo....................................383

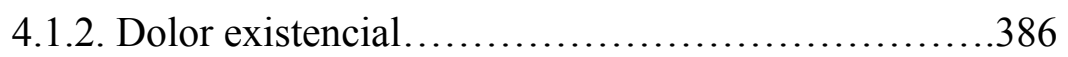

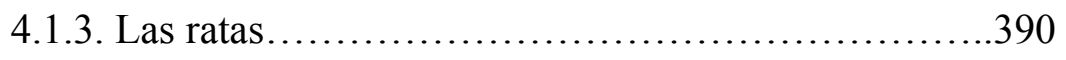

4.1.4. Una alquimia interior..................................... 3.95

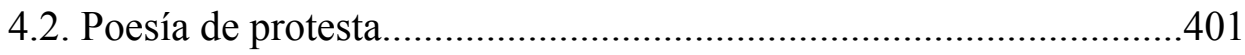

4.2.1. Un lenguaje crítico........................................................401

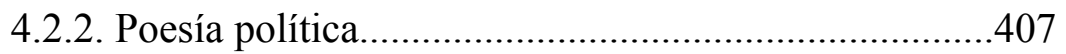

4.2.3. Contra España............................................................. 412

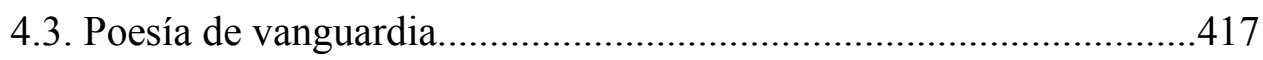

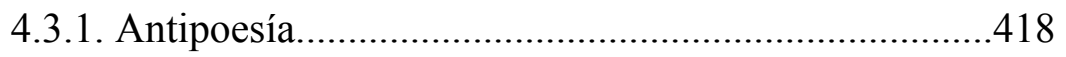

4.3.2. Poesía visual...………………………………….....426

4.3.3. Un lenguaje ebrio.............................................................430

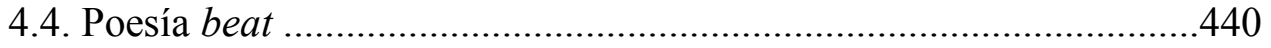

4.4.1. Una generación beatífica................................................440

4.4.2. Una poesía libre y rebelde............................................443

4.4.3. Poesía como meditación................................................451

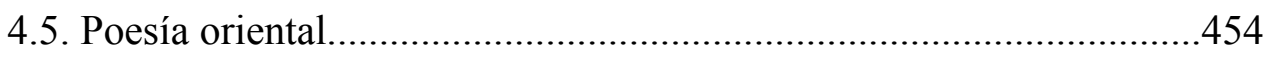

4.5.1. El hinduismo y la no dualidad......................................456

4.5.2. La sexualidad sagrada: el tantra....................................465

4.5.3. El budismo y la imagen de la vacuidad........................475

4.5.4. El taoísmo y el budismo zen.........................................480

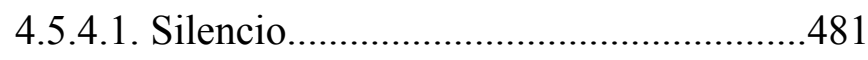

4.5.4.2. Una experiencia directa.............................484 
5. Poesía del recuerdo .490

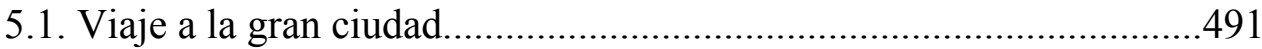

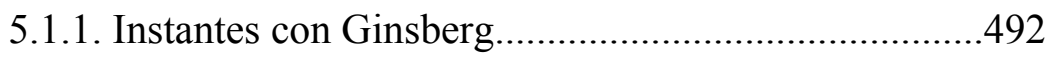

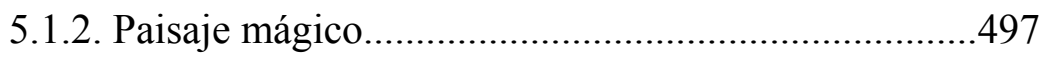

5.1.3. Ángeles en el paraíso.................................................500

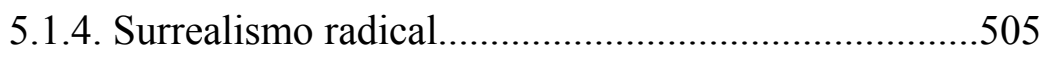

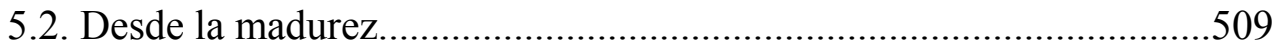

5.2.1. Geografías recordadas............................................509

5.2.1.1. La infancia y el mar..............................509

5.2.1.2. La experiencia mística..........................512

5.2.1.3. La música divina..................................519

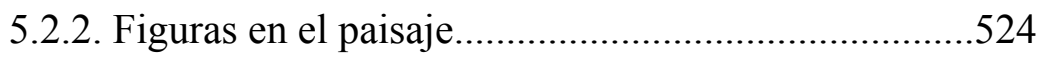

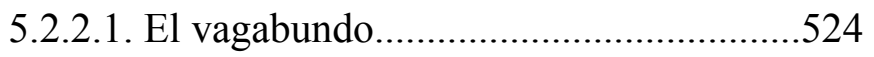

5.2.2.2. Los dormidos.......................................529

5.2.2.3. Los seres intermedios............................535

5.2.2.3.1. Ángeles...................................535

5.2.2.3.2. Héroes, dioses, semidioses.....539

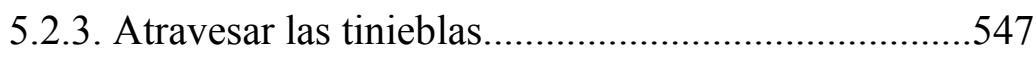

5.3. La existencia recordada.................................................................551

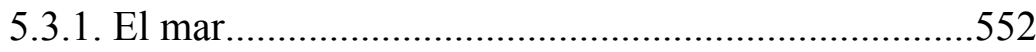

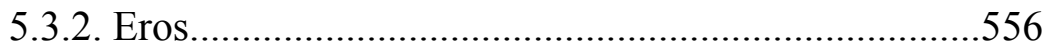

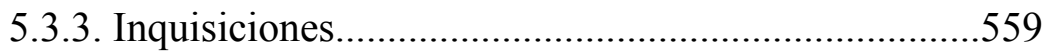

5.3.4. Mística del instante......................................................563

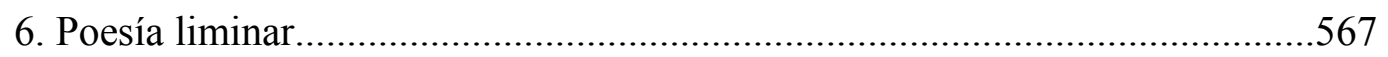

6.1. Cuando el lenguaje estalla: los aerolitos........................................568

6.1.1. Hacia una definición del aerolito..............................569

6.1.2. Identificaciones y exclusiones...................................574

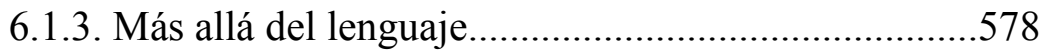

6.2. La poesía se hace imagen: poesía visual...........................................581

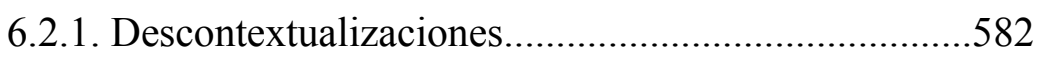

6.2.2. La feminidad como mercancía..................................587 
TECERA PARTE. HERENCIA ORYANA

I. LA ESTELA ORYANA EN LA POESÍA CONTEMPORÁNEA..............................593

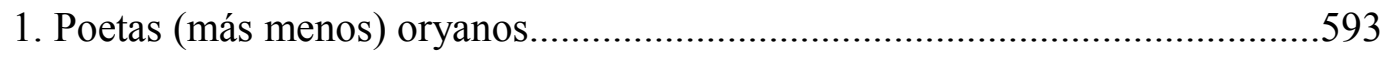

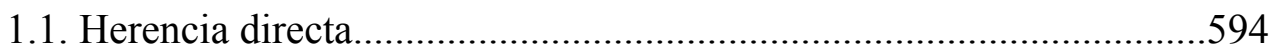

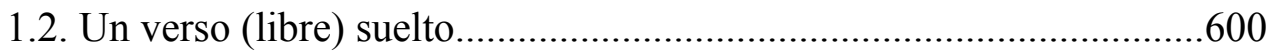

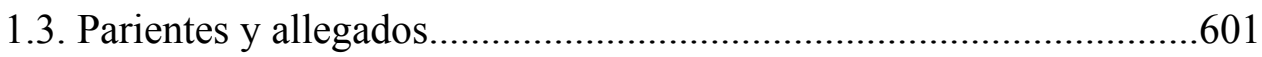

2. Otros poetas bajo el signo de Ory............................................................605

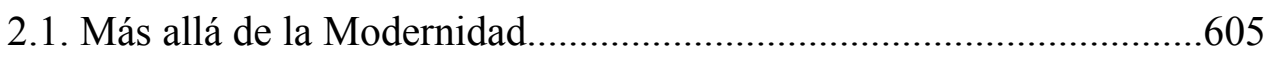

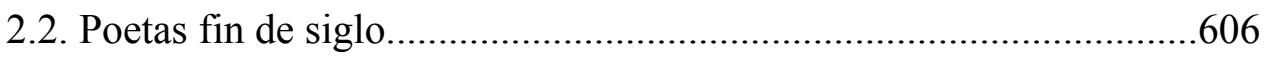

2.3. Los cybernautas del nuevo milenio..............................................612

II. ORY COMO SÍMBOLO LITERARIO_............................................................619

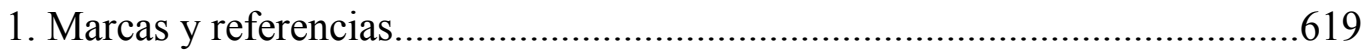

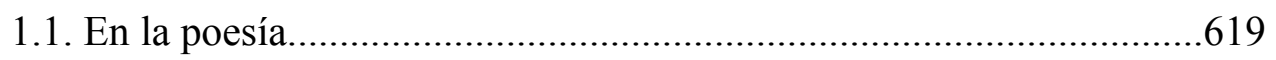

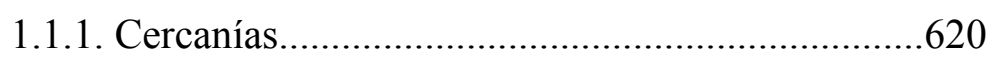

1.1.2. Oryanos a distancia.............................................625

1.2. Como personaje literario e icono cultural.........................................628

\section{CONCLUSIONES}

LA IMPRONTA ACTUAL DE LA ESCRITURA NÓMADA DE ORY. .635

1. La impronta actual de la escritura nómada de Ory.......................................636

1.1. El Postismo como discursdo de la posmodernidad..........................636

1.2. Una poética permanentemente nómada.........................................638

1.3. La huella de una escritura errante, desdentrada y libre...................642 


\section{BIBLIOGRAFÍA}

I. BIBLIOGRAFÍA PRIMARIA.............................................644

1. Obra de Carlos Edmundo de Ory........................................644

1.1. Poesía............................................................644

1.1.1. Antologías particulares.........................647

1.1.2. Presencia en otras antologías.......................648

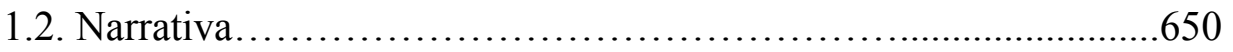

1.2.1. Antologías y libros de relatos.......................650

1.3. Ensayo, crítica, teoría.............................................651

1.3.1. Prólogos e introducciones............................652

2. Sobre el Postismo...................................................653

2.1. Revistas postistas...........................................653

2.2. Manifiestos.................................................653

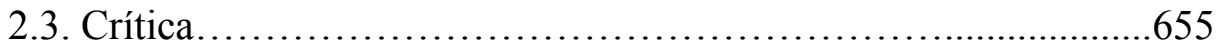

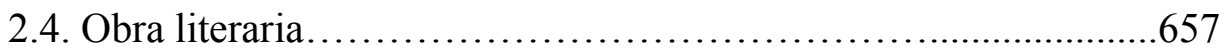

2.4.1. Discurso poético..............................657

2.4.1.1. Panorámicas y antologías.....................658

2.4.2. Narrativa.......................................659

2.4.2.1. Novela inédita...............................659

2.4.3. Obras teatrales...........................660

II. BIBLIOGRAFÍA SECUNDARIA.........................................662

III. EN LA RED ......................................................... 681

1. Sobre Carlos Edmundo de Ory .................................668

2. Sobre el Postismo...............................................683

\section{APÉNDICES}

1. Apéndice I. Poemas postistas comunes en las ediciones de Versos de pronto y

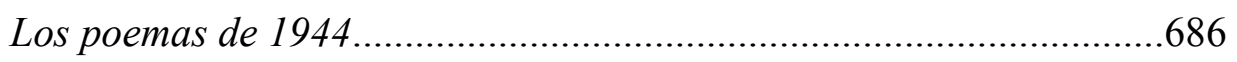

2. Apéndice II. Romances postistas que aparecen en las revistas postistas......697 
3. Apéndice III. Poemas postistas editados en otras publicaciones. .705

4. Apéndice IV. Pomas pertenecientes a Negruras y a Los lejanos lejanos integrados en la edición de Energeia. .713

5. Apéndice V. Poemas publicados en la primera edición de El musiquero de las manos fecundas.

6. Apéndice VI. Poemas pertenecientes a los poemarios que aparecen en las diversas antologías.

7. Apéndice VII. Poemas aparecidos en obras recopilatorias. 738

8. Apéndice VIII. Variaciones de los poemas originales efectuadasen el ciclo de Los sonetos. .749

9. Apéndice IX. Ediciones de La flauta prohibida y de El rey de las ruinas anteriores a la publicación de La flauta prohibida (1979)..... .760

10. Apéndice X. Ediciones de Melos melancolía 767

11. Apéndice XI. Poesía visual. 771

12. Apéndice XII. Collages .774

13. Apéndice XIII. Testimonios de poetas del siglo XX y XXI que certifican su pertenencia a la herencia oryana. 778 
Quiero agradecer especialmente a Santiago Fortuño Llorens y a Jesús Fernández Palacios su labor asesora y sus atenciones. Sin ellas la realización de este trabajo no habría sido posible.

Agradezco además las colaboraciones y aportaciones de Javier Vela, Laura Lachéroy, Jaume Pont, José Ramón Ripoll, Rafael de Cózar, José Manuel García Gil, Ana Sofía Pérez-Bustamante, Amador Palacios, Mercedes Escolano, Pablo Acevedo, Carmen Camacho, Guadalupe Grande, Miguel Ángel García Argüez, José María Gómez Valero, David Eloy Rodríguez, Uberto Stábile, Juan José Téllez, Rafael Adolfo Téllez, Milagros Parrado, Fernando Polavieja, Mercedes Sanz, Margarita Porcar y Ana Rodríguez-Tenorio.

Agradezco también la paciencia y la comprensión de mis seres queridos más inmediatos: Ana Mollar, Gerard Mesado y Marcel Mesado.

Notas a la tesis: en las citas abreviadas de las obras escritas en una lengua extranjera hemos colocado el año de la edición primera y a continuación el año de su traducción al castellano. La bibliografía aparece generalmente citada al final del trabajo en su apartado correspondiente. En el caso de obras que afectan a algún tema puntual y cuya importancia en el trabajo es menor, sus referencias se hallan citadas a pie de página. También utilizaremos el mismo sistema en el caso de usar una edición posterior a la primera. En el caso de los poemas y otros textos de Ory, cabe señalar que la escritura empleada omite los signos ortográficos de puntuación $\mathrm{y}$ en algunos casos también subvierte las normas lingüísticas. 
PRELIMINARES 


\section{PRESENTACIÓN}

Este trabajo pretende establecer la importancia del Postismo y de la poesía de Carlos Edmundo de Ory, su representante más activo y más significativo, en el territorio poético de posguerra española. Para ello, trata de mostrar la relevancia de algunos de los postulados de la poética postista, de situar las propuestas de este movimiento en el ámbito de la poesía de posguerra y de señalar las convergencias con otras poéticas, tanto anteriores como posteriores. De este modo, se analiza la territorialidad poética de posguerra en varias direcciones. Por una parte, se establece un eje diacrónico que divide la posguerra poética en una serie de etapas y, por otra, se estudian las diferentes poéticas que van apareciendo y que muestran sus convergencias y sus rechazos. En este sentido, cabe señalar dos grandes líneas en la poesía de posguerra: una poesía oficial y una poesía marginal. Esta última es aquella que escapa de los códigos poéticos aceptados en el momento histórico de su aparición. La consideración de estas poéticas va cambiando a medida que se insertan en el fluido de los discursos poéticos que aparecen, de modo que varían las convergencias y las rupturas. De este modo, la aparición de nuevas poéticas, con sus rechazos y adhesiones, cambia la consideración de las anteriores, que, a su vez, muestran sus herencias y contactos.

La territorialidad de la poesía oficial en la primera posguerra queda establecida por la poesía imperialista de signo patriótico y por las poéticas realistas que, a pesar de sus diferencias, comparten un mismo código poético: el realismo. En este espacio convergen el tremendismo poético, la poesía existencial y la poesía social, poéticas asentadas en los dogmas de la rehumanización de la poesía, de la mímesis y de la incidencia directa de la práctica poética sobre la realidad. Frente a esta zona central aparecen una serie de poéticas periféricas que, basadas en la destrucción del edificio realista, ocupan el espacio de la marginalidad. La aparición del Postismo en 1945 supuso la inauguración de la poesía de la marginalidad. Este movimiento supone la 
unión de los experimentos poéticos de la Vanguardia histórica con la vanguardia poética de signo experimental que se desarrolla con posterioridad a la guerra civil española y a la segunda guerra mundial. La poética postista significa el germen de la poesía de la marginalidad que va metamorfoseándose a través del tiempo. Los códigos que en un primer momento resultan provocadores o molestos acaban más tarde por ser aceptados. Por ello hay zonas de la poesía de la marginalidad que convergen con algunas zonas de la poética central. En este sentido cabe señalar la aceptación social que a posteriori han tenido algunos postulados de la poesía de los años setenta, cuyo signo era la ruptura del código realista y el establecimiento de una poética veneciana, de cariz intertextual y culturalista. El transcurso del tiempo ha posibilitado también la revalorización de la poesía de Carlos Edmundo de Ory.

En la zona de la marginalidad poética habría que situar la poesía postista, con sus convergencias y su herencia: la poesía vanguardista de Juan Eduardo Cirlot o Joan Brossa, la poesía esteticista de grupo Cántico, cierto territorio de la poesía de los años sesenta representado por José Manuel Caballero Bonald o por Jaime Gil de Biedma, la poesía de los novísimos, la poesía experimental de signo visual, la poesía conceptual y algunos territorios poéticos, de tinte surreal ${ }^{1}$, de la poesía posnovísima. El Postismo y el grupo Cántico de Córdoba fueron las dos grandes herejías que se fraguaron tras la guerra civil, ambas compartieron un espacio mutuo y suponen el inicio de la vanguardia poética que atraviesa la posguerra y llega a la actualidad.

La poesía de Carlos Edmundo de Ory está presente en todo intento de establecer una poesía renovadora. La poesía oryana queda configurada como el gran referente de la poesía vanguardista, innovadora y libre que se desarrolla a partir de la posguerra. Carlos Edmundo de Ory es uno de los maestros, junto a Vicente Aleixandre, Luis Cernuda, Ángel González o Jaime Gil de Biedma, de las generaciones poéticas posteriores, aclamado por multitud de poetas más jóvenes que él. Su poesía, situada ya desde un inicio en el territorio de la heterodoxia, ha contactado con todas las propuestas vanguardistas coetáneas: la poesía surreal, la poesía experimental, la poesía conceptual, la poesía de la Beat generation...

${ }^{1}$ Designamos con la palabra surreal el tipo de poesía fraguada con los materiales surgidos del subconsciente humano. Esta puede tener vinculación con el movimiento surrealista o no. 
En este sentido y en resumen, este trabajo se propone estructurar el territorio que ocupa la poesía oryana, estudiar las constantes que marcan su trayectoria, observar las relaciones que mantiene con otras poéticas y con otros territorios del pensamiento filosófico y cultural. Finalmente, el trabajo propone también establecer la impronta dejada por la obra oryana en la posteridad poética, artística y cultural. 


\section{ANTECEDENTES}

¿Quién habla de una fácil travesía? Las noches se poblaban de sirenas.

Antonio Martínez Sarrión

El primer acercamiento riguroso a la obra de Carlos Edmundo de Ory, y por extensión a la poética postista, viene de la mano de Félix Grande. Dos de sus publicaciones son obras claves que rompen el silencio impuesto a una poesía comprometida con la vanguardia y con la estética, con la experimentación y con el lenguaje. La antología sobre la poesía de Carlos Edmundo de Ory, titulada Poesía (1945-1969) (Grande, 1970a), supone una reivindicación de la obra poética postista frente a los ataques recibidos tanto desde la oficialidad del régimen y de la poesía tradicionalista, como desde la poesía comprometida. Además de presentar un corpus poético disperso y básicamente inédito, ofrece una mirada crítica y detallada sobre la trayectoria de la poesía oryana. Se trata de una sistematización de la obra oryana y de la obra postista. Otros textos completan esta antología. Por una parte, se recoge parte del Diario oryano, desde abril de 1944 hasta mayo de 1952. Por otra, se presentan los romances postistas escritos entre 1945 y 1948 titulados Laocoonte y la luna. También se halla una colección de aerolitos, los tres primeros manifiestos del Postismo, algunos textos oryanos escritos para el Atelier de Poésie Ouverte, el texto Nuestro tiempo: Poesía, considerado como el manifiesto poético del introrrealismo y La historia del postismo escrita por Ory expresamente para esta antología. En Apuntes sobre poesía española de posguerra Félix Grande (1970b: 103) propone que tanto Luis Rosales como Carlos Edundo de Ory son los eslabones perdidos entre la poesía de posguerra y la de la década de los 70, preocupada por el interés estético y culturalista.

En 1971 aparece 30 años de literatura (Clotas y Gimferrer, 1971), obra bidireccional escrita por Salvador Clotas y Pere Gimferrer. Mientras Clotas se ocupa de novela de posguerra, Gimferrer reivindica la poesía de la marginalidad, marcada por la experimentación y el expresionismo, contraponiéndola a la poesía de signo realista sobrevalorada por una burguesía políticamente activa, pero estéticamente conservadora. 
Poesía que en la primera posguerra irrumpe con el Postismo, cuya labor consistió en la demolición del edificio realista, territorio del que surge la poesía oficial: la poesía tradicionalista, la poesía existencial, la poesía tremendista o la poesía social. El Postismo rechaza el elemento realista, propio de la poesía de signo humano. Ello supone el punto de contacto con la poesía anterior a la guerra civil, de signo vanguardista, y con sus desarrollos posteriores. No sólo la experiencia postista se encuadra en el territorio poético de la marginalidad, sino toda poesía que rehuye el dogma realista. Gimferrer territorializa la obra de Carlos Edmundo de Ory y la coloca entre otros dos poetas heterodoxos, Juan Larrea y Leopoldo María Panero. La poesía oryana, para el autor, resalta por su sentido lúdico, por su actitud insumisa y por la práctica de una escritura surgida de la libertad, que subvierte los dogmas del realismo poético (Clotas y Gimferrer, 1970: 104-105).

Un año más tarde Joaquín Marco vuelve a ocuparse de la poesía de Carlos Edmundo de Ory en Nueva literatura en España y América (Marco, 1972). Este autor señala dos elementos interesantes de la poesía oryana. Por una parte, el hecho de que esta poesía no enlaza con el surrealismo español anterior a la guerra civil, sino con las mismas fuentes del surrealismo francés. Por otra, su paralelismo con la poesía de Joan Brossa (Marco, 1972: 201-202). Poesía la de Ory que supone un juego permanente con el lenguaje y una vía de experimentación cercana a la poesía experimental de signo visual. Para este autor la poesía oryana podría ser definida como post-surrealismo marginado (Marco, 1972: 207).

En 1974 Jaume Pont, que estaba preparando su tesis doctoral sobre Ory de la mano de Joaquín Marco y José Manuel Blecua, publica la antología Poesía abierta (1945-1973) (Pont, 1974). La tesis será publicada en 1977 con el título de La poesía de Carlos Edmundo de Ory y aparecerá en formato de libro en 1998 (Pont, 1998). La óptica de Pont se centra en explorar los aspectos mágicos y metafísicos de la poesía oryana, su relación con la poesía órfica y los misterios eleusinos, la alquimia y las corrientes místicas. Elementos desarrollados en sus estudios posteriores como el Epílogo (Pont, 1999) al poemario de Carlos Edmundo de Ory Melos Melancolía, publicado en 1999, y el Prólogo (Pont, 2003) a la segunda antología realizada en 2003 sobre la poesía oryana, Música de lobo. Antología poética (1941-2001). En el Prólogo de esta antología Pont ofrece una sistematización de la trayectoria poética de Ory, 
poesía que nace al amparo de los poetas modernistas y decadentistas, pasa por la etapa surrealista madrileña y se acerca a los presupuestos de la contracultura: la poesía beat, el hinduismo, el taoísmo, el budismo zen... Para Pont, la culminación de esta trayectoria viene trazada por la obra Melos Melancolía (1999), que recoge poemas publicados entre 1977 y 1994 y ofrece una poesía visionaria centrada en mostrar el regreso al origen realizado por un vagabundo errante. Algunas de sus símbolos recurrentes son el mar, el recuerdo y la poesía como elemento que desvela los enigmas y los misterios de la existencia. Con todo, la obra más importante de Jaume Pont se publica en 1987 y se titula El Postismo. Un movimiento estético-literario de vanguardia (Pont, 1987). Se trata de una obra exhaustiva que analiza todos los aspectos relacionados con el Postismo: la historia, las revistas, los manifiestos, las claves de su poética. Además la obra presenta los textos fundamentales del aparato ideológico del movimiento. En 1990 Pont vuelve a analizar, en la obra La letra y sus máscaras. De Villiers de l'isle-Adan a José Ángel Valente (Pont, 1990), la poesía de posguerra y opone la poética postista y la poesía esteticista del grupo cordobés Cántico a la poesía oficial garcilasista, a la poesía existencialista y a la poesía social, poéticas estas últimas de signo realista. El Postismo vuelve a ser tratado por Pont en el artículo «Postismo como post(surreal)ismo», ponencia publicada en 2001 en las Actas del Congreso sobre Surrealismo y literatura en España celebrado en la Universitat de Lleida (Pont, 2001). En él se presenta el Postismo como el enlace de la poesía surrealista de la primera posguerra con algunos movimientos de la Vanguardia histórica como el dadaísmo y el surrealismo, y, a su vez, como el punto de arranque de la neovanguardia española. Sobre la poesía de Carlos Edmundo de Ory, el estudio más extenso y más detallado sigue siendo la publicación (Pont, 1998) que surge de su Tesis Doctoral: La poesía de Carlos Edmundo de Ory.

Otra óptica interesante sobre el Postismo la ofrece Guillermo Carnero en su obra El grupo Cántico de Córdoba. Estudio y Antología (Carnero, 1976). Aunque el tema central sea la poesía esteticista que surgió en torno a la Revista Cántico (1947), Carnero propone como elemento distintivo del Postismo su componente lúdico, irónico y satírico que supuso una subversión de los modelos poéticos coetáneos. Por otra parte, este autor señala a Carlos Edmundo de Ory como el único poeta postista de interés, cuya poesía es una parodia permanente de las corrientes poéticas humanizadoras (Carnero, 1976: 33). 
Rafael de Cózar es uno de los críticos oryanos más importantes, autor de la tercera antología realizada sobre la poesía de Ory, Metanoia (Cózar, 1977, 1990), publicada en 1977 y reeditada con variaciones mínimas en 1990. En ella su autor continúa la labor iniciada por Félix Grande en cuanto a la reivindicación de la poesía oryana. Pero también supone un nuevo intento de sistematización de la obra de Ory. Esta publicación suministra multitud de datos: la edición de toda la obra oryana, las colaboraciones en revistas, la obra crítica, las traducciones, las publicaciones en otras lenguas y una pequeña muestra de la obra gráfica. De Cózar sitúa la poesía oryana como puente entre la vanguardia y el experimentalismo. Carlos Edmundo de Ory es, para el autor, el precursor de la vanguardia poética posterior (Cózar, 1999: 89). Poesía e Imagen. Formas difíciles de Ingenio Literario (Cózar, 1991), obra aparecida en 1991, es la publicación de la tesís doctoral, Fundamentos históricos de la experimentación poética española, presentada en 1984 en la Universidad de Sevilla por Rafael de Cózar. En ella el Postismo se sitúa, por una parte, en la línea de la tradición mágica y hermética que ha operado desde la antigüedad en los juegos letristas como laberintos, acrósticos, caligramas, lipogramas, jeroglíficos... Y, de otra, en los juegos fónicos que arrancan de la poesía trovadoresca, residen en la poesía de los goliardos, en los disparates, en la experimentación quevedesca o calderoniana, en los juegos sonoros del siglo XIX y en la plasticidad lingüística de Valle-Inclán. Rafael de Cózar ofrece también un estudio exhaustivo de las dos revistas editadas en 1945 por el grupo postista, Postismo y La Cerbatana, en Revistas literarias españolas del siglo XX (Cózar, 2005) y señala la coincidencia de la propuesta postista con los movimientos europeos de experimentación literaria como el letrismo francés de Isidoro Isou, el espacialismo de Pierre Garnier o la poesía visiva.

José Manuel Polo de Bernabé, foco difusor del Postismo en Estados Unidos, presenta en el artículo «El universo poético de Carlos Edmundo de Ory y el Postismo» (1978) algunas de las claves del movimiento postista y de la poesía de Carlos Edmundo de Ory. Por una parte, reduce a cinco principios la definición de la estética postista: la supremacía de la imaginación que depende tanto del elemento conceptual como del inconsciente, la utilización de materiales sensoriales, el carácter lúdico y dionisíaco, el control técnico en la investigación de las posibilidades del lenguaje y, finalmente, la voluntad de destruir prejuicios. En cuanto a la poesía oryana, destaca el aspecto metapoético de su poesía, la atracción por la filosofía presocrática y por las filosofías 
orientales, la trascendencia de una realidad degradada a través del poder mágico del lenguaje y el aspecto dionisíaco de la poesía. Propuestas todas que surgen con el Introrrealismo. Con la poesía introrrealista, según Polo de Bernabé, Ory agota las posibilidades del Postismo a la vez que su poesía indaga en las preocupaciones metafísicas de su propio universo poético.

La obra de Raúl Herrero Antología de poesía Postista (1998), siguiendo la línea trazada por Pont, analiza lo que significó la propuesta postista en todas sus direcciones: poesía, narrativa, teatro, plástica, aparato ideológico. Además aparecen antologados poemas y textos que forman parte del canon postista, otros de autores próximos al movimiento como Juan Eduardo Cirlot, Jesús Juan Garcés, Ignacio Aldecoa... y textos de sus antecedentes. De estos últimos se recogen muestras de autores dispersos que van desde el cubismo, el futurismo y el surrealismo en su vertiente española hasta Lope de Vega, pasando por Unamuno. En cambio no aparecen los autores españoles de la tradición expresionista como son Francisco Quevedo o Ramón María del Valle-Inclán.

Resulta interesante la edición, tardía, que Antonio Pérez Lasheras y Alfredo Saldaña (2000) realizan del libro de romances postistas Las patitas de la sombra. Obra que contiene los romances postistas escritos por Eduardo Chicharro y Carlos Edmundo de Ory en 1944 y que aparecía inédita hasta el año 2000. En la introducción los autores se aproximan al Postismo, desvelan las claves de este movimiento antidogmático y resaltan la importancia que tuvo para el desarrollo del la estética vanguardista posterior. Ambos autores consideran que el Postismo supone el inicio de la Posmodernidad en nuestro país y el precedente de algunas propuestas artísticas posteriores como el popart, el happening o el action painting. A este estudio sobre la estética postista se suma un texto de Carlos Edmundo de Ory titulado Sobre el Postismo hoy. Se trata de una conferencia realizada por Ory el 30 de octubre de 1992 en el Museo de Teruel que formaba parte de las Jornadas En torno a Luis Buñuel: el Surrealismo en la posguerra española. Texto además publicado en 1993, en el número 24-25 de la revista Turia. Por otra parte, se ofrece un estudio sobre la obra donde se analizan los presupuestos postistas aplicados en estos romances.

María Isabel Navas Ocaña publica también un estudio sobre el movimiento, $E l$ Postismo (2000), que básicamente es un extracto divulgativo del trabajo El movimiento 
postista. Teoría y crítica (1997). En él se analiza el aparato teórico, los supuestos ideológicos del movimiento y sus relaciones en el contexto de la poesía y la crítica de su época. En este sentido, Navas Ocaña señala que la óptica que marca la mirada sobre la poética postista estaba mediatizada por la actitud de rechazo y de negación del surrealismo que fomentó la crítica de la primera posguerra. Punto de vista éste que consideraba no sólo la práctica de una poética surrealista, sino todo acercamiento a cualquier estética de vanguardia como un hecho anacrónico. Resulta interesante, de otro lado, el análisis de la estela que dejó la impronta postista en la poesía posterior. Por otra parte, en el texto La producción teórica y crítica de Carlos Edmundo de Ory. Un esbozo (Navas, 2002a) esta autora ofrece una reseña de la labor crítica de Ory. Tarea que repasa la actividad ideológica al frente del Postismo, la crítica literaria sobre los poetas postistas y su herencia, la labor teórica en el Atelier de Poésie Ouverte de Amiens, los ensayos sobre Federico García Lorca (Ory, 1967) y Albert Camus (Ory, 1964) y la actividad de crítico de arte que siempre profesó.

En la década de los ochenta del pasado siglo, la crítica reconoce ya la aportación del Postismo a la poesía de la posguerra. En la obra de Fanny Rubio y José Luis Falcó (1981), Poesía española contemporánea (1939-1980), se considera que el movimiento postista supuso el arranque de la poesía vanguardista que se desarrollará de modo paralelo a la poesía realista a lo largo de la posguerra. Sus autores analizan las conexiones de los poetas postistas como Ory, Labordeta, Carriedo o Crespo con la poesía de las nuevas promociones. Rosa María Pereda reconoce en la introducción a la antología, Joven poesía española (Pereda y García Moral, 1982), la huella del Postismo en la generación poética de los años setenta. La autora señala la que la poesía de Carlos Edmundo de Ory es el eslabón que une a la poesía veneciana de los novísimos con el surrealismo del grupo del 27, sobre todo con la poesía de Lorca, de Aleixandre y de Cernuda. También señala que la poesía visual es herencia del Postismo.

Víctor García de La Concha en la obra La poesía española de 1935 a 1975. De la poesía existencial a la poesía social (1987) analiza la poesía postista en profundidad, sus intenciones, sus manifiestos, las etapas... Y señala que es su estética barroca, de signo expresionista, el elemento que subvierte la poesía oficial garcilasista. La poesía de Eduardo Chicharro y la de Carlos Edmundo de Ory suponen las expresiones más claras de ese expresionismo ligado al decadentismo, al dadaísmo y al surrealismo. Como signo 
referencial de la poesía de ambos autores, de la Concha señala la dinamita verbal ofrecida por la literatura de Ramón Gómez de la Serna. Santiago Fortuño Llorens estudia también, unos años después, la importancia del movimiento postista en el desarrollo de la poesía de posguerra. En sus obras, Primera generación poética de posguerra. Estudio y Antología (1992) y Poesía de la primera generación de posguerra (2008), concede al Postismo un papel fundamental en la poesía escrita en los primeros años de la posguerra. En ellas se analiza la propuesta postista con profundidad, su actitud radical y provocadora, sus conexiones con las vanguardias, sobre todo con el futurismo, con el dadaísmo y con el surrealismo.

La antología Las insulas extrañas (1950-2000) (Millán y otros, 2002), realizada por Eduardo Millán, Andrés Sánchez Robayna, José Ángel Valente y Blanca Varela, estudia la relación existente entre la poesía castellana escrita en la península y la producida en el continente americano. El contexto histórico de la sociedad española propició una poesía dogmática de signo realista y ello supuso un empobrecimiento de la poesía, aislada de las corrientes del panorama poético del exterior. La poesía de tradición vanguardista, comprometida con la experimentación, fue relegada al más absoluto silencio. En esta situación el Postismo y la poesía de Carlos Edmundo de Ory adquieren una especial significación porque sufrieron la oposición de la cultura oficial. La poesía oryana quedó como una excentricidad y como una antigualla. Para los autores, el realismo poético imperante fue un simple naturalismo de tintes políticos (Millán y otros, 2002: 26) que ahogó con su retoricismo la poesía que estaba en consonancia con la poesía antipoética de Nicanor Parra, o la poesía de signo lingüístico de Octavio Paz o de José Lezama Lima. En España la poesía que se oponía a la poética realista quedó relegada al territorio de la periferia y de la marginalidad. Esta antología es un reconocimiento más a la poesía de Ory.

También se le dedica un espacio importante a la poesía de Ory en la antología realizada por Francisco Ruiz Soriano (2004), titulada Poetas órficos y publicada en 2004. Su autor estudia las relaciones que se establecen entre la poesía escrita en castellano a partir de la posguerra con las religiones griegas: el orfismo y sus ritos, los misterios, las celebraciones dionisíacas, el pitagorismo, el hermetismo, la alquimia. Entre los poetas antologados se hallan, además de Carlos Edmundo de Ory, poetas como Gabriel Celaya, Juan Eduardo Cirlot, Ángel Crespo, Jaime Siles, Alfonso 
Canales, Leopoldo María Panero, Jenaro Talens y algunos más. La poesía de Ory queda definida como una poesía visionaria que busca mediante el sonido, a modo de las vibraciones de un mantra o de la lira órfica, plasmar la armonía que se desprende de la total unidad de una realidad que vibra en cada instante. Poesía que penetra en lo sagrado y transmite el éxtasis que ofrece la experiencia de transmutación (Ruiz, 2004: 19-21).

Resultan muy interesantes las publicaciones realizadas desde Cádiz. En primer lugar cabe destacar el libro, editado y coordinado por Jaume Pont y Jesús Fernández Palacios, titulado Carlos Edmundo de Ory. Textos críticos sobre su obra (2001), que aparece referenciado en la bibliografía. La obra ofrece una recopilación de artículos escritos por estudiosos y compañeros de Ory como Félix Grande, Francisco Nieva, Rafael de Cózar, Cristobal Serra, María Isabel Navas Ocaña, Francisco Ruiz Soriano, Amador Palacios, Rafael Ramírez Scoto... Por ello supone una mirada plural y poliédrica a la obra y también una reivindicación de la figura de Ory. En 2004 la RevistaAtlántica de poesía, dirigida por José Ramón Ripoll, dedica la separata del no 27 a presentar una serie de documentos sobre Carlos Edmundo de Ory. Entre ellos encontramos artículos escritos por los habituales críticos oryanos como Jaume Pont, Rafael de Cózar, Jésus Fernández Palacios, José Ramón Ripoll y otros de compañeros de viaje como Francisco Nieva o José Manuel Caballero Bonald. Junto a ellos se ofrecen materiales oryanos inéditos como parte de su epistolario, algunos poemas y algunos aerolitos.

En 2012 la revista Insula dedica el $n^{\circ} 789$ a la figura de Ory. Coordinado por jaume Pont, este número ofrece una vez más una mirada plural sobre la obra oryana y su influencia en la poesía posterior. Entre los colaboradores podemos encontrar a José Manuel Caballero Bonald, Francisco Nieva, Guillermo Carnero, Joaquín Marco, Pere Gimferrer y los críticos oryanos más habituales como Jesús Fernández Palacios, José Ramón Ripoll, Rafael de Cózar, Ana Sofía Pérez-Bustamante o Jaume Pont.

Resulta especialmente interesante la tesis doctoral escrita por Pablo Acevedo, titulada Ironía, humor y juego en los discursos estéticos de la Modernidad: una mirada a través del Postimo. En ella se analiza el andamiaje conceptual del movimiento centrado en el elemento lúdico. Para Acevedo el Postismo, como movimiento vanguardista tardío, incorpora la impronta teórica de la ironía romántica: pensamiento 
utópico, anticlericalismo de una mística profana, abolición de la racionalidad, asunción del pensamiento mágico, analogía universal desde la fragmentación. El Postismo se inscribe, por tanto, en la corriente filosófica de la Modernidad y, a su vez, como ocaso de la vanguardia muestra su clausura. Por ello, avanza algunas notas de la condición posmoderna.

La última publicación que se ha realizado hasta ahora sobre la obra de Ory consiste en el número monográfico que la Revista Campo de Agramante, dirigida por Jésus Fernández Palacios desde la jerezana Fundación Caballero Bonald, dedica a finales de 2015 a Ory como homenaje. En ella se analiza su poesía, su narrativa y la correspondencia con algunos autores como Eduardo Chicharro, Mathías Goeritz o Juan Eduardo Cirlot. Entre la nómina de escritores se encuentran los críticos oryanos habituales, entre los que se halla quien esto escribe. Cabe señalar la participación de poetas como José Luis Rey y Antonio Gamoneda.

Frente a todo ello, el interés de este trabajo consiste en valorar la importancia de la irrupción del Postismo en el panorama artístico y cultural de su tiempo histórico, en situar la poesía postista en la territorialidad literaria de la posguerra española y en establecer la estela posterior que esta poética ha dejado. De modo que este trabajo pretende demostrar que el Postismo significó el punto de contacto entre las dos vanguardias poéticas. Por un lado, el movimiento mantiene sus convergencias con la vanguardia histórica, sobre todo celebra la radicalidad y la provocación del dadaísmo, supone la investigación del mundo de los sueños del surrealismo y continúa la dinámica deformadora del expresionismo. El Postismo no mantuvo un contacto estrecho con el expresionismo alemán. Esta estética deformadora y grotesca, para el Postismo, se encuentra en la tradición cultural. Por otro lado, el Postismo significa el punto de aceleración de la vanguardia posterior a la guerra civil y converge con la vanguardia artística que se desarrolla después de la segunda guerra mundial. Zona central que marca la unión de las propuestas de los movimientos de la vanguardia histórica y su herencia que se metamorfosea en un arte de signo experimental.

El presente trabajo se centra, en muchos aspectos, en la poesía de Carlos Edmundo de Ory, ya que se trata de la poesía que, desde los presupuestos de Postismo, irrumpe con más fuerza en el panorama poético y posee una impronta mayor en la 
herencia cultural. La poesía oryana se metamorfosea, a partir de la aventura introrrealista en una metanoia, en un proceso de transformación interior y ello supone un paralelo con los presupuestos de la poesía de la Beat generation de San Francisco. Por otra parte, el exilio francés de Ory posibilita el acceso a un espacio abierto a los nuevos vientos culturales, lo que supone un conocimiento de los presupuestos culturales que irrumpirán en el estallido de la contracultura en la década de los años sesenta del siglo XX. Este trabajo pretende, además, demostrar la relación de la propuesta postista y de la poesía oryana con la poesía beat y con algunos presupuestos de la contracultura. 
PRIMERA PARTE

SOBRE EL POSTISMO 
I. DELIMITACIÓN DEL POSTISMO EN LA TERRITORIALIDAD POÉTICA DE LA POSGUERRA 
1.1. RUPTURA DE LA VANGUARDIA

Tropezando con mi rostro distinto cada día. ¡Asesinado por el cielo!

Federico García Lorca

La poesía de posguerra parte de la ruptura de la línea poética inmediatamente anterior. Este hecho se debe, por una parte, a causas histórico-sociales y, por otra, a cuestiones culturales y literarias, si es que realmente puede realizarse tal separación. El golpe de estado producido por las tropas fascistas trajo como respuesta la movilización del gobierno y la creación de las milicias populares, iniciándose así en 1936 una guerra civil que acabó en 1939 con la derrota del gobierno republicano y democrático. Se inauguró así una dictadura católico-fascista que se caracterizó en un primer momento por una terrible represión establecida contra los vencidos y por una conciencia esquizofrénica que execraba todo lo que escapaba al ideario de su cruzada contra el comunismo universal. La creencia enfermiza en una conspiración judeomasónica contra el régimen dictatorial tuvo sumida a la sociedad española en un radical aislamiento cultural y en una atmósfera de cerrazón y de constante opresión. De otro lado, se inauguró una línea divergente de la poesía irracionalista, simbolista y vanguardista en las postrimerías del inicio de la guerra civil. En el interior de la controvertida y supuesta generación del $36^{2}$ hubo algunas propuestas para la creación de

${ }^{2}$ Etiqueta que aglutina a aquellos poetas que tuvieron una experiencia directa de la violencia de la guerra y de sus consecuencias. 
una poesía que se distanciase del irracionalismo de signo barroco y simbolista y que proclamaban un tradicionalismo de signo clásico. Frente a Góngora esta nueva corriente clasicista reivindicaba la figura de Garcilaso ${ }^{3}$, también hubo un interés por el realismo poético de signo machadiano, sobre todo debido a su poesía realista de raíz ética que parte de Campos de Castilla (1912), e incluso por la poesía de Miguel de Unamuno. Todo ello indica que en el intervalo temporal que coincide con la República se planteó en el ámbito poético una corriente que intentaba rechazar la vanguardia poética y buscar una poesía de base realista. Para algunos poetas este realismo poético significaba una vuelta a las formas más clásicas, para otros, en cambio, era una apertura a una poesía más humana, instalada en una mirada atenta a la realidad colectiva y a las circunstancias en las que se inserta la vida humana.

De todas formas, todo el cúmulo de circunstancias que rodearon el hecho de la guerra civil supone a nivel estético una ruptura radical con los parámetros artísticos de la Vanguardia artística ${ }^{4}$. La poesía anterior se inscribía dentro de las coordenadas vanguardistas europeas en las que transitaron los escritores del grupo del 27 y otros poetas anteriores como Juan Ramón Jiménez, que también había acercado sus presupuestos poéticos a algunos movimientos de vanguardia. Esta poética rechazada es heredera del irracionalismo poético surgido de la revolución romántica. Concretamente supone su última metamorfosis con anterioridad al punto de ruptura representado por el año de finalización de la guerra civil, año de entrada también en el proceso dictatorial y desculturalizador que aconteció en el Estado Español. Ruptura que coincide más o menos con el trascurso de la cultura europea. El fin de la Vanguardia en el exterior inauguró unas estéticas preocupadas por el interés ético, existencial, colectivo y social,

${ }^{3}$ 1936, año en el que estalla la guerra civil, fue el año del centenario de la muerte de Garcilaso de la Vega, que coincidió además con el centenario de la muerte de Gustavo Adolfo Bécquer y con el de José de Espronceda. Año que representa, para estos autores, el punto de bifurcación de dos corrientes que en aquel contexto parecían irreconciliables. Por un lado quedaba la poesía vanguardista heredera de los poetas del grupo del 27 y del simbolismo, perfectamente conectada con las corrientes coetáneas europeas y americanas. De otro, una línea poética que se retrotraía al clasicismo renacentista cuyo signo era la revitalización del soneto. Garcilaso se erigía como símbolo para unos, Góngora para otros. La figura de este último fue reivindicada por varios poetas del 27 debido, entre otras cosas, a su malditismo y a la oscuridad de su discurso basado en la metáfora (Rubio y Falcó, 1982: 25-26).

${ }^{4}$ Para Joaquín Marco (1980: 109-111) la ruptura con la poesía inmediatamente anterior, propiciada por la guerra civil, significó un empobrecimiento significativo de la poesía escrita en la primera posguerra. Ésta no supo conectar con las corrientes poéticas que confluyeron en el grupo poético del 27: creacionismo, ultraísmo, dadaísmo, cubismo y surrealismo. Encerrada en sí misma, y salvando algunas excepciones, la poesía de la primera posguerra se vio alejada de las corrientes exteriores. El panorama poético tras 1939 era, para este autor, devastador. 
cuyo signo fue el realismo. La asociación de surrealismo y revolución significó el canto de cisne del proyecto vanguardista que antaño se caracterizó, sobre todo, por la radicalidad de sus propuestas.

Esta ruptura poética no significaba solamente el rechazo de las estéticas vanguardistas, sino que suponía un cambio radical en los territorios poéticos. Lo que se rechazaba era la poesía de la Modernidad, de signo subjetivista e irracional, que surgió con los poetas románticos alemanes e ingleses, que luego se metamorfoseó en el simbolismo y las demás estéticas del decadentismo y del impresionismo y alcanzó su límite en la Vanguardia. Para Octavio Paz (1987: 56-62) la poesía de la Modernidad ${ }^{5}$ ha supuesto desde sus inicios una reacción contra la propia Modernidad y sus ideologías (Ilustración, razón crítica, liberalismo, positivismo y marxismo). Poesía que se basa en el presupuesto creador del lenguaje, en la idea del lenguaje como doble del universo ${ }^{6}$. De modo que el mundo es un poema y un poema un mundo a su vez. Poesía como realidad propia y autosuficiente. En su radical rechazo de la razón, la poesía romántica se convierte en una descarga de emociones, de afectos, de intimidades. Puro descontrol, ausencia total del elemento conceptual, impudor sentimental, atmósfera subjetiva que ahonda en el interior del poeta y lo despoja de sus capas exteriores hasta radiografiar su realidad más íntima. La propuesta romántica, como rechazo de la ideología burguesa capitalista y de su ideología mercantilista, se configura como un ataque al racionalismo. Por ello, la poesía se acerca a todo aquello que escapa al dogma racional. Poesía que rechaza la realidad racional y abre nuevas vías de conocimiento humano, que desde una óptica subjetiva rastrea el laberinto de las emociones hasta encontrar la zona de lo oscuro y lo demoníaco, conocida bajo la etiqueta de el otro yo. Ello supone la entrada en una zona oscura y desconocida para la razón, donde el elemento consciente se halla ausente.

${ }^{5}$ La Modernidad queda definida para Octavio Paz (1987: 20) como pasión crítica, por ello niega a su vez sus propios discursos.

${ }_{6}^{6} \mathrm{La}$ analogía es aquello que, según Paz (1987: 97-98), los poetas románticos redescubren en el lenguaje de la tradición mística y hermética. Se trata de un sistema de correspondencias que afecta al universo todo, incluido el hombre, ya que el ser humano no es, desde esta concepción, un ser separado. Junto a la analogía se halla la visión del lenguaje como doble del universo. Autonomía de la obra estética, culto al objeto literario. 
La poesía romántica accede, ni más ni menos, al subconsciente freudiano con anterioridad a los estudios del padre del psicoanálisis ${ }^{7}$ y muestra el conflicto subyacente del ser en la cultura occidental. Un ser escindido en dos mitades en conflicto, encerrado en su conciencia y separado totalmente del universo, como si fuese una entidad desconectada de todo lo demás, de los otros seres y de las $\operatorname{cosas}^{8}$. Poesía que se convierte en conocimiento introspectivo y accede al sueño, porque allí no hay control consciente, a la locura, a lo siniestro, lo grotesco, lo raro, lo horrible, lo lúgubre... a aquella realidad que con posterioridad explorarán los surrealistas a través de la escritura automática y demás vías de acceso al onirismo. Para Michel Foucault lo oscuro o inconsciente es lo impensado, aquello que conlleva, impreso, la conciencia racionalista.

Lo impensado (sea cual fuere el nombre que se le dé) no está alojado en el hombre como una naturaleza retorcida o una historia que se hubiera estratificado allí; es, en relación con el hombre, lo Otro: lo Otro fraternal y gemelo, nacido no de él ni en él, sino a su lado y al mismo tiempo, en una novedad idéntica, en una dualidad sin recurso. Esta playa oscura que se interpreta de buen grado como una región abismal en la naturaleza del hombre, o como una fortaleza singularmente encerrada e su historia, le está ligada de otro modo; le es, a la vez, exterior e indispensable: un poco la sombra contenida del hombre surgiendo en el saber; un poco la tarea ciega a partir de la cual es posible conocerlo. En todo caso, lo impensado ha servido al hombre de acompañamiento desde el siglo XIX (1966, 1968: 317).

${ }^{7}$ Freud (1923, 1973: 13-27). La triada psiquiátrica descubierta por Freud señala la conflictividad del ser humano que opera en su estructura psíquica profunda y que es desvelada por la literatura. En la novela positivista decimonónica asistimos a los procesos que desvelan la lucha interna del ego, controlador y separado de lo indeterminado, reflejado en el espejo del personaje problemático situado en el centro del tríptico. Por un lado tira de él el super yo, asociado a la figura paterna, en un impulso hacia la idealización y hacia el reconocimiento social. Por otro lado, el ello lo tiene sometido porque lo encadena a la madre tierra y a la sexualidad. Es el ello, alimentado por la frustración, la represión y la insatisfacción, quien imposibilita la realización del deseo idealizado. Este es el conflicto que se halla en el interior de Emma Bovary, de Ana Ozores y de otros muchos personajes novelescos. La conciencia de estos personajes desvela la imagen mítica del ser humano occidental, ser que se halla en un permanente conflicto interno propiciado por estas dos esferas irreductibles. Revelación del triángulo edíptico que se estructura a base de represiones, pues la historia de la civilización es la historia de la represión de los flujos del deseo. La vida social humana se instaura sobre la libido reprimida. Se trata de la lucha entre el ello como imagen de la madre y el super yo como imagen del padre.

${ }^{8}$ Fromm $(1923,1979: 19-21)$ interpreta a partir del Génesis el mito de la caída como concepto de separatividad. Concepto que podría definirse como el sentimiento humano de sentirse extraño y angustiado ante una realidad inhóspita. Ello sería fruto de la pérdida del ser humano de la conciencia de su unidad con el universo. La pretendida cultura conlleva a su vez la falsa conciencia de la perdida de la relación con el todo indeterminado llamado naturaleza, cosmos, totalidad... 
La estética romántica en su intento de unir vida y arte inaugura el esteticismo, «el arte de mostrarse ajeno de manera activa» como decía Novalis ${ }^{9}$, o «el arte del autoengaño consciente» según Samuel Taylor Coleridge ${ }^{10}$. En cualquier caso se trata de la creación de otra realidad, como doble y como suplantación, más afectiva y más humana que la pura realidad social, mercantilista, capitalista y burguesa. Una realidad paralela, ficticia, pero vivida con total realismo. Este es el camino que seguirán los poetas simbolistas, decadentistas, modernistas y bohemios de finales del XIX. Son ellos los que encontrarán la justificación de la vida en el propio arte y buscarán los paraísos artificiales, el malditismo y la conciencia de la decadencia como rechazo a su particular realidad social.

El simbolismo funciona como desarrollo de la poesía romántica y, a su vez, como reacción ante ella. Se elimina todo elemento metafórico convencional y, sobre todo, la lacrimosidad y la hipersensibilidad de la poesía romántica. El simbolismo (y aquí hay que mencionar que poetas modernistas y noventayochistas participaron en esta poética, tanto en la dirección impresionista como en la expresionista) es la continuación del lenguaje irracional, del ilogicismo poético romántico, y propone un lenguaje abandonado a sí mismo, preludio de la escritura automática del surrealismo, de su lenguaje onírico y de la asociación libre de objetos. Este nuevo lenguaje simbólico surge de la interpretación alucinada de Arthur Rimbaud y su alquimia del verbo. Mediante el desarreglo de los sentidos, propiciado por la utilización de los paraísos artificiales, el poeta accede a una zona mágica y misteriosa que necesita un lenguaje visionario. Los poetas españoles del Modernismo y del Noventayochismo participaron en esta poética, tanto desde una mirada impresionista como desde una mirada expresionista.

Con la Vanguardia el arte pretende romper definitivamente con el modelo de representación tradicional, lo que supone el ataque más radical al modelo realista. La poesía española recibe las directrices de esta estética radical y provocadora. Mediante la entrada en nuestro país del ultraísmo y el creacionismo se pretende romper con la forma tradicional del poema. De este modo, poetas españoles participan de los postulados rupturistas dadaístas y buscan plasmar la simultaneidad representacional de los

${ }^{9}$ Cito por Hauser, Arnold (1951), The Social History of Art, Londres, Routlege \& Kegan; traducción de A. Tovar y F. P. Varas-Reyes, Historia social de la literatura y el arte, Barcelona, Lábor, 1983, Vol. 2, p. 353.

${ }^{10}$ Ibíd., p. 354. 
presupuestas cubistas. Todo ello se traduce en que el poema, como molde clásico y estructura estrófica, estalla ante una nueva conciencia poética nacida de las palabras en libertad, de la propuesta de nuevos modelos como el caligrama o el collage, del juego lingüístico y de la utilización de recursos tipográficos y visuales. Juan Ramón Jiménez en su obra Diario de un poeta recién casado (1917), obra clave en cuanto supone el abandono de la estética modernista, se acerca a la Vanguardia sin abandonar la esencia intimista de su poética. Juan Ramón rompe con el modelo de poema e introduce en su poesía los supuestos poéticos cubistas del perspectivismo y la utilización de la disonancia. Por otra parte, en la obra se adelantan elementos como el interés por el sueño y lo visionario. Los mismos vanguardistas vieron en esta poética el anticipo de técnicas utilizadas con posterioridad. Ahora bien, son los poetas del grupo del 27 quienes muestran un contacto más intenso con las poéticas de la Vanguardia histórica. Existen dos etapas que marcan el devenir de la poesía vanguardista peninsular, una primera marcada por la destrucción del poema y de las poéticas anteriores que se sitúa entre 1919 y 1923. Etapa que se corresponde con la poesía de Gerardo Diego, Jorge Guillén y Pedro Salinas, entre otros. Existe en ella un acercamiento a los postulados poéticos del dadaísmo, del futurismo y del cubismo. La segunda etapa queda centrada entre 1925 y1935 y su signo es el surrealismo. Los poetas más representativos de ella son Federico García Lorca, Rafael Alberti, Vicente Aleixandre y Luis Cernuda. En este sentido, el Postismo, aunque instalado en la primera generación de la posguerra, supone la continuidad de la vanguardia poética.

Para Vittorio Bodini (1963, 1982: 29-31) el surrealismo en España no constituyó movimiento alguno, pero entre sus prácticas poéticas existen varios puntos en común. En primer lugar, la absoluta carencia de elemento teórico. En segundo, la reelaboración poética del material onírico. En último lugar, la interacción de los distintos códigos artísticos. Podría decirse que lo que ofrece la poesía surrealista castellana es un interés poético que prevalece sobre el automatismo puro y un alejamiento sintomático de la destrucción de la expresión poética. Este desarrollo del surrealismo marca una distancia con el grupo francés. Su impronta es el interés estético que se presenta bajo el signo de la elaboración del material surreal. Esta es la herencia que se ve eclipsada por los acontecimientos históricos que posibilitan una serie de cambios en la concepción poética desarrollada con posterioridad a la guerra civil. 
Frente a ello se propone, aunque existen varias líneas divergentes, una poética de signo realista. Poesía neoclásica, existencial, social... que poseen, como denominador común, el modelo poético realista. El realismo artístico aparece en el Renacimiento como el intento de apresar un fragmento de la realidad. Pictóricamente un cuadro significa una ventana abierta al mundo, una representación que ofrece la sensación de realidad.

Data del siglo XV la primera asimilación explícita de la pintura a la imagen de una ventana [...] En la concepción renacentista, la sabiduría del pintor consiste, precisamente, en su capacidad de ilusionar un espacio tridimensional, presentado con total independencia de la tela, rechazando el carácter superficial de ésta y haciéndola devenir cristal $^{11}$.

Obra como simulación de realidad, como pura apariencia, como artefacto que intenta representar la realidad. De ahí la perspectiva, la proporción, la armonía, la unidad..., caracteres que tomará también la obra poética. Mímesis de lo real y por ello una vuelta a los códigos tradicionales de representación. La poesía de posguerra, continuando con la teoría de la verosimilitud y la imagen del reflejo de la obra artística, propone una poética que constate el estado de una determinada realidad. El poeta dirige los ojos hacia la realidad más inmediata, para ofrecer testimonio y dar fe acerca del aquí y del ahora. La poética realista será la pauta dominante. No hay que olvidar que existen varias prácticas divergentes más o menos subterráneas hasta la llegada aventura de la poesía experimental, culturalista y mediática que marcó, a finales de la década de los sesenta, el ocaso de la poesía de posguerra ${ }^{12}$. Poesía esta última que reacciona contra el modelo poético realista e inicia un proceso de convergencia con la antigua vanguardia, sobre todo reactiva la experiencia surrealista

Según las tesis de Carlos Bousoño (1952, 1976, Vol. II: 368-370), aquello que define a la poesía de posguerra es la importancia histórica. Los poetas inauguran una nueva sensibilidad, pero no existe una ruptura total con la poesía de la Modernidad. Por una parte, ello se debe a la propia imposibilidad de tal evento. Por otra, porque el

11 Tomás, Facundo (1985), «Representación, Presentaqción/Producción, Reproducción», Valencia, Eutopías, Instituto de cine, radio y televisión, n 1-2, pp. 181-184.

12 Como antología de importancia vital de la poesía de este período (tras considerar que no es la única, ni son únicos los poetas que en ella aparecen) cabe citar la obra de Castellet (1970), Nueve novísimos poetas españoles. El autor ofrece una serie de pautas definidoras de la poesía de esta generación, los novísimos: distancia de las formas poéticas tradicionales, ruptura con el discurso lógico, presencia de elementos exóticos, estética culturalista (1970: 38-47). 
irracionalismo, para este autor, subyace en todo momento bajo el prisma realista y el deseo humanizador ${ }^{13}$.

El individualismo y el irracionalismo no han desaparecido; simplemente se han enmascarado bajo formas menos llamativas, aunque sustanciales, lo cual, justamente, permite a los poetas actuales aprovechar las geniales conquista expresivas de los últimos cien años (Bousoño, 1952, 1976, Vol. II: 370-371).

Este enmascaramiento provoca la distancia de lo imaginario, del formalismo, del esteticismo y posibilita el acercamiento a la realidad, el interés por la ética y la mirada hacia la colectividad. Para Juan Goytisolo (1986: 22) el cambio de parámetros de la poesía de posguerra se dio, en varios casos, bajo el signo de aquello que se ha denominado realismo socialista o crítica marxista. Interés social o político que prevalece sobre el mero interés literario, concepción de la literatura como programática política, panfletarismo poético, relación necesaria entre poesía y militancia... La crítica marxista se encargó de asociar los conceptos Vanguardia y arte burgués, y propuso una estética reaccionaria en cuanto acogía el modelo realista cuando sus códigos ya habían sido objetos totalmente explorados $y$ agotados en la literatura positivista $y$ posteriormente superados y subvertidos.

Desde la condena de los movimientos de vanguardia por Trotski en sus ensayos de Literatura y revolución, los nuevos vientos del «realismo» y retorno al canon narrativo balzaquiano estaban a la orden del día. En vez de advertir, como Brecht, que el verdadero formalismo estriba en la repetición fija, mecánica del presunto realismo del XIX y no en la búsqueda de lenguajes capaces de interpretar la riqueza, movilidad y contradicciones de la sociedad moderna, los partidarios de una nueva concepción homogénea y normativa del arte profesaban una reverencia casi dogmática a las formas literarias del pasado que cifraban a los ojos de Marx y de Lenin summum de la herencia burguesa. A la convergencia de Revolución y vanguardia artística, preconizada por Maiakovski y el notable grupo de escritores surgido en las postrimerías del zarismo, sucedía así la de la primera y las formas literarias burguesas abominadas por los vanguardistas. En virtud de un mecanismo reiterado en todos los sistemas políticos, ideológica y

13 La poesía de posguerra ha sido definida como poesía rehumanizadora en contraposición a la concepción orteguiana del arte de las vanguardias (Ortega y Gasset, 1925, 2009: 29-30). En este sentido el surrealismo se distanciaría de las poéticas deshumanizadas, como el dadaísmo, el cubismo, el futurismo y sus metamorfosis peninsulares. Distancia que ofrece su acercamiento al interior humano, su intento de dar voz al inconsciente. Dámaso Alonso (1952: 57) prefirió el nombre de neorromanticismo. De hecho el surrealismo estuvo presente aunque de manera heterodoxa y soterrada en la poesía española de posguerra. Para Navas Ocaña (2001b: 340-343) la sustitución de surrealismo por neorromanticismo significó desvincular la poética surrealista de algunos representantes del grupo del 27 del surrealismo francés. 
culturalmente reaccionarios, lo nuevo sería tildado de decadente y antiguo mientras la vieja mercancía gastada se revestiría con las galas de la juventud y perennidad. La creencia ingenua en los valores revolucionarios y humanistas de la sociedad soviética (¿quién ha oído hablar entonces del Gulag?) aclara en parte la miopía y el daltonismo de los intelectuales occidentales y su consabida, machacona denuncia de esos «frutos tardíos del espíritu decimonónico» que, por citar las palabras de Antonio Machado, serían las novelas de Proust y Joyce ${ }^{14}$.

Para Octavio Paz (1987: 207-209) la poesía española de posguerra perdió todo contacto con la poesía europea y con la poesía hispanoamericana. En las páginas de la antología Las insulas extrañas (Millán y otros, 2000: 21-22) sus autores señalan que el alzamiento militar contra la República Española interrumpió el proceso de modernización cultural que se estaba produciendo en la sociedad española desde la generación del 14. Para estos autres, que coinciden plenamente con Paz, una de las principales consecuencias de la ruptura de este proceso fue la fractura de la conexión entre la poesía española y la poesía hispanoamericana. La poesía española, hija de la situación vivida bajo el franquismo, mayoritariamente quedó sumida bajo el dogma del realismo. En este sentido, la guerra civil significó la dispersión de la vanguardia poética española y, además, un supuso un cambio de rumbo radical en el devenir poético. Para Octavio Paz, la principal consecuencia fue la adscripción al realismo socialista:

Los poetas se adhirieron al «realismo socialista» y practicaron la poesía de propaganda social y política. Sacrificio de la búsqueda verbal y la aventura poética en aras de la claridad y la eficacia política. Gran parte de esos poemas ha desaparecido como desaparecen las noticias y las editoriales de los periódicos. Quisieron ser testimonios de una época y la historia los ha borrado (Paz, 1987: 207).

Abandono de la experimentación, de la poesía como experiencia y alquimia lingüística. Regreso a la retórica clásica y al didactismo ideológico. En cambio, la poesía hispanoamericana a partir de los años cuarenta continuó ofreciendo gratamente sus convergencias con la vanguardia. Si en ella hubo un regreso, ello supuso también una crítica contra aquellas tesis de la vanguardia que ahora significaban una nueva academia. Crítica que quedó establecida cuando la radicalidad de los proyectos de la vanguardia había sido absorbida por las instituciones socio-culturales ${ }^{15}$. Discurso

${ }^{14}$ Goytisolo, Juan (1986), «Modernidad y dogmatismo: Jdanov, Joyce y Machado», Madrid, Quimera, $n^{\circ} 43$, pp. 21-24.

${ }^{15}$ Ver Baudrillard y otros (1985), obra cit. en la bibiografía; Baudrillard, Jean (1983) Les stratégies fatales, Paris, Editions Grasset \& Fasquelle; traducción de Julio Vivas, Las estrategias fatales, Barcelona, Anagrama, 1984. Lipovetsky, Gilles (1983) L'ère du vide. Essais 
posmoderno que cuestiona el ocaso de las vanguardias. Esta línea poética que marcaron obras como La fijeza (1944) de José Lezama Lima, Libertad bajo palabra (1949) de Octavio Paz o Costumbres errantes o la redondez de la tierra (1951) de Enrique Molina no fue secundada por la poesía española, preocupada por el realismo y por la temática existencial. La convergencia, en rasgos generales, se producirá unos años más tarde cuando la última generación de posguerra se sacude totalmente la óptica realista y su interés regresa hacia la zona del lenguaje.

sur l'individualisme contemporain, Paris, Éditions Gallimard; traducción de Joan Vinyoli y Michèle Pendanx, La era del vacío, Barcelona, Anagrama, 1986. 


\subsection{INTENTOS SOBRE UNA DELIMITACIÓN}

Entre los huesos de los muertos abría Dios sus manos amarillas.

Juan Ramón Jiménez

Todo límite siempre es impreciso porque la realidad es un nudo sin fin, tangible; y el lenguaje una red conceptual que intenta estructurar esa realidad caótica que siempre se escapa entre los signos. Cualquier intento de limitación será por ello ficticio. Principio ordenador que utiliza la crítica para establecer un campo acotado, líneas imaginarias que tratan de establecer sentidos, parecidos y diferencias. En suma, áreas, mediciones, etiquetas y clasificaciones que pretenden aplicarse a la práctica poética que se produjo con posterioridad a la guerra civil. Muchos son los estudios y antologías que se han dedicado a analizar los supuestos, direcciones y estéticas de la poesía de posguerra. También son varias las sistematizaciones establecidas: etapas, grupos, generaciones... Diversas las reacciones, los pliegues, las transmutaciones. Propuestas poéticas que han rechazado con radicalidad los presupuestos de poéticas anteriores, concepciones sobre el hecho poético totalmente enfrentadas. Los poetas de la última etapa de la posguerra rechazaron los presupuestos del realismo poético $\mathrm{y}$, sobre todo, de la poesía social y establecieron la inutilidad de la poesía como intento de cambiar el mundo. Los poetas de la cotidianeidad rechazaron radicalmente el tremendismo y la poesía angustiada y existencial y en cambio su práctica poética se dirigió hacia una poesía de la narratividad. Existieron además polémicas sobre la función de la poesía: poesía como comunicación propuesta por Vicente Aleixandre y defendida por Carlos Bousoño (1952, 1976, Vol. I: 18-19) y poesía como conocimiento de la mano de Carlos Barral $^{16}$, que cuestionaba el realismo poético. Con todo ello se creó un panorama poliédrico en el que se establecieron toda serie de convergencias y divergencias entre las determinadas prácticas poéticas producidas en este período y que significaron una verdadera proyección en determinadas poéticas posteriores.

${ }^{16}$ Ver Bonet, Laureano (1988), La revista Laye. Estudio y Antología, Barcelona, Edicions 62, pp. 148-150 y Riera, Carme (1988), La escuela de Barcelona, Barcelona, Anagrama, pp. 152-154. La revista Laye, conocida publicación que se editó entre 1950 y 1954 , aglutinó al llamado grupo de Barcelona formado por Carlos, Jaime Gil de Biedma, Luis Goytisolo... En sus páginas Carlos Barral negaba la noción comunicativa de la poesía. 
Para Santiago Fortuño (2008: 73-74) aquello que marca la poesía de la primera posguerra sería el hecho de que los poetas han tenido la experiencia directa de haber vivido la guerra civil y la guerra mundial. Su gesto generacional es de signo existencial. El existencialismo cultural marcó totalmente la sociedad en la que les tocó vivir y, sobre todo, los presupuestos de su poesía, que derivaron de la estética a la ética. Por ello, este autor engloba bajo este supuesto la poesía desde el final de la guerra hasta finales de la década de los cincuenta siguiendo la opinión de Leopoldo de Luis (1992: 8-10) que define como elemento fundamental el hecho de comenzar a escribir tras el trauma de la guerra civil, en un panorama cultural devastado por la violencia y el vacío cultural marcado por unas dificilísimas circunstancias sociales y políticas. Todo ello explica, para el autor, el viraje hacia la óptica poética social, hacia una actitud diferente ante la realidad circundante.

Los poetas de la primera generación de postguerra eran protagonistas - activos o pasivos - de la guerra civil [...] Alguna vez he comparado la generación del 36 con un autobús en ruta. Sus viajeros comparten la contemplación del paisaje, visto con talante y gusto comunes. De súbito, un accidente interrumpe la marcha $\mathrm{y}$ todos deben descender. Cuando el autobús reinicia el viaje, algunos viajeros ya no están: no pueden subir; otros se acomodan en los mismos asientos, se disponen a continuar la aventura, pero otros varios se sienten incómodos y ya no miran el panorama con el mismo entusiasmo ni responden a la misma tesitura (Luis, 1992: 8-10).

Carlos Bousoño señala también que estos poetas han tenido, entre dificultades de todo tipo, el privilegio de inaugurar una nueva etapa poética:

Nuestra generación, desde este punto de vista, nació bajo los auspicios felices de una estrella de lujo, pues la casualidad hizo que entrase al ejercicio de la literatura en el instante mismo en que iba a dar comienzo una nueva época, si es que podemos hablar así desde nuestra perspectiva. Estrenar una sensibilidad siempre es mejor que cerrar un gusto preexistente [...] Los poetas que empezaron a escribir en España con posterioridad a la guerra civil han inaugurado, si no me equivoco, un nuevo estremecimiento estético $(1952,1976$, Vol. II: 369-370).

José Hierro proponía como etiqueta para su poesía y la de su generación la de Quinta del 42. Etiqueta, que además de titular un poemario de este autor, ha sido utilizada por un sector de la crítica para denominar la poesía escrita por el grupo de 
poetas que se aglutinaba alrededor de las publicaciones Corcel (1942) y Proel (1944), y por extensión a toda la poesía de la primera posguerra.

Queda por sistematizar la cuestión de los límites y de las directrices de la poesía con posterioridad a la guerra. Esta acabaría con el ocaso de la poesía novísima, mediática, experimental y veneciana, que sucede a finales de la década de los setenta o a principios de la de los ochenta. La crítica coincide en establecer tres períodos clave. El primero se inicia con el final de la guerra y acaba con el final de la década de los cincuenta, denominado también primera posguerra. El segundo período viene marcado por la poesía de la cotidianeidad realizada en la década de los sesenta. Y el tercero significaría el fin de la posguerra poética, marcado por la experimentación y el culturalismo de la poesía de los setenta. Las opiniones sobre los dos últimos períodos son más o menos unánimes, ahora bien es en el primero donde existen más divergencias interpretativas. Éste es el tramo más extenso, por un lado; y por otro, es el espacio donde existen más pluralidades. Desde el final de la guerra hasta finales de los cincuenta aparecen en la territorialidad poética la poesía tradicionalista o neorrenacentista, la poesía humanizada, la poesía tremendista o existencial, la poesía social, la poesía esteticista o neorromántica y también la poesía de la marginalidad, línea poética subterránea que proponía la continuación de la Vanguardia.

Es en este terreno donde operan varias perspectivas con sus discursos diferenciadores. Aparecen en la crítica diversos conceptos como: Generación de 36, Generación del 40, Quinta del 42 y otros tantos más. En todo caso, sólo funcionan a nivel de etiquetaje. Fanny Rubio (Rubio y Falcó, 1982: 27-28) o Víctor García de la Concha (1971: 15-51) creen que no existió la pretendida generación del 36, que se trata solamente de un grupo de poetas con algunos puntos de contacto entre sí. Leopoldo de Luis (1992: 7-11) propone el término generación del 40 y señala dos líneas poéticas: la poesía garcilasista iniciada en el 36 y la poesía humanista de signo ético y social. Carlos Bousoño (1984: 23-28) señala tres etapas en la poesía de posguerra. La primera generación quedaría establecida por los poetas nacidos entre 1909 y 1923 que representan el realismo poético de signo existencial de las décadas de los 40 y los 50. En esta primera generación es sintomático para Bousoño (1984: 29) el paso del Yo al Nosotros, el transito de la preocupación existencial y humana a la mirada social; poesía dirigida a la colectividad. La segunda generación la formarían los nacidos entre 1924 y 
1938, considerados ya poetas de los años 60 preocupados por la poesía de la cotidianeidad sin abandonar el código realista. Quedarían agrupados en la tercera los poetas que nacieron entre 1939 y1953, generación que marca no sólo una ruptura con la poética realista sino que significa además el fin de una época. Joaquín Marco (1980: 111-113) divide la poesía de posguerra en cinco etapas, las tres primeras marcan la poesía desde la guerra civil hasta la década de los sesenta. La primera traza la línea temporal desde 1939 a 1944 y viene definida por la propuesta tradicionalista y nacionalista del grupo Escorial y del grupo Garcilaso. La segunda posguerra va de 1944 a 1952 y en ella se engloba la propuesta existencial y la propuesta esteticista del grupo Cántico. La tercera etapa se desarrolla entre 1952 y 1963 y centra en la poesía social. Las dos etapas restantes son las que se corresponden con la poesía de los años 60 y de los años 70, considerada esta última la etapa final.

Con todo ello se puede realizar una sistematización, a modo de pequeño esbozo, que englobe el período de la posguerra poética en cinco partes o etapas en las que se ofrecen simultáneamente varias líneas convergentes.

\subsubsection{Posguerra inmediata}

Este es el período que va de 1939 a 1945, desde el final de la guerra civil a la aparición de la revista Postismo (1945). Puede decirse que, ya que la producción poética inmediatamente anterior viene caracterizada por su escaso interés, el panorama poético de posguerra arranca en 1944, año publicación de dos obras claves: Sombra del paraíso de Vicente Aleixandre y Los hijos de la ira de Dámaso Alonso. Por un lado, Sombra del paraíso cierra definitivamente una etapa, marca el final de la poesía irracionalista de signo surrealista. Cabe mencionar en este sentido que cierta parte de la crítica censuró y silenció la asociación entre poesía de posguerra y surrealismo bretoniano establecida por el Postismo ${ }^{17}$, movimiento que supuso continuación de los postulados del surrealismo y del dadaísmo. La realidad poética expresada en Sombra del paraíso queda establecida sobre unos presupuestos míticos que funcionan como plasmación de

17 Ver, Cózar (1978, 1990: 60-78) y Pont (1987: 29-30). Para estos autores el movimiento significa un surrealismo de segunda generación que marca el inicio de la nueva Vanguardia. 
arquetipos ${ }^{18}$ universales que contactan con las filosofías místicas tanto de Oriente como de Occidente. Por otro lado, Hijos de la ira de Dámaso Alonso marca el inicio de una nueva poética. Esta es la obra que abre el camino hacia una poesía humana, existencial e incluso social. En este sentido inaugura los paradigmas que marcan un nuevo panorama poético.

En esta primera etapa de la poesía de posguerra cabe situar la poesía de los poetas de guerra, de aquellos que padecieron la experiencia traumática de la guerra y sus consecuencias. Hay que mencionar, pues, las poéticas de los poetas anteriores a la guerra (algunas de ellas marcadas por el exilio, otras por el silencio o la represión) como la Juan Ramón Jiménez, la de los poetas del 27 o la poesía política de Miguel Hernández. También las poéticas de aquellos que, más o menos, surgen como poetas durante la República y que, tras la guerra, practican una poesía clasicista y rehumanizadora. Algunos de ellos escribieron sus poéticas bajo el signo de Garcilaso agrupados en torno a la revista Escorial (1940), cuyas directrices estaban vinculadas con el régimen franquista. La impronta humanizadora de la poesía escrita por los poetas de la guerra marca, entre varias direcciones, la línea garcilasista de los poetas de posguerra afines a la revista Garcilaso (1943).

\subsubsection{Segunda etapa poética de posguerra}

Este es el período comprendido desde 1945 a 1952, marcado, sobre todo, por la poesía existencial. La obras de Vicente Aleixandre y de Dámaso Alonso inician las poéticas tremendistas y humanizadoras. Surgen nuevas publicaciones que suponen líneas poéticas divergentes y plurales. El grupo de poetas que se aglutina alrededor de la revista Espadaña propone una poesía existencial desde una óptica tremendista y comprometida continuando la propuesta de Dámaso Alonso. La publicación Adonais (1943) compagina la poesía existencial con la reivindicación de las poéticas más

18 Para Carl Gustav Jung (1938, 1994: 85; 1951, 1963: 171) del mismo modo que el cuerpo humano muestra una anatomía general común a toda diferencia étnica, también el pensamiento posee un sustrato que trasciende toda diferencia cultural. Éste es el inconsciente colectivo, común a toda la humanidad, que se manifiesta en los arquetipos: mitos, símbolos o imágenes mentales que poseen carácter universal. Para este autor del mismo modo que los árboles crean hojas el cerebro humano crea mitos, ya que cerebro o árbol son al fin objetos diferentes que pertenecen al todo indiviso que es la realidad. $Y$ su constante fluir supone su crecimiento, hojas en un caso; mitos en el otro. 
humanizadoras del grupo del 27 y la poesía transterrada. La revista Cántico (1947) representa la línea poética esteticista y culturalista que parte de la óptica andalucista de los poetas del 27. En ella se reivindica el cariz intimista y reflexivo de la poética cernudiana. Por otra parte, a través de la revista Postismo (1945) y su continuación, La Cerbatana (1945), se inicia una línea poética marginal que conecta con el gesto enérgico y radical de la Vanguardia. Poética que contacta con la modernidad europea y rechaza radicalmente la poesía humanizadora, realista y ética de la posguerra. De este modo surge una propuesta vanguardista que, aunque incipiente todavía, se proyectará hacia la poesía postsurrealista y la poesía experimental: poesía concreta, poesía visiva, poesía semiótica ${ }^{19}$.

\subsubsection{Etapa social}

Etapa comprendida entre 1952 y 1962, en la que la poesía se decanta, no en todos los casos pero sí mayoritariamente, por el realismo social. Las fechas que delimitan esta etapa coinciden, más o menos, con la publicación de dos antologías, cuyos datos quedan reflejados en la bibliografía. La Antología Consultada, realizada en 1952 por el editor Francisco Ribes (1952), marca su inicio y la antología de Josep Maria Castellet $(1960,1962)$ Veinte años de poesía española, inaugura en 1962 su final. La poesía social queda definida por su intento de cambiar la realidad desde la toma de conciencia por parte del lector. Su interés se desplaza hacia la ética y la política y la búsqueda de un receptor más amplio, que será aquel que con su práctica social finalice el hecho poético. Como portavoces de la poesía social se erigen las figuras de Gabriel Celaya y Blas de Otero. A su vez, manifestando la oposición a la concepción neorrealista de la poesía como valor testimonial, una serie de poetas proponen, tras los pasos de Vicente Aleixandre (entre ellos Carlos Bousoño), sustituir el compromiso por un nuevo concepto de realidad, intimista y humana. Por otra parte, nuevos poetas se suman a la línea poética vanguardista surgida del Postismo.

\footnotetext{
${ }^{19}$ Ver, Millán y García Sánchez (1975: 11-31).
} 
1.2.4. Poesía de la sinceridad, última posguerra

Esta etapa, conocida como la poesía de los sesenta o la poesía de la cotidianeidad, comprende los años que van entre 1963 a 1970. La fecha de inicio la marcan la antologías Poesía última realizada por Francisco Ribes (1963) y la Antología de la nueva poesía española de José Batlló (1968), cuyos datos ofrecemos en la bibliografía. En ellas se establecen, siguiendo los pasos de la Antología Consultada, las pautas de esta nueva promoción de poetas: Carlos Sahagún, Francisco Brines, Claudio Rodríguez, Carlos Barral, José Agustín Goytisolo, José Ángel Valente, Ángel González, Jaime Gil de Biedma, Juan Manuel Caballero Bonald, Félix Grande, Eladio Cabañero... Esta nueva poética surge como rechazo de la poesía garcilasista, existencial y social. Poética de lo humano, de signo ético, reflexivo, instalada en la cotidianeidad que busca lo poético en lo narrativo. Poesía que es método de conocimiento en cuanto organización del recuerdo, autocrítica, análisis y testimonio de lo cotidiano. Se trata de una poesía que viene definida por la sinceridad.

Carlos Barral propone el concepto poesía como conocimiento en contra de la concepción de Carlos Bousoño de poesía como comunicación. La teoría bousoniana presenta la poesía como la comunicación establecida con meras palabras de un contenido psíquico, sensorio-afectivo-conceptual, que se presenta formando un todo en el texto poético ${ }^{20}$. Carlos Barral interpreta el concepto de Carlos Bousoño como realidad comunicativa en el contexto de la poesía humanizadora e histórica, coetáneo a la teoría bousoniana. Y niega la concepción de poesía como elemento vehiculante de conceptos, ya que ello supone una simplificación del proceso poético al ignorar la autonomía del momento creativo ${ }^{21}$. Aquello que se rechaza desde la nueva poética es la teoría social del hecho poético. Barral se distancia así de las tesis del realismo social y de la literatura como compromiso activo.

Por otra parte, la línea poética de vanguardia atraviesa los años sesenta bajo el signo de la poesía experimental: la poesía concreta liderada por Julio Campal, los poetas que se ciernen en torno a la revista Claraboya (1963), los trabajos de Juan Eduardo

${ }^{20}$ Ver Bousoño (1952, 1976, Vol. I: 48). «El arte está configurado para los demás hombres, y en consecuencia por los demás hombres: es social desde su raíz, desde la nebulosa confusa y muda que gira confinada en la mente solitaria del poeta que quiera expresarse» (1952, 1976, Vo II: 48).

${ }^{21}$ Ver Riera, Carme (1988), La escuela de Barcelona, Barcelona, Anagrama, p. 154. 
Cirlot y el equipo catalán Dau al set, la poesía visual de Fernando Millán, y las rupturas lingüísticas de José Miguel Ullán.

\subsubsection{Fin de la posguerra}

Se trata de un período que se inicia en 1970 con la estruendosa aparición de una antología clave, Nueve novísimos poetas españoles realizada por Josep Maria Castellet (1970). Los límites finales en cambio se desdibujan paulatinamente hasta la llegada de la nueva década. La concepción poética de los nuevos autores viene contextualizada por la aparición de un nuevo paradigma cultural, o contracultural para definirlo con más precisión. Estos poetas han conocido directamente la literatura de la Beat generation, el Pop $\operatorname{art}^{22}$, las filosofías psicodélicas ${ }^{23}$ que posibilitaron el Verano del Amor en

${ }^{22}$ Para una visión exahustiva del arte pop ver el capítulo «El pop, arte de la imagen popular» (Marchán Fiz, 1972: 31-49).

${ }^{23}$ Existe una literatura subterránea que a lo largo de los siglos, desde los misterios de Mitra y los de Eleusis hasta ahora, se ha ocupado y se ocupa del estudio de la percepción alterada. En esta línea cabe mencionar autores como Thomas de Quincey y su tratado sobre el opio y Jacques Cocteau y sus anotaciones sobre la cura de la adicción a esta sustancia; Sigmund Freud y sus experimentos con la cocaína; Antonin Artaud, Henry Michaud o Carlos Castaneda y sus experiencias con el petote; o los escritos de Albert Hofman y Ernest Jünger sobre el ácido lisérgico. En California, a partir de los estudios de Aldous Huxley sobre las experiencias visionarias inducidas con mescalina o L.S.D. surge una línea de investigación sobre lo que se llamó la percepción psicodélica. Aquí cabe mencionar autores como Alan Watts, Ken Kesey, Tom Wolf, Timothy Leary... Por otra parte autores de la beat generation como Jack Kerouac o William Burroughs habían tratado ya en sus obras literarias la temática de la droga. En nuestro país este espacio lo ocupa buena parte de la producción de Antonio Escohotado. Ver: Artaud, Antonin (1971), Les Tarahumaras, París, Éditions Gallimard, traducción de Carlos Manzano, Los Tarahumara, Barcelona Tusquets, 1985; Burroughs, William (1953), Yonqui, traducción de Martín Lendínez, Yonqui, Barcelona, Bruguera, 1980; Castaneda, Carlos (1968), The Teachings of Don Juan, A Jaqui Way Knowledge, The Regents of the University of California, traducción de Juan Tovar, Las enseñanzas de Don Juan. Una forma yaqui de conocimiento, Madrid, Fondo de Cultura Económica, 1974; Cocteau, Jacques (1930), Opium, Opio, diario de una desintoxicación, Barcelona, Bruguera, 1983; Escohotado, Antonio (1990), El libro de los venenos, Madrid, Mondadori; Freud, Sigmund (1974), Cocaine Pappers, Nueva York, Robert Byck, Escritos sobre cocaína, Barcelona, Anagrama, 1980; Huxley, Aldous (1954), Doors of perception. Heaven and Hell, Nueva York, Perennial Library, 1970, Las puertas de la percepción. Cielo e infierno, Barcelona, Edhasa, 1977; Kerouac, Jack (1957), On the Road, Nueva York, ViKing Press, traducción de Martín Lendínez, En el camino, Barcelona, Anagrama, 1989; Michaux, Henry, L'infini turbulent (1957), París, Mercure de France,1967, El infinito turbulento, Valencia, MCA, 2000; Plant, Sadie (2001), Wrinting of Drugs, traducción de Ferrán Meler-Ortí, Escrito con drogas, Barcelona, Destino, 2003; Quincey, Thomas de (1821), Confessions o fan English Eater, traducción de Luis Loyaza, Confesiones de un comedor de opio, Madrid, Alianza Editorial, 1984; Usó, Juan Carlos (1996), Drogas y cultura de masas (España 1985-1995), Madrid, Taurus; Watts, Alan (1970), «Psichedelic drugs and religious experience», Doest it Matter?, traducción de Mauricio Rovira, «Drogas psicodélicas y experiencia religiosa», El gran mandala, Barcelona, Kairós, 1971; Watts, Alan (1960), "The new alchemie», This is it, tradución de Enric Tremps, "La nueva alquimia», Esto es eso, Barcelona, Kairós, 1992; Wolfe, Tom (1968), The Electric kool-Aid Acid Test Farrar, Nueva York, Straus and Giroux, Inc., traducción de Jesús Zulaica, Ponche de ácido lisérgico, 
California y la revolución del Mayo del 68 de París. Viven una situación en la que se agotan las viejas utopías de la Modernidad. El proyecto político llega a su fin, lo que conduce a la idea de la inutilidad de la poesía para cambiar la realidad. De otro lado se asiste a la irrupción social de los mass-media y, con ellos, a la creación de la sociedad consumista, reflejada a través y de unos nuevos paradigmas artísticos: el pop. Todo ello desemboca en una postura poética experimental, lúdica y crítica que intenta utilizar los nuevos códigos sociales y, tal como señala Carlos Bousoño (1979b: 27-29), subvertir el lenguaje del poder.

La poesía se convierte en experiencia laberíntica, aventura lingüística, juego referencial, mapa culturalista... experimentación poética. En suma, una poesía que rechaza el realismo poético y los modelos poéticos tradicionales. Y es este rechazo lo que para Castellet (1970: 40-42) define la voluntad artificiosa de esta nueva poesía de matiz culturalista. En este sentido, Carlos Bousoño (1979b: 30-31) señala que la voluntad culturalista responde a la distancia que toma la poesía frente a la realidad. Ello la acerca a posiciones esteticistas, la poesía pasa a ser considerada como ente de fícción.

El poeta se inspira, de modo explícito o connotativamernte, en el arte (literatura, escultura, pintura, arquitectura, música) y no directamente en la vida, pero no por desprecio de ésta, como ocurría entre los estétas del siglo XIX, sino por considerar, tal como antes dije, incognoscible la realidad e inexpresable su experiencia por el sujeto dentro de unos esquemas sociales de carácter represivo cuya función primordial es controlar, manejar y ocultar la realidad (1978b: 35).

Para Jenaro Talens (1981:19-21) hablar de culturalismo consiste en una paradoja. ya que los materiales utilizados por el poeta se componen irremediablemente de vida y escritura:

En este sentido, el material utilizado por el escritor en su doble vertiente (referencial y expresiva) se compone de una mezcla de vida y escritura, amalgamados en un espacio común, la memoria (que es lenguaje), y si la intertextualidad en que consiste toda escritura adopta en la generación que nos ocupa una de sus variantes particulares, la cita, es un problema de grado, no de cualidad (1981: 20).

En ciertos casos la poesía se repliega sobre sí misma distanciándose del referente exterior y se adentra en su interioridad, poesía que se convierte en metapoesía, que es Barcelona, Anagrama, 1997. 
otro de los paradigmas de la poética de esta generación. La metapoesía o función metapoética propone como única realidad referencial de la poesía la realidad del lenguaje. El poema reflexiona sobre sí o, tal como destaca Rosa María Pereda (García Moral y Pereda, 1979, 1982: 29), sobre el mismo hecho de la escritura. Poesía y teoría se fusionan en el poema. Para Carlos Bousoño (1979b: 53-54) el autor del poema hace referencia al mismo poema que está escribiendo. Así el poema muestra de una forma más patente su propia estructura o construcción. Bousoño compara la metapoesía con ciertas obras plásticas de Antoni Tapies o Vaquero Turcios, donde ciertos trazos, tachaduras o fragmentos lingüísticos se inscriben en la realidad del cuadro para desvelar su entramado estructural. La metapoesía, de este modo, desenmascara la propia representación y muestra el propio hecho de representar. Parece que el lector asiste al acto de gestación del hecho poético. Jenaro Talens (1981: 15-19) sostiene que la metapoesía opera en el terreno de lo sobresignificante, en el territorio estricto de la literatura y no en el de la realidad. Distingue así metapoesía y función metapoética o metaliteraria y extrae la siguiente conclusión (1981: 18): «La metapoesía no existe, o bien no existe la poesía: ambas son una y la misma cosa». La metapoesía marca la dirección interna del hecho poético y se relaciona con la intertextualidad, que marca la dirección hacia el exterior. En la intertextualidad el poema se dirige hacia las otras realidades textuales, literarias, artísticas y culturales. Este es el movimiento externo del poema. El poema se dirige así hacia el exterior o hacia el interior. En este último caso, en la escritura metapoética, el poema se hunde en sí mismo. La metapoesía es una reacción contra el realismo poético y al mismo tiempo una de las manifestaciones de la dimensión culturalista de la poesía de esta generación.

La antología que realiza José Batlló (1968), Antología de la nueva poesía española, que se publica en 1968 constituye el puente hacia esta nueva poética al dar cabida a poetas nuevos como Pere Gimferrer, José Miguel Ullán y Manuel Vázquez Montalbán. Pero es la antología de Josep Maria Castellet (1970), Nueve novísimos poetas españoles, la que ofrece la etiqueta perfecta y las constantes de esta poética. Este crítico destaca como rasgos de esta nueva propuesta poética la preocupación formal como rechazo de la estética realista, el elemento culturalista que ofrece un sentido artificioso del poema, el automatismo, la utilización del collage, la utilización de elementos de la estética camp y la recuperación de los poetas malditos (Castellet, 1970: 37-44). Poesía que experimenta, recoge y reelabora los diferentes lenguajes artísticos y 
mediáticos de la sociedad en la que se instala. En esta antología quedan representados como poetas paradigmáticos de la nueva generación los poetas siguientes: Manuel Vázquez Montalbán, Félix de Azúa, Pere Gimferrer, Ana María Moix, Guillermo Carnero, Leopoldo María Panero, Vicente Molina Foix, José María Álvarez y Antonio Martínez Sarrión. Otras muchas son las antologías aparecidas durante estos años que han venido a ampliar la nómina de poetas participantes de esta estética poética renovadora y experimental que enlaza con la Vanguardia anterior a la guerra civil, con la poética vanguardista marginal de posguerra y con las poéticas coetáneas exteriores ${ }^{24}$. Entre diversos autores cabe citar a Fernando Millán, José Miguel Ullán, Jaime de Siles, Jenaro Talens, José Luis Jover, Luis Antonio de Villena, Antonio Colinas, Luis Alberto de Cuenca... En la antología realizada en 1979 por Carmen García Moral y Rosa María Pereda (1979, 1982), Joven poesía española, ya se empieza a hablar de la importancia de las convergencias con sus antecedentes poéticos: el grupo Cántico, el Postismo, Carlos Bousoño, Carlos Barral, Jaime Gil de Biedma, Claudio Rodríguez... (García Moral y Pereda, 1979, 1982: 14-18). Dos autores se erigen como verdaderos maestros de la nueva generación: Vicente Aleixandre y Carlos Edmundo de Ory. El primero aporta el surrealismo de verso largo; el segundo, experimentación, metapoesía, humorismo y heterodoxia.

${ }^{24}$ Ver: Batlló, José (1974), Poetas españoles poscontemporáneos, Barcelona, El Bardo, Barral; Martín Pardo, Enrique (1967), Antología de la nueva poesía española, Madrid, Pájaro Cascabel; Martín Pardo, Enrique (1970), Nueva poesía española, Madrid, Scorpio; Pozanco, Víctor (1976), Nueve poetas del resurgimiento, obra cit. en la bibliografía; Prieto, Antonio (1971), Espejo del Amor y de la Muerte (Antología de poesía española última), Madrid, Bezoar; Prieto, Antonio (1972), Laberinto, Madrid, Retorno; VV.AA. (1971), Equipo Claraboya. Teoría y poemas, Barcelona, El Bardo. 


\subsection{LOS POETAS DE LA GUERRA}

Yo soy del fresco mundo recién creado, tierra.

María Beneyto

La guerra civil, además de muchas otras cosas más, significó una ruptura radical con los parámetros sociales, políticos, artísticos y culturales de la etapa anterior. Territorio arrasado, ausencia total de interés por el conocimiento, represión y venganza, repliegue sobre sí mismo de un sistema fascista en connivencia con la iglesia católica, penuria y hambre, sufrimiento y necesidad, y sobre todo silencio. A nivel poético ello queda traducido como vacío total. Exilio, encarcelamiento, muerte, silencio. Antonio Machado, Juan Ramón Jiménez, Rafael Alberti, León Felipe, Manuel Altolaguirre, Concha Méndez, Ángel Lázaro, Luis Cernuda, Max Aub, Pedro Salinas, Jorge Guillén, Emilio Prados, Juan José Domenchina, José Moreno Vila, José Bergamín, Juan GilAlbert, María Zambrano son poetas que parten al exilio. Otros, como Federico García Lorca, fusilado, y Miguel Hernández, devuelto desde Portugal a las autoridades españolas, encarcelado, enfermo y muerto de forma prematura, no tuvieron tanta suerte. Poetas de generaciones anteriores como Dámaso Alonso, Vicente Aleixandre, Gerardo Diego... quedan sumidos en un silencio momentáneo y reinician su práctica poética bajo la posguerra. De otro lado se hallan los poetas que iniciaron sus prácticas poéticas en tiempos de la II República, en algunos casos contactando con la Vanguardia, y continuaron sus poéticas, dispersas en bastantes casos, desde unos presupuestos tradicionalistas: influjo de Garcilaso en la mayoría de los casos, revitalización del soneto. Algunos críticos han utilizado el término generación del 36 para englobar a estos poetas y marcar entre ellos unas conexiones muy discutibles e incluso, en varios casos, inexistentes. Germán Bleiberg, Dionisio Ridruejo, Carmen Conde, Miguel Hernández, Gabriel Celaya, Luis Rosales, Leopoldo Panero, Juan Panero, Luis Felipe Vivanco, José María Valverde, Ildefonso M. Gil y José Luis Cano son un grupo de poetas, dispares sobre todo en el caso de las trayectorias poéticas de Miguel Hernández y de Gabriel Celaya, que marcan el inicio de la poesía garcilasista, llamada también poesía tradicionalista. 


\subsubsection{Poesía exiliada}

Finalizada la guerra civil con la victoria de las tropas fascistas y la instauración de la dictadura franquista, gran parte de la intelectualidad española partió al exilio. Francia, Inglaterra, México, Argentina, Portugal... fueron algunos de los espacios de acogida a estos intelectuales desterrados. A nivel poético, el exilio de Antonio Machado, instalado en Colliure, al sur de Francia, tras patéticas penurias, constituyó el símbolo del sufrimiento del exiliado. A ello se sumó su muerte prematura. Tragedia colectiva, desierto poético en el espacio de partida. Buen número de poetas tuvieron que partir: Juan Ramón Jiménez, León Felipe, José Bergamín, Max Aub y la mayoría de los integrantes del grupo del 27, Luis Cernuda, Manuel Altolaguirre, Pedro Salinas, Jorge Guillén, Emilio Prados, Juan José Domenchina, José Moreno Vila, Rafael Alberti... Ruptura poética marcada por la nostalgia del espacio perdido, por la amargura del abandono, por las traumáticas experiencias vividas, por el deseo del regreso...

En este sentido cabe destacar la poesía total de Juan Ramón Jiménez ${ }^{25}$ que arranca de La estación total (1939), se trata de una poesía mística que manifiesta la unidad y armonía con el cosmos. Totalidad, presencia interior de la divinidad, integración del todo ser en un cosmos divinizado. En ella se produce un acercamiento total al hinduismo y al budismo. Conciencia cósmica, panteísmo. Obras: En el otro costado (1942), Romances de coral gables (1942), Animal de fondo (1949), Dios deseado y deseante (1949), Una colina meridiana (1950) y Ríos que se van (1953).

La poesía exiliada de Luis Cernuda abandona la rebeldía surrealista y se centra en la imagen del paraíso perdido. Para Jenaro Talens (1975: 96-122), se trata de una poesía que brota de la soledad para refugiarse en el mito, en el inútil y desolado deseo de recobrar el paraíso. A partir de Las nubes (1940) la mirada poética se dirige hacia la cotidianeidad, humanización de la poesía coincidente con la poesía peninsular. El hombre y el mito de la existencia marcan las directrices de su poética: Como quien espera el alba (1944), Vivir sin estar viviendo (1949), Con las horas contadas (1956), Desolación en la quimera (1962). Inutilidad del mito como recuperación del paraíso, desolación extrema.

${ }^{25}$ Ver: Blasco (1982: 325-327; 1988: 78-97). 
Por otro lado, Rafael Alberti inaugura la figura del poeta como agitador social y agente al servicio de la revolución proletaria. Ello dictó su inminente e inevitable exilio. Su poesía exiliada rompe completamente con su óptica surrealista, considerada ahora como producto burgués. Alberti continúa la tarea de agitación emprendida en los años anteriores a la guerra civil y que significó el abandono del surrealismo ${ }^{26}$. Miguel GarcíaPosada (1984: 367-368) plantea el gesto de Alberti como una elección ante un dilema: «o se es revolucionario en el mundo (es decir se acepta el compromiso) o se es revolucionario en el lenguaje (y por tanto un formalista, un reaccionario)» (1984: 368). De este modo, su producción poética en el exilio, de signo tradicionalista y populista, no alcanza ni de lejos el nivel estético de su poética vanguardista-cancioneril ni de su poética surrealista. Obras: Entre el clavel y la espada (1941), Pleamar (1944), A la pintura (1948) dedicada a Pablo Picasso, Retornos de lo vivo lejano (1952), Ora marítima (1953). En todas ellas, tal como apunta Ricardo Senabre (Sanabre, 1977: 7886), se manifiesta una intensa nostalgia hacia el espacio abandonado; poesía como recuperación del pasado y deseo de regreso.

La poesía exiliada de León Felipe también converge en torno al mito del paraíso perdido. El payaso de las bofetadas (1938) escrito en su viaje a México, Español del éxodo y del llanto (1939), Ganarás la luz (1943), Llamadme publicano (1950) y El ciervo (1958) son poemarios donde el mito de la sombra del paraíso es vivido como tragedia (Paulino, 1979: 37-42). Angustia existencial ante una realidad desolada. Son muchas las poéticas exiliadas, diversas y plurales; pero en casi todas el viaje, la pérdida y la lejanía provocan una angustia desgarrada que da paso al recuerdo, paraíso recobrado mediante la memoria.

La pérdida de la guerra supuso para el combatiente Juan Gil-Albert el campo de concentración, el exilio y, finalmente a su regreso en 1947, el silencio de lo que se ha llamado el exilio interior. Es en este silencio donde completa en 1979 su obra poética de la guerra en una recopilación titulada Mi voz comprometida (1936-1939) y donde escribe una obra amplia y callada que aflora en 1972 en la antología Fuentes de la constancia. Título revelador. Mediterraneidad, exaltación de la vida, conciencia de la marginalidad (Aznar, 1980: 76-77). Pero es en su poética americana donde aparece la

${ }^{26}$ Bodini (1963, 1982: 45). Para este autor, es la rebelión surrealista, de signo humano, la que posibilita el paso a la acción política directa. Este tránsito se produce en 1929. 
mediterraneidad como imagen del paraíso perdido. Las ilusiones (1944) muestra una poesía de signo clásico que recupera elementos culturales y míticos de la tradición grecolatina. Sombra del paraíso, exilio, recuerdo.

De otro lado, poetas más jóvenes han vivido también en el exterior debido a otros motivos, por rechazo de unas determinadas coordenadas socio-políticas o bien atraídos por colaboraciones en universidades extranjeras y en organismos internacionales. Son poetas, en todo caso, que han realizado una obra poética fuera de su país y ello otorga a su obra una especial significación: Carlos Edmundo de Ory, Ángel Crespo, José Ángel Valente o José Miguel Ullán, por citar algunos casos.

\subsubsection{Poesía de la ruptura}

Luis Cernuda (1975: 173-174) considera la existencia de tres grupos poéticos en los años de la guerra. El primer grupo quedaba formado por los viejos poetas de la generación del 98, el segundo formado por los poetas de la generación del 27 que, de alguna manera, habían continuado la sensibilidad inaugurada por los primeros. Herederos del irracionalismo poético, estos poetas señalan su límite al entroncar con la radicalidad y la ruptura de la representación del realismo propuesta por la Vanguardia. El tercer grupo representa una tendencia conservadora, caracterizada según Luis Cernuda (1975: 175) por el fervor religioso y por el alejamiento del hermetismo de la poesía anterior. La instauración de la dictadura supuso una ruptura trágica para las poéticas de muchos poetas, sobre todo para aquellos combatientes que sufrieron la muerte, la cárcel, el exilio, el silencio o el olvido. Estos poetas, representantes de la poesía interrumpida por la guerra, comienzan a publicar después de un silencio de años. Para buena parte de la crítica, la poesía de posguerra prácticamente se inicia en 1944 con la publicación de Sombra del paraíso de Vicente Aleixandre y de Hijos de la ira de Dámaso Alonso, creaciones de dos de los poetas representantes de la vanguardia rota.

En el caso de Vicente Aleixandre el silencio ocupó el intervalo desde el 1935, año en que escribió de Mundo a solas, hasta el 1944. Mundo a solas tuvo mala suerte y no apareció publicado hasta 1950. Sombra del paraíso es una obra ambivalente porque cierra una época y abre otra. La poética de Aleixandre se sitúa de lleno en la dirección 
vanguardista, culminación de la poesía surrealista española. La poesía de Vicente Aleixandre, continuando con los presupuestos del grupo francés, supone la búsqueda de una realidad otra, que no se circunscribe al empequeñecimiento de la realidad que significa la óptica racionalista. Realidad onírica, subconsciente, mítica. Realidad total que integra en sí una triple dispersión: lo puramente real, el sueño y el mito. Vicente Aleixandre bucea en los símbolos de las culturas foráneas y en las corrientes herméticas y encuentra aquello que para Carl Gustav Jung expresa todo símbolo o arquetipo, la mística $^{27}$. Conocer y comprender, expresar. Unidad, totalidad. Esto es lo que articula la concepción mística manifestada en Sombra del paraíso. Visión panteísta del universo, danza cósmica en torno al amor, lo elemental como verdadera realidad, cultura como separatividad, el hombre como caída y destierro. Se trata de la presencia absoluta de una divinidad inmanente. La totalidad del cosmos es el ser divino, que está formado por las miríadas de los seres. Acercamiento a las filosofías de Oriente, al sufismo. Carlos Bousoño $^{28}$ observa, por su parte, en esta mística unificadora la expresión de la tradición mística hispana. Para este autor, el panteísmo de Vicente Aleixandre surge del sustrato cultural hispánico denominado por Américo Castro integralismo español en su obra La realidad histórica de España ${ }^{29}$. Siguiendo el concepto de Américo Castro, la mística hispánica se basa en el anhelo de integración del yo particular en el todo divino. En la poética mística de Vicente Aleixandre solamente el hombre, a diferencia de los demás seres, es un ser extraño; separado de la divinidad, único ser no consciente de su unidad primordial, dormido a su verdadera realidad. Estos son los parámetros míticos en los

${ }^{27}$ Jung, Carl Gustav (1950, 1982: 9-21). En el epígrafe «Psicología y poesía» Jung establece que la poesía se sumerge en la corriente subterránea e incontrolable de los acontecimientos, en el estado primordial de la participación mística. Por ello la poesía desvela la experiencia de unidad cósmica de todos los seres. Experiencia íntima e inefable cuyo lenguaje es la poesía. En este sentido en Sombra del paraíso aparecen imágenes arquetípicas de la tradición mística hinduista como la danza cósmica o el vuelo mágico junto a otras pertenecientes a la tradición judeo-cristiana como la caída o los dormidos. Arquetipos que Aleixandre apuntan desde perpectivas distintas, unas por vía afirmativa y otras por vía negativa, a un mismo significado existencial, cósmico, místico.

${ }_{28}$ Bousoño (1956, 1977: 78-80). La concepción mística panteísta de Vicente Aleixandre en su afán globalizador, unificador y místico es, para Bousoño, una expresión de la tradición mística hispana que se interpreta como deseo espiritual de integración del yo con las cosas. De este modo el panteísmo aleixandrino conectaría con la visión de Jorge Guillén, Gerardo Diego o Emilio Prados. Herencia, a su vez, de la filosofía de Ortega y Gasset o la religiosidad de Miguel de Unamuno. En un territorio mucho más alejado se vislumbra la sombra de la mística ascética de Juan de la Cruz o la mística neoplatónica de Luis de León, que adapta las ideas sobre la unidad de la filosofía de Plotino.

${ }_{29}$ Castro, Américo (1954), De la realidad histórica de España, México, Porrúa; ed. actualizada, 1965, pp. 92-95. Para este autor el integralismo es fruto de la convergencia de las tradiciones judaica, islámica y cristiana. Este concepto señala la integración del ser humano en la tierra, en el cosmos. Esta visión del hombre enraizado en la tierra se desarrolla a lo largo de la literatura española hasta la actualidad. 
que discurre la poesía de Nacimiento último, publicado en 1953. La separatividad del ser humano actúa como símbolo existencialista, reflejo de la angustia existencial que se manifiesta en la imagen del hombre como ser durmiente, ser que ha de buscar la iluminación poseída por los demás seres. A partir de aquí, coincidiendo con la poesía de raíz humana y con la poesía social, la poética aleixandrina cambia de presupuestos. Con la publicación en 1954 de Historia del corazón el interés se centra en lo histórico ${ }^{30}$, en la realidad cotidiana. La poesía experimenta un desplazamiento hacia la ética y se centra en la solidaridad humana, en el reconocimiento del ser humano entre sus semejantes. Búsqueda, pues, de un lenguaje más realista. Continúan esta poética En un vasto dominio (1962) y Retratos con nombre (1965).

Dámaso Alonso, perteneciente al grupo del 27 más como crítico y teórico que como poeta, publica movido por las circunstancias en 1944 dos obras clave: Oscura noticia e Hijos de la ira. Su poesía anterior venía de la mano de la vanguardia ultraísta, situada por lo tanto dentro de los parámetros de la vanguardia cubista y dadaísta. Ahora su poesía marca, desde una herencia surrealista y expresionista, el nuevo rumbo de la poética de posguerra. Contactando con el existencialismo francés inaugura la poesía existencial. Para Josep Maria Castellet (1960: 102) la poética de Dámaso Alonso significó el inicio de la poesía social. Para Emilio Alarcos Llorach (1976: 141-142) supuso la subversión de los postulados poéticos de la época debido a la eclosión de un lenguaje vigorizante, renovador y humano. Víctor García de la Concha (1987: 501) establece un claro distanciamiento entre la obra damasiana y la poesía social, «Hijos de la ira no tiene nada que ver, desde luego, con el realismo chato de buena parte de lo que después se llamó poesía social». La propuesta de Dámaso Alonso funciona en la dirección del expresionismo, con bastantes ecos de Francisco de Quevedo en cuanto a la estética feísta, nauseabunda incluso; a la mezcla de registros lingüísticos; a la

30 Bousoño (1956, 1977: 146-156). Este autor estructura la poesía de Vicente Aleixandre en tres etapas. Lo cósmico, lo histórico y la unidad de ambos. La primera etapa es panteísta y en ella el poeta se acerca a las miradas totalizadoras de las diferentes tradiciones. El lenguaje artístico es el surrealista, se trata de un viaje por el mundo onírico traducido en un cierto automatismo y en la radicalidad de su simbología. La actitud de Aleixandre coincide con la rebelión surrealista bretoniana: la huida hacia lo desnudo elemental y hacia lo natural telúrico como rechazo del mundo civilizado agresor o conciencia racional burguesa. La segunda etapa se caracteriza por la raíz ética de la poesía que ahora gira alrededor de lo humano circunscrito en el tiempo histórico. Sustitución de la óptica surreal por el modelo poético realista puesto en boga por la poesía rehumanizada. Si la poesía mística-panteísta expresaba la unidad cósmica de todos los seres ahora la poesía histórica expresa la unidad humana. Sustitución de la imagen mítica por el realismo humano, que expresa la conciencia de la infranqueable solidaridad humana. La última etapa de la obra aleixandrina se articula en la fusión de las dos concepciones anteriores: panteísmo histórico. 
poetización de lo prosaico... Se trata de un grito o de una imprecación sobre la condición existencial. Distancia de la poética realista, sobre todo del garcilacismo; pero también de la poesía deshumanizada. A su vez se trata también de una poesía religiosa en tanto que supone un grito lanzado a un dios trascendente que se encuentra ausente de su mundo creado. Poesía que expresa la realidad circunstancial vivida por el ser humano. Si Vicente Aleixandre recogía la tradición mística universal, la óptica de Dámaso Alonso se centra en la ascética, mística cristiana que transita a través del dolor humano (Silver, 1970: 514-517). Llamas, llagas, purgatorios, supuraciones, torturas, monstruos. Catarsis, al fin y al cabo, ante una realidad desolada. Angustia metafísica. Poesía no realista, simbólica, continuación pues del irracionalismo poético bajo el signo existencialista. Con la obra Hombre y Dios (1959) la poesía deja de ser grito para convertirse en reflexión, poesía conceptual.

Luis Cernuda en su obra Estudios sobre poesía española contemporánea sitúa a la poesía de Miguel Hernández como heredera de la Vanguardia por su vinculación con el surrealismo de Federico García Lorca, Vicente Aleixandre y Pablo Neruda. «Hernández es también la excepción a aquella tendencia conservadora del grupo que antes mencionamos» (Cernuda, 1975: 175). De este modo Cernuda separa la poética hernandiana del clasicismo de los poetas de la llamada generación del 36. Con los tres poetas citados anteriormente, Federico García Lorca, Vicente Aleixandre y Pablo Neruda, Miguel Hernández comparte la visión cósmica, telúrica y panteísta del universo. Es, sobre todo, en El rayo que no cesa (1936) donde tumultuosamente irrumpe el amor como elemento trágico, volcánico, primario y subconsciente (Cano Ballesta, 1971: 126). Abandono de los presupuestos católico-tradicionalistas y acercamiento a Pablo Neruda (Cano Ballesta, 1972: 212). Ello se traducirá en un ferviente compromiso político y en la concepción de la poesía como arma de lucha y voluntad transformadora de la realidad. Viento del pueblo (1937) y El hombre acecha (1939) inauguran la poética de la guerra. Literatura de denuncia, distancia de los presupuestos de la poesía estética. Entre los atisbos y disposiciones del realismo socialista se asiste a una meditación sobre el hombre y la destrucción. Interés por el tema de España, territorio que luego será transitado por los poetas de la posguerra. Miguel Hernández es, sobre todo, un poeta de la guerra, su poesía queda interrumpida y silenciada por su encarcelamiento, la enfermedad y la muerte. Como poesía de posguerra solamente puede considerarse la obra escrita en la cárcel y publicada de 
manera póstuma en el Cancionero y romancero de ausencias y los Últimos poemas (1938-1941) que recogen la producción escrita estos años. Poesía neopopulista que no abandona el componente trágico, el amor cósmico como rito mágico y la fusión vidaamor-muerte. Amor como fecundación y vida, pero a su vez como pasión y destrucción ${ }^{31}$.

\subsubsection{Poesía tradicionalista}

La poesía de los poetas que se consolidaron durante la República aparece caracterizada por su impronta tradicionalista. Recuperación de Garcilaso frente a Góngora, revalorización del Antonio Machado más realista y populista, interés por Miguel de Unamuno, dirección hacia la sencillez y rechazo de toda actitud hermética, revitalización del realismo frente a lo simbólico, retórica clásica frente a la destrucción del poema. Estos poetas son Germán Bleiberg, Dionisio Ridruejo, Carmen Conde, Leopoldo Panero, Juan Panero, Luis Rosales, Luis Felipe Vivanco, Ildefonso Manuel Gil, José Luis Cano y José María Valverde entre algunos otros. Cabe matizar que en el caso de José Luis Cano y de José María Valverde, sólo una parte de su producción poética podría situarse en el territorio de la poesía tradicionalista y, en todo caso, su postura ideológica presenta claras divergencias con la postura ideológica de los demás. En suma, la propuesta común de estos poetas era situarse frente a la poesía formalista, a la que rechazaban como mero juego vacío, y reivindicar una poesía de lo humano. Esta poesía humanizadora queda traducida en poesía religiosa, que se pregunta por la existencia humana y se dirige hacia la figura del dios cristiano, católico, padre, trascendente. De aquí parte la primera poesía de posguerra, como desarrollo de esta poesía de signo tradicionalista y humano. Poesía del hombre y de su circunstancia temporal que lleva impresa un lenguaje conceptual que persigue la comunicación frente a la sugerencia. Destrucción del signo opaco, clarividencia de significados. Para Víctor García de la Concha (1987: 489-490) el componente religioso que caracteriza esta línea

${ }^{31}$ Luis, Leopoldo de (1974: 23-24). Este autor conecta el sentido amoroso hernandiano con lo telúrico. El amor es la fusión de la vida y la muerte. Para él este amor estrechamente vinculado con la vida y la muerte, pues es su celebración, proviene de la concepción de Vicente Aleixandre del amor como destrucción. Amor trágico que conlleva la disolución individual de los amantes y su fusión con el cosmos a través de la muerte. Para de Luis, Quevedo se halla en el trasfondo de esta concepción del amor. 
poética surge de la preocupación existencial y, por ello, se trata de mera poesía existencial.

En estas coordenadas cabe destacar la obra de Luis Rosales La casa encendida (1949). Realismo con dirección onírica, contactos con el realismo mágico. A lo largo de la obra surgen imágenes de signo surreal: muertos que se aparecen, fragmentos de universo en el interior de la casa, recuerdos en forma de visiones... Formas de expresar el misterio que radica en la cotidianeidad del ser humano y en el universo entero. García de la Concha (1987: 853) conecta la obra con la dimensión trascendente de la poética de lo cotidiano. Otras obras importantes son: El descampado (1957) de Luis Felipe Vivanco, Sonetos de la bahía (1942) de José Luis Cano, Poemas del toro (1943) de Rafael Morales, El corazón en los labios (1947) de Ildefonso Manuel Gil o Escrito a cada instante (1949) de Leopoldo Panero. Obras todas escritas en la posguerra dentro de los márgenes de esta poesía tradicionalista. Algunos de estos poetas quedan aglutinados en torno al grupo Escorial, revista aparecida en 1940 en las coordenadas ideológicas de la Falange. Poesía oficial, patriótica, religiosa e imperial. Sus representantes: Luis Felipe Vivanco, Leopoldo Panero, José María Valverde, Dionisio Ridruejo y Luis Rosales. La revista estaba vinculada estrechamente con el régimen e intentaba recrear una cultura de la salvación, vehículo de propaganda de la ideología franquista. Las poéticas de estos poetas vienen estrechamente marcadas por la poesía íntima y religiosa.

La revista Escorial fue la antecesora de la Revista Garcilaso (1943), que dio nombre a una poética, el garcilacismo. Poesía tradicional y programática ideológica, neoclasicismo nacional-socialista, distanciamiento total de la realidad circundante. En suma, poesía narcótica. La publicación aparece en 1943 de la mano de la tertulia del Café Gijón: José García Nieto, Jesús Revuelta, Jesús Juan Garcés, José Fernando Aguirre, Romero Moliner y Pedro Lorenzo. Su propuesta poética e ideológica rehuía todo contacto con la cultura exterior y con el pasado vanguardista. Freud y el surrealismo eran considerados enemigos, al igual que todo lo que tuviese algo que ver con ellos. También Góngora y los ismos. Frente a ello se oponía la figura española y militar de Garcilaso, símbolo de la nueva España imperial. Unión de tradicionalismo y militarismo contra lo foráneo. Frente a la libertad poética, el endecasílabo. Heroísmo, belicismo, triunfalismo, neoclasicismo... que intentaban conectarse con los valores tradicionales de la cultura española, y los valores del antiguo imperio español. Su signo, 
el Siglo de Oro: junto a Garcilaso, Lope de Vega, Fernando de Herrera, Fray Luis de León... despojados todos ellos de cualquier elemento heterodoxo. Regreso a las formas renacentistas: el soneto y la décima como imagen de la cultura de la nueva España. En suma, una poesía desconectada con la realidad de la posguerra, distanciada de la circunstancia social y de la crudeza y la desesperación del paisaje creado después de la batalla. En este sentido puede hablarse de poesía narcótica (Alarcos, 1956: 19), por la creación de una realidad evasiva y artificial, por su aura de triunfalismo y retórica vacía, por la idealización del amor, por sus sentimientos epidérmicos, por su serenidad autoimpuesta, por la supresión de todo aquello que traduce cualquier atisbo de sufrimiento o dolor causados por las consecuencias de la guerra. Vicente Gaos (1971: 349), escritor que publicó varias colaboraciones en las páginas de la revista, define el garcilacismo como la poesía oficial del régimen y puro anacronismo. Ahora bien, a parte de la línea poética garcilacista, Garcilaso publicó obras de poéticas plurales: desde integrantes de la generación del 27 hasta poetas marginales del Postismo como Carlos Edmundo de Ory. 


\subsection{LA POESÍA EXISTENCIAL}

No, ninguno tan horrible

como este Dámaso frenético.

Dámaso Alonso

La poesía existencial de posguerra queda definida como búsqueda del sentido de la existencia. Poesía que se plantea la problemática del ser humano en un mundo caótico y destrozado, la angustia ante la circunstancia vital, la soledad humana frente a la destrucción creada. Poesía que toma un matiz religioso y tremendista, que pregunta a la figura del dios trascendente por el destino del hombre. En algunos casos esta poesía religiosa se pliega sobre sí misma para resaltar la inexistencia de dios a través de su silencio, en otros se configura como antagonismo entre angustia y pasión por llegar al conocimiento del mismo. En todo caso, presencia innegable de la mística cristiana. Salmo hacia la divinidad, extremo dramatismo como oración, preguntas sobre el dolor humano, las repercusiones de la violencia o la España en ruinas. Presencia, por otro lado, de la filosofía existencial inaugurada por Arthur Schopenhauer y Frederich Nietzsche, continuada por Soren Kierkegaard y Martin Heidegger y que desemboca en el existencialismo francés de Jean Paul Sartre y Albert Camus ${ }^{32}$. Conexiones también con la literatura existencialista española: Miguel de Unamuno, Pío Baroja, Antonio Machado $^{33}$. El existencialismo, en la poesía escrita en castellano, pasa de los versos de

${ }^{32}$ Ver, Shopenhauer, Arthur (1819), Die Welt als Wille und Vorstellung, Leipizg, Brockhaus, $2^{\mathrm{a}}$ ed. aumentada con un segundo volumen, 1844, El mundo como voluntad y representación, Madrid, AKAL, 2005; Nietzsche, Friedrih (1887), Zur Genealogie der Moral: Eine Streitscherift, obra cit. en la bibliografía; Kierkegaard, Soren (1844), Begrebet Angest, El concepto de la angustia, Buenos Aires, Editorial Hyspamerica, 1992); Heidegger, Martin (1927), Sein und Zeit, El ser y el tiempo, México, Fondo de Cultura Económica, 1951; Sartre, Jean Paul (1943), L'être et le neant, Paris, Gallimard, El ser y la nada, Bueños Aires, Losada, 2005; Camus, Albert (1942), Le Mythe de Sisyphe, El mito de Sísifo, Buenos Aires, Losada, 1953.

${ }^{33}$ Shaw, Donald (1975), The Generation of 1898 in Spain, Nueva York, Barnes \& Noble; traducción de Carmen Hierro, La generación del 98, Madrid, Cátedra, 1977, pp. 29-30. Siguiendo la óptica de Shaw, cabe citar que las tesis filosóficas de Arhur Schopenhauer y de Friedrich Nietzsche marcaron la línea de los pensadores de esta generación. El pensamiento de los autores españoles supone el desarrollo de la filosofía de estos dos autores alemanes. El existencialismo se halla presente de manera activa en la obra unamuniana: Del sentimiento trágico de la vida (1913), La agonía del cristianismo (1925), Niebla (1914) y San Manuel Bueno Mártir (1933). El pesimismo barojiano es también heredero del existencialismo: La busca (1904), El árbol de la ciencia (1911), El mundo es ansí (1912). Asimismo, el existencialismo, filtrado a través de las ideas bergsonianas, se traduce poéticamente en las primeras obras de Antonio Machado: Soledades. Galerías. Otros poemas (1907). 
Miguel de Unamuno, de Antonio Machado y de Juan Ramón Jiménez a poetas posteriores como Vicente Aleixandre o Miguel Hernández. Estos son la vía por la que penetra en la poesía de posguerra ${ }^{34}$.

La muerte de Dios, el pesimismo humano ante la vida en el peor de los mundos posibles, la existencia como angustia y hastío, la condición humana como productora de sufrimiento y dolor, la tarea del ser humano para crearse su existencia, temas claves de la filosofía existencialista, aparecen en la poesía de posguerra. Ahora bien, no todos los poetas suscriben la intrascendencia de la vida humana del existencialismo y la radical concepción humana únicamente como existencia, ya que no todos aceptan la muerte nietzscheana de la divinidad trascendente, creadora y controladora del mundo y de sus criaturas. José María Valverde, Carlos Bousoño, Vicente Gaos o el mismo Dámaso Alonso increpan a la figura del dios padre, pero no llegan a negar su inexistencia.

Oh, sálvame, Señor, dame la muerte, no me amenaces más con otra vida; dame la muerte y cura así esta herida de mi vida mortal. Haz, Dios, de suerte

que pueda retornar al mundo inerte al que esta ciega noche me convida. Pon sobre mí tu mano detenida, tu mano de piedad, tu mano fuerte.

(Vicente Gaos, «La nada», Arcángel de mi noche, 1944).

34 La poética juanramoniana, desde sus inicios, arranca de una preocupación existencial que la sitúa en la panorámica del existencialismo de corte vitalista. El existencialismo posibilita la concepción de una mística inmanente, que desplaza la figura de una divinidad tracendente hacia la conciencia de una divinidad interior y de una divinidad que encarne el todo. El existencialismo traducido como preocupación existencial recorre obras como Melancolía (1912), Diario de un poeta recién casado (1917), Eternidades (1918)... En el caso de Vicente Aleixandre la concepción del panteísmo cósmico es deudora de la conciencia existencialista en el sentido de la eliminación de un dios trascendente. Por ello las huellas del existencialismo pueden rastrearse en obras como Espadas como labios (1932), La destrucción o el amor (1933) o Mundo a solas (1936) hasta llegar al cénit marcado por Sombra del paraíso (1944) ya en plena posguerra. En la poética cernudiana el existencialismo opera sobre todo en la conciencia del ser humano como ser angustiado ante una realidad opresiva y su intento de rebelión frente a la sumisión respecto a los dogmas sociales. Todo ello queda traducido en obras como Los placeres prohibidos (1931) o Donde habite el olvido (1934). En el caso de la poesía de Miguel Hernández, el existencialismo fecunda la poética trágica que se expresa en El rayo que no cesa (1936). 
Sedientamente meto mi cabeza en tu seno, allá en lo oscuro y fuerte, allá en lo cierto y duro, y salgo ensangrentado, ebrio de sangre, y sueño como sangre que choca sordamente en lo oscuro.

Salgo ronco de amor, y vivo, y moribundo, $\mathrm{y}$ voy dejando un rastro de ti, oh único vivo, y con sangre de Dios goteo oscuro en el mundo mientras camino ciego, libre, ardiente, cautivo.

(Carlos Bousoño, «Comunión», Subida al amor, 1945).

Te persigo en el bosque detrás de cada tronco.

Te busco por el fondo de las aguas sin luz.

¡Oh cosas, apartaos, dadme ya su presencia

que tenéis escondida en vuestro oscuro seno!

Marcado por tu hierro vago por las llanuras, abandonado, inútil como una oveja sola...

Hombre de Dios me llamo. Pero sin Dios estoy.

(José María Valverde, «Salmo inicial», Hombre de Dios, 1945).

Blas de Otero, en cambio, muestra el silencio de dios, y de él deriva su inexistencia. El silencio es visto como la venganza, la tortura y el abandono de un demiurgo cruel que se alimenta del sufrimiento de sus criaturas. El dios padre oteriano es una divinidad que se nutre de la carne de sus hijos. Herencia existencialista de la concepción del ser para la muerte, nihilismo, conciencia pesimista de la existencia huérfana de la figura del padre. Rebelión también contra la figura del padre. Matar al padre significa el nacimiento del hijo, la distancia que supone la autoafirmación de su ideología y de su personalidad ${ }^{35}$.

${ }^{35}$ Freud $(1930,1970: 18)$; Deleuze y Guattary $(1972,1985: 81-82)$. Sigmund Freud interpreta la figura del Dios padre cristiano como una mera representación de lo numinoso. De ahí la concepción de una creencia infantil frente al hecho religioso judeo-cristiano. Matar al padre supone el nacimiento de la conciencia existencialista. El hecho representacional de matar al padre supone la creación del Yo. La óptica del esquizoanálisis, propuesta por Deleuze y Guattari, propone que el asesinato del padre supone la defensa contra el intento de castración a instancias del poder representativo de toda una civilización. La figura del padre no sólo representa al dios trascendente o al poder, sino a la misma estrategia edíptica adoptada por Freud que trata de poner diques al deseo. Edipo se asocia con la norma y la ley, Edipo es el poder social. Edipo marca la familia, y esta se sustenta sobre la represión del deseo dirigido a las figuras parentales. Este hecho está en la base de la vida social, en el acceso del ser humano a la civilización. 
¡Poderoso silencio, poderoso

silencio! Sube el mar hasta ya ahogarnos

en su terrible estruendo silencioso.

¡Poderoso silencio con quien lucho a voz en grito: grita hasta arrancarnos

la lengua, mudo Dios al que yo escucho!

(Blas de Otero, «Poderoso silencio», Ángel fieramente humano, 1950).

Lo que señala el anuncio de Nietzsche en La Gaya Ciencia (1882, 2002: 209$211,333-335,338,341-343,368-370,372)$ sobre la muerte de Dios es el nacimiento del hombre. Aquello que muere es la idea del dios católico, por tanto monoteísta, trascendente, creador y controlador de las vidas humanas. Es el hombre, a partir de ahora, quien construirá desde sí mismo su existencia, sin que ella esté adscrita a voluntades divinas exteriores.

¿No habéis oído hablar de aquel hombre frenético que en la claridad que precede al mediodía encendió una linterna, corrió al mercado y gritaba incesantemente: «¡Estoy a Dios! ¡Estoy a Dios!» Justo allí se habían juntado muchos de los que no creían en Dios, por lo que levantó grandes carcajadas. ¿Acaso se ha extraviado?, dijo uno. ¿Se ha perdido como un niño?, dijo otro. ¿O es que se ha escondido? ¿Tiene miedo de nosotros? ¿Se ha embarcado?, ¿Habrá emigrado?: así gritaban y se reían todos a la vez. El hombre loco se puso de un salto en medio de ellos y los taladró con su mirada. «¿Adónde se ha marchado Dios?», exclamó, «¡os lo voy a decir! Lo hemos matado, ¡vosotros y yo! ¡Todos nosotros somos sus asesinos! (...) ¿No es la grandeza de esta hazaña demasiado grande para nosotros? ¿No tenemos que convertirnos nosotros mismos en dioses para parecer dignos de ella? No ha habido nunca hazaña mayor, iy quienquiera que nazca después de nosotros formará parte, por causa de esta hazaña, de una historia superior a toda la transcurrida hasta ahora!» (1882, 2002: 209-210).

Por ello, la idea de dios no deberá ser buscada fuera de la realidad, sino en ella. El concepto nietzscheano de la muerte de Dios, además de marcar el inicio de la conciencia existencialista, marca el paso de la creencia de un dios trascendente a un dios inmanente (en el sentido de la mística panteísta) que se halla en la cotidianeidad, en el mundo que rodea al ser humano. Y en el mismo ser humano a la vez, divinidad que es amor humano, solidaridad entre todos los humanos divinizados. Postura ética de la poesía existencial. Para Michel Foucault ${ }^{36}$ la muerte de dios, anunciada por Nietzsche,

${ }^{36}$ Foucault (1966, 1968: 312). «¿Acaso no es necesario recordarnos, a nosotros, que nos creemos ligados a una finitud que sólo a nosotros pertenece y que nos abre, por el 
significa la finitud del hombre, la pérdida de la trascendencia humana, la muerte del hombre como creación divina. Finitud que se traduce en entera libertad, libertad en el sentido sartriano. Se trata del nacimiento del hombre trágico, del ser creador de dioses que se ha emancipado de la tiranía del más allá. Otra dirección de la misma cuestión de fondo apunta hacia la concepción pesimista del ser humano. Aquí cobra sentido la imagen damasiana de los monstruos. El ser humano supone el reflejo de esa divinidad cruel, aciaga, maléfica y monstruosa.

\subsubsection{Límites precisos}

La poesía existencial surgió en 1944 de la mano de Dámaso Alonso y de Vicente Aleixandre. Tanto Oscura noticia e Hijos de la ira como Sombra del paraíso son obras que cierran un ciclo y abren un nuevo panorama. Agotan la concepción del poeta refugiado en su mundo aislado y proponen la mirada poética hacia el ser humano en contacto con su realidad coetánea. Víctor García de la Concha (1987: 488-490), aunque considera la obra de estos autores como un verdadero cambio de paradigmas, sostiene que la poesía existencial no parte solamente de aquí. El sufrimiento, la trascendencia, la relación del hombre con el dios creador están en la base de la poesía de la primera posguerra. Para este autor, manteniendo el lenguaje de Dámaso Alonso ${ }^{37}$, la poesía existencial se da tanto en los poetas arraigados como en los poetas desarraigados.

Es cierto que en esa «época existencial», arraigada o no, cuyo frente invade desde 1942 a 1952 la poesía española, Dios y el problema de la religación del hombre con la trascendencia se convierten en temas primordiales (García de la Concha, 1987: 490).

La poesía existencial de Dámaso Alonso, expresada en Oscura Noticia (1944) e Hijos de la ira (1944), parte del dolor humano ante una realidad inhóspita y sufriente. La respuesta es el grito desgarrador y expresionista, el insulto lanzado a un dios que supuestamente ha abandonado al ser humano. En el sentido cristiano, se trata de un dios cruel que se regocija ante la pesadumbre humana. De otro lado, la imagen del hombre es la del monstruo, reflejo del ser humano finito que ha perdido su trascendencia y se

conocer, la verdad del mundo, que estamos atados a las espaldas de un tigre?».

${ }^{37}$ Alonso (1952: 345 y 349). Dámaso Alonso propone la distinción entre poesía arraigada y poesía desarraigada. 
encuentra en un páramo desierto, a solas con su dolor. La pérdida de facultades humanas como la solidaridad es lo que acentúa la sensación de absurdo vital. Absurdo que posee contactos con la narrativa kafkiana ${ }^{38}$.

En cambio, aunque converge en el fondo con la concepción de Dámaso Alonso, la imagen del ser humano que Vicente Aleixandre ofrece en Sombra del paraíso (1944) es bastante diferente. La concepción de la realidad aleixandrina parte de una divinidad inmanente, panteísta. El ser humano es la única criatura que se siente excluida de esa realidad divina. Pesimismo radical traducido en angustia existencial. La imagen de los hombres es la de los dormidos. Dormidos en cuanto que pertenecen a la sombra, a la noche y a la oscuridad. Hombre separado de la totalidad, del cosmos divino. Ser que ha perdido la experiencia directa de las cosas, ya que sus relaciones se hallan mediatizadas por el concepto. Y ello, precisamente, lo aleja del ritmo cósmico, del movimiento vital de la existencia beatífica. Los dormidos son los humanos que han de despertar de su sueño y ser conscientes de su verdadera realidad. El paraíso está aquí pero ellos no lo saben, por ello son seres caídos, ignorantes de su divinidad.

\footnotetext{
¿No sentís en la noche un clamor? ¡Ah dormidos, sordos sois a los cánticos! Dulces copas se alzan: ¡Oh estrellas mías, vino celeste, dadme toda vuestra locura, dadme vuestros bordes lucientes! Mis labios saben siempre sorberos, mi garganta se enciende de sapiencia, mis ojos brillan dulces. Toda la noche en mí destellando, ilumina vuestro sueño, oh dormidos, oh muertos, oh acabados. Pero no; tuertamente callados, como lunas de piedra, en tierra, sordos permacecéis, sin tumba. Una noche de velos, de plumas, de miradas, vuela por los espacios llevándoos insepultos.
}

$$
\text { («Los dormidos», Sombra del paraíso) }
$$

38 Ver. Kafka, Franz (1915), Die Verwandlung, Leipzig, Kurt Wolff Verlag, La metamorfosis, Madrid, Alinaza Editorial, 1966; Kafka, Franz (1925) Der prozess, Berlin, Verlag die Schmiede, traducción de Feliu Formosa, El proceso, Barcelona, Editorial Lumen, 1975. La narrativa Kafkiana significa el punto de partida de la literatura del absurdo. Literatura que supone la intensificación del existencialismo: el absurdo de la existencia humana ante una realidad caótica; el aplastamiento del ser humano por la maquinaria burocrática y legal, de un lado, y la maquinaria económica y política capitalista de otro; la pérdida de relevancia humana del ser social; la angustia vital y la sensación de incomprensión del ser ante un poder monstruoso y devorador. 


\subsubsection{Poéticas existenciales}

La revista Espadaña, aparecida en 1944 de la mano de Antonio González de Lama, Victoriano Crémer, Eugenio de Nora y José Castro Ovejero, propuso una poesía humanizadora y tremendista como sistema de expresión. Síntesis de realismo y neorrealismo. En todo caso, esta publicación, como tal, significó el espacio donde se expresaba la poesía de la primera posguerra y la conectó con las poéticas del 27. En ella publicaron Carlos Bousoño, Gabriel Celaya, Blas de Otero, José Hierro, José María Valverde, Dámaso Alonso, Vicente Gaos y otros. Poetas «mordidos por el diente de la angustia», según la expresión de Gerardo Diego (1947: 415-422). Por otra parte, apareció en 1943 el Premio y la colección Adonais de la mano de Juan Guerrero y de José Luis Cano, autores que pretendían recoger la producción de poetas sin editorial. Ello supuso un espacio poético plural abierto a todas las corrientes. Presencia de las poéticas del 27 , de la poesía exiliada, de la poesía humanizada y de la poesía exterior. Presencia también, muy patente, de la poesía existencial, que marcó de forma insistente las directrices de la colección: Carlos Bousoño, Vicente Gaos, Rafael Morales...

La poesía existencial se expresa de una manera muy especial en la poesía de Blas de Otero. La poesía mística, ascética de la noche, del dolor y del rechazo, desemboca aquí en una estética dramática y tremendista. El dolor instaurado en la cotidianeidad, los desastres de la violencia, el caos y la destrucción presentes en la realidad, marcan una poesía desgarrada que toma la apariencia de un salmo dirigido a la figura del dios padre. Ángel fieramente humano (1950) y Redoble de conciencia (1951) configuran esta poesía angustiada que se plantea como una búsqueda existencial del ser humano ante la mirada callada de dios. Silencio de dios frente a la interrogación del ser humano.

Ahora bien, esta poética existencial quedaba perfectamente inaugurada con la obra Arcángel de ni noche (1944) escrita por Vicente Gaos, propuesta que continuó en Sobre la tierra (1945). Su obra aparece reunida en 1959 en Poesías completas. Subida al amor (1945) de Carlos Bousoño es otra muestra clara de poesía existencial. Poesía metafísica, conciencia trágica de la vida, angustia frente a la muerte, hombre y tiempo... que se continúa en Primavera de la muerte (1946) y en Noche del sentido (1957). Para Santiago Fortuño (2015: 49-53) el existencialismo impregna toda la poesía de signo 
humano de Bousoño y la dota de un sentido reflexivo y meditativo sobre la realidad. Se trata de una poética de lo humano surgida desde la intimidad. En una línea parecida se halla la poesía de José María Valverde contenida en el poemario Hombre de Dios (1945). Tierra sin nosotros (1946) de José Hierro configura una poética carcelaria establecida desde la imagen: cárcel igual a muerte. Poesía del recuerdo observada desde el otro lado de la muerte. También hay que citar a José Luis Hidalgo y su obra Los muertos (1947). 


\subsection{POESÍA TREMENDISTA}

La puerta de mi sangre está en la esquina del hacha y de la piedra.

Miguel Hernández

Aunque el tremendismo es un término literario procedente de la narrativa, más concretamente representa un período que atravesó la novela de posguerra. Este puede aplicarse también a una determinada dirección poética. El tremendismo narrativo, surgido en la primera posguerra, rechazaba la tendencia experimental de la narrativa anterior para basarse en una óptica realista, que diese constancia de unos hechos, testimonial y fotográfica. Neorrealista, en cierto sentido. Como referente puede ofrecerse La familia de Pascual Duarte (1942) de Camilo José Cela por su estética trágica, desagradable y revulsiva, que se regocija en la presentación de los aspectos más escabrosos de la realidad: los desastres de la guerra, la situación extrema y brutal del ser humano, la presencia de la violencia y del horror inmersos en la cotidianeidad más elemental y primaria. Es esta la línea estética que propuso la revista Espadaña.

El término tremendismo ha sido utilizado en poesía por Víctor García de la Concha (1969: 236-237; 1980: 150-154; 1987: 667-693) y Alarcos Llorach (1956: 21), entre otros muchos, para citar la poética propuesta por Espadaña y parte de la obra de Blas de Otero ${ }^{39}$. Para Fanny Rubio y José Luis Falcó (1982: 38) el tremendismo «como actitud de selectividad temática y como sistema de expresión poética está representado por la figura de Victoriano Cremer y la Revista Espadaña». Para ellos funciona como estética que sintetiza realismo y óptica esperpéntica. Poesía testimonial, humana y comprometida con el hombre y con la realidad histórica, social y política. Poesía desarraigada según la terminología de Dámaso Alonso. Tremendista como actitud combativa, como síntesis de realismo y expresionismo, como compromiso con la circunstancia social. Ello supone un rechazo de la poesía formalista y también del tradicionalismo poético, al mismo tiempo que la continuación de la poesía humana iniciada por Dámaso Alonso. Vibración humana frente a perfección formal, lenguaje

${ }^{39}$ El tremendismo poético impregna la primera poesía oteriana: Ángel fieramente humano (1950), Redoble de conciencia (1951) y Ancia (1958). 
directo frente a la retórica de la vaciedad, transmisión de contenidos frente a arquitectura impasible. Poética que a través de la poesía realista de Antonio Machado y la poesía de agitación social de Rafael Alberti y Miguel Hernández conecta con la poesía impura de Pablo Neruda, con César Vallejo y con la impronta combativa de Louis Aragon. Guillermo Carnero (1989: 312) considera que es esta publicación la que inaugura la poesía política clandestina.

Por otra parte, la revista hace de vehículo de expresión de la mayoría de los autores de la primera posguerra poética. Cabe citar aquí la poesía de Victoriano Crémer, Nuevos cantos de vida y esperanza (1951) y Furia y paloma (1956), y la de Eugenio García de Nora, Contemplación del tiempo (1947), que en ambos casos expresan la preocupación por la colectividad.

El tremendismo poético funciona como estética expresionista y puede rastrearse así en la gran tradición literaria y artística española: Francisco Quevedo, Francisco de Goya, Pío Baroja o Ramón María del Valle-Inclán. Estética de lo grotesco, deformación de lo real basada en la expresividad. García de la Concha conecta la estética tremendista con las danzas de la muerte y ofrece una acertada definición (1987: 667):

Prescindiendo de matices, podríamos reducir esta pluralidad a un doble capítulo de intenciones y formas: reflexión ascético-filosófica, que se encarna en un crudo realismo; objetivo de crítica social, concretado en el expresionismo o la esperpentización.

Pictóricamente, esta estética podría conectarse con la parte más expresionista de la pintura de El Bosco o Pieter Bruegel el Viejo: deformación sistemática de lo real, crítica social bajo una visión apocalíptica de lo real. Expresionismo y crítica social. Ahora bien, la pintura de estos autores también ha sido motivo de interés y de inspiración desde la estética surrealista debido a su código visionario. La pintura de estos autores anticipa el lenguaje onírico buscado, desde el automatismo, por los artistas surrealistas. El tremendismo poético, al igual que el surrealismo, contiene una voluntad de incidencia sobre la realidad. Lo que en definitiva se busca es la modificación de la realidad, por ello aúna estética expresionista y voluntad político-social. 


\subsection{POESÍA SOCIAL}

No te busques en el espejo

en un extinto diálogo en que no te oyes.

Vicente Aleixandre

A principios de los años cincuenta el editor F. Ribes (1952) publicó, como ya hemos dicho, la Antología consultada de la joven poesía española. Para su realización preguntó a un vasto número de escritores por los poetas vivos más importantes dados a conocer en la última década. Nueve poetas sobresalieron entre las respuestas de los consultados: Carlos Bousoño, Gabriel Celaya, Victoriano Crémer, Vicente Gaos, Rafael Morales, Eugenio de Nora, Blas de Otero y José María Valverde. De aquí surgieron dos actitudes diferentes frente al contacto entre poesía y realidad: el realismo social y la poesía de la realidad interior.

Por una parte, el realismo social se erigió como reacción contra el esteticismo poético y como preocupación por captar, aprehender y retratar la realidad más inmediata. Poesía se define como instrumento que posibilite un cambio en la realidad, poesía que se acerca a la ética y que va más allá del propio texto en cuanto que se plantea la modificación ética del lector mediante la toma de conciencia. Tarea del publico lector será la modificación de la realidad, de ahí la búsqueda de un público amplio. En este sentido funcionan las poéticas de Blas de Otero, Gabriel Celaya, José Hierro, Eugenio de Nora o Victoriano Crémer. De otro lado, se inauguró una poética que se apartaba de la actitud testimonial, del criterio documental de la poesía como premisa neorrealista. Se trata de un nuevo concepto de realidad que rechaza la simple representación fotográfica y desvela la expresión de la realidad interior. En esta línea se sitúan las poéticas de Carlos Bousoño, Vicente Gaos, Rafael Morales y José María Valverde. Sin embargo, frente al hecho poético en ambas posturas subsiste la concepción aleixandrina de poesía como comunicación y expresión significativa de conceptos. Realismo poético en ambos casos. 
Ya en la poesía existencialista y tremendista existían, como germen, algunas premisas y algunas actitudes propias de la poesía social. Preocupación testimonial, acercamiento a la ética, concienciación del público lector, actitud combativa... Coexistencia de ambas poéticas que parten de una misma mirada. El poeta vuelve los ojos hacia la realidad más inmediata y reivindica el aquí y el ahora. Poesía que se preocupa por las realidad vital que rodea al ser humano, que desvela su problemática en las coordenadas vitales precisas en las que se inserta. La poesía social rescata la actitud combativa y comprometida de la poesía inmediatamente anterior a la guerra $\mathrm{y}$, sobre todo, centra su mirada en la poesía de agitación social y en la poesía de denuncia representadas en las figuras de Rafael Alberti y de Miguel Hernández. Reivindica la impronta de la toma de conciencia de Pablo Neruda y de César Vallejo, la preocupación por la realidad humana y social de Antonio Machado y, también, las consignas del realismo socialista. Como intermediario directo funciona tanto el grito expresionista e increpador de Dámaso Alonso como la poética combativa del tremendismo de Crémer y De Nora, planteada desde la revista Espadaña.

Los planteamientos teóricos de la poesía social se acercan al neorrealismo italiano, en tanto plasmación testimonial de la realidad, y al existencialismo francés de dirección marxista, representado por Jean Paul Sartre. En ¿Qué es la literatura? ${ }^{40}$, obra esencial para los poetas sociales, Sartre concibe el hecho literario como liberación del ser humano y como elemento de cambio social. Desde unos parámetros marxistas considera que el escritor supone una «conciencia inquieta» ${ }^{41}$, crítica respecto a la alienación social. Conciencia que ha de traducirse en un despertar por parte del lector, toma de conciencia que posibilita el cambio social. Por ello, escribir es transformar. La labor del texto no acaba con su lectura, sino que comienza en ella. Literatura como método de cambio de la realidad. Postura ética, política o social de la poesía, arma cargada de futuro en la conciencia de la lucha clasista. La poesía se concibe como proceso que debe ser completado por la acción directa del lector en el panorama social. Josep María Castellet $(1060,1962)$ traza perfectamente en su antología Veinte años de

${ }^{40}$ Sarte, Jean-Paul (1948), Situations, II, París, Gallimard; traducción de Aurora Bernández, ¿Qué es la literatura?, Buenos Aires, Losada, 1950. Sarte se plantea en esta obra qué es escribir, por qué se escribe y para quién se escribe. La conclusión a la que llega es tajante: «nombrar es mostrar y mostrar es cambiar» p. 100. La finalidad última de la obra literaria es la intervención en la realidad. Tesis que se inserta y apoya en la dinámica del realismo social.

${ }^{41}$ Ibíd., p.100. 
poesía española, publicada 1960, la actitud realista: escritura como proceso colectivo. El espacio desde donde habla la poesía es la propia territorialidad social, la colectividad de los seres humanos frente a la mirada de la particularidad de la poética simbolista, tal como enuncia en Un cuarto de siglo de poesía española (1966: 88-94). Poesía dirigida a ese espacio social formado por la inmensa mayoría; poesía que toma un lenguaje colectivo, coloquial y directo, sin ambigüedades. Poesía que se ancla en la realidad, en la conciencia de lucha contra un sistema fascista y represor. Esta búsqueda de un público masivo lleva impreso un rechazo de la oscuridad y del hermetismo del lenguaje del irracionalismo poético. En cambio se proclama la función comunicativa de la práctica poética y sus parámetros históricos. Poesía enraizada en el ser histórico, que rechaza el puro valor estético y reivindica un cierto prosaísmo de tintes narrativos. Esta conciencia poética resalta la denuncia de determinados aspectos políticos y sociales. Poesía de protesta, expresión del deseo de libertad humana como primer acto de necesidad vital, poesía de resistencia frente al lenguaje de un poder macabro y totalizador. Para Castellet lo que la poesía ha significado a partir de la Antología Consultada es la sustitución de la poesía de signo simbolista por el sistema poético realista. Desde la guerra civil hasta la década de los 50 asistimos a la liquidación de un sistema poético.

Años de transición, en los que no existe todavía una completa correspondencia entre el contenido del poema y los medios de expresión utilizados que, en muchos casos, pertenecen aún a la tradición simbolista (Castellet, 1966: 94).

Para los autores de la antología Ínsulas extrañas (Millán y otros, 2002: 21-13) lo que supone la actitud de Castellet en su antología Un cuarto de siglo de poesía española (1966) es el rechazo de la tradición simbolista, banalizada y superada para el autor. Ello quedó patente con la exclusión de la poesía de Juan Ramón Jiménez. Para estos autores más que una poesía realista lo que se produce es un pseudo-realismo, definido por la falta de calidad poética y por un código de expresión altamente ideologizado:

Lo que se conocíó en España con el nombre de realismo fue más bien, en la poesía, un simple naturalismo, fundado la mayor parte de las veces en la facilidad y en la aceptación de cómodas fórmulas, algunas de las cuales acabaron en la banalidad y en el humor chocarrero; la supuesta «desacralización» de lo poético fue absorbida por el aparato ideológico que pretendía cuestionar, y que 
necesitaba del facilismo retórico y con él se hacía fuerte (Millán y otros, 2002: 26).

Carlos Bousoño (1952, 1976, Vol. II: 392-397; 1984: 28-30), por su parte, señala como actitud propia de la poesía social el paso del yo al nosotros. Esto es, el descubrimiento del prójimo. Si la poesía existencial era un soliloquio de la individualidad respecto al vacío nietzscheano, la poesía social es la voz de la colectividad erigida desde su interioridad. En otras palabras, muy tópicas pero que definen la actitud humana y colectiva de la poesía social, puede decirse que el poeta abandona su torre de cristal y baja a la calle a fundirse en los demás. Confundirse, ser hombre entre los hombres. Solidaridad humana, conciencia del ser humano como ser colectivo:

Baja, baja despacio y búscate entre los otros.

Allí están todos, y tú entre ellos.

Oh, desnúdate y fúndete, y reconócete.

(Vicente Aleixandre, «En la plaza», Historia del corazón, 1954).

Esta preocupación por el ser colectivo, histórico y social, lleva implícito el tratamiento desde unas coordenadas concretas de la conciencia patriótica. Es Carlos Bousoño quien inaugura en Subida al amor (1943) el tema de España en la poesía de posguerra $^{42}$. Tema tratado sobre todo en la literatura noventayochista bajo el prisma regeneracionista, Unamuno y Antonio Machado, que se revitaliza mediante la poesía de Otero, Nora, Celaya, Hierro o de Valverde bajo el signo de la reivindicación. Mediante la poesía se lanzaron mensajes conativos hacia la sociedad española con el fin de que ésta despertase de su letargo y de su sueño ${ }^{43}$.

${ }^{42}$ Cano (1957: 13). La poesía de posguerra aparece definida básicamente por dos signos: tiempo y espacio. Poesía que queda perfectamente ligada al ámbito de la realidad española.

${ }^{43}$ Ver Cano (1979). 


\subsubsection{Poéticas sociales}

La poesía social viene definida sobre todo por la actitud comprometida ${ }^{44}$ de los poetas más conocidos: Gabriel Celaya, Blas de Otero y José Hierro. En el caso de Otero, la poesía abandona su tono lírico para convertirse en narratividad. Mediante un pretendido lenguaje coloquial dirige su mensaje a un público colectivo, la inmensa mayoría, para instituirse como descripción de la realidad cotidiana y denuncia. Pido la paz y la palabra (1955) es la obra cumbre de la poética social oteriana continuada por Ancia (1958), título creado a partir de la sílaba que inicia y la que finaliza los poemarios Ángel fieramente humano (1950) y Redoble de conciencia (1951). En obras posteriores como En castellano (1960) o Que trata de España (1964) existe un acercamiento a la experimentación sin abandonar la óptica social. Poesía narrativa con aproximaciones posteriores a la poesía lúdica y experimental. Gabriel Celaya constituye el prototipo de poeta comprometido cuya propuesta consiste en una poesía de denuncia y testimonio. Sus obras más significativas son Tranquilamente hablando (1947) y Las cartas boca arriba (1951). Su trayectoria poética viene definida por la adopción de una poesía antirretórica que desemboca en la poesía experimental. En Campos semanticos (1971) se acerca a la poesía concreta. La poesía de José Hierro surge como poesía humanizada y se convierte en poesía testimonial y comprometida en Quinta del 42 (1953) y Cuanto sé de mí (1958). Poesía comprometida con la colectividad, testimonio directo $\mathrm{y}$ fotográfico de la realidad, instantáneas de una realidad vivida. Pero también se trata de una poesía reflexiva, intimista, que toma la forma de retrospectiva que ahonda en la realidad del recuerdo. Esta mirada íntima desemboca en la poesía como realidad lingüística de El libro de las alucinaciones (1962). Irracionalismo poético, poesía como autoconocimiento y reflexión interior, poesía metafísica que se configura como intento de desvelar el misterio de la existencia y, por último, poesía laberíntica y experimental.

La poesía social se encuentra también en la poesía de Victoriano Crémer y Eugenio de Nora, poetas que desde la revista Espadaña inauguraron la actitud combativa y la poesía testimonial en la posguerra. Obras destacadas serían: España, pasión de vida (1954) de Nora, Tiempo de soledad (1962) de Crémer. También existen

${ }^{44}$ Lechner (1975: 66-84). Lo que marca la poesía social surgida a partir de 1950 es, según este autor, la actitud comprometida. Ahora bien, esta actitud de compromiso no afecta a la totalidad de la obra de la mayoría de poetas. Incluso los poetas más comprometidos y reivindicativos solamente escribieron parte de su obra en estas coordenadas. 
contactos con la poesía social en la obra de Leopoldo de Luis, Teatro real (1957) y Juego limpio (1961). Acercamientos asimismo de la poesía de Rafael Morales, Canción sobre el asfalto (1954) y La máscara y los dientes (1962). De Gabino-Alejandro Carriedo, Política agraria (1963). De Ángel González, Áspero mundo (1956), Sin esperanza, con convencimiento (1961). De Ramón de Garcilasol, Poemas de andar España (1962), Apelación al tiempo (1968)...

Un caso paradigmático es el de poesía de Ildefonso Manuel Gil, poeta comprometido desde los tiempos de la República y encarcelado durante siete meses acabada la guerra. En la cárcel vivió el miedo a ser ejecutado, circunstancia que marca la trayectoria de su obra poética. Para Lechner (1975: 15) se trata del inicio de la figura del poeta como ser comprometido con la realidad política, social y cultural, cuyos signos son el inconformismo y la actitud crítica. La obra Poemas del dolor antiguo (1945) marca, para este autor, el inicio de la poesía social. García de la Concha (1987: 530-532) señala su herencia romántica intimista y lo distancia de la poética clasicista del garcilacismo. En su poética, que va de Bécquer a Antonio Machado, hay un acercamiento a la poesía de Miguel de Unamuno. Intimismo romántico y preocupación por la realidad circunstancial. Dolor ante una realidad maltrecha, convergencia a su vez con la poesía existencial. La obra El corazón en los labios (1947) marca la conexión con la poética metafísica de signo no conceptual juanramoniana.

\subsubsection{Poesía histórica aleixandrina}

No es que la poesía de Vicente Aleixandre se convierta en una poesía social. Nada más lejos. La poesía aleixandrina, en todo momento, tiene como principal punto de mira la propia poeticidad de su discurso y rehuye todo coloquialismo masivo. Voluntad estética, cultista en cierto sentido, heredera de la impronta gongorina y del propio carácter del surrealismo español, consistente en la elaboración poética del material onírico (Bodini, 1963, 1982: 31). Pero, a partir de Historia del corazón (1954) su poesía posee varios puntos de contacto con la poesía social. En primer momento la poesía aleixandrina quedaba enraizada en el sustrato mítico, reflejado perfectamente en un panteísmo cósmico (Bousoño, 1956, 1977: 69-78), que actuaba como elemento místico y como actualización de diversas imágenes arquetípicas de la tradición tanto 
accidental como oriental: desde la mística ascética cristiana hasta la tradición hinduísta y taoísta pasando por la mística sufí. En esta nueva etapa, de signo histórico, se abandonan los postulados y las prácticas surrealistas. Ahora la mirada se dirige a la realidad. Este acercamiento a la realidad marca el punto de contacto con la poesía social: abandono del lenguaje hermético y sustitución por un lenguaje dirigido a la mayoría y anclado en la cotidianeidad, interés por el ser humano en cuanto ser colectivo, compromiso con el tiempo histórico. Carlos Bousoño (1956, 1977: 148-149) nos propone la sustitución de una cosmovisión cósmica por una cosmovisión histórica. Frente a la poética simbólica de signo surrealista se propone una escritura realista, testimonial, que posee algún contacto con la óptica neorrealista. Frente a la mística panteísta se propone la solidaridad humana como unidad del ser humano. Aunque la poesía de Aleixandre siempre ha discurrido bajo el signo de lo humano, es ahora cuando se abandonan ciertos presupuestos estéticos para que se produzca un acercamiento al hombre como ser histórico. Preocupación ética de la poesía que se centra en la cotidianeidad humana, en la solidaridad con los demás.

Todos están pasando. Hay niños, mujeres. Hombres serios. Luto cierto. Miradas.

Y una masa sola, un único ser, reconcentradamente desfila.

Son miles de corazones que hacen un único corazón que te lleva.

(«El poeta canta por todos», Historia del corazón).

Entra en el torrente que te reclama y allí sé tu mismo.

¡Oh pequeño corazón diminuto, corazón que quiere latir, para ser él también el unánime corazón que le alcanza.

(«En la plaza», Historia del corazón).

Esta poesía histórica tiene su continuación en las obras siguientes: En un vasto dominio (1962) y Retratos con nombre (1965). Para Bousoño (1956, 1977: 155), los dos mundos poéticos aleixandrinos se integran perfectamente en una nueva concepción: el panteísmo histórico como fusión de la poesía cósmica y de la realista. En este sentido funcionan las obras Poemas de la consumación (1968) y Diálogos del conocimiento (1974). 


\subsection{POESÍA DE LA REALIDAD INTERIOR.}

Fue imposible acercarse a la espuma de piedra.

José Hierro

Mientras los poetas sociales se comprometen con el ser histórico y colectivo, Carlos Bousoño propone la plasmación poética de una realidad interior. Esta territorialidad será transitada por otros poetas como Vicente Gaos, José María Valverde o incluso parte de la trayectoria del mismo José Hierro. Queda así demarcada una zona abierta en el realismo poético de posguerra: el realismo poético, intimista o interior. Poesía humana heredera de la poética aleixandrina que, en cierto sentido, se aparta de las tesis del realismo social para dirigirse a una poesía íntima que se convierta en exploración de la realidad interna. Poesía desvinculada en ocasiones de la realidad exterior, poesía como experiencia íntima cuyo lenguaje surge de este interior humano. Frente a la poesía social los poetas realistas líricos, como también les ha llamado la crítica (Rubio y Falcó, 1982: 42-45), proponen una poesía subjetivista, intimista e individualista en cuanto que es transmisión de una realidad propia y personal. Poesía que se convierte en autorretrato interior, en autoexploración o búsqueda del conocimiento íntimo. Poesía que abre una zona poética que será recorrida por los poetas de la década de los sesenta y por los poetas mediáticos y experimentales de la década posterior. Ya en la Antología Consultada, y tal como observa Josep María Castellet (1965: 88-89), Carlos Bousoño se desmarca de los postulados realistas imperantes en torno al año de la publicación de la antología. Bousoño concibe su poesía bajo el prisma del irracionalismo poético cuyo signo es la subjetividad frente al lenguaje realista. Continuación pues de la poética simbolista, impresionista y vanguardista. Aquella realidad que transmite el poema solamente puede ser la realidad interior, no la realidad objetiva. En su obra Teoría de la expresión poética Bousoño define la comunicación poética como un impacto preconsciente que causa un determinado placer (o displacer en el caso de la poesía expresionista) estético. Solamente de forma secundaria y previa a este destello irracional puede darse la comunicación conceptual ${ }^{45}$. Esta actitud

${ }^{45}$ Bousoño (1952, 1976, Vol. I: 18). «La poesía debe darnos la impresión (aunque esta impresión pueda ser engañosa) de que, a través de meras palabras, se nos comunica un 
distanciada respecto al modelo realista poético es compartida en más o menos grado y en diferentes ocasiones por los demás poetas realistas líricos.

\subsubsection{Propuestas poéticas}

La poesía de Carlos Bousoño parte de una dirección realista de signo metafísico instalada en sus primeras obras y apartada totalmente del realismo social. Desde aquí su poesía enlaza con la tradición poética irracionalista más etérea, de Bécquer a Juan de la Cruz. Poesía que se concibe como atmósfera o susurro, donde las palabras se sugieren más que se pronuncian. Poesía que es además meditación íntima y callada sobre el misterio de la existencia. A partir de Noche del sentido (1957) la poesía se convierte en meditación, la existencia en irrealidad metafísica, en incerteza. Invasión de la realidad (1962), Oda en la ceniza (1967) y Las monedas contra la losa (1973) ofrecen una poética donde la realidad solamente queda conformada mediante las vivencias humanas interiores. Para Santiago Fortuño (1983: 84-89) estas dos obras marcan un límite respecto a su obra anterior e inauguran una nueva poética en cuanto a su propia trayectoria y en cuanto a la poesía de posguerra. Encontramos aquí algunas de las claves de la poética de los novísimos: voluntad estética, descrédito del racionalismo, inutilidad del realismo literario como elemento para cambiar la realidad, metapoesía. Para Fortuño, Bousoño sería el precursor de los poetas novísimos.

Como en ellos también en Bousoño, en estos dos últimos libros, hay una desconfianza en la razón racionalista entendida como razón abstracta y centralista. De ahí, la dirección hacia un lenguaje irracionalista y crítica al mismo por su incapacidad de conocer la experiencia (1983: 87).

Trayecto parecido recorre la poesía de José Hierro a partir de la obra Cuanto sé de mí (1958). La poesía de Hierro se distancia del realismo social para convertirse en poesía reflexiva. Meditación sobre su vida y su identidad, indagación sobre la realidad. Poesía metafísica en cierto sentido que incorpora una mirada retrospectiva. Con El libro de las alucinaciones (1962) la poesía se aleja ya totalmente de la óptica social y realista.

conocimiento de muy especial índole: el conocimiento de un contenido psíquico tal como un contenido psíquico es en la vida real. O sea, de un contenido psíquico que en la vida real se ofrece como algo individual, como un todo particular, síntesis intuitiva, única, de lo conceptualsensorial (o axiológico)-afectivo». 
Ahora la poesía es pura subjetividad y su lenguaje el irracionalismo. De aquí surge un código poético basado en el fragmentarismo.

Reflexiva y metafísica es también la poesía de José María Valverde a partir de la obra La conquista de este mundo (1960), poesía que se convierte en confesión personal, en experiencia vivida, en reflejo de la cotidianeidad más insignificante. Obras clave son Años inciertos de 1961, la antología, reconocida por sí mismo como la única poesía válida de esa época, Enseñanza de la edad (Poesía, 1945-1970), publicada en 1971, y Ser de palabra de 1976.

La obra de Vicente Gaos también se dirige en esta dirección, desde una perspectiva realista se acerca a la práctica de una poesía metafísica que constituye una interrogación sobre la existencia, la muerte, la eternidad, la divinidad o la nada. Esta poesía reflexiva queda registrada en Profecía del recuerdo (1956), Mitos para mitos para tiempo de incrédulos (1963) o Concierto en mí y en vosotros (1965).

Poéticas, que en su conjunto, suponen la apertura a un nuevo paradigma poético en el que la preocupación por el lenguaje es la voluntad primordial. Esta línea poética, subjetiva, intimista e irracional, será continuada por la poesía de las décadas venideras: poesía como experimento lingüístico, como juego del lenguaje o como provocación. 


\subsection{POESÍA ESTETICISTA}

No quiero la ciudad hecha de sueños grises; quiero sólo ir al mar donde me anegue.

Luis Cernuda

La poesía de posguerra de signo esteticista viene representada por la revista Cántico surgida en 1947 en Córdoba. La crítica considera a Pablo García Baena, Ricardo Molina, Juan Bernier, Mario López, Julio Aumente y Manuel Álvarez Ortega, entre otros, como los integrantes del Grupo Cántico. Su propuesta poética se basa en la recuperación de la obra andalucista del grupo del 27, una poesía de signo neorromántico con matices simbolistas, modernistas e incluso barrocos, cuya impronta es el esteticismo. Poesía que se desmarca de la poesía rehumanizadora, mayoritariamente en boga durante las primeras décadas de la posguerra, y funda su estatuto en la recuperación de la poesía simbolista e irracionalista que había quedado quebrada por los desastres de la guerra y la represión posterior. De este modo, se rechaza cualquier tipo de compromiso y frente a la impronta social se propone la actitud esteticista. Ello significa una poética disidente en la poesía de posguerra, una nueva zona poética independiente, marcada, en cierto modo, por la lectura de poetas extranjeros. Frente al realismo reivindicativo y comprometido, los poetas cordobeses oponían el esteticismo, el irracionalismo y el decadentismo. De la reivindicación de la poética del 27, esta propuesta poética entroncaba con el modernismo decadentista, el simbolismo francés y la estética barroca. Por ello se revitaliza el poder de la imagen y de la metáfora, el signo irracional y simbólico del lenguaje poético, la transformación estética de la palabra. De los poetas de la generación del 27 interesan sobre todo dos: Vicente Aleixandre por su visión cósmica y paradisíaca de la realidad y Luis Cernuda por su tono intimista y reflexivo. La figura de Cernuda, recuperada por estos poetas, fue reivindicada como postura ideológica.

Guillermo Carnero (1976: 34-49) señala como características esenciales la presencia total del elemento intimista que desvincula esta poética de toda conexión con el realismo y, por otra parte, la captación de la sensualidad. En este sentido se trata de 
un acercamiento a la poética impresionista. Otras características señaladas por Carnero son: el análisis introspectivo, la estética barroquista, el vitalismo amoroso, la presencia de la imagen mítica pagana y el elemento culturalista (1976: 34-49). Es la actitud culturalista $^{46}$ la conexión de esta poética con las posteriores promociones de los años 60 y 70. Luis Antonio de Villena (2007: 14) señala como sintomático el acercamiento a la cultura pagana y a sus usos amorosos. La presentación natural del amor homosexual hizo estallar todos los tabúes establecidos desde una jerarquía religiosa totalizadora, castradora y fascista. Por ello, para este autor, esta poesía supuso una actitud mucho más reivindicativa y transgresora de lo que la crítica ha considerado.

La obra de Juan Bernier profundiza en la religiosidad humanista del paganismo y en sus valores hedonistas. Sus obras más significativas: Aqui en la tierra (1948), Una voz cualquiera (1959) y El azar objetivo (1975). En la obra de Pablo García Baena existen conexiones con la poesía más lírica y simbólica de la tradición, de Juan Ramón Jiménez a Luis de Góngora pasando por Luis Cernuda. Sensualidad poética, poesía emotiva, simbología. Sus obras más import6antes son Antiguo muchacho (1950), Junio (1957), Antes que el tiempo acabe (1978). La poesía de Ricardo Molina supone una mística erótica donde el amor supone la puerta de acceso a la armonía existencial, a la integración en un cosmos divino. Todo ello queda expresado en Elegía de Sandua (1948), Elegía de Medina Azahara (1957) o A la luz de cada día (1967). La poética de Julio Aumente transita en territorio del preciosismo decadentista y la huida de lo real hacia un pasado mítico revitalizando los postulados de la estética modernista. Todo ello revela un sustrato nihilista y desencantado muy cercano al existencialismo filosófico más patente en las últimas obras. Como obras sintomáticas cabe citar El aire que no vuelve (1955), Los silencios (1958), La antesala (1983). También hay que destacar en este contexto la poesía de Manuel Álvarez Ortega, sobre todo La huella de las cosas (1948).

${ }^{46}$ Ver Bousoño, Carlos (1979b: 34-36); G. Moral y Pereda (1979, 1982: 30-37); Talens (1981: 19-21). El culturalismo viene determinado por la intertextualidad, el alejamiento de la realidad y el refugio en lo literario en cuanto elemento representacional. Se trata de la ficción sobre la ficción, el hermetismo cultural, la poesía como signo opaco y laberíntico. 


\subsection{POESÍA DE LA MARGINALIDAD}

embarazoso huésped, memo vestido con mis trajes, zángano de colmena, inútil, cacaseno.

Jaime Gil de Biedma

Juan Larrea es el poeta, representante de la vanguardia interrumpida, a seguir por la poesía vanguardista de posguerra. Larrea continúa la línea poética hispanoamericana que va de Vicente Huidobro y César Vallejo a Neruda y al surrealismo. Para Vittorio Bodini, Larrea significa el punto de partida del propio surrealismo español: «Larrea, por lo poco que se conoce de su produción, nunca fue creacionista, sino un surrealista hasta los huesos, padre desconocido del surrealismo en España» $(1963,1982:$ 50). El surrealismo peninsular significó el punto más álgido de la poesía española y su reconocimiento mundial colocaba la figura de poetas como García Lorca, Aleixandre o Alberti a nivel de artistas plásticos conocidos a nivel internaconal como Pablo Picasso, Joan Miró o Salvador Dalí y el cineasta Luis Buñuel. Ahora bien, frente a la proyección extranjera de la poesía surrealista española, en la cultura del interior el surrealismo estaba condenado al silencio y a la marginación. Cierta parte de la crítica ha negado su existencia como corriente poética y, evidentemente, durante la posguerra fue silenciado, perseguido y censurado desde la esquizofrenia de un poder totalitario y acultural. Por su relación con marxismo, el surrealismo fue la bête noire del franquismo. Poetas como Cernuda, Larrea, Prados o Moreno Vila han necesitado mucho tiempo para que una revisión de su obra, o la recuperación de ésta, les haya otorgado la condición de poetas surrealistas. El surrealismo no sólo significaba un peligro para los parámetros del franquismo, sino que además representaba la subversión total de las bases de la conciencia burguesa y del racionalismo como sistema de pensamiento, ya fuese en la posguerra, durante la guerra o en la anteguerra. La poética vanguardista reiniciada en la posguerra no enlaza con los poetas del 27, sino que conecta directamente con el surrealismo francés (Marco, 1972: 201; Pont, 1987: 29-30; Cózar, 2001: 231). 


\subsubsection{El Postismo}

En 1945 apareció la revista Postismo de la mano de Carlos Edmundo de Ory, Eduardo Chicharro y Silvano Sernesi con una enérgica actitud de combate contra la poesía tradicionalista, pero también contra el realismo de la poesía rehumanizada. Posicionamiento en la zona de la marginalidad, línea poética subterránea que subvierte los postulados de la poesía oficial de posguerra. En este sentido, el postismo significó la demolición del lenguaje poético realista ${ }^{47}$. Oficialmente el Postismo apareció en enero de 1954 en el madrileño Café Castilla en medio de un estrambótico ceremonial con tintes de happening. Allí los tres fundadores repartieron sus tarjetas de visita triangulares con el nombre y el número de teléfono de cada uno. Su irrupción en la escena literaria y social significó un ataque frontal contra la tertulia del Café Gijón, escenario del garcilacismo, arropada por José García Nieto y sus contertulios ${ }^{48}$.

La poética postista reivindicaba el gesto espontáneo, desenfadado, radical y provocativo de las estéticas de la vanguardia histórica. No sólo conectaba con el automatismo de André Breton y Phillipe Soupault de Les champs magnétiques (1919), sino que revitalizaba los presupuestos dadaístas de la destrucción de la representación realista y de la poética de las palabras en libertad. Instalada en la estética de la destrucción, la poesía poesía postista incorporaba también las experiencias del cubismo a través de su traducción creacionista y ultraísta (fragmentación, perspectivismo, ruptura del lenguaje clásico) y el gusto por el decadentismo, pasado por el filtro de la poesía modernista hispanoamericana. El postismo, como inicio de la vanguardia de posguerra, significó la revitalización de la vanguardia radical que, desde el lenguaje del inconsciente y la asociación libre de objetos, entronca con el lenguaje metafórico simbolista, como alquimia verbal, provocado por el desarreglo de los sentidos. Por otra

${ }^{47}$ Para García de la Concha (1992: 709, 713-714) el expresionismo que se desprende de las proclamas y de las prácticas poéticas postistas se sitúa como elemento clave en la subversión del lenguaje poético de la posguerra. La poética postista conecta con la poética barroca y sus juegos lingüísticos. En ellos el lenguqje se retuerce y distorsiona como si fuese materia plástica. Rafael de Cózar (1978, 1990: 420-423) sitúa la estética postista en la tradición de los juegos literarios de ingenio que se han manifestado en la Cábala y en el hermetismo en forma de caligramas, laberintos, acrósticos...

48 Aunque existieron los provocativos ataques postistas al tradicionalismo poético representado por la Revista Garcilaso, el poeta postista Carlos Edmundo de Ory publicó reiteradamente varios poemas en esta revista: $n^{\circ} 8$, diciembre 1843; $n^{\circ} 11$, marzo 1944; $n^{\circ} 18$, octubre 1944; $n^{\circ} 24$, abril 1945; n²8, agosto 1945 .

También el poeta garcilacista Jesús Juan Garcés, realizando una extraña intersección, publicó en La Cerbatana sus poemas inéditos Poemas primitivos para ángeles. Por ello aparece entre los poetas postistas. 
parte, el radicalismo y la libertad verbal alejan esta poética del puro esteticismo del grupo Cántico. Frente al esteticismo poético el postismo opone la irreverencia de los juegos lingüísticos de Ramón Gómez de la Serna, pero también de los poetas modernistas oscuros como Julio Herrera Reissig. El postismo, sobre todo, sigue la impronta del surrealismo, del dadaísmo y del expresionismo. Incorpora sus hallazgos y reelabora sus códigos. El movimiento tuvo colaboraciones y adhesiones de importantes artistas de distinto signo. Entre ellos cabe destacar a Eugenio D’Ors, Camilo José Cela, Benjamín Palencia, Wenceslao Fernández Flórez, Juan Ramón Jiménez, Ignacio Aldecoa, Jesús Juan Garcés, Juan Eduardo Cirlot, Julio Trenas, Josep Pla, Manolo Pilares, César González Ruano... Ahora bien, el grupo postista, que se reunía asiduamente en el estudio de Eduardo Chicharro, estaba compuesto por los tres fundadores del movimiento más los siguientes artistas, mayoritariamente escritores y pintores: Nanda Papiri, Ignacio Nieva, Francisco Nieva, Ignacio Aldecoa, Carlos Martínez Rivas, Ángel Crespo, Félix Casanova de Ayala, Tonny Stubbing, Milena Milani, Carlos Cardoso y Juan Alcaide Sánchez.

El Postismo fue ante todo una actitud, una pose desenfadada que unía literatura y artes plásticas con la boutade y las acciones, performances en el lenguaje actual ${ }^{49}$. Revitalización de la bohemia histórica modernista y su espíritu estrafalario y de su programa de destrucción de la conciencia burguesa. Del dadaísmo se toma la radicalidad de Tristan Tzara y el gesto provocativo de Marcel Duchamp. Del surrealismo, el automatismo y la ruptura con el realismo lingüístico. Pero, a su vez, esta poética reivindica el primitivismo, la falsa ingenuidad naïf y la exploración de otros sistemas metafísicos como algunas filosofías orientales, el chamanismo, el ocultismo...

${ }^{49}$ Cózar (1987, 1990: 29). Rafael De Cózar sostiene que las acciones postistas son uno de los antecedentes del happenig, inaugurado por Jonh Cage y Allan Kaprow.

El happenig es un evento multidisciplinar, una acción que ofrece la conexión entre varias areas del arte: la plástica, lo visual, la música, el teatro. Como antecedentes podrían contarse las provocaciones de los movimientos de la Vanguardia histórica. Como inicio del happening cabe señalar el trabajo musical de Jonh Cage basado en el azar y el silencio, que permitían incorporar a la obra los sonidos de la realidad inmediata. Ello se plasmó en 1952 en el concierto de Black Mountain en el que se utilizaron pinturas, proyecciones, discos, aparatos de radios, poemas, textos y coreografías. Por su parte, Allan Kaprow presentó en 1959 en la Galería Reuben de Nueva York 18 happenings in 6 parts, estas acciones unían diferentes perspectivas artísticas: música, escultura, danza, proyecciones... El happenig aparece como un espacio artístico integrador de diversos elementos de la vida cultural. Su formato es espectáculo.

Ver Lebel, Jean-Jacques (1966) Le Happening, París, Editions Denoël, tradución de Enrique Molina, Buenos Aires, Nueva Visión, 1967 y Cárdenas de Becú, Isabel (1975), El teatro de vanguardia. Pollémica y vida, Buenos Aires, Búsqueda. 
Todo ello significó el rechazo de las poéticas imperantes y la apertura del territorio poético de la marginalidad.

A partir de 1947 se incorporaron otros miembros al grupo: Gabino-Alejandro Carriedo, Ángel Crespo, Miguel Labordeta. Otros poetas acercaron sus órbitas al movimiento como Antonio Fernandez Molina, Antonio Leyva, Fernando Quiñones, Julio Marichal, Gloria Fuertes. Y el dramaturgo Fernando Arrabal, se autoproclamó postista bajo las suspicacias de Ory ${ }^{50}$. La trayectoria activa del Postimo como grupo fue breve, pero su estela fue seguida por nuevas experiencias poéticas. El postismo significó la apertura a la nueva vanguardia poética: por un lado a la corriente surrealista y por otro a la poesía experimental (Cózar, 2001: 66).

El Postismo supone la continuación de la poética vanguardista española de primer momento marcada por el elemento sonoro: modernismo, ultraísmo, creacionismo... Incorpora hallazgos de la segunda vanguardia, de signo visual, desarrollados por las estéticas cubistas, futuristas y dadaístas. Y, por último, marca el inicio del tercer momento de la vanguardia, llamada también neovanguardia, transvanguardia o postvanguardia, centrada en el elemento sonoro y acústico del material poético. En este sentido, el postismo coincide con el letrismo francés de Isidore Issou y con los experimentos de Boris Vian. Movimientos y experiencias que significaron el inicio de la experimentación poética europea, que se concretará posteriormente con nuevas aportaciones como el espacialismo de Pierre Garnier, la poesía concreta o la poesía conceptual ${ }^{51}$.

${ }^{50}$ Grande (1970b: 273). Así se expresa Carlos Edmundo de Ory en las páginas de Historia de Postismo: "Fernando Arrabal, coofundador en París del Pánico, se acercó a nosotros en Madrid tan pronto supo la existencia del Postismo; varias veces subió al piso alto de la casa de Chicharro buscando nuestro contacto. Dejaba siempre recado de que había estado a preguntar por nosotros, ausentes cada vez. Me parece que Eduardo lo vio y hablaron; yo, entonces, nunca vi a Arrabal. Pero él nos seguía, cuando no de cerca, de lejos. Arrabal hubiera sido un postista original. No puedo decir lo mismo de algunos jóvenes que vinieron a nosotros por oportunismo, sin verdadera entretela».

${ }^{51}$ Ver Millán y García Sánchez (1975: 20-31). 


\subsubsection{Poéticas postistas}

La obra de Carlos Edmundo de Ory significa la actitud rebelde frente a la línea poética oficial. Actitud vitalista contra el conceptualismo racionalista. Rechazo frontal del realismo rehumanizador y huida de toda lógica poética. Su poética se inicia como búsqueda de las experiencias lingüísticas de la estética modernista y decadentista, bajo la estela de Julio Herrera y Reissig y Leopoldo Lugones; como revitalización de las actitudes rupturistas del dadaísmo y el cubismo traducidas al lenguaje creacionista y ultraísta y como incipiente contacto con el surrealismo bretoniano. Este es el sustrato de sus primeras obras como Las patitas de la sombra (romances postistas), obra escrita en 1944 en colaboración con Eduardo Chicharro, Versos de pronto (1945) o Los poemas de $1944(1973)^{52}$. Esta poética conectó, ya desde sus inicios, con el barroquismo poético de signo expresionista y ello marcó la demarcación frente a las líneas poéticas más o menos oficiales (García de la Concha, 1987: 713-714).

En 1951, Ory publica, junto al pintor Darío Suro, el Manifiesto del introrrealismo $^{53}$, una proclama donde se anuncia la entrada de su poesía en espacios nómadas situados a años luz de los parámetros culturales de la sociedad española. A partir de aquí la poética oryana se aleja del decadentismo para profundizar en el lenguaje hermético y onírico del surrealismo y en la voluntad destructora de las palabras en libertad de signo dadaísta. A su vez, esta poesía radicalmente irracional se vuelve metafísica y se acerca a aquella zona abierta a la filosofía y a la religión que Aldous Huxley (1945) llamó filosofía perenne ${ }^{54}$. Aquí cabría citar obras como Poemas (1969), Técnica y llanto (1971) o Música de lobo (1970) que incluye poemas escritos entre 1957 y 1969.

${ }^{52}$ Ver Mesado (2011a). La obra poética de Carlos Edmundo de Ory se trata de una poesía dispersa que aparece editada en distintas publicaciones literarias y que se halla recogida en varias antologías. Otras obras nunca se editaron en su día y fueron publicadas posteriormente en diversos poemarios cíclicos. También existen algunos poemarios que continúan siendo inéditos. Lo que verdaderamente ofrece unidad y coherencia a esta poética dispersa es su agrupación en ciclos, tal y como su autor estableció.

53 Nuestro tiempo: pintura. Nuestro tiempo: poesía, edición de 250 ejemplares numerados, Madrid, Imprenta Fareso, 1951.

${ }^{54}$ Desde una posición hermenéutica, el término filosofía perenne, que da título a la obra de Huxley, engloba la mística subyacente a los discursos de la tradición filosófica y religiosa universal. De este modo, puede considerarse filosofía perenne a las filosofías del taoísmo, budismo hinayana, budismo mahayana, budismo tántrico, budismo zen, jainismo, hinduismo, sufismo, cristianismo místico, orfismo, chamanismo... Diversos autores se han dedicado al estudio de esta filosofía: Mircea Eliade, Karl Gustav Jung, Aldous Huxley, Alan Watts, Gaston Bachelard... 
Ya instalado el exilio de Ory en Francia, se produce un acercamiento a la poesía experimental o poesía concreta. En 1968 este autor funda en Amiens el Atelier de Poésie Ouverte con la intención de llevar la poesía a la calle y de crear una poesía colectiva que se instale en el territorio de la experimentación. Poesía que mantiene convergencias con la poesía experimental, el happening y las nuevas actitudes vanguardistas. Por otra parte, la búsqueda metafísica confluye en la mística cósmica y en la apertura a todo elemento heterodoxo: Henri Michaux, Carlos Castaneda, los escritores de la Beat generation... Como obras representativas cabe citar Lee sin temor (1976), Miserable ternura - Cabaña (1975) o Angel without a permit (1988), obra traducida al inglés por Allen Ginsberg y Edith Crossman.

El punto final del trazado de esta poética heterodoxa viene marcado por dos obras. Por un lado, Melos melancolía (1999) que muestra de manera poliédrica y cenital el viaje iluminado de un maestro errante (loco, vagabundo, mendicante, místico, lobo estepario, alquimista, taoísta, monje budista, sabio, chamán, amante tántrico, hereje...) que camina en la eternidad de cada instante a través del samsara ${ }^{55}$. Por otro, La memoria amorosa, finalizada en 2007, es la última obra realizada por el autor. Ésta ha sido publicada póstumamente en 2011. Se trata de un viaje circular, escrito en prosa poética, que parte de la luz del Cádiz de la infancia, pasa por el Madrid convulso de la juventud, por el exilio de París y acaba en el espacio lumínico de la sabiduría de ThézyGlimont. Viaje que parte de la luz y a la luz regresa.

También hay que tener en cuenta la obra de Eduardo Chicharro, el otro poeta y teórico del Postismo que estuvo en el grupo desde sus inicios. Aunque él mismo reunió parte de su obra en Algunos poemas (1966), esta fue publicada de manera póstuma en Música celestial y otros poemas (1974). La poética de Chicharro se instala en la trinchera artística del postismo y su negación del realismo en todas sus direcciones. La práctica del humor negro le lleva a la irreverencia gestual de los juegos verbales del surrealismo. De otro lado, la sistemática destrucción del lenguaje poético contacta con la ruptura del discurso del dadaísmo.

55 En el Budismo Hinayana distingue el nirvana del samsara, el ciclo de las reencarnaciones que se establece en el aquí. El Budismo Mahayana niega tal separación al proponer que el nirvana no puede hallarse más allá del samsara. El samsara equivaldría, de algún modo, a la realidad. 
Del postismo tardío surge la obra varios poetas como Gabino-Alejandro Carriedo, Gloria Fuertes, Ángel Crespo o Félix Casanova de Ayala. Gabino-Alejandro Carriedo es el poeta cuya obra está más ligada a la propuesta postista. Esta se halla contenida en la antología de su primera poesía Nuevo compuesto descompuesto viejo (1980); obra que contiene La piña sespera (1948), La flor de humo (1949) y Los animales vivos (1950). La obra de Gloria Fuertes se caracteriza por la práctica de una poesía de lo cotidiano en clave humorística y naïf, en ella cabe destacar Aconsejo beber hilo (1954). La obra de Ángel Crespo que más se acerca a la poética postista es su poesía primera. Esta se halla reunida en la antología Primera antología de mis versos (1949), que incluye la poesía postista por excelencia contenida en la obras Loco de atar (1945-1946) y Música celestial (1945-1948). Otro representante de la poesía postista es Félix Casanova de Ayala, cuya obra postista queda recogida en Conquista del sosiego (1958). En ella se encuentran El paisaje contiguo (1946-1948) y La vieja casa (19461948).

Juan Eduardo Cirlot, perteneciente también al grupo poético catalán Dau al Set, no formó parte activa del Postismo, pero sí que mantuvo contactos con el movimiento. Su poética surrealista traza un espacio paralelo a la práctica poética postista. En este sentido, las obras más sintomáticas son Elegía sumeria (1949) y Lilith (1949). Miguel Labordeta tampoco perteneció al Postismo. Ahora bien, su poesía se aproxima muy de cerca a los postulados de este movimiento. En este sentido cabe citar el poemario Sumido 25 (1948).

\subsubsection{Poesía surreal}

Del grupo postista surge una nueva poesía surreal, llamada también por la crítica postsurrealismo ${ }^{56}$, cuyos representantes (postistas algunos, simpatizantes o próximos al movimiento otros) son Miguel Labordeta, Gabino-Alejandro Carriedo, Ángel Crespo y Juan Eduardo Cirlot. En el caso de éste último, su producción poética es paralela a las prácticas del Postismo y estas, en ocasiones, se entrecruzan. De hecho, se trata del desarrollo poético del movimiento surrealista español iniciado por la nueva

${ }^{56}$ Ver Bodini (1963, 1982: 8); Pont (1987:29). Para Bodini el Postismo marca la tercera oleada del surrealismo poético español. Pont concibe el Postismo como una actualización del surrealismo y de los demás movimientos de vanguardia precedentes. 
estética del Postismo que conecta totalmente con la última etapa del surrealismo francés. Poesía concebida como marginalidad y heterodoxia frente a los cánones realistas de las poéticas sociales. Pero también diáspora, punto de contacto entre la vanguardia y la poesía de las siguientes promociones. Ory, desde su exilio en Amiens, crea el Atelier de Poésie Ouverte como punto de dispersión de su poética marginal y como punto de contacto entre la poética surrealista y la poesía experimental. Su figura heterodoxa será recuperada mediante la edición de varias antologías. En torno a Miguel Labordeta se crea la Oficina poética internacional, punto de reunión de un grupo de poetas aragoneses entre los que destaca Manuel Pinillos. De otro lado, la figura de Cirlot actúa como agente de difusión del surrealismo y de contacto con las actitudes vanguardistas poéticas y estéticas, sobre todo con la experimentación poética de la poesía escrita en catalán, en la que destaca Joan Brossa, su compañero de viaje experimental que perteneció también al grupo Dau al Set. La poesía de Cirlot parte de una estética expresionista y del interés por el surrealismo para adentrarse en la práctica de una poesía hermenéutica que profundiza en la Cábala, en la mística sufí, en la magia o en las tradiciones orientales. Su surrealismo desciende directamente de Breton, con quien mantuvo una intensa relación epistolar. Otro desarrollo de su poesía viene a ser la experimentación permanente que se intersecciona con las artes plásticas, el cine y la música. En una línea similar se halla la labor de Ángel Crespo, que ejerce de punto de conexión del surrealismo con el radicalismo de la poesía experimental. Desde la dirección de la revista Deucalión se abre un espacio de convergencia para todas las estéticas vanguardistas. Allí encontramos ilustraciones de Antonio Saura, Gregorio Prieto o Francisco Nieva.

Esta línea poética surreal penetra en la década de los sesenta bajo el signo de César Vallejo y será Félix Grande quien se sitúa en primera línea del frente. El surrealismo atraviesa toda la obra de este autor ya desde su primera obra, Las piedras, aparecida en Biografia (1964-1971), publicada en 1971. Cabe destacar también las obras En secreto y Las rubáiyátas de Horacio Martín editadas ambas en 1978. El lenguaje surrealista aparece también en las primeras obras de Pere Gimferrer, Arde el Mar (1968) y La muerte en Beverly Hills (1968). A partir de aquí, el surrealismo se va a convertir en una constante que recorre la obra de este poeta hasta la actualidad. Cabe destacar, en este sentido, Lecturas de Octavio Paz (1980), Mascarada (1998) y El agente provocador (1998), las dos últimas obras son traducciones de su poesía en 
catalán. También, en esta década, la poesía de José Miguel Ullán sigue los caminos recorridos por la estética surreal, presente en El jornal (1965), Amor peninsular (1965) o Mortaja (1970). El surrealismo marca el punto de partida de la poética de este autor que se convertirá en uno de los paradigmas de la poesía experimental.

En la década de los setenta se produce, como reacción a la tendencia social y política, la conciencia de la decadencia de los modelos utópicos y el descrédito en los postulados de la Modernidad. Fruto de ello resulta la irrupción, pronto convertida en constante, de la noción de «imposibilidad» de la poesía para cambiar la realidad ${ }^{57}$. De ahí se deriva la concepción de la poesía como aventura lingüística y experimentación, a la vez que revitalización de lo imaginario. Todo ello queda traducido en un interés por el surrealismo por parte de todo un conjunto de poetas jóvenes, novísimos, que intentan establecer una subversión del lenguaje del poder. Junto a la estética pop-art, a la aceptación de las filosofías del underground $^{58}$ a través de los autores de la Beat generation y al conocimiento de la literatura psicodélica, se produjo el acercamiento al surrealismo y a la revitalización de todas sus técnicas (automatismo, lenguaje onírico, asociación libre de objetos, juegos verbales, collage) encaminadas a destruir el lenguaje poético conceptual.

Existen elementos surrealistas en la obra de Guillermo Carnero, en El dibujo de la muerte (1967), en El sueño de Escipión (1971) y en Ensayo de una teoría de la visión (1979), obra prologada Carlos Bousoño y que recoge toda la producción del autor desde 1966 a 1977. La obra de Antonio Martínez Sarrión conjuga cultura underground, surrealismo y experimentación en Pautas para conjurados (1970), Teatro de

\footnotetext{
${ }^{57}$ Ver García Moral y Pereda $(1979,1982: 27-28)$ y Subirats, Eduardo (1985), «El diseño y la cultura tardo-moderna», Los Cuadernos del Norte, $\mathrm{n}^{\circ} 33$, Oviedo, p. 61.

${ }^{58}$ Ver Racionero, Luis (1982), Filosofías del undergroud, Barcelona, Anagrama; Villena, Luis Antonio de (1975), La revolución cultural (desafío de una juventad), obra cit. en la bibliografía; Savater, Fernando y Villena, Luis Antonio de (1989), Heterodoxias y contracultura, obra cit. en la blibliografía; Antolín Rato, Mariano (1985), «Madrid underground: 1963-1973)», Los Cuadernos del Norte, $n^{\circ} 33$, Oviedo; Gofman, Ken (2004), Counterculture Through the Ages, Nueva York, Villard, traducción de Fernando González Corugedo, La contracultura a través de los tiempos, Barcelona, Anagrama, 2005. El término underground viene a significar las corrientes de pensamiento subterráneas que han existido a lo largo de la historia de la humanidad. Éstas normalmente han sido filosofías prohibidas, marginadas por la ortodoxia; o bien han sido desechadas e instaladas en el territorio de la marginalidad. En todo caso, siempre han cohabitado con el imperante discurso del pensamiento oficial. Esta etiqueta hace referencia en el siglo XX a las filosofías, modelos de pensamiento o miradas culturales que hicieron posible el cambio de mentalidad que operó alrededor de 1968 en California y París, y desde aquí irradió a todo el espectro social de casi todo el territorio mundial: filosofías irracionales y visionarias, filosofías orientales y filosofías psicodélicas.
} 
operaciones (1976), Una tromba mortal para los balleneros (1975). Conectado con la herencia de los poetas malditos y siguiendo los pasos de Antonin Artaud, el surrealismo pretende en la poesía de Leopoldo María Panero convertirse en el lenguaje de la locura. Conjunción de la poesía visionaria con las filosofías contraculturales y la cultura pop. De esta zona abierta surgen obras como Por el camino de Swan (1968), Así se fundó Carnaby Street (1970), Teoría (1973), Narciso (1979), El último hombre (1986) o Tensó (1997), obra escrita junto a Claudio Rizzo. El surrealismo también impregna la obra de Jesús Munárriz, Viajes y estancias (1975) y Cuarentena (1977). El automatismo deshilvana su discurso poético desde la adopción de una óptica rupturista con la representación poética tradicional. La poesía de Luis Antonio de Villena también es heredera del surrealismo, este aparece en Sublime Solarium (1971) y ya nunca se abandonará. Syrtes (2000) es un claro ejemplo.

Otros autores que han practicado el surrealismo poético, cuya obra merece formar parte de la poesía surrealista española, que se prolonga más allá de la posguerra, son Ana Maria Moix, Ramón Pedrós, Juan de Loxa o Javier Villán. Con una conexión más estrecha con la cultura subterránea, hay que citar a Juan Luis Panero y Eduardo Haro Ibars. También cabe mencionar al grupo Poesía 70 de Granada. Esta línea poética, que surge de la irradiación del postismo, configura la dirección que tomó el surrealismo español en su segunda etapa, coincidente con el canto del cisne del surrealismo francés y europeo.

Si la poesía surrealista surge, en la posguerra, en los territorios de la marginalidad y de la heterodoxia, a finales de los años setenta ya se ha convertido en un lenguaje más o menos admitido y comprendido por gran parte del tejido social. La poesía surrealista continúa existiendo, pero ahora ya no necesita refugiarse en el subsuelo cultural porque ha pasado a ser un lenguaje aceptado por el público lector. El surrealismo ha perdido su capacidad de provocación. El arte como provocación, tan en boga en estos días, heredero de las experiencias artísticas (los ready-made) de Marcel Duchamp, se ha convertido en un arte meramente decorativo utilizado por el poder. Arte que se ha desprendido de todo elemento revulsivo y agitador, arte que ha sido absorbido por los instersticios del sistema y utilizado por los discursos económicos del marketing y la publicidad. El surrealismo poético es un lenguaje que atraviesa los años ochenta y noventa y penetra en el siglo XXI. Lenguaje practicado, en este nuevo siglo, tanto por 
poetas vanguardistas de la primera generación poética de posguerra como Carlos Edmundo de Ory, como por poetas de última generación como Antonio Lucas o José Luis Rey, este último declarado admirador de la poesía novísima. Entre estos dos extremos existe una verdadera práctica poética visionaria de signo subconsciente y onírico.

Carlos Edmundo de Ory no abandona nunca el lenguaje surreal y ello se muestra en obras como Sin permiso de ser ángel/Angel without a Permit (1988) o Melos Melancolía (1999). Poetas de las generaciones posteriores como Pere Gimferrer, José Miguel Ullán, Antonio Martínez Sarrión, Luis Antonio de Villena o Leopoldo María Panero continúan manteniendo sus poéticas surrealistas en los inicios del nuevo siglo. En la poética de fin de siglo hay que mencionar dos obras importantes, De una niña de provincias que se vino a vivir en un Chagall (1980) de Blanca Andreu y Poemas \& híbridos (1990) de Bernardo Atxaga, y la creación en 1987 del Grupo Surrealista de Madrid, que desde su inicio edita la Revista Salamandra.

Luis Antonio de Villena (2010a: 10-13) establece la existencia de dos generaciones poéticas en el desarrollo de la poesía en este país desde 1980 hasta nuestros días. Para este autor de la generación poética de 1980, llamada también poesía de la experiencia, surge, como desarrollo, una poesía que gradualmente va rechazando los postulados de la generación anterior hasta que se establece una ruptura total. Esta es la generación de 2000, que se caracteriza por una poesía de voluntad intelectual y por un acercamiento a la poesía novísima. Para Villena (2010a: 23) la ruptura entre estas dos generaciones poéticas se produce por la propuesta de una poesía más cuidada, que sea construcción intelectual y no sólo resultado de la pura emoción. Una poesía reflexiva de signo metafísico, filosófica que intenta desprenderse del lenguaje realista de la llamada poesía de la experiencia. El lenguaje poético de la generación posterior resulta más intelectualista, más meditativo y más culturalista.

En el interior de esta última generación puede observarse una deriva hacia una poesía de signo totalmente irracionalista, donde se halla de manera patente la presencia del lenguaje surrealista, onírico, subconsciente y visionario. Este es uno de los puntos de contacto que se establece entre una zona de la poesía de esta generación con la poesía de la generación de los novísimos. No sólo puede establecerse esta convergencia, sino que 
este lenguaje surreal procede, en última instancia, de la poética del Postismo. Poesía hermética, intelectualista de signo irracional que se observa en autores como José Luis Rey o Antonio Lucas, autor de Los mundos contrarios (2009), que escriben una poesía visionaria de signo surreal. Junto a estos autores, la presencia del lenguaje surrealista se observa en los juegos intelectuales, cercanos al hermetismo, de Carlos Pardo, Jorge Gimeno, Andrés Navarro, Lorenzo Oliván y otros muchos poetas más. El lenguaje onírico ya no posee la radicalidad intempestiva de los primeros surrealistas, ni la voluntad de demolición del edificio realista de la poesia de posguerra que tenía el proyecto postista. Ahora, este lenguaje ilógico, irracionalista, ha quedado incorporado al lenguaje poético desprovisto del elemento provocador. De manera que la poética surrealista, presente en esta poesía última, ha sido asimilada por los poetas jóvenes como elemento integrante del lenguaje poético. Y ello, en cierto sentido, ha supuesto una operación de normalización y de asimiliación de un código que ya no resulta extraño.

\subsubsection{Poesía experimental}

En los años 50 Ángel Crespo y Pilar Gómez Bedate, desde la revistas Deucalión y Revista de Cultura Brasileña, delimitan una zona poética abierta y radical que se aleja del surrealismo para establecerse en la pura experimentación. En estas publicaciones aparece la Poesía concreta de la mano de las experiencias de Deccio Pignatari y del grupo brasileño Noigandres. Crespo y Carriedo difunden los hallazgos de la nueva poesía brasileña. Frente al surrealismo la poesía concreta o experimental, paralela a la poesía visual de Joan Brossa, revitaliza el elemento visual tomado del collage y del caligrama propuestos por la vanguardia dadaísta, futurista y cubista. La poesía parte de esta voluntad de ruptura con el discurso poético tradicional y su modelo poemático y desecha definitivamente todo elemento semántico. De manera que el poema queda reducido a su elemento fónico mínimo: sonido y silencio. La reivindicación de lo visual reactiva el elemento tipográfico como agente estructural. Este modelo poético experimentador busca un discurso basado en la ruptura fonética, sintáctica y semántica del lenguaje. El elemento lingüístico estalla ante el juego experimental, mediático, audiovisual. Como precedentes de la poesía experimental podemos citar a poetas y escritores aventureros de signo diverso como Stéphane Mallarmé, James Joyce, 
Guillaume Apollinaire, Tristan Tzara, Filippo Tomasso Marinetti, Wladimir Maiakovski, Joan Salvat Papasseit, Vicente Huidobro, Álvaro de Campos (heterónimo del Fernando Pessoa más vanguardista), Issidore Isou, el happening y las acciones y performances del arte visual y corporal. En cierto sentido esta poética se acerca a la abstracción pictórica, al arte conceptual, al body-art, a las experiencias del grupo Fluxus, al espacialismo (fundado en 1963 por Pierre e Ilse Garnier), a la poesía visiva del Grupo 63 y del Grupo 70 (Eugenio Miccini, Luciano Ori y Michele Perfetti) o a la poesía semiótica de Anna Oberto y Martino Oberto ${ }^{59}$.

En los primeros años sesenta aparece Problemática 63, publicación dirigida por el poeta experimental Julio Campal, que se instaura como espacio abierto a la poesía concreta y a la difusión de la vanguardia poética internacional. Dos integrantes de este grupo continúan en la línea trazada y se dedican a la trasmisión de la poesía visual y experimental. Ignacio Gómez de Liaño crea la Cooperativa de Producción Artística y Fernando Millán el grupo N.O., fundado en 1968. En 1963 la revista Claraboya se apuesta por el experimentalismo y por la poesía concreta. La alternativa planteada es ahora la poesía dialéctica, un intento de internacionalizar la poesía concreta dotándola a su vez de una dimensión histórica. En ella se notan las influencias de BrechaEnzensberger, Weis, Kosic y Hikmet. En 1964 se funda el grupo Zag integrado por diversos autores españoles y extranjeros. Las aportaciones más significativas de este grupo son las obras de Walter Marchetti y de Juan Hidalgo, autores preocupados por la intersección de la vanguardia musical y la poesía experimental. Conectada con este grupo se halla la radical propuesta escénica de Esther Ferrer y sus acciones corporales ${ }^{60}$. En 1969 aparece el grupo N.O. que lanza algunas de las publicaciones más interesantes en este sentido: las antologías Situación uno y Situación tres y las obras Concretos uno de Enrique Uribe y Este protervo zas de Fernando Millán. Es este autor el representante por excelencia de la vanguardia visual poética escrita en castellano. Su propuesta consiste en una poética de convergencia, donde confluyen el lenguaje mediático, la publicidad, la ilustración y el diseño industrial. En su obra cabe destacar el título antes

${ }^{59}$ Esta línea de experimentación poética arranca de 1945, año en el que Isou funda el Letrismo, movimiento que ensalza la letra y no la palabra como elemento principal del lenguaje poético. Recordemos que 1945 es también el año en el que se funda en Madrid el Postismo, paralelo movimiento renovador.

60 Ver Iker Seisdedos (2014), «Zaj, un sonoro grito artístico en plena dictadura», El País, Madrid, 28 de diciembre, p. 46. 
mencionado y publicado en 1969 junto a otras obras como Textos y antitextos publicado en 1970, Mitogramas (1968-1976) que apareció en 1978 y Prosae de 1981.

Paralela a la práctica poética de Millán, en Cataluña la experimentación poética está dirigida por los poetas de tradición vanguardista Cirlot y Brossa que proponen ambos una poesía visual. De la poesía experimental de Cirlot cabe mencionar Donde nada lo nunca ni (1968), Bronwyn, I al VII (1969) y Inger Stevens permutacions (1971). En el caso de Brossa su poética, marcada por la presencia de la poética comprometida de Joao Cabral de Melo, se presenta como antipoesía, en consonancia con los antipoemas de Nicanor Parra y de aquí se dirige hacia el juego conceptual de la poesía visual. En este sentido hay que destacar obras como El saltamartí (1969) y Pluja (1973). Por otra parte, la poética de Guillem Villadot se inscribe en el territorio de la poesía visual catalana trazado por los autores anteriores.

En los años setenta surgen nuevas propuestas en la poesía española que recogen las aparecidas en la década anterior: el espacialismo de Pierre Garnier, la poesía visiva de Miccini y Perfetti, la poesía semiótica... La aparición a partir 1972 de nuevos espacios dedicados a la experimentación poética marca la importancia que adquiere la poesía experimental, cuyo periodo de esplendor se halla entre los años discurridos de 1972 a 1975. En este sentido surge el grupo Parnaso 70, del que destaca la obra de José María Montells, origen de la revista Poliedros, la colección El Toro de Barro dedicada a la poesía experimental, la revistas Artesa y Poesía 70, el grupo Base 6... Se publican además varias antologías dedicadas a la poesía experimental. Alfonso López Gradolí recopila la obra de diez autores en la revista Fablas, Ignacio Gómez de Liaño y Felipe Boso publican una antología de veintinueve autores en la revista alemana Akzente, Antonio L. Bouza presenta su selección en Odología poética (1975) y Fernando Millán y Jesús García Sanchez realizan el estudio más extenso dedicado a la poesía experimental: La escritura en libertad. Antología de poesía experimental (1975). La aparición de esta última antología significa el reconocimiento público de la experimentación poética. En ella se hallan textos de autores conocidos como Celaya, Cirlot, Brossa... pero también de otros autores menores, en la época, como José Miguel Ullán, el anteriormente mencionado Felipe Boso o Alberto Corazón. 
La poética de Ullán propone un experimentalismo comprometido y lúdico de signo visual: juegos asociativos de carácter conceptual, collages y caligramas... Su poesía visual no prescinde del signo lingüístico, de la cadena de significantes, sino que experimenta con ellos la ruptura del lenguaje, su supresión o su destrucción. Tachaduras, garabatos, imágenes alternan con el lenguaje, lo dibujan o lo desencajan. Lo estructuran. Su obra es muy extensa y ha sido ilustrada por artistas plásticos como Eusebio Sempere, Eduardo Chillida o José Hernández. En la trayectoria de José Miguel Ullán cabe destacar Amor peninsular (1965), Maniluvios (1972), Frases (1975), Alarma (1976), Bethel (1977), Soldadesca (1979).

Desde unos planteamientos semejantes surge la obra de autores como Rafael de Cózar, Pablo del Barco, Carlos de la Rica o Francisco Pino. Por otra parte, el grupo Marejada, que nació en Cádiz en 1971 y del que es miembro el artista antes mencionado Rafael de Cózar junto a Jesús Fernández Palacios o José Ramón Ripoll, muestra sus convergencias con el Postismo y se muestra heredero de la poesía de Carlos Edmundo de Ory. La preocupación por la poesía experimental lo sitúa, sobre todo en su última etapa, en la vanguardia poética.

No puede obviarse la aportación que proviene desde Cataluña, que mediante las poéticas de Brossa y de Cirlot, desemboca en el grupo Tarotdequince y en la poesía de Josep María Figueras. 


\subsection{UNA MIRADA DE RECHAZO}

Lama, laúd, polilabial ginesta, ¡qué lindas son las hierbas de la noche!

Eduardo Chicharro

Los acercercamientos de la crítica sobre el Postismo y la obra de los autores postistas han sido tardíos debido al rechazo que se efectuó desde las instancias oficiales hacia este movimiento. Las dos publicaciones postistas, consideradas como órgano propagandístico y teórico del movimiento, fueron censuradas y prohibidas. La revista Postismo surgió en enero de 1945 y de ella sólo se logró publicar un único número. Como reacción ante este secuestro ideológico y cultural, sus autores, considerados el núcleo duro del movimiento, Eduardo Chicharro, Carlos Edmundo de Ory y Silvano Sernesi, realizaron otra maniobra ideológica con la publicación de La Cerbatana en abril del mismo año. Aunque hubo adhesiones, colaboraciones y felicitaciones de importantes críticos, poetas y artistas, las directrices culturales del régimen no podían tolerar la existencia de un movimiento estético que mantenía abiertamente sus contactos con los movimientos vanguardistas de signo más radical como el Dadaísmo o el Surrealismo. Las proclamas y los manifiestos postistas suponían una botefada a la cara de la sociedad franquista. Para la cultura del franquismo, el Postismo significaba un peligro social debido, sobre todo, a su reivindicación del Surrealismo. Movimiento que, desde que André Breton proclamara en 1930 el acercamiento del movimiento al proletariado y la colaboración con el marxismo en el Segundo Manifiesto del 
Surrealismo (1962, 2009: 146-147, 156-157), era considerado subversivo y comunista, enemigo radical de la política fascista, nacional y católica del franquismo. Ello hizo que el silencio cayera sobre los agentes postistas. Por otra parte, los presupuestos estéticos y poéticos del Postismo rehuían las poéticas rehumanizadas en boga en la posguerra, el lenguaje postista chocaba de frente con el realismo poético y, más todavía, con la poesía social y su preocupación por la colectividad. Tanto desde la poesía tradicionalista, anclada en la bendición de la nueva realidad sociopolítica, como de la poesía comprometida se frivolizaron los presupuestos postistas y el movimiento quedó asociado únicamente a una vacía e irreverente provocación. Las críticas más airadas acerca de las propuestas postistas provienen de los poetas representates del realismo poético (Navas, 2000: 37-51; Pont; 1987: 48). Son los poetas de Espadaña, Victoriano Crémer y Euenio García de Nora, los autores que atacan de modo más vehemente los postulados postistas. Su punto de mira se centra en la figura del poeta Carlos Edmundo de Ory, a quien tildan de paradigma de la intrascendencia, cuya obra será definida como producción esquizofrénica, estética paranoide o enfermiza.

Todo ello explica el silencio de la crítica frente a los paradigmas y las propuestas del Postismo y, de otro lado, respecto a la obra de sus autores, sobre todo a la de Eduardo Chicharro y a la de Carlos Edmundo de Ory, verdaderos ejes vertebradores de una nueva mirada vanguardista. Isabel Navas Ocaña (2001: 339-359) señala, como punto de partida, que el motivo del rechazo de la propuesta postista se basa en la reticencia hacia el surrealismo que la crítica de este país tuvo en la posguerra. Según la óptica de la autora, en la posguerra se negó la existencia del surrealismo obviando totalmente la poética postista. La crítica trató la obra del grupo poético del 27 desvinculándola de todo contacto con el movimiento surrealista. De este modo, la expresión poesía surrealista desapareció y fue sustituida por un nuevo eufemismo, poesía neorromántica (Navas, 2001: 339). Vittorio Bodini (1963, 1982: 31) define la poesía surrealista española como una poesía preocupada sobre todo por el interés poético, poesía que rechaza el automatismo puro frente a una organización del material surreal. Carlos Bousoño (1979a: 373-375) considera que el surrealismo poético español no reside, tampoco, en el automatismo, sino en la estructura ilógica del enunciado poético. El superrealismo es la culminación del irracionalismo poético iniciado en la 
poética simbolista ${ }^{61}$. Bousoño considera que el surrealismo poético, tal cual, sólo se da en Pasión de la tierra (1935) de Vicente Aleixandre, obra escrita entre 1928 y 1929. La producción aleixandrina posterior es considerada por el autor como posuperrealismo ${ }^{62}$ (1979a: 75).

Si la existencia de la poesía surrealista fue cuestionada por la crítica de la posguerra, la poesía postista fue relegada al más hermético de los silencios. Ningún poeta postista aparece en la Antología de la nueva poesía española publicada en 1957 por José Luis Cano. El autor presenta una poesía definida por el realismo y el componente humano (1957: 13). Tampoco vuelven a aparecer ni Carlos Edmundo de Ory, ni ningún otro representante de este movimiento en la selección de poetas que efectúa Castellet para sus dos antologías: Veinte años de poesía española (1939-1959), publicada en 1960, y Un cuarto de siglo de poesía española, editada cinco años después. Castellet defiende en ellas una poesía social de signo realista, cuya óptica rechaza la plasticidad de la poética postista, de signo expresionista. Desde los cánones poéticos realistas que imperaban en la posguerra, la experimentación y la ruptura de la tiranía de la lógica, propias de la poesía postista, eran vistas como un retorno a unos códigos ya superados, como un intento por reactivar los juegos vacíos de unos modelos que ya habían dejado de funcionar. Castellet no valoró con la intensidad merecida el intento de subversión del lenguaje realista que supuso el movimiento postista. Tampoco aparece ningún poeta que tenga alguna conexión con la poética postista en las antologías realizadas por Francisco Ribes (1952) y José Batlló (1968).

El caso de Carlos Edmundo de Ory resulta paradigmático, pues es considerado en plena posguerra como poeta retrógrado, maldito, heterodoxo, irreverente, frívolo. Su poesía fue totalmente banalizada y su imagen radicalmente caricaturizada, fue llamado el Rimbaud andaluz y Lautremoncito. Años después, en su exilio voluntario en Francia y con una vasta obra publicada, es reconocido por la crítica como el padre de la poesía de posguerra. Entre los autores que han considerado, a posteriori, su impronta como

${ }^{61}$ Bousoño (1979: 70-75). Para Bousoño, el irracionalismo poético posee cinco etapas: el Modernismo, representado por Rubén Darío; el impresionismo, marcado por el primer Antonio Machado y el primer Juan Ramón Jiménez; la poesía pura de herencia cubista y futurista con Jorge Guillén, Pedro Salinas y el Juan Ramón de la pureza poética; la madurez del irracionalismo, cuyos representantes son el García Lorca del Romancero gitano y el Alberti de Sobre los ángeles; y el superrealismo marcado por Vicente Aleixandre.

${ }^{62}$ Sic. 
germen de la poesía posterior cabe citar a Josep María Castellet, José Luis Cano o José Batlló. En 1978 José Batlló manifiesta el reconocimiento de su poesía y su contribución al Postismo y a la renovación de la poesía española. El mismo Ory nos lo cita en su diario, correspondiente al 30 de octubre de 1978 (2004: Vol. III, 87-88):

Una alumna me dijo, durante la clase, que tenía una antología de poetas españoles contemporáneos, en francés, publicada en Francia, y que vio dos poemas míos traducidos. No me supo dar más detalles.

Fui a una librería y lo compré. Se trata del libro titulado: «La Nouvelle poésie castellane d'Espagne». Choix et traductions d'Annie Salager, con una introducción de José Batlló [...] Hete aquí que, en su prólogo, Batlló me llama «padre» de la poesía de posguerra y del postismo.

La misma actitud de rechazo es la que lleva a Guillermo de Torre a no incluir al moviento postista en su obra Historia de las Literaturas de Vanguardia ${ }^{63}$. Aquí lo paradójico es que se habla de superrealismo $\mathrm{y}$, aparte de los integrantes del grupo francés, sólo se nombre a Juan Larrea y al grupo de Tenerife como únicos representantes del surrealismo español. No se cita, tampoco, a los autores postistas como representantes del surrealismo que se desarrolla a partir de 1940.

Por paradójico que parezca, tampoco aparece el nombre de Carlos Edmundo de Ory, ni ninguna referencia acerca del Postismo, en la obra La escritura en libertad. Antología de poesía experimental, preparada por Fernando Millán y Jesús García Sánchez en 1975. En cambio sí que aparecen en la antología autores como Gabriel Celaya, Juan Eduardo Cirlot, Joan Brossa, Guillermo Cabrera Infante u Octavio Paz. No se explica este silencio cuando precisdamente el Postismo es el punto de unión entre la vanguardia poética anterior a la guerra civil y la poesía experimental, de signo visual, que se desarrolla en la posguerra española y que entronca con el desarrollo de la vanguardia poética mundial. Para Rafael de Cózar (1978, 1990: 55-57), precisamente el Postismo significa el inicio de la poesía visual y del experimentalismo poético en España.

63 Torre, Guillermo de (1965), Historia de las Literaturas de vanguardia, Madrid, Guadarrama, pp. 363-450. 


\subsection{REIVINDICACIONES}

Lo lejos otra vez mi lejos

Nosotros acerca lejosle.

Carlos Edmundo de Ory

Fue Félix Grande (1970a) quien rescató la poesía de Carlos Edmundo de Ory del silencio al que la oficialidad del régimen y la doctrina política inspiradora del dogma realista, cuya poética pretendía cambiar la realidad, habían relegado. Tanto la obra postista como la propuesta introrrealista se hallan en las antípodas de los territorios culturales de la ortodoxia poética de la sociedad española. La transgresión de la poesía postista supuso la demolición del edificio realista y la postura del Introrrealismo íntegro significó el acercamiento a la preocupación metafísica y a la concepción mística desde territorios alejados totalmente de las preocupaciones triunfalistas o combativas. La poesía oryana se erigía en el glosario de un proceso perpetuo de transformación y de iluminación, su interés transitaba por espacios culturales totalmente extraños: mística cristiana, sufismo, hinduismo, budismo hinayana, budismo mahayana, budismo zen, tantristo, taoísmo, chamanismo, orfismo, hermética, alquimia... Ello significó el ingreso en la zona poética de la marginalidad y Carlos Edmundo pasó a ser la figura del gran heterodoxo de la posguerra cultural. Su exilio autoimpuesto en 1955 y la actitud insumisa llevada a cabo en todo momento ofrecían la imagen de un poeta maldito a modo de Arthur Rimbaud o Henry Miller, visionario como William Blake. Tampoco sus acercamientos a la Beat generation, a la contracultura o al pop-art contribuyeron a la popularidad de su poesía ${ }^{64}$. Todo ello impidió la difusión de su poesía y favoreció su desconocimiento.

\subsubsection{Desde la generación del undergroud}

La reivindicación de la poética oryana, efectuada por Grande (1979a), supuso también una revalorización del Postismo. Son los poetas de la generación de los setenta

${ }^{64}$ Ver, Mesado (2011b; 2016). 
quienes se interesan totalmente por el Postismo, pues sus preocupaciones estéticas coinciden. Entre ellas dinamitar el enquilosado lenguaje realista y buscar una poesía comprometida con la realidad del propio lenguaje y con la experimentación de nuevos modelos y códigos. La concepción, sostenida por esta nueva generación poética, acerca de la imposibilidad de la poesía para transformar el mundo suponía la distancia de la preocupación política. De otro lado, la proximidad al radicalismo y a la provocación, propias de la poesía de esta nueva generación, fueron actitudes propuestas también por el Postismo. Sin hacer ninguna referencia al Postismo y su huella en esta nueva generación poética, Josep María Castellet (1970: 89-90) nombra, en el estudio que precede a la antología dedicada a los poetas de esta generación, las coincidencias de esta poesía y de la poesía postista. Ambas poéticas rompen de forma radical con el compromiso político y su lenguaje romo, excesivamente coloquial. La ruptura establecida de la poesía novísima frente a la poesía social es el punto de unión con la concepción de la poesía como realidad autónoma y autosuficiente. Poesía que es juego e investigación lingúística, objeto de creación. Este es el punto de unión que conecta esta nueva poesía con la vanguardia poética. Otros signos, según Castellet, de la poética de los poetas novísimos son la reivindicación apasionada del surrealismo, el uso del collage, el acercamiento a la cultura pop y a la contracultura, el irracionalismo, la recuperación de los poetas visionarios y malditos... Elementos ya existentes en la poetica postista y, sobre todo, en la poesía heterodoxa de Carlos Edmundo de Ory, figura que actúa de agente precursor.

La poesía de la generación de los años setenta está mucho más cercana al Postismo, por su carácter dadaísta y surrealista, que a la poesía de la generación de las décadas de los años cuarenta y cincuenta. Carlos Edmundo de Ory es el hermano mayor de los poetas novísimos ${ }^{65}$. Comparte el mismo tiempo histórico y las mismas preocupaciones, poéticas, ideológicas, estéticas... Existe una total coincidencia en sus referencias poéticas: Arthur Rimbaud, Isidoro Duchase o Conde de Lautréamont, André Breton, Tristan Tzara, Walt Whitman, Ezra Pound, T. S. Eliot... También los poetas de

${ }^{65}$ Una constante en las poéticas de los poetas de esta generación fue la reivindicación del surrealismo. De los poetas más citados cabe señalar a André Breton y a Vicente Aleixandre. Menores son las referencias que apuntan al asentimiento de la influencia del Postismo y de la poesía oryana. En todo caso hay que mencionar su aceptación por parte de Vicente Molina Foix (Castellet, 1970: 186), José Luis Jover (García Moral y Pereda, 1979, 1982: 290-291), Guillermo Carnero (García Moral y Pereda, 1979, 1982: 307). Luis Alberto de Cuenca Cita a Cirlot como influencia (García Moral y Pereda, 1979, 1982: 351). 
los años setenta comparten con Ory el acercamiento a la contracultura: el conocimiento de autores pertenecientes a la Beat generation como Allen Gisnsberg, Jack Kerouac, William Burroughs o Gary Snyder; el interés por las filologías orientales de la mano de Alan Watts o Daisetz Teitaro Suzuki; el establecimento de unas coordenadas totalmente diferentes que marcan una nueva cultura pop que posee sus propios iconos como la música de The Beatles o Pink Floyd, la pintura de Andy Warhol o Richard Hamilton; y, finalmente, la experiencia literaria psicodélica de la mano de autores como Aldous Huxley o Carlos Castaneda. Tanto en ellos como en Ory se produce la ruptura y el distanciamiento con las coordenadas culturales anteriores y el ingreso en la cultura undergroud. No olvidemos que en el año 1968, considerado el año del mayo parisino y del verano del amor de California, Carlos Edmundo de Ory se hallaba dirigiendo el proyecto del Atelier de Poésie Ouverte en la Maison de la Culture de Amiens, espacio totalmente abierto a los nuevos vientos culturales y a las nuevas revoluciones. Para Santos Sanz Villanueva, tal y como manifiesta desde las páginas que cierran la antología editada por Víctor Pozanco, Nueve poetas del resurgimiento, uno de los signos definidores de la poesía escrita en esta década consiste en la recuperación de las corrientes subterráneas de la poesía de posguerra, la de Carlos Edmundo de Ory, Miguel Labordeta, Juan Larrea o Carlos Barral (Pozanco, 1976: 273-274).

Antonio Martínez Sarrión en su poética publicada en Nueve novísimos poetas españoles (Castellet, 1970: 89-93) propone una poesía que cree una realidad autosuficiente, una realidad autónoma, poética, desligada del contenido y de la realidad. Una poesía de creación con el punto de mira puesto en la vanguardia. En todo ello puede observarse un ataque frontal a la poesía realista, hija del realismo social, cuyas claves son la importacia del contenido y transformación de la realidad. En esta reivindicación de una poesía de signo surrealista ${ }^{66}$, preocupada y comprometida con el lenguaje poético, con la magia, el juego y con la cultura pop, se observa un estrecho contacto con la poesía postista. Ahora bien, el guiño más claro realizado al Postismo por

${ }^{66}$ Castellet (1970: 91-92). «En mi caso particular tengo que hablar, creo que es visible en mis poemas, del eco del primer Eliot, tal vez de Pound y sin duda alguna de los surrealistas, movimiento éste mal entendido por casi todos aquí o deformado para su repugnante uso por algunos filibusteros incalificables.

Ciertos alumbramientos de Breton, Benjamin Péret, Soupault, Char o Queneau, permanecen vigentes y ultilizables dentro de un contexto cultural específicamente español que despoje a aquellos de abstracciones y vagorosidades insuflándoles humor y acidez». 
este autor aparece en el soneto, perteneciente a Una tromba mortal para los balleneros (1975), titulado «Homenaje al Postismo»:

Hube de subvenir a unos zapatos, perdón, quise decir a unos zapatos que, si se portan bien, yo no los atossigo con mis lazadas. A los patos

he echado mis zapatos garabatos desmigándolos bien. O sea, en los tratos con los tenderos pido unos zapatos que no sean caros y no sean baratos.

No me entienden.Me lanzan los ingratos pares de saldo, letras impagadas, miradas de lujuria... Mas, los ratos que así pierdo, se vuelven sosegadas horas acariciando a mis dos gatos cuando vuelvo a la clínica a patadas.

El Surrealismo no sólo es un movimiento reivindicado por Martínez Sarrión, sino que prácticamente se trata de una reivindicación colectiva, como consta en las poéticas escritas por casi todos los poetas de esta generación: José María Álvarez (Castellet, 1970: 111), Félix de Azúa (Castellet, 1970: 138), Pere Gimferrer (Castellet, 1970: 156), Vicente Molina Foix (Castellet, 1970: 186), José Luis Jover (García Moral y Pereda, 1979, 1982: 290-291)... En el caso de estos dos últimos, la reivindicación del surrealismo se hace extensible a su desarrollo en la literatura de posguerra de este país. Es decir, al Postismo. Para Molina Foix, la poesía de los años setenta es heredera de la libertad surrealista, cuyo nexo de unión es la poesía esteticista del grupo Cántico, la poesía postista y la de algunos poetas de transición como José Ángel Valente, Jaime Gil de Biedma, Carlos Barral o Francisco Brines (Castellet, 1970: 186). En términos parecidos se pronuncia Guillermo Carnero, que propone como enlace entre la poesía de los años setenta y la del 27 al grupo cordobés, al Postismo y a autores como Luis Rosales, Carlos Bousoño y Jaime Gil de Biedma (García Moral y Pereda, 1979, 1982: 307). Luis Antonio de Villena define la poesía de los setenta como un rechazo frontal de las poéticas dominantes de la posguerra y como la recuperación de la vanguardia poética y del simbolismo. Para él, la poesía supone una actitud de apertura que trasciende la cultura más cercana e inmediata y, a la vez, que lleva a recuperar las 
poéticas disidentes: la poesía Cántico y el Postismo (Garcia Moral y pereda, 1979, 1982: 385; Villena, 1996: 239). Para Víctor Pozanco (1976: 15-16) la poesía de esta generación posee un signo neobarroco que la une a la poesía del Siglo de Oro, a la de la Generación del 98 y a la vanguardia poética del 27.

Otra constante que une la poesía de esta generación con la poesía oryana es el componente mágico y visionario que convierte la actividad poética en una práctica metafísica y sagrada. Así lo expresa José Luis Jiménez Frontín (Pozanco, 1976: 212), poeta que comparte también la atracción por las filosofías orientales: «El poema, como en los cantos populares, será meditación o no será. Y además, conjuro. Empeño vano, pero quizá único posible y digno de ser vivido a través de la escritura». Esta concepción misteriosa y mágica de la poesía, en cuanto supone un intento de plasmación del misterio de la existencia, es compartida por muchos poetas. Entre ellos, estarían Félix de Azúa, Pere Gimferrer, Jaime Siles o Marcos-Ricardo Barnatán. La poesía no sólo queda transformada en indagación y plasmación del misterio existencial de la realidad, sino que además es música, vibración.

En este sentido Gimferrer y Carnero exploran el valor rítmico que posee la palabra poética, que es, para ambos autores, la base de la estructura del lenguaje poético. Ello supone una reelaboración o relectura de la euritmia ${ }^{67}$ postista, concepto heredado del simbolismo y del parnasianismo, que proponía la exploración lúdica de las posibilidades que posee el especto fónico y musical del discurso poético. La euritmia consistía, en la poesía postista, en la práctica de la asonancia y de la onomatopeya, en la proximidad fónica, en la rima extraña, en los cortes repetitivos y en la reiteración obsesiva. La convergencia entre música y poesía, siguiendo los patrones de la poesía órfica, se halla ya desde un principio en la poesía oryana y, con el transcurso del tiempo, adquirirá un significado metapoético. La poesía, para Ory, es reflexión sobre el poder metafísico y mágico de la palabra, magia simbolizada en la música, elemento de transformación personal, de transmutación de la realidad interior, elemento de expresión de la integración del ser en la totalidad cósmica. En este sentido son pertinentes las palabras de Jaime de Siles, poeta preocupado también por la magia del aspecto musical de la palabra y por la capacidad de desvelar los conceptos que enmascaran una realidad

${ }^{67}$ Chicharro, Eduardo, Primer Manifiesto del Postismo, Revista Postismo, n ${ }^{\circ} 1$, enero de 1945, pp. desplegables 4-5, 12-13. 
infinta y primordial (Pozanco, 1976: 172): «Poetizar es un acto de Realidad y de Lenguaje: transformar los nombres hasta el sustrato primigenio, indagar tras el concepto originario, pulsar el Ser desde lo uno hasta lo múltiple, devolver la realidad a la Realidad». Cristina Peri Rossi se pronuncia en términos distintos, pero con una misma actitud subyacente: «Escribo por amor a todo lo vivo y pasajero, a los seres, que van y vienen» (Pozanco, 1976: 123).

También la poesía novísima posee otra deuda con el Postismo: el humor y la ironía. Hasta entonces, con muy pocas excepciones, como ciertas zonas de la poesía de Jaime Gil de Biedma o de la poesía de Carlos Barral, la poesía de posguerra se había caracterizado por una seriedad extrema. Por ello, poetas de los años setenta, como Jesús Munárriz, José María Álvarez, Félix de Azúa, José Miguel Ullán o Antonio Martínez Sarrión, al rescatar el humor e incorporarlo a la práctica poética recuperan la óptica expresionista y lúdica que ofrecía el Postismo ${ }^{68}$.

A Vietnam se fue mi amor.

Ye, ye, ye...

A Vietnam se fue mi amor.

Luchando lleva ya un año.

Ye, ye, ye...

Y solita quedé yo.

Regresa a bailar conmigo,

haz una tregua de amor.

Regresa en paracaídas, mátame de corazón.

Luchando lleva otro año.

¡Ay del Pentágono!

Y no regresa mi amor.

Llorando paso los días.

¡Ay del Pentágono!

Llorando, mi amor, llorando.

Dicen que la selva tiene

color de sangre y rencor.

${ }^{68}$ Fortuño Llorens, Santiago (2011). Este autor, a colación de un poema satítico de Carlos Bousono titulado «La prueba» en el que la gordura es la prueba de la existencia de Dios, apunta que el humor en la poesía de posguerra surge en los años 1945 y 1956 por parte de la otra generación del 27 , de la propuesta postista y de sus coetáneos, herederos de la vanguardia que propiciarán la aparición del grupo Dau al Set en 1948.

Sobre la otra generación del 27, ver Bruguera y Fortuño ed. (1998), Vanguardia y humorismo. La otra generación del 27, obra cit. en la bibliografía. 
Pero mi amor aún no viene a bailar conmigo el rock.

A Vietnam se fue mi amor.

Ye, ye, ye...

Y se ha pasado al Vietcong.

(José Miguel Ullán, "Lamentaciones de una muchacha yanqui a eso de la medianoche").

La poesía de José Miguel Ullán supone una reivindicación de la propuesta postista en cuanto inicio de la poesía visual. José Miguel Ullán recoge la experimentación poética que se produjo en las zonas interiores del Postismo y próximas a él, tanto en las dos revistas publicadas por el movimiento como en las obras de sus representantes u otros agentes cercanos al movimiento. Como ejemplo cabe destacar el poema titulado «Una y él» ${ }^{69}$ publicado en la revista La Cerbatana (1945) y escrito por Juan Ramón Jiménez. Poema poliédrico de signo experimental en el que se hallan huellas de la lírica tradicional y del proyecto de reactualización de la poesía popular efectuada, llamado también neopopularismo, desde el grupo del 27 por poetas como Federico García Lorca o Rafael Alberti:

- ¡Ayayay, ayayay!

¿Qué es, di tú, sin amor el vivir?

¡Me querría ahora mismo matar!

¡Ayayay!

- Flajinsterio, termifa, cachumbo.

¡Purumpúm, purumpúm, purumpúm!

- ¡Ayayay, ayayay!

¿Qué es la vida, di tú, sin amar?

¡Me quisiera ahora mismo morir!

¡Ayayay!

- Desidelio, flamina, catumpo.

¡Purumpúm, purumpúm, purumpúm!

El poema juanramoniano marca el componente lúdico de la poesía postista, la experimentación fonética, su convergencia con el letrismo. Éste es el territorio poético del que arranca la poesía experimental de José Miguel Ullán.

${ }^{69}$ La Cerbatana, Revista Ilustrada de la Nueva Estética, n 1 y único, Madrid, abril 1945 , p. 7. 
Por último, cabe citar que la pretendida actitud de poeta maldito adquirida por Leopoldo María Panero no sólo supone la actualización del dandismo negador de la moral burguesa o la puesta en escena de la figura esquizofénica de Antonin Artaud, sino que tal propuesta es deudora, en cierta medida, de la imagen que la crítica de la posguerra ofrecía del poeta Carlos Edmundo de Ory.

\subsubsection{El Grupo Marejada de Cádiz}

Otro foco de reivindicación de la poesía del Postismo y del autor Carlos Edmundo de Ory es el grupo de poetas que se aglutina en torno a la publicación Nueva Poesía 1: Cádiz (1976), cuyo prólogo fue escrito por el propio Ory. Se trata de varios poetas que siguen la estela de su maestro, entre ellos se encuentran Jesús Fernández Palacios, Rafael de Cózar, José Ramón Ripoll o Antonio Hernández, cuya obra Metaory (1979) supone un ejercicio intertextual que parte de la obra oryana. De ellos, los tres primeros formaron parte del grupo Marejada de Cádiz (1971). Frente a las ediciones poéticas que se publicaron en esta década en el marco de este país, esta antología señalaba la situación de marginalidad de los poetas no sólo de Cádiz sino de toda Andalucía respecto a los grupos poéticos pertenecientes a espacios centrales como Madrid o Barcelona, rodeados de mecanismos publicitarios más efectivos.

El Grupo Marejada nace el día ocho de mayo de 1971 en el Café Parisien de Cádiz como grupo literario que trata de dinamizar la actividad cultural y, sobre todo, poética, gaditanas. Sus miembros fundadores son Jesús Fernández Palacios, José Ramón Ripoll, Francisco Crespo, Fernando Samaniego, Emilio Martínez, José Ramón Casais y Rafael de Cózar. De esta conjunción surgen una serie de tertulias periódicas que duraron hasta mayo de 1974, dos montajes poético-teatrales, El nacimiento y el niño (1972) y La Orygénesis (1973) y la publicación en 1973 del único número de la revista Marejada. El grupo poético estaba formado por Rafael Damián, Francisco Lorenzo Munoz, Manuel Fernández Bago, Alfonso Sánchez, Francisco Sánchez y los tres poetas que conforman el núcleo duro del grupo: Jesús Fernández Palacios, José Ramón Ripoll y Rafael de Cózar. Su propuesta supone una poesía libre, de signo vanguardista. Poesía que rechaza de pleno la territorialidad realista y se define como continuación de la propuesta postista en cuanto voluntad experimental y apertura hacia la poesía concreta y visual. El grupo 
Marejada mantuvo vinculaciones y conexiones con publicaciones interesadas en la experimentación poética como Fablas, Artesa, Trece de Nieve, Problemática 63, Deucalión o Poliedros. Sustancialmente el territorio poético que establece la propuesta de Marejada enlaza con la poesía andaluza más vanguardista de la Generación del 27, el surrealismo heterodoxo de Juan Larrea y la poesía de dos poetas andaluces de posguerra: Fernando Quiñones y Carlos Edmundo de Ory, poetas ambos que apoyaron la actividad del grupo.

El primer contacto con Ory, que vivía su retiro en su cabaña de Amiens, fue protagonizado en 1971 por Jesús Fernández Palacios, poeta al que unirá una intensa amistad con el maestro, y Fernando Samaniego. Sorprendidos por la antología preparada por Félix Grande, solicitaron a Ory una colaboración para las páginas culturales del Diario de Cádiz, a lo que Carlos Edmundo de Ory respondió mandando un poema «Ovario materno», que se publicó el 25 de abril de este año (Lanza y Téllez, 1996: 39). A partir de aquí surgió una estrecha relación entre los integrantes del grupo y el poeta maestro. El 14 de agosto del mismo año algunos miembros del grupo se reúnen con el poeta autoexiliado para realizar una lectura de algunos de sus poemas más recientes (contenidos en Música de lobo, Técnica y llanto y Poesía 1945-1969). En el Diario de Ory queda registrada esta intensa amistad con algunos poetas del grupo, sobre todo, con Jesús Fernández Palacios, Rafael de Cózar y José Ramón Ripoll. El 14 de septiembre aparece la primera mención hacia el grupo (Ory, 2004, Vol. II: 279), se trata de unos comentarios sobre la carta mandada por Israel Sivo, heterónimo de Jesús Fernández Palacios, donde le dedica el poema «Treinta monedas de pus» ${ }^{70}$. En él se hallan contenidas muchas referencias compartidas por ambos poetas, y por extensión compartidas también por la totalidad de Marejada: el interés por el pensamiento heterodoxo, el ataque al racionalismo como ideología que define a la civilización occidental, la presencia del hinduísmo, de la experiencia dionisíaca, de la psicodelia o de la actitud bohemia y combativa de los poetas beat. Al igual que en la poesía oryana, en este poema, y en toda la poesía de Fernández Palacios, se han suprimido los signos de puntuación.

ME asomo al cesto de los papeles

31 Mayfiel Road veo flores

${ }^{70}$ Nueva poesía 1: Cádiz, obra cit. en la bibliografía, pp. 129-130; Lanz y Téllez (1996: 96-97); Poemías, Sevilla, Ediciones en Huída, pp. 19-20. 
en Sutton veo dos flores rosadas La matrona es una furcia cascarrabias gruñe grita le duele la tiroides escupe la mierda del cóndor y luego pide perdones violetas En el cesto de los papeles hay un hospital en Londres dos topos que escarban la tierra -libertas rara avis estUnos jóvenes cubiertos de pieles rezan drogan ríen bailan extasian Omar Iben Ibrahim el Khaiami mercader vende su nacimiento por un vaso de vino La religión Hindú sin drogas fuentes de inagotables especies ecos el mundo se está destruyendo a pesar del llanto de las madres dos soldados se besan en la frontera Rómulo Remo La Loba Capitolina sangre sangre sangre sangre sangre -dos mil años de cultura de pusse coagula en mundo por el frío Trajes largos sofisticados celestes Hombre con ojos de hormiga baila se arodilla agita las manos corta el aire el silencio la mueca Las Brevas Se habla español a tientas Vuelve a tu interminable Avenida enciérrate en el Yo de todos los hombres Ciegos Ciegos Ciegos Ciegos Ciegos Se resbala el hashish cucarachas Bob Dylan La conciencia cósmica un niño como oruga encima del Eje Howl aullidos de los Allen Ginsberg de los Gregory Corso de los Ferlinghetti de los Jack Kerouac de los Whitman Tienen destrozados los tendones Dumbo La Virgen Torquemada El Ladrón Las vibraciones mágicas genéticas Harold Lloyd Emily Brontë Tobias Brutales borracheras cara marcada arrugas en el cuello bajo los pelos dos cicatrices la sandía se desliza Llantos histéricos Desesperación Hermenéutica sine nómine vulgus Pan espacial para los que desfallecen Los gladiolos se están marchitando. 
La poesía de Jesús Fernández Palacios, al igual que la oryana, sigue las pautas de la escritura improvisada, loca y arrolladora, propuesta por los beatniks. Escritura que se define por la velocidad, por ser una descarga incontrolada de imágenes que se suceden a modo de monólogo interior o automatismo. Fue Jack Kerouac quien propuso en su primera novela, On the road (1957), esa prosa enérgica y acelerada, a la que la crítica llamó estilo bop por su paralelismo con el jazz y sus ritmos improvisados. Prosa que se halla mediatizada por la experiencia con la benzedrina ${ }^{71}$. Esta misma escritura lunática, escrita casi sin mediatización del pensamiento, visceral y visionaria es la que se encuentra en la poesía de los poetas beats. La atracción por la poesía beat es un eje que une a los poetas del grupo Marejada, sobre todo a Jesús Fernández Palacios, con la poesía de Carlos Edmundo de Ory.

Por otra parte, algunos de estos poetas se convirtieron en críticos y estudiosos de la poesía postista y en verdaderos elementos de difusión de la obra de Carlos Edmundo de Ory y de la literatura postista. En este sentido, cabe señalar la labor de Rafael de Cozar, gran estudioso de la poesía visual, del postismo y de la poesía oryana. Jesús Fernández Palacios también ha dedicado gran parte de sus energías al estudio, a la difusión y a la edición de la poesía oryana. En 1984 publica en Los Cuadernos del Norte una entrevista con Carlos Edmundo de Ory (1984: 119-124), que más que una entrevista usual es una conversación entre amigos. En ella se habla de las constantes de la obra oryana, de su relación con los beatniks, de la mística no monoteísta, de la herencia postista... En estas líneas el poeta define su poesía como una meditación más allá del lenguaje conceptual: «crisis del lenguaje de la experiencia normal» (Fernández Palacios, 1984: 124). En 1987, Jesús Fernández Palacios coordina, en los Cursos de verano de la Universidad de Cádiz en San Roque, las jornadas Érase una vez...EL POSTISMO $^{72}$. En ellas Jaume Pont, Rafael de Cózar y el propio Carlos Edmundo de Ory impartieron conferencias sobre el movimiento, se celebró un recital de poesía en el que intervinieron, entre otros, Antonio Chicharro (el niño Toni que dibujaba en la revista Postismo, hijo de Eduardo Chicharro y Nanda Papiri) y el propio Ory, así como una exposición de diversos documentos del movimiento.

${ }^{71}$ La benzedrina es uno de los tipos de anfetamina como la simpatina, la profamina, la centramina, la dexedrina...

${ }^{72}$ San Roque (Cádiz), Colegio Público Maestro Gabriel Arena, 15-17 de julio, 1987. 
En 2001, Jesús Fernández Palacios edita y coordina, junto a Jaume Pont, Carlos Edmundo de Ory. Textos críticos sobre su obra ${ }^{73}$, obra que recoge desde textos clásicos de Félix Grande, Eduardo Chicharro, Lasse Söderberg o José Manuel Polo de Bernabé a otros nuevos de amigos y críticos oryanos como los propios editores, Francisco Nieva, Francisco Ruiz Soriano, Rafael de Cózar, Victoria Cirlot, María Isabel Navas Ocaña... En 2004 Jesús Fernández Palacios y José Ramón Ripoll dedican unos Documentos $^{74}$ a Carlos Edmundo de Ory. En ellos se encuentran artículos de los llamados críticos oryanos: Francisco Nieva, Jaume Pont, José Manuel Caballero Bonald y Rafael de Cózar... Aparecen también algunos poemas y aerolitos inéditos y parte de la relación epistolar del autor con Juan-Eduardo Cirlot, Gabriel Celaya, Roberto Bolaño, Jesús Lizano o Arcadio Pardo. Todo ello ilustrado con dibujos de la compañera de Ory, Laure Lachéroy. Este mismo, año Jesús Fernández Palacios prologa y edita el diario completo de Carlos Edmundo de Ory, del que anteriormente se habían publicado algunos extractos, Diario (1944-2000). También este mismo autor prologa la obra póstuma de Ory que sale al mercado poco después de la muerte del poeta, La memoria amorosa (2011), obra que consta de diversos fragmentos de prosa poética y que significa una mirada retrospectiva al itinerario íntimo del propio autor.

\subsubsection{La Orygénesis}

La Orygénesis es el segundo de los dos montajes poético-teatrales que el grupo realizó. El primero es El nacimiento y el niño, que se inauguró el 27 de enero de 1972 en el Colegio Oficial de Médicos de Cádiz. La propuesta consistía en la unión de poesía, música y montaje teatral bajo los parámetros de un espectáculo total, nada exento de crítica social. Sobre la base narrativa, representada por el crecimiento humano y las etapas de la vida, que articula la estructura de la obra, se intercalan poemas de poetas como Miguel Hernández, Rafael Alberti, Pablo Neruda, César Vallejo, Ángel Leiva, Manuel Pacheco, Iván Gerardo Campanioni o Alfred Edward Housman.

La Orygénesis supuso la continuación del montaje anterior, pero centrada ahora en la figura del poeta Carlos Edmundo de Ory. En cierto modo se trataba de la

\footnotetext{
${ }^{73}$ Fernández Palacios y Pont (2001).

${ }^{74}$ Documentos Carlos Edmundo de Ory, Separata de la RevistaAtlantica, Cádiz, n 27, 2004.
} 
realización de un homenaje con motivo del cincuentenario de su nacimiento, pero se trató de una total reivindicación de la poesía, transgresora, heterodoxa, visionaria, metafísica y mística, de este autor. Ello confiere al espectáculo un aspecto totalmente vanguardista. Si El nacimiento y el niño transmitía la preocupación político-social del grupo, La Orygénesis expresaba su voluntad vitalista y experimental. La obra, bajo la dirección de Jesús Fernández Palacios, se estrenó el 25 de mayo de 1973 en el Colegio Mayor Chaminade de Cádiz. Se trata de una puesta en escena experimental siguiendo los pasos del teatro vanguardista o underground de la época. El espacio escénico tradicional queda abolido, sustituido por un escenario multiple. Dos microespacios se conectan por un pasillo, de manera que el público, sentado en sillas, rodea completamente el espacio teatral. Queda así eliminada la distancia entre actor y público, elemento que posibilita la interconexión. El montaje toma la apariencia de un happening permanente, a la manera de las disparatadas acciones postistas, donde se mezcla la música del sitar de Raví Sankar con poemas (entre ellos poemas y romances postistas), textos, aerolitos o cartas del propio Carlos Edmundo de Ory y con canciones y poemas-homenaje, escritos por otros autores. Los demás elementos teatrales, como el maquillaje, el vestuario, las máscaras, la iluminación... apuntan a resaltar el carácter mítico de la representación, que (en cierto sentido y bajo el prisma de la distorsión) se acerca a la tragedia clásica.

La Orygénesis representa el universo mítico y particular del propio Carlos Edmundo de Ory y persigue que el público se sienta envuelto en la realidad representacional y vital del poeta. Los personajes encarnan los distintos yoes, o perspectivas, que forman el yo plural oryano: Bufón Orygénico, Oralma, Cuérpory, Sexóry, Corazonory, Nécrory, Mentedmundo o Puéblory, personaje colectivo este último. La obra intenta representar fragmentos de la poética oryana.

\subsubsection{Otras reivindicaciones.}

Otras reivindicaciones de la poesía postista han venido de otros ámbitos poéticos dispares, como el grupo poético-musical de rock progresivo Hovno de Santa Cruz de Tenerife, del que era partícipe Félix Francisco Casanova Martín, hijo del poeta postista Féliz Casanova de Ayala, que murió en 1976 a los veinte años. Se trata de un poeta 
maldito que se sitúa en la línea de Rimbaud, Baudelaire o Lautréamond. Su novela experimental El don de Vorace (1975) rompe con todos los clichés narrativos.

Otro grupo que reivindica la herencia del Postismo, es el Peismo, movimiento que surge en 1978 con sede en Valencia. En su manifiesto, publicado en su órgano publicitario y teórico, el grupo se define como continuador y actualizador del Postismo: «El Peismo continúa la línea dada en el plano surrealista en el espacio postista añadiendo una nueva dimensión a la estética: la paranoia industrializada ${ }^{75}$. Detrás del movimiento se hallan poetas como Francisco Cabezas, Ricardo Usón, Alfredo Usón, Juan Vicente Piqueras o Rafael Navarro.

También se proclama, desde 1975, continuador del Postismo el grupo de Mataró dedicado a la poesía visual dirigido por Juan Manuel Calleja. Otro heredero del Postismo es el poeta y crítico postista Amador Palacios, seguidor de la poesía de Ángel Crespo y Carriedo y autor de Ejercicios de versificación (1979) ${ }^{76}$. Para él la poesía de herencia postista hay que situarla en la Escuela de poesía La Camama ${ }^{77}$, grupo integrado por autores como José del Sanz Orozco, Manuel San Martín, Carlos Asorey o Luis Lloret.

Se define también artista postista el pintor, crítico de arte y escritor Antonio Beneyto $^{78}$ que dirigió la colección barcelonesa Esquina, donde publicaron autores como Joan Brossa, Juan Eduardo Cirlot, Carlos Edmundo de Ory...

${ }^{75}$ Manifiesto, «Novedades Técnicas e Industriales», Boletín $n^{\circ} 3$, Valencia, 1978; se cita en Jesús Férnandez Palacios (1984).

${ }^{76}$ Palacios, Amador (1979), Ejercicios de versificación, Cuenca, El Toro de Barro; (1991), Jueves Postista, obra cit. en la bibliografía.

${ }_{77}$ Saz Orozco, José del, San Martín, Manuel y Asorey, Carlos (1982), La Camama. Escuela de Poesía. Manifiesto y Poemas, Cuenca, El toro de Barro.

${ }^{78}$ Beneyto, Antonio (1974), Algunos niños, empleos y desempleos de Alcebate, Madrid, Lumen. 


\section{TRASCENDENCIA DEL POSTISMO}

Ángeles o círculos radiantes.

Ángeles cantando en mis labios.

Juan Eduardo Cirlot

Después de haber desbrozado y explorado el territorio poético de la posguerra y tras haber delimitado el espacio donde se sitúan las diferentes corrientes poéticas, los grupos y los movimientos, después de haber sobrevolado por esa tierra de nadie donde se efectúan las conexiones, a veces durante espacios dilatados de tiempo, queda por establecer lo que significó el punto de inflexión que se produjo en la primera posguerra con la gestación del Postismo.

\subsection{Aperturas}

Por una parte, este movimiento de carácter poético y pictórico supuso el enlace, a contracorriente, de la poesía de posguerra con los hallazgos de las poéticas de Vanguardia. El Postismo quedaba definido en sus manifiestos ${ }^{79}$ como un movimiento de signo surrealista, dadaísta y expresionista, pero además significaba el enlace de una territorialidad poética, instalada en la marginalidad, con la poesía de signo irracionalista que surgió en el inicio de la Modernidad bajo el signo romántico y simbolista. Por otra parte, la irrupción de la propuesta postista significa el punto de partida de la poesía vanguardista de posguerra y coincide con el desarrollo de la vanguardia poética que, a

${ }^{79}$ Chicharro, Eduardo, Primer Manifiesto del Postismo, Rev. Postismo, Madrid, Gama Artes Gráficas, Madrid, 1945, pp. 4-5 y 12-13; esta publicación también se encuentra en edición facsímil en la Rev. Poesía, separata del n² 2, Madrid, 1978.

Chicharro, Eduardo, Ory de, Carlos Edmundo, Sernesi, Silvano, Segundo Manifiesto del Postismo, Rev. La Estafeta Literaria, número extraordinario, Madrid, 1946.

Chicharro, Eduardo, Tercer Manifiesto del Postismo, El Minuto, n 1, II Época, suplemento del diario La Hora, Madrid, 1947.

Chicharro, Eduardo, Ory de, Carlos Edmundo, Cuarto Manifiesto del Postismo, 1948; documento inédito hasta la publicación de Eduardo Chicharro (1974), Música Celestial y otros poemas, Ed. de Gonzalo Arnero, Madrid, Seminario y Ediciones, Trece de Nieve.

Los manifiestos se encuentra tambíen en Carlos Edmundo de Ory (1970), Poesía (1954-1969), ed. de Félix Grande; en Eduardo Chicharro (1974) y en Jaume Pont (1987). Obras cit. en la bibliografía. 
nivel mundial, se metamorfosea después de la guerra mundial en una poesía de signo visual, que surge de la unión de todas las expresiones artísticas como un hecho total y colectivo y cuyos representantes más destacados serían: Isidoro Isou desde el letrismo, Decio Pignatari, Augusto de Campos, Oyvin Falhatröm o Eugen Gomringer desde la poesía concreta, Pierre Garnier desde el espacialismo, Allan Kaprow, Jonh Cage y el grupo Fluxus, precursores de happenig y de la interdisciplinariedad artística, Joseph Kosuth desde la poesía conceptual y Martino Oberto desde la poesía semiótica...

De todas formas, la práctica poética propuesta por el Postismo significó la demolición del edificio realista que constreñía al lenguaje poético entre sus estrechos márgenes. El Postismo significó la liberación de la imaginación, la explosión de la subjetividad reprimida, la búsqueda de los elementos oníricos, el rescate del humor y de la irreverencia... Todo ello conducía a la práctica de una poesía libre y salvaje, una poesía que otorga plenos poderes a la palabra, que se convierte en transgresión de toda normativa oficial, que busca hacer estallar el lenguaje. En suma, el Postismo realizó una labor de demolición y de reconstrucción del lenguaje poético. Amplió los límites de la poesía y legó para la posteridad un lenguaje poliédrico y experimental. Sin saberlo, significó una apertura a la poesía que se escribía en el exterior y, en algunos casos, fue el elemento precursor de varios movimientos. Para Amador Palacios, el Postismo fue una bomba atómica que produjo varias reacciones en cadena que llegan hasta la actualidad. Para este autor Julio Cortázar sería, sin saberlo, un perfecto postista; como lo fue, sin duda, en el pasado Ramón Gómez de la Serna (Palacios, 2001:183-184).

De las prácticas poéticas postistas surge la poesía de tendencia surrealista, de signo mágico, desarrollada por Ory, Cirlot o Crespo, que desemboca en la poesía de los años setenta y en el underground, poesía que ultimamente es reactivada por algunos poetas de la generación del 2000. El Postismo significó el compromiso de la poesía con el propio lenguaje, hecho que conllevaba que la poesía se desprendiera de otros compromisos. Tal actitud fue acogida y nuevamente articulada por la poesía veneciana de los poetas novísimos, cuya actitud nace de un nuevo postulado: la imposibilidad de la poesía para cambiar el mundo. 


\subsection{Convergencias con la Beat generation}

El Postismo subvirtió el lenguaje del poder, tanto de la oficialidad como de las poéticas realistas preocupadas por la transformación social. Por ello este movimiento sufrió la prohibición, la censura y el silencio y quedó desterrado a la zona exclusiva de la marginalidad. El Postismo, como actitud vital, rechazaba los valores imperantes de la burguesía, tanto las representaciones triunfalistas del régimen fascista como los programas del realismo socialista que intentaba combatir la opresión del régimen y establecer la lucha política. La postura de los postistas era la actitud de disidencia y de no colaboración con el sistema político, social y cultural que establecían las coordenadas temporales. Por ello se revalorizaba la propuesta bohemia de los poetas simbolistas franceses, de algunos pintores impresionistas y de los artistas decadentistas y modernistas que rechazaban de pleno los valores de la vida burguesa. En este sentido, el Postismo mantiene sus convergencias con la actitud rebelde de los poetas de la Beat generation americana.

La propuesta marginal de Carlos Edmundo de Ory y su ruptura con la sociedad española trazada, en su exilio voluntario a Francia en 1955, coincide con la trangresión de los poetas americanos. Ya en 1951 Ory publica junto al pintor Darío Suro Nuestro tiempo: pintura. Nuestro tiempo: poesía, texto considerado como el Manifiesto del Introrrealismo integro. En él se proclama un arte y una poesía de signo interior, metafísico y místico. Resulta muy interesante, pues, la coincidencia de las fechas en las que se inicia la revuelta beat.

En 1944, un año antes de la irrupción del Postismo, William Burroughs conoce a Jack Kerouac y a Allen Ginsberg y los anima a ser escritores. En 1948 Jack Kerouac acuña el término Beat Generation. Beat significa, por un lado, la libertad y la improvisación de los ritmos bohemios y salvajes del jazz y del be-bop, y, por otro, la expresión viene de la visión beatífica. Libertad y beatitud, parámetros ambos que definen la poesía beatnik. En 1951 Jack Kerouac y Neil Cassady realizan el viaje perpetuo hacia ninguna parte de los Estados Unidos que inaugura el modo de vida beat. El texto que transcribe esta experiencia de una manera radicalmente novedosa entre la escritura automática, la improvisación naïf y la ruptura del realismo es la novela En la carretera, que ningún editor se atreve a publicar hasta 1957. En 1953 Burroughs publica 
su primera novela Junkie. En 1956 Allen Ginsberg lee, junto a otros poetas como Gary Snyder, Philip Lamartina, Philip Whalen, Michael McLure y Kennet Rexrot, el poema «Aullido» en la Six Gallery de San Francisco. Este evento marca el inicio de la poesía beat. En 1957, Burroughs, después de matar accidentalmente a su mujer, se traslada a Tánger y en plena adicción a la heroína escribe El almuerzo desnudo, obra que hace estallar las normas dogmáticas de la narrativa. En 1958 Kerouac publica Los vagabundos del Dharma, obra que significó una vía de acercamiento al budismo zen y al taoísmo. En 1964, Ken Kessey formó el grupo llamado Los alegres bromistas. Sus integrantes realizaron un viaje desde California a Nueva York al estilo beat, esta vez experimentando con L.S.D., en un autobús pintado para saludar a Jack Kerouac. Tom Wolfe relata este viaje en su obra Ponche de ácido lisérgico en 1968, año en que la revuelta beat ya está consumada y sobreviene la irrupción de la contracultura. Este es el año en el Carlos Edmundo de Ory crea el Atelier de Poésie Ouverte ${ }^{80}$ en la Maison de la Culture de Amiens.

La poesía beat y la poesía oryana convergen plenamente en una serie de puntos. En primer lugar, ambas proponen una poesía libre, salvaje, experimental, que busca vías alternativas al discurso del racionalismo burgués, una poesía lunática que se acerca a la inocencia de la niñez, una poesía de signo oral que sea un grito. Pero tambíen se trata de una poesía meditativa, metafísica, visionaria a la manera de William Blake, ebria y mágica $^{81}$. Si los poetas beat reivindicaron el taoísmo y el budismo, sobre todo el budismo zen, la poesía de Ory desde la aventura introrrealista queda constituida como metanoia, una permanente trasformación alquímica interior, esta poesía presenta la orografía de un proceso de iluminación. Como los poetas beat, la poesía oryana se acerca también a las tradiciones orientales: hinduismo, taoísmo, tantrismo, budismo mahayana y budismo zen. Ya el Postismo reivindicó el primitivismo artístico o actitud naïf y el acercamiento a una estética organicista en consonancia con una realidad fluida, también incorporó aspectos de la lógica paradójica del budismo zen. Ory exploró otros territorios heterodoxos como las filosofías de la antigüedad pagana, el sufismo, la mística cristiana, la alquimia y el ocultismo. Carlos Edmundo, por su actitud de rechazo de los espacios oficiales y de los valores culturales establecidos, fue considerado en gran poeta bohemio, el gran heterodoxo, el poeta automarginado y marginal, el poeta

\footnotetext{
${ }^{80}$ Ver Fernández Palacios (1986).

${ }^{81}$ Ver Kerouac (1970: 7), «Los orígenes del gozo en poesía».
} 
más raro de la posguerra española. La poesía oryana se acerca también a los territorios de la contracultura y supone la continuación de la línea subterránea que atraviesa la zona crítica del pensamiento occidental representada por William Blake, Friedrich Nietzsche, Gerard Nerval, Charles Baudelaire, Arthur Rimbaud, Walt Whitman, Tristan Tzara, André Breton, Paul Éluard, Boris Vian, Wilhem Reich, Herman Hesse, Georges Bataille, Antonin Artaud, Henry Michaux, Norman O. Braun, Carlos Castaneda, Ken Wilber, Gilles Deleuze... y se manifiesta como el viaje perpetuo de un maestro errante, loco y visionario, a través del misterio de la existencia.

Podríamos decir que la actitud postista prefigura la actitud rebelde y trasgresora de la Beat generation y que Carlos Edmundo de Ory fue asimismo un poeta beat, tal como lo consideró su amigo y colaborador Allen Ginsberg. En el Diario (1976-2000), correspondiente al tercer volumen, de Ory (2004: Vol. III, 302-303) tenemos un testimonio de esta amistad:

Copio aquí un parráfo de una carta que me escribe Jesús Fernández Palacios, fechada en Cádiz, 26.12.93, a propósito de un recital de Allen Ginsberg en Madrid, últimamente:

«José Ramón fue al recital de Madrid y me contó que estuvo interesantísimo. Ya te contará Ripoll: hablaron y J.J.R. le enseñó la Revista y le dijo que íbamos a publicar tus traducciones. Le gustó la Revista y dijo que tú eras el único, el mejor poeta beat de España. Estuvo simpático».

Con que yo, poeta beat. No está mal la definición. Esto me recuerda lo que a mí me dijo el mismo Ginsberg en Nueva York, después de escuchar mis poemas en un recital que di en Gas Station, la noche del 31 de octubre de 1987. Me dijo: - Tenemos el mismo élan (creo que me dijo élan, significando arranque o impulso, o ímpetu, o entusiasmo). Luego, me comparaba con su propia poesía. Ambos somos aventureros espirituales buscadores de la «X» mística. Holísticos, tántricos, budistas y gestaltistas del «totalismo místico». 
II. LA GEOGRAFÍA ACCIDENTADA DEL POSTISMO 


\subsection{INICIO DE LAS POÉTICAS TRAS EL DESASTRE}

Y no habrá uñas sin besos ni heridas sin alivio para esta sed de peces y de alondras doradas.

Carlos Edmundo de Ory

Tras la guerra, abatido el país por la cruzada de liberación nacional, queda un páramo devastado: tabula rasa cultural, desertización extrema provocada a sangre y fuego, exterminio del enemigo pasado por el filtro ideológico. Fusilamientos, cárcel, ignominia, infamia, exilio, silencio. El triunfo del ejército fascista trae consigo el establecimiento de un totalitarismo de referencias imperiales y la restauración del segundo imperio español que nace sobre las cenizas de las hordas socialistas, comunistas, anarquistas, masónicas, nutridas de otros agentes de distorsión social. Enemigos todos de los valores tradicionalistas que conformaban el espíritu de la cruzada imperial capitaneada por el Generalísimo Francisco Franco, autoproclamado Jefe de Estado o gran dictador. La dinámica de la represión conlleva el silencio cultural y el exterminio del enemigo. Ello implica, a nivel literario, la condenación de la vanguardia, la excomunión total de todo aquello relacionado con los oníricos y oscuros deseos freudianos, el atrincheramiento ante el surrealismo vinculado con el comunismo, el 
ataque a toda experimentación dadaísta o cubista relacionada con la idea de terrorismo libertario y cultural, el exterminio de toda literatura de signo combativo o políticosocial. La intelectualidad resulta sospechosa. Pablo Neruda, Pablo Picasso, Luis Buñuel, Rafael Alberti y una extensa nómina de artistas e intelectuales consiguen el estatuto de figuras malditas para el nuevo régimen. Estas coordenas marcan una ruptura radical con la geografía cultural de la República, hecho que se traduce en un vacío total de actividad intelectual.

En la geografía poética, el silencio se va fracturando desde varias grietas que permiten la expresión poética, unas más cercanas al poder y otras más marginales. Estas grietas, que resquebrajan el silencio poético y que surgen al mismo tiempo en diferentes lugares, abarcan todo el espacio ideológico y demarcan su propia territorialidad alrededor de una serie de publicaciones. Son las revistas literarias el espacio desde el que irrumpe la poesía en la zona de devastación. La revista es el tipo de publicación más o menos autogestionaria que puede surgir en un sistema totalitario que intenta silenciar toda expresión cultural considerada como peligro o subversión. Algunas publicaciones tuvieron el apoyo institucional, otras la mirada de la sospecha dirigida hacia ellas. Lo cierto es que la censura permitió, hasta cierto punto, la proliferación de estas publicaciones con el afán de tener su control. Ahora bien, cuando el poder tuvo que intervenir, ello se hizo de forma taxativa: censura, prohibición y silencio. Cabe citar la situación de escándalo y revuelo social suscitados por la edición de la revista Postismo y su continuación La Cerbatana. Uno de los artículos publicados en estas páginas y firmado por Eduardo Chicharro, se titulaba «Nos echan de la poesía» ${ }^{82}$, título sintomático donde los haya. Y en él su autor anotaba en clave simbólica los motivos de la cesura sufrida:

Porque nosotros obramos sin retórica, porque nosotros obramos sin cálculo y sin medida, porque somos inocentes y sin resquemor ni aparente celo, porque no nos apercibimos al choque, porque sacamos a la luz de las más duras sombras nuestra Hoja, entera y no parcelada, enhiesta y no sesgada, amplia como mantel o sábana y con su mismo perfume de ellos de limpieza y aire; porque sólo con amor emprendemos la ruta, atacando su aspereza a golpe de verso candente y su sinfín más bien con el paso cansado de quien anda ya firme. Por eso dicen pisamos la Ley, sembramos malos instintos y sentamos piedra de escándalo. Y por eso nos echan de la Poesía [...]

\footnotetext{
${ }^{82}$ Rev. La Cerbatana, publicación cit p. 4.
} 
Errabundos iremos cuando se nos cierren las puertas del Parnaso con el letrero de «Reservado el derecho de admisión» [...]

¡Alejados, arrojados de la Poesía, eso seremos! Pero, y digo yo: ¿tanta sombra les hacemos? ¿Tanto estorbamos su patoplano andar? ¡Qué equivocados van! Otro rumbo llevamos, que lo suyo de ellos no nos atañe. Los desconocemos, pero ellos parecen no creer desconocernos a nosotros. Por eso nos echan, porque en sus sentimientos, los pobretes, no pueden ignorarnos ni cubrirnos de su desprecio. ¡Y bien fácil les sería, ellos que tan dados son al desprecio!

La revista literaria, debido a su pequeño circuito de difusión, era el espacio perfecto para la expresión de la poesía prohibida o exiliada. En sus páginas podían aparecer textos de Pedro Salinas, Rafael Alberti o Juan Ramón Jiménez junto a otros poetas extranjeros prohibidos sin que ello comportase ningún efecto de relevancia social. En la revista Espadaña se publicaron las «Nanas de la cebolla» escritas en la cárcel por Miguel Hernández. Poemas que gracias a Antonio Buero Vallejo pudieron escapar de la penitenciaría y salir a la luz pública. Revistas como Insula (1946) o Índice (1945) significaron el enlace con la poesía exiliada. También estas publicaciones suponían la existencia de un espacio para la experimentación y un enlace con la vanguardia más radical. En sus publicaciones el grupo postista marcó un gesto rupturista, radical y enérgico, con la expresión poética coetánea a la manera del grupo dadaísta de Zurich y del grupo surrealista de París. Gesto vanguardista que supone el inicio de la segunda etapa del surrealismo peninsular, dotado, a diferencia del surrealismo anterior a la guerra civil, de elemento teórico siguiendo los pasos de la vanguardia europea. Las revistas significaban también un espacio de apertura hacia el exterior, un punto de contacto con las prácticas poéticas coetáneas extranjeras. También espacio de difusión, de intercambio y de expansión de las poéticas establecidas bajo la dictadura en todas sus direcciones. Las revistas a su vez funcionaban como elemento dispersor de las prácticas poéticas y como elemento teórico. En sus editoriales, proclamas, manifiestos, declaraciones... aparecía el discurso teórico de las diferentes direcciones poéticas.

Si en Garcilaso aparecen las bases del discurso poético del poder, la propuesta poética que aparece en las páginas de Corcel se desmarca del tradicionalismo patriótico $\mathrm{y}$, partiendo del surrealismo de signo aleixandrino, se acerca a la territorialidad humanizada. En en número seis de la Revista Cisneros, editada en el Colegio Mayor 
Cisneros de Madrid, Antonio González de Lama ofrecía las tres constantes que definirán el proyecto poético propuesto por Espadaña: la supremacía de lo humano frente a lo poético, el lenguaje directo frente a la retórica de la vaciedad, y, finalmente, la preocupación por la transmisión del contenido. En las revistas del grupo Postista es donde la proclama, la declaración de intenciones y el manifiesto toman un talante más importante y radical, siguiendo los modelos ofrecidos de las publicaciones vanguardistas europeas como Les Soirées de Paris (1912) dirigida por Guillaume Apollinaire, Dada (1917) auspiciada por Tristan Tzara y 391 (1917) por Francis Picabia $^{83}$, Les Champs Magnétiques (1919) de André Breton y Philippe Soupault, las revistas dirigidas por el grupo surrealista Littérature (1919), La Révolution surréaliste (1924), Minotauro (1933) y Documents (1933) dirigida por Georges Bataille; o de publicaciones escritas en castellano, tanto en el ámbito peninsular y en el americano, como Perseo (1919), Reflector (1920) dirigida por Guillermo de Torre, VLTRA (1921), Prisma (1922), Proa (1922) dirigida por Jorge Luis Borges y Macedonio Fernández, Creación (1924), Martín Fierro (1925) fundada por Eva Méndez, Plural (1925)... o en catalán como Un enemic del poble (1917) editada por Joan-Salvat Papasseit o en portugués como Orfeu (1915).

Por otra parte, lo que caracterizó a las revistas poéticas de la primera posguerra fue el eclecticismo. Aunque cada publicación marcó las líneas territoriales que articulaban la geografía poética, en sus páginas se ofrecía un espacio a poetas situados en otros márgenes. Tal vez fue Cántico la revista más alejada de ese espacio común. Las revistas Corcel y Proel marcaron ese espacio ecléctico que aglutinó a la mayoría de poetas que vivían en el franquismo y escribían una poesía realista y humanizada, poetas a los que la crítica ha otorgado la etiqueta de la Quinta del 42. En ambas revistas escribieron José Hierro, José Luis Hidalgo, José Luis Cano, Carlos Bousoño, Rafael Morales o Vicente Gaos. También publicaron poetas con trayectorias anteriores a la poesía de posguerra como Gerardo Diego o Vicente Aleixandre.

${ }^{83}$ En Barcelona se concentró un grupo de artistas vanguardistas, de signo dadaísta, que huían de la participación en la Primera Guerra Mundial. Allí estuvieron Francis Picabia, Artur Cravan, Marie Laurencin, Max Goth, Otto Lloyd, Max Jacob... Como resultado de todo ello surgió en enero de 1917 el primer número de la revista 391. En Barcelona sólo se publicaron cuatro números de la revista, escrita en francés. La redacción y la administración estaban domiciliadas en las Galerías Dalmau. La revista se editó posteriormente en Nueva York de la mano de Francis Picabia y Marcel Duchamp. 
Ahora bien, la red establecida entre las diversas poéticas creó un espacio plural que permitía el trasvase de las líneas. Así en Cántico publicaron el poeta garcilacista por excelencia Jesús García Nieto y también el poeta más heterodoxo, Carlos Edmundo de Ory. En Espadaña publicaron poetas paradigmáticos de la vanguardia como Juan Eduardo Cirlot, Carlos Edmundo de Ory o Gabino Alejandro Carriedo junto a representantes de la poesía más tradicional como Dionisio Ridruejo (en un primer momento), José García Nieto o Luis López Anglada. En Postismo apareció un caligrama escrito y acompañado por una tarjeta triangular, imitando a la utilizada en la presentación de la revista y del movimiento, con los nombres de sus autores, Rafael Montesinos, José María Valverde y Jesús Juan Garcés, poetas cuya poesía se hallaba bastante alejada de los derroteros vanguardistas. Este último publicó en La Cerbatana sus Poemas primitivos para ángeles, poética que se erige como elemento precursor del concretismo poético. También Juan Ramón Jiménez publicó el poema «Una y él» siguiendo unos parámetros parecidos. Para Carlos Edmundo de Ory, estos poetas, cuya procedencia nada tiene que ver con el movimiento de la Nueva Estética, forman, en cierto sentido, parte del Postismo. Acerca del primero Ory nos dice, en La historia del Postismo (Grande, 1970a: 270), que: «este oficial de Garcilaso se alejó de sus cuarteles para pedir entrada en nuestro manicomio. Nos traía sus «Poemas primitivos para ángeles» y le dejamos pasar».

Para Félix Casanova de Ayala, como nos dice en 1964 en su «Teoría y práctica del postismo», Jesús Juan Garcés es «un garcilacista recién incorporado al postismo» (Pont, 1987: 542). A Juan Ramón Jiménez, Ory lo describe como «un elegíaco panteísta andaluz» y escribe de él lo siguiente en su Historia del postismo (Grande, 1970a; 267):

Yo no tengo nada que ver con Juan Ramón (salvo una influencia natural adolescente), lo que no es óbice para que Juan Ramón hiciera «postismo», sin saberlo yo; Juan Alcaide Sánchez nos envió el poema titulado «Una y él» de Juan Ramón Jiménez, interrogándose sobre su posible «postismo», y como lo consideramos, en efecto, verdaderamente postista, lo publicamos en $L a$ Cerbatana.

La revista Garcilaso, paradigma del clasicismo poético más retrógrado, supuso, en cierta medida, un espacio abierto donde publicaron poetas cuya poesía pertenecía a otras territorialidades. En sus páginas aparecieron poemas de poetas representantes de diversas líneas poéticas, desde poetas consagrados del grupo del 27 como Gerardo 
Diego, Vicente Aleixandre y Dámaso Alonso, a poetas heterodoxos como Eduardo Chicharro y Carlos Edmundo de Ory ${ }^{84}$. En este sentido, Santiago Fortuño (2008: 44) señala el carácter divulgativo y acogedor de la revista, que ofreció sus páginas a muchos poetas que luego criticaron severamente su labor.

Este elemento ecléctico se dio, sobre todo, en las publicaciones de la primera posguerra. En todas ellas aparece una triple dimensión: la impronta teórica, el eclecticismo, marcado por las colaboraciones, y la labor de traducción de la poesía foránea. Más tarde las revistas poéticas acotarán mucho más su territorio especializado. Entre ellas, cuyo espacio abarca todo el espectro (desde el centro a todas las aristas) de la poliédrica geografía poética, las más significativas serían: Escorial (1940), Garcilaso (1943), Espadaña (1944), Insula (1946), Índice (1945), Corcel (1942), Proel (1944), Verbo (1945), Postismo (1945), La Cerbatana (1945), Cántico (1947), Planas de Poesía (1947), Acanto (1947), La isla de los ratones (1948), Cuadernos Hispanoamericanos (1948), Deucalión (1951), Papeles de Son Armadans (1956), Primer Acto (1957), Problemática 63 (1963), Claraboya (1963), La trinchera (1962), Poesía 70 (1968), Fablas (1969), Artesa (1972), Aquelarre (1970), Trece de Nieve (1971), Poliedros (1972), Marejada (1973)...

Frente a la importancia que la crítica ofrece a las revistas poéticas, la nota discordante la ofrece Luis Cernuda (1957: 181). Para él, la proliferación de revistas es un rasgo peculiar de la orografía poética tras la guerra. Pero ello no supone un síntoma de la buena «salud literaria», sino un espacio que propiciaba la labor del poeta aficionado que diseminaba «sus versitos por todos lados».

Las revistas Postismo y La Cerbatana fueron los canales, por excelencia, de expresión de movimiento postista. En ellos aparecían sus escritos programáticos y sus expresiones pictóricas y literarias. 24 y 28.

${ }^{84}$ Carlos Edmundo de Ory colaboró con la revista Garcilaso en los números 8, 11, 18, 


\subsubsection{Postismo}

La revista Postismo se editó en enero de 1945 como órgano programático y propagandístico del movimiento postista. La financiación corrió a cargo de Silvano Sernesi. De la maquetación se encargó Eduardo Chicharro, ayudado por Jaime Pol Girbal, Eduardo Chicharro fue también el redactor jefe («redactor técnico postista»), el cargo de director fue ocupado indistintamente por Carlos Edmundo de Ory y Silvano Sernesi. La Redacción estaba situada en la Calle Barbieri, $n^{\circ}$ 10, de Madrid, en el local de la imprenta GAMA, Artes Gráficas, S. A. El precio de la publicación era de 2 pesetas.

La revista tiene una estética vanguardista que plásticamente se expresa en el grafismo de signo cubista y futurista, en los dibujos de Benjamín Palencia y de Luis Lasa, en el caligrama en forma de copa escrito por Rafael Montesinos, José María Valverde y Jesús Juan Garcés, y en la fotografía de la portada, en la que aparece en el espacio central una fotografía de Gregorio Prieto con el torso desnudo, con un sombrero sideral y con un naipe flotando sobre su pecho. El título de la revista remite a una ampulosa estética modernista realizada a base de arabescos y recargados trazos florales. También se da en ella la estética naïf en los apartados dedicados a la infancia a través de los dibujos de Tony, el hijo de Eduardo Chicharro, y la caligrafía infantil. Como dice Jaume Pont (1987: 165), toda la estética postista está reflejada en la fotografía de la portada: el sombrero futurista que aporta la vanguardia, la desnudez que representa la pretendida ingenuidad y el naipe que apunta al elemento lúdico.

Postismo es un espacio pluridimendional. Ofrece los elementos teóricos del movimiento, sus prácticas estéticas tanto pictóricas como literarias (poéticas y narrativas), una mirada poliédrica acerca de la vanguardia y un acercamiento al mundo mágico y creador de la infancia. Participan en la publicación además de los tres agentes postistas, Wenceslao Fernández Flórez, Benjamín Palencia y Tomás Borrás.

El Postismo se define, en la introducción al Primer Manifiesto del Postismo (p. 5), como un movimiento constituido por su componente teórico y por sus elementos artístico y literario. Y es en las prácticas de sus autores donde mejor se encuentra el significado del movimiento: 
Un manifiesto establece unas premisas, concreta un credo, denuncia simpatías y antipatías, pero nunca dará, sino en forma abierta y de principio, las normas en detalle de una tendencia. Ingenuo y ligero será quien crea poder hacer Postismo puro después de leídas estas condiciones. El patrón habrá que buscarlo en las obras, en la obra Postista.

Desde esta óptica, Postismo ofrece una serie de prácticas artísticas. La pintura está representada por la obra El niño muerto, óleo de Eduardo Chicarro impreso en tinta marrón. Eduardo Chicharro y Silvano Sernesi representan también la narrativa postista, su cuento titulado «Un hombre poco común o el hombre de los pañuelos» (p.14) instala la ficción en pleno centro de la cotidianeidad. Del choque de lo extraño y de la realidad surge el elemento absurdo, claro precedente del realismo mágico. La poesía está representada por la sección titulada Liricoteca (pp. 8-9), compuesta por once poemas y que funciona como primera antología de poesía postista. Se trata de once romances escritos por los tres poetas postistas, entre ellos cabe destacar el «Romance de Laooconte y la luna» de Carlos Edmundo de Ory.

Postismo, además, contenía los siguientes escritos programáticos:

· 1. «España Lanza el Postismo», p. 1.

Situado en la primera página, está firmando por La Dirección. En él queda definido, de manera exageradamente provocativa, el Postismo como un movimiento amplio y total:

El último, el más nuevo, el mejor, el post y el ismo, el ismo y el post de todo lo que hasta hoy se ha dicho en materia artística. Movimiento plásticoliterario de carácter vanguardista que sólo quiere dar a la moderna estética un camino y un sentido desde hace mucho perdidos y olvidados.

-2. «Primer anuncio del Postismo al mundo», p. 2, p. 15.

Empieza en la página dos y continúa en la página quince. Se trata de la entrevista realizada en noviembre de 1944 a los autores postistas.

· 3. Primer Manifiesto del Postismo, pp. 4-5, pp. 12-13.

Situado en las páginas desplegables. 
-4. «En el que el lector que leyere verá cosas quizás más de nuestro interés que de su agrado, y otras posibilidades que se sugieren».

El texto ocupa la contraportada de la revista y viene firmado por La Redacción.

\subsubsection{La Cerbatana}

La Cerbatana es la segunda publicación postista que aparece meses después de que la censura decretara el cese de Postismo, por ello supone su continuación. La revista lleva un subtítulo, Revista Ilustrada de la Nueva Estética. La redacción está situada en la misma dirección, Calle Barbieri $\mathrm{n}^{\mathrm{o}} 10$ de Madrid. Los directores son los tres integrantes del grupo y el Redactor Jefe es Jaime Pol Girbal. La impresión y la tipografía corren a cargo de GAMA, Artes Gráficas, S. A. El precio, 2 pesetas.

La revista sigue la misma línea artística trazada por su antecesora, constituir una mirada plural ante el panorama artístico de vanguardia y ser el vehículo portavoz de un movimiento global. Como tal, la revista ofrece los resultados de la prácticas postistas. En este sentido resulta una publicación más literaria que teórica. Por otra parte, la revista toma conciencia de ser un espacio marginal en el horizonte cultural y, a la vez, ello confiere una dirección reivindicativa. Eduardo Chicharro denuncia abiertamente esta situación en su artículo «Nos echan de la poesía» (p. 4). También se dedica un apartado a la magia de la infancia y a la recuperación de esa conciencia naïf.

El grafismo sigue ofreciendo una estética de vanguardia en la que palabra e imagen entran en una estrecha relación. Para Rafael de Cózar (2005: 117-118), La Cerbatana supone la apertura hacia la poesía experimental, basada en la poesía fonética. Tanto los poemas de Jesús Juan Garcés como el poema de Juan Ramón Jiménez trazan esta dirección que entronca con la poesía visiva y concreta. La maquetación aparece más cuidada que la en la entrega anterior y existe una presencia mayor de los recursos tipográficos. Se juega con los distintos tipos y tamaños de las letras de los títulos, los subtítulos, las secciones, los caligramas, los collages... De forma irónica, ello queda señalado en la portada con las palabras «iViva Gutemberg!» Y de manera menos irónica y más explícita con la geometría de los grafismos. 
Desde la portada, se observa ya una mayor presencia de la imagen. En ella aparece sobre un fondo rojo, cortado por el blanco y negro de las líneas trazadas por las palabras, la reproducción de una pintura en blanco y negro de J. Biero. En la contraportada aparece un motivo taurino con una caricatura de Manolete de Luis Lasa que muestra sus referencias a la estética vanguardista de signo expresionista. En el interior la imagen supone un constante guiño a la vanguardia. En la primera página nos encontramos con un retrato de una figura femenina, pintada por Benjamín Palencia, cuya estética remite al cubismo y al expresionismo de signo picasiano. El dibujo de Ory de la página dieciséis remite al surrealismo más onírico. En las páginas décima y undécima tenemos dos óleos de Ochoa pintados bajo la estética del simbolismo pictórico. En la página tres, el cuadro de Durero Niño con larga barba señala el aspecto más extraño, misterioso y siniestro del surrealismo. En el artículo firmado por Eduardo Chicharro titulado «La patética expresión del arte», situado en la página doce, se halla una selección de pintura que representa las referencias de la pintura postista: PierreAuguste Renoir, Nijinski, Gaston Le Roux, Odilon Redon, Georges Braque, Marc Chagall.

La revista ofrece, por otra parte, las prácticas literarias postistas. La narrativa está representada por los textos de los miembros fundadores del movimiento. Silvano Sernesi escribe el cuento titulado «Casi casi los casó Voronoff» en la línea de la narrativa fantástica con tintes surrealistas. Carlos Edmundo de Ory presenta «Venus supermega», texto formado por fragmentos de la novela inédita Mèphiboseth en Onou, diario de un loco, y el cuento titulado «La mujer de los tres trapos». Eduardo Chicharro, por su parte, escribe el cuento titulado «Viaje». En la parte interior de la contraportada, sin numerar, tenemos tres cuentos cortos, cada uno firmado por sendos postistas fundacionales. Se trata de un ejemplo de lo que en la actualidad se conoce como microrrelato. En ellos a la brevedad hay que sumarle la ironía. De algún modo son haikus narrativos, poseen la sugerencia, la poeticidad y la ruptura de la lógica. Como el haiku, transmiten atmósferas. Son un breve susurro al oído, y a la vez, forman una historia. Pues los tres textos poseen una continuidad narrativa, claro ejemplo de escritura colectiva. 
Era vez de una chiquilla que era muy blanca y se murió y fue más blanca todavía.

\section{Carlos Edmundo de Ory}

Luego las campañas se callaron mientras que a su lado terminaban las flores. Era una mañana.

\section{Silvano Sernesi}

Buscaba la suerte de un minuto, y la tuvo. Pero luego no recordaba ya en qué hora había sido.

\section{Chicharro Hijo}

Texto de textos que crean una misma unidad gráfica. Se trata de un ejemplo de literatura interactiva, como lo fue la obra La diosa número 2 (1931) escrita a cuatro manos por Alfonso Hernández-Catá, José Francés, Alberto Insúa ${ }^{85}$ y Concha Espina, en la que cada uno de ellos es autor de uno de los cuatro capítulos que forman la novela ${ }^{86}$.

El género dramático viene representado por la breve pieza, con cierto parentesco con el teatro del absurdo, titulada «Historia natural, breve comedia en dos actos». Este será un claro ejemplo de microteatro.

\section{A Bernard Shaw}

Personajes: una jirafa, un galápago, un principe.

Acto primero

JIRAFA.- ¡Si yo fuera alta!

GALÁPAGO.- ¡Si Yo fuera bajo!

EL PRÍNCIPE.- Ustedes son idiotas; os habéis

Equivocado lamentablemente.

GALÁPAGO.- ¡Sí!, ¡Sí!...

JIRAFA.- ¡Sí!, ¡Sí!...

EL PRÍNCIPE.- No juego. Lo habéis hecho

Queriendo. Habana.

${ }^{85}$ Alberto Insúa es el seudónimo de Alberto Galt y Escobar, escritor nacido en La

86 Insúa, Alberto (2003), Memorias, selección e introducción de Santiago Fortuño, Madrid, Fundación Central Hispano. 


\section{Telón}

Acto segundo.

JIRAFA.- ¡Si yo fuera galápago!

GALÁPAGO.- ¡Si yo fuera galápago!

JIRAFA.- ...entonces, si yo fuera jirafa.

EL PRÍNCIPE.- (Muere)

\section{Fin de la historia}

La poesía es el discurso literario que tiene más presencia en la revista. Además de los poemas escritos por los autores postistas («De lo más a lo menos» de Eduardo Chicharro, «Anna» de Silvano Sernesi y «Soneto paranoico» de Carlos Edmundo de Ory) está presente la poesía de matiz letrista de Juan Ramón Jiménez, «Una y él», el soneto de Ángel Crespo (que escribe por primera vez como poeta postista) dedicado a Ory y titulado «De mi loco al loco de Carlos Edmundo», los Poemas primitivos para ángeles de Jesús Juan Garcés, un poema de Petito Vella titulado «Al niño muerto de Chicharro Hijo», «Arlequín asimético» de Conrado, El poema «Minero» que aparece manuscrito y casi ilegible y un caligrama de Manolo Pilares y las «Pequeñas fábulas para niños siniestros» de Fernand Marc, que tienen su texto paralelo construido por los postistas mediante la técnica del enderezamiento (que comentaremos a fondo más adelante). Cabe resaltar el poema de Manolo Pilares titulado «Minero» incluido en la página-collage realizada a base de la correspondencia recibida: dibujos, textos $\mathrm{y}$ manuscritos:

Ser el superglóbulo de la sangre del mundo Hacer cielos de plomo con torres de humo $\mathrm{y}$, de pronto, fusilar el murmullo de todos los arroyos.

Quedarse solos, únicos, victoriosos, hasta que el embrujo del verde sea roto con vagones de mineros y acorazados osos. 


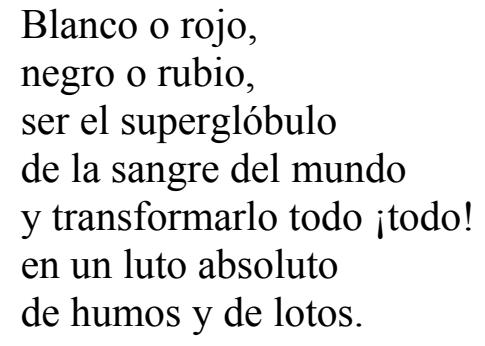

Además, la redacción publica, entre los otros materiales, una serie de pulgas, micropoemas realizados a base de frases cortas $y$ directas que remiten a la instantaneidad del haiku y al desconcierto del koan, a la vez que funcionan como breves aforismos. Estos, influenciados totalmente por las greguerías de Ramón Gómez de la Serna, son el antecedente de los aerolitos de Carlos Edmundo de Ory. En la página diez aparece el siguiente texto que sirve como ejemplo:

¡Pobrecillos! Ellos creen que hacen algo bueno porque escriben palabras raras.

Los postistas buscan romper moldes, derribar las barreras que separan los géneros, ensayar nuevos vehículos expresivos. Se trata de una escritura libre que intenta hacer una demolición de los códigos literarios imperantes, para ello se utiliza la valentía a la hora de transgredir las normas establecidas, el poder de la imaginación y el carácter lúdico y humorístico.

Las prácticas poéticas ensayadas en las páginas de esta publicación anuncian dos direcciones que serán recorridas por la escritura poética posterior. Por una parte, los sonetos de Carlos Edmundo de Ory y Ángel Crespo abren un camino que llevará a la poesía de signo surrealista escrita por los poetas novísimos de la generación de los setenta del pasado siglo, que rechaza plenamente el lenguaje anquilosado y referencial de la poesía de posguerra y que, entre otras muchas cosas, reivindica un acercamiento al lenguaje onírico y a la asociación libre de objetos. El poema «De mi loco al loco de Carlos Edmundo» escrito por Crespo y que aparece en la quinta página de la revista es un claro ejemplo de ello:

Amigo, dulce amigo, dulcilando de luces pegajosas en lo espeso, dándole el beso de la luz al beso y la sombra a la noche le quitando. 
Dulcecito de esparto, como Orlando: furioso con la espada y con el peso de un seso sin por qué, casi sin seso, con un perro en la nuca te matando.

Deshojador de hojas deshojadas, matador de los muertos que te esperan en la noche más fría. Desmontadas.

tus jinetas cabalgan. ¿Cómo eran? ¿Cómo eran, Dios santo? ¡Qué acabadas, mi dulcilando amigo, revivieran!

El poema escrito por Carlos Edmundo de Ory que se titula «Soneto paranoico», y que se halla en la página séptima, supone también una muestra de lenguaje laberíntico de signo surrealista instalado en la arqueología de la experimentanción poética de posguerra, reivindicada por la poética de la generación del 68, como se la ha denominado también (Bousoño, 1979: 11):

Sólo en el mundo con mi media oveja y una cortada flor en el semblante bajo la mina honda del diamante que no tiene raíz ni tiene reja.

Mas como soy del odio tenue abeja manada de algún duende nigromante peinaré de mi espalda el monte amante y con heces de concha de la almeja.

Mi paranoia de Iolao y Averno, ¡hola, pato de oro; hola, marea donde la mar merece su medusa!...

$\mathrm{Y}$ creo que de cebra tengo un cuerno $y$ de llama una pata panacea que se gasta en mi alma y que se usa.

La otra línea poética iniciada desde las páginas de esta revista viene representada por el poema, que aparece en la página séptima, «Una y él» (presentado ya con anterioridad) escrito por Juan Ramón Jiménez y por los poemas de Jesús Juan Garcés, que se encuentran en las páginas octava y novena. Esta poética se asienta en la recuperación del collage y de los experimentos de la vanguardia poética y, a su vez, supone la ruptura con el lenguaje poético y sus moldes clásicos. Por ello, este gesto 
suponía la ruptura total con las poéticas de posguerra y la iniciación de una dirección heterodoxa que abre la puerta hacia la experimentación poética. Junto a las experiencias de Joan Brossa y de Cirlot, la dirección iniciada por las prácticas poéticas de Juan Ramón Jiménez y de Jesús Juan Garcés supone el inicio de la poesía experimental.

Los Poemas primitivos para ángeles de Garcés se estructuran en once cantos, de los que cabe mostrar algunos ejemplos, ya que en ellos se muestra una palabra poética articulada desde el sonido que se basa en el juego y en la sorpresa. Se trata de una poesía que se basa en la repetición fónica, en la disonancia, en la asociación sorpresiva de sonidos, en la creación de significantes inexistentes provocados mediante injertos de sonido. Poesía de signo fónico y que se configura como laberinto de sonidos. En la octava página aparece el «Canto segundo»:

(El Arcángel Triste)

Arcangelandrero

lirio liralero.

Arcangenlincenso

auricensilero.

Laro lerocino

luciferino.

Arcangelanceno

duardiancenliceo

divinacileno

eno...

eno...

eno...

Otro ejemplo sería el «Canto noveno», que aparece en la novena página:

(Bienaventuranza de San Arjá Arcángel)

ARJÁ artá lará

Atralará abá

Angel Angel

Atracalradarabará 
Arcángel Arcángel

tristeleble del salto

atraclarabadá

Argangelero SANTO

Arjá...

Arjá...

Arjá...

Esta práctica de la euritmia supone el punto de contacto de las poéticas de la vanguardia histórica con la vanguardia poética posterior.

La práctica artística, que hemos mostrado, viene respaldada por el elemento teórico y programático que La Cerbatana ofrece:

·1. « А la una... a las dos... a las tres!», p. 1.

Texto firmado por La Dirección, se trata de un editorial que funciona como una declaración de principios en la que se reivindica la provocación, la euforia, el humor, el juego y la locura frente a la rigidez de los valores del sistema burgués.

-2. «Nos echan de la poesía», p. 4.

Artículo firmado por Eduardo Chicharro.

- 3. «Entrevista a un hombre que se ríe sentado y fuma con la mano y con la boca», p. 11.

Texto escrito por Silvano Sernesi. En él el autor propone la exaltación de todas las cualidades que escapan a la lógica, al racionalismo y a su representante, la cultura burguesa: imaginación, extrañeza, locura. Señala además, siguiendo el modelo bretoniano ${ }^{87}$, que la belleza se encuentra en lo misterioso, lo maravilloso, lo extraño, lo desconocido, lo convulso.

${ }^{87}$ Breton (1962, 2009: 29). «Considero que el buen gusto es una formidable lacra». 
Sernesi se apoya en la visión que tuvo Breton de un hombre atravesado por una $v_{\text {ventana }}^{88}$, tal como indica el Primer manifiesto del surrealismo, para presentarnos su particular visión obsesiva y paranoide: «Un hombre que se ríe sentado y fuma con la mano y con la boca». Imagen que rompe con toda lógica y se erige como apertura al absurdo postista. El humo es aspirado y expulsado al mismo tiempo por la boca y por la mano y ello, precisamente, provoca una sonrisa en los labios, tal y como queda representado de manera gráfica junto al titular. Ésta es la lógica del Postismo, una lógica que parte del absurdo, una lógica estéticamente paradójica y jovial. La lógica (del absurdo y lo extraño) postista descansa en la voluntad estética. La estética postista es una estética de la extrañeza y de la rareza que se opone a la estética de lo real.

Nuestra obra artística, nuestro credo estético es «imaginación»; nuestra imaginación es «obra artística», es «credo estético». Obramos y creemos en virtud de las imágenes fantásticas que, más o menos locas, más o menos extrañas, sacamos a la luz. No nos importa su sentido lógico, su evidencia palpable. Pero sí nos importa su belleza, su verdad de imagen en cuanto arte. Amamos la locura, la locura bella y reluciente como las manos cortadas del fantasma de una mujer, como las manos recortadas de una mujer fantástica. Eso puede ser la belleza.

Un homme traversé par la fenêtre. Imaginación quizá, imaginación loca tal vez, pero también absurda, inhumana, antiestética, antipática.

«Un hombre que se ríe sentado...» Ya no es imaginación; no, ya no es locura; no, ya no es absurdidad. Pero ¡cuántas imágenes, cuántas locas absurdidades y sobre todo cuánta inconsciente e impensada belleza! Una belleza sin lógica, dadaísmo; una lógica sin lógica, surrealismo; una belleza con su lógica; postismo.

La belleza del hombre que llora el canto del gallo, de la mujer que cuenta las estrellas de su cabellera, del niño muerto, del caballo que vive, del conde de olivares, del loco que sufre. Una belleza escondida entre las faldas de una muñeca sin ojos; una belleza hundida tras los escombros de una madrugada y cabalgando en el viento de cuatro estaciones.

Belleza, locura, imaginación, locura, belleza, postismo.

88 Íbíd., pp. 34-35. «El caso es que una noche, antes de caer dormido, percibí, netamente articulada hasta el punto de que resultaba imposible cambiar ni una sola palabra, pero ajena al sonido de la voz, de cualquier voz, una frase harto rara que llegaba hasta mí sin el menor rastro de aquellos acontecimientos de que, según las revelaciones de la conciencia, en aquel entonces me ocupaba, y la frase me pareció muy insistente, era una frase que casi me atrevería a decir estaba pegada al cristal. Grabé rápidamente la frase en mi conciencia, y, cuando me diaponía a pasar a otro asunto, el carácter orgánico de la frase retuvo mi atención. Verdaderamente, la frase me había dejado atónito; desgraciadamente no la he conservado en la memoria, era algo así como «Hay un hombre a quien la ventana ha partido por la mitad», pero no había manera de interpretarla erróneamente, ya que iba acompañada de una débil representación visual de un hombre que caminaba, partido, por una ventana perpendicular al eje de aquél. Sin duda se trataba de la consecuencia del simple acto de enderezar en el espacio la imagen de la ventana. Pero debido a que la ventana había acompañado al desplazamiento del hombre, comprendí que me hallaba ante una imagen de un tipo muy raro, y tuve rápidamente la idea de incorporarla al acervo de mi material de construcciones poéticas». 


\subsection{GÉNESIS DE LA POESÍA DE LA MARGINALIDAD}

Angel Angel

Atracalradarabará.

Jesús Juan Garcés

1.2.1. Mil duros, irrupción del Postismo como subversión

1945 es un año especial en la historia de la literatura y en la historia de la humanidad. Es el año en que en Francia Isidoro Isou funda el Letrismo, Boris Vian conoce a Raymond Queneau y finaliza la primera novela, Vercoquin et le plancton, que se publicará dos años más tarde. La Galería Drouin presenta la serie Otages del pintor Jean Fautrier, punto de partida del informalismo en pintura. Año en el que William Burrougs y Jack Kerouac, entonces dos autores totalmente desconocidos, escriben And the hippos were boiled in their tanke ${ }^{89}$, la primera obra de la generación beatnik que permaneció inédita hasta el año 2008. Estamos a una distancia de tres años del tercer manifiesto bretoniano, Prolegomenos a un Tercer Manifiesto surrealista o no (1942), publicación que supone, de algún modo, el canto del cisne del movimiento surrealista, y por extensión de la vanguardia histórica europea, y que, de otro lado, vislumbra un cambio total en los conceptos artísticos y en el funcionamiento de las coordenadas que articulan realidad. En este año se producen dos hechos fundamentales: el fin de la Segunda Guerra Mundial y el lanzamiento de las bombas atómicas sobre Hiroshima y Nagasaki. En Madrid se presenta el Postismo, movimiento respaldado por su órgano propagandístico: las revistas Postismo y La Cerbatana, aparecidas también en este mismo año.

En realidad, la génesis del Postismo se produjo en el año 1944 con el encuentro fortuito entre Eduardo Chicharro y Carlos Edmundo de Ory en el Café Pombo de Madrid, tal como lo cuentan los propios autores ${ }^{90}$. Carlos Edmundo de Ory abandona

${ }^{89}$ Burroughs, William y Kerouac, Jack (2008), And the Hipos Were Boiled in The Tanks, Nueva York, Grove Press; traducción de Fernando González Curogedo, Y los hipopótamos se cocieron en sus tanques, Barcelona, Anagrama, 2010.

${ }^{90}$ Chicharro, Eduardo, "Carlos Edmundo a machamartillo», El Español, Madrid, 10 de noviembre de 1945. "Yo le descubrí una noche en el Café Pombo; le descubrí enseguida. 
definitivamente su vida en Cádiz y se instala en Madrid el 20 de julio de 1943, tal como él mismo indica en Historia del postismo (Grande, 1970a: 261). Este mismo año se intala también en Madrid Eduardo Chicharro, que había vivido en Italia desde la niñez. Allí conoció al otro miembro fundador del Postismo, el italiano Silvano Sernesi, que se traslada también a Madrid el mismo año y aquí reside hasta 1946. En verano de 1944, Eduardo Chicharro, su esposa, Nanda Papiri, y Carlos Edmundo de Ory pasan unos días en Ávila, como queda reflejado en el Diario de Ory (2004: Vol. I, 17-19). Allí sucede la verdadera gestación del proyecto postista, Eduardo Chicharro se compromete a realizar un manifiesto del movimiento. En Madrid contacta con Silvano Sernesi, poeta italiano y amigo, y queda establecido el grupo nuclear del movimiento postista, formado por dos poetas y un pintor. Surge la necesidad de editar una publicación que muestre el proyecto programático del movimiento, para ello se recurre al padre de Sernesi que era el director de la sucursal de la Banca di «Lavoro» en Madrid, quien concede un crédito de 5.000 pesetas para la realización del proyecto literario del grupo.

La primera manifestación del movimiento se produce el 15 de noviembre de 1944. Se trata de una entrevista realizada en Radio S.E.U., en ella los postistas contestaban a las preguntas del poeta Salvador Pérez Valiente y proclamaban las bases del movimiento: la unión de la imaginación y del surrealismo, la libertad onírica sujeta a la creación estética. Parte de este documento fue publicado en la revista Postismo con el título de «Primer anuncio del Postismo al mundo». Aquí aparece el ideario neovanguardista del movimiento:

El Postismo es la herencia inmediata e inevitable de los demás movimientos que se ha dado en llamar ismos. Post-surrealismo, post-cubismo, post-ultraísmo... se llama POSTISMO, es decir, el ismo que viene después de los otros ismos..$^{1}$

El texto presenta también la diferencia entre las tesis formuladas por el grupo surrealista francés y por el Postismo. Frente al automatismo psíquico puro del

Primero vi su figura despistada y fuera de aquel lugar, y cuando me dijeron que se trataba de un poeta, entonces le descubrí y dije: Este es un poeta. Traté enseguida de acercarme a él, y así le atraje a mi órbita y yo entré en la suya» (Pont, 1987: 452; Grande, 1970a: 266). Ory de, Carlos Edmundo, Historia del postismo (Grande, 1970a, 267). «Nos encontramos, es exacto, en el Café Pombo».

91 «Primer anuncio del Postismo al mundo», Postismo, n 1, enero, 1945, p. 2. 
surrealismo, el Postismo propone la reelaboración del material surreal guiada por la voluntad estética.

El surrealismo dice: escribe o pinta absolutamente lo que se te antoje, pero sin moral, lógica y estética. El Postismo dice: escribe o pinta lo que se te antoje, por disparatado que sea; pero has de perseguir, sobre todo, la belleza (estética), y debe ésta responder a una lógica rigurosa, por loca que sea... ${ }^{92}$

En este sentido, cabe señalar que la propuesta postista, frente al automatismo psíquico, coincide en cierto modo con los postulados de los poetas surrealistas españoles pertenecientes al grupo del 27. Tanto la poesía de Vicente Aleixandre, como la de Luis Cernuda o la de Rafael Alberti reelaboran el material onírico y surreal con una finalidad poética, buscando una coherencia que permita la creación del edificio poético. A ello se refiere Bodini $(1963,1982: 171)$ con el concepto de equilibrio poético.

La presentación oficial del movimiento se produjo el 5 de enero, día mágico por ser la noche de los Reyes Magos, en el Café Castilla situado en la Calle de las Infantas. Allí se escenificó un happening avant la lettre en el que los tres integrantes del grupo repartieron, en actitud ceremonial a modo de boutade, unas tarjetas de visita triangulares con el nombre y el número de teléfono de cada uno de ellos. A partir de aquí el Café Castilla se convirtió en la sede de movimiento, el sitio donde se realizaron las tertulias postistas. Otro centro de interés del movimiento fue el estudio del pintor Eduardo Chicharro, espacio donde se realizaron múltiples sesiones postistas cuyo signo era el disparate teatralizado, la provocación, las acciones en las que diversas prácticas artísticas confluían. Es decir, la performance, tal y como se la conoce en la actualidad. Además el grupo postista, que muy pronto aumentó de integrantes, llevaba la provocación a otros espacios: a la tertulia del Café Pombo, a la del Café Gijón, a la de la peña Los noveles. Su estética de la provocación supuso una crítica de los parámetros de la poética de la oficialidad.

El 31 de enero de 1945 se editó la revista Postismo, que se erigía como órgano propagandístico de este movimiento transmisor, de su actitud rebelde y combativa, de su carácter lúdico y subversivo, de su práctica de la provocación, de su lenguaje libre y

$$
{ }^{92} \text { Ibíd., p. } 15 .
$$


creativo, de su defensa a ultranza del poder de la imaginación. Las constantes boutades de los postistas, basadas en las acciones dadaístas, supusieron un peligro para la cultura oficial. De modo que, dos meses después de su aparición, la revista se suspendió por orden del delegado de prensa Juan Aparicio, que había dado respaldo al movimiento postista mientras creía tenerlo bajo control. La publicación del Primer Manifiesto del Postismo fue uno de los desencadenantes de la censura. Otro era el ataque a la poesía tradicionalista e imperial, representante del discurso del poder. Ataque que se hizo extensivo a la totalidad de los parámetros culturales franquistas, anquilosados, obsoletos. Para Ory, el Postismo fue una brisa de aire liberador que escapaba a los controles del poder, tal como nos lo cuenta en su Historia del postismo (Grande, 1970a: 271):

El Postismo fue, ante todo, un intento de despertar a la vida lo dormido; fue un sacudir perezas mentales y legañosas; fue una dinamita de la imaginación. Quiso ser recuperado por el momento como una fiesta dominguera (Juan Aparicio gritaba ¡Viva el Postismo! cada vez que nos despedía de nuestras visitas a su despacho de Director de Prensa) y viendo que no nos casábamos con nadie, nos cortaron el vuelo. La revista Postismo, sufrió suspensión de la censura, recibí una carta oficial de Juan Aparicio comunicándomelo. Protestamos. Pedimos entrevista con Juan Aparicio; éste, incompetente a una respuesta satisfactoria, nos mandó a su superior, el Sr. Arias Salgado, Director General de Información y Turismo. Allí fuimos, se nos recibió y nos sentamos a discutir con el hombre oficial durante un tiempo extraoficial: dos horas largas. Nosotros: - ¿Por qué?, y él - que si habían recibido cartas de obispos y de padres de familia escandalizados - .

Como consecuencia de su actitud transgresora, los tres integrantes del movimiento postista decidieron mantener la existencia del movimiento cambiando el título de su agente expresivo. De este modo, en abril de 1945 surgía la revista La Cerbatana con idéntica voluntad de agitación y subversión. La única referencia que se encuentra en el Diario de Ory, documento que ofrece minuciosamente datos de interés sobre su actividad cultural, que apunta a la publicación de la revista data del 14 de abril (2004, Vol I: 20):

El martes sale La Cerbatana.

Hoy guardo pruebas del número junto a las pruebas de Postismo. 
El resultado de la nueva aventura, acto de verdadera resistencia cultural, consistió en la ampliación del grupo postista. En este sentido, hay que señalar que al grupo inicial, formado por los verdaderos teóricos, se sumó la labor de agentes provocadores como Ignacio Nieva, Francisco Nieva y Ángel Crespo.

En 1946 surgió el Segundo Manifiesto del Postismo, firmado por los tres miembros teóricos fundacionales y publicado en La Estafeta Literaria, cuya finalidad era clarificar los puntos esenciales del movimiento a la vez que defenderse de los ataques y ofrecer una respuesta airada a los detractores. Este año supuso también la integración en el grupo de Ignacio Aldecoa. Esta se produjo a raíz del revuelo organizado por el segundo manifiesto, cuya actitud defendió Aldecoa, quien por otra parte compartía piso con Ory. En 1947, Eduardo Chicharro publicó el Tercer Manifiesto del Postismo en El Minuto, suplemento de la revista La Hora. En este año se incorporó al Postismo Gabino-Alejandro Carriedo. Sus convergencias arrancan del año 1945, año de la creación en Palencia de la Peña Nubis, integrada por poetas como Fernández Nieto, Buisán Cítores, Fernández Luengo, López Cancelo o Carriedo. Un año más tarde el grupo palentino lanzó el Manifiesto del Pletorismo, movimiento hermanastro del Postismo para García de la Concha (1987, Vol II: 683). En 1947, concincidiendo con su traslado a Madrid, Carriedo entró definitivamente en el grupo postista.

En 1948 el Postismo desarrolló su dirección pictórica. Se inauguraron dos exposiciones postistas. La primera se realizó el 27 de abril en la Galería Buchoiz de Madrid bajo el título Exposición de 16 artistas de hoy. En ella figuraron obras de Daniel Vázquez Díaz, Nanda Papiri, Francisco San José, Antonio Rodríguez Luna, Luis Lasa, Agustín Rodela, Gregorio del Olmo, Luis Planes, Rafael Vázquez Aggerholm, Molina Sánchez, Juan Castelló, Antonio Fernández Carpe, Enrique Núnez Castelo, Camilo José Cela y Carlos Edmundo de Ory. La segunda exposición, titulada Pintura moderna y Postismo, se realizó el 17 de mayo en Zaragoza, en la Galería de Arte Macoy. En ella se expusieron obras de agentes postistas como Eduardo Chicharro, Nanda Papiri, Toni (el hijo de ambos, que en las publicaciones firmaba como «el niño»), Lilla (hermana de Toni), Carlos Edmundo de Ory, Luis Lasa y de otros artistas como Francisco San José, Gregorio del Olmo, Núñez Castelo o José Caballero. Pictóricamente la propuesta ofrecida mantenía contactos con la estética surrealista por una parte, pero, de otro, lado muestraba sus convergencias con la vanguardia pictórica 
coetánea: la abstracción, la pintura matérica, el informalismo. Más concretamente, la pintura postista sensu stricto englobaría la producción pictórica de Eduardo Chicharro y la de Nanda Papiri, los collages de signo conceptual de Carlos Edmundo de Ory que tratan de unir imagen y poesía y los dibujos de Francisco Nieva.

Entre 1945 y 1948 discurre el primer período del Postismo, cuyas señas de identidad fueron la transgresión de los cánones establecidos y la irrupción de una estética de agitación basada en la agresividad, la parodia, el humor, el culto a la imaginación, la exploración onírica, la libertad creativa, la agitación cultural... En este sentido, Félix Casanova de Ayala (Pont, 1987: 546), agente postista y partícipe de la bohemia literaria del Madrid de la posguerra, se expresa con estas palabras:

\begin{abstract}
Al postismo le cupo el honor - aún no justipreciado - de haber lanzado el «kikirikí» de alerta y rebeldía contra aquel ablandamiento narcicista de nuestra poesía posbélica. Su impacto, en los momentos iniciales, fue terrible y ancestral y poco faltó para que toda la edulcorada rima neoclasicista pasara por su estrecho aro funambulesco.
\end{abstract}

\title{
1.2.2. El Postismo en serio
}

A partir de 1947, el Postismo, observando las dificultades de publicar en Madrid, realizó su viraje a Ciudad Real. Allí el órgano propagandístico fue el diario Lanza y el principal agente teórico fue Ángel Crespo. Su colaboración con el nuevo espacio editor se inició en 1946. Allí publicó el 6 de febrero el artículo "Alcaide y el Postismo», verdadero elogio al poeta Juan Alcalde, que había apoyado significativamente al Postismo. A partir de aquí las colaboraciones de los postistas en este medio serán habituales. Estas publicaciones, que se realizaron hasta 1949, suponen para María Isabel Navas Ocaña (2000: 81) el canto del cisne del movimiento. Para Pont el punto de inflexión que marca el declive del movimiento viene trazado en 1947 por el Tercer Manifiesto del Postismo, pues para él la actividad del grupo, como tal, acaba en 1950 (1987: 10).

En 1949 ya se evidencia una división interna del grupo. Por un lado se hallan los tres miembros fundacionales, representantes del Postismo más transgresor y agresivo. 
Por otro, los representantes de una línea que trata de unir junto al interés existencial vanguardia y planteamiento social: Ángel Crespo, Gabino-Alejandro Carriedo y Félix Casanova de Ayala. La punta del iceberg fue la entrevista realizada en Radio S.E.U. a dos de los tres postistas representantes del Postismo humano, Carriedo y Casanova de Ayala, y a María del Pilar Sandoval, escritora y poetisa argentina difusora del Postismo en su país. La entrevista se tituló «En serio sobre el Postismo» (Pont, 1987: 519-525) y se emitió el día 9 de agosto de este mismo año. En la entrevista, cuyo locutor representaba totalmente la óptica de los entrevistados, aparecieron citadas las tesis de esta variante del Postismo: el rechazo del componente frívolo, humorístico, absurdo y provocador del movimiento, por un lado; y la defensa de la dimensión humana del hecho poético, por otro. Así se expresaba Carriedo en la citada entrevista (Pont, 1987: 520-521):

El Postismo no ha sido tomado en broma más que por sus descubridores [...] Esto de que no crean en él sus descubridores no quiere decir que el postismo deje de ser una verdad de bulto, pues largas observaciones y prolongados estudios nos han hecho ver tanto la realidad de su existencia histórica como la conveniencia de su ampliación restringida, es decir, del empleo del postismo como norma gimnástica y formacional, primeramente, y después, recogiendo las oportunas y dosificadas aportaciones que han de lograr la culminación estética sin disparates de mayor cuantía que velen e impidan la luminosidad, humanidad $\mathrm{y}$ trascendencia del poema.

Aquí figuran las tesis de este Postismo en serio: el intento de acercamiento a una poesía más humana y el ofrecimiento de una preocupación existencial. En el fondo existe una cierta convergencia con la poesía social. Es esto lo que lleva a rechazar toda actitud frívola y cínica. En cambio, se propone la trascendencia de la poesía y el compromiso con el ser humano. La supresión de la actitud lúdica, agresiva y desafiante supone, desde los postulados dadaístas y surrealistas, un ataque a la exaltación de la imaginación, a la libertad creadora y a la plasmación del lenguaje del inconsciente, verdaderos ejes del movimiento. Ataque que supone un acercamiento a las tesis del realismo poético. Pues para los autores del radicalismo vanguardista, como Breton o Traza, el humor es en sí mismo un revulsivo social y, a su vez, un acto poético. Tal como Breton nos dice, en la Antología del humor negro escrita en 1939, el humor es «la rebelión superior del espíritu» (1966, 1991: 10). También se expresa de modo irónico en el Segundo Manifiesto del Surrealismo de 1930 (1962, 2009: 139): 
El acto surrealista más puro consiste en bajar a la calle, revólver en mano, y disparar al zar, mientras a uno le dejen, contra la multitud. Quien no haya tenido, por lo menos una vez, el deseo de acabar de esta manera con el despreciable sistema de envilecimiento y cretinización imperante, merece un sitio entre la multitud, merece tener el vientre a tiro de revólver.

La actitud combativa, el talante enérgico, la voluntad de provocación... son signos de la radicalidad propia que irrumpe en la Vanguardia. En todo acto provocador siempre existió un gesto irónico, lúdico, humorístico. Gesto muy presente en el arte de Marcel Duchamp ${ }^{93}$ y que el Postismo incorpora en su discurso y en sus actitudes. El rechazo de la radicalidad provocativa suponía un intento de conjunción entre vanguardia y realismo.

Para Carlos Edmundo de Ory, tal como dice en su Historia del postismo (Grande, 1970a: 274), la entrevista en la Radio S.E.U. fue un acto de traición, una maniobra para desbancar a los teóricos del primer Postismo y tomar las riendas del movimiento. Para Jaume Pont (1987: 67-83) ello marca un cisma en el movimiento y supone la inauguración del Postismo de segunda hora. Sin embargo, Navas Ocaña sostiene que no existe tal etapa (2000: 75-76), que aquello que rechaza el Postismo en serio es el histrionismo de las actitudes de Eduardo Chicharro y, sobre todo, de Carlos Edmundo de Ory. Crespo, Carriedo y Casanova de Ayala, molestos por el hecho de que la crítica sólo atendía a las boutades de los postistas, creen que la provocación dificulta la expresión de las tesis postistas. Por ello, rechazan totalmente cualquier elemento frívolo y buscan el acercamiento una poética más humana. Esta será la poética perseguida por la poesía posterior de Carriedo, Política agraria (1963), y de Crespo. Antonio Martínez Sarrión (1980: 9-10) señala que la poesía de Carriedo parte del tremendismo poético, elemento que ya no abandonará nunca, aunque a partir del Postismo esta se abra a las corrientes vanguardistas. Para Pilar Gómez Bedate (2011: 47), la auténtica poesía de Crespo surge con la publicación de Una lengua emerge (1950), cuando ya la impronta del Postismo se había diluido casi totalmente. Para la autora. esta poesía formaría parte de aquella zona poética que la crítica ha dado el

${ }^{93}$ La voluntad de provocación lleva a Marcel Duchamp al abandono de la pintura y a la creación de un arte conceptual basado en el ardid mental que actúa como verdadera dinamita cerebral, en una bomba de relojería contra el gusto burgués. En 1913 realiza la obra Rueda de bicicleta, una rueda colocada sobre un taburete de cocina. En 1915 crea Aire de París, una ampolla de vidrio sin contenido alguno enviada a Nueva York. El mismo año presenta al jurado de Artistas Independientes de Nueva York la obra Fuente, obra que consiste en un urinario colocado al revés. Estos hallazgos recibieron el nombre de ready-made. 
nombre de realismo mágico (Ayuso, 1995) o La otra generación poética de los 50 (García Jambrina, 2009). La poesía de Crespo comparte, junto a la de Cirlot y Ory, la concepción de la poesía como elemento visionario, mágico y esotérico. Concepción heredada de la poética simbolista y que se opone totalmente a las tesis del realismo poético.

Esta nueva dirección del Postismo tuvo sus agentes propagandísticos: las revistas El pájaro de paja (1950), Deucalión (1951), Doña Endrina (1951) y Trilce (1952). El Postismo se diluyó con la progresiva desaparición de estas revistas.

\subsubsection{Otros ensayos tras el Postismo}

De los tres agentes postistas fundacionales fue Carlos Edmundo de Ory el miembro más activo, su voluntad de agitación cultural no cesó con el ocaso del movimiento postista. Su constante experimentación, contacto con la vanguardia y búsqueda de nuevos horizontes provocaron dos nuevos proyectos: el Introrrealismo integro en colaboración con el pintor Darío Suro y el Atelier de Poésie Ouverte desarrollado en Amiens.

\subsubsection{El Introrrealismo íntegro}

A principios de 1951 Carlos Edmundo de Ory y el pintor Darío Suro publicaron Nuestro tiempo: pintura / Nuestro tiempo: poesía, texto que en realidad significaba un manifiesto en toda regla. Esta declaración de principios ha sido denominada por la crítica como el manifiesto del Introrrealismo, movimiento que persigue una estética surgida de la realidad interior, que exprese las preocupaciones metafísicas y místicas del ser humano y manifieste el misterio mágico de la realidad. El manifiesto tuvo escasa resonancia en unas coordenadas marcadas por el lenguaje realista imperante. De todas formas, fue saludado por un pequeño grupo de intelectuales y poetas, entre los que se encontraban Eugenio D’Ors o Vicente Aleixandre. Así lo recoge Ory en su Diario (2004, Vol I: 123-124): 
14 abril, sábado

Carta de Vicente Aleixandre (manuscrita)

Queridos amigos Carlos Edmundo de Ory y Darío Suro:

Quiero agradecerles el envío de su cuaderno Nuestro tiempo: Poesíapintura, y manifestarles el lector que he sido de las palabras ardientes de Ory sobre una poesía «esencialista, profunda y simbólica» y las incisivas de Suro sobre «la búsqueda de la forma desde la vida». La vibración de estas páginas es un bien, cualquiera que sea la adhesión que Vds. obtengan, y les deseo el mejor éxito de «agitación» que ellas muy justamente puedan producir.

Su amigo.

Vicente Aleixandre.

(7 de abril de 1951)

2 de mayo

$[\ldots]$

Carta de Eugenio D’Ors

28 abril 1951

Sres. Darío Suro y D. Carlos Edmundo de Ory

Mis distinguidos cofrades y amigos:

Hasta ayer no había encontrado la clave de la conexión que les unía a VV. la bella revista, cuyo ejemplar número 0 recibí. Ahora, estamos ya entendidos; y sabemos que punto podemos realizar, unidos, el viaje a los astros.

«Eructabo abscondita a constructione mundi.»

No puedo menos que recibir fraternalmente una poesía y una pintura, que tratan de penetrar en el mismo recinto, que es tan habitual a la filosofía.

Muy cordialmente, les saluda.

Eugenio D’Ors.

Tal como señalan las respuestas al manifiesto ofrecidas por Aleixandre y D’Ors, puede verse cómo el Introrrealismo consiste en la expresión de la esencia metafísica y mística de la propia poesía. Esta debe expresar la totalidad del universo, la experiencia de la profunda unidad de todos los seres, el ritmo cósmico y sagrado de la vida. La poesía, tal como la magia y el chamanismo, debe transmitir el misterio y debe percibir, de manera intuitiva, natural y automática, la energía interna que hace que la realidad sea algo fantástico y trágico, pero sobre todo algo misterioso. De este modo se expresa Ory en el manifiesto:

No interesa el fragor (hay una poesía llamada tremendista). No interesa la evidencia. Toda poesía es oscura en su propio plan. Esta poesía ama íntimamente la transfiguración, el idealismo mágico y la concreción sensual de las cosas. No interesa el tema. La poesía no tiene temática. Siempre se canta a algo. «Arte para mi bien». «Poesía para mi corazón». Mi corazón es el tema. Lo llamo íntegro, por su carácter de totalización introrreal correspondiente a la intensidad lírica infundida. 
Las cosas reales están ahí, pero sin nuestra hondura no son nada. Esta poesía es hija del beso de la realidad exterior y el mundo interior (Grande, 1970a: 310).

El poeta se configura aquí como un ser mágico, cuya voz lo es también, que puede atravesar el velo de las apariencias y observar la verdadera realidad, tal cual es. En el hinduismo el velo de maya ${ }^{94}$ representa lo aparente, formado por los nudos y las trampas que traza nuestra realidad representacional basada en el lenguaje. Aquel ser, Atman, que aspira al conocimiento y a la unidad con Brahma, debe ser capaz de ver más allá de las apariencias y captar la realidad sin lenguaje. El poeta debe acercarse a la iluminación perseguida por el budismo mahayana o el budismo zen. Alcanzar la budeidad significa percibir la realidad en sí misma, de manera automática y natural, sin conceptos. La poesía tiene la capacidad de romper los límites del lenguaje, de hacer estallar la red de símbolos que constituye nuestro pensamiento conceptual. El significado emocional de la poesía penetra hacia la realidad tangible deshaciendo oposiciones conceptuales como interior y exterior, cuerpo y mente, espíritu y materia, alegría y dolor... El lenguaje del introrrealismo es holístico y el último significado de la poesía es la experiencia de totalidad, de la perfecta integración y armonía de todos los seres en el cosmos.

Evidentemente, existe un acercamiento a las filosofías orientales: al hinduismo, al tantrismo, al taoísmo, al budismo mahayana, tibetano y zen. Pero, además, el interés deriva hacia toda expresión de lo sagrado: la mística cristiana, el sufismo, el orfismo, el chamanismo, la magia, la alquimia... De modo que este lenguaje queda establecido en una zona totalmente marginal y periférica del centro de interés de la cultura y de la poesía de posguerra. Carlos Edmundo de Ory, desde este momento, será la representación del gran poeta heterodoxo. El poeta es un ser visionario que busca expresar el ritmo orgánico de la existencia. Para ello la poesía se erige como una meditación, como un proceso de iluminación que tiende al contacto con lo sagrado. Carlos Edmundo de Ory recurre así a los grandes seres visionarios que han interpretado la realidad más allá de las palabras: Novalis, Hölderlin, Carlyle, Friedrich Nietzsche, Arthur Rimbaud, William Blake, Gerard Nerval, Walt Whitman... Tal actitud es

${ }^{94}$ Watts, Alan (1963, 1990 : 84). Maya en el Vedanta significa la realidad creada por las ilusiones del pensamiento. Para acceder a la verdadera realidad, a aquella realidad que se halla más allá de los conceptos, cabe romper el velo de maya que la enmascara. 
asumida por el poeta, que se convierte en ser que, a través un proceso de transformación interna, es capaz de plasmar la totalidad del cosmos en su discurso.

Se trata, pues, de una poesía vivida como realidad interior, como constante transmutación. Una poesía surgida del centro de lo humano, «esencialista, profunda y simbólica» en palabras que figuran en el documento (Grande, 1970a: 308), que plasma la verdadera situación existencial al integrar la unión indisoluble del interior humano y la realidad exterior. La poesía deberá desvelar el misterio de la existencia, tal como se expresa Ory en su diario el 12 de enero de 1951 (2004, Vol I: 111):

Es necesario conllevar en sí mismo el misterio de uno y de todos; el misterio de nuestro yo y el del mundo de los otros. Somos hombres: pertenecemos al cosmos, al universo.

1951, año de la publicación de Nuestro tiempo: pintura. Nuestro tiempo: poesía, es también el año en el que Jack Kerouac y Neil Cassady, cuyos nombres son Dean Moriarty y Sal Paradise en la ficción, realizaron el viaje a ninguna parte a través de los paisajes más bohemios, etílicos y desencajados de los Estados Unidos. Este se narra en la novela En la carretera, publicada en 1957 ante el rechazo de las editoriales. Kerouac escribió sus experiencias en un rollo de teletipo de cuarenta metros e inauguró una nueva narrativa que contenía los supuestos del lenguaje beat. La experiencia de Kerouac marca también, como en todos los integrantes del grupo beat, una voluntad de ocupar el espacio de la marginalidad cultural y el rechazo total de los valores del sistema sociocultural imperante. Hecho que señala la convergencia con el gesto de Carlos Edmundo de Ory al rechazar totalmente las coordenadas establecidas en la cultura española de posguerra y situarse en pleno centro de la heterodoxia. Rechazo que se verá respaldado con su autoexilio a Francia en 1955.

\subsubsection{El Atelier de Poésie Ouverte}

En 1967 Carlos Edmundo de Ory ocupó el cargo de bibliotecario en la Maison de la Cultura de Amiens. En 15 de octubre de 1968 Ory emitió una convocatoria en el Journal de la Maison de la Cultura de Amiens para la creación del A.P.O., Atelier de Poésie Ouverte. Se creó el proyecto de una práctica poética colectiva, establecida en 
grupos de trabajo formado por veintiuna personas y dirigidos por el poeta Carlos Edmundo de Ory. La propuesta consistía en llevar la poesía a la calle e instalarla en pleno centro de la cotidianeidad. Unir vida y poesía, como ya realizaron los poetas románticos, simbolistas, modernistas y vanguardistas. Participar activamente del hecho poético de manera libre, auténtica y experimental, sin ataduras ni límites expresivos. En el Journal de la Maison de la Cultura fueron apareciendo, a partir del mes de noviembre, las Propositions ${ }^{95}$. Estas hay que concebirlas como una prolongación de los aerolitos oryanos, especie de breves sentencias o aforismos que marcaban la actividad del grupo. En total resultan 240 proposiciones, de las que cabe destacar algunas:

001. Vaciarse. Estar vacío.

002. La palabra es una energía.

010. Mezclar lo cotidiano con la metáfora.

026. Pregunta a tu vecino si escribe poemas.

027. Que los adolescentes nos traigan sus poemas y no lo oculten más.

051. Escucho esto: «La palabra poética es, en su esencia, un riesgo, el del apátrida». Aclaro: El poema es mi patria.

073. Di algo que no sabes decir.

085. Desarrollad la atención. No seáis aturdidos.

099. Sed todo lo que íntimamente sois.

109. Nuestras acciones poéticas no serán ni educativas ni culturales, sino una congregación de individuos en busca del acuerdo del juego y del y del significado de la vida.

145. Trata de comprender. Mira. MIRA.

151. No hay más que dos clases de hombres: los vivos y los muertos.

167. El ciclo eterno de los deseos pasando de hombre a hombre.

195. El hombre ha matado la antigua fiesta. Toda magia fundamental, el sentido de los misterios, la significación del mundo y las tinieblas humanas, rehuyendo física y moralmente la profundidad de las cosas, lo desconocido, los símbolos, la noche primordial.

196. Antaño, la magia era un oficio permanente del hombre.

197. La ciencia no es científica: es fantástica.

201. Escribir cartas abiertas en sobres abiertos (sin sellos) y dejarlas en la calle. Dirección: el primer peatón que las recoja.

205. El último poema será siempre el primero. La poesía es inagotable.

237. Mucha gente (no sólo en Inglaterra) tiene perros y gatos en sus casas. En la mía, yo tengo una hormiga.

240. Lucidez del alucinado.

Como se ve, estas proposiciones no son meras citas y juegos literarios, sino pautas de un proceso de transformación o de iluminación. En cierto modo, algunas de

${ }^{95}$ Propositions, Journal de la Maison, Amiens, $\mathrm{n}^{\circ} 11,13,24,25,32$ y 37. 
ellas se parecen al koan del budismo zen ${ }^{96}$. De hecho, Carlos Edmundo de Ory, de algún modo, representaba el papel de maestro, ya que los talleres estaban destinados al inquieto público joven del año 1968 francés. Las experiencias de los talleres se llevaban también a la escuela para que los niños realizasen juegos basados en el lenguaje poético. Desde el nacimiento del postismo se había establecido ya la relación entre poesía e infancia, entre poesía y lenguaje naïf. Una línea de investigación del A.P.O. era el aspecto lúdico de la poesía. En los talleres se trabajaba con rigor y seriedad, en ellos el juego era un elemento transversal estructurador. Ory entendía la actividad poética como una meditación y una trasformación personal, para él la poesía quedaba integrada dentro de la mística (no necesariamente cristiana y teísta). Por ello, los talleres poéticos consistían, además, en una vía de expansión de la conciencia. El A.P.O. trató de unir, de una forma práctica y colectiva, poesía y crecimiento personal.

El A.P.O. supuso a su vez un acercamiento a la poesía experimental, a la creación de una poesía colectiva o grupal, pues en los talleres se realizaba la práctica poética a base de juegos con el lenguaje: collages colectivos, experiencias letristas, poemas grupales, caligramas... Los talleres intentaban expandir la poesía, por ello se llevó su actividad a otros espacios como fábricas, espacios públicos... Su actividad irradió hacia espacios más periféricos y tomó contacto directo con los jóvenes trabajadores. En todo caso, la experiencia fue demasiado peligrosa para la institución de la que Ory era mero trabajador y, por ello, la dirección de la Casa de la Cultura de Amiens decidió su destitución. En el Diario Ory nos ofrece estos datos al respecto de esta cuestión (2004, Vol II: 310).

\section{1 enero, lunes}

Mi situación aquí, en mi puesto de trabajo en un organismo oficial, se hace cada vez más insoportable y más dificultosa. Mis puntos de vista se oponen por completo a la directiva. En la última reunión del sábado (no asistió el director) se produjo una neta ruptura entre el equipo directivo y yo. Me negué a seguir sus pautas [...] Mi lucha exterior se desarrolla, con peligros y amenazas, en el centro oficial donde tengo un empleo remunerador que me fuera concedido por el equipo precedente de liberales burgueses, y que ha sido

${ }^{96}$ El Koan en un método para alcanzar el satori, la repentina iluminación, que el monje budista zen de la escuela Rinzai utiliza además del zazen, meditación. El Koan es una especie de paradoja o dinamita cerebral que utiliza el maestro para conocer el estado del discípulo. El koan plantea un enunciado lingüístico que busca una respuesta no lingüística. Apunta a la percepción directa de la realidad, sin concepto ni lenguaje.

Ver Suzuki (1934, 1992: 143-170) y Watts (1958a, 1971: 191-202). 
reemplazado por otro distinto, y un director que quiere despedirme y busca como hacerlo, cuanto antes mejor para él. Si lo logran, peor para mí, que me quedo sin sueldo [...] En fin, que mi situación económica sufrirá menoscabo si pierdo el puesto en el organismo cultural de Amiens. La pobreza no me da miedo. Estoy acostumbrado a vivir con muy escaso dinero...

Queda claro que la actividad oryana a cargo de los talleres poéticos creativos formaba parte del ambiente de insumisión y revuelta que caracterizó al mayo del 68 francés: una apuesta por una cultura abierta que se sustentaba en el rechazo radical de una sociedad capitalista acomodaticia basada en el adocenamiento en las aulas, en la represión burocrática y en el servilismo de los partidos políticos. El fin de la utopía política entendido como proyecto liberador, surgido con la Modernidad, marca el inicio de una nueva situación, la Posmodernidad. En el año 1968 asistimos al descrédito de tres de los proyectos sustentadores de la idea de progreso impulsada por la Modernidad. El proyecto político ha sufrido ya su desencanto, el proyecto tecnológico ha mostrado también sus peligros irreparables y el proyecto mediático, desde sus inicios, aparece filtrado por el poder. El gesto de Ory supone un acto de rebeldía, al buscar la autenticidad en el pensamiento, ante la situación de malestar cultural vivida en este tiempo histórico. 


\subsection{LOS MANIFIESTOS Y OTRAS PROCLAMAS}

Sangre Sangre Sangre Sangre Sangre: dos mil años de cultura de pus.

Jesús Fernández Palacios

\subsection{Los Manifiestos del Postismo}

El 22 de fefrero de 1909 apareció el Manifiesto futurista firmado por Filippo Tomasso Marinetti. Ello marca el punto de partida de una serie de proclamas que intentaron, a su manera, liquidar, o al menos subvertir, el lenguaje representacional realista. Es decir, romper con el pasado. Pasado artístico o cultural que supone una ruptura también con la cultura burguesa presente. En 1912 se publicó Una bofetada a la opinión pública de la mano de Vladimir Maiakovsky y Víctor Klebnikc, el 1916 el Manifiesto del señor Antipirina y en 1918 el Manifiesto Dadá, ambos escritos por Tristan Tzara. En 1924 André Breton firmó el Manifiesto del surrealismo. A estos se sumaron una infinidad de declaraciones y proclamas $^{97}$ que transmitían una nueva concepción artística (filosófica, social o incluso política) definida por la radicalidad de la ruptura con la ideología y la expresión de la cultura racionalista. La tarea de todas estas aperturas, instaladas frente al anquilosado lenguaje artístico burgués, suponía la voluntad de demolición de los presupuestos existentes y la creación de un lenguaje nuevo, convergente en la multiplicidad de las propuestas artísticas que aparecieron. El signo de este nuevo lenguaje era la irracionalidad extrema. Los manifiestos postistas participaron también de esa radicalidad y de esa voluntad provocadora y rupturista, propias de los movimientos de vanguardia anteriores, pues el Postismo se erigió como un movimiento más de esa vanguardia que, en los años de la publicación del Primer Manifiesto del Postismo, ya lanzaba su particular canto del cisne. De hecho, fue el movimiento último.

${ }^{97}$ Entre los manifiestos cabe citar, por su caracter surrealista y transgresor y por sus convergencias con el Postismo, el Manifest Antiartístic Català, también denominado «Manifest groc», firmado por Salvador Dalí, Lluis Montanyà y Sebastià Gash y publicado en Barcelona en marzo de 1928. Este manifiesto fue editado por sus autores e impreso en Fills de Sabater. (Brihuega, 1979: 157-161). 
Todo manifiesto es escritura híbrida y plural, en ella queda fundido el discurso teórico y la práctica poética o artística. En la mayoría de las ocasiones esta escritura suele ser colectiva y abarca la multiplicidad de discursos que forman el lenguaje artístico. El manifiesto es ambivalente, es a la vez texto teórico y texto poético. Queda configurado como una poética crítica, o un discurso teórico emocional. El Postismo puntualizó sus bases y mostró su programación en sus manifiestos. En ellos estableció las convergencias con otras estéticas y poéticas, también puntualizó sus rechazos y, sobre todo, expuso sus teorías y manifiestó sus hallazgos. Los manifiestos postistas son textos plurales, su óptica es multiforme ya que integra diferentes perspectivas: poesía, pintura, escultura, música... El Postismo supone una estética total que integra diversas prácticas artísticas.

Son cuatro los manifiestos del Postismo y cada uno responde a una determinada situación. El Primer Manifiesto del Postismo, firmado por Eduardo Chicharro, aparece en 1945 en las páginas de la revista Postismo y su finalidad es ofrecer una definición global del movimiento y establecer teóricamente sus diferentes postulados. El Segundo Manifiesto del Postismo, firmado por Ory, Chicharro y Sernesi, se publica en 1946 en La Estafeta Literaria. Su función es perfilar algunos puntos del programa postista, establecer las convergencias del movimiento y responder a las críticas recibidas. El Tercer Manifiesto del Postismo está escrito por Eduardo Chicharro y aparece publicado en 1947 en La Hora, suplemento de El Minuto. El manifiesto supone una definición del movimiento con relación a los diferentes movimientos de vanguardia, en él se ofrece todo un catálogo de las convergencias y las incompatibilidades. Por ello queda definido por sus autores como una simple estadística.

El Primer Manifiesto fue un proclama; el Segundo, una larga Carta que escribimos nosotros a España; este Tercero es, simplemente, una estadística. Con él intentamos dar satisfacción a una pregunta que siempre se nos hizo: ¿Qué es el Postismo? (Grande, 1970a: 300).

En él se define el Postismo como un movimiento de carácter surrealista, dadaísta y expresionista. Con el dadaísmo comparte ruptura, agresividad y búsqueda de la ingenuidad ${ }^{98}$; con el surrealismo comparte el conocimiento del subconsciente y del

${ }^{98}$ Aquí la ingenuidad no cabe ser interpretada como desconocimiento, sino como otra vía de conocimiento que rechaza el sistema lógico y racional y tiene mucho que ver con el lenguaje, más allá de las palabras, de la niñez, de algunas culturas primitivas o a la experiencia 
mundo onírico y el código de la extrañeza; y con el expresionismo comparte la deformación y la expresión de la esquizofrenia ${ }^{99}$ :

El Postismo como parentesco, será: hijo del Surrealismo, nieto del Dadaísmo y sobrino del Expresionismo. ¿Qué hereda del Dadaísmo? Muy poca cosa: tal vez la intuición y la pureza de todo primitivismo. ¿Qué del Surrealismo? La exploración del subconsciente. ¿Y qué del Expresionismo? La expresividad; además coincide con él en su parecido con la producción artística de los perturbados mentales (Grande, 1970a: 304).

Existe, todavía un Cuarto Manifiesto del Postismo, escrito por Eduardo Chicharro y Carlos Edmundo de Ory probablemente poco después de que Silvano Sernesi se marchara definitivamente a Italia en 1947. Este permaneció inédito hasta 1974, año en que se publicó Música Celestial y otros poemas de Eduardo Chicharro, obra que contenía el manifiesto ${ }^{100}$. Se trata de un grito de protesta ante el proceso de marginación del movimiento, establecido desde el poder cultural y desde la ortodoxia poética realista.

Los manifiestos postistas son discursos bidireccionales. Por una parte, muestran las directrices teóricas, y por otra, son textos autosuficientemente creativos y estéticos. Es decir, son productos postistas, textos de práctica postista. En ellos se hallan muchos de los postulados del movimiento: la agresividad, la ironía, el humor, el juego, el absurdo, la sintaxis deshilvanada... Ahora bien, como escritos teóricos, muestran muy claramente los elementos de la estética postista y sus convergencias con las diversas prácticas artísticas, tanto coetáneas como históricas. El Segundo Manifiesto del Postismo nos ofrece las referencias de movimiento: Sigmund Freud, Ramón Gómez de la Serna, Guillermo de Torre, Pablo Neruda, Rafael Alberti, Federico García Lorca (estos tres últimos conocidos a través de las poéticas creacionista y ultraísta), André Breton, El Bosco, Pieter Brueghel, Tenniers, Alberto Durero, Salvador Dalí, Max Ernst, Franz Kafka, el cubismo, dadaísmo, surrealismo... Pero además:

directa del Budismo zen.

${ }_{99}$ Ver Deleuze y Guattari $(1972,1985)$. Según los autores toda cultura, sobre todo el capitalismo, organiza los flujos naturales de deseo en base a la estructura social productiva. Todo lenguaje consiste en poner diques al deseo. Por ello la esquizofrenia supone la alteración de los códigos impuestos represivos. "Si la esquizofrenia es lo universal, el gran artista es aquél que franquea el muro esquizofrénico y llega a la patria desconocida, allí donde ya no pertenece a ningún tiempo, a ningún medio, a ninguna escuela». p. 75.

100 Chicharro, Eduardo (1974), Música Celestial y otros poemas, ed. de Gonzalo Armero, Madrid, Seminarios y Ediciones, Trece de Nieve, pp. 311-312. 
Ya hemos dicho que los más altos entre los primeros patrones del Postismo son el Quijote, Santa Teresa, la Sagrada Biblia, las varias mitologías, la música en general (no las modernas formas onomatopéyicas) y, en lo que a plática se refiere, el arte chino (Grande, 1970a: 297).

En el Tercer Manifiesto se amplían las referencias hacia los ismos: simbolismo, fauvismo, futurismo, dadaísmo, cubismo, ultraísmo, surrealismo, expresionismo, existencialismo. Y también hacia autores y otras estéticas, a veces lejanas: la estética china, el arte primitivo azteca, cretense..., la ornamentación abstracta árabe, La Divina Comedia, El Quijote, La Biblia, Homero, Erasmo, Rabelais, Bruegel, El Bosco, Durero, Tristan Tzara, Pablo Picasso, George Braque, Juan Gris, Fernand Leger, Sigmund Freud, Salvador Dalí, André Breton, Max Ernst, Francis Picabia, Ives Tanguy, Hans Arp, Joan Miró, Marc Chagall, Paul Klee, Edgar Alan Poe, Charles Baudelaire, Ramón Gómez de la Serna, Oscar Wilde, Bernard Show, Jules Verne, Arthur Conan Doyle, Wenceslao Fernández Flórez, Charles Chaplin o James Joyce. Pero también las referencias apuntan hacia el movimiento orgánico de la vida, movimiento que el taoísmo y su estética han expresado desde la antigüedad:

Hay postismo en la morfología animal: infusorios, radiolarios, mundo submarino, insectos, flores, ramificaciones, cristalización; en monstruosidades, equívocos mimetismos, metamorfosis, onomatopeyas naturales, lo que hay en toda forma de arte primitivo, desde lo rupestre, salvaje, infancia, discordante, hasta la improvisación popular (Grande, 1970a: 306).

En definitiva, el Postismo entronca con todo aquello que escapa al racionalismo artístico. Frente a los modelos abstractos euclidianos o platónicos, considerados formas puras, que son producto del pensamiento abstracto, la estética postista opta por el ritmo orgánico de la naturaleza palpable y tangible. No opera con abstracciones y conceptos, sino con realidades experimentales: rugosidades, accidentes, organismos. Intenta traducir el movimiento vital que surge del interior de las cosas y se dirige afuera ${ }^{101}$. Es

${ }^{101}$ Watts, Alan (1958b, 1988: 51-52). «El estilo arquitectónico y artificial del cristianismo donde se ve con más claridad es en la idea de Dios como creador del mundo, y, por tanto, en la idea del mundo como un artefacto que ha sido construido de acuerdo a un plan, y que por ello tiene un fin y una explicación. Pero el modo de acción de I Tao se denomina wu wei, traducible a la vez por «no esforzarse»y por «no hacer». Pues desde el punto de vista de la filosofía taoísta las formas naturales no son hechas sino desarrolladas, y existe una diferencia radical entre lo orgánico y lo mecánico. Las cosas que son hechas, como las casas, los muebles y las máquinas, son un ensamblaje de partes que se reúnen, o se forman, como la escultura, de fuera hacia adentro. Pero las cosas que se desarrollan se configuran a sí mismas de dentro hacia afuera. No existen ensamblajes de partes originariamente distintas; se parten a sí misma, 
decir, opera con un paradigma holístico y se dirige a la experiencia directa de la realidad, no hacia la realidad abstracta y conceptual. En este sentido funciona la estética taoísta y su influencia en Occidente: el irracionalismo romántico, el simbolismo poético, la estética modernista, el impresionismo pictórico, el primitivismo, el surrealismo, la plástica de Klee, la pintura de Henry Michaux, los grafismos de Cy Twombly, la pintura psicodélica... De hecho, algunos autores señalados en las páginas del manifiesto que nos ocupa han utilizado un lenguaje paradójico. Tras la violencia, propia de su discurso combativo con la referencialidad realista, se escondía la expresión de una elementalidad que intentaba expresar el lenguaje fluído y natural de las cosas, tal como suceden por sí mismas, alejadas de cualquier intervención mental humana. Este sería el caso de autores como Picabia, Tzara, Gris, Ernst, Tanguy, Arp o Klee

Este manifiesto deja también muy claras las incompatibilidades. El Postismo, pues, rechaza el elemento populista (para los propios postistas) de origen ultraísta. Frente al ultraísmo, el postismo posee una posición ambivalente. Se ensalza la greguería, el poder de la imagen visionaria y la estructura metafórica del poema ${ }^{102}$ En cambio, se rechaza la búsqueda de la tradición popular realizada en la poesía de Juan Ramón Jiménez, Rafael Alberti o Federico García Lorca. De este modo se expresa el tercer manifiesto postista en su definición del código poético ultraísta:

Ultraísmo. - Movimiento literario y poético español, creado por una corriente de moda y de mal gusto, pretendió sacarnos de la sensiblería y el clasicismo de nuestros románticos, y parodia, en cierto modo, Futurismo, Dadaísmo y Surrealismo, se respaldó en la valentía de Góngora - aunque sin seguir de él más que el ejemplo -, exaltó desaforadamente la metáfora y cobró carácter gracias al ingenio de Gómez de la Serna haciendo de la técnica una constante greguería; con la modalidad «extrainsubstanciada» de J. R. Jiménez y la gitanería de salón de Lorca, es la peor peste literaria que haya podido contaminar a España en lo que va de siglo; Alberti, aunque más personal, no ha podido evitar el contagio, y su rebeldía le ha llevado todo lo más a cubrirse con un barniz de falso Surrealismo (Grande, 1970a: 302).

elaborando su propia estructura desde el todo a las partes, de lo simple a lo complejo».

102 Prisma, Buenos Aires, $n^{\circ}$ 1, noviembre-diciembre, 1921. La poética ultraísta quedaba definida del siguiente modo: «Reducción de la lírica a su elemento primordial: la metáfora. Tachadura de las frases medianeras, los nexos y los adjetivos inútiles. Abolición de los trebejos ornamentales, el confesionalismo, las prédicas y la nebulosidad rebuscada, Síntesis de dos o más imágenes en una, que ensancha así su capacidad de sugerencia. Los poemas ultraístas constan, pues, de una serie de metáforas, cada una de las cuales tiene sugestividad propia y compendia una visión inédita de algún fragmento de la vida... Si la poesía ha sido hasta hoy desarrollo, en adelante será síntesis. Fusión de varios estados anímicos. Simultaneísmo. Velocidad espacial». Aquí se puede observar la influencia del cubismo, del futurismo y, en menor medida, del dadaísmo poético. 
Paradójicamente, para Víctor García de la Concha (1987: 702), aunque los postistas desprecian el elemento popular de la poesía de Alberti y de Lorca, los romances postistas tanto de Carlos Edmundo de Ory como los escritos junto a Eduardo Chicharro, recogidos en Las patitas de la sombra, convergen plenamente con el lenguaje poético lorquiano. También Fanny Rubio (1988: 118-119) reconoce la influencia lorquiana en la poesía postista o cercana al surrealismo de signo postista, ejercida en autores como Carlos Edmundo de Ory, Juan Eduardo Cirlot, Ángel Crespo, Gabino-Alejandro Carriedo o Miguel Labordeta. Esto puede observarse en el «Romance del ronquido del niño», escrito por Eduardo Chicharro y Carlos Edmundo de Ory, publicado en la revista Postismo:

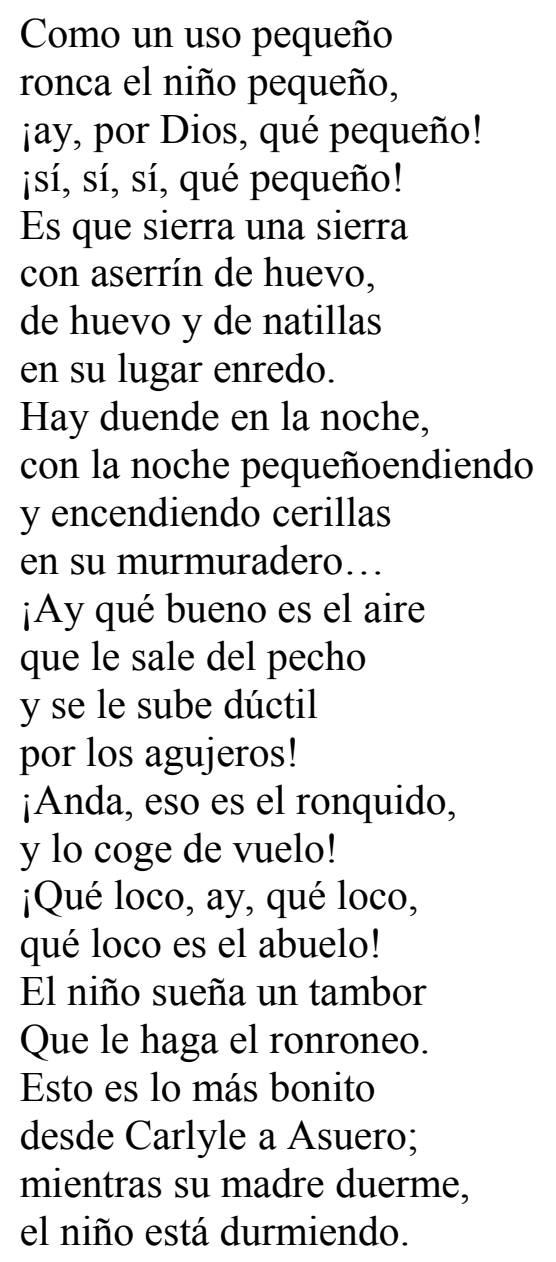

El Cuarto Manifiesto del Postismo supone el mejor ejemplo de la bidireccionalidad de los manifiestos. Si el primero suponía la definición teórica, el segundo era la definición pública aclaratoria y el tercero la definición estadística; el 
cuarto ofrece la definición poética del movimiento. El texto posee, sobre todo, una finalidad intrínsecamente poética, ya que se ofrece como práctica de la estética postista:

Este es el canasto de las torres, aquel manifiesto lírico -el Ejemplar- que tanto prometimos y ahora vomitamos con sueño y música [...] Señores amigos nuestros y muy distinguidos colegas; no en balde se os gritará que... Que el postismo, según definición epiléptica, no cabe en la mano, porque... Porque la definición del Postismo es una mano... Una mano de tres dedos; helos aquí: la discordia, el adulterio y la mágica palabra, o para ser más claros: la paloma, el gerifalte y el tres de picas que tiene el gato (Pont, 1987: 291-292).

El Postismo significó un intento de subvertir los paradigmas de la cultura racionalista burguesa, asentada en el conocimiento lógico que separa la realidad en una serie de falsas dicotomías como mente y cuerpo, espíritu y materia, razón e instinto, consciente e inconsciente, sensatez y locura... Por su herencia platónica y cristiana, la civilización occidental siempre ha ensalzado la idea, pura representación lingüística, sobre la realidad caótica de los fenómenos. El Postismo entronca con los ataques filosóficos a la racionalidad occidental, se basa así en la subversión nietzcheana del conocimiento racional, en la revolución romántica contra el imperio omnipotente de la razón, en la visión divina de William Blake o en la superrealidad surrealista, integradora de la existencia consciente y de la existencia onírica. De este modo se expresan Chicharro y Ory en último manifiesto:

Es inagotable nuestro incomparable postismo. Libertad de creación cien por cien; perjuicios cero. Nuestro horóscopo es la Sensación.

La Sensación tiene su cueva en los pies. En ellos amanece caliente la poesía. En el cuerpo (busto) conservamos el don de la pintura con el objeto de pintar. ¡Restreguemos el cuerpo en los lienzos! ¡Pintemos con cuerpo y alma, bien! Pero el cuerpo que se vea. La locura siempre es un mal, y en el postismo no. Queremos alcanzar la sublime dignificación de la alpargata. ¡Viva el artístico culto de la alegría [...] El Postismo es un movimiento incomparable de la creación, de la imaginación y vida de la idealidad en vísperas de la sabiduría intuitiva y desenfrenada (Pont, 1987: 292).

De lo que se desprende de las tesis enunciadas en los cuatro manifiestos del Postismo, este movimiento, aunque se defina como el desarrollo de la vanguardia precedente ${ }^{103}$, mantiene sobre todo relaciones con tres movimientos vanguardistas,

${ }^{103}$ Eduardo Chicharro, Primer Manifiesto del Postismo, rev. Postismo, publicación cit., p 4. «El Postismo es la resultante de los «ismos» precedentes. Nosotros no hemos elaborado este Postismo tan sólo para crear un nuevo «ismo», dándole luego leyes por nosotros 
negadores del racionalismo y su sistema realista de representación: el surrealismo, el dadaísmo y el expresionismo. Así queda expresado de manera muy clara en el Tercer Manifiesto del Postismo:

Pácticamente, todos los ismos (menos Impresionismo y Existencialismo), al romper con la función imitativa de casi todas las artes, es decir, al pasar de ser objetivos a ser subjetivos, es claro que buscan su principal sostén en la imaginación y en el «irracionalismo», y su aliento en el yo intuitivo. Algunos tienden aún más allá: se dirigen al subconsciente; éstos son, en particular, Expresionismo, Surrealismo y Postismo. He aquí pues, una primera hermandad; y de aquí también una filiación en orden cronológico y derivativo: Dadaísmo, Surrealismo, Postismo (Grande, 1970a: 304).

establecidas caprichosamente y a voluntad nuestra. Tampoco pretendemos con nuestras libertades y nuestros hallazgos «épater» a nadie. Nosotros hemos recogido lo que hay de latente en las posibilidades de hoy, lo hemos estudiado y lo hemos definido, dando además un nombre a la tendencia para que, al nombrarla, sus elementos y factores se coagulen en un cuerpo característico». 


\section{CONVERGENCIAS}

\subsection{CON EL SURREALISMO}

Tú guardas en la boca un lagarto dormido

Ángel Crespo

En sus manifiestos el Postismo aclara su posición respecto al surrealismo y establece con él sus conexiones y relaciones. El surrealismo es el principal movimiento sobre el que se asienta el edificio postista, de modo que el Postismo ha quedado definido como un postsurrealismo (Pont, 1987: 101), un surrealismo de segunda hora en el espacio europeo (Cózar, 1978, 1990: 64) o la tercera fase del surrealismo peninsular (Albí y Fuster, 1952). Para estos autores, el surrealismo español posee tres etapas, la primera estaría representada por los poetas artistas relacionados con el grupo francés y por los representantes de la poesía surrealista del grupo del 27 , la segunda se inicia en 1936 y la tercera parte queda inaugurada con la aparición del Postismo. Para Cózar (1978, 1990: 67) lo que distingue al Postismo y a la Facción Española Surrealista de Tenerife respecto a los demás productos surrealistas hispánicos es el carácter colectivo de ambos grupos. Hecho que los distingue de las producciones individuales anteriores y los emparenta con los movimientos de la Vanguardia europea, marcados por las prácticas artísticas colectivas. 


\subsubsection{La realidad oculta}

El Postismo celebra la realidad onírica y se erige como vía de expresión del inconsciente humano. Al igual que el surrealismo, el Postismo concibe el inconsciente humano y mundo onírico como estratos que ensanchan la concepción de la realidad. El Primer Manifiesto del Postismo así lo expresa ${ }^{104}$ :

Cuando el hombre duerme, su imaginación trabaja también; pero separada de él. La imaginación crea mundos, $\mathrm{y}$, episódicamente, en estos mundos, hechos e imágenes. Si el hombre domina con su imaginación los elementos que le rodean, con el tiempo llega a poseer un mundo propio rico en imágenes. Si el hombre de débil imaginación padece las influencias exteriores es dominado por el sentido común, la rutina y el mal gusto; ese hombre no tendrá un mundo propio [...]

El Postismo preconiza la existencia y el triunfo de estos mundos específicos, individuales o colectivos (las religiones son la más alta expresión anímica de los mundos colectivos; el arte, la expresión sensorial más pura común a todos los mundos); el Postismo afirma que el subconsciente es quien facilita la materia en bruto de toda creación pura. Y la exégesis de la obra postista se fundará, pues, en este axioma: el subconsciente ha de crear (es el que crea), y el subconsciente ha de entender (es el que entiende).

El Postismo plantea, primeramente, la existencia de varios estratos de realidad. Algunos de los cuales escapan al modelo de realidad planteado por el racionalismo. En este sentido el Postismo, como el surrealismo, se acerca a concepciones paradójicas o irracionales preconizadas por el chamanismo o la magia. Por otra parte, las otras realidades humanas como pueden ser la realidad artística, las realidades conceptuales expresadas en el mito o las realidades anímicas, inexpresables mediante el lenguaje basado en el significado lógico (pero sí mediante en el significado emocinal), poseen un sustrato inconsciente. Así, el lenguaje mítico y el lenguaje artístico expresan la realidad interior, en algunos casos irreconocible, del ser humano. Esta concepción es la utilizada por la hermenéutica junguiana que considera que el símbolo humano es expresión de su inconsciente ${ }^{105}$. Para el surrealismo las realidades que aparecen en los sueños también poseen estatuto de existencia real, por ello la realidad total o surrealité queda formada al integrar la realidad onírica a la esfera del ser humano. Esto es lo que André Breton anuncia en Manifiesto del Surrealismo de 1924 (1962, 2009: 26-27):

104 Obra cit, rev. Postismo, p. 5.

105 Ver, Jung (1951, 1963: 31-58); Fromm, Erich (1951, 2012: 15-23); Bachelard, Gaston (1970), Le droit de rêver, París, Presses Universitaires de France, traducción de Jorge Ferreiro Santana, El derecho de soñar, México D. F., Fondo de Cultura Económica, 1985, pp. 187-202. 
Creo en la futura armonización de estos dos estados, aparentemente tan contradictorios, que son el sueño y la realidad, en una especie de realidad absoluta, en una sobrerrealidad o surrealidad, si así se le puede llamar. Esta es la conquista que pretendo.

En 1953, André Breton, en el escrito El Surrealismo en sus obras vivas, acerca sus posiciones a la hermenéutica. Mediante la práctica surrealista Breton pretende desvelar el significado del mito y del símbolo. Signos que expresan siempre una ocultación establecida desde el lenguaje de la racionalidad (1962, 2009: 273):

Para el surrealismo, lo decisivo fue llegar a convencerse de que tenía en la mano la «materia prima» (en el sentido de los alquimistas) del lenguaje [...] Hasta el presente momento hemos procurado sacar provecho de que la comparación de los productos de esta escritura dirigiera los focos hacia aquella región en la que el deseo impera ilimitadamente, que es, al mismo tiempo, aquella en la que nacen los mitos.

El lenguaje surrealista provocó la fractura en el sistema representacional racionalista, subversión que atrajo el interés por los otros discursos que el lenguaje de la racionalidad marginaba ${ }^{106}$. Así surgió la seducción provocada por el arte africano, por la alquimia, por la locura, por los autores malditos, por la poesía visionaria, por las corrientes místicas, que desde siempre han intentado sondear el misterio de la existencia. De este modo finaliza Breton El surrealismo en sus formas vivas (1962, 2009: 279):

Unicamente la intuición nos proporciona el hilo que nos lleva al camino de la Gnosis, en tanto en cuanto conocimiento de la realidad suprasensible, «invisiblemente visible en el seno del eterno misterio».

El Postismo, por otra parte, pretende restaurar el lenguaje del ello ${ }^{107}$ al afirmar que «el subconsciente ha de crear (es el que crea), y el subconsciente ha de entender (es

106 Foucault, Michel (1970, 1973: 14-18). Para Foucault existen unos discursos socialmente excluidos, entre ellos la civilización occidental ha censurado aquellos que se asientan sobre el cuerpo y el deseo: la locura y la sexualidad.

107 Ver Deleuze y Guattary (1972, 1985: 23-27) y Reich (1948, 1995 : 389-390). Para los primeros el lenguaje del ello es el de la esquizofrenia, cuyos límites y signos no coinciden con el código social, ya que éste es el lenguaje que nace del deseo. Para Reich el lenguaje del ello se acopla perfectamente a lo que la biología describe como los procesos naturales. Entre ellos el autor destaca la sexualidad como expresión del deseo humano natural. En este sentido, el orgasmo placentero es la experiencia humana del ritmo expansivo y productivo del ritmo dinámico de la existencia. 
el que entiende)». En este sentido, el lenguaje del ello se busca no sólo en el sueño, sino en lo raro y en lo extraño, en el absurdo y en el disparate. La búsqueda de la extrañeza inaugura el interés postista por los discursos marginados y marginales, reivindicados por el surrealismo. Así se expresa el Segundo Manifiesto del Postismo (Grande, 1970a: 293):

Queremos desentrañar la cifra del inexplorado misterio que se encuentra en lo que la gente llama burdamente «lo raro». Queremos proyectar nuestro arte sobre el sentido profético, intuitivo y subconsciente (no siempre) del espíritu. Queremos sacar de los medios de expresión el mayor partido posible: hacer del lenguaje no sólo un «medio», sino, y especialmente una fuente directa de inspiración. Y queremos ser libres; libres totalmente; hasta hacer culto del Disparate; hasta desterrar la sensatez aparente de lo convencional; encontrar la Belleza del desiquilibrio de formas y valores; estudiar los arcanos de la producción artística y literaria de los mensajes, plásticas y pinturas mesiánicas, así como el secreto del arte de los enajenados, de los niños y los salvajes.

\subsubsection{Una lógica paradójica}

La definición del Postismo que aparece en el Primer Manifiesto muestra totalmente sus convergencias con el surrealismo, pero también resalta su divergencia: el valor poético del texto postista ${ }^{108}$.

El Postismo es el resultado de un movimiento profundo y semiconfuso de resortes del subconsciente tocados por nosotros en sincronía directa e indirecta (memoria) con elementos sensoriales del mundo exterior, por cuya función o ejercicio la imaginación, exaltada automáticamente, pero siempre con alegría, queda captada para proporcionar la sensación de belleza o la belleza misma, contenida en normas técnicas rígidamente controladas y de índole tal que ninguna clase de prejuicios o miramientos cívicos, históricos o académicos puedan cohibir el impulso imaginativo.

El Postismo se distancia del surrealismo en cuanto al automatismo psíquico. El surrealismo propone la escritura automática como un proceso alejado de cualquier control racional, estético o ético, tal como se define el movimiento en 1924 en el Primer Manifiesto del Surrealismo. Definición que parodia totalmente el significado denotativo del lenguaje racional (Breton, 1962, 2009: 39):

${ }^{108}$ Obra cit., rev. Postismo, p. 5. 
SURREALISMO: sustantivo, masculino. Automatismo psíquico puro por cuyo medio se intenta expresar, verbalmente, por escrito o de cualquier otro modo, el funcionamiento real del pensamiento. Es un dictado del pensamiento, sin la intervención reguladora de la razón, ajeno a toda preocupación estética o moral.

El Postismo no propone el automatismo psíquico puro, explorado por Breton y Philippe Soupault en los Champs Magnetiques (1919), ya que el producto ofrecido por la escritura o pintura automática supone un conglomerado de material subconsciente carente de estructura artística y semántica. Frente a ello el Postismo supone la práctica de una estructura estética que unifique el material surreal y lo dote de un determinado sentido. Este sentido o control, técnica como lo llama el Postismo, supone una lógica paradójica, cuyo significado no apunta a la lógica, sino a la emoción. La técnica postista es una lógica poética, artística. El Tercer Manifiesto del Postismo aclara la posición del movimiento respecto al surrealismo. En él el movimiento postista aparece definido como un movimiento que busca un lenguaje que exprese el subconsciente, un lenguje inspirado principalmente en el inconsciente en cuanto receptáculo de lo instintivo, lo oculto, lo reprimido... El subconsciente es el sótano del consciente, habitación donde residen las represiones, los traumatismos, las insatisfacciones y las frustraciones. Pero en él se encuentra asimismo la intuición y la sugerencia, verdaderos ejes de la poesía y del lenguaje onírico.

Lo que diferencia al Postismo del surrealismo francés es el rechazo del automatismo puro. El subconsciente postista posee un signo poético, para el Postismo es la poeticidad el principio que estructura el material inconsciente. Se trata, pues, de una selección consciente de ciertos fragmentos del subconsciente. En este sentido se expresa el Tercer Manifiesto del Postismo:

Postismo - Se llama así tan arbitrariamente como se denominan Futurismo (ya que es un «pasadismo»), Ultraísmo, Surrealismo (o «Sobrerrealismo»-nunca «superrealismo», que más bien debió llamarse «transrealismo»); quiere decir Postismo, después de los ismos; y más concretamente es un neo-surrealismo y un neo-expresionismo; a semejanza de estos dos ismos, recaba gran parte de inspiración y materiales del subconsciente; a difenrencia del Surrealismo, no admite automatismo absoluto; selecciona el material subconsciente $\mathrm{y}$, también a diferencia del Surrealismo, no elude la Estética, sino que por el contrario, la busca (una estética especial, libre de cánones y prejuicios); tampoco rehuye la Lógica, la convierte en técnica; ni la Moral, la traslada al entusiasmo, a la alegría de los sentidos, la acerca a su expresión intuitiva e instintiva; propugna la más amplia libertad (poniendo freno allá donde ésta conduzca a lo anodino, a lo no 
puro, a lo anti-arte), el juego frenético de la imaginación, el imperio de la forma (morfología) y del decorativismo rítmico-animal (euritmia), y por ende, la exaltación expresivo-sensorial (Grande, 1970a: 303).

El interés técnico, estético o moral se refiere a la exaltación de la libre imaginación creadora. Ésta es la técnica, una lógica no basada en lo racional sino en el absurdo y la libertad; una ética amoral que rechaza el sistema de valores de la burguesía y queda configurada como una marginalidad bohemia y reivindicativa de una existencia más humana, en la que vida y arte puedan unirse. La ética postista consiste en vivir cotidianamente la poesía, el absurdo y el disparate. Postura vital vivida de manera alegre y optimista, postura, en ocasiones, muy cercana a la frivolidad. La paradoja es el signo del lenguaje postista. La paradoja preside el siguiente fragmento del Tercer Manifiesto Postista, que corresponde a las incompatibilidades del movimiento (Grande, 1970a: 305):

Surrealismo. Contra automatismo, control; contra «escritura automática», poesía; contra misterio, enigma; contra irracionalismo subconsciente, racionalismo subconsciente o irracionalismo consciente; contra abstracción, morfología; contra fantasmagoría, «locura inventada»; contra negación de la lógica, lógica de los sentidos (lógica técnica); contra negación de la Estetica, «Nueva Estética» (euritmia y decorativismo animal); contra negación de la Moral, euforia contagiosa («locura inventada»).

Con todo, el Postismo no preconizaba un cambio social y cultural a todos los niveles; pero sí que implicaba un corte con un sistema representativo, el realismo, y una reacción contra el modelo social e ideológico racionalista.

Los intereses postistas por hacer consciente lo inconsciente, por revelar aquello se que esconde en él, contactan con la teoría y la práctica del método critico-paranoico de Salvador Dalí, esbozado en La conquista de lo irracional (1935) y en El mito trágico de «El Ángelus» de Millet», escrito en 1933 y publicado treinta años más tarde. Dalí centra su atención en los mecanismos internos de los fenómenos paranoicos y delirantes y busca un método experimental basado en el poder inmediato de las sistemáticas asociaciones propias de la paranoia. El mito trágico de «El Ángelus» de Millet» ofrece teoría y práctica acerca del método crítico-paranoico, cuya importancia radica en la imagen doble, que simultáneamente representa de modo fantasmagórico dos realidades diferentes, o dos facetas diversas de esa realidad superior: 
La simple constatación de los desplazamientos, analogías y relaciones permite llegar a la conclusión de una coherencia continuada en el encadenamiento de las imágenes a las que acabo de referirme y que han sido retenidas y utilizadas en mis cuadros [...] Esas imágenes sorprenden de inmediato -sin que sea necesario un estudio analítico más profundo- por la sistematización evidente de su contenido delirante.

De modo que la naturaleza de esas imágenes corroboraría de una manera concreta la noción que podríamos hacernos de la imagen paranoica en general: en ella habría una sistematización en sentido evolutivo que coexistiría con el núcleo de las ideas delirantes y constituiría una parte sustancial de él. La idea delirante se presentaría como portadora en sí misma del germen y de la estructura de la sistematización: de ahí el valor productivo de esa forma de actividad mental que se encontraría no sólo en la base misma del fenómeno de la personalidad, sino que, incluso, constituiría su forma más evolucionada del desarrollo dialéctico (1963, 2002: 42-43).

El método utilizado por Salvador Dalí intenta sistematizar la realidad artística a la vez que pretende explorar la realidad interna. El Postismo busca su lógica paradójica en el metodo crítico- paranoico, definido por su autor como un método espontáneo basado en la objetivación de las asociaciones de los fenómenos delirantes. Los postistas buscan estas asociaciones de ideas que se rigen mediante el discurso de la obsesión y de la locura. Tanto la lógica paradójica como el lenguaje daliniano suponen el establecimiento de una sistematización de las imágenes caóticas surgidas del subconsciente humano. De hecho, la pintura de Dalí es un intento de ensamblar onirismo y clasicismo. Entre los referentes propios de la pintura de Salvador Dalí se encuentran pintores realistas de la talla de Velázquez, Leonardo, Vermeer, Claude Loraine... 


\subsection{CON EL DADAÍSMO}

-Desidelio, flamina, catumpo. ¡Purumpúm, prumpúm, purumpúm!

Juan Ramón Jiménez

\subsubsection{Provocación y ruptura}

El dadaísmo es el movimiento de vanguardia que irrumpió con más estruendo y fragor contra la cultura occidental racionalista y burguesa. Su actitud combativa marcada por la agresividad y la radicalidad de sus teorías y, sobre todo, de sus prácticas pretendía la demolición de todo un sistema de valores y de ideas: romper con el pasado cultural y con el presente actual, ya que ambos eran frutos de un sistema ideológico racionalista transmutado en un sistema económico capitalista que tendía a la represión humana. El dadaísmo intentaba liberar al ser humano de la esclavitud de los engranajes socio-culturales. Para ello pretendía hacer tabula rasa de los mecanismos ideológicos que se encontraban no sólo en el aparato político y legal, sino también en las representaciones culturales. De aquí la voluntad (metafórica) de quemar los museos, la ruptura total de un pensamiento basado en la lógica racional. Ruptura de un sistema de conocimiento casi atávico, metamorfoseado en el siglo XIX en positivismo, cientificismo, capitalismo...

El Postismo, de algún modo, recoge la herencia rupturista del dadaísmo y la adapta a sus propias circunstancias. Por ello el movimiento de la nueva estética supuso una ruptura total con los parámetros culturales instaurados en los primeros años de la posguerra española. Airadamente el Postismo rechazó la triunfalista cultura imperial del franquismo y las tesis que sostenían la vigencia del realismo artístico. Con este fin los postistas utilizaron la agresividad de las acciones y la radicalidad de las tesis planteadas por agentes dadaístas como Tristan Tzara, Francis Picabia, Marcel Duchamp... Si el Postismo supuso algún peligro para la sociedad y para el poder institucional, se debió a la dinámica de la provocación. 
La provocación sistemática aparece en todas las proclamas, en todas las declaraciones y, sobre todo, en los manifiestos. El Primer Manifiesto se expresa así:

Los postistas lanzamos nuestro manifiesto no con insultos, pero sí con violencia; sentamos nuestro credo y consignamos nuestras afirmaciones más inmediatas. Empezamos así: todos los poetas postistas nos parecemos necesariamente; los pintores tendremos mayor amplitud de expresión; no escondemos tampoco; es decir, lo declaramos abiertamente (no, pues, como admisión u homenaje, sino como legítima defensa y demostración de no parentesco), que en poesía pisamos directamente sobre las pálidas cenizas de Lorca y Alberti, pero sin hollarlas y sin empolvarnos; que somos hijos adulterinos de Max Ernst, de Perico de los Palotes y de Tal y Cual, y de mucho semen que anda por ahí perdido, aunque ya desecado y pulverizado en mónadas ingrávidas pero levantiscas ${ }^{109}$.

Presencia de la violencia, de la agresividad y de la provocación. El Postismo rechaza el sentimentalismo y la poética de academia y, sobre todo, el arte que se desprende del sistema represor (cultural y ético) burgués. Ello se muestra en otro fragmento del Primer Manifiesto Postista:

A vosotros, sobre todo a vosotros, poetas va el ruego, o el consejo, o el diablo despoblado, o como queráis llamarlo, que os dirigimos. Pero vosotros, pintorcetes, arquitectonales escultores o escultóricos arquitectos, así como vosotros, burgueses apestantes y cursis novelistas, no os hagáis los disimulados: también vosotros tenéis materiales plásticos, y cuatro o cinco dimensiones, y posibilidades ilusorias, y escamoteos, y colorines y coloretes con matices y contramatices para demostrar, si os da la gana, que no sois del rebaño de los sensatos y pentapedantes devoradores de cocido casero, ensuciadores de calcetines zurcidos o portadores de monóculo, lo cual se llama monoculóforos ${ }^{110}$.

La ruptura postista no sólo se dirige al arte burgués, sino a la misma cultura y a su tradición:

Todo lo que gana el hombre en cultura y en experiencia lo pierde en pureza de espíritu. $\mathrm{Y}$ tres elementos poderosos se conjuran para cohibir el impulso imaginativo y minar los más elementales principios de sensibilidad: el precedente de las antiguas escuelas, la cultura general y la vulgaridad del gusto de los públicos.

Pero no se crea que nosotros tenemos nada contra los mencionados elementos. Las antiguas escuelas merecen todo nuestro respeto como testimonio que son de momentos sublimes en que, allá en los años, factores múltiples se reunieron; no seremos nosotros quienes preguntarán a los desaforados si conviene o no incendiar el Museo del Prado [...] Pero, así como toda nuestra ira

${ }^{109}$ Obra cit., rev. Postismo, p. 5.

110 íbíd., p. 12. 
verdaderamente divina se dirige al público (que no al pueblo), también se vuelve a él toda nuestra clemencia amorosa y didáctica. Nosotros no somos cerrados y herméticos, nuestro movimiento se brinda a la gente, a esa gente que si no entiende no es precisamente por su culpa; y se brinda precisamente a los más humildes ${ }^{111}$.

La diferencia más clara entre el Postismo y la ruptura dadaísta reside, precisamente, en la aceptación postista de los antecedentes del movimiento inscritos en la tradición cultural occidental ${ }^{112}$. El Postismo es deudor de la cultura del pasado y reconoce la influencia de determinados discursos culturales precedentes, algunos de ellos muy alejados en el tiempo. El dadaísmo, en cambio, pretende distanciarse totalmente de la civilización occidental decadente instaurada en un sistema de pensamiento también decadente: cientificista, utilitarista, economicista, colonial, militarista... El dadaísmo es dinamita cerebral, un explosivo que trata de hacer estallar el sistema representativo y cultural basado en el poder absoluto de la lógica y la razón. El dadaísmo se establece como sistema que atenta contra la posibilidad de establecer cualquier sistema, que en última instancia siempre se basa en la clasificación y la especulación conceptuales. Aquello que se rechaza es, en definitiva, el pensamiento lógico, base de la cultura occidental. Ello es lo que se desprende del Manifiesto Dada, escrito por Tzara en 1918:

El pensamiento es algo muy bonito para la filosofía, pero es relativo. El psicoanálisis es una enfermedad peligrosa, adormece las propensiones anti-reales del hombre y sistematiza la burguesía. La dialéctica es una máquina divertida que nos conduce / de una manera banal / a las opiniones que hubiéramos tenido de todas maneras. ¿O es que se cree que, mediante la lógica, se ha demostrado la verdad y establecido la exactitud de nuestras opiniones? Lógica ceñida por los sentidos es una enfermedad orgánica. A los filósofos les gusta agregar el siguiente elemento: El poder de observación. Pero precisamente esta magnífica cualidad de la mente es la prueba de su impotencia. Uno observa, uno mira de uno o de muchos puntos de vista, uno los escoge entre los millones que existen. También la experiencia es un resultado del azar y de las facultades individuales. La ciencia me repugna en cuanto se vuelve especulativa-sistema, pierde su carácter utilitario - tan inútil- pero por lo menos individual. Odio la objetividad grasa y la armonía, esa ciencia que encuentra que todo está en orden. Sigan, hijos míos, humanidad... Dice la ciencia que somos los servidores de la naturaleza: todo está en orden, hagan el amor y rómpanse la cabeza. Sigan, hijos

111 Ibíd., p. 13.

${ }^{112}$ Recordemos que en el Tercer Manifiesto del Postismo el movimiento mostraba sus contactos con la tradición cultural, tanto occidental como foránea. Así el Postismo reivindica el primitivsmo cretense y azteca, el lenguaje taoísta chino, la geometría árabe, la exaltación de la imaginación de la literatura clásica (Dante, Cervantes), la pintura deformadora de El Bosco o Brueghel. Por otra parte, el Postismo también reivindica la herencia vanguardista, mucho más próxima (Grande, 1970a: 306). 
míos, humanidad, gentiles burgueses y periodistas vírgenes... Estoy contra los sistemas, el más aceptable de los sistemas es no tener, por principio, ninguno (1963, 1972: 19-20).

\subsubsection{La subversión poética}

La propuesta postista de subvertir el lenguaje del poder entronca perfectamente con la dinámica dadaísta y su voluntad de quiebra total de toda ideología de signo racionalista. El Postismo es deudor de la anti-literatura dadaísta, de las palabras en libertad y de la ruptura del poema. El Postismo sigue la senda dadaísta de la palabra liberada, tal como se expresa en el Primer Manifiesto del movimiento español:

¡Es tan poco libre el hombre! Y, sin embargo, con una sensatez de vaca, el muy insensato anda como con miedo de hacer uso libre de aquello que precisamente es más libre, es completamente libre el pobrete. ¡Rompe ya de una, descomunal y vulgarísimo antropiteco; rompe ya de una con tus miramientos, tu idiotez congénita, e introduce las manos hasta los codos en el maravilloso cesto y saca las palabras a puñados, las más bellas, las que más te agrade ensamblar; pero no para decir cosas que, por lo general, son tonterías o para emitir juicios profundos que no suelen importarle a nadie, sino para gozar de oírte a ti mismo o para que te oigan HABLAR! Aprovéchate de este cesto de juguetes e inúndate de alegría diciendo cosas hermosas, pobre renacuajo aplastado de hombre que eres y no sabes divertirte más que con tu sucia sexualidad o con la torpe y pesada noria de tu cerebro ${ }^{113}$.

Se trata de librear la palabra de la tiranía del significado conceptual y de la dinámica de la utilidad comunicativa, de este modo la expresión se torna producto lúdico, juego del lenguaje donde la palabra adquiere poderes mágicos. La poética postista es deudora del collage dadaísta. De hecho el texto postista conecta directamente con el siguiente fragmento, titulado «Cómo hacer un poema dadaísta», perteneciente a Dada, manifiesto sobre el amor débil y el amor amargo, escrito en 1919 por Tristan Tzara, verdadero texto instructivo sobre la elaboración del collage dadaísta $(1963,1972: 50)$ :

Coja un periódico.

Coja unas tijeras.

Escoja en el periódico un artículo de la longitud que cuenta darle a su poema.

Recorte el artículo.

Recorte en seguida con cuidado cada una de las palabras que forman el artículo y métalas en una bolsa.

${ }^{113}$ Obra cit., rev. Postismo, p. 12. 
Agítela suavemente.

Ahora saque cada recorte uno tras otro.

Copie concienzudamente.

en el orden en que hayan salido de la bolsa.

El poema se parecerá a usted.

$\mathrm{Y}$ es usted un escritor infinitamente original y de una sensibilidad hechizante, aunque incomprendida del vulgo.

La diferencia entre ambos textos, que responde a las diferentes tesis de los dos movimientos, estriba en la voluntad poética de la práctica postista frente a la destrucción total del modelo dadaísta, propuesta caótica esta última que se expresa en el concepto de antiarte o antipoesía. El texto de Tzara supone un collage escrito por el azar, tal como indica la siguiente expresión: «Copie concienzudamente / en el orden en que hayan salido de la bolsa». En este sentido, la práctica poética dadaísma suprime el elemento humano, lo que en el lenguaje orteguiano suponía una poética deshumanizada. En cambio, la poética postista asume una voluntad poética capaz de estructurar la libertad textual. Ella supone un elemento conceptual, o consciente para decirlo de otro modo, que imprime una semántica poética. Esto es lo que nos indica el texto postista: «saca las palabras a puñados, las más bellas, las que más te agrade ensamblar». Frente a la ruptura dadaísta de la idea de belleza, y con ella la ruptura del arte, la propuesta o técnica postista exige la aceptación artística, la poeticidad de la práctica literaria. La poética postista asume la liberación de las palabras, pero en ella el elemento humano siempre presidirá el edificio poético. Ello no significa que el Postismo acepte la idea tradicional de belleza, pues para la nueva estética la belleza no es el mismo concepto racionalista adherido a la idea de bien y a la estética del realismo. La belleza, tal y como la concibe el Postismo, será convulsa y misteriosa; una belleza de signo surrealista. La diferencia más clara que existe entre el Postismo y el dadaísmo queda expresada en el Tercer Manifiesto Postista:

¿En qué se diferencia mayormente, dentro de estos parecidos? Del Dadaísmo, en que tiende a una creación artística madurada técnicamente y en que no siempre rompe con la tradición (Grande, 1970a: 305).

El Postismo no hace tabula rasa de la tradición artística, de ella extrae una serie de antecedentes sobre los que erige su edificio. 


\subsubsection{Lo naïf}

Otro punto de contacto con el dadaísmo es el primitivismo, que ofrece la estética salvaje o naïf. En este sentido, poseen signo dadaísta el interés postista por la infancia y la búsqueda de la pretendida ingenuidad, de la libertad, de la espontaneidad y de la belleza del lenguaje infantil. El Postismo se propone encontrar la fascinación ante la realidad que provoca la mirada emotiva de la niñez. Una mirada prístina y clara, no enturbiada por los conceptos y los prejuicios. Esta es la mirada cristalina de los ojos que miran por primera vez. Este interés por lo naïf supone también un rechazo de los valores de la cultura occidental basada en el sentido crítico de corte racionalista. Frente a ello, se propone el disparate y la ingenuidad, el juego y la imaginación, la creatividad y la libertad. La autenticidad de la mirada humana queda opuesta a la hipocresía social, tal y como propugnaban también los surrealistas en 1924 en el Manifiesto del Surrealismo ${ }^{114}$. Ello queda perfectamente expresado en el siguiente fragmento perteneciente al Primer Manifiesto del Postismo:

Tan sólo la niñez se halla en estado de gracia (¡Bendita niñez!, que nosotros defenderemos hasta el aburrimiento de quienes quieran escucharnos. La adolescencia posee el caudal de la fuerza ciega, pero ya semiconsciente y abastardada; mas, por desgracia, ya ha malgastado gran parte de su herencia imaginativa. Y el hombre maduro de nuestros tiempos, después de perder toda su imaginación, pierde también su espontaneidad; es en este momento horrible cuando, lleno de falsa experiencia, es presa del egoísmo) ${ }^{115}$.

Un sentido análogo posee el siguiente fragmento del Segundo Manifiesto del Postismo:

El mundo puede ser un valle de esperanzas e intuiciones. Al nerviosismo, a los odios y a la tristeza de hoy no debemos oponer un arte frío, pobre, académico, sino las maravillas de la imaginación, la libertad. Los hombres no encontrarán el bálsamo que necesitan hasta volver otra vez a la Espontaneidad. La más bella definición del Postismo la ha hallado un poeta, no podría ser menos; Carlos Edmundo de Ory ha dicho: «EL POSTISMO ES LA LOCURA INVENTADA» (Grande, 1970a: 293).

${ }^{114}$ Breton (1962, 2009: 54). "El espíritu que se sumerge en el surrealismo revive exaltadamente la mejor parte de su infancia [...] Quizá sea vuestra infancia lo que más cerca se encuentra de la «verdadera vida»; esa infancia tras la cual, el hombre tan sólo dispone, además de su pasaporte, de ciertas entradas de favor; esa infancia en la que todo favorece la eficaz, y sin azares, posesión de uno mismo».

${ }^{115}$ Obra cit., rev. Postismo, p. 13. 
Se trata de encontrar la alegría primordial, la percepción sin mediatizaciones de la experiencia directa, del perpetuo juego que es la realidad. El sentido lúdico del Postismo no propone sólamente un arte que sea puro juego superficial o la búsqueda de una belleza que trivialmente resida en el absurdo, sino que apunta a un verdadero cambio en los paradigmas culturales y existenciales. Se busca un reencuentro con una realidad que, en definitva, es juego eterno, creatividad permanente y, sobre todo, puro goce y éxtasis, alegría primordial. La locura inventada supone la búsqueda de una nueva óptica existencial que rompa con lo que Freud $(1923,1973$ : 138-144) denominó principio de realidad.

El Tercer Manifiesto del Postismo establece, una vez más, que la conexión del movimiento español con el dadaísmo se basa en la búsqueda de la espontaneidad, actividad constantemente reprimida por el peso de la cultura occidental. El adamismo ${ }^{116}$, concepto postista aparecido en este manifiesto, es el contacto más estrecho entre ambos movimientos. Así queda explicado en este fragmento:

Cada ismo puede ser definido con una idea representativa: Futurismo, dinamismo, Dadaísmo, adamismo [...] Pero expongamos algo más por extenso [...] Dadaísmo. - También se llama «Dadá» y «papá Dadá»; pasa por su fundador el poeta Tristan Tzara; propugna el retorno a los primeros balbuceos del hombre y los pueblos salvajes; se inspira en las reacciones infantiles, de ahí su nombre, palabra que en Francia usan los niños para designar un montón de cosas y personas (Grande, 1970a: 301).

El dadaísmo rechaza de pleno el sistema filosófico racionalista, ya que este supone las bases de una sociedad basada en el terror humano, en la práctica militarista del genocidio y en la represión humana. El dadaísmo, inmerso en su gran ruptura, no acepta el valor de la lógica, estrategia suprema del conocimiento racionalista, ni su dinámica del concepto. Todo concepto es producto mental, pura representación lingüística que apunta a un fragmento de la realidad. De este modo, el pensamiento conceptual intenta ordenar y estructurar una realidad que en sí misma es caótica, como un nudo sin fin donde cada elemento (si así se puede decir, porque en ella no hay nada que esté separado) está totalmente conectado con los demás formando una unidad total. El concepto en cambio, separa y ordena, y por ello supone una traición a esa realidad multidimensional y poliédrica. Los dadaístas rechazan precisamente este sistema

\footnotetext{
${ }^{116}$ Así aparece, y no adanismo, en el texto postista.
} 
representacional. No la realidad en sí, donde no existen conceptos. Esto es lo que Tzara nos dice en el Manifiesto Dada:

La dialéctica es una máquina divertida que nos conduce / de una manera banal / a las opiniones que hubiéramos tenido de todas maneras $¿ \mathrm{O}$ es que se cree que, mediante el refinamiento minucioso de lógica, se ha demostrado la verdad y establecido la exactitud de nuestras opiniones? La lógica ceñida por los sentidos es una enfermedad orgánica (1963, 1972: 19-20).

La lógica es una complicación. La lógica siempre es falsa. Ella tira de los hilos de las nociones, palabras, en su exterior formal, hacia objetivos y centros ilusorios. Sus cadenas matan, miriápodo enorme que asfixia a la independencia (1963, 1972: 22).

Yo proclamo la oposición de todas las facultades cósmicas a esta blenorragia de un sol pútrido salido de las fábricas del pensamiento filosófico (1963, 1972: 25).

Emulando el discurso de Nietzsche, Tzara pretende romper con el sistema lógicorepresentacional realista considerado como responsable del desastre militar y cultural de la civilización occidental. Para Nietzsche (1882: 337-338) la decadencia cultural era fruto de dos tradiciones religiosas: el judaísmo y el cristianismo, cuya sombra es el racionalismo. Muerto el padre, Tzara pretende asesinar a su sombra para que la realidad cósmica pueda ser percibida sin las distorsiones efectuadas por el pensamiento conceptual racionalista. El ataque del dadaísmo no sólo se dirige a la ideología del sistema representacional de la burguesía, sino que va directamente dirigido al centro su ética, una ética de la esclavitud. Así se expresaba Tzara en 1918 en el Manifiesto Dada:

Destruyo las gavetas del cerebro y las de la organización social: desmoralizar por todas partes y echar la mano del cielo al infierno, los ojos del infierno al cielo, restablecer la rueda fecunda de un circo universal en las potencias reales y en la fantasía de cada individuo (1963, 1972: 18).

Estoy contra todos los sistemas, el más aceptable de todos los sistemas es no tener, por principio, ninguno $(1963,1972: 20)$.

La moral atrofia como todo azote producto de la inteligencia. El control de moral y de la lógica han inflicto la impasibilidad ante los agentes de la violencia -causa de esclavitud-, ratas pútridas de las que está repleto el vientre del burgués (1963, 1972: 23-24). 
La moralidad es la infusión de chocolate en las venas de todos los hombres. Esta tarea no fue ordenada por una fuerza sobrenatural, sino por el cartel de los mercaderes de ideas y los acaparadores universitarios $(1963,1972: 24)$.

\subsubsection{Budismo zen.}

Este sistema de percepción de la realidad más allá de las palabras, anhelado por el dadaísmo, es el que preconiza el budismo y, en su interior, de una manera mucho más directa el budismo zen, conjunción en Japón del taoísmo y del budismo mahayana. Carlos Edmundo de Ory, en Historia del postismo, relaciona la poética naïf postista con el budismo zen, ya que, mediante la búsqueda de la espontaneidad, el Postismo trataba de encontrar una percepción de la realidad alejada de la lógica y de los conceptos, más allá del lenguaje racional. La locura inventada exigía un lenguaje alejado de la lógica, un lenguaje de signo simbolista capaz de captar la sugerencia y la emotividad y de transmitir atmósferas y estados anímicos, un lenguaje despojado de carga conceptual, un lenguaje basado un significado emocional. Este lenguaje se estructura en base a una lógica paradójica y absurda. Paradoja y absurdo son dos signos muy claros del budismo zen. De este modo se expresa Ory en la Historia del postismo:

¿Qué fue del postismo? Como definición clásica se daba por entonces una fórmula mía: «La locura inventada». Nosotros, ni Eduardo ni yo, nunca dábamos definición escolástica. Decíamos lo que no era. Yo tendría que comparar el postismo con el budismo Zen y no lo hago hoy aquí. Mi poesía, en aquellos años, era analizada por los psiquiatras y uno de ellos encontró elementos de sensibilidad china. Como dice Gogol en el Diario de un loco, España y China es una y es la misma cosa y donde se escribe España se lee China. Pero, sin duda, el budismo zen, que no es chino sino japonés, no es extraño a mi sensiblidad (Grande, 1970a: 276).

El budismo zen rehuye a cualquier concepto, por ello rehuye también cualquier tipo de definición. El zen pretende una percepción sin lenguaje, más allá de las palabras, ya que se trata de una experiencia que no se limita a una visión dualista de los fenómenos. Es una experiencia que rechaza de pleno toda especulación analítica y todo significado conceptual, porque el concepto mediatiza la percepción de la realidad, la traiciona. Pues la realidad escapa a las categorías del discurso, se escapa entre ellas como el agua en una red. Taisen Deshimaru (1974, 2002: 34) define el zen como el abandono de todo y el sentarse en silencio con el «rostro iluminado, sensación de 
libertad, espíritu apacible» sin ningún objetivo ni fin. El zen es el proceso natural, inconsciente y automático que lleva a la percepción y a la integración de la energía cósmica de la que todos los individuos y todas las cosas forman parte. Mediante la práctica del zazen, o meditación sin objetivo aquí y ahora, todo individuo puede obtener el satori, repentino despertar o budeidad. Es decir, alcanzar la naturaleza de los budas. Con estas palabras se expresa Deshimaru, maestro de la escuela Soto-zen que se trasladó a Francia y fundó el Dojo en París (1974, 2002: 36):

Nos tienta siempre considerar de un lado las ilusiones y de otro el despertar (satori). Ahora bien, ¿qué es satori? No es un estado en particular, es el regreso del ser a su condición normal, originaria, hasta cada una de las células de su cuerpo. Satori se sustrae a toda categorización, a toda conceptualización; la lengua no puede dar cuenta de él. No se puede aprender o recibir de otro. Es preciso experimentarlo uno mismo. El maestro sólo puede ayudar, el verdadero satori es vacuidad $(k u)$. Lo incluye todo, incluso las ilusiones. En el sutaru hannya shingo se dice: «La forma no se diferencia del vacío y el vacío no es más que la forma». $K u$, el vacío, encierra todos los fenómenos. El ejercicio del za-zen es en esencia satori: no vivimos por nosotros mismos, somos vividos por el sistema cósmico.

El zen consiste en pensar sin pensamiento y supone un lenguaje sin lenguaje, es por su propia naturaleza paradójico y absurdo. Su lenguaje no se rige por la lógica, sino a través de la parábola, de las historias de los maestros zen, de las preguntas sin respuesta conceptual, del koan y del haiku. Se trata de un lenguaje disparatado y misterioso y que, en muchas ocasiones, trata de llevar al absurdo lingüístico, a hacer estallar el propio lenguaje. Esto sucede, sobre todo, cuando el maestro zen plantea un koan a su discípulo. Un koan como Cuál es el sonido de una sola mano exige una contestación no lingüística por parte del discípulo. La respuesta será un salto sobre el lenguaje, Pam, el golpe de una mano sobre otra. El koan, como brevemente se ha visto con anterioridad, busca una respuesta extralingüística porque el zen supone la aprehensión de lo real sin lenguaje, la experiencia directa de la realidad. El zen es ilógico porque la comprensión a la que se dirige se realiza trascendiendo los conceptos. Un ejemplo de este pensamiento paradójico viene trazado en el siguiente fragmento perteneciente a la Gâtha de Jenye escrita por Shan-hui (497-569), conocida más comúnmente con el nombre de Fudashi (Fu-tai-shih) (Suzuki, 1934, 1992: 77): 
Paso con las manos vacías, y ¡mira!, la azada está en mis manos:

Yo voy a pie y a caballo, al mismo tiempo a lomos de un buey;

Cuando paso sobre el puente,

no es el agua la que corre, sino el puente.

El zen subraya que el lenguaje no puede concordar con la realidad, ello viene expresado mediante las paradojas, que forzosamente señalan la inadecuación del lenguaje con lo real. Tal experiencia exige la ruptura del lenguaje y sus dicotomías, pues qué son el invierno y el verano, la noche y el día, la vida y la muerte. En última instancia son conceptos cuya separación es ficticia, conceptos que en ocasiones no se ajustan a la realidad. Pues la muerte es la propia vida, sin ella no existiría la vida, la muerte está instalada en la cotidianeidad ya desde el mismo nacimiento.

El zen es totalmente ilógico y caótico, ni es una religión ni es una filosofía. Desprecia toda autoridad doctrinal y toda palabra dogmática. Su lenguaje es críptico e ilógico, rechaza toda la literatura sagrada, a la que considera poco más que basura. El zen rompe con toda especulación ideológica y con toda abstracción, va más allá del lenguaje y se dirige a la misma percepción. Por eso su lenguaje está impregnado de poesía, porque atiende a las sensaciones en el aquí y en el ahora. La meditación zen asesina el pensamiento, podría definirse como un pensamiento sin pensamiento, sin objeto y sin finalidad. Su interés es restituir de forma automática y natural el contacto con la gran energía cósmica que penetra en cada ser. La impronta del zen es la sencillez inmediata que expresa el haiku.

El viejo estanque, salta una rana: el sonido del agua.

Basho (1643-1694)

En la campana del templo, posada, duerme la mariposa.

Buson (1716-1783) 
Por ello el zen está en la base de la espontaneidad dadaísta, de su rechazo visceral del pensamiento racionalista. De hecho, algunas proclamas dadaístas parecen estar cifradas en el lenguaje del zen (Tzara, 1963, 1972: 27-28, 54):

No hay nada ninguna importancia no hay transparencia ni apariencia.

Escribo porque es natural como orino cuando estoy enfermo.

No buscamos NADA nosotros afirmamos la VITALIDAD de cada instante.

La anti-filosofía de las acrobacias ESPONTÁNEAS.

En este momento odio al hombre que cuchichea antes del entreacto - agua de colonia- teatro gris. EL VIENTO ALEGRE.

Si cada uno dice lo contrario es porque tiene razón.

Dadá es una cantidad de vida en transformación transparente sin esfuerzo y giratoria.

El Postismo también adopta este lenguaje ilógico, caótico y espontáneo. El lenguaje zen sustenta una lógica paradójica, que, en cierto modo, es la misma que estructura el lenguaje postista. Ella se encuentra en la definición de la locura inventada, en el aspecto lúdico y disparado del movimiento. En este sentido, la zona postista donde más penetra el lenguaje zen es en la poesía de Carlos Edmundo de Ory, dirección que recorrerá toda su poesía posterior y que estudiaremos más adelante.

Ha cantado el primer gallo, el día ha estrenado su traje blanco en aquel tejado.

Sombras y pájaros (1940). 


\subsection{CON EL EXPRESIONISMO}

¡Qué rudo ruido de rodar redondo!

¡Qué espesura de silos, y yo solo!

Eduardo Chicharro

Las convergencias del Postismo con el expresionismo apuntan a la estética de la crueldad y de la desesperación. El Postismo ofrece, de forma enraizada con la expresión del absurdo, la estética de la deformación grotesca. El Postismo trata de plasmar lo oscuro y lo siniestro, aquello que el consciente esconde a la luz propia del racionalismo y a la hipócrita moral burguesa. Ahora bien, frente a la expresión del terror humano desatada por el expresionismo alemán, el Postismo ofrece una estética irónica y caricaturesca, propia de la tradición hispánica. Óptica burlesca que arranca de las fiestas carnavalescas, de la poesía de los goliardos, del realismo grotesco representado por Juan Ruiz, Fernando de Rojas y Francisco Delicado, por el teatro ambulante y popular y por el teatro bufonesco, por la deformación patética de Quevedo y Goya, y ,sobre todo, por la estética esperpéntica de Valle-Inclán y de Gómez de la Serna. Respecto al expresionismo alemán, la deformación postista se erige como una estética irónica, lúdica y desenfada. El juego postista es la base de su estética deformadora, idea que aparece ya en el Primer Manifiesto:

En el Postismo el juego es ya la base de su técnica. El simple ritmo en poesía o en música es «juego». La composición en pintura y arquitectura es «juego». El retorno a una idea, una frase musical, una o unas palabra-símbolo, o palabrapersonaje, o palabra-clave, en las formas que tiene sucesión, es «juego»; y la rima, es «juego»; y la asonancia, es «juego»; y el mismo ambiente anímico o tonal-color, es «juego»...

Pero, ¿qué es precisamente el «juego» en el Postismo? Todo cuanto se ha dicho, pero llevado a la categoría de técnica-base, o de factor-principio de lo emocional directo (pues la técnica-base es factor emocional -en este segundo aspecto- indirecto, o coadyuvante). Además, determinados aspectos de relación y determinada preferencia (cuya expresión se descubre en la repetición, el insistir y la vuelta o retorno) por formas ideológicas, lingüísticas, de materiales o de objetos, así como una positiva diferenciación en todos los elementos 
expresivos y expresables, hasta llegar a rozar el monstruosismo, el desequilibrio y la desintegración, es del dominio del «juego» ${ }^{117}$.

Es el juego la óptica deformadora que muestra una estética grotesca frente a los modelos oficiales y las poéticas realistas. La expresión postista, en este sentido, propone un discurso ampuloso, desmesurado que se basa en la lógica paradójica de la extrañeza y en la constante deformación de unos discursos heredados o de la misma realidad. El discurso postista supone un lenguaje especular distorsionador, y por ello funciona, en cierto sentido, como estética expresionista. Cabe señalar que uno de los antecedentes más importantes de esta estética de la deformación se encuentran en la pintura flamenca, en las obra de El Bosco y de Pieter Bruegel el Viejo. Antecedentes que no podían pasar por alto a un pintor como Eduardo Chicarro y a un poeta interesado por la imagen como Ory.

\subsubsection{El lenguaje de la atrocidad}

El expresionismo alemán, nacido del lenguaje esquizofrénico de la pictura de Vincent Van-Gogh y del salvajismo deformador de la pintura de Paul Gauguin, propugna un arte basado en la intuición, en el subjetivismo y en la búsqueda del lenguaje primordial en las culturas foráneas como las africanas, las asiáticas.... El expresionismo, sobre todo el expresionismo pictórico de primera ola, representado por Edgard Munch, James Ensor, Emil Nolde y el grupo Die Broche, nacido en 1905, cuya figura eje es Ernst Kirchner, expresa la angustia humana y explora el ámbito existencial de lo siniestro, el miedo y el terror, el desasosiego y la repugnancia. A través esta estética angustiada, basada en la selección de los aspectos más desfavorecidos y grotescos de la cotidianeidad, se presenta una realidad mórbida y repugnante, delirante y siniestra. Esta estetica de la fealdad y de la crueldad supone, en una cierta dirección, un acercamiento al lenguaje de la locura, presente en la pintura de Munch, Nolde, Kirchner o Marc ${ }^{118}$. Es en este punto, precisamente, donde reside el interés del Postismo por el expresionismo alemán. El Tercer Manifiesto del Postismo muestra sus equivalencias:

117 Obra cit., Rev. Postismo, p. 13.

${ }^{118}$ En el discurso de la esquizofrenia cabe destacar la pintura de Van-Gogh, la poesía de Ezra Pound, la literatura de Antonin Artaud, la pintura de Henry Michaux... y entre ellos cierta zona de la pintura expresionista alemana, donde cabe destacar de la Egon Schielle. 
Expresionismo. Pintura, escultura; irracionalismo patológico, expresión, símbolo; paradigma: psicología (Grande, 1970a: 303).

¿Qué hereda del Dadaísmo? [...] ¿Y del Expresionismo? La expresividad; además, coincide con él en su parecido con la producción artística de los perturbados mentales (Grande, 1970a: 304).

El Postismo se declara como vehículo explorador del discurso de la locura, de la rareza y del absurdo existencial. Ahora bien, el Postismo no propone una óptica de la angustia, sino que elabora el discurso de la locura desde una posición optimista, desafiante y provocativa: la locura inventada. Tal actitud comporta una práctica poética enfermiza trazada desde una óptica lúdica y desenfadada, un lenguaje de significado absurdo que se proyecta hacia lo oscuro y lo misterioso, que trata de hacer consciente lo inconsciente, de desvelar los significados emocionalmente ocultos.

La transformación y la distorsión del lenguaje, la asociación libre, el encuentro fortuito (definido por el Conde de Lautréamont como el encuentro de un paraguas y una máquina de coser en una mesa de disección ${ }^{119}$ ), la sorpresa semántica creada al asociar conceptos totalmente alejados..., todo ello si se lleva al extremo desemboca en el discurso de la locura. El Postismo llega a la locura exacerbando la imaginación, la locura inventada equivale a la imaginación desatada. Así queda expresado en el Primer Manifiesto:

La invención postista puede por medio de la imaginación recorrer un ámbito tan dilatado que va desde lo perfectamente normal a la locura ${ }^{120}$.

La herencia expresionista más fructífera que incorpora el Postismo es el gusto por lo raro, lo extraño, lo enfermizo, lo alucinado, lo atroz. El Postismo propone una estética de la extrañeza.

119 Ducasse, Isidore (1969), Chants de Maldoror; traducción de Julio Gómez de la Serna, Los Cantos de Maldoror, prólogo de Ramón Gómez de la Serna, Madrid, Bibioteca Nueva, 1923, Canto sexto, p. 202. "jY sobre todo, bello como el hallazgo fortuito sobre una mesa de disección, de una máquina de coser y de paraguas».

${ }^{120}$ Obra cit., rev. Postismo, p. 12. 


\subsubsection{Representaciones de la realidad interior}

El Postismo define al Expresionismo como una estética basada en la subjetividad simbólica, en la intuición. Estética que parte del interior humano e intenta expresar esta misma interioridad. En este sentido, existe una relación muy clara entre el Postismo y la propuesta que parte del grupo Der Blaue Reiter, creado en 1911, y capitaneado por Vasili Kandinsky. Los postulados del grupo alemán, formado por el mismo Kandinsky junto a Franz Marc, August Macke, Gabriele Münter, Alfred Kubin y Paul Klee, estriban en un acercamiento hacia la abstracción como lenguaje idónea para expresar la realidad interior del ser humano. Sus signos son el simbolismo del color y la tendencia hacia el arte expresivo primitivo e infantil, puntos compartidos totalmente por la estética postista. Ahora bien, el viaje hacia la expresión de la realidad interior, propuesto por Kandinsky y, de algún modo, efectuado ya en el Postismo, se realizará con mayor interés y profundidad en la posterior poética introrrealista de Carlos Edmundo de Ory.

Para Kandinsky, el lenguaje de la abstracción pictórica es un intento de radiografiar la psicología humana. El Postismo recoge este acercamiento a la expresión de los mapas mentales y de los paisajes de la mente. Aunque no comparte, como tal, la existencia de una estética abstracta, sí se interesa por la expresión de la interioridad del ser humano. En este sentido, es heredero de las tesis de Kandinsky, que propugnan un arte de naturaleza intuitiva que explora los estados anímicos y espirituales del ser. La óptica de Kandinsky surge de la concepción mística de la pintura y se configura como un método de trasformación personal y de desarrollo del ser (1912, 1996: 101-102):

La verdadera obra de arte nace misteriosamente del artista por vía mística. Separada de él, adquiere vida propia, se convierte en una personalidad, un sujeto independiente que respira individualmente y que tiene una vida material real. No es pues un fenómeno indiferente y casual que permanece indiferente en el mundo espiritual, sino que posee como todo entre fuerzas activas y creativas. La obra de arte vive y actúa, colabora en la creación de la atmósfera espiritual [...] La pintura es un arte, y el arte, en su aspecto global, no es una creación inútil de objetos que se deshacen en el vacío sino una fuerza útil que sirve al desarrollo y a la sensibilidad del alma humana.

Este viaje hacia el interior del ser humano exige un lenguaje cuyas bases son la intuición y la improvisación, postulados también del discurso postista. Para Kandinsky es la intuición el elemento que estructura la creación artística, en la praxis únicamente 
opera la sensibilidad. La teoría, en cambio, no es un código artístico (espiritual en el lenguaje propio del autor) sino que pertenece al lenguaje de la racionalidad (1912, 1996: 68-69). El arte, de este modo, se concibe como una operación interior que exige un código interno en el que la belleza cambia de paradigma. El concepto de belleza se halla ligado a la coherencia anímica y no a la mímesis representacional.

Si el artista es sacerdote de la «belleza», ésta se debe buscar según el principio del valor interior que ya vimos. La «belleza» sólo se puede medir por el rasero de la grandeza y de la necesidad interior, que hasta aquí tan buenos servicios nos ha prestado.

Bello es lo que brota de la necesidad anímica interior. Bello es lo que es interiormente bello (Kandinsky, 1912, 1996: 104).

El Postismo participa también en el viaje representativo hacia el interior humano, en el interés por las experiencias místicas y sus representaciones. Esta línea mística será recorrida en un futuro por la poesía de Carlos Edmundo de Ory que explora la mirada heterodoxa y se interesa por las tradiciones culturales de la antigüedad como el orfismo, la alquimia, la Cábala y las llamadas filosofías orientales. El Postismo significa su punto de partida.

Por otra parte, el Postismo comparte con la estética de este expresionismo de segunda oleada el interés por la importancia de la música. La música es el arte más abstracto de todos $\mathrm{y}$, por ello, supone la vía de entrada en la abstracción pictórica. La música supone la expresión humana más apartada de materialidad de lo real, pues el sonido como tal no tiene un objeto hacia el que tiende su referencialidad. En su acercamiento a la abstracción, la obra pictórica rompe sus relaciones con el mundo objetual y, como la música, busca el ritmo interno del ser humano y el dinamismo intrínseco de la realidad expresado mediante la intuición humana. Para Kandinsky, al igual que para la poética postista, basada en la euritmia, la palabra, desmaterializada de su objeto referencial, adquiere nuevos poderes. Despierta una vibración humana interior parecida a la que produce el color en la pintura. La palabra, como puro sonido en el sentido del mantra oriental, posee propiedades mágicas y supone una vía de conocimiento y de transformación interiores:

La palabra es un sonido interno que brota parcialmente (quizás esencialmente) del objeto al que la palabra sirve de nombre. Cuando no se ve el objeto mismo y 
sólo se oye su nombre, surge en la mente del que lo oye la imagen abstracta, el objeto desmaterializado, que inmediatamente despierta una vibración en el corazón [...] El empleo hábil (según la intuición) poética de una palabra, la repetición, necesaria interiomente, de esa misma palabra dos, tres y más veces consecutivas, conducen no sólo al desarrollo del sonido interior, sino que pueden descubrir otras insospechadas cualidades espirituales de la palabra. Finalmente, la continuada repetición de una palabra (que constituye un juego predilecto de la juventud, que luego se olvida) hace que ésta pierda el sentido extremo del nombre. Del mimo modo se olvida hasta el sentido, abstracto ya, del objeto designado y se descubre el puro sonido de la palabra (Kandinsky, 1912, 1996: $39-40)$.

El Postismo, al igual que la abstracción pictórica, opera mediante el valor fónico de la palabra, que es considerada como vibración mágica.

Después de haber analizado los manifiestos postistas, podemos decir que el Postismo tiene contactos con todos los movimientos de la Vanguardia histórica. Del surrealismo celebra el poder de los sueños, del dadaísmo toma la búsqueda de la elementalidad, del expresionismo se apropia de su estética psicológica basada en la intuición, del cubismo incorpora el perpectivismo, del impresionismo la impresión óptica y el color, del fauvismo la deformación expresiva y la extrañeza, del ultraísmo la greguería, del futurismo el dinamismo expresivo. Según Rafael de Cózar (1978, 1990: 67) el Postismo supone la definitiva incorporación de la vanguardia europea a la literatura hispánica. 
Soy el superglóbulo de la sangre del mundo.

Manolo Pilares

La euritmia es una de las propuestas fundamentales de la literatura postista, se trata de la investigación, la exploración y el juego con el aspecto fónico y musical de la poesía, que consiste en la práctica de la asonancia, la onomatopeya, la proximidad fónica, la rima extraña, los cortes repentinos, la reiteración obsesiva... El interés en el elemento fónico del lenguaje, en el puro sonido, proviene de la poesía modernista, sobre todo de autores como Rubén Darío, Leopoldo Lugones o Julio Herrera y Reissig. De aquí se toma la creación de nuevos ritmos, de rimas extrañas y el juego permanente en la deconstrucción métrica. La euritmia aparece definida en el Primer Manifiesto de Postismo como la unión de poesía y música:

La música es, de las manifestaciones libres, la más postista, porque es la más abstracta; es también la más, la única, perfectamente patética [...] Nosotros, como se ha visto, damos la preferencia a la música sobre la poesía ${ }^{121}$.

${ }^{121}$ Obra cit., rev Postismo, p. 4. 
Para el Postismo la palabra poética forma parte de la música, significa buen ritmo. La música, a su vez, simboliza el poder metafísico y mágico de la palabra, elemento de transformación personal, elemento de transmutación de la realidad interior y de la realidad exterior, y elemento de expresión de la integración del ser en la totalidad cósmica. Este es el sentido que posee la música en el orfismo poético, práctica que evoca los ritos y los misterios de Eleusis (Ruiz Soriano, 2004: 13-15). El poeta órfico es el ser que experimenta el goce permanente de la alegría y de la ebriedad de Dionisos, ser humano transmutado en ser divino, que ha convertido para sí la realidad en constante éxtasis. Orfeo ha descendido a los infiernos y ha escuchado la música de la locura y de la desesperación y luego regresa a la vida trasformado en ser divino que se siente partícipe de la divinidad cósmica ${ }^{122}$. Como él el poeta órfico transmite en su poesía el éxtasis permanente, su música divina. De este modo, la música, para el Postismo, y sobre en la trayectoria poética de Ory, intenta ser método de conocimiento y vía de acceso al estado mágico y primigenio de la realidad. La palabra será, por ello, una palabra mágica cuya esencia es el puro sonido, una vibración capaz de una transformación mística. La palabra postista recupera los poderes de celebración de la vitalidad dionisíaca $^{123}$, de la participación cósmica. Nietzsche cree que el origen de la poesía se halla en la música y su función consiste en transformar al ser humano en un ser divino, es decir en facilitar la cercanía entre el ser humano y las divinidades (1882, 2002: 156-157):

En virtud del ritmo, una vez que se había notado que el hombre conserva mejor en la memoria el verso que la prosa, se aspira a que se les quedase grabado a los dioses más profundamente algo que interesa mucho al hombre; asimismo, uno creía hacerse audible a mayores mediante el tictac rítmico; la oración rítmica parecía llegar mejor al oído de los dioses [...] Por tanto, se trataba de forzarlos mediante el ritmo y de ejercer un poder sobre ellos: se les lanzaba la poesía como si de un lazo mágico se tratase.

122 En el mito Orfeo, figura asociada a Tracia y a una reforma del culto de Dionisos durante el siglo VI a C., con su lira encantaba a las rocas, a las plantas y a los animales e incluso a los guerreros tracios. Sus canciones contaban el origen del universo. Orfeo realiza la bajada a los infiernos para recuperar a Eurídice, pero al mirar atrás ésta regresa a él. La muerte del héroe a manos de las Ménades tracias lo convierte en el símbolo del desmembramiento sacrificial de los ritos dionisíacos y de las corrientes herméticas y alquímicas.

En los misterios eleusinos la experiencia psicodélica funciona como experiencia de descenso a los infiernos, experiencia de muerte y resurrección, de partir y regresar. Este es el sentido del desmembramiento, una experiencia de romper con los límites del propio ego y de expandirse en el océano de la realidad. Ver Eliade (1956, : 132-133).

123 Nietzsche, Friedrich (1872, 1973: 56-60). Para el autor, Apolo es el dios que representa los límites, el ego personal; en cambio, Dionisos, dios de la desmesura, representa el todo, la ausencia de límites. 
La euritmia postista parte de la consideración de este lenguaje mágico que configura la poesía, que tiene la propiedad de ahondar en la realidad interior humana y el poder de trasformación del ser humano. La poesía, como la música, es pasión, amor, dolor o éxtasis, y, sobre todo, una vibración que emite armonía y vitalidad y liga al ser humano con los elementos cósmicos: el aire, la tierra, el agua, el fuego... La concepción de la unión entre música y poesía tiene sus contactos con el pitagorismo y con el neoplatonismo. En este sentido funciona la idea de la música de las esferas que emana de la cítara tañida por la divinidad, música que se traduce en el movimiento armónico del cosmos, del universo celeste donde trazan su órbita los planetas. Esta concepción mágica y mística de la poesía significa la vía de interés del Postismo hacia la magia, la alquimia o el hermetismo y hacia de idea neoplatónica de un mundo divinizado, reflejo de la divinidad de creador $^{124}$. Se trata de la idea de una divinidad inmanente, punto de contacto del cristianismo con otras religiones de cariz panteísta. Esta concepción mágica (ya que la poesía es vibración), metafísica y mística de la poesía acompañará toda la trayectoria poética de Carlos Edmundo de Ory.

El Primer Manifiesto de Postismo nos da las claves del poder mágico de la palabra y de la concepción musical y fónica de la palabra poética:

Hay palabras como burro, churro y culo que pueden ser poéticas, entre otras cosas, porque son bellas fonéticamente, así como caca, vaca, nene y nata; que hay oídos terriblemente sensibles que con todo derecho rechazan algunas de ellas (a pesar de figurar con todas sus letras en el Diccionario de la Academia Española); que la poesía lo mismo nace de la idea de que del sonido, de la imagen plástica o de la palabra, y que la palabra, manejada sabiamente, adquiere valores insospechables aún no estudiados; que el ritmo es inexcusable en las formas musicales, plásticas y poéticas; que uno de los ejercicios puros en poesía es el metro, con su hermana la rima, pudiendo surgir de su más severa y atinada disciplina (se pone de movimiento todo el mecanismo subconsciente) una fecunda fuente de poesía [...] como conclusión de lo dicho, el vocablo resulta ser fuerza motora y no tiene únicamente el valor que nos indican en su frialdad el Diccionario y la Gramática, sino aquel valor que le confiere la situación en la

${ }^{124}$ Eliade, Mircea (1969, 1999: 58-60). El punto de contacto entre Oriente y Occidente quedó configurado por la tradición hermética. Marsilio Ficino tradujo la literatura hermética e intentó armonizar hermetismo y cristianismo. Este mismo camino fue transitado por Pico de la Mirándola, Giordano Bruno, Nicolás de Cusa, Campanella... Eliade parte de la idea de que Marsilio Ficino, fundador de la Academia platónica y traductor de la obra de Platón y de la de Plotino, realizó por encargo de Cosimo de Medici la traducción al latín de un manuscrito que posteriormente fue reconocido como el Corpus Herméticum. En 1463 la traducción ya estaba acabada, en ella se ofrecía el saber de las misteriosas religiones de Egipto y Persia.

Ver. Renau Nebot, Xavier (1999), Textos Herméticos, Madrid, Gredos. 
cláusula, por no hablar de aquel otro que nos brinda la palabra con sus raices ocultas y su poder ascensional ${ }^{125}$.

Esta concepción eurítmica de la poesía es lo que permite el incipiente contacto de la poética postista con la poética clasicista establecida por el garcilasismo. Ahora bien, el espíritu aventurero y explorador del Postismo, hace que mediante la euritmia se ahonden las posibilidades experimentales de la palabra poética, lo que liga la poética postista con la poética de Joan Brossa, que experimenta con las posibilidades métricas y, sobre todo, con el modelo del soneto. El soneto es también para Ory uno de los espacios de sus experimentaciones. La euritmia señala también el contacto del Postismo con la poesía intuitiva, salvaje y vibratoria, de signo oral como el grito o el susurro del haiku, de los poetas beats. La poesía postista es, sobre todo, sonido y se basa en la combinatoria fónica, en el juego métrico y en la exploración de las posibilidades estróficas. La euritmia forma parte del barroquismo poético postista basado en las rimas inusuales (de tradición modernista), en las cacofonías, en la extrañeza fónica... La euritmia supone la parodia y la subversión de los modelos poéticos clásicos, basado, según Lasheras y Saldaña (2000: 27), en las transgresiones fónicas. La euritmia es un aspecto más de la óptica lúdica del movimiento postista, juego establecido en este caso sobre el sonido. Para Rafael de Cózar (1978, 1990: 65), la euritmia supone la apertura hacia la poesía experimental y subraya también la conexión con la poesía de Cirlot, poeta preocupado por la plasmación poética de los experimentos musicales de Schoenberg y la música dodecafónica y por las representaciones letristas de la literatura hermética y cabalística.

La euritmia crea esa poesía postista ampulosa que une el automatismo surrealista a la tradición más extravagante. Une a Breton y a Dalí con Góngora y Quevedo, de modo que de ello resulta un discurso deshilvanado, extraño y desmesurado, como puede observarse en el poema de Carlos Edmundo de Ory titulado «Soneto paranoico» ${ }^{126}$, perteneciente a la obra Laocoonte y la luna (romances postistas. 1945-1948):

Solo en el mundo con mi media oreja y una cortada flor en mi semblante bajo a la mina honda del diamante

${ }^{125}$ Obra cit., rev. Postismo, p. 12.

${ }^{126}$ Rev. La Cerbatana, p. 7; (Albi y Fuster, 1952: 151; Grande, 1970a: 243; Cózar,1978, 1990: 118-119; Pont, 2003: 62). 
que no tiene raíz ni tiene reja

Mas como soy del odio tenue abeja manada de algún duende nigromante peinaré de mi espalda el monte amante y con heces de concha de la almeja

Mi paranoia de Iolao y Averno ¡hola pato de oro hola marea donde la mar merece su medusa!

Y creo que de cebra tengo un cuerno y de llama una pata panacea que se gasta en mi alma y que se usa.

En el «Romance del loco chillón», que pertenece a la misma obra (Grande, 1970a: 255256; Ory, 1978: 76-77) y es uno de los poemas más representativos de esta poética extraña y barroca, pueden hallarse ecos sonoros que provienen de la poesía modernista y de la elaboración popular lorquiana.

\footnotetext{
ABRIÓ la gran ventana del plenilunio introito y le sacó la lengua con rictus indevoto ¡Qué miedo! ¡Qué ruido de firmamento monstruo! Una luz de alta tea le pulía los hombros y de sus pies salían voces de medio tono Ya pinta misereres en su pecho incoloro destripando tinieblas como un extraño vómito Ay lo hijo no gimas ni animes melancólico de sucias energías tu garganta de loco ¿Por qué canturreas con gangrena en el rostro? Tenía en sus pupilas un volcán misterioso Ahora ya grita a gritos gritando como loco Gran animal divino y tanto doloroso ¡Que la luna me coma!
} 

¡Dios mío yo no importo!
La dinastía es mía
y es casada en el cosmos
Mi muerte será aupada
en el celeste coro
Cerró la alcoba negra
Yéndose con su lobo.

En cambio, el poema «Romance al poeta postista Silvano Sernesi», perteneciente también a la misma obra, (Grande, 1970a: 249-250; Pont, 2003: 63-64) nos remite, sobre todo, a la poesía expresionista de Quevedo. En él encontramos rupturas lingüísticas que posibilitan la coexistencia de diferentes registros, la invención de palabras, un léxico totalmente extraño o asociaciones fónicas inesperadas:

Me encuentro desmochado

Silvano de mi alma y tú estas persiguiéndome con auras delicadas y un duende tuyo pélame la cáscara del alma Gorgonas por mi cuarto plantas-piedras y águilas dilapidan mi vida mientras la tuya salta como una pantomima negrísima. Di amigo ¿con caballos soñabas? ¿con manuales carnes femeninas y pálidas? Háblame con tu lengua de sonoras arañas que comienza tu voz a hilarme una cañada Ya he visto la voz curva bajar todo lo baja que se puede en el mundo para que suene alta ¿Qué heptacordo lenguaje sale de tus palabras! ¿Eres un eucalipto de musicales plantas? Ay estoy mal de veras conviértete en estatua tanto concierto ecoico hace temblar mi casa Meandrinas por mi cuarto tubiponas coralias 
cariófilas y fungias

anémonas y astreas

me salpican y crecen

por el cuerpo ¡ya basta!

Sí Silvano los versos

son como las covachas

deben pisarse a tientas

con una vela blanca

Yo no puedo decirte

mi secreto y ni sábana

y mi mirobalano

Mas te diré mi lágrima

y mi begonia triste

y mi mullida bávara.

El siguiente fragmento del poema de Ory, titulado «Amigo fuma» ${ }^{127}$ (Pont, 1974: 55-56; Cózar, 1978, 1990: 149-150; Pont, 2003: 298-299), escrito en 1948, es también un ejemplo claro de la práctica de la euritmia:

Las putas están cerca de los cuarteles al viento anda despacio en su palacio Dios está solo en su ascensor parado En esta noche hay algo de navíos de carnaval de Navidad en Navacerrada de carne y vendaval noche de nochas noche de San Bartolomé perdonamé noche de la Edad Media a media noche Noche del Renacimiento y de remordimiento

Se oyen besos por todos los rincones de la casa.

Como también lo es el romance escrito por Chicharro y Ory titulado «Vida y muerte», perteneciente a Las patitas de la sombra, obra escrita por los dos poetas postistas. De hecho toda la obra está plagada de textos eurítmicos. Copiamos aquí un fragmento de «Vida y muerte» que resulta especialmente importamte (Lasheras y Saldaña, 2000: 97-98):

Toma azúcar cuervecillo de la miel de mis pupilas.

Musical mosquita muerta.

Hijo, ¡vente a mis rodillas!

127 Este poema, que representa totalmente la poética postista, no está inscrito en ninguna obra. Fue escrito en casa de Francisco Nieva y apareció por primera vez en 1974, en la antología de Jaume Pont, Poesía abierta (1945-1973), obra cit. 
Toma pan y toma vino.

Toma almendra y toma espiga.

Toma esto y toma lo otro.

Tómate la toma tila

tómate lo que tú quieras

traga pan con la saliva

sorbe caldo poco a poco

toma rama y toma encina

toma toma toma come

come pan y toma hormiga.

La marea del lenguaje arrastra a las palabras en su corriente incontrolada, éstas se asocian por la semejanza del sonido y ello, a su vez, resalta el contraste semántico. La lógica significativa queda abolida en este lenguaje a la deriva. Como enuncia Pilar Gómez Bedate (2011: 30-31), se trata del lenguaje de los encantamientos y de los conjuros. El poeta es un mago, un encantador de palabras que las moldea a su gusto creando una expresión enigmática. Este lenguaje postista se configura como un signo opaco, un muro que hay que atravesar de manera mágica. En este sentido, junto a la herencia del espiritismo, la teosofía, el ocultismo y la mística, Bedate (2011: 33) señala la influencia de autores como Juan Ramón Jiménez, Ramón Gómez de la Serna, Rafael Cansinos Assens, Vicente Huidobro, Nicolás Guillén ${ }^{128}$, Guillaume Apollinaire o Wladimir Maiakovsky. Esta interpretación del poeta como mago también nos la ofrece Jaume Pont en el Prólogo de la antología de Ory, Poesía abierta (1974: 11). El poeta es un ser mágico que nos desvela los misterios que se ocultan tras las apariencias de la realidad y su lenguaje tiene la capacidad de penetrar en el significado del misterio de la existencia.

Varias son las referencias que Carlos Edmundo de Ory realiza en su Diario hacia la música como método de profundización en el misterio de la existencia. Música que es metafísica y mística:

11 de enero (de 1947)

${ }^{128}$ Cabe destacar, en este sentido, la plasticidad fónica y experimental del lenguaje cubano de Guillén, coetáneo a las experiencias vanguardistas, presentado en Sóngoro Cosongo (1931). Los rasgos expresivos rítmicos y el juego con el sonido provienen del son cubanos y de la música de las Antillas. De aquí surge la onomatopeya extrema, la rima aguda y, sobre todo, la jitanjáfora. Ver Madrigal, Luis Iñigo (1983), ed. de Nicolás Guillén, Summa poética, Madrid, Cátedra, pp. 25-31. 
¡Los conceptos son música! ¡Vamos a hacer de conceptos cabales un logogrifo denso, una babel densa y sonora, una poesía ilógica, logomáquica y logomágica! ¡Viva el misterio creado!

Quiero concretar, exhaustivamente, mi noción del misterio. Para esto, necesito, a fondo, el misterio común (2004, Vol. I: 26).

2 de mayo (de 1949)

Pura inspiración. Puro lenguaje. Puro silencio sibilino. Hago magia cuando entro en la soledad espiritual. Hago música cuando vuelvo mil veces herido de presenciar y ser tocado por la salpicadura hostil. Odio con cólera y desprecio santos la impiedad de los hombres. Aborrezco y abomino sus manejos serviles, sus movimientos estudiados, su carencia de ideales, su pobre mirada de impotencia.

«¿Quién, si yo gritase, me oiría desde los órdenes angélicos?»

Esto oyó Rilke. Palabras traidas por la brisa celeste. Así oigo yo los versos enteros y los escribo sin cambiar sus profundas sílabas estelares. Oigo versos enteros, macizos, cuya intensidad rítmica resuena en mí hasta que los mato en el papel (2004, Vol. I: 64-65).

28 de noviembre (de 1949)

$[\ldots]$

Sobre música

[...] El músico Vito Frazzi, autor del Rey Lear, creía firmemente en la existencia de un acorde inicial fijo, absoluto, que no procede de los hombres porque es de origen sobrenatural, o sea, transmitivo por Dios. Ese acorde son los armónicos que nos dan cualquier sonido puro. Cuando a Saint Saëns le preguntaron: «¿Qué nota da esa campana?», respondió: «Muchas».

La humanidad de la música nace del sentimiento que despierta en los corazones. Este sentimiento es de tristeza. La vida de la música está sensiblemente unida a la vida del dolor. La música y la fiebre, la agonía, la muerte. En vísperas del tránsito, o en las melancolías del amor, el espíritu desea hundirse en un más alto país irracional. En busca de las armonías puras, beatíficas y calmas. Estando para morir, Sócrates sintió que su demonio le repetía: «Sócrates, haz música, estudia la música». La música es bella y triste, sí. Bella y triste. Herodoto cuenta que mientras permaneció en Egipto no oyó más que una canción, y era una canción triste. La melancolía es inherente a la música. Tal cosa lo demuestra también Jessica, en El mercader de Venecia, cuando dice: «Nunca estoy alegre al escuchar dulces melodías». El pobre Nietzsche (que exigía gustos especiales en la música, y gustaba tan distintas músicas) escribió: «Yo no sé hacer diferencia entre las lágrimas y la música».

La música me duerme. La música me despierta, No puedo dormir cuando oigo dulces sonidos. Entonces muero de dolor y siento que vivo. Y siento que he caído en el lugar donde todo lo que existe es hermoso y amoroso, y considero la 
calma de mi espíritu mecido por esas horribles, digo verdaderas, olas de misteriosos sonidos (2004, Vol. I: 69-70).

11 diciembre, domingo (12 noche) (de 1949)

[...] Dos engendros productores de poesía son: el grito extraño, el grito exterior, de entrañas para afuera, y lo ebrio, es decir, la significación especial de una potencia feliz impuesta por las diversas divinidades del cuerpo humano, sean el amor, el alcohol o la misma poesía.

Cuando las palabras no son gritos o no son signos ebrios del sentimiento inflamado, todo lo que la poesía dice es poco natural y no es nada sobrenatural (2004, Vol. I: 77). 


\subsection{El ENDEREZAMIENTO}

¡Ay tus ojos

gluglioluscidios!

Jesús Juan Garcés

El enderezamiento es una práctica postista mediante la cual se pueden crear infinitos textos partiendo de un texto matriz injertando una serie de cambios en algunos segmentos, sean sonidos o palabras. Mediante este técnica postista, a partir de un texto se pueden crear textos infinitos. Se trata de la práctica de la intertextualidad y de la deconstrucción cuando todavía no habían surgido estas teorías.

En las páginas 8 y 9 de la revista La Cerbatana aparece trazada la práctica del enderezamiento. En ellas los escritores postistas crean textos paralelos a las ocho Pequeñas fábulas para niños siniestros, escritas por Fernand Marc. He aquí algunos de los resultados:

Texto de Marc:

Campanas campanas sonad por el misterio del recién nacido el descanso de los muertos Campanas campanas sonad por la desdicha y el gozo el casamiento de los reyes Campanas campanas sonad por la labor de los humanos los pobres a medio camino de las piedras y el pan.

Texto postista:

Campanas, campanas, sonad por el misterio del recién nacido en el descanso de los blancos muertos.

Campanas, campanas, sonad por la desdicha y por el negro gozo del casamiento de los reyes godos. Campanas, campanas, sonad 
por la labor de los humanos humos

los pobres pobres a medio camino

de las piedras e hiedras y del pan.

Texto de marc:

Las aves son verdes

las rocas azules

el agua clara

como tus votos

El cielo es rosa

las flores bermejas

Tu aire triste

me lleva al sueño

Los besos de ceniza

las caricias de musgo

No tengo nada en venta

Fuera.

Texto postista:

Las aves son verdes, las rosas azules; el agua clarosa como tus tres voces. El cielo es rosado, las flores bermejas. Tu aire, que es triste se lo lleva el sueño.

Los besos ceniza, las caricias musgo.

No tengo ya en venta nada de tu Fuero.

El enderezamiento es una práctica más del juego postista, un ejercicio en el que se pueden crear una serie de textos paralelos mediante la sustitución de segmentos textuales basados en su parecido fónico. En este sentido, el enderezamiento posee un valor provocativo, lúdico, que pretende crear la sorpresa mediante las asociaciones establecidas. En él se halla la presencia del encuentro fortuito surrealista (Breton, 1962, 2009: 51), del arte como provocativo juego dadaísta (Tzara, 1963, 1972: 17-18), de la práctica de la incongruencia de la greguería e incluso de las asociaciones sorpresivas de términos alejados del conceptismo barroco. El enderezamiento, como práctica fonéticolúdica, parte del aspecto sonoro del lenguaje ${ }^{129}$, de modo que el texto producido debe

${ }^{129}$ En este sentido, el enderezamiento es una de las direcciones que toma la euritmia postista. Juego fonético basado en la alteración del modelo, contrafactura. 
poseer el mismo ritmo, la misma rima y el mismo esquema métrico que el texto original. Alterando algunos rasgos fónicos se crea la copia, texto con mínimas diferencias pero con una semántica diferente. El enderezamiento supone un trayecto que parte de la música y la fonética y se dirigirse a la semántica. En este sentido, resulta una semántica absurda e intempestiva, humorista y provocativa que se basa en la ruptura de los códigos lingüísticos usuales. La alteración textual produce aspectos cómicos basados en la jitanjáfora, en el contraste de los registros empleados, en la injerencia de elementos considerados prosaicos en el contexto literario.

Todo ello se encuentra en el texto enderezado surgido del conocido poema «Retrato» de Antonio Machado, escrito por Carlos Edmundo de Ory y titulado «Retrete» ${ }^{130}$ (Lasheras y Saldaña, 2000: 186-187):

Mi estancia con los cerdos un pato y una silla y un tuerto avaro conde que apura su dinero mijo caliente y caños que entierra la semilla mi zanahoria en unos ocasos ¡qué más quiero!

Ni un seudo autor mañana ni un adoquín transido yambo me veís y es porque soy niño hindú o ario mas recio y ya la fecha quemé sino tupido llamé manto de estrellas pues dan que ver hostiario

¡Ay de mis penas rotas! Desanglo hemoglobina caro universo mota minimal de ser heno irás con nombre iluso quién sabe de su orina voy en el tren sentado como una cabra ajeno $[\ldots]$

El enderezamiento postista, practicado en la década de los cuarenta, es el antecesor de los ejercicios de estilo practicados por Raymond Queneau en L'OUVROIR DE LITÉRATURE POTENTIELLE, conocido como OULIPO, grupo fundado en 1960 en París por algunos miembros del Collage de Pataphysique. El mismo Ory, en su Diario (2004, Vol. III: 342), señala que:

Si en su encadenamiento con los «ismos» precedentes el Postismo engarza una serie de eslabones sutiles que van desde el balbuceo elemental y la vitalidad

${ }^{130}$ Acerca de este poema, no tenemos noticias de que esté publicado en ninguna obra concreta. Sólo conocemos su existencia porque aparece en el texto Sobre el Postismo hoy, escrito por Ory como epílogo a la edición de Lasheras y Saldana de Las patitas de la sombra (2000), obra cit. 
nihilista de DADA hasta la PATAFÍSICA, no es cosa rara encontrar equipolencias y relaciones entre los hijos y los nietos de Alfred Jarry: surréaliste dans l'absinthe.

El enderezamiento presenta, con veinte años de anterioridad, un paralelismo total con los experimentos literarios de OULIPO, basados en la aplicación de una matemática lingüística sobre un texto original. En ambos casos, partiendo de un texto de origen se crea un segundo texto como copia alterada a base de una serie de operaciones quirúrgicas y terapéuticas. En la página 8 de La Cerbatana aparece descrito el ejercicio postista como una apropiación de cualquier texto. Mediante la deformación del texto original se crea un texto paralelo que muestra sus conexiones, pero también sus diferencias y sus cambios de significado:

El «juego» puede adaptarse como un barniz de nobleza a cualquier expresión que no sea la nuestra. Esto es lo que llamamos el enderezamiento postista. Se rige el enderezamiento en leyes naturales que otros pueden aprender de nosotros - nosotros ya las conocemos - o descubrirlas por ellos mismos.

El enderezamiento es, al fin y al cabo, la práctica consciente de la intertextualidad explícita; ya que en el fondo todo texto remite a otro texto. Por necesidad todo texto, sea literario o no, siempre remite a otros textos anteriores y, por ello, se convierte en texto múltiple en sentido borgiano ${ }^{131}$. Un texto siempre mantiene relaciones con todos los demás, de manera que todos ellos forman el texto colectivo de la cultura, texto de textos. Este es el sentido que posee la definición de intertextualidad propuesta por Julia Kristeva en $1969^{132}$. El texto queda concebido como productividad, tejido o cruce de otros textos. El enderezamiento, además de conjunción textual, se convierte en un texto metalingüístico ${ }^{133}$, en un discurso establecido sobre otro discurso. Pero también el enderezamiento se trata de la práctica de la deconstrucción, propuesta por Derrida ${ }^{134}$, el texto postista exige reconstruir el texto original para ser reconstruido nuevamente. Los cambios efectuados en el texto original mediante el injerto, la marca $o$

131 Borges, Jorge Luis, Prólogo a Francisco Quevedo, Antología Poética, Madrid, Alianza Editorial, 1982, pp. 12-13. La lectura de un texto, en la tradición literaria europea, significaba la activación de los textos anteriores.

132 Kristeva, Julia (1969), Sémiotique. Recherches pour une sémanalyse, Paris, Éditions du Seuil; traducción de José María Arancibia, Semiótica 1, Madrid, Fundamentos, 1978, pp. 235-237. XXI, 1980.

${ }^{133}$ Barthes, Roland (1957), Mitologías, traducción de Héctor Scmucler, México, Siglo

${ }^{134}$ Derrida, Jacques (1967), De la gramatologie, Paris, Minuit; traducción de O. del Barco y C. Ceretti, De la gramatología, México, Siglo XXI, 1971. 
la diseminación ${ }^{135}$, ofrecen un discurso deconstruido. El texto enderezado queda permanentemente unido al texto original y es, al mismo tiempo un texto diferente. Se trata pues de un texto secundario productor de una significación distinta, pero para ello necesita la referencia del texto original. Podríamos definir el texto enderezado como un texto adosado, que toma prestados los términos y los materiales del texto anfitrión.

En este sentido, la reescritura que exige la práctica del enderezamiento cuestiona el principio (básico en la Modernidad) de la autoría y amplia el sujeto de la enunciación, tan practicado en la Posmodernidad. A partir de los procedimientos vanguardistas como el collage, el frotage, el ready-made, la Posmodernidad desarrolla discursos esrtructurados como procesos que remiten a otro texto u otros textos de los que surgen y a los que se engarzan y acoplan. Por ello, se trata de textos que se arrancan y se reescriben. Esta reescritura literaria posee su paralelismo en la música pop en lo que se ha venido en llamar el samplig. El samplig es un injerto, o adaptación de un fragmento, o un rif de guitarra eléctrica, de una canción que se coloca en otra posterior. Se trata de la misma técnica utilizada por los pintores pop-art como Andy Warholl o Roy Lichtenstein, donde el arte remite al arte. Este procedimiento ha sido utilizado con anterioridad por Salvador Dalí en su reelaboración de Arcimboldo o El Bosco, Pablo Picasso en sus Meninas o Francis Bacon en los estudios sobre el Papa Inocencio X pintado por Velásquez. Todas estas prácticas están en la base de lo que Túa Blesa (2001: 223-337) denomina la estética del plagio. Una escritura que, según Blesa, cuestiona los límites de la legalidad y se acerca, en ocasiones, al puro delito. Por ello, transgrede la dinámica del capitalismo y cuestiona los territorios de la economía y de la jurisdicción. Instalados en plena Posmodernidad, se puede afirmar que la literatura o el arte no representan la pura realidad, sino que representan una realidad mediatizada por el arte. Si la matriz sustentadora del producto cultural o artístico es otro objeto cultural o artístico, la estética del plagio propone que el texto matriz, producto cultural generador, pierda autoría y se convierta en un texto de todos. La práctica cultural supone un signo de apropiación, el artista o el escritor se apropia de unos referentes y los adscribe a su nueva obra mediante una nueva contextualización. El enderezamiento supone un antecedente de esta escritura intertextual. 125-163).

${ }^{135}$ Ver Ullman, Gregory L., «El objeto de la poscrítica» (Baudrillard y otros, 1983, 1985: 
El enderezamiento es un ejercicio postista con voluntad provocativa, ya que en sí mismo supone una subversión del texto original, que normalmente pertenece a la tradición literaria. Las alteraciones o injertos, en unos casos meramente fonéticas y en otras léxicas o morfosintácticas, tienden a provocar un efecto cómico y disparatado. El enderezamiento, pues, supone un texto adosado que consiste en la ruptura del texto original, ruptura concebida como juego y provocación: profanación de las sagradas escrituras de la literatura. 
SEGUNDA PARTE

SOBRE LA POESÍA DE CARLOS EDMUNDO DE ORY 
I. APUNTES SOBRE UNA BIOGRAFÍA 
Estas son las palabras escritas en la arena infinita del tiempo por demás infinito.

Carlos Edmundo de Ory

La biografía de Carlos Edmundo de Ory es un viaje a través de la luz en busca del misterio de la existencia. Viaje constante hacia espacios nómadas que le llevarán también a situarse en la periferia de los espacios culturales. Esta incesante búsqueda del misterio existencial, tal como el mismo poeta se expresa en su Diario $^{136}$, articula la idea de hermandad universal y trasciende todo límite localista y nacionalista. Por ello, fue considerado el gran apátrida, el vagabundo que intenta hallar las ramificaciones que le unen al cosmos en la diáspora cultural universal: hispánica, europea, americana, africana o asiática. Su obra se configura como resultado de este recorrido y puede definirse como la poesía de un maestro errante inmerso en un incesante viaje iniciático. El viaje físico, de algún modo, tiene su traducción en el viaje cultural. Viaje que comienza en la luz de la infancia de Cádiz y termina en la visión iluminada de ThèzyGlimont. Queda así completada esta trayectoria dedicada a la búsqueda permanente de la luz.

1.1. Cádiz, entre el mar y la luz

Carlos Borromeo Edmundo de Ory nace el 27 de abril de 1923 en el número 1718 de la Alameda Apodaca de Cádiz, ciudad del mar y de la luz que representa el abrazo de una realidad mágica y enamorada. Luz del mar y de sus infinitas olas, espacio abierto a la libertad sin fronteras, energía del cosmos que reposa sobre los cuerpos de los hombres. La luz de Cádiz es la luz que ilumina los recuerdos de la infancia y los sueños. Así se expresa Ory en la introducción de la antología Nueva poesía 1: Cádiz, titulada Los cuatro jinetes:

${ }^{136}$ «Es necesario conllevar el misterio de uno y de todos; el misterio de nuestro yo y el del mundo de los otros. Somos hombres: pertenecemos al cosmos, al universo» (Ory, 2004, Vol. I: 111). 
En honor a mi odio por todo lo turístico, como un símbolo onírico, guardo en la imaginación ese hondo recuerdo. Nada sé del Cádiz moderno como ámbito convivencial. Lo único que sé, cósmicamente hablando, es que el mar no ha cambiado, ni la luz. Y el nativo que lo habita, si ANDA CON LUZ, es andaluz de casta y gaditano por añadidura, lo que no es poco. Y si no anda así, pues será un ortodoxo extranjero cualquiera (1976: 14).

Y en este fragmento de su obra póstuma, La memoria amorosa:

Mis mejores disfrutes siempre han sido el mar, las playas desiertas y las dunas, y las rocas. Me entusiasma un ancla. Me conmueven los procesos físicos, el hierro oxidado, la herrumbre, lo enmohecido, lo musgoso. Todo lo que se enfrenta con las aguas alguna vez hasta perder su uso y queda en la apariencia sólida, aunque en ruina. Ah, las ruinas, itálica famosa (2011: 26).

El agua marina es la textura de ese espacio mítico, cargado de onirismo, que recorre su obra poética y al que regresa mediante el recuerdo en su última obra. En la prosa poética de La memoria amorosa los recuerdos de la infancia se entrecruzan con las imágenes del lenguaje mítico de la humanidad y con las experiencias que la realidad, tanto tangible como cultural, ha ido ofreciendo al poeta a lo largo de su camino. Ya en diciembre de 1948, Ory manifestaba en las páginas de su Diario (2004, Vol I: 72) que: «Mi poesía es de Cádiz, es decir, del mundo, de América y, sobre todo, del mar». O el 5 de abril de 1951:

La poesía sale de la niñez. Somos poetas si hemos tenido infancia [...] El poeta verdadero amasa y forma su atmósfera con los materiales más olvidados de su vida; con materiales inolvidables. Yo viví en un puerto de mar. Yo viví una infancia viva, pero triste en el fondo, y angustiosa. Era como perseguido y estaba solo. Amaba. Sólo tenía ojos para mirar el mar (2004, Vol. I: 121-122).

Carlos Edmundo de Ory es hijo del poeta modernista Eduardo de Ory, amigo de Rubén Darío, Amado Nervo, Salvador Rueda, Manuel Reina, Enrique Gómez Carrillo..., antólogo de poetas del modernismo americano, fundador de revistas como España y América, Azul y Diana. Por ello, desde su primera juventud, Carlos Edmundo se siente atraído por la poesía, de signo simbolista y decadentista, leída en la extensa biblioteca de casa: Julio Herrera y Reissig, Leopoldo Lugones, Alfonsina Storni, José Asunción Silva, Rubén Darío, Amado Nervo, Juana de Ibarbourou, Delmira Agustini, Juan Ramón Jiménez, Paul Verlaine... Esta toma de contacto con el simbolismo poético 
recorrerá la trayectoria poética oryana, cuya presencia es más agudizada en la primera poesía, y será la base de su ideario poético. En estas lecturas se encuentra ya el germen de su postura heterodoxa y de la rareza de su poesía.

En 1930 inicia sus estudios primarios en el Colegio San Felipe Neri, estudios que continuará en 1934 en el Instituto Provincial y en la Escuela Náutica a partir de 1936. El estallido de la guerra civil paraliza totalmente su tarea estudiantil. En 1937, alentado por su padre, Carlos Edmundo de Ory inicia su práctica poética tras los pasos de poetas como Juan Ramón Jiménez, Federico García Lorca, Rafael Alberti, Luis Cernuda y los poetas modernistas. En 1939 muere su padre y Carlos empieza a publicar sus poemas en revistas gaditanas. A partir de ahora su poesía transgrede la sombra paterna y se convierte en un ejercicio de autoconocimiento, una profunda meditación y una metafísica interior. En 1940 escribe su primer poemario, Sombras y pájaros, obra en la que ya se halla contenida la impronta metafísica y el acercamiento a la poesía oriental, características notables de la poesía oryana posterior. Estas primeras obras ${ }^{137}$ de adolescencia, que suponen una introducción a la auténtica poesía oryana, permanecieron inéditas hasta la tardía publicación de Poesía primera (1940-1942) en 1986. La poesía de Ory se configura, ya desde sus inicios, como la íntima geografía de un proceso de transformación. De aquí surge la idea de la poesía como melos, música que vibra como energía cósmica presente en todo elemento del tejido universal ${ }^{138}$. Música que proviene del océano que baña las costas de Cádiz. Son estas las bases sobre las que se erige la arquitectura de la futura poesía oryana, simbolista, hermética, visionaria, mágica, misteriosa y heterodoxa ya desde sus inicios.

1.2. Madrid, ciudad de algarabía, bohemia y rebelión

En 1942 Ory se traslada a Madrid con su familia. Abandona la luz periférica del mar para ingresar en el escenario de la ciudad, en pleno centro de la cultura peninsular de la posguerra. Madrid es el verdadero eje de un territorio cultural, marcado por la

137 Sombras y pájaros (1940), La canción meditada (1941), Elisa (1941), Canciones amargas (1942), Paladín de Ponto (1942) y Las niñas del nácar (1943).

138 Ramos Ortega relaciona el concepto de musicalidad como base misteriosa de la poesía de Carlos Edmundo de Ory con la música con raigambre de Manuel de Falla y la poesía luminosa y marítima de Rafael Alberti, dos gaditanos universales (2004:15-16). 
rigidez, en el que Carlos siempre se sintió extranjero, dislocado ${ }^{139} \mathrm{y}$, por ello, ocupó el espacio más excéntrico posible. En 1943 es nombrado bibliotecario del Parque Móvil de Ministerios Civiles, cargo que ocupa durante una década. Paralelamente inicia su labor en los círculos poéticos de la ciudad, publica en las páginas de espacios culturales muy diversos como El Español, Garcilaso, Fantasía, El Espectador, La Estafeta Literaria, Insula, Cuadernos Hispanoamericanos y Poesía Española. Además sus publicaciones pronto trascienden los límites de la ciudad y llegan a las páginas de otros espacios geográficos como Verbo en Alicante, Destino en Barcelona o Lanza en Ciudad Real. Madrid es, pues, la ciudad en ebullición donde Carlos traza nuevas alianzas, el espacio agitado donde ensaya rebeliones y disidencias y, también, el punto de contacto con la realidad político-social.

En 1944 conoce al pintor Eduardo Chicharro Briones y comienza a escribir su Diario $^{140}$, dos sucesos que resultarán fundamentales en la vida de Carlos. Del encuentro con Eduardo Chicharro surge una gran amistad y la fundación del Postismo, hecho que determina la situación del discurso oryano en la territorialidad cultural de la posguerra española. Por otra parte, el Diario supone un permanente ejercicio de introspección y un acta constante de sus encuentros culturales. En suma, una radiografía íntima de la cotidianedidad. Jesús Fernández Palacios lo define, en las páginas dedicadas a la introducción (2004a: 7), como la física y la metafísica de su autor. Para él se trata de:

Una obra surgida de la necesidad y fruto de una mecánica singular que, según reconoce el propio Ory en distintos pasajes, se fundamenta en el libre albedrío, en los cambios y rupturas de contenido, en las interrupciones forzosas y abandonos momentáneos, en los huecos misteriosos, largos intervalos de vacío temporales, olvidos, transformación plástica de la propia caligrafía, desbarajuste dialéctico, tónica unitaria de la miscelánea, escritura errante, salvaje, fatal y heterogénea, que conoce fluctuaciones y fugas peligrosas, una escritura rápida, a quemarropa, sin literatura, que aspira a la brevedad, a la quintaesencia, a la elipsis y discontinuidad, a los saltos, digresiones, balbuceos (2004a: 8).

${ }^{139}$ En este sentido existe una conexión entre el sentimiento nómada oryano y la imagen albertiana que se desprende de Marinero en tierra (1925).

140 Diario (1944-2000), 3 Vol., edición y prólogo de Jesús Fernández Palacios, Cádiz, Servicio de Publicaciones de la Diputación, 2004. Con anterioridad a esta edición ya se habían publicado algunos fragmentos de este diario. La antología realizada por Félix Grande (1970a) contiene fragmentos, algunos de ellos distintos de los de la última edición, del diario que va de 1944 a 1953. En 1975 Barral publica, en la colección Ocnos, un primer volúmen del diario, Diario (1944-1956). En 1984 la editorial malagueña Begar Editores publica bajo el titulo de Eunice Fucata (Diarios, 1976-1984) otro fragmento. Otros han aparecido a lo largo del tiempo en diversas revistas. 
Definición que coincide con la escritura rizomática establecida por Gilles Deleuze y Félix Guattari ${ }^{141}$, una escritura poliédrica, multidireccional, construida a base de plegamientos y aristas, basada en un lenguaje descentrado que va transformándose continuamente, cambiando de registro a cada segmento. Se trata, en fin, de un lenguaje orgánico, mutante e ilimitado. Un lenguaje sin dirección premeditada, que presenta su propia organización, que no ofrece un reflejo de la vida, sino que se pliega sobre la vida misma ofreciendo sus ramificaciones. El Diario de Ory surge del fondo de la intimidad $\mathrm{y}$ ofrece segmentos de realidad vivida, filamentos de existencia. Allí encontramos múltiples líneas recorridas, retazos de meditación, fragmentos de experiencia. El Diario es el mapa íntimo donde queda reflejada la gestualidad poética y cultural de Carlos Edmundo de Ory, sus afinidades, sus lecturas, sus publicaciones, los trabajos inéditos, la correspondencia, la muerte de los amigos y de los autores que han sido elegidos como referentes vitales y culturales.

El 1945 funda, en compañía de Eduardo Chicharo y Silvano Sernesi, el Postismo y participa activamente de la vida bohemia y cultural del Madrid de la posguerra. Este mismo año aparece publicada, por primera vez, una selección de sus versos con el título Versos de pronto $^{142}$ e inicia la escritura de la novela Mèphiboseth en Onou o el diario de un visionario frenético, novela que la censura franquista impide publicar en 1953 y que su autor corrige entre 1955 y 1956 para una nueva edición. Finalmente la novela se publica en 1973 con el título de Mèphiboseth en Onuo. Diario de un loco ${ }^{143}$. En 1947 Ory inicia su labor de traductor, traduce a Rimbaud, Mallarmé y Paul Valéry para varias revistas literarias. A partir de 1951 se propone, junto al poeta Alejandro Busuioceanu, la tarea de traducir los versos de Pierre Jean Jouve ${ }^{144}$.

En 1948 conoce al teórico y pintor vanguardista Mathías Goeritz, hecho que acentúa todavía más su interés por las artes plásticas ${ }^{145}$ y su trabajo como crítico

${ }^{141}$ Deleuze y Guattari (1980, 1988: 11-17).

142 Versos de pronto, Madrid, Rev. Fantasía, Semanario de Invención Literaria, n 19 , julio de 1945.

${ }^{143}$ Mèphiboseth en Onuo. Diario de un loco, Las Palmas de Gran Canaria, Inventarios Provisionales, 1973.

${ }^{144}$ Ver Voice-Brey, Lilica (2013), «Tres poetas ante el espejo de la amistad», en Coordenadas, III Jornadas en torno a Carlos Edmundo de Ory, Cádiz, Fundación Carlos Edmundo de Ory.

${ }^{145}$ La atracción de Carlos Edmundo de Ory por las artes plásticas, compartido por los dos fundadores del Postismo, pero sobre todo por el pintor Eduardo Chicharro, es la base sobre la que se asienta el edificio postista. Además Ory era amigo de Juan Eduardo Cirlot, quien mantuvo una relación epistolar con André Breton y fue una figura central en la vanguardia 
artístico. Además este año comienza su trabajo en la pintura y en la experimentación con el collage poético. Participa también en las dos exposiciones realizadas por los postistas en la madrileña Galería Bochholz y en las Galerías de Arte Macoy de Zaragoza. Un año más tarde publica, junto a Mathías Goeritz, Los Nuevos Prehistóricos $^{146}$, una proclama por un arte vanguardista, y en 1951 aparece el documento Nuestro tiempo: Pintura. Nuestro tiempo: Poesía, firmado junto a otro pintor, el dominicano Darío Suro. La propuesta introrrealista, aunque no sufrió los ataques padecidos por el Postismo, tampoco logró obtener la comprensión del público intelectual. En 1952 Ory logra publicar dos de sus cuentos bajo el título de El Bosque ${ }^{147}$.

La incompresión, el rechazo y el silencio provocan que el discurso oryano se sitúe en la zona periférica de la marginalidad. Por ello Madrid aparece como espacio de silencio y opresión en la vida del poeta y así lo expresa Carlos Edmundo de Ory en su diario el 18 de agosto de 1952:

...Estoy condenado de todos modos a una vida de fuego interior, soledad y pobreza; luego lo que venga y encuentre entre lo que llamo la evasión, será bienvenido.

Mi vida de ahora es el ocio. Como en los primeros años de mi juventud. Echado en la cama, duermo todo lo que quiero y leo todo lo que quiero. No puedo escribir. Escribir me parece imposible aquí en España (2004, Vol I: 208).

Madrid es el símbolo del desencanto ante la cultura franquista, un espacio que es necesario abandonar en búsqueda de otros horizontes, desérticos y nómadas, para explorar. Los espacios más frecuentados de la geografía intelectual oryana quedaban muy alejados del escenario madrileño de la posguerra: Carlyle, Friedrich von Schiller, Friedrich Hölderlin, Johan Wolfgang Goethe, Jonh Keats, Novalis, Lord Byron, Gerard Nerval, Arthur Schopenhauen, Friedrich Nietzsche, Fedor Dostoievsky, Stéphane Mallarmé, Paul Verlaine, Charles Baudelaire, Arthur Rimbaud, Edgar Allan Poe, Franz Kafka, Isidoro Ducase o Conde de Lautréamont, André Breton, D.H. Lawrence, Octavio Paz, Pico della Mirándola, Baruch de Spinoza, Meister Eckhart, Lao-Tsé, Heráclito de Éfeso, la literatura budista... Filosofías individualistas, visionarias y místicas, totalmente heterodoxas en la cultura del franquismo.

artística de la posguerra española.

${ }^{146}$ Goeritz, Mathías y Ory de, Carlos Edmundo (1949), Los Nuevos Prehistóricos, Madrid, Galería Palma, enero.

${ }^{147}$ El Bosque, Santander, Col. Hordino, 1952. 
1.3. París, el horizonte abierto del desierto

En 1955, después de una serie de viajes y estancias en París, Ory realiza finalmente su exilio voluntario a esta ciudad. Deja atrás una cultura añeja, agobiante y anacrónica y se aventura, sin ataduras, en un desierto inexplorado bajo el cielo abierto de la inmensidad. En el último texto perteneciente a la tercera parte de La memoria amorosa, denominada «Lutecia», es decir París, encontramos este fragmento, que resulta muy revelador en este aspecto:

Me alejé sin volver la cabeza. De nada valía llamar con grandes señas. Mientras me iba, los brazos sobre la cabeza ritmaban mis pasos.

Miro alrededor mío y no me asusta nada. Soy todo lo que estoy mirando. Estoy enamorado del universo: el aire ondulante. Y oigo el trino de los pájaros. No sé lo que pensarán de mí los amigos. Ellos siempre me han tratado de loco.

Jardines para estar contigo. Mariposas verdes. Rosas azules (2011: 99).

En París reencuentra a su amigo Francisco Nieva y conoce a Denise Breuilh, persona con la que inicia una relación sentimental que acabará en matrimonio en 1956.

En 1954, ya ausente del espacio literario peninsular y viviendo largas temporadas en París, se publica en Madrid el segundo libro de relatos oryanos: Kikiriquí-Mangó ${ }^{148}$. En 1955 Ory conoce personalmente al poeta francés Pierre Jean Jouve, objeto de sus traducciones. Entre ambos se incicia una gran amistad y una intensa relación epistolar que finalizó con la muerte de Jouve en $1976^{149}$. Además Jouve le presenta a su amigo Jean Cassou, escritor con quien Ory traba una amistad íntima. Carlos Edmundo de Ory viaja en 1957, junto a su esposa Denise, a Chosica, Perú, donde trabaja como profesor de castellano en la Escuela Normal Superior de la Cantuta hasta 1958. Allí nace su hija Solveig en 1957. En su estancia en Perú colabora en el diario La Prensa de Lima. A su regreso a Francia en 1958, Ory trabaja como profesor de español en la École Alsacienne y en el Institut Catholique de París.

${ }^{148}$ Kikiriquí-Mangó, Madrid, Imprenta Saez, Col. El Grifón, 1954.

${ }^{149}$ Fruto de esta amistad son dos poemas oryanos dedicados a Jouve, que aparecieron en la antología realizada por Félix Grande en 1970: "Jouve encadenado», escrito en París en octubre de 1955 (Grande, 1970a: 1959-1960) y «Jouve libertado», escrito en Chosica, Perú, en junio de 1958 (Grande, 1970a: 169-170). 
París es el espacio que permite las incursiones culturales a través de territorios nómadas, a la vez que se convierte en refugio para el trabajo solitario que necesita el oficio de la escritura. El itinerario cultural oryano se amplia considerablemente, pero vira, siempre, hacia el pensamiento heterodoxo. Se acrecienta la preocupación metafísica en todas direcciones y la actividad poética es concebida por Ory como silencio y meditación. Sus referentes son el taoísmo de los autores clásicos como LaoTsé o Chuang-tzu o de autores contemporáneos como Lin Yutang ${ }^{150}$; el hinduismo presente en la Bhagavad-Gitâ o en autores como Sri Aurobindo ${ }^{151}$ o Rabindranath Tagore; el budismo de la Dhammapada o el enseñado por Daisetz Teitaro Suzuki ${ }^{152}$; el sufismo de Kabir, Kahlil Gibran o Sadegh Hedayat; el esoterismo antiguo de Giordano Bruno o el moderno de René Guénon ${ }^{153}$; la magia y el chamanismo estudiados por Carl Gustav Jung ${ }^{154}$; el existencialismo de Sören Kierkegaard y de Martin Heidegger; y, también, la literatura de todos los autores visionarios y exploradores del misterio de la existencia como Raymond Rousel, Antonin Artaud, Henry Michaux ${ }^{155}$, Aldous Huxley $^{156}$, Gaston Bachelard ${ }^{157}$ o Herman Hesse.

Por otra parte, su discurso crítico aparece en publicaciones como Réalités Secrètes y Nouvelle Revue Française de Francia, Il Café de Italia, Upptakt de Suecia, Bandarra de Portugal o las españolas Poesía Española, Índice, Cuadernos

${ }^{150}$ Yutang, Lin (1946), My Country and My People, Nueva York, Halcyon House; (1948), The Wisdom of Lao-Tse, Nueva York, Random House, Modern Library.

151 Sri Aurobindo (1948), The Syntesis of Yoga, Madras; (1971) The Mind of Light, Nueva York, E.P. Dutton.

152 Suzuki, Daisetz Teitaro (1927, 1933, 1934), Essays in Zen Buddhism, 3 Vol., Londres, Luzac.

153 Guénon, René (1945), Le règne de la quantité et les signes des temps, París, Éditions Gallimard; traducción de Ramón García Fernández, El reino de la cantidad y los signos de los tiempos, Madrid, Ayuso, 1976.

154 Jung, Carl Gustav (1942), Paracelsica. Zwei Vorlesungen über den Artz und Philosofen Theophrastus, Zurich, Rascher A.G., Verlag; traducción de Manuel Plana Pesarrodona, Paracélsica, Barcelona, Kairós, 1989; (1954) Von den Wurzeln des Bewusstseins, Zurich, Rascher \& Cie. A. G.; tradución de Miguel Murmis, Psicologia y simbólica del arquetipo, Barcelona, Paidós, 1982; Jung, Carl Gustav y Wilhem, Richard (1929), Das Geheimnis der Goldenen Blûte, Olten, Walter-Verlag A.G.; traducción de Roberto Pope, El secreto de la flor de oro. Un libro de la vida chino, Barcelona, Paidós, 1982. obra cit.

${ }^{155}$ Michaux, Henry (1956), Misérable miracle, la mescaline ;(1957) L'infini turbulent,

156 Huxley, Aldous $(1945,2010)$, The Perennial Philosophy, obra cit. en bibliografía; (1954) Doors of perception. Heaven and hell, obra cit.

${ }^{157}$ Bachelard, Gaston (1950), L'air et les songes. Essai sur l'imagination du mouvement, París, Librarie José Cortí; traducción de Ernestina Champourcin, El aire y los sueños, México D.F., Fondo de Cultura Económica, 1959; (1957) La poétique de l'espace, París, Presses Universitaires de France; traducción de Ernestina Champourcin,Poética del espacio, México D.F., Fondo de Cultura Económica, 1963. 
Hispanoamericanos, Platero, Verbo, Revista de Cultura Brasileña, Papeles de Son Armadans... En 1962 se editan en francés sus aforismos y pensamientos con el título de Aèrolithes $^{158}$, en 1963 se publican Los sonetos ${ }^{159}$, en 1964 aparece su estudio Camus o el ateísmo "in extremis" ${ }^{160}$ y el libro de relatos titulado Una exhibición peligrosa ${ }^{161}$, en 1965 se publica La flauta prohibida ${ }^{162}$.

1.4. Amiens, la ciudad y la cabaña

En 1967, tras su separación matrimonial, Carlos Edmundo de Ory se aleja de la capital y se traslada a Amiens para trabajar como bibliotecario de la Maison de la Culture de esta ciudad de Picardía. En el turbulento año 1968 Ory funda, desde una óptica trasgresora, el Atelier de Poésie Ouverte en la Maison de la Cultura con el fin de dinamizar la realidad cultural. La apertura de parámetros culturales que significó la práctica de los talleres poéticos significó tal apertura de parámetros que supuso un choque total con la rigidez de las estructuras político-culturales y ello provocó el cese del cargo de bibliotecario. Los talleres recogieron la actitud airada y combativa que flotaba en el aire y que se manifestó de una forma más concreta en el mayo parisino. Revuelta que significaba un intento de demolición de unas estructuras ideológicas anquilosadas y una apertura hacia nuevas formas de vida basadas en la libertad personal.

En esta nueva etapa Ory entra en contacto, siempre desde su posición heterodoxa, con el pensamiento contracultural y undergroud de la época. Nuevas referencias aparecen en su itinerario cultural: Norman O. Braun ${ }^{163}$, Wilhem Reich, Thomas Merton ${ }^{164}$, Alan Watts ${ }^{165}$, Carlos Castaneda ${ }^{166}$, Jack Kerouac y los beatniks, el

158 Aèrolithes, París, Imprimerie Rougiere, 1962; Aerolitos, Madrid, Cuadernos Hispanoamericanos, $\mathrm{n}^{\circ} 181$, enero de 1965.

${ }^{159}$ Los sonetos, Madrid, Taurus, Col. Palabra y Tiempo, 1963.

${ }^{160}$ Camus o el ateísmo "in extremis", Madrid, Editora Nacional, Col. Ateneo, 1964.

161 Una exhibición peligrosa, Madrid, Taurus, 1964.

162 La flauta prohibida, Palma de Mallorca, Papeles de Son Armandans, n 114, septiembre de 1965.

163 Braun, Norman O. (1959), Life Agains Death; traducción de Franc, Eros y Tánatos. El sentido psicoanalítico de la historia, México D.F., Fondo de Cultura Económica, 1967; (1966) Love's body, traducción de E. L. Revol, El cuerpo del amor, Ed. Sudamericana, 1972.

164 Merton, Thomas (1948), traducción Aquilino Tur, La montaña de los cuatro círculos, Barcelona, Edhasa, 2008.

${ }_{165}$ Watts, Alan (1958), The way of cen, obra cit. en bibliografía; (1960) This is it, obra cit. en bibliografía; (1963) The two hanhs of god, obra cit. en bibliografía. 
tantrismo, el budismo tibetano, el budismo zen... Su Diario refleja el proceso de trasformación interior, su metanoia, el intento de conseguir la iluminación o budeidad:

No soy místico ni ocultista. Tampoco mago o chamán. Sin embargo, he estudiado todas las principales religiones del mundo. Soy budista, o más bien, aspiro al estado de Buda [...] No tengo ni sigo reglas. Como cuando tengo apetito, duermo cuando tengo sueño. Estoy preparado para vivir así. No soy ni un héroe ni un santo. Ni vivo milagrosamente. Decidí un retiro para poner en orden mis «pensamientos almacenados».

Estos pensamientos me acompañan, así como el ejemplo de los grandes místicos del «sendero directo». Mis pilares son el Tao, el Zen y el Vedanta.

También me inspiran y me enaltecen los profetas del Antiguo Testamento y la Kábala. He estudiado el ocultismo en sus obras de más difícil acceso (en la Biblioteca Nacional de París y en mi ardiente búsqueda por Europa y América en las librerías de libros esotéricos).

He aprendido casi todo lo que me sirve para estar despierto -digo DESPIERTO- en las enseñanzas de ciertos hombres que he nombrado ya en cuadernos anteriores de este Diario (2004, Vol. II: 354-355).

Desengañado, Ory se retira a su cabaña, una buhardilla de un viejo caserón situado a las afueras de Amiens. Este será el espacio de silencio desde el que surge la actividad poética y literaria. A su vez, espacio onírico y mítico, hábitat donde sueño y mito confluyen y se proyectan en los objetos, que actúan como verdaderos fetiches, producidos desde una autoría como pinturas, fotografías y collages o anónimos, como piedras, fragmentos de madera, clavos... encontrados en sus paseos $\mathrm{u}$ otras cosas halladas en los viajes. En La memoria amorosa se encuentra el siguiente fragmento titulado «Mis paredes» (2011: 112-113) que, de algún modo, describe este microespacio uterino, santuario simbólicamente particular:

Aunque no las tenga ahora delante de la vista, me acuerdo de todas aquellas visiones y las miro con ojos cerrados. Son estampas polícromas, láminas desprendidas de algún libro de Historia de la Humanidad. Entre ellas, la serie de objetos preciosos encontrados en Mecenas. Antigüedades exóticas. Vasijas indias o indo-persas, trajes y adornos de los egipcios y etíopes, trajes árabes de Turquía y de Marruecos. Grabados de libros de ilustración decimonónicos [...] Nunca hago culto de nada ni de nadie. Mi único empeño es llenar las paredes de imágenes que me impresionan. Cuando me canso de mirarlas las reemplazo por

${ }^{166}$ Castaneda, Carlos (1968), The Teachings of Don Juan (A Jaqui Way of Knowledge), obra cit; (1971) A Separate Reality (Further Coversations with don Juan), traducción de Juan Tovar, Una realidad aparte. Nuevas conversaciones con Don Juan, México D.F., Fondo de Cultura Económica, 1974, (1972) Journey to Ixtlan. The lessons of Don Juan, traducción de Juan Tovar, Viaje a Ixtlán. Las lecciones de Don Juan, México D.F., Fondo de Cultura Económica, 1975; (1976) Tales of power, traducción de Juan Tovar, Relatos de poder. Las lecciones de Don Juan, México D.F., Fondo de Cultura Económica, 1976. 
otras buscando y escogiendo las que más interesan a mis gustos y obsesiones. Sobre todo lo que choca a mi ánimo o lo que más me encanta. Hubo épocas dedicadas al horror absoluto y otras, a la erótica insólita. De cualquier modo una fiesta de la mirada para mí.

En estos años comienza a publicarse la obra oryana: Música de lobo ${ }^{167}$, el Alfabeto griego ${ }^{168}$, Poesía (1945/1969) ${ }^{169}$ en 1970 y Técnica y llanto ${ }^{170}$ en 1971. Ello crea la imagen de Carlos Edmundo de Ory como el gran hereje y el poeta más heterodoxo de los poetas españoles, aclamado por los poetas de última generación. Pero, a la vez, también significa el reconocimiento de su labor literaria. En 1971 se inicia la relación con Jesús Fernández Palacios, en aquella época poeta y teórico del grupo Marejada de Cádiz, que con los años se convertirá en compañero, amigo, estudioso y difusor de la obra oryana. En 1972 Ory empieza a trabajar como profesor de lengua y cultura españolas en la Universidad de Picardía, tarea docente que durará hasta 1988. Este es el año en el que toma contacto con los autores fundacionales del grupo surrealista de Canarias: Domingo Pérez Minik, Pedro García Cabrera y Eduardo Westerdhal. En esta época inicia su relación sentimental con la pintora Laura Lachéroy, con quien contraerá matrimonio mucho tiempo después, en el año 2000. En 1973 aparece su obra postista Los poemas de $1944^{171}$ y partir de aquí la obra oryana será editada con regularidad: la colección de relatos titulada Basuras ${ }^{172}$ en 1975, Lee sin temor $^{173}$ en 1976, La flauta prohibida ${ }^{174}$ en 1979 o Miserable ternura / Cabaña ${ }^{175}$ en 1981.

La década de los ochenta significa para Ory el reconocimiento total de su discurso: poético, narrativo y teórico. Son años de reencuentros y recuperaciones. Las amistades trazadas en Cádiz posibilitan la difusión de su obra y la recuperación del espacio de la niñez. Carlos participará en talleres, congresos, conferencias, aulas abiertas. No sólo en Cádiz y el espacio peninsular, sino que su presencia atravesará fronteras. Ory se convierte en un autor cuyo legado es internacional. En 1987 participa,

${ }^{167}$ Música de lobo, Madrid, Grupo N.O., 1970

${ }^{168}$ El alfabeto griego, Barcelona, Col. La Esquina, 1970.

169 Obra cit.

170 Técnica y llanto, Barcelona, Llibres de Sinera, Col. Ocnos, 1971.

171 Ory de, Carlos Edmundo (1973), Los poemas de 1944, Madrid, J. Giménez Arnau, Col. Aguaribay.

172 Basuras, Madrid, Júcar, 1975.

${ }^{173}$ Lee sin temor, Madrid, Editora Nacional, 1976.

${ }^{174}$ La flauta prohibida, Madrid, Zero/Zyx, 1979.

${ }^{175}$ Miserable ternura / Cabaña, Madrid, Hiperión, 1981. 
junto a autores como Ángel González, José Ramón Ripoll, Ana Rossetti o Allen Ginsberg, en el foro Spanish Poets in New York, celebrado en la neoyorquina Gas Station. De aquí surge un nuevo libro de poemas bilingüe, Angel Without a permit / Sin permiso de ser ángel ${ }^{176}$, traducido por el mismísimo ángel de la poesía beat, Allen Gisberg, acompañado de Edith Grossman y publicado en Nueva York. De la amistad con Ginsberg surge una mutua admiración y una serie de traducciones cruzadas ${ }^{177}$. En 1988 se publica otra obra crucial, Soneto $v i v o^{178}$, en donde aparece desarrollado todo el ciclo de los sonetos, que comenzó en 1941 y finaliza en 1987. Los juegos, variaciones y experimentaciones con este modelo poético significan la dignificación, la modernización y la deconstrucción del soneto y acercan el discurso oryano al de otro gran experimentador del soneto en el siglo XX, Joan Brossa ${ }^{179}$.

${ }^{176}$ Obra cit.

${ }^{177}$ El primer encuentro con Ginsberg se produjo en 1987 en la lectura de poemas de Gas Station. De aquí surgen varias citas y una amistad, de hecho el 31 de octubre, durante la estancia neoyorkina de Carlos y Laura, visitan, junto Osvaldo Gomariz, a Ginsberg en su casa. El segundo encuentro tiene lugar en Nueva York el 16 de mayo de 1992 (Ory, 2004, Vol. III: 294-295). Luego los dos poetas amigos se vuelven a ver en varias ocasiones (Ory, 2004, Vol. III: 337-338).

Ver Diario 16/Culturas, 21 de noviembre de 1987. Aparece el poema de Ginsberg «Proclamación dedicado a Ory»:

Soy el rey del universo.

Soy el Mesías de la Nueva Providencia.

Disculpa que haya pisado un clavo.

Un equívoco.

Quizás no sea el capitalista del Cielo.

Puede que sea el guardían de las Columnas de Perlas.

No es cierto, realmente soy Dios mismo.

Nada humano. Con esos tipos no me asocien.

En cualquier caso, puedes creer cada palabra que digo.

Ver Diario 16/Culturas, 3 de octubre de 1992. Aparece una entrevista a William Burroughs realizada por J. A. Millán: «Drogas, bombas, libros y sexo». La ilustran una muestra de los poemas que Ginsberg y Ory se intercambian: «Proclamación» de Ginsberg y «Visitanoche a Allen Ginsberg» de Ory, de su poemario Sin permiso de ser ángel.

178 Soneto vivo, Barcelona, Antrophos 1988.

179 Pérez Montaner, Jaume (1982), Pròleg a Joan Brossa, Els ulls de l'òliba, Valencia, 3 i 4, pp. 8-10. Para este autor la experimentación brossiana nace del aspecto lúdico de la poesía y se dirige en varias direcciones, hacia el automatismo surrealista, hacia la poesía visual y hacia la propia tradición. En este último espacio cabe situar el juego y la experimentación con el soneto, considerado como el modelo poético representativo de la tradición poética europea. Aspectos totalmente compartidos por la poesía oryana. 
1.5. Thézy-Glimont, refugio entre los árboles y el agua

Tras abandonar en 1989 la labor docente en la Universidad de Amiens, Carlos Edmundo de Ory y Laura Lachéroy se trasladan un año más tarde a Thézy-Glimont. Nuevo escenario en la trayectoria oryana, producto de la mentalidad mística totalizadora de Carlos. La conciencia de su integración cósmica le lleva a la experiencia de un contacto más estrecho de la realidad, experiencia que conlleva el abandono de la ciudad. En una carta escrita a su amigo Jesús Fernández Palacios, fechada el día 11 de septiembre de 1990, Carlos describe el nuevo espacio de su refugio (2004, Vol. III: 282):

Jesu, aquí, al borde del Avre, pequeño río que desemboca en la Somme, dentro de un joyero de verdura, rendimos culto a nuestros penates como los antiguos romanos que habitaron en este lugar, llamado entonces Tacéacum, que luego fuera Taisiacum y después Theisy antes de transformar su ortografía en Thézy, que se refiere al agua, ¡todavía impoluta!

Thézy-Glimont es una aldea, con pocos habitantes, cercana a Amiens. Espacio donde experimentar el contacto directo con el océano de la realidad, con la fragancia y la inmediatez de los elementos primarios como los árboles, el cielo azul o el agua del río. Por otra parte, este espacio, situado en los últimos tramos del trayecto de Carlos Edmundo de Ory, como la espiral, retrotrae a Cádiz, espacio marítimo de la infancia. Thézy, Tarsis, espacio de la luz que enmarca, al fin y al cabo, un trayecto circular.

Circularidad que se traduce con las conexiones establecidas con Cadiz. En 1991 la Diputación de Cádiz publica Iconografías y Estelas ${ }^{180}$, obra que recoge la mayoría de su obra ensayística. De otro lado, Carlos Edmundo mantiene una estrecha relación con sus amigos de Cádiz, poetas discípulos que lo proclaman como maestro y padre de la poesía libre nacida en la posguerra y cuya herencia se proyecta hasta la actualidad. Ory, autoproclamado gran poeta heterodoxo y autoexcluido de la sombra de la oficialidad, constantemente persuadido por sus discípulos, comienza a aceptar algunos de los reconocimientos ofrecidos en su tierra natal. Por ello acepta en 2003 el nombramiento de Hijo Predilecto de la Provincia, concedido por la Diputación de Cádiz, posteriormente es nombrado tambíen Hijo Predilecto de la Ciudad e Hijo Predilecto de

180 Iconografías y Estelas (ensayos 1946-1983), Cádiz, Servicio de Publicaciones de la Diputación, 1991. 
Andalucía. En 2004 la Junta de Andalucía le otorga el Premio Luis de Góngora por su obra literaria. Año en que la Diputación de Cádiz edita en tres volúmenes su Diario $(1944-2000)^{181}$.

Melos melancolía ${ }^{182}$, poemario editado en 1999, es la obra cumbre de la poesía oryana. En ella aparece descrita la imagen del poeta como un vagabundo que viaja constantemente a través del océano de la existencia en busca de su misterio. Poeta que es un apátrida permanente, maestro errante o monje mendicante cuyo país no tiene límite alguno, pues su casa es el universo. Esta autobiografía poética supone una retrospectiva hacia la infancia y el mar. Por ello, es, en cierta medida, un retorno al origen. Otra imagen de esta retrospectiva de luz queda representada por su obra póstuma, La memoria amorosa ${ }^{183}$, que en clave poética ofrece una serie de radiografías íntimas de la trayectoria vital de su autor. Trayectoria que acaba en la luz filtrada por el verde de las hojas de los árboles y el azul lejano del mar, tal y como queda expresado en el siguiente fragmento (2011: 107):

Ahí están los animales, cabezas silenciosas de la naturaleza, criaturas nunca mudas empero. Hablan de maravilla. Honor a sus ruidos armónicos e inarmónicos. Música encantada, regalo de la tierra, aquí abajo. Lo otro, lo de arriba, son las estrellas, perlas del cosmos [...] Mis orejas son tan felices oyendo el la del bosque, el rumor sordo de la caracola, el escándalo sonoro de la mar.

Thézy-Glimont supone el espacio ocupado por el ser que trasciende los límites de su piel y experimenta su unión con todos los espacios posibles y todos los seres que habitan el espacio infinito del cosmos. Allí, ya en la vejez, Carlos Edundo de Ory, se siente parte activa de la totalidad. Espacio que conjuga bosque y mar, vejez e infancia, y es también espacio de espera de una muerte serena.

\footnotetext{
181 Obra cit.

${ }^{182}$ Melos melancolía, Montblanc, Tarragona, Ígitur,1999.

${ }^{183}$ La memoria amorosa, Madrid, Visor, 2011.
} 


\section{EPÍLOGO}

Dic silenci

i tot em parla.

Jaume Pont

En los primeros días de octubre de 2010 Jesús Fernández Palacios y su compañera y esposa vuelan hacia Amiens para visitar a Carlos Edmundo de Ory, ya convaleciente de una grave enfermedad y presintiendo la presencia de una muerte liberadora, para pasar allí unos días y despedirse de él. En su estancia, Carlos Edmundo formula a Jesús una triple petición: la búsqueda de un buen editor para su última obra, el ofrecimiento de ayuda a Laura, esposa del poeta, en la tarea de sobrellevar su tristeza y la voluntad de depositar sus cenizas en Cádiz. Unos días más tarde, el 11 de noviembre, la muerte acaba con la leucemia padecida y con un cuerpo ya envejecido por los años.

El día 20 de diciembre se realiza en el Aula Magna de la Facultad de Filosofía y Letras de Cádiz el acto La memoria amorosa. Homenaje al poeta. Entre los familiares, asisten su esposa, Laura Lachéroy, su hija, Solveig de Ory, y su sobrino, José Antonio de Ory. Intervienen como ponentes Félix Grande, Jaume Pont, Jesús Fernández Palacios, Rafael de Cózar, José Ramón Ripoll, José Manuel García Gil y Juan José Téllez, además los cantautores Luis Eduardo Aute, Fernando Polavieja, Juan Luis Pineda y Fernando Lobo. También se leen textos de adhesión de los siguientes escritores: Pablo García Baena, José Manuel Caballero Bonald, Francisca Aguirre, Pilar Paz Pasamar, Ossias Stutman, Amador Palacios, Alberto Porlan, Javier Barreiro, Alejandro Luque, Rafael Mesado Gimeno e Ignacio Martínez-Castiganani. Quien esto escribe envió el siguiente texto:

No he conocido personalmente a Carlos Edmundo de Ory. Por la edad podría haber sido mi abuelo, ahora bien no es tanta la distancia que nos separa. Carlos siempre fue un pionero y un explorador, ello hace que la espiral de su poesía atraviese la línea de la espiral de mis días y se enrosque en ella. He conocido a Carlos a través de su obra, pues unió vida y obra con la pregnancia de la palabra poética de tal modo que su poesía nos revela la geografía precisa de su existencia. 
Así he conocido al poeta triste y decadente de sus inicios, al poeta postista de la locura inventada, al poeta de vanguardia y su práctica de la provocación, al poeta bufón transgresor de los límites de lo establecido, al poeta alquimista ante la combustión de su lenguaje, al poeta beat amigo de Allen Ginsberg, al poeta místico y su éxtasis ante la realidad, al amante tántrico de la sexualidad sagrada, al monje budista y el silencio de su meditación, al chamán nagual explorador del infinito, al intelectual heterodoxo e insumiso, al maestro errante y vagabundo que caminaba en la eternidad de cada instante.

Carlos ha sido el gran maestro de la poesía española de posguerra, cuya sombra planea todavía sobre la poesía de la actualidad; punto de partida de la poesía experimental y precursor de la poesía novísima. Para ello tuvo que realizar la demolición de un viejo edificio y emprender un viaje constante y solitario a través de territorios desérticos.

Carlos ha sido fiel a su destino, ha encontrado el satori que había buscado, se ha fundido con el todo. No se ha ido a ningún sitio, se ha quedado en el aquí.

Al día siguiente, el 21 de diciembre, se constituye en una reunión celebrada en el Centro Reina Sofía de Cádiz la Fundación Carlos Edmundo de Ory, presidida por la viuda del poeta, Laura Lachéroy, que guardará el legado literario del autor. El patronato está formado por la Presidenta, Solveig de Ory, José Antonio de Ory y cuatro portavoces designados por el poeta.

El 9 y 10 de octubre de 2011, se celebran en Cádiz unas jornadas, Visiones sobre Carlos Edmundo de Ory, y se depositan las cenizas del poeta en una glorieta de la Alameda Apodaca, muy cercana a la casa donde nació. A finales de este mes se publica el número 16 de la revista gaditana Caleta, segunda época, dedicada a Carlos Edmundo de Ory. En ella escriben numerosos autores que configuran una territorialidad cultural plural. Éstos son: Pablo Acevedo, Francisca Aguirre, Jorge de Arco, Luis Eduardo Aute, Matías Ávalos, Javier Barreiro, Luis Felipe Barrio, José Manuel Benítez Ariza, Felipe Benítez Reyes, Isabel Bono, José Manuel Caballero Bonald, Juan Luis Calbarro, Carmen Camacho, Ricardo Cano Gaviria, José María Conguet, Rafael de Cózar, Mercedes Escolano, Jesús Fernández Palacios, José Fernández de la Sota, Marco Fonz, Miguel Ángel García Argüez, Pablo García Baena, José Manuel García Gil, Pilar Gómez Bedate, Juan Gómez Macías, José María Gómez Valero, Félix Grande, Guadalupe Grande, Antonio Hernández, José Jiménez, José Jurado Morales, Alberto Lauro, Rosa Lentini, Carlos Manuel López Ramos, Antonio Lucas, Alejandro Luque, Ignacio Martínez-Castigniani, Rafael Mesado, César Antonio Molina, Francisco Nieva, José Antonio de Ory, Amador Palacios, Arcadio Pardo, Pilar Gómez Pasamar, Ana 
Sofía Pérez-Bustamante, Ángel Petisme, Juan Vicente Piqueras, Jaume Pont, Alberto Porlan, Antonio Puente, Raúl Quinto, Rafael Ramírez Escoto, Manuel J. Ramos Ortega, José Luis Rey, José Ramón Ripoll, David Eloy Rodríguez, Ana Rodríguez-Tenorio Sánchez, Andrés Sánchez Robayna, Miguel Sánchez-Ostiz, Antonio Serrano Cueto, Andrés Sorel, Uberto Stábile, Osías Stutman, Juan José Téllez, Rafael Adolfo Téllez, Eduardo Tijeras, Fernando Valls, Nievas Vázquez Recio, Javier Vela y Luis Antonio de Villena. En este mismo otoño aparece La memoria amorosa, obra póstuma prologada por Jesús Fernández Palacios ${ }^{184}$.

En 2012 continúan los homenajes, en septiembre la revista Insula ${ }^{185}$ dedica un monográfico, coordinado por Jaume Pont, a Carlos Edmundo de Ory. En él escriben José Manuel Caballero Bonald, Manuel Ramos Ortega, Rafael de Cózar, Guillermo Carnero, Joaquín Marco, Ana Sofía Bustamante Mourier, José Ramón Ripoll, Jesús Fernández Palacios, Pere Gimferrer, Pilar Gómez Bedate, Sánchez Robayna, José Luis Calvo Carilla, Francisco Nieva y Jaume Pont. El 28 de septiembre se celebra el Oleaje asturiano a Carlos Edmundo de Ory, organizado por la Alianza Francesa de Gijón que preside Ana Isabel Moledo Vigil, amiga del poeta. El 8 de octubre se celebra otro Oleaje a Carlos Edmundo de Ory en el Instituto Cervantes. El 9 y el 10 de octubre en Cádiz se dedican también unas jornadas a Carlos Edmundo de Ory en el Espacio de Creación Comtemporánea (ECCO) tituladas Latitudes. Estas son las segundas de las jornadas que todos los años organiza la Fundación que lleva su nombre. En 2013 se titularon Coordenadas y quien esto escribe presentó el miércoles 9 de octubre la conferencia «Ory: poesía y silencio» (Mesado, 2013c). En 2014 las jornadas se dedicaron al Postismo y en 2015 a la figura de Juan Eduardo Cirlot; en ellas se erigió en la Glorieta Carlos Edmundo de Ory, situada en la Alameda Apodaca frente a la casa natal del poeta, su escultura en bronce realizada por el artista Luis Quintero. La estatua se halla al lado de la caja metálica que contiene sus cenizas. La Fundación dedica su

${ }^{184}$ Nueve textos de esta obra ya habían aparecido en la revista Campo de Agramante, $\mathrm{n}^{\circ} 15$, primavera-verano de 211, pp. 7-12. Los textos son: "La fuga", "Caminatas votivas", "Las mujas", "¡Oh vanitas!", "La mesa limpia", "Estoy contento de que haya lechuzas", "Rosas azules", "Los andamios de la dicha" y "Elogio de la nariz". A continuación el artículo "Abismos y mesetas. Territorios radicales de la poesía de Carlos Edmundo de Ory”, de Rafael Mesado, pp. 15-26, ofrece la contextualización de estos fragmentos en la extensa obra de su autor y el artículo de Pilar Gómez Bedate, "El pensamiento mágico en la poesía española de mediados del siglo XX", pp. 29-50, ofrece el contexto generacional.

${ }^{185}$ Rev. Insula, nº 789, Madrid, septiembre de 2012. 
espacio y sus esfuerzos a la actividad cultural y poética que corverge con la figura del Ory intectual.

Como se puede comprobar, todo ello forma parte del proceso de reivindicación de la importancia para la literatura y el pensamiento de la figura de Carlos Edmundo de Ory. 
II. SOBRE LA POESÍA ORYANA. 


\section{UNA POESÍA CÍCLICA}

Mi profecía es mi memoria:

mi esperanza de ser lo que ya he sido.

Juan Manuel Caballero-Bonald

La poesía de Carlos Edmundo de Ory se halla dispersa en colaboraciones en $\operatorname{revistas}^{186} \mathrm{y}$ en poemarios que durante mucho tiempo permanecieron inéditos. La publicación tardía de su obra poética se debe a la conciencia de la propia marginalidad por parte del autor y a la imposibilidad de difusión de una obra rara y heterodoxa, considerada en todas circunstancias como un cuerpo extraño de difícil encaje en la territorialidad poética de posguerra. Ory ha sido un insumiso de la palabra, su poesía ha roto los cauces establecidos $\mathrm{y}$ ha transgredido todos los límites impuestos. Pues, tal como manifiesta Pere Gimferrer, «La poesía de Ory, liberadora por esencia, empieza por dejar en libertad a las palabras» (Clotas y Gimferrer, 1971: 104). Se trata de una poesía periférica y marginal que ha permanecido diseminada e inédita largo tiempo, pero que su autor siempre ha conservado clasificada y ordenada. Los poemarios oryanos se editaron bastantes años después de ser escritos, fueron las antologías editadas por otros autores las encargadas de recuperar esta poesía escondida. La antología efectuada

186 La poesía oryana aparece en las siguientes revistas: Acanto, Madrid; Alaluz, University of California; Alcance, León; Alcaraván, Arcos de la Frontera; Almanaque «El Grifón», Madrid; Almanaque Maravillas, San Sebastián; Almud, Ciudad Real; Andarax, Almería; Antípodax, Auckland (Nueva Zelanda); Antorcha de Paja, Córdoba; Arquero de Poesía, Madrid; Artesa, Burgos; Aulas, Madrid; Bahía, Algeciras; Balbuena, Valdepeñas; Bandarra, Porto (Portugal); Barcarola, Albacete; Cahiers de Poétique et de Poésie Ibérique et Americaine, Université de París; Caleta, Cádiz; Camp de l'Arpa, Barcelona; Cántico, Córdoba; Caracola, Málaga; Córdoba, Córdoba; Cuadernos, París; Cuadernos de Sanlúcar, Sanlúcar; Cuadernos Hispanoamericanos, Madrid; Cuadernos Literarios del Centro Cultural de la Generación del 27, Málaga; Dabo, Palma de Mallorca; Diario de Cádiz, Cádiz; Litoral, Torremolinos; El Bosque, Zaragoza; El Ciervo, Barcelona; El Día (Suplemento El Gallo llustrado), México; El Pájaro de Paja, Madrid; El Viejo Topo, Barcelona; Escandalar, Nueva York; Eslabón, La Línea; Espadaña, León; Et Caetera, México; Fablas, Las Palmas; Fantasía, Madrid; Fin de siglo, Jerez de la Frontera; Flechas y Pelayos, Madrid; Garcilaso, Madrid; Halcón, Valladolid; Hora de Poesía, Barcelona; Índice, Madrid; Insula, Madrid; La Cerbatana, Madrid; La Estafeta Literaria, Madrid; La Isla de los Ratones; Santander; La mano en el cajón, Barcelona; Litoral, Málaga; Marejada, Cádiz; Mensaje, Tenerife; Norte, México; Nubis, Palencia; Nueva Estafeta, Madrid; Páginas Marianas, Vitoria; Papeles de Son Armadans, Palma de Mallorca; Pérgola, Bilbao; Platero, Cádiz; Pliego, Universidad de Sevilla; Pliegos Literarios, Universidad de Granada; Poesía de España, Madrid; Poesía española, Madrid; Postismo, Madrid; Raíz, Madrid; Río Piedras, Universidad de Puerto Rico; Signos, Madrid; Silvestra, Málaga; Verbo, Alicante y Vora-Tosca, Olot. 
por Félix Grande (1970a), la primera de las publicadas, muestra gran parte de la obra inédita y recupera parte de la poesía postista ${ }^{187}$. La de Pont (1974) amplía el panorama poético oryano hasta 1973, ofrece gran parte de la poesía inédita y recupera también algunos poemas publicados en revistas. La antología publicada por Rafael de Cózar $(1978,1990)$ se dedica, en gran medida, a ofrecer la poesía que se escondía en las publicaciones poéticas: periódicos, revistas y antologías. En ella su autor detalla perfectamente la procedencia de cada poema y establece una perfecta sistematización de la obra oryana. Por otra parte, en ella aparece también una muestra de los aerolitos y de los collages, dos prácticas enraizadas en la actividad poética oryana.

Pero es en Energeia (1978), la antología realizada por el propio autor, donde aparece la poesía oryana estructurada en una serie de ciclos poéticos. Estos funcionan con independencia de la cronología de su escritura y de su publicación. De manera que la poesía de Ory toma la forma de una espiral que recoge materiales antiguos y los actualiza. El ciclo poético mantiene una poesía abierta, susceptible de cambios y de reelaboraciones. La poesía oryana es dinámica y está sometida, como la espiral, a un proceso de continua reestructuración. En las páginas de esta antología el propio poeta define su poesía como una poesía dinámica, hecho que la diferencia de las antologías de José Hierro, de Carlos Bousoño, de Vicente Gaos, de Leopoldo de Luis..., que presentan una retrospectiva de fragmentos de una poesía estática:

La mayor parte de la escritura aquí ubicada permaneció inédita hasta hoy. El juego de las divisiones manteniendo la sucesión con la evidencia cronológica, fue posible gracias a la observancia formal de fechas y la denominación de lugar. Este requisito de la data procura aprehender la «correlación» procesual de los diversos «ciclos» en su movimiento temporoespacial ${ }^{188}$.

No siendo ajena, rechazo la exposición antológica por parecerme incompatible con la unidad ingénita de la obra, dentro de su transcurso. De ahí, la exigencia de un título global de esta edición de autor que sustituye a las habituales retrospectivas de libros editados. Tal ventaja, en mi caso personal, no podía cumplirse de ningún modo. Carezco de bibliografía autorizada para ello. Quiere decirse que la corriente fluida de mis libros poéticos justifica su curso en la obra ininterrumpida, independientes de su ineditez. No encontró obstáculo, en este sentido, para su propio desarrollo (1978: 9-10).

187 Se trata de los romances y otros poemas escritos entre 1945 y 1948, que se incluían en las publicaciones postistas, titulados Laocoonte y la luna (Grande, 1970a: 243-260) y Cinco poemas edmundianos (Grande, 1970a: 55-56).

188 Sic. 
El ciclo poético recoge y amplía una unidad de significado, su función es la reestructuración de la semántica poética anterior, la adición de nuevos gestos que reconstruyen los viejos signos. El ciclo poético oryano podría definirse como una serie de variaciones sobre un mismo tema. Multiplicidad de ópticas que agrandan el contexto significativo de la propia poesía. El mismo poeta destaca la «capacidad polifónica» (1978: 12) de esta poética cíclica. La génesis del ciclo queda estructurada por el tiempo, el espacio y la semántica de la escritura. En este sentido, Jaume Pont (1998: 18) señala la dispersión del punto de vista en la aprehensión sobre la realidad que se ofrece en la poética oryana:

Se trata de sellar una voz en un cúmulo de voces posibles. En ellas el poeta ensaya su personal forma de conocimiento de la realidad desde coordenadas espacio-temporales y puntos de vista distintos.

El ciclo poético permite establecer la siguiente estructuración de la poesía oryana:

\subsection{Poesía crepuscular}

Bajo este epígrafe se engloba la poesía escrita entre 1937 y 1943, considerada una primer acercamiento a la práctica poética, cuyas raíces conectan con una concepción de la poesía que queda desechada por los nuevos rumbos que toma la poesía realista en la posguerra española. Se trata de una poética inmersa en un consciente proceso de decadencia, que fija la mirada en la poética de unos modelos que ya declinan, como son el simbolismo, el modernismo y el decadentismo. Esta es una poética situada al borde del ocaso, pero en ella se vislumbran ya los derroteros poéticos futuros.

Una muestra de ella aparece editada en Energeia (1978: 28-47) ${ }^{189}$, pero hasta 1986 esta poesía no surge a la luz pública. Este es el año en que la Fundación Municipal del Cultura de Cádiz publica Poesía primera, una edición realizada por el autor donde

189 Aparecen poemas pertenecientes a las siguientes obras: nueve poemas de Sombras y pájaros (1940), quince poemas de Poemas de adolescencia (1940-1941), un poema de La canción meditada (1941), cuatro poemas de Canciones amargas (1942) y seis poemas de Las niñas de nácar (1943). 
este recupera y selecciona parte de esa poesía inicial. La obra queda estructurada de forma cronológica y presenta sucesivamente una serie de poemarios mecanografiados y organizados en forma de libro: Sombras y pájaros (1940), La canción meditada (1941), Romancero de amor y luna (1941), Elisa (1941), Paladín de Ponto (1942) y Canciones amargas (1942). Por otra parte, ofrece también una muestra de la poesía recogida en algunos de los cuadernos manuscritos por el autor: Poemas Nuevos (1940), Más adolescencia (1941), Sol y Espigas (1941), La sombra de la Alondra (1941), Romances y sonetos (1941), 20 canciones delgadas (1942) y Poemas escritos en Sevilla y en Cádiz (1942-1943). Se trata, pues, de una poesía escrita en una serie de libros y cuadernos inéditos, no pensados para su publicación. Con todo, solamente se han publicado los poemas recogidos en las obras mencionadas anteriormente. Ellos son los que conforman la obra perteneciente a este ciclo poético ${ }^{190}$. De todas formas, este ciclo quedaría integrado por las siguientes obras:
·(1940) Sombras y pájaros.
• (1941) La canción meditada.
· (1941) Romancero de amor y luna.
• (1941) Elisa .
· (1942) Paladín de Ponto.
- (1942) Canciones amargas.
• (1943) Las niñas de nácar.

${ }^{190}$ Libros de artesanía en ejemplar único ilustrado: Sombras y pájaros (1940), prólogo manuscrito de José María Pemán, ilustraciones de Antonio Pleguezuelo, Cádiz; La Canción meditada (1941), prólogo manuscrito de Miguel Martínez del Cerro, ilustraciones de Luis Benítez, Cádiz; Hijos de la aldea (1941), Cádiz, poema dramático, dividido en un prólogo y tres actos; Romancero de amor y luna (1941), 2 vol., Cádiz; Elisa (1941), Cádiz, prosa poética; Paladín de Ponto (1942), prólogo de Fernando de los Ríos y de Guzmán, Cádiz; Canciones amargas (1942), prólogo manuscrito de José María Pemán, Cádiz, Las niñas de nácar (1943), Cádiz-Madrid.

Cuadernos manuscritos: Mis primeros disparates... (1939), Cádiz; Poemas Nuevos (1940), Cádiz; Más adolescencia (1941), Cádiz; Sol y espigas, versos espirituales, 1941, Cádiz; La sombra de la alondra (1941), Cádiz; Natiel (1941), Cádiz, poema dramático en tres actos y siete cuadros, leyenda lírica, Cádiz; Romances y sonetos, Teatro de Shakespeare en seis sonetos (1942), Cádiz; Versos Nuevos de 1942 (1942), Cádiz; 20 canciones delgadas y la niña sutil (1942), Cádiz, pliegos; Poemas escritos en Sevilla y Cádiz (1943), Cádiz-Sevilla.

Como se puede observar, las amistades poéticas de Eduardo de Ory, padre de Carlos Edmundo, arropan en forma de prólogo la primera poesía oryana. 


\subsection{Poesía postista}

Esta es la poesía escrita, en cierta medida, entre 1944 y 1950 . Una poesía ya definitoriamente personal que sustituye a unos modelos anquilosados por la novedad vigente, anclada ya totalmente en la vanguardia. De alguna forma, esta poesía supone el avance en la dirección más onírica y surreal que se presentaba de modo solapado en la poesía inicial. De la incipiente influencia de Alberti y Lorca, la poética de Ory se instala en un surrealismo radical, extremo y demoledor. Las obras que integran este ciclo poético son las siguientes:

•(1944) Versos de pronto, Madrid, Fantasía, no 19, julio 1945.

- (1944) Los poemas de 1944, escrito en Madrid y editado en 1973 en Madrid por Joaquín Giménez Arnau.

- (1944-1945) Las patitas de la sombra, escrito junto a Eduardo Chicharro en Madrid y editado por Antonio Pérez Lasheras y Alfredo Saldaña, Madrid, Mira Editores, 2000.

- (1945-1948) Doblo hablo, escrito en Madrid con una introducción de Eduardo Chicharro. La introducción figura en Energeia (978: 62-64). Contiene, por una parte, Cinco poemas edmundianos, publicados en Poesía (1945-1968) por Félix Grande (1978a: 55-56), en Energeia (Ory; 1978: 67-67) y en la antología de Jaume Pont, titulada Música de Lobo (2003: 59-61). Por otra, la obra de romances Laocoonte y la luna, que incluye los romances presentados en las publicaciones postistas y editados en su totalidad posteriormente por Félix Grande (1970a: 243-260). Parcialmente aparecen en Energeia (Ory, 1978: 7277) y en la antología citada anteriormente de Pont (2003: 62-66). El poema titulado «Soneto paranoico», que se publicó originariamente en la página 7 de la revista La Cerbatana, aparece también en la antología sobre la poesía surrealista española realizada por Albi y Fuster (1952: 51), en la antología de Félix Grande (1970a: 243) encabezando la obra Laocoonte y la luna, en la de Rafael de Cózar (1978, 1990: 118-119) y en la segunda antología realizada por Pont (2003: 62), titulada Música de lobo. 
A este ciclo pertenecerían también los poemas publicados de manera dispersa en las revistas literarias y los recogidos en las antologías ${ }^{191}$.

\subsection{Poesía nómada}

Con la aventura introrrealista, que Carlos Edmundo de Ory realizó junto al pintor Darío Suro, se inicia en la poesía oryana una nueva deriva hacia unos espacios periféricos e inexplorados por la cultura peninsular de la época. Espacios diametralmente opuestos a las preocupaciones poéticas instaladas en la territorialidad central de la posguerra española, como ya hemos comentado. Esta incursión en una territorialidad nómada viene acentuada por su exilio voluntario en Francia en 1955. A partir de aquí, la poesía de Ory se convierte en un ciclo de ciclos, en un constante viaje a través de unos espacios poco transitados por la cultura occidental al que le llevan sus preocupaciones metafísicas. En la espiral que traza la poesía oryana pueden rastrearse las siguientes huellas:

- (1946-1969) Poemas, Madrid, Rialp, 1969. Ciclo que integra las obras Negruras (1946-1962), Los lejanos lejanos (1947-1964) y El musiquero de las manos fecundas (1966-1969). Escrito en Madrid, París, Amiens.

- (1949-1952) Academia fantástica. Inédito escrito en Madrid. En Energeia (1978: 95-99) se recogen algunos poemas.

- (1951-1953) Órgano constante, escrito en Madrid. Poesía que permanece inédita hasta la publicación de Energeia, en ella Ory (1978: 100-127) incluye de manera íntegra dos obras, Órgano constante y Genitalia. Algunos poemas de Órgano constante se incluyen también el el ciclo de Los sonetos.

- (1954-1967) ${ }^{192}$ La flauta prohibida, Bilbao, Zero Zyx, 1979. Este ciclo integra las siguientes obras: Clausi tenebris carcere, El rey de las ruinas, Música de lobo y Todo es una gota de fuego. Los poemas están escritos en Lima, Madrid,

${ }^{191}$ Ver Apéndice III.

192 Nos atendemos a los datos que ofrece el autor en Energeia (1978: 238). 
París. Música de lobo apareció publicada en 1970 en Madrid por Poesía N.O., también aparece íntegro en Música de lobo. Antología poética (1941-2001), realizada por Pont (2003: 89-113). En Energeia (1978: 143-153) se añaden algunos poemas a Todo es una gota de fuego. Pont (1998: 24) alarga este ciclo hasta 1979, año de la publicación de la obra. Por ello, en su última antología (2003: 219-222) añade varios poemas que habían aparecido en otras publicaciones. Ricardo Cano Gaviria y Rosa Lentine también amplían el ciclo hasta 1979. Los poemas añadidos por Pont («César Vallejo», «Persona non grata», «Delos»y «Pablo de Chile») fueron escritos con posterioridad a 1969. Concretamente se escribieron entre 1973 y 1974, pero aparecen en la edición de 1979 de La flauta prohibida. Lo mismo ocurre con otros poemas ${ }^{193}$. Todo apunta a que Clausi tenebre carcere fue añadido por el autor con posterioridad a 1967. De modo que el ciclo concluye en 1979.

- (1968-1875) Cabaña. Escrito en Amiens. Consta de dos obras: Agua y La miel indefensa. Se publica en 1981 junto a Miserable ternura.

•(1969-1970) Técnica y llanto, Barcelona, Llibres de Sinera, Col. Ocnos, 1971.

· (1970-1971) Lee sin temor, Madrid, Editora Nacional, 1976. Incluye las obras: Agni de 1970, Lee sin temor de 1971, Los poemas de Karl Borromaüs de 1971 y Silencio de 1971. Los poemas de Karl Borromaüs aparecieron junto a Poema Dantesco en la Rev. Río Piedras, Universidad de Puerto Rico.

193 El poema titulado «César Vallejo», que aparece en Música de lobo. Antología poética (1941-2001) realizada por Jaume Pont (2002: 219) y en la antología de Cano Gaviria y Lentine (2001: 73), se publica por primera vez en septiembre de 1974 en la revista Río Piedras de la Universidad de Puerto Rico, $n^{\circ}$ 5-6, p. 205. En 1974 Pont lo incluye en Poesía Abierta (1974: 146) y lo fecha en el 31 de agosto de 1973. Más tarde Rafael de Cózar la incluye en su antología, Metanoia (1978, 1990: 298). "Persona non grata», que aparece en la última antología de Pont (2003: 220) y que se publicó anteriormente en Metanoia (Cózar, 1978, 1990: 299), fue escrito en 1973. Rafael de Cózar no lo incorpora a ninguna obra. También Pont (2003: 222) añade a este ciclo el poema «Pablo de Chile» escrito en 1973 y que se publica por primera vez en el Homenaje a Pablo Neruda, titulado Chile en el corazón, cuya edición realizan Aurora de Albornoz y Elena Andrés. El poema aparece también en la antología de Cózar (1978, 1990: 302-303). En este caso, Cózar tampoco lo integra a ninguna obra en particular.

Otros poemas incluidos en La flauta prohibida, cuya escritura es posterior a 1967 son los que pertenecen a Clausi tenebris carcere. 
• (1971-1972) Miserable ternura. Aparece publicado en 1981 junto a Cabaña en Madrid, Hiperión.

- (1973-1976) Arte de la fuga o Rig. Algunos poemas se publican en Energeia (1978: 209-215), otros en Poesía Abierta (Pont, 1974: 148) y uno en Metanoia (Cózar, 1978, 1990: 300).

•(1975-1977) Tambor de sicomoro, se publica íntegro en Energeia (1978: 217232).

\subsection{Ciclo de los sonetos}

Para Carlos Edmundo de Ory el soneto se ofrece como modelo a reverenciar, en cuanto a signo que refleja el peso de toda una tradición y, de otro lado, como modelo a destruir, ya que se ofrece como soporte de experimentación. Admiración y experimentación son las señas de la poética oryana respecto al soneto. Este es el signo más representativo de la poesía de la cultura occidental, tal como La Gioconda de Leonardo se erigió en icono de la pintura clásica occidental. No sólo se trata de un símbolo de la poesía, sino que su sombra recorre una extensión muy amplia de la cultura occidental. Asociamos el soneto a los modelos poéticos renacentistas, innovadores en su momento, transmisores de una cultura que conjuga platonismo y realismo, marcada por unos presupuestos mercantiles y cartesianos. También el soneto posee la impronta de de los estallidos de los fuegos artificiales del ingenio barroco, por ello también se erige como plasticidad poética y vehículo de deformación. El culto al soneto recorre la territorio de la poesía clasicista de la década de los cuarenta, instalada en la primera posguerra española. El gesto de Ory supone, por una parte, un ademán de respeto y de sumisión frente a los presupuestos de una tradición que se acoge; $\mathrm{y}$, por otra, un exabrupto parecido al de Marcel Duchamp al rechazar de forma vehemente el peso de toda una cultura con un acto de total violencia al pintar barbas y bigote, como si de la travesura de un niño se tratase, a la reproducción de la Mona Lisa de Da Vinci. En la parte inferior, fuera ya de la reproducción de la obra clásica figura el acto más irreverente cometido por la vanguardia. Se trata de unas mayúsculas con las letras L.H.O.O.Q. que señalan el título del ready-made (1919). Conociendo las intenciones del 
autor, en castellano podría leerse como ella tiene el culo caliente. Tal actitud fue practicada por Carlos Edmundo de Ory en el poema titulado «Satán al aparato», escrito en París en 1959 y perteneciente a Los sonetos (1963):

¿Quién está al otro lado que no entiendo su voz tan sorda tan oscura tan cavernosa que más mi oído tiendo menos entiendo? ¡Diga! -Soy Satán

¿Quién dice ser? ¡Repita! No le entiendo Habla usted como un trueno un huracán como un ciclón un torbellino horrendo y no le entiendo ¡Diga! -Soy Satán

¿Cómo ha dicho? ¡Por Dios hable más bajo! ¿Con quien hablo? Le escucho Presto oreja Ahora su voz se aleja se me pierde

-Soy Satán Sa... ¿SA QUÉ?... tan tan ¿TAN QUÉ? ¡No atajo! -Digo que soy Satán ¡Su voz se aleja! Repita se lo ruego ¿quién es? -MERDE

No se trata únicamente de un ejercicio provocativo de destrucción, sino que es también un homenaje al soneto como modelo poético y a herencia poética y cultural. Este es el caso del soneto titulado «Sobre los vivos y los muertos», escrito en 1986 y publicado en Soneto vivo, que supone un guiño a la poesía conceptista quevediana, transmisora la idea de la muerte cotidiana ${ }^{194}$ :

Todo bebé que llega en viaje a viejo arrastrándose empieza por los suelos pronto se empina corre y monta en vuelos

${ }^{194}$ Una de las direcciones de la poesía existencial de Francisco Quevedo gira en torno a la idea de la muerte. Muerte presente en cada instante de la vida, muerte que se fragua ya desde el mismo instante de la vida (la cuna) y no sobreviene de modo abrupto con la llegada de la muerte (la sepultura). En Quevedo vida y muerte se enhebran y se solapan, de modo que se rompe la línea divisoria que las separa. La muerte queda insertada en cada instante del trascurso de la vida. Ello se expresa en los siguientes versos:

Vivir es caminar breve jornada, y muerte viva es, Lico, nuestra vida.

O en los siguientes:

Ya no es ayer; mañana no ha llegado; hoy pasa, y es, y fue, con movimiento que a la muerte me lleva despeñado. 
conservando salud salva el pellejo

Y si los vivos rompen el espejo donde se miran sin quitarse velos gesticulando a semejanza de los peleles ya no queda más reflejo

Pero como los vivos son muy vivos de la vida aprovechan mil motivos y el hoyo en la hora mala ven venir

A los muertos se llora y sin embargo ellos en su leteo en su letargo nunca han de despertar para morir.

Este ciclo, que transcurre de 1941 a 1987, es el más extenso de todos. Pont (1998: 24) lo incluye en los ciclos mayores, aquellos que abarcan un período largo y poseen un carácter abierto. Frente a estos, este autor opone los ciclos menores, que se caracterizan por su breve duración y por su talante puntual y cerrado ${ }^{195}$. Soneto vivo, publicado en 1988, supone en realidad la actualización de Los sonetos, obra editada en 1963 y que abarca el período de tiempo que va desde 1944 a 1963. Soneto vivo modifica la estructura de Los sonetos, suprime y añade algunos poemas. Además de los sonetos escritos propiamente para Soneto vivo, incluye nuevos poemas pertenecientes a otras obras como Poesía primera, Poemas, Poesía (1945-1969), Técnica y llanto, Lee sin temor, Metanoia, Energeia y La flauta prohibida. El ciclo consta de dos obras:

• (1944-1963) Los sonetos, que contiene Lapis Lazarius, Morir si hay un espejo en el abismo, Para algunas sensibilidades y Satán al aparato.

- (1941-1987) Soneto vivo. Ciclo formado por Para algunas sensibilidades (1941-1954), Lapis Lazarius (1959-1964) y Soneto vivo (1970-1987).

${ }^{195}$ Pont (1998: 24). Los ciclos mayores, para este autor, están formados por Poemas, Energeia, La flauta prohibida, Los sonetos y Soneto vivo. Mientras que los ciclos menores los constituirían Poesía primera, Los poemas del 44, Doblo hablo, Órgano constante, Música de lobo, Técnica y llanto y Lee sin temor. 


\subsection{Poesía del recuerdo}

La poética oryana, a través del inextricable laberinto que ofrecen los días transcurridos, se convierte ya en una poética de madurez. Una poética que se configura como el permanente viaje en busca de la iluminación, ejercicio interior o meditación que trata de desvelar el misterio de la existencia. Si la poesía oryana llevaba, ya desde sus mismos inicios, una impronta existencial, es en esta poesía madura donde esta dirección se funde con una mística inmanente ${ }^{196}$ de signo cósmico. La imagen de la divinidad es el todo, infinito e ilimitado. El todo que abarca todo espacio, desde lo más interior hasta lo más lejano. Infinito que se mueve en todas direcciones, hacia dentro de cada ser y hacia lo más lejano. De este modo se expresa Ory de en clave simbólica en su Diario (2004, Vol III: 337):

Uno siente hasta los huesos la nostalgia del infinito. Y la mística de la Nostalgia original vuelve los ojos a la infancia del mundo. Somos niños acabados de salir de la cuna, nos erguimos buscando el horizonte. Allá donde se junta, en apariencia, el cielo con la tierra. Hemos visto el horizonte amplio y ya atisbamos la meta entre las treinta y dos direcciones [...] No hay más rumbo que el que conduce a lo desconocido.

Esta poesía mística, en cierta medida, supone una vía de conocimiento de la realidad y un método de autoconocimento y transformación. Poesía que es meditación y metafísica. Su lenguaje, como toda mística, es sumamente simbólico, ilógico y paradójico. Su signos son la hermética y la hermenéutica. Una hermética que proviene de la destilación de todas las tradiciones metafísicas, religiosas y místicas que han

196 Por mística inmanente entendemos la consideración de una divinidad no trascendente, no antropomórfica, sino de signo pánico, panteísta y total. La totalidad cósmica sería la imagen de la divinidad oryana, arraigada sobre todo, en el aquí. No en los lejanos mundos especulativos imaginarios. Si las representaciones de otras realidades consideradas sutiles o espirituales interesan a la mirada oryana, lo hacen como metáfora de la mente humana, que reside en el aquí. La mistica oryana es la mística de la materialidad, entendida como el rechazo de la excesiva especulación y conceptualización de los mundos celestes y de sus panteones.

En el Diario Ory rechaza de pleno el racionalismo cartesiano y la imagineria platónica sublimizada. Comentando el tomo I de las Obras completas de José Ortega y Gasset, nos dice lo siguiente (2004, Vol III: 28):

(pág. 217, 218) «Reflexión, ciencia es purificación de lo espontáneo psíquico». Después de esto, abro el libro de Hubert Benoit, La Dotrine Supreme selon la Pensée Zen, y he aquí la oposición más rotunda al racionalismo orteguiano. Réflexion et pensée discursive ne mènent à rien; ¿c'est comme une lampe en plein midi; aucune lumière n'ent sort.

Es que el Budismo Zen, ya nos lo dijo el Dr. Suzuki, «detesta toda forma de intelectualismo». 
surgido a lo largo de toda la diáspora cultural. Y una hermenéutica que trata de interpretar los textos, los símbolos y las imágenes míticas de las culturas clásicas y antiguas ${ }^{197}$. Este ciclo último recoge tres obras que poseen tres códigos diferentes que se fundamentan en un mismo signo, el viaje. Viaje físico y viaje interior. El eje que articula este viaje es el recuerdo, que abarca desde el pasado reciente hasta la infancia. En este sentido se trata de una poesía que intenta un retorno hacia el origen:

- (1988) Angel without a permit / Sin permiso de ser ángel propone una poética de signo beat que se inscribe en el interior de un viaje a la ciudad de Nueva York. El viaje queda configurado como una retrospectiva sobre instantes cercanos.

- (1999) Melos melancolía supone una hermética donde se conjugan todas las visiones metafísicas de la humanidad, desde la más remota antiguedad hasta la actualidad más inmediata. La idea del viaje existencial marca la mirada del poeta, que aparece como un vagabundo del Dharma, ser errante que busca el misterio del samsara. La obra, que contiene Érase una vez una voz y Nabla, traza la mirada, desde la vejez, hacia el pasado lejano. Ella abarca, según Pont (1999: 118), un espacio cronológico que va desde 1977 a 1994 y supone una reconstrucción de la poesía oryana de este período a partir de poemas que habían aparecido en revistas literarias. En 2003 una segunda edición añade un poema más.

- (2011) La memoria amorosa está codificada en forma de retrospectiva. El recuerdo estructura los instantes vividos situándolos en base a los espacios existenciales vividos. La prosa poética, en la que está escrita la obra, presenta una simultaneidad de planos a modo de un gran caleidoscopio que nos ofrece trazos de existencia, radiografías de intimidad e instantáneas de vida.

De este modo, la imagen del ciclo, ciclo de ciclos, desemboca en una gran espiral que abarca íntegramente la topografía existencial del poeta. Espiral que muestra

197 Ver Gadamer, Hans-Georg (1960), Wahrheit und Methode. Grundzuge einer philosophischen hermeneutik; traducción de Ana Agud Aparicio y Rafael Agapito, Verdad y método. Fundamentos de una hermenéutica filosófica, Salamanca, Sígueme, 1977. 
el laberinto de laberintos de Carlos Edmundo de Ory. La memoria amorosa funciona como una espiral inversa que nos retrotrae a la imagen del mar. Viaje, pues, al origen. 


\section{POESÍA CREPUSCULAR}

Vértigo de ensambladura y amapola de sadismo.

Julio Herrera y Reissig

La poesía de Carlos Edmundo de Ory siempre ha ido a contracorriente. Se inicia en 1940, en plena vigencia de las prácticas clasicistas de la Generación del 36 y del neotradicionalismo imperial, e irrumpe ya a trompicones en la territorialidad poética de su tiempo. Desde su nacimiento es una poesía desubicada porque no se ciñe a los cauces establecidos. En pleno auge del realismo poético y de la poesía rehumanizada Ory propone una poesía crepuscular que conjuga tradición simbolista y vanguardia. La herencia simbolista está presente en la impronta dejada por sus autores más importantes como Charles Baudelaire, Paul Verlaine o Arthur Rimbaud y en sus desarrollos impresionistas, decadentistas y modernistas como Juan Ramón Jiménez, Leopoldo Lugones o Julio Herrera y Reissig. Por otra parte, el acercamiento a la vanguardia se produce a través del ultraísmo, el creacionismo (que al fin y al cabo son desarrollos del cubismo) y del surrealismo peninsular por vía de la poesía de Federico García Lorca, de Rafael Alberti o de Luis Cernuda.

Se trata de una poesía que no se ajusta a los engranajes de su tiempo, una poesía que, a pesar de dirigir la mirada al pasado, resulta paradójicamente mucho más moderna y renovadora que la poesía de signo clásico, escrita a inicio de la posguerra. Poesía crepuscular porque se erige como un homenaje, a modo de canto del cisne, a un mundo cultural que perece arrastrado por nuevas modas. También por una concepción de la práctica poética basada en un realismo de signo interior. Esta poesía primera, de signo crepuscular, se instaura a su vez como punto de partida de la experimentación. Pues es la poesía de Ory la que marca el inicio de la experimentación poética de la posguerra. Espacio poético que confluye, sobre todo, con la poesía de Cirlot. Se trata de una poesía que no comparte los rasgos que, según Víctor García de la Concha (1987, Vol. II: 838840), definen la nueva poesía que surge en las inmediaciones de la guerra civil: el recuerdo como elemento de captación de la realidad y un pretendido interés espiritual. 
Por ello la propuesta poética oryana queda excluida, ya desde sus inicios, de la geografía poética central situándose en un espacio totalmente periférico. Y periféricas son las constantes poéticas que se enuncian en esta poesía primera y que luego marcarán el devenir de la poética oryana: la impronta metafísica y la unión de poesía y música. En el prólogo titulado Bienio gaditano de un joven poeta inédito, escrito para la publicación de Poesía primera (1940-1941), Carlos Edmundo de Ory reconoce, con una especie de lenguaje alquímico, la presencia de estas preocupaciones poéticas en su obra posterior y define esta poesía crepuscular como el territorio donde se inicia su viaje poético (1986: 7-8):

Mi hora de la alquimia del verbo sonaría, acaso, en el porvenir. Y ahora caigo en la cuenta de la unidad armónica que relacionan mis inicios poéticos con mi obra madura. En este sentido contemplo aquel pretérito mío como laboratorio de quintaesencias y elixires.

Manuel Ramos Ortega (2004: 16), después de enunciar varios de los antecedentes de la primera poesía oryana como Juan Ramón Jiménez, Gustavo Adolfo Bécquer, Paul Verlaine, Rubén Darío, Amado Nervo, Rafael Alberti..., señala que:

Lo que en otros poetas supondría una estación de llegada, en Carlos es sólo un simple punto de partida, una pista de despegue que le ayuda a coger el impulso suficiente con el que remontar el vuelo con la perspectiva de otros horizontes más amplios.

Se trata, pues, de una poesía a contracorriente en la que se atisban los extraños hallazgos y la particular rareza de su poesía posterior. 


\subsection{ESTÉTICA SIMBOLISTA}

Amé, fui amado, el sol acarició mi faz.

¡Vida, nada me debes! ¡Vida, estamos en paz!

Amado Nervo

Todas las obras que conforman la poesía crepuscular están escritas bajo la alargada sombra del modernismo ${ }^{198}$. Sombras y pájaros (1940), La canción meditada (1941), Elisa (1941), Paladín de Ponto (1942), Canciones amargas (1942), Las niñas del nácar (1943) y algunos poemas pertenecientes a manuscritos conservados se hallan en el vértice que une la herencia modernista, de signo visionario, con la vanguardia poética peninsular. Poesía de la emoción, de la sugerencia, que transmite pinceladas de sentimientos, que crea atmósferas sin definición concreta. Se trata de una poesía que es un susurro al oído como lo es el sonido del oleaje del mar. De ese mar de Cádiz, cuyo rumor, según Ramos Ortega (2004: 15), crea la música océanica o conciencia cósmica en la poesía de Carlos Edmundo de Ory. Una poesía que supone un lenguaje fluido y anárquico, totalmente preconsciente y alejado la lógica referencial, más apto para expresar una realidad fluida e ilimitada. Un lenguaje vivencial, porque la poesía (desde el simbolismo) se vive. Lenguaje que une poesía y vida. Lenguaje poliédrico, como la realidad misma, que se basa en una palabra vehemente, condensada, capaz de proporcionar miles de matices por estar desligada de su tarea referencial. Saul Yurkievic (1976: 22) nos habla, en este sentido, de una poesía de superficie, donde esta se libera de todas sus ataduras frente a la realidad. La poesía modernista se sacude el modelo realista basado en la copia y se erige como una nueva realidad creativa que dicta los signos de su propio funcionamiento. Se trata de una poesía autónoma. Así lo explica Yurkievich (1976: 22-23):

Los modernistas desechan la pretendida profundidad romántica, no buscan ni el espesor ni la espesura sustanciales. Se proponen desgarbar el poema de servidumbres extratextuales para reorientarlo hacia su más concreta inmediatez:

${ }^{198}$ Ver la edición de José Olivio Jiménez (1979), El simbolismo, Madrid, Taurus. En ella diversos autores estudian este movimiento desde sus precursores, como son la mística inefable de San Juan y la poesía intimista de Bécquer, hasta la poesía de signo impresionista de Machado y Juan Ramón, pasando por la poesía modernista hispanoamericana y su herencia. 
la configuración de la palabra a través de un experto manipuleo. Trabajar en superficie significa aceptar el predominio de la materialidad del texto, que ante todo es una peculiar disposición del lenguaje sobre la extensión de la página en blanco. El arte de superficie colinda con el arte decorativo. Tanto las artes plásticas como la literatura de fines de siglo XIX insisten sobre lo decorativo como opuesto a la copia de lo natural, como afán de estilización, como poder de abstracción. El arte no tiene función reproductora. Estiliza el abigarramiento de lo real sensible para abstraer una configuración sintética, ordena la maraña de lo inmediatamente percibido representándolo por una forma simbólica. En pintura es el primado de la línea, del arabesco, en poesía es el primado de tracerías, follajes y volutas verbales. En las artes plásticas se da el auge del art nouveau, del modern style, en las artes verbales impera su correspondiente literario, el simbolismo. Todas estas manifestaciones son correlativas, provienen de un mismo contexto estético. En ellas se da la búsqueda de los ritmos melodiosos y de las asociaciones sugestivas, una misma imaginería, parecidos iconos, igual voluptuosidad.

La poesía crepuscular oryana posee la impronta simbolista de configurarse como realidad poética y no como mera copia de lo real. Poesía que une expereciencia y escritura, donde la poesía se vive y la realidad se poetiza. Poesía, en cierto sentido, de signo esteticista, porque supone un intento de vivir una realidad poética con un total realismo.

\subsubsection{Herencia modernista}

La poesía inicial oryana toma el lenguaje ampuloso, desmesurado, ondulante, impresionista $\mathrm{y}$, sobre todo, sensual de la estética modernista y lo adapta a sus coordenadas poéticas temporales. Este lenguaje basado en el culto a la imaginación será desarrollado en posteriores actividades poéticas y atravesará la totalidad del laberinto poético oryano hasta su fin. En el poema «Voz lejana», perteneciente a La canción meditada (1941) encontramos los ecos imaginativos de la estética modernista:

Búscame si me encuentras en los lotos del espacio nimbado y en las lentas suavidades del aire alimenticio.

Muéveme sin contagios que aún intacto me mezo en hojas inimaginables de un nocturno perpetuo elemental. 
Y como el ave inmota déjame

viva estatua tocada por tus besos

más estanco escuchar tu voz lejana.

Se trata de un lenguaje poético que nos recuerda la poesía de Leopoldo Lugones, la de Julio Herrera y Reissig, la de Rubén Darío o la de Ramón María del Valle-Inclán. Lenguaje plástico y ondulante, excesivo y gozoso, sometido a un proceso de forja semántica. El poema «Luna», perteneciente a Poemas de adolescencia (1941), supone también una relectura del modernismo hispanoamericano:

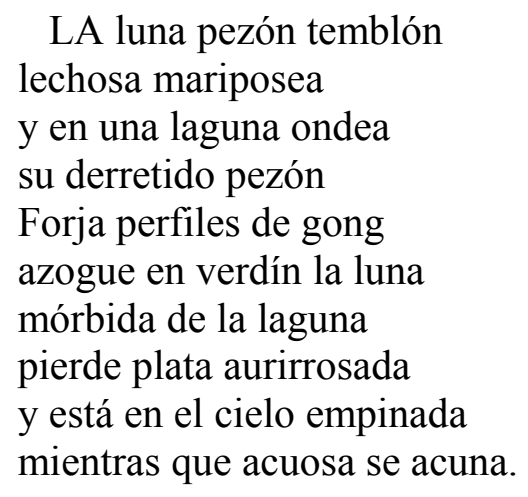

Aquí está más presente la extremosidad alucinada de la poesía de Herrera y Reissig, con sus rimas extrañas y la sugerente presencia de la estética oriental. Resulta fácil notar la simbiosis entre ambos poetas.

Flota sobre el esplín de la campaña una jaqueca sudorosa y fría, y las ranas celebran en la umbría una función de ventriloquía extraña.

La Neurastenia gris de la montaña piensa, por singular telepatía, con la adusta y claustral monotonía del convento senil de la Bretaña.

Resolviendo una suma de ilusiones, como un jordán de cándidos vellones la majada eucarística se integra; 
y a lo lejos el cuervo pensativo sueña acaso en un Cosmos abstractivo como una luna pavorosa y negra.

(Julio Herrera y Reissig, «Julio», El éxtasis de la montaña, 1904).

Los signos de la poesía del poeta modernista uruguayo se observan también en el soneto «Angelus» que pertenece a Sol y espigas (1941).

ARRULLAN sus palomitas la campaña del Angelus pacífico sigilo de alondra nueva que renueva el hilo de su canción en la penumbra aldeana

Hora de ocaso Va la tarde cana apoyada en un junco en el asilo de las luces enfermas Llora un tilo Baila la luna únicamente sana

Sangra el momento laten seres y aves El aire tiembla con melancolismo de ruina solar Un ángel arde

Todo está lleno de rumores claves Se oye el silencio y hay un misticismo de monje en la clausura de la tarde.

Nótese el parecido de la poesía de Leopoldo Lugones con la primera poesía de Ory:

La tarde, con ligera pincelada que iluminó la paz de nuestro asilo, apuntó en su matiz crisoberilo una sutil decoración morada.

Surgió enorme la luna en la enramada; las hojas agravaban su siguilo, y una arana en la punta de si hilo, tejía sobre el astro, hipnotizada.

Poblóse de murciélagos el combo cielo, a manera de chinesco biombo; tus rodillas exangües sobre el plinto 
manifestaban la delicia inerte, y a nuestros pies un río de jacinto corría sin rumos hacia la muerte.

(Leopoldo Lugones, «Delectación amorosa», Los crepúsculos del jardín, 1905).

Las huellas de los modernistas hispanoamericanos están impresas en la poesía inicial oryana: Rubén Darío, Leopoldo Lugones, Julio Herrera y Reissig, Amado Nervo, Manuel Gutierrez Nájera, José Juan Tablada o Enrique González Martínez. A todos ellos Carlos Edmundo de Ory tuvo acceso en la biblioteca familiar ${ }^{199}$, pues su padre, Eduardo de Ory, tuvo con ellos una amistad poética y una relación epistolar ${ }^{200}$.

\subsubsection{Impresionismo poético}

También se halla en la poesía oryana inicial la influencia de poetas peninsulares como Antonio Machado, Valle-Inclán o Juan Ramón Jiménez, más ligados con el impresionismo pictórico y, en cierto modo, distanciados del lenguaje ampuloso y multiforme de los arabescos y de la ornamentación decorativa y superflua. El poema «La tristeza amarilla», que forma parte de Poemas de adolescencia (1941), apunta directamente al poema juanramoniano «Primavera amarilla» perteneciente a Poemas mágicos y dolientes (1911) y que expresa una mística unificadora de la oscuridad humana y la muerte ${ }^{201}$ :

199 Ramos Ortega, Manuel (2012: 5-7). En la Fundación Carlos Edmundo de Ory se hallan varios de los libros y documentos de Eduardo de Ory. Entre ellos destacan algunos que influyeron decisivamente en la poesía de Carlos Edmundo. Hay ejemplares de la revista Azul, fundada y dirigida por Eduardo de Ory, colaboraciones con Salvador Rueda, con Andrés González Blanco, una dedicatoria a Rubén Darío, prosas de Manuel Ugarte, prosas de Juan Ramón Jiménez y el ejemplar más raro de todos, Rarezas literarias. Florilegio de composiciones curiosas y extravagantes de autores antiguos y modernos recopiladas $y$ ordenadas por Eduardo de Ory.

${ }^{200}$ En la Fundación Carlos Edmundo de Ory ha aprecido, entre los documentos de Carlos Edmundo de Ory, una carta de Marinetti dirigida a Eduardo de Ory. Entre ambos poetas existió una relación epistolar. Eduardo de Ory colaboró en la revista milanesa Poesía, fundada por Marinetti.

${ }^{201}$ Este es el sentido de los versos juanramonianos:

Entre los huesos de los muertos abría Dios sus manos amarillas.

Se trata aquí de una divinidad que acoge, como el símbolo arquetípico taoísta del yin y el yang, la polaridad extrema y la unifica en una misma línea existencial trascendiendo las divisiones representacionales. De modo que vida y muerte son conceptos necesarios y no 
LA tristeza amarilla de la tarde dimana

de un dorado fulgor que enjoya los caminos

Como pinceles de oro gigantescos los pinos

forjan el claroscuro de la noche cercana

Templanza agreste de pintura aldeana

matriz de mies y tono de los trinos

instrumentos de música divinos

contrapuntos de alondra y de campana

Mientras el río entre los juncos osa

pálpitos de serpiente voluptuosa

y el suelo es solio de un inmenso olfato

Todo es orquestación puesto en aroma

cuando la noche humilde asoma

asustadiza y negra con carita de gato.

El modernismo oryano se distancia de las ampulosidades de los poetas hispanoamericanos y se acerca al intimismo de signo impresionista, transitado por autores como Antonio Machado y, sobre todo, Juan Ramón Jiménez. Tanto el poema jaunramoniano como el de Carlos Edmundo de Ory evocan, de algún modo, esos cielos amarillos impresionistas de los paisajes campestres de Vincent Van-Gogh. Impresionismo de un amarillo esquizofrénico. Van Gogh es el pintor del amarillo, cuyo símbolo central es el sol. Sus matices y tonalidades, a modo de reflejos solares, se encuentran en la textura del cielo, en las extensiones de la hierba, en las superficies terrosas, en las paredes de las casas y en la piel de los cuerpos humanos. Vasili Kandinsky (1912, 1996: 73-74) lo asocia, entre otras cosas, a la locura:

El amarillo contemplado directamente (en cualquier forma geométrica) inquiere al espectador, le molesta y le excita y descubre el matiz de violencia expresado en el color, que actúa descarada e insistentemente sobre su sensibilidad [...] Comparado con el estado de ánimo de un hombre, podría corresponder a la representación cromática de la locura; no de la melancolía o la hipocondría, sino de la locura furiosa, la rabia ciega, el delirio.

excluyentes, partes de un mismo imán que si lo rompemos vuelven a surgir. El mismo sentido tendría el proverbio chino que indica que la noche comienza al mediodía. Integración de la muerte en una divinidad cósmica, que se alimenta de los seres. En el hinduismo el Atman, o ego (quien muere), está indisolublemente unido a Brahman, o todo, eterno e lilimitado (que permanece). Krishna, séptima encarnación de Visnu, le dice al guerrero Arjuna: «Yo soy la vida en todos los seres que existen» (Bhagavad-Gita, Madrid, EDAF, 1996, p. 62). 
El amarillo es el color de la desmesura, de la inmensidad del sol y apunta a la inmediatez de lo dionisíaco, a la energía exultante de la plenitud vital y la ruptura de moldes y límites que significa todo crecimiento o trascurso vital. El poema de Ory aparece como un lienzo pintado con los trazos cromáticos de la existencia, donde el amarillo de la vida diurna, posado en los caminos, en la aldea, en el río , en el cielo..., anuncia la oscuridad de la noche. Una noche contenida en los matices del amarillo solar. La imagen de la noche comparada a una «carita de gato» transmite esta conjunción cromática del sol y su ausencia, la oscuridad. Los tonos ocres y amarillos, que resaltan sobre los matices oscuros y el negro, dibujan la cara de un gato.

En el poema «Remordimiento» de Sombras y pájaros (1940) aparece por primera vez el amarillo existencial de Juan Ramón Jiménez. Color amarillo que trasciende la concepción de amarillez romántica que lo ligaba a la muerte y supone, en el siguiente fragmento, el mismo pálpito desbordante de la vivencia:

En el mar amarillo de mis horas se revuelcan los pájaros enfermos con un temblor de alas imprecisas.

A flor de sol y espuma se ha mecido la angustia taciturna de mi ser.

Ya otra vez soy el mismo que aquel día que fui sin ser de mi contorno ausente: Porque llevo la luna entre las manos, cuando el negro silencio que despierta las brisas me consume el espíritu.

Amarillo de la existencia, de la intensidad y de la estridencia, que Kandinsky compara con la música aguda e intensa de instrumentos como la trompeta, el clarinete o el violín (1912, 1996: 73).

Otra referencia a la poesía juanramoniana se encuentra en el poema «Pureza» de Sombras y pájaros (1940), que supone un guiño a la poesía desnuda de este autor y apunta, en definitiva, al poema metapoético «Vino, primero, pura» de la obra Eternidades (1918): 
Primero te vi blanca...

Después desnuda y blanca.

Y cuando me mirabas

parecías de nácar

y después de plata.

¡Pero siempre muy blanca!

El poema oryano erotiza el discurso de Juan Ramón al trasladarlo sobre el cuerpo femenino. En este sentido encontramos como una huella la influencia de la verticalidad femenina bequeriana. Mujer de nácar y plata, cuerpo blanco y puro. Presencia aquí de la mujer desposeída de su cuerpo, fruto de la cultura occidental misógina y patriarcal. En la mítica occidental cristiana la mujer ha sido, desde el Génesis, el territorio de las tentaciones del diablo y la condenación del ser humano (masculino por excelencia) a los fuegos eternos del infierno. Más tarde quedó convertida por Dante y los poetas petrarquistas en ángel incorpóreo que olvidó las artes amatorias de Venus. Incluso Boticelli la pintó a la misma Venus de forma pudorosa y asexual, tapándose el pubis con el velo de su propia cabellera rubia. Mujer desposeída de los poderes de su sexualidad, ángel blanco asociado a la pureza virginal sin mácula de María. El otro arquetipo femenino, representado por el ángel negro es la mujer morena asociada al cuerpo erótico y lozano. Las mujer fatal que incorpora todos los atributos de la sexualidad, cuya imagen más extrema es la prostituta.

En las rimas de Bécquer, dentro de los parámetros de la tradición petrarquista, la verticalidad convierte lo inmediato en sublime, el amor en religiosidad y la mujer en objeto de culto y adoración. Mujer desposeída de su cuerpo para ser convertida en un dechado de pureza, cuerpo femenino alejado de la sexualidad, amor platónico sin el contacto de la corporeidad. El cuerpo femenino queda velado tras la blancura de las telas y de la geografía de la blancura de la piel. Mujer angelical, convertida en puro ángel, tras el secuestro de su cuerpo. Ser incorpóreo, puro fantasma, ser sin existencia. Esta es la pura imagen de la musa. La presencia de la pureza femenina, de herencia becqueriana, en la primera poesía oryana es bastante frecuente. En el prólogo a la tardía edición de este material poético pretérito, el propio autor tilda el proceso de verticalidad que conlleva la idealización amorosa como simple esquizofrenia adolescente: 
Pese a la esquizofrenia de aquel idealismo vespertino de sendas, sombras y pájaros y su brocado tropológico, el instinto rítmico dominante convertía los motivos en terca musicalidad vaporosa (1986: 7).

Esquizofrenia porque no se percibe la realidad tal cual es. La verticalidad becqueriana se plasma, aparte del intimismo de Machado o Juan Ramón, en la expresión de una realidad etérea, casi desdibujada, donde los objetos quedan envueltos por los velos de las nubes y las neblinas. De su traducción en el escenario humano surge la imagen de una amada etérea, pura proyección mental de la adolescencia, y por ello puro ser vacío, inexistente. Ello es lo que se desprende del poema titulado «En mí», perteneciente a Sol y espigas (1941):

EN este triste estar siempre tan lleno de ti sin ti pastor de los olvidos besos que han sido oyendo en sus oídos $\mathrm{y}$ un tibio albor de acariciares pleno

Me sabe el aire a almíbar y a veneno escucho cerca tus pisares idos $\mathrm{y}$ en un susurro de árboles heridos dice la tarde su plegaria de heno

En este triste estar sin tu mirada con que me vieras en la lejanía tendré tu nueva forma de quimera

Que estás en todo aunque no estés en nada porque al entrar en mí por poesía en ella vivirás de igual manera

La amada, en todo caso, supone un mero pretexto para la escritura de una poesía amatoria apolínea. En Elisa (1941), especie de prosa poética con una unidad narrativa que presenta un imaginado amor consumado, asistimos al juego de la profanación decadentista. En él la amada se presenta como imagen virginal y sublime:

Y tu nombre en mis labios -Elisa- será un rezo de amores que endulzará mi boca que se muere de sed.

Y mientras en el teclado nuevo del silencio aunado, las nevadas magnolias de tus manos monjiles, aprenderán las sonatas de la caricia tímida.

Que tu presencia sea en esta hora, junto a mí, bajo el ritmo prodigioso de tu alma de niña asustada, una milagro exquisito de hostia pura de amor. 
Adoro el clavicordio que palpita en tu espíritu, cuando el nido de tu alma es todo musical y etéreo, como el aroma de incienso.

La figura de la amada aparece descrita con los atributos de la inocencia, del ser virginal, del cuerpo inmaculado, de la imagen de la diosa, de la estatua de mármol...: «desnudez de estatua», «desnudez de lumbre», «desnudez de ámbar», «velo sedoso... el transparente pudor de la inocencia», «niña adolescente mimada en un convento», «novia virgen», «cuerpo...inmaculado», «bucles de ángeles», «veste blanca», «tu desnudez es humo», «nívea pureza». El fragmento acaba con la expresión de un deseo apolíneo de admiración y de adoración de la belleza sublime, no con la profanación de un erotismo dionisíaco:

La dignidad de mi buen amor en la raya pictórica de tu desnudo de imán.

Yo prefiero tu desnudez en mi honor que en mi furia lasciva.

Así supe ser artista y admiré tu busto encantado, tu ruta de caderas que era sombra siluetada y a flor de pulso ebrio.

La perfección griega de tu cuerpo tenía una armonía de líneas aristocráticas y olímpicas.

Y el texto finaliza con la confirmación de que se trata de un amor soñado. El fragmento resulta ser, al fin y al cabo, mero sueño de amor. Amor adolescente, en el que se muestra una devoción religiosa, cristiana, por el ser femenino amado. Diosa cuyos vértices la asocian con la monja y con la Virgen, mujeres cuya sexualidad queda neutralizada y abolida.

El impresionismo poético oryano, basado en la plasmación de las tonalidades cromáticas que dibujan la atmósfera del poema a modo de una nebulosa donde se suman las pinceladas de los sonidos, nos sugiere en un primer momento la impronta de Juan Ramón Jiménez. Pero también se halla presente el influjo de la poesía evocadora de Antonio Machado y de la de Manuel Machado. En «Romance de otoño», perteneciente a Sombras y pájaros (1940), asistimos a la representación dinámica de un atardecer que nos remite a la sensación de pesadumbre que trasmiten algunos paisajes poéticos del atardecer en la poesía de Antonio Machado:

La lengua verde del viento está lamiendo la tarde, ya los caminos se acuestan 
en las sombras de los árboles.

Un cielo de añil recorta

algodón de nubes mates.

Medio sol le guiña al día

bañando su sueño en sangre.

En el espejo de un río

la luna baña su alfanje.

Los pájaros van bordando

fugas de vuelo en el aire

y las hojas en las ramas

trazan finos susurrantes.

Una estrellita sin voz

se está peinando en su cauce.

Grillos visten la campiña

de murmullos ambulantes.

El silencio medio loco

no encuentra sitio en la tarde.

El día sucio se esconde

en el ocaso sangrante,

la brisa con sus dedillos

le picotea la carne,

y hay un olor de resina

$y$ un perfume de azahares.

(¡Otoño se paseaba

de la mano del paisaje!).

El impresionismo de Ory, como en la poesía de todos los poetas impresionistas, mayoritariamente se manifiesta mediante el cromatismo y el sonido. En este caso se da también la presencia, aunque en menor medida, del tacto y el olor. El poema nos muestra la representación de la realidad mediatizada por estos sentidos. Descripción cromática, auditiva, olfativa y táctil de un atardecer. Los matices cromáticos del poema se ofrecen,como si de pinceladas se tratasen, en las siguientes notas:

- La «lengua verde del viento» (v. 1) describe la extensión vegetal.

- Las «sombras de los árboles» (v. 4) marcan la oscuridad de los caminos, y del follaje.

· Sobre el «cielo añil» (v. 5), imaginado como «algodón de nubes mates» (v. 6), se destaca el blanco de las nubes.

- El color oscuro de la tierra queda representado por la «sangre» (v. 8). 
- Sobre la oscuridad «el espejo de un río» (v. 9) atraviesa el espacio pictórico y una línea azul.

- En ella aparece reflejada la tonalidad luminosa de la luna: «la luna baña su alfanje» (v. 10).

Acaba aquí la intensidad cromática y sobreviene en las dos siguientes estrofas la descripción auditiva. Estas son sus notas:

- Las «fugas» musicales de los «pájaros» (vv. 11-12).

- Las hojas de los árboles que «trenzan finos susurrantes» (vv. 13-14).

· El canto de los grillos: «Grillos... murmullos ambulantes» (vv. 17-18).

• «El silencio... no encuentra sitio en la tarde» (vv. 19-20).

Se trata de un atardecer vivo donde todos los objetos retratados gesticulan y emiten su mensajes. En el resto del poema todavía se ofrecen impresiones táctiles y olfativas. El «olor de resina» (v. 25) y el «perfume de azahares» (v. 26) marcan las notas olfativas, mientras que la caricia estridente de la brisa (vv. 23-24) marca la presencia del tacto («la brisa con sus dedillos / le picotea la carne»).

El impresionismo oryano, sobre todo, opera mediante la suma de color y sonido. Ello puede observarse, una vez más, en la «Canción del ocaso» de la obra Canciones amargas (1942):

En el agua verde

de la tarde lila

tu canción se pierde.

En la tarde lila -música de sedatu canción celeste.

¡Música de seda!

Alma ruiseñorica

de violines breves.

Y todo tenía un morir callado de sonrisas tenues. 
De este modo, al igual que ocurre en las descripciones poéticas de Antonio Machado y de Juan Ramón Jiménez, se crea un paisaje fluctuante, poliédrico, inmediato y dinámico. Estos atardeceres están íntimamente conectados con los paisajes de Claude Monet, de Pierre-Auguste Renoir, de Alfred Sisley, de Camille Pissarro, de Edgar Degas, pero sobre todo con esos campos abiertos estructurados a base de brochazos superpuestos que se muestran en la pintura de Paul Cezanne y con los paisajes agitados de Vincent Van Gogh. En ellos se ofrece un escenario vivo en el aquí y el ahora. Paisaje que requiere de la tarea del observador, ya que esas manchas, esos trazos superpuestos y tramposamente anárquicos, esos arabescos completan, con la distancia de la mirada, el paisaje en los ojos y en el cerebro de quien mira. El impresionismo significó la recuperación del color en el arte de Occidente y, a partir de aquí, en la poesía. La poesía impresionista supone una palabra pintada, donde el color toma la misma intensidad y vehemencia que posee la palabra poética, poliédrica, multidireccional, plural y simbólica. El color, como nos dice Gaston Bachelard ${ }^{202}$ refiriéndose a la pintura impresionista de Monet y Van Gogh, se transforma en acto creativo del pintor. El color crea, actúa en la materia y modifica la realidad, pues el color muestra la dimensión de la intimidad de quien pinta. Los pintores crean nuevos colores y con ellos y con su luz particular crean nuevas realidades, ya sea figurativa o abstracta la pintura practicada. Paralelamente, desde el simbolismo la palabra poética crea realidades autónomas.

\subsubsection{Poesía visionaria}

La primera poesía oryana, como el color de los pintores impresionistas, posee propiedades visionarias. En cierta medida, Ory actúa como el poeta simbolista visionario que se erige como medium, a través del desarreglo de los sentidos, para expresar una realidad oculta a la mayoría de los humanos. Verlaine, Rimbaud y Baudelaire son sus maestros de ceremonias, los creadores de un nuevo lenguaje que rechazaba la dimensión puramente pragmática y mercantil del lenguaje humano. Este lenguaje nuevo, distanciado totalmente del lenguaje utilitario, es un lenguaje abandonado a sí mismo, al propio oleaje de las palabras, un lenguaje cuyos signos son la sugerencia y la percepción. El poeta es el vidente que percibe la vida de forma ilimitada

${ }^{202}$ Bachelard, Gaston (1970), Le droit de rêver, París, Presses Universitaires de France; traducción de Jorge Ferreiro Santana, El derecho de soñar, México D. F., Fondo de Cultura Económica, 1985, p. 41. 
y libre, que como William Blake ${ }^{203}$ rechaza de pleno el racionalismo por su incapacidad de desvelar los misterios que encarna la verdadera realidad, una realidad que sólo se aprehende mediante una percepción no contaminada. Para él, el racionalismo cultural obtura y sella las puertas de la percepción, de modo que el hombre solamente puede vivir en el engaño de las apariencias. El lenguaje simbolista es un lenguaje raro y decididamente perverso que en un principio, debido a su actitud combativa y al rechazo social inherente, tomó los rasgos de lo maldito. Lenguaje mediatizado por la alteración de la percepción y el trasvase de los sentidos. Fue el poeta romántico Samuel Taylor Coleridge quien, debido al uso terapéutico del láudano ${ }^{204}$, encontró el lenguaje visionario al escribir su poema inacabadao Kubla Khan. Luis Antonio de Villena (1975: 132-133; 1982: 128-129) nos dice que, en sus sueños opiáceos, Coleridge vio un poema en el que las imágenes se adecuaban sin ninguna labor consciente y sin ningún tipo de premeditación. Según Villena, cuando se despertó todavía tenía conciencia del poema soñado y se puso a escribirlo, pero la inesperada visita de un amigo interrumpió la tarea. Más tarde cuando intentó de nuevo finalizar el poema, fruto de una visión, ya no pudo. Por ello quedó inconcluso. El poema es una suma de imágenes y metáforas, donde los sonidos podían ser vistos y los colores ser escuchados. Esto es, la sinestesia.

Este lenguaje visionario, para Carlos Bousoño (1952, 1976, Vol. II: 187-370), se basa en la irracionalidad y rechaza la asociación lógica entre las palabras, base del racionalismo poético. A este lenguaje Bousoño le otorga el nombre de irracionalismo poético y, para este autor, sus signos son: la imagen visionaria, la visión y el símbolo ${ }^{205}$. El irracionalismo poético, aunque se ha producido a lo largo de la historia como sería en caso de la poesía mística de San Juan de la Cruz y en algunos casos de la poesía romántica, surge, para Bousoño (1979a: 12-16), a partir de los poetas simbolistas.

${ }^{203}$ Cazamian, M. L. (1984), William Blake, Madrid, Júcar, p. 33-34.

${ }^{204}$ El láudano es un medicamento creado por el médico y alquimista Paracelso a base de vino y opio.

${ }_{205}$ Siguiendo con la retórica bousoniana (1952, 1976, Vol. II: 187-370), podemos establecer una definición más simplificada. La imagen es una ecuación significatica cuya estructura sería $(A=B)$, el término real queda asociado a un término evocado mediante una relación de parecido. Esta ecuación puede ser lógica o irracional (preconsciente, onírica...), de modo que tenemos por una parte la metáfora tradicional y la imagen visionaria. La visión es la apropiación indebida de una propiedad que el objeto no posee (A $[B])$, entre ella tenemos la personificación, la sinestesia, el desplazamiento... Y el símbolo ofrece sólo una parte de la imagen, el término evocado, pues se trata de una mera sustitución (B). 
La primera poesía oryana, crepuscular y simbolista, es una poesía visionaria e intimista. Poesía de signo irracionalista surgida del sensualismo y del impresionismo poético y que se acerca hacia un ilogicismo más radical. Se trata de una poesía irracionalista fundamentada en el simbolismo y en el modernismo y que se acerca a los movimientos de vanguardia, sobre todo el creacionismo y al ultraísmo, desarrollos ambos de la estética cubista, y desemboca en lo que sería vendría a ser un presurrealismo cuyos representantes serían Rafael Alberti, Federico García Lorca y Luis Cernuda.

Por una parte, es una poesía del adjetivo, que potencia la pluralidad de matices perceptivos como el cromatismo, las sonoridad, lo olfativo... y persigue la sensualidad. En este sentido, la visión, tal y como la define Carlos Bousoño ${ }^{206}$, entronca con el adjetivo, ya que este ofrece la propiedad que se aplica indebidamente al objeto. Esta adjetivación, semánticamente absurda, queda asociada al lenguaje de la sinestesia, y en la poesía oryana conlleva el germen del simbolismo poético y su herencia poética irracionalista. Por otra, se trata también de una poesía del sustantivo basada en la imagen. La imagen, a diferencia de la visión, incide en el sustantivo y ofrece una poesía más visual, cuyo signo reside en la relación de igualdad de los objetos, en sus parecidos y en sus divergencias. La práctica de la imagen en la primera poesía oryana supone un acercamiento a la vanguardia, al onirismo y a la libertad asociativa del surrealismo.

Este lenguaje simbolista de la sinestesia y de la incongruencia está plasmado perfectamente en esta poesía de Carlos Edmundo de Ory. Su primer poemario Sombras y pájaros (1940) se erige como dominio perfecto de la irracionalidad. Como ejemplo de esta semántica absurda ${ }^{207}$ del adjetivo podemos destacar el poema «Hora»:

\footnotetext{
El paisaje se duerme como un triste afligido. El sol de cara lívida siente cansancio y frío.
}

206 (1952: 232-233). En la visión no existen dos planos, uno real y otro imaginario, como en la imagen o en la metáfora. En ella sólamente existe una «atribución de cualidades o de funciones imposibles a un objeto» (la cursiva es del autor).

${ }^{207}$ Decimos que la visión ofrece un lenguaje semánticamente absurdo porque su impacto emocional preconsciente reside en la incongruencia semántica, en la imposibilidad lógica de aplicar una propiedad tal a un objeto que no la posee. El lenguaje visionario no es un lenguaje absurdo, como podría ser el lenguaje onírico o el lenguaje procedente del automatismo. 
(Un pájaro lleva en el pico

la hora desvanecida).

Hastío...!

Los árboles y los caminos

sueñan un viento peregrino.

Tedio, el silencio canta

con la música de un grillo.

(Hora)

Romanticismo de la hora

En que todo es lento y amarillo.

Tenemos aquí varias visiones que se pueden traducir al lenguaje del adjetivo: «El paisaje se duerme» o paisaje durmiente (v. 1), «El sol... siente cansancio» o sol cansado (v. 3), «Los árboles y los caminos sueñan» o árboles y caminos soñadores (vv. 8-9), «el silencio canta» o silencio cantor o sonoro (v. 10) que a su vez funciona como una imagen, como un «grillo» (v. 11).

La gramática del adjetivo recorre toda la poesía crepuscular oryana, algunas de sus muestras son las siguientes: «sonrisa amarga», «besos amarillos», «sol mutilado», «risa verde», «lechosa mariposa», «tiempo leñador», «beato temblor», «silencio monocromo», «luces enfermas», «silencio errante», «sueños lunados», «tristeza amarilla», «templanza agreste», «noche asustadiza», «soles enfermizos», «ramas confidentes», «aire alimenticio», «ojos bebedizos», «viento submarino», «agua callada», «mar amarillo», «estrellas pensativas», «viento verde», «tarde ciega», «duras chispas», «dulce alfiler», «cementario azul», «sonrisas pisadas», «música delgada», «horas descalzas», «guitarras ahogadas», «poeta azul», «silencio alado», «lácteo escalofrío lunero», «peces somnolientos», «azul silencio derretido», «sombras sonámbulas», «polen sideral», «oro dulce», «nervio amargo», «sangre incolora», «eco largo», «yacientes estrellas desnudas», «sueño azul», «negra fiebre» «mariposas pensativas», «blancos carnavales», «tarde íntima», «sombra mojada», «hora gris», «angustia alegre», «estellitas lavadas», «terror amanecido», «voz derretida». Se trata de un lenguaje que manifiesta paisajes interiores, radiografías de intimidad. 
Otras visiones poseen la misma función que el adjetivo incongruente, pero aumentan el grado de lo absurdo y de lo ilógico: «El viento peina la tarde», «Toda la tarde se asomó a tus ojos», «se despeinan los caminos», «La luna está cerrando los ojos», «me acariciaban las horas», «La tarde se ha caído / de una estrella», «Y sangraba el silencio en el atardecer», «Las sombras soberanas sumergen el camino», «Se emborrachaba de estrellas / el cielo», «La tarde se sienta en una piedra / a mirar esta lluvia de hilos»... Se trata de una poesía como introspección que progresivamente se despoja de las estridencias modernistas y acoge totalmente el lenguaje irracional intimista de Juan Ramón Jiménez, su idea de poesía pura ${ }^{208}$.

Este lenguaje intimista, ilógico y visionario se tiñe de decadentismo en el poema «Noche - Silencio», perteneciente a Sombras y pájaros (1940):

En los mudos violines del viento, carne de noche sin deseo palpan los dedos del silencio.

Es la hora en que las sombras van bordando su misterio, estrangulando momentos.

La noche es un pájaro negro que lleva en el pico el esqueleto de esta tarde que se ha muerto.

La luna está cerrando los ojos porque ha visto pasearse el miedo en las alas de un cuervo.

El día ha perdido la vista. $\mathrm{Y}$ aún se sostiene con tanteos de ciego.

${ }^{208}$ Blasco (1982: 179-192). La poesía pura juanramoniana rechaza la noción de poesía como pura creación intelectual y abstracta de Paul Valéry, cuyo desarrollo significó en la poesía española la poesía de estética cubista de Gerardo Diego y de Jorge Guillén, Ilamada poesía hermética, y reivindica las tesis de Henri Bremond, partidario de la pura inspiración y del rechazo de toda lógica. La pureza poética juanramoniana supone la afirmación de un lenguaje poético emocional de signo becqueriano. 


\subsubsection{Estética de la enfermedad}

Otra de las direcciones de la poesía crepuscular oryana es el decadentismo. Esta es la dirección que toma la poética modernista, continuadora de la conciencia del malditismo de los poetas simbolistas franceses, que propone el gusto por todo lo que perece, por lo enfermizo, por lo siniestro... Se trata de una estética de la enfermedad y de la muerte que, a su vez, supone un homenaje a un mundo que se acaba. La poesía de los ocasos y los nocturnos de Ory participa de esta dirección. Poesía de la melancolía y de la angustia que sigue los pasos de Antonio Machado y establece sus convergencias con el existencialismo filosófico de los seguidores de Schopenhauer y Nietzsche. Así expresa Ory su angustia existencial en el poema «Signo» de Sombras y pájaros (1940):

Meditabundo, cabizbajo, solo, voy recorriendo el páramo desierto, con mi dolor a cuestas.

Soy un pobre latido cuya savia va gastándose así poquito a poco como una hoja cuando amarillea.

O en el poema titulado «Angustia» que pertenece a La canción meditada (1941).

Se va la tarde. Lenta exprime un zumo agrio de horizontes. (Pasan muchachas pálidas llorando) ¡Se va la tarde lenta!

En el pozo estrellado de la noche Crecen las hiedras de la brisa, -húmedas--

También el soneto que se titula «Era como», perteneciente a Poemas de adolescencia (1941), participa del gusto por la apesadumbrada oscuridad:

ERA como un beato temblor de rosas suaves La tarde -flor de lila- se dejaba caer Y sangraba el silencio en el atardecer bajo un precioso cobertizo de aves

En la campiña escueta de azules tintes graves la faz flava del día que ya deja de ser 
se enmascara de estrellas en el estremecer

de la tierra que abre la coche con sus llaves

Era también un irse calladamente como sabe pie de andariego o camino bovino respirando en lo ancho bocanadas de azul Ha teñido el ambiente silencio monocromo Las sombas soberanas sumergen el camino y el cielo posa en lo alto del añoso abedul.

La misma obra ofrece otro homenaje al misterio de la noche, esta vez como espacio propicio del erotismo. Se trata de «Besos en la floresta», soneto que explora una zona poética casi inexistente en la época:

HA caído un jirón de noche en esta hora letal de soles enfermizos En la tarde polífona de hechizos Agoniza de besos la floresta

Hay un misterio de infinita fiesta puesto en silencio en dos labios mellizos Preguntan las caricias en los rizos de la mujer por lo que no contesta

Se abrió la rosa del silencio en una fuga de balbuceos y miradas entre un rumor de ramas confidentes

Y una sonrisa amiga de la luna dejaba ver como en un cuento de hadas el estanque de cisnes de los dientes.

El decadentismo oryano recorre también la senda del malditismo y la amoralidad. Los simbolistas franceses inauguraron el gesto de insumisión frente a una realidad mezquina y a sus engranajes mercantiles, su gesto significó la transgresión de la dinámica social burguesa y la ruptura airada de todas sus normas. La conciencia del malditismo atraviesa la poética modernista y se instala en la vanguardia combativa: sus iconos son el Marqués de Sade, Edgar Allan Poe, Charles Baudelaire, Arthur Rimbaud, Williers de l'Isle-Adam, Isidore Ducasse o Conde de Lautréamont o el bohemio Ramón María del Valle-Inclán. La actitud de poeta maldito marcará, desde su incio, el gesto de Ory en toda su trayectoria, tanto poética como cultural. Una de las transgresiones establecidas en esta primera poesía oryana es la presencia de la erótica. Ella queda 
expresada de forma evidente en este poema que pertenece a Paladín de Ponto (1942) y que se ofrece en clave popular:

\section{SEXO Y ESPALDA}

(Estampa de playa)

\section{Bañista \\ desnuda y blanca \\ sobre cojines de mar}

Queremel

La niña que se bañaba

era una niña de nata y algas.

La niña casi desnuda pero el bañador tapándola: dulce sexo oculto espalda de mármol clara.

Monta a la mar, niña, monta la verde jaca.

No te quedes en la playa.

Juega en la orilla si no, con cisnes de olitas blancas.

Erótica, sin duda, donde se juega con la inocencia y la perversión, entre la pureza sagrada y sin mácula de la adolescencia y la su profanación. También el erotismo pretendidamente ingenuo o naïf está presente, codificado en forma de canción popular siguiendo las directrices neopopulistas del gripo del grupo del 27, en las estampas poéticas que forman 20 Canciones delgadas (1942), poemario manuscrito en forma de pliegos:

\section{VII}

Ay, ay, muchacha desnuda que sudas alma en el sueño.

Desnuda y mortal, soñando con esta flor de mis dedos. 
Dedos borrachos y pálidos por el río de tus senos.

\section{XVIII}

Me está pisando los ojos

el corazón de tus labios.

Sangre antigua me sorprende

por todo el cuerpo delgado.

Ponte desnuda otra vez

-caña de nervio amargo-.

Es en la prosa poética de Elisa (1941) donde se encuentra de una manera más radical la transgresión de la normativa amorosa. Ory se reafirma en la mirada del malditismo y sigue, a cierta distancia, los pasos de la literatura del Marqués de Sade, de Los Cantos de Maldoror del Conde de Latréaumont y de Las sonatas de Valle-Inclán. En un ambiente decadente, profundamente marcado por la expresión de lo siniestro (conventos, cementerios, alcobas, ángeles), asistimos a un juego de profanaciones. En la línea de Un chien andalou (1929) y L'Âge d'Or (1930), provocativo cine surrealista de Luis Buñuel y Salvador Dalí, la irreverencia oryana consiste en situar la erótica entre dos polos: el plano de lo sagrado y el plano de lo profano. Profanación de lo sagrado que nos recuerda los amoríos satánicos entre el Marqués de Bradomín y su enfermera monja en la Sonata de invierno (1905). A través una prosa modernista de signo decadentista, que explora los aspectos enfermizos de las cosas, los nocturnos misteriosos y los escenarios siniestros, asistimos a los vahos de un sueño que muestra una erótica enfermiza basada en la profanación de lo puro y virginal. La estética de la muerte es el escenario perfecto para esta ceremonia fantasmal. Pues no existe el amor real y físico de los cuerpos, sino los espejismos brumosos propios de deseos y sueños. Por ello se trata de un amor de espectros y de fantasmas, de seres sin cuerpo, tal como se desprende del texto final:

Otra vez, la angustia movible. Lirios pálidos por mis ojos y no más que algún que otro verso-oro-crepúsculo de sus ojeras y un agua de beso, vedada por lagunas idas en fango de cilanco.

No estaba...! Pero yo sonreía contento porque pude verla en mi vertiginoso anhelo (anhelo de flor, afán de niebla), que ella vivía en mis sueños despiertos, cuando sueño dormido su abundancia de menta. 
Aunque la erótica no se dé en el plano de la realidad, no por ello deja de ser erótica. Erótica del deseo, que se proyecta sobre un ser femenino puro y virginal, focalizado en la imagen de la amada adolescente y angelical ${ }^{209}$, signo de la verticalidad becqueriana y de la tradición cultural platónica. Como ya hemos visto, la imagen de esta amada-ángel apolínea queda asociada al arquetipo de la monja, mujer asexuada y símbolo de la sublimación cultural amorosa:

Sus manos febriles, en cada dedo guarda una esperanza muerta y una ilusión marchita.

Un rosario que reza son mis horas de luto. Por cada padrenuestro un beso que se fue $[\ldots]$

¡Oh Elisa... mi amor! Es tu nombre como el de esa monja en el mundo pequeño de mi ser, que ayer yo la llamaba Sor Alegría y hoy es para mí la Madre Soledad $[\ldots]$

-i Por Dios, monjita, calla!-

Mientras tanto, el gato de Angora de la noche se entretenía en partir con sus colmillos el hábito gris de la tarde-monja que se alejaba en una paz de seda para tomar la hostia de la Luna en comunión sagrada.

Yo aún oía su voz.

$-i . .$. no recuerdas la dulce querella emocionada?

Y la caricia blanda por la orilla tan sólo en la playa sin algas de su honestidad, y donde su latido era como un temblor de marea sin olas.

En la noche, la sexualidad del yo masculino, símbolo de un ser sátanico, profana la geografía corpórea de la pureza que otorga la virginidad. La voluptuosidad aparece como un gusano que mancha la textura del ángel blanco y deja en su cuerpo las marcas de las heridas provocadas. El yo amante es descrito en el texto como un reptil u oruga que habita en el limo de la tierra: «sacrilegio las lagartijas de mis caricias», «la fiebre mala de mis caricias», «gusano del cieno terrenal». Simbología que contacta con la representación de las hormigas y de los insectos como expresión de angustia y remordimiento ante una sexualidad reprimida que ofrece la pintura de Salvador Dalí. Ello puede observarse en obras como El juego lúgubre (1929), Acomodación de los deseos (1929), El gran masturbador (1929) o La persistencia de la memoria (1931). Un significado análogo expresa la viscosidad de los reptiles de la poesía surrealista de Vicente Aleixandre en obras como Espadas como labios (1932) o La destrucción o el amor (1933) y que desarrollará con posterioridad en Sombra del paraíso (1944).

${ }^{209}$ Encontramos aquí los ecos de la prerrafaelismo poético de Gabriel Rossetti. 


\title{
2.2. CONTACTOS CON LA VANGUARDIA
}

Yo, que no soy piedra, sino camino que cruzan al pasar los pies desnudos.

Luis Cernuda

En la primera poesía de Carlos Edmundo de Ory no sólo está presente la estética simbolista, también aparece todo aquello que estaba ahí de modo sincrético: la poesía popular revitalizada por los poetas modernistas y por algunos integrantes del grupo del 27, los movimientos de estética cubista como el ultraísmo y el creacionismo, la greguería de Ramón Gómez de la Serna y el surrealismo de Lorca, Alberti y Cernuda. Ello hace que no se trate de una simple traducción de la poesía modernista o de un intimismo poético emocional, sino de una poética original muy cercana, en ocasiones, al surrealismo poético español. La conexión con la estética surrealista hace que esta poesía crepuscular sea la antesala de la poética postista, ya de signo barroco. El siguiente fragmento del poema titulado «Poema final», que pertenece a los manuscritos Poemas escritos en Sevilla y en Cádiz (1943), ofrece este lenguaje extraño y eurítmico, de signo cacofónico, que inaugura la poética postista:

\author{
¿Y por qué no no se dice \\ «caléndima», «soloto» \\ «falacrán» $\mathrm{y}$ «antice»? \\ ¿Por qué rima «laúd» \\ con «salud» que es la vida \\ y luego con «ataúd»? \\ ¿Por qué tenemos pelo? \\ ¿Por qué hay fuego en el mundo \\ y en el no mundo hielo? \\ No sé lo que es el trigo, \\ lo que son las gacelas \\ y la palabra «amigo».
}




\subsubsection{Raigambre popular}

Una de las direcciones la poesía inicial oryana queda conformada por una mirada hacia la tradición poética popular reelaborada por poetas como Antonio Machado, Salvador Rueda, Juan Ramón Jiménez ${ }^{210}$, Federico García Lorca o Rafael Alberti. En este sentido Ory reactiva, deconstruye y reconstruye, los modelos poéticos populares que ofrece la tradición poética castellana: el romance, la canción, la nana, la copla... Juega con la plasticidad poética de este material acercándolo, a través de las experiencias de Alberti y de Lorca, a la experimentación vanguardista. La óptica cubista y surrealista planea sobre esta actualización de la poesía de raigambre popular.

El poema titulado «Pregón» de su primera obra, Sombras y pájaros (1940), se constituye como muestra palpable del acercamiento a esta poética tradicional:

En la ventana de tus ojos iba la noche pregonando: ¿Quién me compra otro secreto por una hora en mi regazo?

Noche pregonera, noche que en mi oído vas danzando siempre tu pregón al viento.

Vendo secretos baratos...!

Tú, inédita entre mis manos Y la noche mirándome en el dintel de tus párpados.

Más interesante resulta el acercamiento efectuado desde la base de la tardición popular al creacionismo y al surrealismo que se desarrolla en obras posteriores. Carlos Edmundo de Ory sigue de cerca el modelo de Rafael Alberti ofrecido en Marinero en tierra (1925). De él toma la asimilación de la libertad poética y del nuevo lenguaje cubista que desestructuró los modelos tradicionales. Otro de los referentes ineludibles es

${ }^{210}$ Ver Hierro, José (1981), «El romance de Juan Ramón Jiménez», Cuadernos del Norte, $\mathrm{n}^{\circ} 10$, diciembre 1981. Para el autor, el conocimiento de Juan Ramón sobre la estética modernista, que tuvo a través de la poesía de Rubén Darío, le lleva a realizar un viaje al pasado para buscar el intimismo poético en la tradición. El romance proporciona a Juan Ramón el elemento naïf que se halla presente en su poesía pura, pretendidamente inocente. La revitalización juanramoniana del romance supuso el abandono de estilo ampuloso de poesía modernista y la apertura a nuevas posibilidades que serán recogidas por los poetas del 27. 
el modelo lorquiano, propuesto en Romancero gitano (1928) y en Poema del cante jondo (1931), que aúna raíces culturales andaluzas y surrealismo. Ello puede observarse en el siguiente fragmento del poema de Romancero de amor y luna (1941) que se titula «Romance de viento y luna»:

Una estrellita sin canto sueña las aguas perdidas, ángeles de viento verde columpian sus duras chispas.

La tarde ciega de mirtos se está quedando dormida, pájaros con cinco años buscan un cine de orillas.

Los árboles sin merienda beben cervezas de brisas, con peines de duros peces y ángeles de pesadilla.

La luna blanca de blanco viene despacio aburrida como una reina en su trono pálida de altas marismas.

En el siguiente poema, que pertenece a Paladín de Ponto (1942), Ory amalgama canción popular y vanguardia, traducida en lenguaje creacionista y ultraísta:

CORAJE

(Marinero gitano)

Yo, marinero en mi barca, pobre pescador.

Él con su traje muy blanco y en la manga un galón.

Yo, solo en mi barca con la alta mar sin sol.

Él con ella al mediodía, con su yacht.

Un día se caerá al agua: ¡Quiera Dios!

Yo, marinero en mi barca... Él, inglés.

Y yo español. 
Esta poesía inaugural de Ory, que reactiva el modelo de Alberti, está repleta de instantáneas que nos presentan, a modo de marinas pictóricas, escenarios de la vida marítima. Ello posee sus conexiones con los espacios míticos mediteráneos presentados, desde una óptica que conjuga futurismo y cubismo poético con elementos de la tradición popular, por la poesía de Joan Salvat-Papasseit:

Damunt mon vaixell
l'arc de Sant Martí
com un gran cinyell.
Totes les sirenes
Engronxant-se en ell.

(«Damunt mon vaixell», L'irrigador del port i les gavines, 1921).

Quina grua el meu estel, quin estel la meua grua! -de tant com brilla en el cel sembla una donzella nua.

L'espurneig que em fereix l'ull són els seus pits quan s'inclina: si fa un mirall de l'escull parleja a l'arena fina $[\ldots]$

(«Quina grua el meu estel», El poema de la rosa als llavis. 1923).

Estética similar poseen los siguientes veros oryanos:

Que ${ }^{211}$ olorcito a mar que huele a barcas -cunas sin niñoslocas en la mar alegre.

La luna - niña indecentesobre el mar, desnuda, busca un espejo para verse.

Y no lo tiene. 
La luna -pobre muchacha-

que no encuentra espejo, porque

está el mar lleno de barcas.

(«Mar de madera», Paladín de Ponto, 1942).

Primero un pañuelo blanco:

el ¡adiós!...

Luego ya una gaviota

loca del mar a la tierra

sin ton ni son.

Después -pañuelo y gaviota-

¡niña!, carta de tu amor.

(«Carta», Paladín de Ponto, 1942).

La poesía popular oryana desemboca en el surrealismo lorquiano anterior a Poeta en Nueva York (1929), obra que representa al surrealismo poético español más radical $^{212}$. Un ejemplo de ello nos lo ofrece el siguiente poema del poemario manuscrito 20 canciones delgadas (1942):

Amor te canta en los ojos un grillo sabio y verde.

-Amor, un ruiseñor muerto

por tu boca muda viene.

El mundo es un caracol

en tus oídos de fiebre.

Una aceituna da gritos

en la plata de tu frente.

En tus manos juega

Tu corazón caliente.

Para Fanny Rubio (1988: 116-119), la poesía de Lorca, pese su malditismo, es junto a la de Machado y a la de Juan Ramón una de las más leídas en la cultura del

${ }^{212}$ Poeta en Nueva York (1929) de García Lorca y Pasión de la Tierra (1935), escrita esta última entre 1928 y 1929 por Vicente Aleixandre, son las obras más próximas al surrealismo francés. En estas obras el lenguaje de signo onírico se presenta totalmente criptico y desorbitado, alejado de todo control. Ello supone la cercanía al automatisto propuesto por el grupo francés. 
franquismo, incluso en la primera década. Ello explica la presencia de Lorca en la poesía de posguerra, primero en los poetas aglutinados frente a revistas como Corcel y en los poetas postistas y simpatizantes del movimiento, como Juan Eduardo Cirlot; luego en poetas como Claudio Rodríguez, Pere Gimferrer y los demás poetas de su generación. Incluso en la actualidad la poesía lorquiana sigue teniendo un fuerte impacto en el extranjero.

\subsubsection{Estética cubista}

La primera poesía de la vanguardia histórica española se halla bajo el signo de la estética cubista. La literatura de Ramón Gómez de la Serna, el ultraísmo y el creacionismo, exportados por Jorge Luis Borges y por Vicente Hiudobro de Sudamérica, y la estética desarrollada a su sombra por los integrantes de la generación del 27 como Gerardo Diego, Jorge Guillén o Pedro Salinas llevan implícita la impronta de la destrucción de la mirada mimética del realismo ${ }^{213}$. Frente a la mirada unilateral propia de la copia de la realidad, la vanguardia poética propone una óptica caótica mucho más acorde con la geografía socio-cultural coetánea. Sus signos son la multiplicidad de ópticas y el simultaneísmo, hallazgos propios de la estética cubista. Ello implica, tanto en pintura como en poesía, la ruptura del objeto representado en una variedad de planos y la destrucción del punto de vista unilateral. Ruptura total con un modo de representación, de modo que el poema y el cuadro quedan convertidos en un objeto quebrado, que ha estallado totalmente ante una mirada única. La mirada mirada dispersa y fragmerntaria del cubismo exige el collage como expresión de la simultaneidad de aristas de espacio y tiempo.

Esta estética rupturista, que en definitiva no es más que la consecuencia lógica del gesto transgresor de Guillaume Apollinaire, se halla presente en la poesía primera de Carlos Edmundo de Ory. En ocasiones sus conexiones quedan enmascaradas bajo la

${ }^{213}$ Blanch, Antonio (1976), La poesía pura española, Madrid, Gredos, pp. 339-341. La vanguardia poética afectó, en el caso de los poetas integrantes de la generación del 27 de signo cubista, sólo a algunas zonas de su poesía. Frente a ella hubo un rechazo basado en una poesía en la recuperación de los modelos clásicos y en la exaltación del ingenio y la técnica creadora. Este nuevo territorio poético, que rechazaba el aspecto visionario y sensitivo del simbolismo, fue denominado por la crítica poesía pura. Aquí cabe situar la poesía hermética de Jorge Guillén o la poesía clasicista de Gerardo Diego. 
utilización de los moldes poéticos populares, en otras resultan más evidentes. En todo caso la poética vanguardista estaba ahí y fue asimiliada por la poesía de Ory. En ella observamos la presencia de la estética visual propia de la poesía cubista y sus desarrollos $^{214}$, la voluntad de ruptura con la disposición poética realista, la utilización del collage y de la óptica simultánea. Encontramos conexiones con Vicente Huidobro, Gerardo Diego, Jorge Luis Borges o Ramón Gómez de la Serna.

En Sombras y pájaros (1940) encontramos el siguiente poema, titulado «Paisaje», que se erige como un retrato paisajístico dinámico y perspectivista:

Borrachera de caminos

Los árboles empinados

(¡El paisaje descalzo!)

Y la luna riéndose del gran sol mutilado.

(¡El paisaje descalzo!)

En el carro de la tarde

¡Cinco pájaros llevaban el paisaje de la mano!

En él se halla presente la multiplicidad de ópticas que traslada el foco de interés del espacio retratado a la luna, al sol, a los caminos o a la arboleda. La velocidad posibilita la confluencia de distintos objetos, tal como establece la mirada fragmentaria y perspectivista del cubismo pictórico. Parece que el poema esté estructurado a base de pocos trazos veloces. Otro poema de la misma obra, estructurado mediante esta estética, ofrece una representación desencajada y simultaneísta del amanecer muy próxima a las escenas domésticas representadas por Pablo Picasso. Incluso posee conexiones con la obra de Joan Miró, La masía (1922):

${ }^{214}$ La poesía de vanguardia supone un rechazo de la estética de lo sonoro propia de la poesía modernista. En ella lo sonoro queda sustituido por lo visual. 


\author{
ESTAS SON LAS PAREDES DE LA VIDA \\ (poema ultraísta) \\ Desayunando estrellas \\ el gallo parecía \\ una mano del alba \\ que diluía su acento, \\ colgando en la madrugada \\ el peine de su voz de aguardiente \\ entre los cabellos verde-rubios despeinados \\ de un viento cristalino y juguetón. \\ Y el reloj abrió los brazos \\ y se llenó de besos, \\ y se animó de luz. \\ El gallo se ha rociado con su canto \\ y ha despertado a los gusanos \\ de la caverna de la ambición. \\ Aurora, alba en flor: \\ carcajadas de alondra va desnudando el ambiente. \\ El día sigue dando sus pasos de jirafa. \\ -¡Yo sigo siendo yo! \\ Y Dios como una uva sin azufre caída \\ en las bocas de todos sin comer.
}

La misma estética visual, en cuanto a juego con los espacios poemáticos y destrucción del modelo de estrofa, se observa en el poema «Nostalgias de otoño», perteneciente mismo poemario:

\footnotetext{
Esta tarde gris

de ceniza pálida

siento que me muerden

canes de nostalgias, hambrientos de vida y aullantes de ansias. No sé qué murmullo de músicas lánguidas de músicas frágiles de músicas blandas: lánguidas...! frágiles...! blancas...! Me traen los perfumes de tardes lejanas
} 


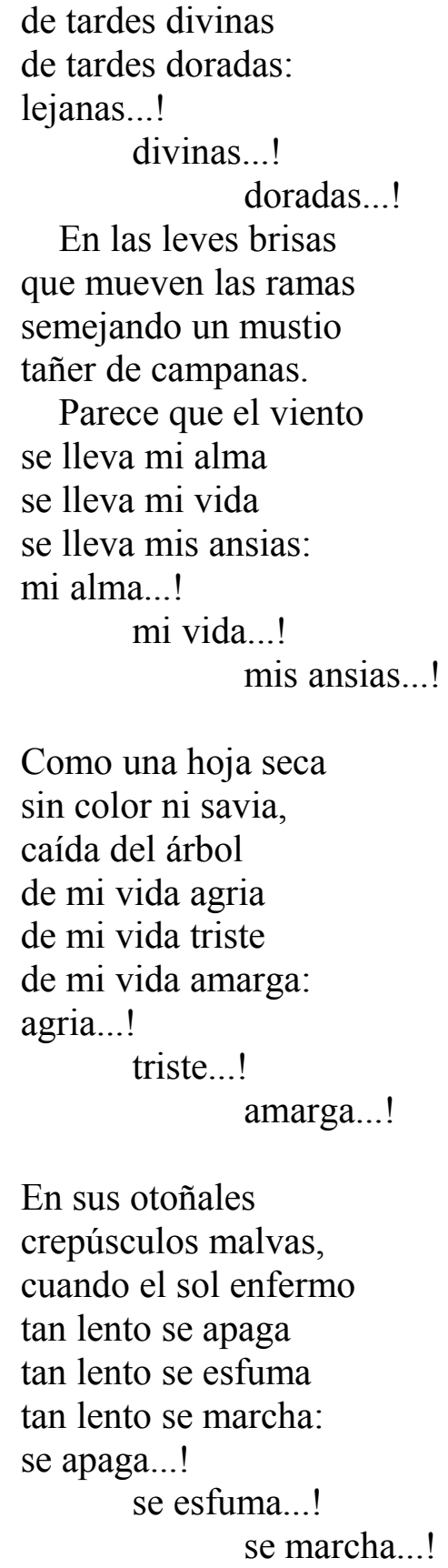

Las continuas repeticiones, que ofrecen el anticlímax producido al final de cada estrofa e intensificado al final del poema, y el juego con la disposición tipográfica recuerdan la estética vanguardista de la poesía de Juan Ramón Jiménez y la de poesía plástica de Vicente Huidobro. Un guiño, una referencia, hacia la poesía creacionista de Gerardo Diego lo tenemos en el siguiente poema, de 20 canciones delgadas (1942), que nos recuerda nítidamente al poema «Guitarra» que pertenece su obra Imagen (19181921): 
La guitarra es un corazón

con agua pasada.

Un corazón de niña

y de giralda.

La guitarra es un corazón

con seis espinas amargas.

No tocad el corazón de la guitarra

que se vuelve loca y canta.

La guitarra es un corazón

de plata.

El siguiente poema, perteneciente a Paladín de Ponto (1942), supone una referencia abierta al poeta cubano Nicolás Guillén y a su poesía mestiza y sonora de Sóngoro Cosongo (1931). Se trata de la descripción de una muchacha negra, paradigma del ángel negro asociado a la corporeidad y a la sexualidad femeninas. Mujer que es símbolo del amor corpóreo, del fuego de la pasión, de la pura carnalidad desligada de todo romanticismo literario. Mujer erotizada, paradigma del arquetipo de la prostituta y de Venus, Afrodita ${ }^{215}$, diosa de la práctica sexual:

\section{MARI SABEL \\ (recuerdo mulato)}

Un día me iré

a ver la negra bembona:

Mari Sabel. ${ }^{216}$

(a ver la veré)

¡Ay qué calunga me da

-niña- su cuerpo café,

cuando en su puro cadombe

hace acordeón su piel.

Un día me iré

a ver a la negra bembona:

Mari Sabel.

${ }^{215}$ Escohotado, Antonio (1993), Rameras y esposas (Cuatro mitos sobre sexo y deber), Barcelona, Anagrama, pp. 137-149. Para este autor, en la antiguedad la prostitución era entendida como culto voluntario a las deidades femeninas como Ishtar o Venus.

${ }^{216}$ El nombre Sabel contacta, puede ser de manera consciente o no, con el personaje de Emilia Pardo Bazan de Los pazos de Ulloa y de su continuidad, La madre naturaleza. Personaje que representa el arquetipo del ángel negro femenino, símbolo del ello, la materialidad, la tierra, el erotismo, el amor sexual adúltero, prohibido y trasgresor. 
(a ver la veré)

A respirar aquel aire que huele a sexo y a sien. Dame un beso, que si no me voy con Mari Sabel. Aquella negra de Cuba que nació en Caney y siempre que me veía me decía «ecobio fiel».

Dame un beso niña sal como una negra de miel. Aquella negra del puerto de la otra vez, que en la tarde tropical me encontré en un cabaret con su cadera mulata bailando al son de un aé.

Un día me iré a ver a Mari Sabel: a la negra bembona que me daba «Camel» y a veces dice mi nombre en inglés.

(a ver la veré)

Pero dame un beso tú. si no me lo das te canto un embó como Guillén, para matar la culebra:

¡Mayombe -bombe- mayombé!

Santiago Fortuño ${ }^{217}$ estudia en la novela escrita en 1922 por Alberto Insúa, El negro que tenía el alma blanca, la cultura de la negritud y su imagen en la sociedad europea. Como ocurre en la novela de Insúa, la figura del negro supone una amenaza social y funciona como vehículo de la liberación social representado por la cultura del jazz, del ragtime y del blues que surgía en Harlem y en Nueva Orleans en las primeras décadas del pasado siglo. La imagen del negro venía mediatizada por el primitivismo, por la corporeidad y la sensualidad que se asocia a la música intempestiva que provenía, en última instancia, de África. Música de la mala vida y expresión de una disipada vida bohemia y que, de algún modo, era portadora de los ecos satánicos. La negritud fue

${ }^{217}$ Fortuño Llorens, Santiago (1998), ed. de Alberto Insúa, El negro que tenía el alma blanca, Madrid, Castalia. 
tratada también por Federico García Lorca en Poeta en Nueva York, tema que aparece asimismo en el poema de Rafael Alberti titulado «Casi son», perteneciente a 13 banderas y 48 estrellas (1935).

\subsubsection{Un tímido surrealismo}

La poesía de Carlos Edmundo de Ory, a través de la territorialidad poética popular de Federico García Lorca y de Rafael Alberti, se acerca al surrealismo. Una poesía que, aunque no abandona el elemento sonoro y musical, se acerca a lo visual, cuyo signo es la imagen ${ }^{218}$ poética. Una imagen visionaria, libre de la ataduras de la logica, tímidamente onírica. Se trata pues de un irracionalismo del sustantivo, ya que la imagen opera como una ecuación semántica que une dos planos, el real y el imaginario. $\mathrm{Su}$ estructura reside en la igualdad $(\mathrm{A}=\mathrm{B})$. Predominio pues del sustantivo. Esta estética rechaza el lenguaje de la visión basado en las propiedades ofrecidas por el adjetivo.

En este surrealismo incipiente de signo sustantivo de la primera poesía oryana encontramos imágenes que nos recuerdan al surrealismo lorquiano. El siguiente poema, que pertenece a Sombras y pájaros (1940), posee una semblanza con el lenguaje de la poesía de Lorca:

\section{NOCTURNO DE LA ALAMEDA}

(Décima)

\section{A Antonio Pleguezuelo}

Nocturno de la alameda, se está riendo la luna.

Cádiz en flor como una novia vestida de seda, inquieta en la brisa leda.

${ }^{218}$ Bousoño (1979a: 70-74). Para este autor existen cinco estadios en el proceso del irracionalismo poético: el modernismo cuyo representante sería Rubén Darío, el impresionismo de Machado y Juan Ramón Jiménez, la poesía pura representada por Salinas, Guillén o la pureza poética del propio Juan Ramón y, finalmente, el surrealismo de Lorca, Alberti, Cernuda o Aleixandre. Los cuatro estadios primeros están basados en el irracionalismo adjetivo de la visión (sinestesia, desplazamientos calificativos...) y el último, el superrealismo, se basa en el sustantivo, en la imagen visionaria. 
Mariposa de azahar,

llena de azul su mirar

y encendida de rubor.

¡En una cita de amor

se ha asomado a ver el mar!

Destacamos las imágenes visionarias que aparecen: «Cádiz en flor como una / novia», «Mariposa de azahar». El poema oryano tiene conexiones evidentes con este fragmento de la «Baladilla de los tres ríos» del Poema del cante jondo (1931):

El río Guadalquivir

tiene las barbas granates.

Los dos ríos de Granada, uno llanto y otro sangre.

El poema titulado "Quimera», que pertenece a la misma obra oryana, posee también el mismo lenguaje ilógico lorquiano basado en las imágenes encadenadas:

Y no habrá uñas sin besos ni herida sin alivio

para esta sed de peces y de alondras dormidas.

Todo serán tijeras para cortar el tiempo que se queja de un hondo cansancio sin ventura.

Todo será un latido y un jirón de raíces, y un gris remordimiento de degollar las horas.

Pero habrá uñas con besos y una venda de heridas para curar la sed.

Tenemos aquí varias imágenes visionarias como «uñas sin besos», «sed de peces y de alondras» o «cansancio sin ventura». La segunda supone un desarrollo imaginativo porque posee dos planos imaginarios.

$$
\text { Sed }(\mathrm{A})=\text { peces }(\mathrm{b} 1)+\text { alondras }(\mathrm{b} 2)
$$

Imágenes que nos transmiten, como en la poesía de Lorca, la precisa impresión del dolor que, sobre todo, se agudizará a partir de Poeta en Nueva York (1940): 
Por el suelo, ya sin norma, brincan sus manos cortadas que aún pueden cruzarse en tenue oración decapitada.

Por los rojos agujeros donde sus pechos estaban se ven cielos diminutos $\mathrm{y}$ arroyos de leche blanca. Mil arbolillos de sangre le cubren toda la espada y oponen húmedos troncos al bisturí de las llamas. Centuriones amarillos de carne gris, desvelada, llegan al cielo sonando sus armaduras de plata [...]

(Federico García Lorca, «Martirio de Santa Olalla», Romancero gitano, 1928).

La mayoría de imágenes visionarias de la poesía Carlos Edmundo de Ory tienen un aire lorquiano: «lengua verde del viento», «mudos violines del viento», «carne de noche sin deseo», «dedos del silencio», «la noche es un pájaro negro», «una lluvia de lunas», «mi carne tiene árboles aburridos», «prisa de manos», «silencio de oro», «atardecer de cristal», «zumo agrio de horizontes», «dolor de cántico», «sueño de nieve», «ángeles de viento verde», «tarde gris de mirtos», «cada verso es un pez / en sus aguas de papel», «olor de columna», «estanque de cisnes de los dientes»... Veamos algunas imágenes de Federico García Lorca pertenecientes a su poesía popular: «luna de pergamino», «sendero de cristales y laureles», «noche llena de peces», «rosa azul de tu vientre», «dura luz de naipes», «cuerpo lleno de lirios», «pez de sombra», «la noche se puso íntima / como una pequeña plaza», «muslos de amapola», «agua de las alondras», «piel de nocturna manzana», «voz de clavel varonil», «silencios de goma oscura / y miedos de fina arena», «lluvia oscura / de luceros fríos», «estrellas de cristal»... Ello señala la proximidad de estas dos propuestas poéticas y refleja el acercamiento a ese surrealismo que Lorca conjugó con la tradición popular. Este otro fragmento recuerda perfectamente al surrealismo lorquiano:

Me acariciaban las horas con una lluvia de lunas. Era una espera sin forma con humedades de flor. 


\section{$[\cdots]$}

Me acariciaban las horas

en mis negras cicatrices

con una prisa de manos.

(«Elegía VI», La canción meditada, 1941).

Esta poesía de signo surrealista significa el preludio de la poética postista oryana. Se trata de un surrealismo de tradición poética popular castellana, desligado de cualquier acercamiento a la estética onírica francesa, mucho más caótica y radical. El surrealismo oryano, que es uno de los componentes de esta primera poesía sincrética de signo crepuscular, gravita sobre un triple eje: la poesía de Rafael Alberti, la de Federico García Lorca y la de Luis Cernuda. Un surrealismo que supone la aceptación de la tradición poética y significa su reelaboración y su actualización. En el caso de Cernuda esta aceptación de la poesía heredada se efectúa bajo el prisma de un intimismo reflexivo. Por otra parte, el mismo Ory señaló desde su labor crítica la impronta que la poesía de Salvador Rueda dejó en la poesía lorquiana ${ }^{219}$.

219 «Salvador Rueda y García Lorca», Cuadernos Hispanoamericanos, n 25, Madrid, marzo 1975, también en Iconografías y estelas (1991), pp. 231-258. 


\subsection{POESÍA RIZOMÁTICA}

Yo te arrojé de mi cuerpo yo, con un carbón ardiendo.

Rafael Alberti

Desde su inicio la poesía de Carlos Edmundo de Ory se pliega sobre otros estratos territoriales poéticos, sobre otras escrituras que se agencia hasta formar un cúmulo estratificado. Pliegues y sustratos, se trata de una poesía horizontal que se expande sobre otros territorios múltiples mostrando sus conexiones de forma implícita o mediante la evidente explicitación: la mística simbólica de Juan de la Cruz, el intimismo vertical y platónico de Bécquer, la poesía romántica visionaria y siniestra de Nerval, Poe o Carducci, el malditismo simbolista de Verlaine, Baudelaire y Valle-Inclán, el modernismo de Rubén Darío o Amado Nervo, el impresionismo de Machado y Juan Ramón, las incursiones vanguardistas de Borges, Huidobro y Gerardo Diego y el surrealismo de Alberti, Lorca y Cernuda. Se trata de una escritura que expone abiertamente las zonas sobre las que se pliega, los sustratos literarios sobre los que emerge. Escritura culturalista en el sentido que le otorga Bousoño (1979b: 32), como ficción en cuanto ficción, una poesía que se sustenta sobre experiencias poéticas ajenas. Escritura intertextual que practica el guiño cómplice o la cita expresa, que muestra las referencias sobre las que se pliega y se estructura a modo de rizoma. En este sentido, Gilles Deleuze y Félix Guattari (1980, 1988: 10-11) distinguen dos escrituras: la del libro-árbol y la del libro-raíz. La primera imita la realidad y se sustenta en el pensamiento, en la representación. Por ello supone una abstracción, una representación bidimensional, binaria y dicotómica. Como representación, se halla separada de la realidad, ya que se trata de una mera descripción y, como tal, producto de la ficción humana. La segunda intenta reproducir el lenguaje orgánico de la realidad, multidimensional, poliédrico, mutante e ilimitado. Esta es la escritura rizomática, que no se sustenta en una única raíz, sino que ofrece raíces múltiples. Una escritura fluida que se agencia territorialidades ajenas y las reorganiza extendiéndose y expandiéndose sobre ellas como un organismo multiforme (1980, 1988: 17). Decodificación y 
desterritorialización de los códigos para reterritorializarlos y recodificarlos en un nuevo espacio poético.

La poética oryana actúa como el rizoma atravesando territorialidades ajenas y disformes. En ella hemos señalado algunos agenciamientos ${ }^{220}$ evidentes de la poesía de Juan Ramón Jiménez, de Antonio Machado, de García Lorca... Ahora bien, la escritura oryana señala abiertamente los territorios ocupados a modo de linealidades y dibuja el trazado de sus expansiones y plegamientos. Ella se ofrece como un territorio de territorios donde se trazan las conexiones entre ellos y sus ramificaciones. La poesía oryana atraviesa la territorialidad ultraísta borgiana que se ramifica en la territorialidad de Huidobro o Diego que, a su vez, se estructura sobre la de Apollinaire. Escritura con múltiples ramificaciones y direcciones. Esta poética pluriforme será una constante en toda la poesía futura de Carlos Edmundo de Ory, que se erigirá como un constante proceso de agenciamiento y de exploración de territorios ajenos. Una escritura nómada e itinerante.

Esta primera etapa de la poesía oryana funciona, en este sentido, como un ejercicio de señalización de las divergentes territorialidades que atraviesa. El territorio poético del malditismo está señalizado perfectamente en algunos poemas. El poema titulado «Como Nerval», perteneciente a Canciones amargas (1942), muestra los siguientes signos inequívocos de la poesía que surge de los paraísos artificiales:

¿Pero eras tú o no eras?

Porque te vi cuando iba como Nerval el poeta con la boca de absintio amarga y te veían mal mis ojos de niebla sin espíritu y casi sin pupilas

\section{$[\ldots]$}

Malo será mi fin como el de Charles de las flores del mal o Rubén inca. Pero porque te quiero y quiero hacer mi abulia entre al copa y la lascivia.

220 Tomamos el sentido que Deleuze y Guattari (1980, 1988: 14) otorgan al este término, no contemplado en el léxico castellano: «Un agenciamiento es precisamente ese aumento de dimensiones en una multiplicidad que cambia necesariamente de naturaleza a medida que aumenta sus conexiones. En un rizoma no hay puntos o posiciones, como ocurre en una estructura, un árbol, una raíz. En un rizoma sólo hay líneas». 
En «Romance de otoño», de La sombra de la alondra (1941), mediante un lenguaje extraño de herencia simbolista que prefigura la estética postista, aparecen diversos trazos que oblicuamente apuntan hacia la óptica desencajada de la poesía de Valle-Inclán y atraviesan otros territorios poéticos agenciados:

Ulula un buho nictálope e insomne, su clave aciaga dogmatiza; en tanto el éxodo de la cigüeña se implanta en el espacio, y el viento y el silencio no se hablan.

Parece que está la tarde presidida por un hada de cabellos de azafrán y aún el alma de crisálida.

\section{$[\ldots]$}

Una escuadrilla de alúas o gema de luminarias, al margen de los arroyos, sus fosforescencias cambian: cocuyos que son estrellas, crisoberilos con magia.

Y en camposantos del cielo dos luceros filtran llamas; Edgar Allan Poe los mira y un enigma de ojos canta: ¿Serán los de Annabel Lee muerta, su más dulce amada?

Yo leo versos de Verlaine y el Otoño no me cansa: un leimotiv ${ }^{221}$ de misterio preside Erato. El neorama pone enfermo a Flammarion, y una vena nietzscheana en la tarde filosófica de mi romance de estampa con cipreses de Carducci 
Otra referencia a Poe y a su poema The raven aparece en el poema de Canciones amargas (1942), «Pasa un cuervo»:

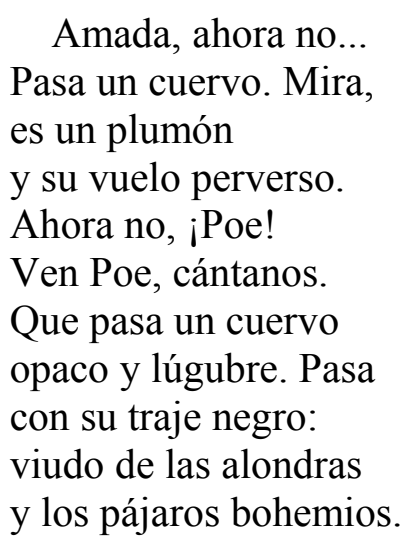

La prosa poética de Elisa (1941) ofrece referencias a la literatura crepuscular de Baudelaire, de José Asunción Silva, de Amado Nervo y de Bécquer. También aparecen «los ángeles buenos de Alberti», expresión que posee como referente inmediato la obra albertiana Sobre los ángeles (1927), una de las obras claves del surrealismo español. Para Bodini (1963, 1982: 62), los ángeles de Alberti se desligan del universo religioso cristiano para insertarlos en la cotidianeidad y representan estados de ánimo y comportamientos míticos de los seres humanos: «las raíces cuadradas del misterio que rodea nuestros sueños más humanos». Imágenes incrustadas entre lo sagrado y lo satánico. El ángel será una de las imágenes recurrentes en el itinerario de la poesía oryana, imagen que da título a uno de sus poemarios, Angel witthout a permit / Sin permiso de ser ángel, traducido por Ginsberg, otro poeta para el que los ángeles tienen existencia real. El Diario de Ory da fe de la creencia del poeta en estos seres sutiles y reales, humanos beatíficamente divinos como su aura indica y seres ficticios que son como espejos donde los humanos se observan. En todo caso, fragmentos de lo humano (2004, Vol. III: 310):

Esta mañana carta de Roberto Bolaño, respuesta de mía del 19 de febrero pasado, hablándome de ángeles. Le digo: «Tú no ignoras que los grandes drogadictos místicos de la beat generation se sentían preocupados por cosas tan opuestas como el pecado y los ángeles». Yo creo firmemente en los ángeles y me paso horas escribiendo en las páginas de mi diario sobre ELLOS. 
La carta de Roberto Bolaño de la que nos habla Ory está publicada en RevistaAtlántica de Poesía $a^{222}$ y en ella Bolaño irónicamente le contesta lo siguiente:

Por supuesto, yo también creo en los ángeles. Sobre todo, en los ángeles de la guarda. El mío es un bromista empedernido.

Te enviaré un poema donde hablo de esto. A mi ángel favorito, no obstante, lo llamo Musa.

Otras marcas nos señalan algunos de los agenciamientos de la poesía de Rafael Alberti. En este caso se trata de dos citas del autor presentes en dos poemas de Paladín de Ponto (1942), obra que se extiende sobre el territorio de la poesía popular de signo lorquiano y albertiano. Plegamiento sobre plegamientos a modo de estratificación de discursos, pues esta territorialidad poética se establece sobre varios discursos poéticos, entre los que cabe señalar la poesía de cariz popular de Machado y Juan Ramón, que, a su vez, se establece sobre la territorialidad poética popular castellana. El mismo Juan Ramón es citado en otro trazo del camino que supone esta poesía oryana, señalización que toma también la forma de la cita, esta vez presente en el este fragmento del poema «Efebo del mar»:
Como si yo fuera Juan Ramón digo que tiene la Alameda un vago olor eterno por todas sus calles eternas. ¡Que es como un relente de oro que hasta el corazón se entra!

Fernando de los Ríos señala en el texto titulado «Del Prólogo (Fragmentos)», que evidentemente prologa esta obra, que en ella la escritura oryana se pliega, ante todo, sobre la poesía de Juasn Ramón Jiménez, Alberti y Lorca:

Influido, sugestionado por los espíritus originales, grácilmente líricos, de Juan Ramón Jiménez, de Rafael Alberti, de Federico García Lorca, Carlos Edmundo de Ory, tras una revelación ignicente, se remonta en sus alas poéticas por itinerarios de luz, estrellando el alba y la aurora y la rosa, y el topacio del nuevo día, el recién translúcido, cara al mar de los sueños [...] 
En Canciones Amargas (1942) aparecen otras marcas territoriales que apuntan hacia el intimismo poético de Bécquer y a su epígono Juan Ramón Jiménez. El poema titulado «Juan Ramón y yo» es un verdadero ejercicio de intertextualidad que se apunta al conocido título juanramoniano Platero y yo. Referencialidad directa hacia el autor, su personaje poético y a uno de los maestros de la introspección poética íntima. El poema, a su vez, es también un homenaje:

Ven Juan Ramón, yo quisiera que tú vinieras conmigo.

La tarde tísica tiene un blanco de luna antiguo, trompetas de niños tristes, cisnes difusos y lirios. Ven Juan Ramón.

Porque Bécquer ha muerto, ha muerto y te sigo a ti ahora que estás lejos y estás enfermo.

\section{Yo grito}

tu nombre y no me contestan. Y yo pregunto a los niños y a la tarde y a los cisnes difusos y al blanco lirio.

Cabalgando en tu Platero: Anda, vente tú conmigo.

En Poemas de adolescencia (1941), el poema «Todo es puente» figura encabezado por una cita de Gerardo Diego. En Poemas escritos en Sevilla y Cádiz, Ory dedica un poema a la poesía mística simbólica de San Juan de la Cruz, «Juan de la Cruz, viador $^{223}$ místico». Romances y sonetos, Teatro de Shakespeare en seis sonetos (1942), poemario manuscrito, gravita sobre la obra de William Shakespeare. En él aparece la geografía teatral del dramaturgo barroco, sus conflictos, sus escenarios, sus personajes... El soneto titulado «Hamlet» es en ejemplo de ello:

223 Sic. 
Rumor de sombra en la nocturna calma: acento vago del clamor paterno.

¿De dónde - pozos ígneos del Averno

o empíreas luces- se trasmuda al alma?

Filial querencia, oh Hamlet ya demente, filósofo amador de Ofelia pura; «la venganza» midiendo en la insegura mano de un recto espíritu obediente.

De Dinamarca príncipe lloroso, hijo de madre adúltera, Geruta.

De Fengo, por cainismo rey, sobrino.

Húmeda piel de la infeliz cual fruta por exprimir. Matanzas en reboso y Fortimbras cuan presto al magno sino.

Otras señales y marcas referenciales explícitas apuntan, de forma culturalista, a Ángel Ganivet, Daniel Defoe, Ovidio, Pericles, Corot, Chopin, Wagner, Verdi, Grieg, Schuman y Beethoven. Se trata pues de una poesía que se expande, como los rastrojos, sobre otros territorios culturales. 


\subsection{POESÍA Y SILENCIO}

¡El jardín y la tarde tranquila!...

Suena el agua en la fuente de mármol.

Antonio Machado

Para Pont (1998: 118) el conocimiento del poeta mejicano José Juan Tablada a través de la biblioteca de su padre, supuso para Carlos Edmundo de Ory el descubrimeinto del haiku. De aquí surge el interés por la literatura oriental y por sus filosofías. El viaje a Oriente es una de las contantes que estructuran su posterior trayectoria poética. De Tablada Ory recoge el gusto por el haiku y el concepto oriental de poesía como silencio. Tablada fue el introductor del haiku en la poesía española ${ }^{224}$. En todo caso, la poesía oryana queda insertada, desde sus inicios, en la poética del silencio. Uno de los ángulos de la poesía poliédrica oryana consiste en la exploración del silencio. En este sentido la poesía se configura como meditación, como la práctica de abismarse en el silencio. Por un lado se dirige hacia el haiku y explora las atmósferas que este transmite. De otro, hacia el koan y su significado paradójico, más propio de los aerolitos y de la semántica absurda. En la poesía oryana crepuscular predomina el lenguaje del haiku, este es el vehículo que posibilita el acceso al silencio.

El silencio supone el negativo del lenguaje, su otro lado irremediable y necesario. De modo que si hay lenguaje es porque existe el silencio. Es el contraplano donde se proyecta el lenguaje, el espacio donde se incrusta el sonido. Es la hoja en blanco donde queda dibujada la escritura, es el silencio quien delimita las palabras. Estas son como pequeñas islas rodeadas por la textura vacía del silencio. El silencio es

${ }^{224}$ Para Luis Antonio de Villena (1982: 122), el acercamiento a la poesía japonesa de José Juan Tablada fue puramente ornamental y respondía a la búsqueda del exotismo poético trazada por poetas como Julio Herrera y Reissig. El interés suscitado en el arte y la literatura oriental desde la poesía y la decoración modernista y desde la pintura impresionista no sólo responde a una huída de los engranajes mercantilistas de Occidente, sino al deseo de conocimiento de otros parámetros culturales. El deseo de huída, de signo modernista, tiene su paralelo con el rechazo de los valores burgueses. Por ello, la estética modernista propone el amor al lujo y el culto al objeto inútil. La impronta decorativa de la poesía modernista y sus desarrollos posteriores implica totalmente una postura social: el rechazo de la concepción positivista, mercantilista y liberal de la sociedad occidental. Según Octavio Paz (1986: 132) el culto aristocrático a lo inútil supone una crítica social por parte del modernismo hispanoamericano. 
el relieve donde las palabras se instalan, el vacío desde donde surge el sonido. El silencio estructura la cadena de los significantes, separa y une, articula el discurso. Es el vacío necesario que posibilita la palabra, que recorta sus geografías. El silencio es como la rama de la que surgen las hojas cada primavera. El silencio es la ausencia necesaria donde podemos percibir las presencias. De igual manera es la muerte el fondo necesario desde donde podemos percibir la vida. El silencio es inherente al lenguaje, su relación es polar y necesaria. El silencio no es la negación del lenguaje, sino aquello que lo hace posible. El silencio no es tampoco lo que se calla, pues lo que no se dice también forma parte del discurso, como aquello que se presupone o aquello que necesariamente no se quiere decir, pero se entiende. Los pliegues del discurso dan voz a aquellos significados de lo no dicho. El silencio hace posible también las pluralidades significativas y los dobles sentidos. El silencio es la voz de la existencia, es la ausencia de límite, la ausencia de concepto, pues este, cuyo soporte es la palabra, recorta y articula el silencio. El lenguaje es una red que pone límites en una realidad caótica, que delimita conceptualmente un engrudo sin forma. El lenguaje sería la red y el silencio el vacío que queda entre sus celdillas. El lenguaje es una red conceptual que estructura una realidad no conceptual. Por los agujeros de la red escapa siempre la realidad. La realidad percibida directamente, sin lenguaje, ni concepto, es una vasta extensión de silencio.

La poesía es el discurso que, de alguna manera, puede aproximarse al silencio, ya que se trata del discurso de la subjetividad. Esta transmite emociones, sensaciones y sentimientos, posee un significado emocional que resulta del rechazo de la referencialidad objetiva de la pragmática comunicativa. La palabra poética funciona a base de sugerencias y como un susurro al oído presenta atmósferas, nebulosas donde las palabras se enganchan mediante enlaces no conscientes. Por ello la palabra poética se erige como una palabra de silencio y, por ello precisamente, puede penetrar en el misterio de la existencia. Este lenguaje fluido y dinámico, anárquico y simbólico, caótico y preconsciente puede ofrecerse como portavoz a la existencia, puede prestarle la voz para que esta se manifieste y desvela su misterio. Justamente la transgresión de la rigidez de la normativa comunicativa supone una cercanía al misterio infinito, automático y continuo de la realidad. El discurso poético supone un rechazo del ruido establecido por otros discursos más acordes con la inmediatez como el discurso informativo o el discurso crítico. Incluso rechaza también el ruido de otros lenguajes literarios como el narrativo. El lenguaje poético opera por condensación, supone una 
palabra vehemente, que reside en la pluralidad significativa. El silencio inherente a ella potencia los matices de las palabras. El silencio del poeta, la supresión de su óptica egocéntrica, supone el lenguaje del misterio existencial. La supresión del ruido de fondo personal posibilita la expresión de la realidad no conceptual, como ocurre en el caso del conocido poema XI de Soledades (1907) de Antonio Machado. En él el silencio de la primera persona, silencio del discurso del autor, hace que puede expresarse lo real por sí mismo, directamente:

\section{Y todo el campo un momento se queda, mudo, sombrío, meditando. Suena el viento en los álamos del río.}

Cuando todo calla se manifiesta el misterio a través del silencio, sólo se oye el viento. Así, mediante la supresión del pensamiento del yo, se expresa el propio atardecer. Algo parecido se halla en el poema «Otoño» de los Sonetos espirituales (1917). Cuando todo el diálogo interno calla, cuando cesa el lenguaje del yo y se desvanecen los conceptos, aparece la realidad, elemental y primigenia. Cae el velo de maya, concepto hinduista visto con anterioridad, y se observa la realidad tal como es:

En una decadencia de hermosura, la vida se desnuda, y resplandece la excelsitud de su verdad divina.

Este lenguaje de silencio, fluido, inmediato y capaz de desvelar el movimiento orgánico de la existencia, es el que se ha expresado en Oriente en el taoísmo y el budismo zen. Ory ha formado parte de ese interés por el viaje a Oriente realizado por el impresionismo pictórico al rescatar los arabescos de las estampas y el minimalismo de líneas de las atmósferas de la pintura taoísta, por el simbolismo poético al buscar la sugerencia y un lenguaje no consciente, por la vanguardia y su transgresión del racionalismo (mental y social) y la búsqueda de lo naïf, por la poesía beat americana y su búsqueda de un lenguaje libre, por el underground como experimentación de nuevas formas de conocimiento y de prácticas vitales. Evocación de la inmediatez, meditación sin concepto, captación del instante eterno y fluido. En la primera poesía oryana ya 
queda impresa esta constante metafísica que su autor ya no abandonará más: la plasmación inconsciente y automática del misterio

Ello es precisamente el lenguaje del haiku. Este podría definirse como una expresión de satori, como el relámpago automático de la repentina iluminación. Se trata de una poesía breve, naïf, que, en el taoísmo y el budismo zen, expresa el Tao. El haiku, como se ha vista con anterioridad, manifiesta un instante de plenitud percibido sin concepto, es decir, una instantánea de la budeidad. Capta de forma instantánea la inmediatez de la realidad mediante la percepción directa que ofrece el za-zen. Se trata de una poesía sin ego, donde el silencio del poeta hace posible el lenguaje del silencio, que rechaza los sistemas filosóficos conceptuales para intentar expresar la metafísica de cada instante. El haiku es como una pedrada en el estanque que provoca una serie de ondas, como la reverberación del sonido de una campana. En el haiku no existe la expresión del ego. La ausencia, o silencio, de la persona verbal es la condición para que se exprese el Tao, traducido en la realidad más inmediata. El haiku supone la poesía de la cotianeidad, en él se expresa el éxtasis por la presencia de la materialidad más cercana. Su brevedad, pues consta de tres versos solamente, condensa la admirada gratitud por aquello que repentinamente se percibe. Por ello el haiku resulta totalmente metafísico. Citamos como ejemplos algunos haikus clásicos:

Se va la primavera.

Lloran las aves, y son las lágrimas los ojos de los peces.

$$
\text { Basho (1643-1694) }
$$

Bajo el agua, sólo quedan sobre la roca las hojas caídas.

Joso (1661-1704)

Este lenguaje de silencio, cargado de sugerencia, ha penetrado de manera subrepticia en la poesía castellana. Se halla en el impresionismo poético de Antonio Machado, cuyos signos son la evocación y la sensualidad. El siguiente fragmento equivale a un haiku: 
La blanca cigüeña,

como un garabato,

tranquila y disforme ;tan disparatada!

sobre el campanario.

(«LXXVI», Galerías, 1907).

La estética del haiku está presente también el la poesía de Vicente Huidobro, libre y transgresora de la poesía clásica:

¡Oh qué cansancio!

Una lluvia de alas

cubre la tierra.

(«Otoño», El espejo del agua, 1916).

También la poesía vanguardista de signo futurista y antipoética de Salvat-Papasseit utiliza el haiku:

La pluja rosega el vidre

glaçat...

Quantes molles s'hi deixa.

(L'irrigador del port y les gavines, 1921).

Y, sobre todo, la poesía esteticista y orientalista de José Juan Tablada:

Trozos de barro, por la senda en penumbra saltan los sapos.

(El jarro de flores, 1922).

También aparece el haiku en la poesía total de Juan Ramón Jiménez, esta vez con un sentido mucho más metafísico: 
En el río me voy, adonde quiera el agua, entre las dos orillas.

(«El pajarito verde», Poesía, 1923).

Y en el irracionalismo poético de corte popular, cercano al surrealismo, de Emilio Prados:

Cielo gris.

Suelo rojo...

Quedó la luna enredada

en el olivar.

(«Vega en calma», Tiempo, 1925).

O en la poesía de Manuel Altolaguirre:

Las de dos en dos, como sandalias del viento puestas a secar al sol.

(«Playa», Islas invitadas y otros poemas, 1926).

Carlos Edmundo de Ory recoge la tradición de esta poesía de silencio y su poder de evocación. La presencia del haiku en la poesía oryana inicial supone la expresión, a modo de susurro, de gratitud ante lo que percibe la mirada. En Sombras y pájaros (1940) la presencia, explicíta o encubierta, del haiku y su lenguaje de silencio es numerosa. Cito aquí algunos ejemplos:

El landó de la tarde iba perdiéndose despacio con el sol en el pescante.

Con sus dedos sin forma arañan los caminos las uñas de las sombras. 
Noche pregonera, noche que en mi oído vas danzando siempre tu pregón al viento.

En los rasos del viento

van bordando los pájaros

muñequitos de vuelo.

Este último haiku expresa, sobre todo, la fluidez de la poesía oryana que, como el impresionismo plástico, retrata un instante fugaz. Poesía fluida que nos recuerda a los posteriores haikus de Jack Kerouac:

The moon had a cat's mustache For a second.

(Some Wester Haikus, 1968).

A partir del primer poemario la presencia de este lenguaje de silencio atravesará toda la poesía inicial y será retomado en ocasiones a lo largo del itinerario poético de Carlos Edmundo de Ory:

Los pies llenos de lágrimas la cabellera enorme del silencio sobre la almohada.

(«Urna Diurna», Tambor de sicomoro, 1975) ${ }^{225}$.

En Canción meditada (1941), segundo poemario oryano, el haiku sigue totalmente presente:

En el pozo estrellado de la noche crecen las hiedras de la brisa, -húmedas-.

Por la tarde a la noche

va la brisa

con la voz quebrada de la neblina.

${ }^{225}$ En Energeia (1978), obra cit., p. 218. 
En obras posteriores el haiku se adapta al lenguaje popular de tradición que se da bajo el signo de Alberti y Lorca, como se muestra en los siguientes ejemplos:

Desnudez, luz de caricias.

Las alas del eco llevan

espejos de luna y tarde.

(«Canto en gracia», La canción meditada, 1941).

En mis noches neptúneas

qué loco pensamiento

-nerviosa lechuza-.

(«Nauta dulce», Paladín de Ponto, 1941).

Igual que una uva, le van pisando los ojos

los pies de azogue de la luna.

(«Siete nanas», Poemas escritos en Sevilla y Cádiz, 1942).

Dentro de la brisa

baila una hoja oscura

de ramas de oliva.

(«La luna de Dios (para niños)», Poemas escritos en Sevilla y Cádiz, 1942). 
3. POESÍA POSTISTA 


\subsection{UNA POESÍA LIBRE Y SURREAL}

Y fui huésped inmóvil en las ruinas

En la ciudad de la sal y el ojo azul

Marcos Ricardo Barnatán

Como ya se ha visto con anterioridad, la poesía postista se nos presenta, por una parte, en una gran variedad poemas sueltos publicados de manera dispersa. Por otra, toma la forma de romance en Las patitas de la sobra (2000), obra escrita por Ory y Chicharro en 1944, y en la oryana Laocoonte y la luna, escrita entre 1945 y 1948 . Y de otro lado la hallamos también recogida en forma de poemario en dos publicaciones: Versos de pronto (1945) y Los poemas de 1944 (1973).

Versos de pronto (1945) y Los poemas de 1944 (1973) funcionan como una unidad inseparable. Respecto a la poesía anterior, representan un verdadero corte y un total distanciamiento. Ambas obras suponen un acercamiento al surrealismo y la adquisición de unos presupuestos poéticos de signo barroco basados en el juego poético. Víctor García de la Concha (1987: 712-713) señala este elemento barroco como base del nuevo lenguaje oryano y de la estética postista. El barroquismo está en la base del elemento lúdico del movimiento postista y de la poesía de estos dos poemarios de Carlos Edmundo de Ory. El acercamiento a la poesía barroca, para el mismo autor, puede hallarse en la presencia de la erótica y de la preocupación existencial. Esta estética barroca, lúdica y oscura, irrumpe en Versos de pronto y se acentúa todavía más en los Poemas de 1944 y en la obra postista posterior. Precisamente es el elemento lúdico el punto de contacto más visible de la poesía oryana con la vanguardia poética. Ambas obras funcionan como una misma poética. Versos de pronto recoge de algún modo todas las preocupaciones que circulaban en el ambiente poético de $1944^{226}$.Aquí encontramos poesía neotradicionalista de signo garcilacista, neorromanticismo becqueriano, poesía existencial, preocupación metafísica. Ahora bien lo que distingue la

${ }^{226}$ Con la excepción del poema 1, sin título en la obra y titulado posteriormente «Para algunas sensibilidades», que está escrito en 1954, todos los demás poemas fueron escritos en 1944. 
propuesta poética oryana de las propuestas coetáneas es la cercanía a un surrealismo radical, efectuada, sobre todo, en la poesía onírica de Los poemas de 1944.

La unidad de ambas obras se observa en el hecho de que en Los poemas de 1944 se reproducen y modifican algunos poemas aparecidos en Versos de pronto. Son cuatro los poemas comunes: «Lamentación del amor que llega», «Bajo fondo», «Amiga»y «Oda a una extraña mujer», titulado «Oda a una mujer extraña» en Los poemas de 1944. En las antologías posteriores, incluida la realizada por el propio autor, aparecen las versiones modificadas en Los poemas de 1944 (ver apéndice I). Ambas obras operan como corte frente a la poesía anterior y como ruptura de la referencialidad poética. En este sentido, José Manuel Polo de Bernabé (1978: 166-168) señala el carácter lúdico como el signo de la ruptura del realismo poético y de la transgresión lingüística.

\subsubsection{Acercamientos al surrealismo francés.}

La adopción del lenguaje surrealista posibilita la ruptura con el lenguaje referencial. La poesía oryana se concibe ahora como un lenguaje inmerso en su propia marea, totalmente propio y personal, alejado de la significación colectiva. Un lenguaje propio que viola la lógica de la palabra, un lenguaje terriblemente emocional basado en la creación de estructuras simbólicas (Polo, 1978: 667). El propio Eduardo Chicharro nos dice ya en 1945, en su artículo «Carlos Edmundo a machamartillo» (Pont, 1987: 441; VVAA, 2001a: 22), que el lenguaje poético oryano surge de la emoción libre. Poesía dinámica y espontánea que se acerca al lenguaje libre del surrealismo. Ory conocía el surrealismo poético español contenido en la poesía de Federico García Lorca, en la de Rafael Alberti o en la de Luis Cernuda. Pero el contacto con Chicharro acercó sus posiciones a las del surrealismo francés: Max Ernst, Jean Arp, Francis Picabia, André Breton, Luois Aragon, Pablo Picasso, Salvador Dalî́27... Lenguaje onírico, asociación libre de objetos, liberación de la tiranía de la lógica, belleza revulsiva... son

${ }^{227}$ Pablo Picasso, Salvador Dalí y Joan Miró mantuvieron contactos muy estrechos con el movimiento surrealista francés. De hecho los dos últimos militaron en él. El arte de Picasso, en cambio, atravesó como una estela todos los movimientos vanguardistas. André Breton reconoce la contribución picasiana al movimiento en Le surrealisme et la peinture (1925). En el llamado primer Manifiesto del surrealismo (1924) Breton enumera a los artistas integrantes y simpatizantes de la estética surrealista. De Picasso dice lo siguiente: «Picasso caza por los alrededores» (1962, 2009: 30). 
los signos comunes de la poesía oryana y del surrealismo francés. El surrealismo oryano rebasa los límites poéticos que los poetas del 27 impusieron a la radical propuesta surrealista y desecharon el automatismo puro. Frente a él, los hallazgos surrealistas de la poética del 27 se instalaron en la práctica del equilibrio poético que suponía una reelaboración del material subconsciente y onírico desde unos presupuestos poéticos.

La poética de Carlos Edmundo de Ory adopta, en este sentido, el discurso del ello. Discurso que se ofrece como la voz del inconsciente y se presenta en la textura del propio significante. La escritura es el espacio de producción de lo inconsciente, espacio especular y doble del yo consciente. El surrealismo significó la subversión del discurso del poder. Cualquier discurso supone un ejercicio de poder y control sobre otros discursos ${ }^{228}$, como lo efectuó el discurso científico y burgués de las primeras décadas del siglo XX. El discurso de ello supuso, en el contexto sociocultural en el que apareció el surrealismo, la voz de lo reprimido: el cuerpo, la sexualidad. Un discurso que desvelaba la insatisfacción, la frustración, el deseo no realizado..., que abría las puertas del sótano oscuro donde el ser humano guarda su sombra más espesa y viscosa. El ello quedó impreso en la textualidad, emergió de la profundidad y se instaló en el poema. Todo discurso desvela el funcionamiento de las estructuras profundas, pero el lenguaje surrealista perfora más rápidamente y se ofrece como portavoz del inconsciente ${ }^{229}$. Sus métodos son el lenguaje onírico, el automatismo y la asociación libre.

En los sonetos de Versos de pronto hallamos este lenguaje surreal ensamblado a una poética basada en el barroco juego de contrastes. Versos de pronto consta de dos partes, la primera, titulada «Sonetos», la componen veintiún poemas y la segunda, «Poemas», está compuesta por veintiocho composiciones de tipo diverso: liras, odas, romances, sonetos. Un ejemplo de la convergencia entre surrealismo y expresión barroca es el último terceto del «Soneto $3 »$ :

228 Barthes (1982, 1986: 315); Foucault (1970, 1973: 22). Para Roland Barthes, el lenguaje ejerce un acto de poder, pues cuando se habla se ejecuta una voluntad de poder. Para Foucault unos discursos ejercen una labor de control, presión y sometimiento sobre otros. De modo que el discurso del poder, cuya práctica consiste en la conquista del espacio cultural central y en la expulsión de otros discursos a espacios periféricos, se asienta en la voluntad de verdad. Así el discurso del Ello supone un discurso socialmente y culturalmente marginal.

${ }^{229}$ Fromm $(1951,2012)$. Para este autor, el lenguaje onírico forma parte del lenguaje simbólico. Lenguaje que es universal porque surge del cuerpo y que ha producido todos los mitos de la humanidad. 
Cuando me acuesto ardiendo bajo cero, en las innumerables nieblas rosas del ojo cojo de mi llanto mudo.

O, en este fragmento del «Soneto15»:

CABÍA yo en el mundo y en tu mano como un dormido pájaro, y tenía un racimo redondo de alegría para ti y para mí como un hermano.

Los sonetos están llenos de imágenes surrealistas. Más interesante resulta el funcionamiento del surrealismo en los demás poemas polimétricos. Encontramos huellas del surrealismo lorquiano de Poeta en Nueva York (1940), como puede verse en este fragmento del poema «Lamentación del amor que llega»:

Como mares que arrastran son los brazos ¡los brazos del amor pueden con árboles! y los llevan y dejan en las orillas tintas.

Llega como terrible desperezo de ánima de arcángel en lo oscuro posado por la espalda. Convida a besos a pestañas de besos que creosotan ${ }^{230}$ los poros y amargan la saliva ¡maldito licopodio de los huesos! Mentira, grande signo de falsedad, mentira. Solo toro de luz, toro de las estrellas Persiguiendo a la corza caliente de la médula pisando puras sangres y simientes de fósforo.

El verso del mismo poema, que presentamos a continuación, tiene un inconfundible aroma lorquiano:

pequeño niño a tientas con un sapo en la boca.

Este surrealismo radical de signo lorquiano, paradigma paralelo al surrealimo francés, lo encontramos también en el poema «Oda a los jardines». Extenso poema del que extraemos algunos fragmentos que resultan especialmente significativos:

230 Sic. 
los huesos no encuentran sus anillos ni el girasol se dobla para siempre.

Oh los jardines de usada ceniza

y de carbón yacente y de curvas orladas

$[\ldots]$

En medio de ti cáscara de marfiles

mármol de amor brillante con pasos entre astillas

y una mirada astática de oloroso destino.

Soy yo encima de la noche como encima de un elefante.

$[\ldots]$

Noche ennochada por los frutos, por los cortes frutales

por una loca losa húmeda de trasmundo

en la pequeña atmósfera de madera y de ángel

donde el ciprés boca abajo del vacío florece

hacia la punta de la tierra y la toca despacio.

Silencio, oh jardines fábricas de luna

corredores siniestros de la yedra y de la seda,

bellos cuartos forrados de yeso musical

$\mathrm{y}$ de quejidos negros igual que acordeones.

$[\ldots]$

Yo lo he hecho este silencio, yo lo he hecho para soñar un derramado humo de paloma, una cadencia pacífica de buen ángel y olvido.

Los jardines han dejado brotar sus minerales porque mi voz encuentre un choque ilustre mientras suben mujeres y mujeres y musgo por la escalera de caracol de mi espalda mientras el Amor con rostro en los pies pregunta sin motivo con su idioma de talco: - ¿Qué sinfín de lobómunos desacordados balan entre tus dulces pasos de alquitrán geotérmico?»

$[\ldots]$

Los jardines son para mí un maldito pasillo lleno de besos y de cucarachas

de nata y muselina y de sobres abiertos.

Estoy aquí porque soy un príncipe sin dientes

que ha muerto sin rezar en una cama baja

$[\ldots]$

Pero aunque no haya puertas la muerte tiene puertas

sin llaves muy hermosas de sal y crisantemos

para huir como vine más príncipe que nunca

y montado en el caballo blanco de un cisne 
$[\ldots]$

Puedo decir a Eva que venga con escolta

de monos o aliviados tigres rituales

y puedo besar con su pelo entre las bocas

y puedo más todavía, dormir con ella un libre

paraíso parado por dos bultos de piel feroces

y todavía puedo verla agonizar terriblemente

$[\ldots]$

Los jardines: ¡ay, palacios ocultos donde las mariposas

se posan en la luna

donde la muerte pasa con bufanda y con canto

y yo me llamo zaravitz del mundo.

El poema toma la forma de un desarrollo imaginativo surrealista, donde las imágenes se enganchan en versos largos, en los que los objetos son presentados de forma caótica y absurda. Ello nos recuerda totalmente al lenguaje de Poeta en Nueva York, terriblemente críptico y angustioso, aunque emotivamente aceptable y comrensible. En la obra lorquiana el ser humano se halla prisionero de una infernal máquina de deglutir. En el poema de Ory, la ciudad nos presenta bajo esta imagen tan radical, pero sí posee un aura totalmente fantasmal. Este surrealismo oryano, al igual que el lorquiano, queda expresado en la acumulación caótica de imágenes dispares, cuya relación surge del automatismo psíquico. Ello puede observarse totalmente en el siguiente fragmento:

Los jardines son para mi un maldito pasillo

lleno de besos y de cucarachas

de nata y muselina y de sobres abiertos.

Tenemos aquí una imagen enganchada a una visión que se continúa de manera onrírica. El objeto real A «jardines» queda asociado al objeto imaginario B «pasillo» y éste queda indebidamente calificado por $(\mathrm{C} 1)^{231}$ «lleno de besos», (C2) «de cucarachas», (C3) «de sobres». A su vez, C2 funciona como un término real de una nueva imagen

${ }^{231}$ Tal como vimos en las páginas 250 , cita 205 , y 270 , la estructura de la imagen suponía una relación de igualdad, consistente en la asociación de dos objetos. Su esquema es: $A=B$

La visión consiste en la atribución indebida de una propiedad (B) a un objeto. En su estructura la propiedad, semánticamante impropia, la presentamos entre paréntesis para diferenciarla del objeto. Su estructura se representa mediante el siguiente esquema:

A (B) 
que lo asocia a dos términos evocados D1 «nata» y D2 «muselina». Tenemos pues la siguiente estructura imaginativa:

$$
\mathrm{A}=\mathrm{B}(\mathrm{C} 1)+[(\mathrm{C} 2)=\mathrm{D} 1+\mathrm{D} 2]+(\mathrm{C} 3)
$$

La presencia del surrealismo queda impresa, sobre todo, en la imagen onírica que asocia «cucarachas» a «nata» y a «muselina».

Ejemplo de este lenguaje lorquiano resulta el poema «Los llantos». Poema que posee un signo totalmente telúrico, típico del surrealismo francés, aunque también recuerde al surrealismo de Aleixandre:

QUERÉIS llorar?... Yo tengo

la garganta y la mano

con rescoldos de polvo.

Y en mi voz hay un pájaro abierto por la alas.

¿Queréis llorar? Los llantos se abren sitio en la tierra

y levantan un árbol hasta el cielo... Hay pasos de lluvia entre los ojos del hombre. Y no hay gusanos nada más que en la carne y no en el llanto amargo. Los dulces muertos lloran llantos sin ojos largos.

Por la noche los muertos cantan con llanto cantos. Pero en la tierra hay tristes mujeres con pedazos de llantos fríos, hórridos por los ojos colgados. Y hay muchachas que lloran por la frente y los brazos con llantos amarillos y azules llantos vagos. Y hay niños locos, tristes con los ojos parados secos de llanto y negros de negros llantos raros. Y hay hombres que no lloran iporque lloraron tanto! 
En él aparecen visiones totalmente oníricas, fruto de la óptica automática que supone la práctica violenta y extraña de la poética surrealista. Visiones raras y sorprendentes, que surgen de una encadenación de elementos extraños a los que se aplican cualidades impropias.

Y en mi voz hay un pájaro abierto por las alas

El objeto real A, «voz», no puede poseer como cualidad (B), «hay un pájaro», la existencia de un pájaro. Este elemeto, a su vez, se convierte en un nuevo objeto $\mathrm{C}$, «pájaro», al que no le corresponde la propiedad que se le aplica (D), «abierto por las alas».
A (B)
C (D)

Esta estructura visionaria rebela el siguiente proceso asociativo:

$$
\begin{aligned}
& \mathrm{A}+\mathrm{B}+\mathrm{C} \\
& (\text { voz }+ \text { pájaro }+ \text { alas }) .
\end{aligned}
$$

De la misma manera funciona el siguiente fragmento que semánticamente equivale a lagrimas que lo envuelven todo:

$$
\begin{aligned}
& {[\ldots] \text { Los llantos }} \\
& \text { se abren sitio en la tierra } \\
& \text { y levantan un árbol } \\
& \text { hasta el cielo [...] }
\end{aligned}
$$

Aquí el elemento real A, «llantos», no pueden excavar la tierra (B) y hacer germinar un árbol (C). Tenemos pues dos propiedades impropias de este elemento real. A su vez, «árbol» queda convertido en un nuevo elemento real D a quien se le aplica otra propiedad imposible. Ello crea una incongruencia semántica, ya que este objeto no puede llegar al cielo (E).
A (B)
B) + (C)
(C)
D (E) 
El texto activa la esfera semántica vertical del riego y del crecimiento:

$$
\begin{aligned}
& \mathrm{A}+\mathrm{B} \text {----- } \mathrm{C} \text {----- } \mathrm{D} \\
& \text { (agua }+ \text { tierra } \text {----- árbol ----- cielo) }
\end{aligned}
$$

De la misma manera funciona el siguiente engarce de visiones:

Y hay muchachas que lloran

por la frente y los brazos

con llantos amarillos.

Las «muchachas», elemento real A, pueden «llorar», pero no «por la frente y los brazos» (B). Visión que se engancha con las siguiente: el elemento real C, «llantos», no posee la propiedad que se le aplica «amarillos» (D).

$$
\mathrm{A}(\mathrm{B} 1+\mathrm{B} 2) \text {----- } \mathrm{C}(\mathrm{D})
$$

La asociación libre opera con los siguientes objetos:

$$
\begin{aligned}
& \mathrm{A}+\mathrm{B} 1-\mathrm{B} 2+\mathrm{C} \\
& (\text { llanto }+ \text { frente }- \text { brazos }+ \text { amarillo })
\end{aligned}
$$

El poema, además, presenta un constante juego de sonidos. Sonidos que o bien se repiten o son ellos la clave en la elección de las palabras, tal como ocurre en el verso:

$$
\text { cantan con llanto cantos }
$$

Tenemos aquí la presencia de la euritmia postista bajo la poliptote, figura retórica.

El acercamiento al surrealismo francés se intensifica más en Los poemas de 1944, revisados y publicados finalmente casi veinte años más tarde. Esta es la primera obra en la que la escritura oryana, como expresión de subversión, prescinde voluntariamente de los signos de puntuación, característica que acompañará a la poesía de Ory hasta su final. Se trata de un surrealismo radical marcado por una escritura 
profundamente onírica y, en ocasiones, automática. Ello puede observarse en el poema titulado «Trenes de roja noche»:

Peces llorando en un sueño que tuve

Campanas respirando como pájaros tontos

$\mathrm{Y}$ vi maderas dignas de violines

¿por qué quiero escuchar un ruido de rosas?

Oliendo a mar se gasta la mañana

Cuando amanezco yo pintado de oro

Corazón mío aterrizado aquí

cose la lluvia gota a gota cósela

Hay en mi sueño colas y gemidos

Ya no están las doncellas ya no están las doncellas

¿Los muertos que se amaron se besan allí dentro?

Madre soy un ciclista y no sabes de mí

que ruedo en carreteras oscuras y me duermo

Roja noche los trenes de roja noche van

llevando locos a otros sitios alejados

Las sombras como goma se pegan a mis dedos

Como leones ardiendo veo barcos

Sueño color las vacas y castillos castillos

Azul es mi garganta de tanto opio mío

Mis amigos antiguos han bajado a los pozos

Todo esto veo en sueños de roja noche mía.

El poema se configura como una descarga de imágenes encadenadas que desafía todo control racional y toda objetividad referencial. Imágenes que se enganchan creando atmósferas pictóricas semejantes a las que aparecen en la pintura de Salvador Dalí ${ }^{232}$, de Giorgio Chirico, de Paul Delveaux, de Max Ernst o de Ives Tanguy. El poema «Material de los sueños» es otro ejemplo de esta óptica onírica oryana y nos recuerda las imágenes de aquellas plazas desiertas, extrañas y absurdas, de los cuadros de la pintura metafísica de Chirico. He aquí un fragmento:

De mis sueños las puertas sí las puertas

De mis sueños las calles más horribles

Tropiezo con algún ángel mal vestido

Y sigo errando mucho hasta llegar

${ }^{232}$ Carlos Edmundo de Ory siempre explotó una imagen iconoclasta y provocativa, sobre todo en su aventura postista. Este gesto teatral, que no abandonó jamás, supone un intento de unir vida y arte tal como se proponía en el decálogo de Postismo. Actitud tomada de la excesiva e histriónica teatralidad de Salvador Dalí, personaje que jugó con los media para crearse una imagen pública marcada por la provocación y la paradoja. La teatralización de Dalí desemboca en la propaganda constante de la imagen del artista efectuada por Andy Warhol, verdadero símbolo del arte mediático. 
a la gran plaza donde duermen autos

Cada uno de mis sueños es como una trompeta

que me despierta en ciertas madrugadas

Jamás sabré por qué los suicidas conversan

entre ellos riendo entre ellos riendo

Esta óptica absurda juega con el lenguaje onírico, con sus símbolos y sus objetos, y explora las profundidades del subconsciente y las galerías de lo humano. Desvela la irremediable soledad humana, sentida y expresada como arquetipo de la caída. Ello se muestra en el poema titulado «Himno noche», que muestra un mundo oscuro que se descompone tal y como lo extraño y telúrico aparece en los paisajes urbanos de la pintura de Delveaux:

Profundo siempre y que sacudo en la osamenta una mota de alarido me transformo en pasos de unos pies en el baldío Navego solo en mi tabla roída con una soga vieja de sangre en el pulmón

Desde que un sueño me chupó los ojos aspiro acaso al habla natural Esos largos jardines de llamas salamandras en el nacer de hombre con frente de veneno Esos pasillos de verdad y mentira con la aguja de un grito inoxidable ¿Oh de dónde? De donde estar se estuvo Caminarme hacia el antro como trono de nieve Sin sombra y sin camino estáte ahí con un final de túnel terreno nochedad

Ory, a través de los sueños, explora las profundidades del ser, cuyos símbolos son la noche, la sombra, los túneles, las alcantarillas, los topos, los reptiles, los búhos, la sangre... Símbolos telúricos de lo desconocido humano. Encontramos aquí la presencia del lenguaje del ello, creado a base de frustraciones, insatisfacciones, represiones y traumas. La oscuridad como símbolo del subconsciente planea a lo largo de toda la obra. El sueño queda configurado como método de expresión y de conocimiento, significa el acceso a una realidad más profunda y velada. Por ello la poesía será una hermenéutica que intenta desvelar los misterios de las profundidades humanas ocultos tras los símbolos. Interpretar los símbolos es acceder a la zona misteriosa del ser. Los títulos de los poemas son muy reveladores: «Oscuro mar del sueño», «Material de sueños», «Oda 
del dolor», «Oda a la sangre», «Ojos dentro de una corriente funesta» o «He comenzado a ver cosas». Las imágenes oníricas encadenadas bajo los parámetros automatismo tienen la capacidad de desvelar lo oculto, de acceder a la corriente telúrica del misterio. Ory, siguiendo la herencia de la poesía visionaria, romántica, simbolista y surrealista, se erige como un médium a través del cual se expresa el misterio oculto del ser. $\mathrm{Su}$ escritura está dictada por el mismo misterio existencial, ejemplo de ello resulta este fragmento del poema «Hombre de pie»:

Estoy aquí como una columna derrotada Y estoy como una luz oscura que es peor Montañas interiores del pecho ahí subí pero no sé qué hacer con el reptil extraño Me paseo por calles donde hay búhos Pero tampoco encuentro los brazos del amigo Aunque una amada llore en su confín nublado mi retrato en sus ojos divinos Mi carne soñolienta erra y erra por vez Aquel hombre de pie se hizo pedazos Si el humo fuera mármol y la cadera leve de aquello que mi instinto devoró Pudiera levantarme y ahora sería el mismo hombre de pie la gran columna Ya no me quedan más que pájaros y nubes con que poder herir mi vacío infinito

\subsubsection{El juego, de lo barroco a la vanguardia}

Si Versos de pronto es una obra barroca, Los poemas de 1944 supone la primera obra vanguardista de Carlos Edmundo de Ory. Ambas proponen un surrealismo radical y son una amalgama entre surrealismo y vanguardia. Según Pont (1998: 132):

Queda claro, pues, el carácter transicional de este ciclo que, en cierto modo, realiza el papel de gozne y de fusión entre el surrealismo y la ya inminente aparición de la propuesta postista. Sin duda, la amistad y el magisterio de Eduardo Chicharro, que se iniciará en 1943 -Chicharro era un amplio conocedor de las tesis surrealistas- jugó aquí un papel decisivo.

García de la Concha (1987: 713), cuya senda será recorrida por Pont y la mayoría de críticos oryanos, señala la base barroca de los sonetos y de los demás 
poemas pertenecientes a Versos de pronto. Este elemento barroco consiste en el juego, en la plasticidad de la poética barroca caracterizada por el contraste, la extrañeza y la oscuridad. En este sentido la poesía oryana se presenta como una poesía oscura, de signo visionario y hermético, que persigue una función mágica, cuyo lenguaje es el surrealismo. Poesía que rechaza la referencialidad poética realista y que posee la voluntad de explorar los límites del lenguaje, por ello se erige en una poesía del juego y de la imaginación. El carácter lúdico de esta poesía lleva implícito un deseo de libertad, de búsqueda de un lenguaje libre que se ponga al lenguaje de la oficialidad poética coetánea. Ello supone una transgresión de los límites establecidos.

Son muchas las referencias poéticas de Versos de pronto que apuntan hacia la poesía de Francisco Quevedo, tanto en el sentido metafísico, erótico, lúdico como humorístico. De Quevedo, Ory toma la óptica expresionista que se agudizará mucho más en los romances postistas. La deformación de lo real y el juego poético del contraste son los signos de este lenguaje lúdico, cuya presencia encontramos en este fragmento del «Soneto 2 » que posee una aureola totalmente quevediana:

QUE le importa a gente que yo muera y que me duela el pecho y que en el paso parezca un muerto próximo, un fracaso del amor y del hombre, un polvo fuera

de sitio, un árbol que se estremeciera sin pizca de aire, acaso en el ocaso, una madera abierta, un roto vaso que otra rotura más, más lo rompiera.

El juego barroco, basado en este caso en la poliptote, se observa de una forma muy patente en el siguiente fragmento del «Soneto $20 »$ :

Si ayer lloraba llanto y lloraría llanto de carne y de dolor y de amores hoy no puedo llorar aunque me llores porque llorar no puedo de alegría.

Tu desamor, amor, desamoraste que si lloraba yo también lloraste y un solo llanto era el tuyo y mío. 
Encontramos los juegos conceptuales del conceptismo de Quevedo en el poema titulado «Mosca». En cierta medida, el conceptismo consistía en agrandar, mediante las asociaciones imprevistas, el significado conceptual de un término. En este caso el término «mosca»:

COMO especie de espíritu como erótica forma de beso como la palabra final de un muerto te posas en mi frente...

y qué frío latido continuo me robas y te bebes y por qué dejas de zumbar $\mathrm{y}$ habitas en mi sien viva...

Ay, rey feísimo del aire no sé si triste o riente, pero mareador y horrible cercano a las pestañas...

Habla, sólo te falta hablar, decir si Dios te ha hecho cuando estaba sentado en su butaca.

Mosca: dedal de un duende.

En este sentido, el poema, cuyo último verso supone una greguería, se trata de una imagen visionaria continuada. Se asocia el elemento real A «mosca» con los siguientes elementos imaginarios B1 «espíritu», B2 «beso», B3 «rey feísimo», B4 «dedal de un duende», que se desarrollan cada uno por su parte. El elemento B2 se compara a su vez con otro elementos imaginario $\mathrm{C}$ «palabra final de un muerto». La imagen tendría pues la siguiente estructura:

$$
\mathrm{A}=\mathrm{B} 1+\mathrm{B} 2[=\mathrm{C}]+\mathrm{B} 3+\mathrm{B} 4
$$

El desarrollo del juego poético supone la entrada de la poesía oryana en la vanguardia. De modo que la poética postista oryana podría definirse como surrealismo más juego lingüístico, de aquí surge la idea de poesía como experimentación. En Versos de pronto ya puede observarse este gusto por el contraste, por la repetición y por la dislocación de términos, propia de la semántica absurda. El juego poético puede 
observarse en la «Oda a Eduardo Chicharro, hijo», de la que mostramos estos fragmentos:

HAS llegado hasta el germen de las rosas para cerrar las puertas de la arena contra tu pecho de león lechoso y vago amigo mío de la tierra

Y hoy quisiera cantar por tu estatura el hormigueo de tu sangre abierta sobre una almohada de cantueso dulce donde reposarías la cabeza.

Oh tú tumultuoso y desmandado como un leopardo de mirada ciega que te dejas llevar por el crepúsculo como una llama de carbón y fresas.

$[\ldots]$

Azul amigo, deja que lo diga porque en el fondo azul de tu presencia hay un leopardo que camina herido siempre detrás de una interior gacela.

Yo sé que me comprendes, que tú sabes que hay en tus manos lisas y perfectas una forma de nada y de cristales que te sangran los bordes de las yemas.

El juego barroco también queda establecido, aunque en menor medida, en Los poemas de 1944. En esta obra el juego poético desemboca apresuradamente en la estética vanguardista postista. Ejemplos de la poética barroca, basada en el retruécano, los encontramos en los siguientes fragmentos del poema titulado «Más muerte»:

En tus ojos de hombre desvelado hay maldad La maldad de más muerte en la vida y de más tinieblas en el trono de todas las tinieblas Voces fías heladas de muertos que se quejan a través del verdín como campos de odio Y si lloran los muertos que lloren mientras yo me pregunto si acaso ya me quedan preguntas.

Los poemas de 1944 posee una impronta totalmente vanguardista, ya hemos dicho que es la primera obra en la que la escritura de Ory prescinde de los signos de 
puntuación. Aquí el surrealismo se radicaliza y, de otro lado, el componente lúdico se agudiza totalmente hasta crear un discurso deshilvanado, donde la palabra adquiere plena libertad. En este poemario toma forma clara la euritmia postista.

La poesía rizomática oryana establece, en este punto, dos claros agenciamientos: la escritura barroca, con muchos guiños a Quevedo, y el lenguaje onírico surrealista. Como conjunción de ello surge la poética postista, libre, lúdica, provocativa... que se apropia de los ensamblajes de la ruptura dadaísta y de la deformación expresionista. Todo ello confluye en una escritura humorística, espontánea y provocativa, tal como queda definida, por este mismo autor en el Segundo manifiesto del Postismo, como la locura inventada (Grande, 1970a: 293). Una escritura basada en el juego lingüístico, en una sintaxis ebria que transgrede toda norma, en la deconstrucción léxica. Por ello se crean palabras nuevas a partir de la destrucción léxica. Ello puede observarse en el siguiente poema, que aparece sin título. En él aparecen expresiones como «carlostú», «fieleste» o «asutadóloro»:
A veces alguien dice mi nombre carlostú
La lluvia dice mi nombre creo yo
o la toalla allí colgada siempre
o el tintero mi objeto más fieleste
Pero yo miro todo asustadóloro
y todo me parece que me nombra
Todos los que dijeron mi nombre en esta vida
¡benditos sean yo los escuché!
Luego miro mis dedos mi medalla
el reloj que parece un miembro mío
y también dicen mi nombre carlostú

Son muchas las transgresiones léxicas que se encuentran en el poemario, como ejemplo podemos citar algunas: «tristear», «lluviante», «nochedad», «me lluvio yo», «ciérrate en tu cama», «pajariarca», «su RR ealista» o «yoquesoy». A parte de estas palabras inventadas o destruidas, en todos los poemas aparece un lenguaje extraño y raro. Las palabras se estructuran por su parecido fónico, ellas sirven de imán para atraer a otras, de manera que se crea una sintaxis extraña y disonante, tal como se puede comprobar en el siguiente fragmento del poema titulado «Inventos»: 

Palabra por palabra
si mi boca se rompe
nadie tiene la culpa
de que invente la noche
Desnudos en la cama
con el coma de amores
Hay mujeres dormidas
en cada mano El hombre
lleva sacos de amor
siempre de noche al monte
Un monte es la mujer
lo sabe quien no es monje
y no es tampoco tonto
que su noche conoce

Un ejemplo de lenguaje postista lo tenemos en el poema «Soneto», claro ejemplo de distorsión semántica que se dirige en una dirección esperpéntica:

Dormida así ¿qué mira si no mira?

Por el sueño doncella por el sueño

¡Ay que la turba un ruiseñor pequeño!

¡Ay que la turba el viento! ¡Ay de la lira!

¡Ay que se calle que se calle el viento!

Que yo apago mis labios que yo apago

mis labios porque sueño un sueño vago

y suena solo como un viento lento

Déjala así déjala así respira

Dormida así ¿qué mira si no mira?

¿Que no mirarla debo yo tampoco!

Doncella por el sueño por el sueño

que no la turbe un ruiseñor pequeño

¡yo no la toco nunca si la toco!

El poema «Loplop» nos da todas las claves de esta escritura rizomática extraña, ebria... postista: extrañeza barroca, surrealismo, transgresión y voluntad de vanguardia:

Bajas de un hilo de Helios

con tu gimnasia helena y pajariarca

Sencillo viejo urbano

Loplop dentro de la noche

Enciende vías venas y pañuelos de lava

acalla con tus plumas las rencillas del viento 
Oh generoso monseñor del cielo

Loplop Loplop energúmeno alado

No sé por qué te canto es la verdad

De una vigilia de Max Ernst amortiguada

naces como de huevo

como de concha Venus

¿viste desnuda a la mujer de 100 cabezas?

Ser verdaderamente deslumbrado

y poseedor de anillas

No contaré tu historia sobre el mundo

te duelo entre las calles

tus contrarios desvelos

Loplop su RR ealista

Esta escritura lúdica, donde el juego es el elemento estructurador del discurso, tiene su paralelo en la narrativa experimental de Julio Cortázar, que supone también una liberación de las estructuras lógicas del discurso ${ }^{233}$.

${ }^{233}$ La experimentación literaria de Julio Cortázar le lleva a jugar con el soneto, subrayando el paralelo total con la experimentación oryana. De este modo crea un soneto reversible que puede leerse de forma convencional y al revés, de abajo a arriba:

\section{ZIPPER SONNET}

de arriba abajo o bien de abajo arriba este camino lleva hacia sí mismo simulacro de cima ante el abismo árbol que se levanta o derriba

quien en la alterna imagen lo conciba será el poeta de este paroxismo en un amanecer de cataclismo náufrago que a la arena al fin arriba

vanamente eludiendo su reflejo antagonista de la simetría para llegar hasta el dorado gajo

visionario amarrándose a un espejo obstinado hacedor de la poesía de abajo arriba o bien de arriba abajo

(Un tal Lucas, Madrid, Alfaguara, 1979 pp. 189-190)

Poema que. a su vez, posee su paralelo en el «Sonet reversible» de Joan Brossa:

TEMPESTA devastada, ullal joiós, unglada de llum i gran remell del cel, bon por celest i bocaplena rel, paller del cant i cornell fruitós;

bull astral, cercle ardent, llevant festós mar i fogada, plenitud, model, arbre i lleó, rellotge clar i fidel, bastida essència, escut, fat brillós. 


\subsubsection{Una erótica del fuego}

El sueño y el material onírico revelan en estas obras una polaridad entre Eros y Thánatos:

Conmigo vas y no lo sabes oh la ignota gruta de las rodillas de la muerte La muerte es una mantis religiosa que se oculta en la arena de los vientos

Si no hubiera viento para mí no vendría la muerte silenciosa La manera de hablar del viento es única Sólo la muerte nos enseña a callar

Mi dueña enorme malacostumbrada que sabes capturar a otros insectos Y tú viento majestuoso rey de la noche de noches que en tu cueva esperas

(«Conmigo vas y no lo sabes oh la ignota», Los poemas de 1944)

Amor y muerte, temática fundamental de la poesía de Francisco Quevedo y que se convierte en signo de expresión del suerrealismo. Muerte y erotismo se hallan de lleno en las preocupaciones del surrealismo y en su intento de expresar la sexualidad reprimida, producto de los dictados del superego social. La erótica oryana se alimenta de las propuestas surrealistas que intentaban expresar la belleza extraña ${ }^{234}$, l'amour fou. y dinamitar, de otro lado, las barreras represivas mediante la liberación del cuerpo y sus

\footnotetext{
Feixa i nassum, bastó, senyal i ocell dónes, gran Sol, essent camí del guany: real rael de tu arreu brotant,

travesses, Sol gran, arborat ramell temporal de tempesta millorant. Encén tal Prometeu un tal afany.
}

(Els ulls de l'òliba, obra cit., p. 92).

234 Breton (1962, 2009: 252). Para Breton el azar objetivo supone un acto de amor, ya que el deseo erótico está en el centro mismo de la realidad oscura y prohibida que el surrealismo pretende desvelar. Así el encuentro Lautréamontiano del paraguas y la máquina de coser es un acto de amor sobre la mesa de disección. 
mecanismos deseantes. En este sentido, para Georges Bataille ${ }^{235}$ todo erotismo, en definitiva, surge de un acto de destrucción en el que los amantes se disuelven en el juego del amor, en la existencia sin forma. Por ello:

El erotismo abre a la muerte. La muerte abre a la negación de la duración individual $^{236}$.

Óptica que es compartida por el concepto aleixandriano del amor como destruccción, que a su vez conecta con el concepto hinduísta de la danza cósmica (Watts, 1963, 1999: 83-118). Según la concepción de Vicente Aleixandre, expresada en La destrucción o el amor (1935) y en toda su poesía, la muerte, que hace girar el movimiento cíclico de la existencia, es una cuestión del eros cósmico. La existencia, que es amor, se alimenta de la muerte de sus seres, los amantes. Sólo así el movimiento de la existencia puede continuar en la incesante danza que realizan todos los seres, que se alimentan, como en un acto de infinito amor, de la muerte de otros seres.

La erótica oryana supone una intensa reivindicación del cuerpo. Reivindicación que significa, en su espacio cultural determinado, una provocación y una liberación de parámetros mentales. La erótica oryana toma conciencia de su capacidad revulsiva y coloca su punto de vista en la dirección del malditismo. Los agenciaminentos producidos pasan por toda la literatura maldita: el Marqués de Sade, Rimbaud, el Conde de Latréamont, Breton, Dalí o Buñuel. Primacía del cuerpo, como receptáculo de una divinidad dionisíaca, sobre el concepto de espíritu, como agente cultural represor. Se trata de una erótica de la provocación, tal y como nos muestra el siguiente poema que pertenece a Los poemas de 1944:

Ojos dentro de una corriente funesta

de un callado glacial

Ojos en las fatales cerraduras

y en lo huérfano

Ojos tuyos que siempre fueron míos como un regalo íntimo como un altar vacío ¿No es esto el mundo hostil

${ }^{235}$ Bataille, Georges (1957), L'érotisme, París, Éditions de Minuit; traducción de Antoni Vicens, El erotismo, Barcelona, Tusquets, 1979, p. 32.

${ }^{236}$ Ibíd. p. 39. 
que machaca las flores?

Como dulces jazmines yo mordí

los dulcísimos pechos

de muchachas de veinte años

Tener un árbol siempre amigo

es caminar calladamente

Queda clara en el poema la voluntad de profanación de los signos más representativos de la cultura occidental y peninsular por excelencia. Erótica que rechaza totalmente los símbolos del cristianismo, a los que alude como contrafactura, y proclama una religiosidad dionisíaca. Esta erótica provocativa se acerca a la erótica fetichista de Luis Buñuel, desafiante y sacrílega; pues subvierte signos y conceptos de la ortodoxia cristiana en aras de una liberación de sus dogmas. Recordemos que para Michel Foucault $^{237}$ la historia de civilización occidental supone la historia del cuerpo secuestrado. Secuestro del cuerpo en aras del intelecto y de la estabilidad de un sistema social, llevado a cabo mediante las instancias represoras como la religión, la medicina, la penitenciaría, el psicoanálisis y la terapéutica hasta convertirlo en mero engranaje. La erótica oryana restituye esa corporeídad. Francisco Ruiz Soriano (2001: 210) señala la corporeídad erotizada de esta poesía. Las partes del cuerpo forman parte activa de la poesía de Ory: ojos, labios, bocas, manos, uñas... sangre forman parte de la insurgencia contra la normativa establecida. Amor erótico que supone una liberación del cuerpo. El amor, para Ory, es un culto no al dios cristiano, sino al dios Eros. El amor es pasión, fuego, llama; pasión enraizada en el cuerpo, que desafía todo platonismo mental. Amor pasión que ha sido expresado con anterioridad en la poesía amorosa de Quevedo o en la poesía de Juan de la Cruz, donde la unión erótica es el símbolo de la unión mística. Este fragmento del «Soneto 19» de Versos de pronto señala la procedencia quevediana de este amor oryano visto como pasión corpórea. El concepto de amor-pasón reside en la metáfora del amor como fuego, telúrico volcán interno:

ESTA voz, esta sangre que te llama, esta nocturna enredadera loca que me sube del pecho hasta la boca donde no tiene más presión la rana

${ }^{237}$ Foucault, Michel (1963) Naisance de la clinique. Une archéologie du regard medical, París, PUF, El nacimiento de la clínica. Arqueología del examen médico, México. Siglo XXI, 1966; (1975) Surveiller et punir. Naisance de la prison, París, Gallimard, traducción de Aurelio Garzón del camino, Vigilar y castigar. Nacimiento de la prisión, México, Siglo XXI, 1976. 
Oh amor que no me oyes, roja llama, ya no gacela, ya, que se desboca

junto a la fuente triste y a la roca

del mar, ya no gacela que me ama.

Concepto telúrico y cósmico del amor que liga esta erótica con la concepción amorosa de Pablo Neruda, Vicente Aleixandre o Miguel Hernández. El siguiente fragmento resulta totalmente revelador:

¡Oh lo maravilloso de cada largo beso!

Detrás de cada cuita cada temblor: la carne sin freno, los corceles diminutos, altísimos de la sangre, de los nudos ahogados, todo, todo, irremediablemente derrocados, huídos como rosas dejadas caer, como si dedos abandonaran cintas, como tigres dormidos, hambrientos, ultralocos en otro mundo, preciso, como ganando sed.

$[\ldots]$

Amor, amor enorme que vives más, que ardes con abierta llama...

(«Poemas de Ganando sed», Versos de pronto, 1945).

En el poema «Lamentación del amor que llega», común a los dos poemarios, aparece la imagen del amor como volcán:

Y el corazón se precipita y amanece en volcán y en un hermoso monte sin yerba ni manzana. Luego sobre la frente nos escupes, nos besas, ¡fenómeno brutal! ¡siempre junto a las yemas!

(Versos de pronto, 1945). 
El corazón se agita y amanece en volcán

Esa ya un hermoso monte alfombrado de astros

(Los poemas de 1944, 1973).

El poema «Amiga», común también a ambas obras, es un ejemplo claro de este amor cósmico y corpóreo, cuya irradiación alcanza a todos los seres. Así se expresan los siguientes fragmentos:

Busca un rápido bosque de esperanza, busca un labio cubierto de manzana.

Se mueve como un pequeño bulto de cristal mi corazón.

Muevo dentro de mí mis manos como frutas de arena.

$[\ldots]$

Seré tuyo como un enloquecido humo de la sangre, tuyo entre dolor y paz de lejana cintura.

(Versos de pronto, 1945).

Busca un labio violín

Se mueve

extraño bulto de cristal mi corazón

Muevo dentro de mí mis manos como conchas de nácar En la vida del viento se ahogan tus ojos azules de color azul

[...]

Seré tuyo echando humo

humo sangriento y tú perdonarás

mi olor del que ama que conoces

sólo la paz no tiene olor Amiga

galopante

Amo besar la flor en el silencio

de tu mejilla caliente en la lluviosa

noche

(Los poemas de 1944, 1973).

Aquí aparece la imagen del humo, el humo de la combustión, el humo del fuego del amor. Volvemos a encontrar la misma imagen en el poema de Los poemas de 1944 titulado «Parte perdida de un horrible soneto»: 
Tú no vienes de nada tú de nunca

Tú no recoges ese vuelo mudo

de esa mujer con piernas diferentes

De tanto amar estoy cabeza trunca acostumbrado al fuego de humo sudo y de besarte ya no tengo dientes

En este sentido, Octavio $\mathrm{Paz}^{238}$ señala, a propósito del conocido poema de Quevedo «Amor constante más allá de la muerte», que el humo expresado en el poema se trata del humo de una pira funeraria. De modo que esta concepción del amor como fuego posee sus raíces en las creencias de la antigüedad, en las que la erótica (el dios Eros del poema de Quevedo) era una pulsión cósmica que tenía su paralelo en una erótica interna. Para Paz, se trata de una profanación de la tradición platónica y de su herencia, la tradición cristiana. No hay un viaje del alma a las perfectas formas etéreas, ni a una realidad celeste. Sino conjunción de cuerpo y alma en una eternidad deseante ${ }^{239}$. Una erótica del cuerpo, de los huesos, de las venas... de la sangre, cuya combustión produce el humo (enamorado).

Por otra parte, existe también una erótica opaca agazapada tras el lenguaje surreal. Erótica que se esconde en las imágenes y los símbolos oníricos de la misma manera que lo hace la erótica de Salvador Dalí. En sus cuadros esta se manifiesta en multitud de elementos sexuales y escatológicos diseminados entre los objetos, lo que exige una lectura mucho más atenta. El surrealismo poético de Ory ofrece también una erótica que se enmascara bajo el significante simbólico. Cuerpo y objetos se hallan erotizados, impulsos y deseos se hallan desatados en plena libertad. El poema perteneciente a Los poemas del 1944 que se titula «De mis sueños» es un claro ejemplo de este lenguaje opaco donde la erótica está totalmente presente. Lenguaje del ello, en definitiva:

En la ondulada vida de mis sueños

En las puertas de arena de mis sueños

En las orillas de betún de mis sueños

En las alcantarillas tórridas de mi sueño

67.

${ }^{238}$ Paz, Octavio (1993), La llama doble, Amor y erotismo, Barcelona, Seix Barral, pp. ${ }^{239}$ Ibíd. 
Tropiezo con los ángeles antiguos

Y tropiezo con fuentes y con muslos

Mi sueño es un atroz horno de humo

$\mathrm{Y}$ en mis sueños se queman mis manos cada vez

«Alcantarillas tórridas», «muslos», «manos»... combustión, humo, fuego... Una vez más presencia del cuerpo bajo el prisma de la erótica de la pasión, cuyo signo es el fuego. El cuerpo humano aparece descrito mediante símbolos y objetos fetichistas, que lo transfiguran en los elementos de la ensoñación. Ello es lo que muestran los siguientes fragmentos:

En la tarde con lluvia una mujer sin sexo una mujer de aire y gasa yerra Voy hacia ella y no existe Veo sólo sus ojos y su boca y su pelo Pero no existe no No hay nadie Estoy solo Mi alma es un gran arco del violín del silencio en un cielo de amor Me asomo a la ventana... Sigue lloviendo Sigue... Una mujer amarga llora esta noche con la nostalgia divina de una cosa lejana La lluvia hace en la noche una guitarra en flor

$$
\text { («Silencio», Los poemas de 1944) }
$$

\author{
Vasos y sillas manos \\ inocentes utensilios \\ Cristal madera carne \\ cosas raras \\ La mano es la princesa del secreto \\ el pájaro de la carne de la carne \\ Las sillas con arañas \\ y esos vasos las mujeres \\ Manos de amor maniáticas
}

(«Vasos y sillas manos», Los poemas de 1944).

En el primer fragmento, la presencia de una figura femenina sin cuerpo, presentada bajo una espectral fantasmagoría como «mujer sin sexo» o «mujer de aire y gasa», señala la presencia corpórea del sujeto poético masculino. La inexistencia de sus órganos («ojos», «boca», «pelo») se recorta sobre la soledad del yo amante, que queda erotizada por la presencia textual del vacío cuerpo femenino. El deseo erótico se expresa a través de la música y sus símbolos: «mi alma es un gran arco del violín...» y «la lluvia 
hace en la noche una guitarra en flor». La erótica del cuerpo queda trasferida al exterior, a esa noche que, como un todo, envuelve los cuerpos de los amantes. El erotismo surge del cuerpo ausente de la amada y atraviesa el cuerpo masculino erotizado para expandirse en el espacio de la noche celeste.

En el segundo fragmento la simbólica traza un movimiento hacia el cuerpo humano. Los objetos exteriores, los «vasos» y las «sillas», se encarnan, se convierten en fragmentos del cuerpo de la mujer. «Cristal» y «madera» que la erótica trasmuta en «carne». Las «manos» se asocian al «secreto» y al «pájaro». Detrás de ellos está el gran desierto de la «carne», que es el fondo erotizado donde resaltan los objetos: «sillas»y «vasos» que quedan asociados a «mujeres»y «arañas». Fácil resulta ya transferir este último significado al cuerpo de la mujer:

$$
\mathrm{A} \ll \text { mujer» }=\mathrm{B} \text { «araña» }
$$

Como puede observarse, la erótica convierte el cuerpo de la mujer en amenaza para el amante masculino. Araña, abeja o mantis religiosa. La erótica oryana se pliega alrededor de la dinámica del amor como destrucción. En este sentido, Salvador Dalí ${ }^{240}$ interpreta la escena de El Ángelus (1867) de Jean-François Millet como un acto de amor erótico. Al interpretar el cuadro de Millet, Dalí observa que la relación amorosa se sustenta en el canibalismo. La posición de la figura femenina queda asociada a la de la mantis religiosa que devora a su amantes después de la ceremonia del amor. Según esta concepción todo impulso amoroso consiste en comerse al amante. Así este queda trasmutado en el cuerpo del otro, concepto que aparece expresado en diversos escenarios de la pintura daliniana. El cuadro que expresa este amor caníbal de una manera más clara es el titulado Canibalismo otoñal (1936). En él dos amantes armados de cubiertos devoran sus cuerpos entre pedazos de pan, fragmentos de filetes de carne, piezas de fruta y diversos frutos secos. La pintura daliniana simpre ha incorporado la simbología de la comida, erotizándola y convitiéndola en puro fetiche, objeto del deseo. De la misma manera que se expresan los objetos en la pintura de Dalí o en las imágenes del cine de Buñuel, la erótica oryana convierte los objetos en fetiches. Son objetos erotizados por el deseo, que remiten en última instancia al cuerpo del amor: los ojos, las manos, los pechos, las piernas....

${ }^{240}$ Ver El Mito Trágico de «El Ángelus» de Millet», obra cit., pp. 139-141. 


\subsubsection{La caída, una poesía existencialista}

Tanto en Versos de pronto como en Los poemas de 1944 se halla presente una poesía existencialista de herencia quevediana:

Vivir dentro de mí, vivirlo fuera: vivir cada año es desvivir la vida, es ir viviendo muerte sin retraso.

(«Soneto 14, Versos de pronto»).

Presencia de la poesía existencial de la muerte cotidiana, de esa muerte que se halla impresa en cada instante de la vida. Para Víctor García de la Concha (1987: 712-713), la problemática existencial forma parte del pathos barroco de la poesía oryana, que muestra una conciencia trágica de la existencia. En este sentido funciona la imagen poética de la caída y de su icono más común: el ángel caído.

Un niño extraviado en la niebla es lo peor Toca el mármol del humo creyendo tocar algo Rey cruel es el llanto y soy su esclavo enano Hasta el año pasado tenía veinte años Sé que es inútil todo guerrero vulnerable De rabia pisoteo un ángel caído en tierra

(«No viene nadie a hablarme de espadas o de laúdes», Los poemas de 1944).

La imagen del ángel caído se halla en muchos poemas:

Todo es frío jardín de fuentes negras

Que no me baje un ángel con un cisne me basto

(«Tránsito sombrío», Los poemas de 1944).

Contrariamente, algunos poemas señalan la inexistencia del ángel, su abandono. Ángel que es símbolo de la divinidad, de una existencia divina abandonada. Huída de una realidad divina, conciencia de la soledad. 
Nadie conoce el ángel que lleva oliva o tréboles

En tus ojos de hombre desvelado hay maldad

La maldad de más muerte en la vida y de más

tinieblas en el trono de todas las tinieblas

(«Más muerte», Los poemas de 1944).

Esta visión del ser humano como ser caído coincide paralelamente con la visión del ser humano como ser dormido que aparece en Sombra de paraíso (1944) de Vicente Aleixandre o en Un río, un amor (1929) de Luis Cernuda. Espectros, seres fantasmales que han perdido el contacto con una realidad mágica y divina. Seres grises, angustiados, que se hallan prisioneros en la sombra oscura y viscosa de la existencia. Seres incapacitados para el amor porque han sido expulsados del paraíso y sus lazos con la divinidad han sido cortados. Se trata pues de una divinidad cósmica, no antropomorfa. Esta imagen de la caída es interpretada por E. M. Cioran como una caída en el tiempo:

Tras haber echado a perder la eternidad verdadera, el hombre cayó en el tiempo, en el que logró, ya que no prosperar, al menos vivir: lo que es seguro es que se ha amoldado a él. El proceso de esa caída y ese amoldamiento se llama Historia.

Pero, mira por dónde, lo amenaza otra caída, cuya amplitud resulta aún difícil de apreciar. Esta vez ya no tratará de caer de la eternidad, sino del tiempo, y caer del tiempo es caer de la Historia, es -suspendido el porvenir- encenagarse en la inercia y la tristeza, en el absoluto del estancamiento [...] Y entonces, tras haber perdido hasta el recuerdo de la eternidad verdadera, de su primera felicidad, dirigirá sus miradas a otros puntos, al universo temporal, a ese segundo paraíso, del que habrá sido desterrado ${ }^{241}$.

Pérdida de la idea circular del tiempo, cuyo significado es la eternidad, que conlleva un concepto de tiempo lineal. La linealidad del tiempo comienza con la concepción judaísta de un génesis. Un tiempo que comienza mediante un instante creador y que se proyecta unidireccionalmente hacia un final futuro. Esta es la imagen occidental del tiempo que fue adoptada por los monoteísmos cristiano, islámico y judío, así como sus desarrollos filosóficos como el historicismo hegeliano, el evolucionismo darwinista, el marxismo... Tiempo dirigido hacia un final que otorga un sentido y una finalidad al transcurso humano. Este es el tiempo de la tradición sobre el que se fundamenta el tiempo de la modernidad. Pero, a su vez, significa una pérdida del sentido de la

${ }^{241}$ Cioran, E. M. (1964), La chute dans le temps, París, Gallimard; traducción de Carlos Manzano, La caída en el tiempo, Barcelona, Tusquets, 1993, p. 167. 
existencia, una pérdida de la sacralidad de la realidad que afecta, sobre todo, a la geografía cultural occidental. Caída que es descomposición total de una civilización.

La caída, como símbolo arquetípico, toma los signos de una angustia existencial cósmica, de un cataclismo trágico y profundo. Una fractura interior, producida en la sangre, cuyos signos son: soledad, tristeza, desolación, siniestra angustia oceánica, tal y como queda expresado en los siguientes poemas que pertenecen a Los poemas de 1944:

\section{SINFONÍA DE LA MUERTE}

Un rostro en el olvido se me cae

De los dedos la luz también se cae

Del aire una paloma se me cae

Un llanto cae cae

Un piano cae como agua

Uvas caen como cosas

Naranjas nieve caen

y lágrimas y rosas todo cae

Sangre que cae infinita

pájaros hechos polvo

estrellas tan lejanas

y lejanos destellos

Cayó tu amor

Cayeron tus palabras

tus uñas los crepúsculos

Todo ha caído dentro de los pozos

Y así se cae el corazón

como un cuchillo de plata

No existen llaves para lo caído

aunque sean pañuelos

Aunque se caiga Dios

\section{TODO CAE}

Se cae el corazón como un anillo

Caen pañuelos y llaves caen las risas

junto a cipreses junto a fuentes secas

sobre desiertos sobre playas

Se caen estrellas ángeles y Dios

Todo se cae al fondo del espíritu

$\mathrm{Y}$ los pesados bueyes del amor

se caen sobre las olas temporales

También el mar se cae

También se cae la tierra

$\mathrm{Y}$ el aire con sus ramas y sus piedras 
donde cayeron muertos de ojos verdes

Un rojo olvido hay vasos quebrados

caballos de cartón y caballos reales

donde cayeron carnes y saliva

donde caí yo vestido de arrayanes

Terrible fractura cósmica que evidencia el aislamiento del ser en una geografía existencial inhóspita y enemiga.

Frente a ello, el yo poético se refugia en pequeños archipiélagos aislados que, como mesetas, flotan en un espacio que se descompone. Son fragmentos nómadas que delimitan una separación, una territorialidad periférica, una posición ajena a aquel espacio que se derrumba. Este alejamiento del centro supone un refugio en los símbolos de la marginalidad, en los símbolos baudelerianos de la exclusión. El yo poético queda identificado en las siguientes figuras: el deshonillador, el pirata, el alquimista, el fauno, el león, el clown...:

\section{MUERTE}

Cuando mi noble carne de pigmeo sumiso deje de amar su paso solariego en la tierra y cuando sobre espumas huya mi pie piadoso seré como un reptil fosfórico que rampa las simas del olvido las cimas del desvelo Nuevas luces vendrán a pulir mi otro cutis y no me acordaré de mis manos mugrientas Caminaré seguro buscando en mi derrota un rincón de aire alpino y me estaré contemplando las águilas con ojo anacoreta

(Los poemas de 1944).

La conciencia de la marginalidad marca el rumbo futuro de la poesía oryana, cuyo signo más evidente será la heterodoxia cultural. 


\subsection{LOS ROMANCES}

Verdes dragones, sombras chinescas, trágicas farsas funambulescas.

Ramón María del Valle-Inclán

Dos obras son las que contienen los romances postistas: Las patitas de la sombra, escrita en 1944 por Eduardo Chicharro y Carlos Edmundo de Ory, y Laocoonte y la luna, conjunto de romances escritos por este entre 1945 y 1948 que forma parte de la obra Doblo hablo. Las dos obras permanecieron inéditas durante un tiempo dilatado debido al hecho de que suponían una transgresión radical del lenguaje poético coetáneo y, a la vez, un rechazo de la geografía cultural de la oficialidad y de la literatura realista que, desde posiciones políticas, buscaba un cambio social. Entre ambas direcciones, la poesía oficial y la realista, existe una multitud de relaciones y un mismo lenguaje común. Ello hace que las dos constituyan una misma unidad de significación poética, justamente aquella de la que la poesía postista quiso rechazar. Esta distancia significó el silencio editorial, más aún en el caso de los romances postistas. Algunos poemas, pertenecientes a ambas obras, se publicaron en las dos revistas postistas ${ }^{242}$, tal como se muestra en el Apéndice II. Por otra parte, en la edición de Música celestial y otros poemas $^{243}$ de Eduardo Chicharro, publicada en 1974, aparecen tres poemas de Las patitas de la sombra.

Los romances postistas constituyen, por sí mismos, una poética totalmente periférica que combatía los presupuestos poéticos de los espacios poéticos dominantes. Sus signos son la primacía de los valores de la imaginación, la total libertad expresiva y el carácter lúdico de la escritura. Presupuestos que ya fueron presentados teóricamente en los diversos manifiestos postistas. Como muestran Pérez Lasheras y Saldaña (2000: 25) en su estudio introductorio sobre Las patitas de la sombra, los romances postistas suponen un ataque a los valores sociales imperantes, a la pedantería y a la hipocresía de

242 «Soneto paranoico» aparece en la revista La Cerbatana; «Laocoonte y la luna», «Romance al poeta postista Silvano Sernesi» y «Romance del loco chillón» lo hacen en la revista Postismo; «El ronquido del niño», escrito por los dos poetas, aparece en Postismo.

${ }^{243}$ Obra cit. En ella aparecen "Las patitas de la sombra», "Auras campestres» y «Romance del Conde-Duque de Olivares», pp. 267-269. 
una sociedad encorsetada por una cultura represiva. Frente a ello, ofrecen un grito subversivo y liberador, basado en el aire fresco que conlleva la aceptación de una óptica dionisíaca.

\subsubsection{Práctica de la parodia y la contrafactura.}

Los romances postistas suponen diversos agenciamientos ${ }^{244}$ de la escritura rizomática planteada por Carlos Edmundo de Ory y por Eduardo Chicharro. Esta escritura se pliega sobre la literatura tradicional infantil, la lírica tradicional de dirección oral, la literatura absurda de los disparates, los juegos de ingenio, la tradición humorística del teatro popular, la poesía satírica... Sus signos son el humor y el absurdo. El modelo adoptado es el romance, modelo que se acepta para ser deconstruido, pues la óptica postista opera mediante la subversión de los moldes originales sobre los que aparece un nuevo modelo a modo de copia. Por otra parte, la subversión postista opera también en la propia dirección literaria de su propio período histórico. En este sentido, la práctica del juego libera el lenguaje de su dirección pragmática y se convierte en el elemento estructurador del discurso. Por ello queda abolida la dinámica existente entre el lenguaje y la realidad, en la que la lógica inherente entre el signo y lo real queda sustituida por una lógica paradójica y extraña. De este modo el discurso postista significa una quiebra en el concepto aristotélico de la mímesis, base del realismo literario. Estos romances suponen una ruptura con el realismo, su lógica ya no puede representarse mediante la imagen renacentista de la ventana abierta al mundo. El reflejo de lo real no se ofrece a través de la superficie plana del realismo, sino filtrado a través de los espejos deformantes del expresionismo. Esta es la estética que se reclama en el poema «El Dorado» de Las patitas de la sombra. La sorpresa y el humor actúan como agentes corrosivos que destruyen la solemnidad del lenguaje dominante:

Cae la lluvia todo empapa

el suelo se barre solo,

las raíces de los árboles

se descubren como flojos

tendones descarnecidos,

${ }^{244}$ Deleuze y Guattari (1980, 1988: 14). Concepto que, como ya se ha visto, señala la reterritorialización efectuada por una escritura que se constituye en multiplicidad. 
son muertos de todos modos.

El jinete en su caballo

entra andando en el fenómeno.

¡Qué esperanza de la estrella

le conduce por los ojos!

El campo es un cementerio

lleno de sombras y soplos.

Pero el triste dromedario

busca un destino espantoso

como viene de la muerte

tiene costras en el rostro.

Su espada lleva al cinto.

Su alma yace en el infierno.

En busca de El Dorado

sigue el sueño fabuloso.

Anda valiente el viandante

percutiendo lo incoloro:

Digámoslo sin ambajes

El Cabellero está loco.

El modelo contrafactual elegido es el romance, modelo que es deconstruido al modificar la matriz de su discurso. El elemento narrativo propio de este modelo elegido, asocido con la épica militarista castellana, con los usos amorosos o con las tareas de la cotidianeidad, queda abolido por la irrupción de lo raro, lo absurdo, lo ignoto y lo disparatado. El juego y la libertad lingüística toman plenos poderes en la estructuración del discurso. La extrañeza sustituye a la narración y se convierte en el eje poético generador. Ello puede observase perfectamente en el oryano «Romance del loco chillón» que pertenece a Laocoonte y la luna y que ya mostramos anteriormente al analizar la euritmia postista. En todo caso cabe señalar el siguiente fragmento que resulta totalmente ilustrativo:
Abrió la gran ventana
del plenilunio introito
y le sacó la lengua
con rictus in devoto
¡Qué miedo! ¡Qué ruido
de firmamento monstruo!
Una luz de alta tea
le pulía los hombres
y de sus pies salían
voces de medio tono
Ya pinta misereres
en su pecho incoloro
destripando tinieblas 
como un extraño vómito

Ay lo hijo no gimas

ni animes melancólico

de sucias energías

tu garganta de loco

Se trata de una poesía que se abandona al oleaje de las palabras, cuyos signos más específicos son la libertad y la imaginación. Ambas, siguiendo los parámetros de la poética barroca, provocan la extrañeza que nace de la lejanía existente entre los términos que se asocian. La poética barroca queda ligada a la asociación libre de objetos del surrealismo. Como resultado surge una estética extraña que atenta contra las normas del buen gusto y que, paralelamente, busca la rareza, la extravagancia, la disonancia, el absurdo y lo grotesco. Los romances postistas ofrecen una estética sincrética en la que se conjuga la liberación del lenguaje y la presencia de la provocación, propias del dadaísmo, la belleza extraña y onírica del surrealismo y la deformación grotesca de la realidad propuesta por el expresionismo.

Si los romances postistas suponen la contrafactura paródica de un género, es porque realizan una subversión del lenguaje del poder. Se trata de un discurso que rechaza el ideal heroico y que, por tanto, excluye toda solemnidad posible, un discurso que rehuye todo sentimentalismo y se inserta en la sátira popular. Parodia de la épica, de la sensiblería propia de las formas populares, del petrarquismo y de la poesía religiosa. La contrafactura épica se observa en poemas como «El Dorado», «Romance del CondeDuque de Olivares» o «Encuentro de Garibaldi y Víctor Enmanuel», pertenecientes a Las patitas de la sombra. Parodia que afecta a los ideales, a los símbolos y a los valores de la España imperial. En «El Dorado» aparece la parodia del arquetipo del caballero español, «Romance del parto negro» y «Parábola del sueño», también de la misma obra, se configuran como un alegato contra el tradicional machismo social. Se ataca también el honor y la honra en «Recuerdo para morir con herencia», de Laocoonte y la luna. En ocasiones la sátira se aleja de los símbolos del poder y, bajo la parodia del bucolismo, afecta al ser humano social y anónimo. Este es el caso del poema titulado «Canto magnífico a los pastores béticos» de Laocoonte y la luna, del que extraemos en siguiente fragmento:

¡Venid a mí los míos niñoncitos hombriantes 


seres de pan y queso
mudos como las cumbres!
Se engolfa vago agora
dormido y oh con una
enternecida capa
los pensarientos ${ }^{245}$ únicos
que escuchan las estrellas
decir escupitajos
con su licor de noche
Son ellos los sonámbulos
su sueño bajo Sirio
su sueño suena a siglos
su superior pulmón
y se calienta al frío
sabiendo que el invierno
azota sus artículos
y así la lluvia parla
con tono parisílabo
cayendo en su cabeza
de pobre pastorcito

Se parodian también algunos arquetipos culturales religiosos como la imagen de Adán y Eva en el romance «El genio del mal, en forma de serpiente, tentando a Eva» o la iconografía de la enunciación en «Thamar y Amnón», pertenecientes ambos a Las patitas de la sombra. Frente a los usos amorosos socialmente aceptados, el romance de la misma obra titulado «El padre de la vida» evoca, entre elementos escatológicos y resonancias masturbatorias, la práctica de la prostitución. El romance titulado «Los dos hoplitas», perteneciente a Laocoonte y la luna, muestra también una erótica grotesca. A su vez, «Cuita de Marís de Nido», que pertenece a la misma obra, supone una degradación esperpéntica de la idealización femenina que se corresponde a los cánones del amor platónico desarrollados por la tradición poética, tal como muestra el siguiente fragmento. La imagen resultante de la amada nos recuerda algunos trazos de la poesía satírica de Quevedo o de la de Juan Ruiz:

-¡María! ¿Estás borracha?

Los cambios de la luna

dejan en mi alma amiga

sus profundos cimientos

¡Estás vieja!

-Estoy coja

245 Sic. 
me enredé en el camino

como mala paloma

-¿En qué piensas cejuda?

-Estoy cazando lobos

Estoy perdiendo el hábito

de remontar los tiempos

-¿Qué dices di María?

En el ostento máximo

del enajenamiento

¿por qué tú te sorprendes

de la superflua hélice

que te rozó los labios?

Por los amestros pólenes

de Celestina aquella

que visitó la unípara:

dime aunque lo viole

tu sueño el dulce tuyo

-¡Los puentes del Olvido!

-¡María no ese el otro!

-¡Las luces que hay en Viena!

-¡María no seas lejos!

$-i Y$ del nupcial armario

allí la piedra pongo

allí van las campanas

con su único camello!

No corras las cortinas

los nombres se me rompen

Estoy sola en las aguas

de mi semblante muerto

-No estás vieja estás bella

En tu mirada el postre

titánico me bebo

-la golondrina góndola

y el álamo de té

y la araña quiróptera

Menciono sólo el sueño

de la cifrada boda

-María ayer mañana

Estoy ronco no oigas 
-Los hombres son pigardos

pigmentos pies de historia.

Como se puede observar, esta estética degradada utilizada en la representación del personaje femenino, posee contactos la tradición satírica, con la literatura medieval misógina, con la estética de Fernando de Rojas referida a los personajes femeninos marginales y con la estética esperpéntica que Valle-Inclán aplica a las tarascas y a los demás personajes femeninos.

«El ronquido del niño» $\mathrm{y}$ «El niño sigue roncando», poemas de Las patitas de la sombra, suponen la parodia de la nana:

\section{EL RONQUIDO DEL ÑINO}

Como un huso pequeño ronca el niño pequeño.

¡Ay, por Dios, qué pequeño!

¡sí, sí, sí, qué pequeño!

Es que sierra una sierra

con aserrín de huevo

de huevo y de natillas

en su lugar enredo.

Hay un duende en la noche, con la noche pequeño $\mathrm{y}$ encendiendo cerillas en su murmuradero... ¡Qué loco, ay, qué loco qué loco es el abuelo! ¡Ay qué bueno es el aire que le sale del pecho y se le sube dúctil por los dos abujeros! $!^{246}$ ¡Anda, eso es el ronquido, y lo coge de vuelo! El niño sueña un tambor que le haga el ronroneo. Esto es lo más bonito desde Carlyle a Asuero: mientras su madre duerme, el niño está durmiendo. 
El poema de Las patitas de la sombra «En la hora del perfume y del fantasma» es una parodia del soneto, dirección que será retomada más adelante por Carlos Edmundo de Ory hasta constituir una constante en su poesía:

\author{
En la hora del perfume y del fantasma \\ el beso de tu seno es mi desvío \\ y el ansia de besarte desvarío \\ cruje una secreción de su ectoplasma. \\ El húmedo calor de cataplasma \\ husmea por el humus del baldío \\ azar de toda cosa ardiente frío \\ después del pus que das y en pos del alma. \\ Se asoma una paloma por la luna \\ la luna de paloma se amotina \\ y nadie nunca nombra la letrina. \\ Los brazos de la noble mujeruna \\ me causan gran placer y yo respeto \\ tercero reto peto y parapeto.
}

La actitud que muestran los romances postistas supone un ejercicio de parodia contrafactual, deconstructiva y metaliteraria. Este es un ejercicio de la práctica de la euritmia postista, que no es otra cosa que la aplicación de la estética de la extrañeza al nivel fónico del discurso poético. La mirada paródica reside en la utilización de una fonética extraña, cuyos signos son la rima rara e inusual, la rima interna basada en la disonancia, la repetición de sonidos cacofónicos. Las palabras se eligen por su proximidad fónica tal como ocurre en la repetición de sonidos como «pus»y «pos» del verso octavo, o en el juego que se establece en el último verso mediante la repetición de un mismo segmento de sonido en las palabras «reto», «peto» y «parapeto». El primer cuarteto se establece en base a la repetición de unos sonidos similares. Así las palabras quedan agrupadas en base a esta similitud fónica, de modo que «asoma», «paloma»y «amotina» quedan ligadas de un lado, mientras que de otro se unen los vocablos « «luna» $\mathrm{y}$ «letrina $»$. También quedan unidas las palabras «nadie», « Por otra parte, la rima queda establecida mediante la utilización de palabras antipoéticas como «fantasma», «ectoplasma», «cataplasma» $\mathrm{o}$ «mujeruna». Estas son las claves de la práctica paródica contrafactual que, en este caso, dirige la mirada hacia el soneto como modelo poético. 


\subsubsection{Presencia de una estética expresionista.}

Los romances postistas suponen agenciamientos literarios de la óptica del esperpento de Valle-Inclán, de la poesía satírica de Quevedo y de la literatura del humor, representada por la greguería de Ramón Gómez de la Serna y por la otra generación del $27^{247}$. Su poética posee los signos de los espejos deformantes de ValleInclán: radicalidad, ruptura, agresividad, estética del absurdo, parodia, demolición de la representación realista. Como el esperpento, esta estética funciona como expresionismo radical, interesado en una permanente deformación de lo real cuyo producto ofrece la creación de un objeto literario extraño y deforme. Como estética expresionista, los romances postistas suponen una mirada caótica que se basa en la presentación de los aspectos más grotescos de la realidad, en la absoluta degradación del mundo literario representado, en el humorismo corrosivo y en la presentación descarnada del absurdo y del disparate. Como en el esperpento vallinclanesco, se trata de una estética telescópica que consiste en agrandar la distancia entre el mundo presentado y el lector, en la demolición de la posible identificación del lector con la realidad literaria. Los elementos personales presentados en los romances postistas quedan circunscritos bajo la óptica de la degradación. Son personajes deshumanizados, muñecos, títeres, fantoches, sombras chiñescas. Este es el retrato que se ofrece del Conde-Duque de Olivares en Las patitas de la sombra, en el romance que lleva su nombre. Retrato que nos evoca la deformación grotesca de los personajes satirizados por Quevedo o reflejados en los espejos cóncavos y convexos del esperpento de Valle-Inclán:

\footnotetext{
Espera que su cara se llene de boquetes... espera que las barbas le crezcan y le crecen Le entraba la manía de enseñarle los dientes $\mathrm{y}$ tiene todo frío como le dicen los jueces ¡Ay del Mambrú a caballo por los pinares verdes! cómo se ve lejana su figura de nene con su sota de bastos que a su lado se mueve
}

${ }^{247}$ Ver Bruguera, María Luisa y Fortuño, Santiago (1998), obra cit. 
¡Duque Olivares duque...!

vedle por donde vedle

con su traje flamenco

y los ojos de liebre

La cosificación acentúa todavía más la despersonalización de este personaje. El retrato de muerto en «El ahorcado», romance que pertenece a la misma obra, posee todos los rasgos descarnados de los personajes de la literatura quevedesca:
¿Qué llanto por la boca
de un enfermo sin fiebre!
Con una mano en el sexo
lo ha encontrado la muerte.
Le quitan los zapatos
y le afeitan los sieses.
Una niña le mete
un dedo entre los dientes
y tiene el culo frío.

La presencia de la escatología liga totalmente la poética de los romances postistas a la literatura quevedesca, como ocurre en el poema de la misma obra «Como se dirá más tarde», que nos muestra la siguiente representación de la masa social:
Todos piden mocos dulces
y con ellos han de hartarse
Son Pinzones, Calatravas
Se le agravan las narices
Se les hinchan, se les ponen
hay un culo rosa al aire
Es el culo del alcalde
Hay personas son rosiles
el muy falto de respeto
cae de culo por la tarde
Se levanta y grita gritos
o que se verá mas tarde

Esta estética deforme se observa perfectamente en el retrato del personaje del «Romance del loco chillón», perteneciente a Laocoonte y la luna:

Ay lo hijo no gimas

ni animes melancólico 
de sucias energías

tu garganta de loco

¿Por qué canturreas

con gangrena en el rostro?

Tenía en sus pupilas

un volcán misterioso

Son todos ellos personajes infrahumanos, marionetas ajadas, material de derribo, deshechos, detritus. Resulta imposible la identificación del lector con los personajes y justamente esta distancia traza el principio básico de esta estética grotesca.

En este sentido la estética esperpéntica se acerca a las experiencias de la vanguardia. Encontramos aquí convergencias con la radicalidad del teatro de Alfred Jarry, con la literatura absurda y trágica de Franz Kafka, continuada por el teatro del absurdo de Eugène Ionesco y de Samuel Beckett, convergencias con el teatro de la crueldad de Antonin Artaud, con el cine del expresionismo alemán y su contrastes luminosos, con el humor descabellado de Jardiel Poncela y de Miguel Mihura. Existen también acercamientos a la pintura de Edgard Munch, James Ensor, Emil Nolde, Ernst Ludwing Kirchner, Pablo Picasso, Georges Rouault, George Grosz... por su estética feísta y distorsionada, basada en la presentación de los aspectos más sórdidos de la existencia humana. Cabe citar también las intersecciones con la narrativa de Pío Baroja. Ello puede observarse en el siguiente fragmento de «La procesión de los trasgos», perteneciente a Las patitas de la sombra, que posee una impronta totalmente valleinclanesca:

La luna está redonda sobre un asno esquilado vuelven las tristes vacas con el rey mahometano $y$ vuelven del infierno con el belfo mojado La luna está cuadrada lucha un león y un milano No sé por qué me engañan si tengo siete hermanos y tengo una pistola con los ojos en blanco ¡Malhaya mi pistola si no mato a los trasgos! (una mosca en el vientre 
del pérfido verano).

Esta misma estética degradada está presente también en este fragmento del romance de la misma obra titulado «Parábola del sueño»:

\author{
¡Ay Dios mío qué paciencia \\ acostarse y no moverse \\ ver nacer de noche en día! \\ Ruge el órgano en horrísono \\ canturriar $^{248}$ de la espesura. \\ Andan libros sobrepasa \\ polvo enorme que amarilla. \\ El marido mata pronto \\ a la esposa traicionaria \\ y le rompe a furia lenta \\ su abanico de mantilla. \\ ¿Y qué hacemos con los hijos? \\ La pregunta se destina: \\ ellos son luz de tu cuerpo \\ enhebrados en almíbar \\ ¡Si pudiera muerta hablarme! \\ Y si te hablo me querías. \\ Por ejemplo ella pudiera \\ contestar en esta guisa: \\ Je ne suis pas donna immobile \\ rosa mística cautiva. \\ Vuela el aire en ataúdes \\ tablas negras barcos guían \\ las personas por la atmósfera \\ y las cosas en la luna. \\ Sola en la arena la Muerte \\ ve en las aguas su berlina \\ cacerola carcelaria \\ rosaleda rosalinda.
}

Estética expresionista, personajes que son fantoches degradados, parodia del código del honor, ataque a una cultura machista, presencia de los elementos de la Galicia intemporal. Este fragmento supone un claro pliegue de la poética postista con la estética de Valle-Inclán, paradigma del expresionismo radical ibérico. Antonio Risco, en su obra La estética de Valle-Inclán ${ }^{249}$, sitúa los antecedentes de la estética esperpéntica en la tradición castellana, en la práctica de la distorsión efectuada siglos atrás por Quevedo y

249 La estética de Valle-Inclán en los esperpentos y en el Ruedo Ibérico, Madrid, Gredos, 1966. 
Goya, maestros del expresionismo estético. Del primero Valle-Inclán rescata el humor como visión caótica del mundo, la plasticidad del lenguaje, la distorsión expresiva y la degradación de la realidad. Del segundo la deformación grotesca de la aristocracia y la representación de lo monstruoso y de lo siniestro.

La estética de la distorsión, practicada por los romances postista, no sólo es deudora de la mirada expresionista de Valle-Inclán, Quevedo o Goya, verdaderos representantes del expresionismo ibérico, sino va mucho más allá. Posee contactos con la pintura satírica flamenca de El Bosco y Bruegel, con la pintura de Pedro Berruguete, con la de Alberto Durero, con los retratos de los personajes marginales de Caravaggio, con la pintura de los bufones de Velázquez, con la pintura modernista de Ramón Casas o de Isidre Novell y con la pintura de expresionista de Solana y de Zuloaga. Esta estética se inscribe en territorio de la tradición del primitivo carnaval ${ }^{250} \mathrm{y}$ desde aquí se proyecta a la literatura ${ }^{251}$. En este sentido encontramos antecedentes en la literatura de Juan Ruiz, Arcipreste de Hita, en los pasajes deformes del Libro de buen amor, en la poesía de los goliardos, en el territorio de la literatura que se ocupa de la marginalidad que arranca en La Celestina y se desarrolla en la picaresca, sobre todo en El Buscón de Quevedo, y en la producción cervantina. En el caso de Cervantes, las líneas convergentes afectan tanto a sus entremeses como a su obra narrativa. También se encuentran convergencias entre el lenguaje expresivo cervantino, extraído de la marginalidad, y el lenguaje caótico y explosivo del esperpento que confluye en los romances postistas.

Por otra parte, los antecedentes teatrales de los romances postistas surgen de la estética carnavalesca que se halla en el inicio del teatro en la literatura castellana ${ }^{252}$ y en el teatro ambulante y popular, cuyo representante más conocido es Lope de Rudea. Los

${ }^{250}$ Oliva, César (2003), El fondo del vaso. Imágenes de don Ramón M. del Valle-Inclán, Valencia, Universitat de València, p. 85-86.

251 Bajtin, Mijail (1965); traducción de Julio Forcat y Cesar Conroy, La cultura popular en la Edad Media y en el Renacimiento. El contexto de François Rabelais, Vol. II, Madrid, Alianza Editorial, 1987, pp. 10-24. Para este autor, el carnaval surge de las fiestas paganas de origen agrícola que celebran la circularidad temporal y el renacimiento de la vida. Se trata de una parodia de los ritos serios y persigue la subversión de las ceremonias y de la ideología del catolicismo. Frente a la austeridad ideológica que la iglesia tenía reservada al pueblo, el carnaval propone la risa y el juego, la abolición de los límites sociales y la práctica del mundo al revés. La estética carnavalesca desemboca en el realismo grotesco y la práctica de la degradación.

252 Ibíd., p. 35. Para Bajtin, «el realismo grotesco se desarrolla plenamente en el sistema de imágenes de la cultura cómica popular de la Edad Media y alcanza su epopeya artística en la literatura del Renacimiento». 
pasos, los entremeses, las jácaras, las mojigangas... son representaciones festivas, espectáculos colectivos que celebran de manera humorística la alegría de la vida que penetrarán en el teatro barroco bajo los nombres de Cervantes y Hurtado de Mendoza, cuya expresión será el entremés. Otros antecedentes pueden observarse en el sainete paródico de Torres Villarroel y Ramón de la Cruz. Xosé Riveiro ${ }^{253}$ sitúa los antecedentes más próximos al esperpento, y por lo mismo antecedentes también del Postismo, en la literatura gallega burlesca e irrespetuosa que se manifiesta en las Cantigas d'escarnho e maldizer y en los introitos o carnavales. De aquí surge una rica tradición de formas teatrales populares que no poseen el estatuto del documento escrito como el teatro de fiesta, la representación, la catarsis o simplemente el espectáculo.

Para Pérez Lasheras y Saldaña (2000: 35) los romances postistas se inscriben perfectamente dentro del molde del disparate poético, practicado por Juan del Encina, cuyos antecendentes serían los dezires, las preguntas o los chistes poéticos. En este sentido, el eje central de los romances postistas es el elemento absurdo y disparatado. Línea que une la noción tradicional y barroca del mundo al revés con la irracionalidad extrema propia del surrealismo, que desemboca en la lógica extraña y paradójica del Postismo. Los romances postistas exploran la extrañeza y el sinsentido de la ciertas zonas de la pintura de Pieter Bruegel. El siguiente poema, perteneciente a Las patitas de la sombra, titulado como dos personajes rabelesianos «Gargantuel y Pantacrais» 254 posee contactos evidentes con la óptica disparatada de pinturas de Bruegel:

Una mierda pa tu boca

oh lector desconocido

el riñón desconectado

ya me baila en el ombligo.

¡Ay Quevedo folletines

cómo folla contra el frío!

Todos vanse a misa pronto

por oírse el sermoncillo.

Si uno solo te hace caso

qué te vale ser tan listo.

Cuatro carros a transporte

con doce yuntas servidos

hanse se han necesitado

y el rosario llenvaríanlo.

253 Riveiro, José (1994), «Valle-Inclán y Blanco-Amor», Barcelona, Anthropos, $\mathrm{n}^{\circ}$ 158/159, julio-agosto 1994, pp. 117-118.

${ }^{254}$ El título del romance parodia la obra de Rabelais Gargantua y Pantagruel. 
Cuatro mil golpes de pecho se acaba de dar un niño; la madre pide camilla y el infante pequeñito dice que quiere casarse por estar libre de vicios. Gargantúa apadrinándole le regala un obelisco, pide el niño una alta grúa y a propósito un bolsillo. Al borde de un ser humano se adelanta un precipicio.

El poema representa, pues, un mundo subvertido como lo es el universo satírico y expresionista de la pintura satírica de Pieter Bruegel. En Los refranes neerlandeses (1559) encontramos una verdadera antología del disparate que muestra los engranajes de la dinámica social de la época: la hipocresía, la apariencia, el arribismo... Todo ello queda ilustrado bajo la presencia de cientodieciocho refranes representados de manera plástica. En Juegos infantiles (1560) se presenta una sociedad que juega infinitamente. Más mordacidad poseen los juegos representados en La riña entre el Carnaval y la Cuaresma (1558), verdadera disección de un mundo al revés. Aquí se muestra el lado más corrosivo de la descripción social mostrando procesiones religiosas disparatadas y otros absurdos sociales.

Para Rafael de Cózar (2001: 240-243) la estética de los romances postistas es heredera de la tradición del disparate y de los juegos sonoros del siglo XIX, cuyas referencias más importantes son autores como A. Ribot y Fontseré y W. Ayguals de Izco. La estética esperpéntica de Valle-Inclán supone su revitalización:

¡El gato que runfla! ¡La puerta que cruje!

¡La gotera glo-glo-glo!

(«Rosa de pecado», El pasajero, 1920)

¡Tan! ¡Tan! ¡Tan! Canta el martillo, el garrote alzando están, canta en el campo un cuchillo, y las estrellas se van al compás del estribillo con que repica el martillo: 
¡Tan! ¡Tan! ¡Tan!

(«Garrote vil», La pipa de kif, 1919).

Ejemplos de esta poética del juego sonoro se encuentran también en varias obras que recopilan juegos de ingenio y formas literarias difíciles. Entre ellas cabe destacar los Estudios de humanidades o ensayo de versificación en los géneros que ofrecen mayor dificultad (1872) de Bartolomé Comellas, Esfuerzos de ingenio literario (1890) de León María Carbonero y Sol, Ejercicios de análisis y composición castellana (1894) de Ricardo Girón Severini, Las poesías más extravagantes de la lengua castellana (1920-1930) de Agustín Aguilar y Tejera o Rarezas literarias (1928) de Eduardo de Ory, padre de Carlos Edmundo de Ory .

A esta estética del absurdo grotesco hay que sumar el absurdo propio de la óptica surreal. La presencia del surrealismo poético realza todavía más la extrañeza y la sorpresa. En todos los poemas encontramos la presencia de la incoherencia surrealista en las imágenes y en las asociaciones libres. Así ocurre en este fragmento del poema de la obra Laocoonte y la luna, titulado «Romance para que no se diga»:

Para que no se diga te llevaré esta noche mis labios que han perdido los topes de la noche Me esconderé en los bronquios los bálsamos de Tolu y al albur de mis brazos un barranco habrá enfrente

$\mathrm{O}$ en este fragmento del poema «Romance con lápiz rojo» que pertenece a la misma obra:

Me cederéis en vínculo a la puesta del viento cuando engendran los rábanos patatas en el cielo O cuando suena a tientas la prez mortal del ángelus Sueño purpúreas flamas Sueño que trabo dulces 
monólogos contigo

Con ti la que la envidia

puso horquillas de fuego

Lo mismo ocurre en este fragmento del «Romance de Ariel» de las Patitas de la sombra:
Animal de cola larga
bicho que no tiene padre
espíritu de la alcoba
tú tendrás cama de estambre
y morirás en los dedos
regalados de un infante
La luna te hará un sudario
de papel de chocolate

$\mathrm{Y}$ en este fragmento del poema «Auras campestres» que pertenece a la misma obra:

La tarde que expira pronto

huyendo por las encinas

se adelanta, canta, tañe,

llora zánganos de mirra.

\subsubsection{Una poesía lúdica.}

El juego es uno de los presupuestos más importantes del Postismo, de aquí el carácter jovial y eufórico del movimiento que proponía desde una óptica lúdica rescatar la libertad de un lenguaje no sometido a los diques normativos ${ }^{255}$. El juego postista significó una radical provocación hacia el lenguaje y la cultura de su tiempo. Por ello los romances postistas suponen una ruptura del sistema poético convencional, ruptura que otorga al juego el papel principal de la práctica poética. Los romances postistas poseen un significado lúdico que desecha cualquier finalidad que no sea el propio juego. El juego libera el discurso de sus servidumbres tanto normativas como literarias, frente a ello tenemos una fractura poliédrica: fractura de la semántica, de la fonética, de la

255 En este sentido las tesis postistas se basan en las tesis orteguianas del arte intrascendente establecidas en La deshumanización del arte (1925: 20-21). Para Ortega la intrascendencia artística libera al arte de las ataduras del rigor formal y de los dogmas académicos y supone la apertura hacia la creación y la experimentación (1925: 50-52). 
sintaxis y de la poética. Pues la libertad queda desatada en todas direcciones creando un lenguaje ebrio y extraño que desborda todos los diques de contención. Este lenguaje de signo dadaísta, liberador y terriblemente experimental, puede observarse en el «Romance al poeta postista Silvano Sernesi» que forma parte de Laocoonte y la luna. Reproducimos algunos fragmentos:
¿Qué hetacordo lenguaje
sale de tus palabras!
¿Eres un eucalipto
de musicales plantas?
Ay estoy mal de veras
conviértete en estátua
tanto concierto ecoico
hace temblar mi casa
Meandrinas por mi cuarto
tubiporas coralias
cariófilas y fungias
anémonas y estreas
me salpican y crecen
por el cuerpo ¡ya basta!

Lenguaje que evoca totalmente el lenguaje experimental de la literatura más lúdica de Julio Cortázar. La literatura de Cortázar y el Postismo suponen dos movimientos que avanzan en paralelo y pretenden jugar con la ruptura del código lingüístico y experimentar otras vías de expresión. La cuentística de Julio Cortázar supone una intensa experimentación con los modelos narrativos y busca nuevos puntos de vista que rompen con el relato tradicional. Internamente el relato presenta dos realidades diferentes cuyo punto de contacto es un límite que las une, límite franqueable que supone un acceso a otra realidad diferente, mágica, maravillosa, onírica o terrible. Los romances postistas, efectivamente, surgen de lleno en esta otra realidad, mágica y terriblemente disparatada. Como la literatura de Cortázar, intentan romper todos los muros que impone la normativa literaria, todos los diques que impone la convención: la tradición literaria, el género dicursivo y el propio discurso lingüístico. Como los romances postistas, Rayuela (1963) es una obra que subvierte todos los esquemas: la novela como único producto lector, el discurso como productor de una única historia, el de la linealidad del discurso narrativo, el propio código lingüístico. Como ejemplo de este último aspecto citamos el famosísimo capítulo 68 de la novela, que supone un semántica subvertida: 
Apenas él le amalaba el noema, a ella se le agolpaba el clémiso y caían en hidromurias, en salvajes ambonios, en sustalos exasperantes [...]

En este fragmento se observan los contactos entre la subversión narrativa de Julio Cortázar y el lenguaje ebrio del Postismo. De este modo se expresan Eduardo Chicharro y Carlos Edmundo de Ory en Las patitas de la sombra, «Romance de Ariel»:

\author{
Libélula especialista \\ con tornasol de cambiantes \\ mosca topo pillo pato \\ trasgo loco del estanque \\ bulto móvil abalorio \\ serafín de las postales \\ reluciente abeja clara \\ clavada en los vendavales.
}

Experimentalismo poético que presenta su contrafactura con el conceptismo de Gracián y Quevedo, pues el concepto significaba el ensanchamiento contextual de un término poemático. En este caso resulta evidente el parecido que ofrece el texto postista con la décima titulada «El mosquito de trompetilla», escrita por Francisco de Quevedo:

\footnotetext{
Saturno alado, ruido con alas, átomo armado, bruja ave, aguijón alado, cruel sangrador zumbido, menestril, pulga, cupido, clarín, chinche, trompetero; no toques, mosca barbero, que, mosquito postillón, le vienes a dar rejón, sin ser marido, a mi cuero.
}

El juego poético se dirige a subvertir el funcionamiento de la sintaxis. De manera que frente a la coherencia discursiva, los romances postistas ofrecen un discurso deshilvanado, cuyo signo es la disonancia. Las palabras no se agrupan sintagmáticamente por sus valores semánticos, sino por su parecido fónico, por el ritmo o por su contraste. Tenemos pues una sintaxis disparatada o desbocada que libera a las palabras de la esclavitud de gramáticas y diccionarios. Se trata de un lenguaje que juega 
consigo mismo, tal como se muestra en los siguientes fragmentos del romance «El genio del mal, en forma de serpiente, tentando a Eva», que pertenece a las Patitas de la sombra:

¡Ay! ¿Qué vive? ¿Quién? ¿Por qué lo manda?

¡Vida de una hora la vive!

¡Vive! ¡Vive! ¡Vive de una llamarada!

¡Hijo de langosta, vete, muera!

¡Filibustero, mal parto, canalla!

Retintín, Kilimanjaro,

pitiminí de Alaska.

Tú el cocodrilo sin patas

la sérpula serpentaria

Espíritus, dejadle solo

con su violín y su espada

al hombre Adam, a la hembra

aletargada dejadla.

Un árbol como una escoba

echa a correr por las Pampas.

Desde entonces las gallinas

ponen huevos de manzana.

¿Sabéis lo que dio a luz Eva?

Dio a luz a una oruga.

Tenemos aquí la presencia de un lenguaje ingenioso que juega y se repliega sobre sí, heredero, según Cózar (2001: 243), de los antiguos juegos de palabras literarios como los acrósticos, los caligramas, los laberintos... Lenguaje que asocia las palabras mediante una lógica caprichosa donde las palabras escapan de su contexto semántico y adquieren nuevos sentidos. Esta sintaxis dislocada se observa perfectamente en el siguiente fragmento del romance «Como se dirá más tarde», incluído en Las patitas de la sombra:

Todo el río bajo el agua pasa el puente

Tus olvidos no me olvides son la planta

la raíz, el tronco adusto de mi infanta.

¡Con qué gusto por tus brazos te estrechara!

¡Con qué espanto por tus ojos me cayera!

¡Cuán castígame tu ira! 
Esta sintaxis extraña se nutre de la alteración de los segmentos sintagmáticos a la manera de la sintaxis ampulosa barroca de signo latinizante. El desplazamiento sintagmático y la presencia del hipérbaton se encuentran perfectamente en el discurso disparatado de los romances postistas. Así lo muestra esta fragmento del romance «Las patitas de la sombra»:

¿qué les pisa que es la casa

donde dormidos tan se hunden?

$\mathrm{O}$ el siguiente del romance «Recuerdo para morir con herencia», que pertenece a Laocoonte y la luna:
De la rompiente el reino
vi rebasar la espuma
de la fluial vendimia
De la colmena aquella
que hizo temblar el cielo
semejante borrasca.
¡Qué pávido quedéme!
¡Qué sobresalto abísico!

Este lenguaje extraño se retuerce y manipula, se distorsiona para que adquiera una plasticidad poética donde las palabras se asocian mediante una semántica extraña, como se observa en el poema oryano que pertenece a la misma obra «Canto magnífico a los pastores béticos»:
Venid pastores bellos errantes sedentarios penibética pena trayendo bueyes flacos Por lomas y lentiscos clamando en sus climáticos cabrerizos de oriente cual cismontano duende ¡Venid a mí los míos niñoncitos hombriantes seres de pan y queso mudos como las cumbres! 
En la «Historia de la hormona y el gusarapo», que forma parte de Las patitas de la sombra, encontramos el siguiente fragmento donde se juega con el significado ambiguo de la palabra «cerilla»:

\author{
Nicanor y su mujera \\ han pedido agua y lavabo \\ una cerilla se fuma \\ fuma selo se el cigarro \\ Y el cigarro se la fuma \\ la cerilla de la oreja
}

Esta semántica opera por la distorsión del significado que unas veces asocia las palabras mediante la similitud fónica como «clamando en sus climáticos» o por el contraste semántico, «errantes sedentarios»o «niñoncitos hombriantes». Sin duda, esta semántica ebria se basa en la disonacia y en la parodia ${ }^{256}$ y en el humor. Es la parodia de los modelos clasicos el eje estructurador de la poética de los romances postistas y esta óptica paródica opera también en el nivel semántico.

Este lenguaje ebrio se basa en el juego léxico, en la proliferación de cultismos, de vocablos arcaizantes, de vulgarismos, de expresiones escatológicas, de palabras inventadas, de etnologismos, del lenguaje popular, de expresiones propias de la oralidad, de palabras con incorrecciones gramaticales y de un léxico pretendidamente antipoético. La suma de todo ello crea un léxico extraño de signo expresionista, que busca una estética feísta y crea un lenguaje que puede defirnirse como una auténtica dinamita verbal. Para Amador Palacios (2001: 181) la elección de este lenguaje, que tiene su origen en la tradición carnavalesca ibérica, responde a que sus autores sabían que bajo las formas poéticas tradicionales se había escrito mucha heterodoxia. A esta heterodoxia se suma la radicalidad dadaísta y su liberación de lenguaje de los límites racionalistas. Se crea así un lenguaje extraño basado en un léxico anticonvencional, que Víctor García de la Concha (1987: 706) define como «ludismo verbal». Es el juego el gesto que articula todos estos elementos léxicos. En el poema de Las patitas de la sombra titulado «Dos que no se entienden» encontramos varios fragmentos que ilustran los mecanismos del juego léxico:

256 Pérez Lasheras y Saldaña (2000: 27) señalan el componente paródico de la subversión postista. 
No te entiendo libro abierto

Es que te hablo muy de prisa

$\mathrm{Y}$ enterastereteroso

No me entiendes lindo pino

Escucharasmeterelo

La tris la tris la tristeza

es un tris del Universo

Lo que di di di di dices

no me lo meremezcolo

Es tu silla de algo de algo

que me vengo con tu silla

con tu silla de oricalco

mi tristeza escapularia

nuestri ti tijeretazo

Apetito topa el topo

aúpa la úpupa del pato

¡Calla tu latín de iglesia

de ininenteligible diálogo!

¡Ele ele ele ele!

¿po qué has pomío tanto?

Qué liliácela y luna y lenta

qué lar de alas libó Lalo

que la losa que le alumbra

solamente es de asfódelo

A cual más galimatías

colorido colorado

dale dado dilo lido...

¿La le li? ¡lo lu! ¡escándalo!

La euritmia es una práctica poética del juego postista que consiste en la expresión de la musicalidad del discurso. Se trata del juego del lenguaje basado en su proximidad fónica. La música y el ritmo resultan ser el eje generador del poema. La euritmia provoca, como hemos visto ya, el ritmo discordante, la rima extraña, la repetición de un mismo sonido, el juego que se genera entre las palabras asociadas a partir de la proximidad del sonidos. De este modo se crea una poesía basada en el sonido y la disposición de la palabra, una poesía basada en la tradición de la palabra liberada, en la ruptura de los modelos poéticos ${ }^{257}$. Fue una vía de acceso a la posterior poesía experimental. Los romances postistas en su totalidad suponen un ejemplo de ello, no obstante los siguientes fragmentos forman parte de la práctica del juego postista:

${ }^{257}$ En este sentido el Postismo recupera la poética rupturista del cubismo, del dadaísmo y del futurismo. 
Musical mosquita muerta

Hijo, ¡vente a mis rodillas!

Toma pan y toma vino.

Toma almendra y toma espiga.

Toma esto y toma lo otro.

Tómate la toma tila

tómate lo que tú quieras

traga pan con la saliva

sorbe caldo poco a poco

toma rana y toma encina

toma toma toma come

come pan y toma hormiga.

(«Vida y muerte», Las patitas de la sombra).

-¡Ahé ayé aranda landa!

amarga pisa condena

bajo tu luz no te hundas

-Lucas desde la veredaaa...

-No me nombres obedece

¡Ahé de la mala hebra!

- ¡Aranda landa la casa!

-¡Cava-la-vaca-la-senda!

-No la cavo ni la podo...

-Mata las ramas más secas.

-¡Minerooooo!

-¿Por qué me llamas?

-¡Para arreglar una cuenta!

(«Romance del aprendiz de brujo», Las patitas de la sombra).

Cuando lleguen los trenes, cariño, por la noche, no tomará su leche que tiene miedo el nene que el nene que mi nene, que la nana mi nene, que la nona lo mece, que a la una la luna, que su mano le envuelve mientras canta el sereno que está sereno y llueve que llueve de puntillas 
que llueve que te llueve.

(«El niño sigue roncando», Las patitas de la sombra).

La noche pronunciaba

su sermón matutino

tras de sí de una voluta

nadie lo quiso dijo

decir lo quiso nadie

digo por negativo

vocablos o por flautas

(«Romance de Laocoonte y la luna», Laocoonte y la luna).

No dudes de mi imagen

ni dudes de los surcos

No dudes nunca nunca

de la sutil elipsis

Duda de la retráctil

mácula de los halos

pues estamos malditos

y pendientes de un hilo.

(«Romance del amigo sangriento», Laocoonte y la luna»). 


\subsection{POEMAS POSTISTAS DISPERSOS}

Mil caballitos persas se dormían en la plaza con luna de tu frente.

Federico García Lorca

Sin olvidar las dos obras postistas Versos de Pronto (1945) y Los poemas de 1944 (1973), la producción poética postista oryana posee dos territorios diferentes: el espacio de los romances postistas y la geografía, mucho más dispersa, de los poemas. Territorio este último mucho menos accesible, pues, aunque Carlos Edmundo de Ory catalogue su poesía en una serie de ciclos, esta posee una textura informe y a su vez poliédrica que imposibilita su clasificación. De hecho, la poesía oryana escrita entre 1944 y 1951 tiene evidentes signos postistas aunque quede integrada en obras pertenecientes a otros ciclos. De otro lado, la poesía postista quedaría conformada por los poemas que forman parte de Doblo-hablo (1945-1948) y por los poemas que se editaron en revistas literarias y otras publicaciones. Dolo-hablo no tomó forma unitaria al no poder publicarse en su día, pero podemos reconstruir su estructura a partir de la edición de sus textos en las publicaciones oryanas. La obra posee un breve estudio de Eduardo Chicharro, que funciona como prólogo, escrito en 1948 para la solapa de la edición no efectuada. Este aparece en la antología realizada por el propio autor en 1978, Energeia. Además la obra contiene el poema «Texto postista», especie de escritura automática estructurada bajo una disposición poética, los «Cinco poemas edmundianos» y el libro de romances Laocoonte y la luna, publicado íntegramente en la edición realizada en 1970 por Félix Grande.

Por ello la poesía postista quedaría conformada por «Soneto paranoico», que se publicó en la Revista Postismo y que queda integrado en la obra de romances postistas edmundianos Laocoonte y la luna, por el experimento vanguardista titulado «Texto postista» y por los «Cinco poemas edmundianos». A éstos podríamos añadir los poemas editados en otras publicaciones y que han sido recogidos en antologías posteriores, tal como se muestra en el apéndice III. Son poemas escritos entre 1945 y 1949. También podemos considerar que forman parte de la poesía postista algunos poemas que 
pertenecen a Poemas (1969), poemario que recoge poemas escritos entre 1946 y 1968. Este contiene la obra Negruras, compuesta por poemas creados entre 1946 y 1950, y el libro Los lejanos lejanos, integratado por poemas que se escribieron entre 1946 y 1964. Ambas obras se completan con nuevos poemas que aparecen en 1978, cuando la propia antología de Ory, Energeia, los ofrece al público, tal como se recoge en el Apéndice VI. Hay que considerar Poemas como una obra que supone un cierre y al mismo tiempo una apertura. De una lado, Ory abandona con ella (con muchos martices ya que los hallazgos postista y la impronta vanguardista se mantendrán en su poesía futura) la poesía postista $\mathrm{y}$, por otra parte, en ella se ofrece una poética de signo metafísico y místico. Poemas significa la inauguración del introrrealismo poético. Postistas pueden considerarse también los poemas «Costumbres orgánicas» y «Estudio de estética» (ver Apéndice III) que pertenecen a la obra Academia fantástica, obra formada por cinco poemas que Ory saca a la luz en su antología Energeia (Ory, 1987: 95-99).

La poesía postista supone una óptica más desde la que se ofrece el lenguaje extraño, onírico y automático, provocador y experimental que se hallaba contenido en los romances postistas y en otro tipo de expresiones, tanto literarias como artisticas, que se articularon alrededor de los órganos expresivos del Postismo. Recordemos que las revistas Postismo (1945) y La Cerbatana (1945) ofrecieron en sus páginas la teoría y la práctica del Postismo, práctica que se efectúa desde todos los discursos posibles: discurso poético, narrativo, teatral, pictórico y crítico. En los poemas postistas dispersos se encuentran todos los hallazgos de la estética postista: el acercamiento al surrealismo, la práctica de la provocación, el rechazo del discurso basado en la referencialidad comunicativa, la deformación expresiva, la libertad expresiva, la trasgresión experimental, la escritura lúdica y la euritmia. Ahora bien, la poesía postista oryana ofrece algunas particularidades que cabe señalar.

\subsubsection{Surrealismo y provocación}

Estos poemas dispersos contienen el lenguaje surrealista cuyo código fue ensayado anteriormente en Versos de pronto y En los poemas de 1944. El surrealismo prácticado por el Postismo establece una conexión directa con el surrealismo francés. Para Joaquín Marco (1972: 201-202), la poesía postista de Ory no proviene de los 
poetas surrealistas del 27, sino que bucea en los mismos postulados bretonianos. Para este autor, poesía oryana ofrece sus conexiones con la poesía de Cirlot y la de Brossa, dos poetas que llegan desde presupuestos diversos a un mismo lenguaje surreal. Para Fanny Rubio (1988: 116-118), en cambio, es la huella de Lorca, sobre todo la impronta de Poeta en Nueva York (1940), la que marca la presencia del surrealismo en la primera generación de posguerra y, sobre todo, en la poesía oryana. Ahora bien, el surrealismo oryano está fuertemente enraizado con la poesía poesía popular de Rafael Alberti y de García Lorca, dirección a la que se llega a través de la poesía naïf, de signo popular, juanramoniana. Frente a los poetas del 27, que practicaron el surrealismo poético, el surrealismo oryano ofrecía un componente teórico y una voluntad de erigirse como lenguaje poético particular. Los autores del 27 plasmaron los códigos surrealistas únicamente en una de sus etapas, para Ory el surrealismo fue la adopción de una lenguaje cuya práctica jamás abandonó. El lenguaje surrealista oryano significó, de un lado, la ruptura total con el lenguaje del discurso racional y, de otro, una óptica desde la que ofrecer la práctica de la provocación. Provocación que se ofrece en dos direcciones: de forma ideológica hacia la conciencia burguesa y de forma expresiva contra el discurso central establecido. De modo que tanto la ideología como la expresión sitúan el discurso oryano en la geografía periférica de la marginalidad.

La ruptura del discurso establecido se efectúa mediante la adaptación del lenguaje y de las técnicas propuestas por el surrealismo francés: escritura automática, poética onírica y asociación libre de objetos. Recordemos que, desde la situación sociocultural de su tiempo histórico, el regreso a los presupuestos del surrealismo en plena primera posguerra fue considerado como un anacronismo por parte de un amplio sector poético preocupado por una poesía humana que dirigía la mirada hacia la realidad más inmediata. La presencia de un lenguaje libre y provocador, basado en el automatismo psíquico y en la libertad creativa, hacía estallar los diques que trataban de contener la insumisión poética y encauzar la expresión constriñéndola en los estrechos límites de la expresión realista. La poesía oryana se edifica sobre un discurso deshilvanado, sobre una escritura ebria, que bajo los presupuestos de la definición oryana de la locura inventada establecida en el Segundo Manifiesto del Postismo (Grande 1970a: 293), rechazaba la lógica del discurso poético y proponía una poética basada en la relación lúdica de las palabras. Ello se muestra perfectamente en el 
siguiente fragmento del poema titulado «Amigo fuma» ${ }^{258}$, escrito en 1948 en casa de Francisco Nieva:
¿Qué muchacha misteriosa odiosa abre su armario de luna y saca sus pechos de verdad y de mentira y me estrega uno y a ti otro? Las putas están cerca de los cuarteles el viento anda despacio en su palacio.

Esta escritura deshilvanada, de signo totalmente surreal y onírico, se establece mediante una semántica dislocada y extraña en la que las palabras se rebelan contra la tiranía pragmática del significado y se enlazan en base a presupuestos lúdicos. De manera que el poema toma la forma de un simple juego de niños basado en la similitud de sonidos y en las asociaciones preconscientes. Lenguaje que produce versos como:

el viento anda despacio en su palacio

anteriormente citado o:

y descubro que vivo de restar animal vivo

y con otro animal malucho de ser mucho

que también pertenecen al mismo poema. La repetición y la disonancia son las claves de esa semántica ebria que articula otro fragmento del mismo poema:

En esta noche hay algo de navíos de carnaval de Navidad en Navacerrada de carne y vendaval noche de noche noche de San Bartolomé perdonamé noche de la Edad Media a media noche Noche del Renacimiento y de remordimiento Se oyen besos por todos los rincones de la casa.

258 Este poema se publica por primera vez en la antología Poesía abierta (1974) realizada por Pont, pp. 54-55; más tarde aparece en otras antologías y publicaciones: Metanoia (1979, 1990), llevada a cabo por Cózar, pp. 149-150, en El Postismo. Un movimiento estéticoliterario de vanguardia (1987), pp. 355-356, y en Música de lobo. Antología (1941-2001), pp. 298-299, obras realizadas por Pont. 
Aquí la similitud fónica es el enlace que amalgama las palabras. El término «noche» queda asociado a «navíos», que a su vez supone el origen de otras palabras como «carnaval», «Navidad», «Navacerrada». Es la presencia de los sonidos «nav» el elemento productor de tales vocablos. Por otra parte, del término «carnaval» se desprenden otros dos: «carne»y «vendaval». El proceso productor de tales términos quedaría esquematizado del siguiente modo:

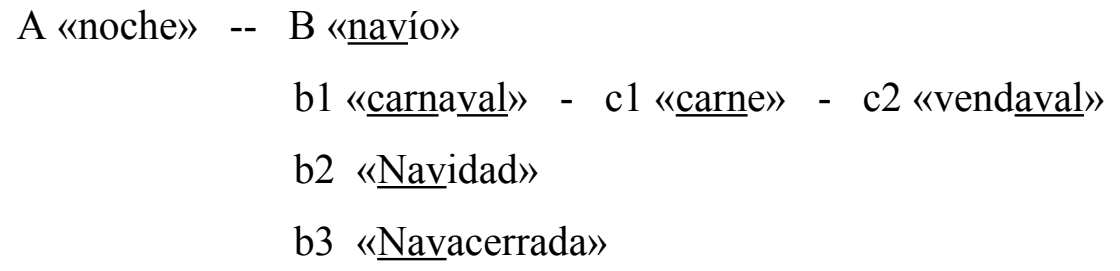

Por otra parte, la palabra «noche» se va enganchando con otras como «San Bartolomé» que se une con «perdonamé» por su similitud en la rima, de carácter arcaico. Esquematizamos el proceso poético del siguiente modo:

$$
\begin{aligned}
& \text { A «noche» -- } \mathrm{B} \text { «San Bartolomé» - b1 «perdonamé»» } \\
& \mathrm{C} \text { «Edad Media» - } \mathrm{c} 1 \text { «media noche» } \\
& \mathrm{D} \text { « } \underline{\text { Renacimiento }} »-\mathrm{d} 1 \text { « }
\end{aligned}
$$

Se trata, de algún modo, de la práctica de la asociación libre y del azar objetivo. Aquí es la proximidad del sonido el mecanismo que produce tales asociaciones. Ahora bien, en el poema también tenemos la presencia de la escritura automática:
Lucky Strike tazas portalámparas mi vientre está tranquilo mi culo está tranquilo mi cama y tu cama tranquilamente esperan que nos tumbemos a la barcarola tu madre y tu hermano friegan la sala de los valses tu abuela barre la luna con su cabeza muerta tu padre quita los piojos a los ángeles

El automatismo psíquico también está presente en «Poema de colores» ${ }^{259}$ que se publicó por primera vez en el Catálogo de la exposición 16 artistas de hoy que se realizó del 27 de abril al 10 de mayo de 1948 en la Galería Buchholz de Madrid:

${ }^{259}$ Aparece también en Verbo, Alicante, marzo-abril 1949 y en Metanoia (1987), ed. de Cózar, pp. 141-143. 
Compongo rosas mi corazón cantar cantar en el vientre escupe la almohada del tesón su camisa llega apartando caracoles tristes confituras de consuelo registran la amargura del elefante pobre pelusín de color y su frente de dinero pensativa no duerme ni planta acelgas en el bolsillo ajeno el tranvía chillando se avalanza a su madre en el oro del atardecer

La otra técnica surrealista utilizada por la poesía oryana es el viaje al insconsciente: explorar el subconsciente mediante la utilización de la simbología onírica. El lenguaje onírico permite a Ory adentrarse en el misterio de la realidad que se halla oculto a la conciencia objetiva. El símbolo onírico puede penetrar en el secreto y desvelar, como ocurre en la pintura de René Magritte ${ }^{260}$, las paradojas y las oscilaciones que se presentan en el plano de la realidad. Este lenguaje lo observamos en el poema «Estudio de estética», que pertenece a Academia fantástica y que se publica por primera vez en 1978 en Energeia, aunque fue escrito en 1949.

\author{
ARRIBA está la parte viva \\ de fuego incontestable de féretro \\ y de cristal de las llamadas \\ y de las llamaradas \\ del triste tren que rueda triste \\ Y el extraño marido de la noche \\ o el hombre suave \\ entre nosotros el que hablaba \\ hablaba familiar el que posó \\ $y$ jefe de la luna \\ con su susurro amargo \\ Podemos almorzar con la musa \\ que tañe solitaria \\ con el liviano fantasma color de humo \\ y largas cabezas de mulas
}

Al hombre triste al tren que zumba y que fornica oculto la noche de verano el tren

${ }^{260}$ Para Foucault $(1973,1981:$ 63-74), la pintura de Magritte escapa de las semejanzas y opera con las similitudes. La similitud escapa a la tiranía de la referencialidad y ofrece el contacto de unos objetos con otros, es decir la simulación. De modo que los cuadros de René Magritte son meros simulacros, objetos desgajados del plano de la realidad donde ellos mismo imponen su propio modelo. 
el tren de motor soñoliento

barría sacudía cocinaba

nubes en el histérico bote

mientras desciende el agua frágil

y torpe alhaja

El poema presenta una realidad misteriosa, un paisaje nocturno en el que un tren, descrito como un ataúd con cristales, viaja en la noche echando bocanadas de humo bajo la luna. El poema se presenta ante los ojos del lector de manera plástica, como si se tratase de un cuadro en el que se plantea un enigma. De hecho, el título intensifica la plástica del poema, de modo que éste queda convertido en un paisaje intrigante donde el tren avanza susurrando y gimiendo, como si hiciese el amor, y su humo al dispersarse se convirtiese en varias cabezas de mulas. Trasmutación del objeto de las mulas, que en vez de tirar del transporte, se alejan despedidas como nubes. Se trata de un tren que sueña, o más bien un tren soñado. Este paisaje enigmático está representado desde la misma óptica, en este caso poética, desde la que Magritte presenta un tren que atraviesa la pared de una chimenea y su humo se cuela por su orificio. En el cuadro de René Magritte, titulado La duración apuñalada (1938), se plantea una escena en la que se altera el funcionamiento de la realidad mediante un hecho extraño y ello hace que el impacto provocado llene de misterio todo el escenario. De manera que el espejo, la chimenea, los candelabros y el reloj adquieren proporciones inquietantes y enigmáticas al irrumpir en el escenario pictórico el tren atravesando la chimenea. El poema de Ory muestra también una realidad inquietante y alterada, donde el revisor del tren se erige como símbolo del hombre, amante, «marido de la noche» y «jefe de la luna».

En poema escrito en 1949 que se titula «Academia fantástica» ${ }^{261}$ y que está relacionado con el poema anterior, ya que forma parte de la obra Academia fantástica $^{262}$, contiene el mismo lenguaje onírico. Este poema es el primero que presenta mediante un lenguaje visionario la imagen del poeta como ser órfico, símbolo de una poesía que pretende desvelar el misterio de la existencia. El lenguaje onírico resulta idóneo para

${ }^{261}$ El poema aparece por primera vez en la antología realizada por Pont, Poesía abierta (1974), pp. 63-64. También se publica en El Postismo. Un movimiento estético-literario de vanguardia (1987) del mismo autor, pp. 357-358 y en la última antología que Pont preparó, Música de lobo. Antología (1941-2001), pp. 309-310.

${ }^{262}$ Academia fantástica consta de seis poemas escritos entre 1949 y 1952. Aparece en Energeia, pp. 95-99. A ellos hay que sumarle el poema que lleva el mismo título. 
presentar al poeta como mago y medium a la manera de William Blake. Así ocurre este fragmento:

Es tu secreto de sonámbulo

Porque nadie es capaz de no dormir

sin pijama sobre un cajón de huevos

Con la cabeza vendada de abejas

el noble heredero de Orfeo doma

el largo caimán

Este lenguaje surreal ${ }^{263}$ toma la impronta de la provocación, violenta y agresiva. Verdadera actitud de enfrentamiento contra otras actitudes poéticas coetáneas.

\author{
El poeta enterizo entrega sus mamas \\ y no va a los banquetes ni salona ${ }^{264}$ \\ como los favoritos de la fama \\ los versolaris de gaita y tatatá \\ Ellos sacan sus pechos de pelota maciza \\ y enseñan dentaduras de caballo \\ se suben a los pianos los revientan \\ Y ríen como flores matinales \\ Leen libros que son bronquios \\ conocen el problema de la noche \\ el porvenir de las piadosas piedras \\ $\mathrm{Y}$ escupen sangre de sufrir a solas
}

Se trata de una poesía convertida en metapoesía, una poesía que habla de sí misma y de la función del poeta, que declara la concepción poética, terriblemente vital y visionaria, del propio de poeta y de la poesía que escribe: una poesía mágica, que surge de la vivencia misma del ser, de la vívida intimidad y que declara perseguir el enigma de la existencia. La metapoesía será una de las constantes que queda enraizada en la espiral de la poesía oryana.

${ }^{263}$ Bousoño (1979: 82-83). Desde la óptica bousoniana, se puede definir la asociación libre y, por extensión, el lenguaje surrealista como la unión de tres presupuestos: la inconexión lógica, la iconexión emocional y la ruptura entre la relación el desencadenante y el desencadenado.

264 Sic. 


\subsubsection{Sueños eróticos.}

Otra dirección de este lenguaje surrealista provocador es la erótica, una erótica basada en la idea de la belleza convulsa, presentada por André Breton (1964: 190) en Najda (1928) en las últimas palabras que cierran la novela: «La beauté sera CONVULSIVE ou ne sera pas» ${ }^{265}$. El amor queda convertido en el oscuro objeto del deseo (recordando el film de Buñuel) porque es una amor tumultuoso que surge del propio tuétano y se expande hacia afuera hasta alcanzar las distancias infinitas del cosmos. Un amor cuya vibración afecta a cada átomo de cada ser vivo. Se trata de un amor cósmico que surge del pozo oscuro de incosciente, ese sótano humano alimentado por la frustración y la represión, ligado a las fuerzas telúricas cuyos flujos no pueden contener los diques y los muros que la civilización y su cultura edifican. El poema «Vientos de invierno» ${ }^{266}$, escrito en 1948 y publicado ese año en la madrileña revista Raiz, presenta un amor que se transforma en un beso cósmico, un beso terrible que surge de la oscuridad y que irradia su energía en todas direcciones. Besa la noche, el viento, la sombra, los seres, la muerte. Todo participa en este beso cósmico:

Cuando se besan nuestras bocas en la noche

Cuando se besan de noche nuestras bocas

Cuando de noche la noche besa al suelo

allí lejos se enfrían allí lejos

allí lejos el gran invierno gime

allí lejos el gran lejano trueno

lanza un suspiro inmenso y besa al mundo

Te escucho oh beso tumultuoso

corazón de estearina caliente

oh la noche es una boca de negros dientes

y nos besan bocas de animales grandes

bocas pequeñas de animales grandes

bocas de mina y nalgas de la noche

pasos de paquidermo sobre el vientre

${ }^{265}$ Artaud (1938: 104-110). El teatro de la crueldad significa el mismo gesto convulso que supuso la revolución surrealista, este pretende agitar las conciencias mediante la presentación de la violencia y de la autenticidad de la experiencia mítica. La representación mítica de lo humano se dirige a un territorio más allá del racionalismo. Por ello concuerda perfectamente con estas parabras de Breton.

266 Raíz, Madrid, $n^{\circ}$ 3, diciembre 1948, p. 15. También aparece en Cuadernos Hispanoamericanos, Madrid, n 182, febrero 1965, p. 240; en Poesía 1945-1969 (1970), ed. de Grande, p. 82, en Metanoia (1979, 1990), ed. de Cózar, pp. 143-144; en la antología Poesía surrealista en españa (1974), ed de Pablo Corbalán, Madrid, Centro, pp. 245-246; en Antología de poesía postista (1998), ed. de Herrero, pp. 127-128 y en Música de lobo. Antología poética (1941-2001) (2003), ed. de Pont, pp. 296-297. 
Salta en invierno con sus muslos de nieve

Salta y agita sus brazos de ladrillo

Salta como un horrendo gorila beodo

Besamos ojos de mujeres bestiales

Nos besamos besando la nada y la sombra

besamos las bocinas de automóviles fríos

de barcos fríos con faroles tristes

besamos encendidos termómetros de hielo

dentro de la habitación habitual conventual

En este fragmento observamos cómo el terrible beso que surge de las entrañas de la noche irrumpe como un estallido e, inmerso en un movimiento expansivo, va pasando de objeto en objeto. Beso oscuro ligado al secreto, al deseo oculto y telúrico, que asciende a la superficie. En el poema las imágenes se enganchan formando un cadena de términos que se asocian mediante diversos signos de sugestión. El elemento real A «beso» se asocia con B «noche», que a su vez sirve de enlace de otros elementos imaginarios: B1 «frío», B2 «invierno (que gime)» y B3 «trueno». Este amor oscuro, cuyo símbolo es el «beso tumultuoso», está inmerso en un movimiento cósmico que pasa de interior a exterior. Amor que reside dentro de los seres, en la «estearina» de sus grasas, en los «dientes»y en las «nalgas», y en el interior de la tierra, en la «mina». El amor es un «beso», este es el término real A que ahora queda asociado al elemento evocado $\mathrm{C}$ «boca» $\mathrm{y}$ de aquí se desprenden otros elementos más: $\mathrm{C} 1$ «mina», $\mathrm{C} 2$ «nalgas (de la noche) D1» y C3 «pasos (de paquidermo) D2». El amor que emana del interior surge, en la tercera estrofa, hacia el exterior. Aquí el desarrollo imaginativo recorre varios elementos. Una nueva imagen asocia A «invierno» con B «gorila», y de B se desprenden otros términos visionarios: $\mathrm{B} 1$ «muslos» queda asociado con $\mathrm{C} 1$ «nieve», B2 «brazos» se asocia con C2 «ladrillo». Son asociaciones de objetos que resaltan la frialdad, no sólo de los elementos naturales de la realidad, sino de los objetos manufacturados producidos por la civilización y que funcionan como símbolos de la ciudad y el tráfago de la sociedad occidental: «bocinas de automóviles», «barcos», «faroles», «termómetros». La estrofa termina de forma paradójica con la coincidentia opositorum «besamos encendidos termómetros de hilo». Paradoja que se desarrollará a continuación:

Estamos en un hospital de muertos crisantemos estamos dentro de una nevera encendida 
estamos bajo un palacio de mantas invernales

y los besos los besos lloran todavía lejos

todavía lejos en los campos en las nubes

Los términos paradójicos ligan los símbolos sociales con la ausencia de amor: «hospital de muertos», «nevera encendida», «mantas invernales». Mientras el amor queda ligado a la realidad exterior natural: «campos»y «nubes». El final del poema señala la concepción del amor cósmico, telúrico y oscuro, ligado a la vida y también a la muerte:

Se besan los hombres de la muerte en el viento

Se besan los vientos y la noche y la muerte

El invierno baja de un tranvía esta noche

Damos besos en la pared estamos solos

Estamos solos estamos solos en el humo del té

Amor, que es danza incesante que liga la vida con la muerte. Amor que es existencia, vida y muerte unidas en cada instante. En el instante habita el amor como lo hacen también la vida y la muerte. Amor que habita sobre todo en la soledad. El poema supone la escenificación de una serie de encuentros, en ellos se deslizan o, en algunos casos, chocan diversos objetos. De estos encuentros surge un escenario sombrío y terriblemente sorpresivo, donde la noche nos remite a los paisajes del sueño, tal como ocurre en la pintura de Paul Delvaux. En este escenario nocturno se desatan las realidades del inconsciente: la represión de la desnudez y de la sexualidad, la presencia de la muerte y de la destrucción y la violencia que, escondida detrás de los objetos, anida en cada instante. El poema oryano, al igual que los cuadros de Delvaux, nos muestra una cósmica danza macabra en la que eros y thanatos se dan la mano. Ese es el significado del amor presentado por Ory, conjunción de amor y muerte. Amor que fundamenta la vida.

La misma ligazón entre el amor y la muerte se observa en el poema escrito en 1949 que se titula «Los días como brazos de mujer». Poema que Ory incorpora a Los lejanos lejanos en 1987 en su antología Energeia ${ }^{267}$. En él la imagen de la mujer, como sugiere Dalí en su pintura ${ }^{268}$, se metamorfosea en un cuerpo amenazante en el que están presentes, como símbolos, multitud de elementos escatológicos que la asocian a la

\footnotetext{
${ }^{267}$ Obra cit, pp. 89-90.
} (1929).

${ }^{268}$ Ver El juego lúgubre (1929), Primer día de primavera (1929), Placeres iluminados 
putrefacción. La representación daliniana de la mujer la dota de la presencia de multitud de objetos punzantes y cortantes que aluden a la mutilación. Ory se apropia de esta óptica daliniana ${ }^{269} \mathrm{y}$, explorando la simbología onírica y mediante la utilización de la asociación libre, logra presentar una geografía poética inquietante y perturbadora donde lo bello y lo siniestro se alían ${ }^{270}$. Como producto de esta alianza surge una erótica misteriosa en la que se despoja el velo de lo bello para que lo siniestro aparezca en escena. El poema se estructura bajo la imagen que asocia la mujer con los días, es decir, el tiempo, la existencia.

LOS días se pueden ver como un brazo largo de mujer no conozco otro añadido pero desafiando todo himen matutino al despertar estirando serpientes

Así los días ya no un rabo un específico sistema de redondez y de deseo son las fechas como un brazo femenino las he visto tiradas en el lecho y dulcemente heridas en su eros porfiado sucumben después se yerguen melenudas como animales lentos ¿Quién las hizo? ¿Quién hizo los días? Una mujer y un día tornan estallido feraz destila miel y melenas lo comparo a instantes de lameduras abandono donde el serrín del tiempo hace su nido

Tiempo y deseo, visto como lo curvilíneo («redondez» que sería símbolo de la feminidad, redondez de los senos, de las caderas), se unen en una erótica amenazante que se produce en el escenario de un cuerpo cuyos atributos preludian lo siniestro: «serpientes», «serrín», «estallido». Es el tiempo quien une eros y violencia («las he visto tiradas en el lecho y dulcemente heridas», «estallido feraz», «instantes de lameduras») en un espacio oscuro, que supone otra imagen que se desarrollará en las siguientes estrofas:

${ }^{269}$ El interés de Ory respecto a la pintura de Salvador Dalí puede observarse en algunos pasajes de su diario. El 18 de enero de 1952 Ory (2004, Vol I: 173) escribe: «Debo preparar Mèphiboset para tenerlo listo antes de que llegue un editor. Quiero que esta novela me la ilustre Dalí».

${ }^{270}$ Ver Trías, Eugenio (1982), Lo bello y lo siniestro, Barcelona, Seix Barral, $8^{\mathrm{a}}$ ed., 2001, pp. 27-28. Para el autor, lo siniestro es la condición y límite de lo bello. Es lo siniestro lo que dota a lo bello del poder de fascinación. 
$\mathrm{A} \ll$ mujer» $=\mathrm{B} \ll$ noche»

Sí la mujer es un túnel dentro del sol ${ }^{271}$

Sus piernas tienen siglos de paciencia

Acostada es un túnel de huesos elegidos

y el bosque de las horas censura su pereza

Comparas mal la mujer ya es la noche

de pestañas atribuidas a ratas de charco

Esos cisnes se hundieron en un deseo más

de Leda insatisfecha ¿donde amarras tus ojos?

Mujer que es B1 «túnel» (C1 «dentro del sol» + C2 «de huesos elegidos»), cuerpo oscuro cuyas «pestañas» son «ratas» $(\mathrm{A}=\mathrm{B})$. Mujer que es tiempo, porque el amor es muerte, simbolizada por la «ceniza», el «sueño» y la «tumba»:

Los días cargados de besos acosa al hombre

un seco brazo un seco muslo piezas secretas

productos de muerte serán favorables fracasos

que enseñan alhajas y cintas portátiles

¡Deseo los días las horas deseo el deseo!

$\mathrm{Y}$ atizo tu lumbre mujer en tus brazos

amontono ceniza en tus piernas desnudas

Sin esas costumbres extremas el cuerpo blancuzco

sin eso lo mismo que el tiempo sin días

los días sin horas ahí tu cabello

¿qué es el amor ululando en la tumba del sueño?

271 En la tradición precristiana, en las cosmovisiones primitivas animistas, en las religiones solares, en el hinduismo y el tantrismo... El universo fue creado por una acto de amor entre la luna y el sol, por ello el fuego, la llama ha sido el símbolo universal básico del amor. Jung (1951, 1963: 161-164) interpreta la creación del fuego como la metáfora del acto sexual y señala que la vinculación del fuego con la sexualidad se produce en todas las culturas. En el tantrismo el fuego estaría provocado, al igual que en el rito de la creación del fuego, por la unión del lingam (pene) y el yoni (vagina). Las lenguas de fuego de las diosas hinduístas simbolizan, para este autor, la energía sexual. Para Mircea Eliade (1956, 1974: 39-40) la primitiva producción del fuego supone un ritual que reproduce la creación del mundo, el fuego es así producido por la sexualidad y tiene una doble dirección simbólica. Por una parte tenemos el significado de crear, de encender, significado que en la cultura occidental asociamos con la figura del ser supremo, el Dios creador. De otro lado, tenemos el significado de abrasar, de la destrucción, significado que queda asociado a la figura del diablo. La imagen del fuego en la herencia platónica se asocia a la purificación. El propio Freud (1900, 1966, Vol. III: 120-121) señala que la producción del fuego simbolizaba el acto sexual para los antiguos indios americanos y para los habitantes del África meridional. 
En lo más profundo se esconde la imagen del deseo de muerte, pues el cuerpo femenino, simbolizado por el «seco brazo» y el «seco muslo», no es otra cosa que el cuerpo de la muerte.

El lenguaje surrealista, con sus indagaciones en la oscuridad del subconsciente y con su voluntad de desvelar los secretos más escondidos del deseo, es el vehículo de la erótica oryana. En poemas como «Erzulie (icono creolo)» ${ }^{272}$ o «Soneto a Greta Garbo ${ }^{273}$, ambos escritos en 1947, el cuerpo de la amada se convierte en puro fetiche, objeto de verdadera adoración de una profesada sexualidad sagrada. El poema queda convertido en ceremonia, en la que el sentimiento oscuro que subyace a la culpabilidad irrumpe, como una profanación, en el escenario del amor. Ello se observa en estos versos de «Erzulie (icono creolo)»:

La lumbre celestial de tu semblante y el negro humo de mis manos tiernas mis pesadillas y tus maravillas

El sentimiento de culpabilidad aparece en la poesía oryana mediante la presencia del dolor y de la oscuridad, cuyos símbolos son la sombras, el humo, el llanto. Por ello existe un paralelismo claro con la pintura de Dalí, donde el sentimiento de culpabilidad (asociado a la sexualidad y sobre todo a la masturbación) aparece expresado por la presencia de los insectos ${ }^{274}$. Recordemos aquí la secuencia de Un chien andalou (1929), dirigida por Buñuel y Dalí, en la que un hormiguero surge de una mano. Sentimiento de dolor produce la imagen contenida en «Soneto a Greta Garbo», en la que se asocian los términos «corazón» $\mathrm{y}$ «abeja» en el juego amoroso imaginario:

${ }^{272}$ Publicado por primera vez en 1978 en la antología que el propio Ory preparó sobre su poesía, Energeia, p. 82; también aparece editado en la antología de Pont, Música de lobo. Antología poética (1941-2001), p. 228.

${ }^{273}$ Aparece por primera vez en 1963 en Los sonetos, p. 88; luego en la antología realizada por Grande en 1970, Poesía (1945-1969), p. 75; también forma parte de la antología Poesía erótica realizada en 1974 por M. R. Barnatán y J. García Sánchez, p. 293; aparece también en Metanoia (1978), antología realizada por Cózar, p. 136; recogido en la obra de Pont El Postismo. Un movimiento estético-literario de vanguardia (1987), p. 353; asimismo en Antología de poesía postista (1998) realizada por Raúl Herrero, p. 126; y en la última antología de Jaume Pont, Música de lobo. Antología poética (1941-2001) (2003), p. 229.

${ }^{274}$ Ver La mano. Arrepentimiento (1928) o El gran masturbador (1929) 


\begin{abstract}
Ábreme las dos puertas de tu casa quiero besar tu boca que me deja adivinar el aire cuando pasa tu corazón envuelto en una abeja
\end{abstract}

Dolor que equivale a putrefacción, cuyo significado tendría además otro referente sexual más escondido en los últimos versos de este poema.

Quiero besar tu boca en estas horas muertas que mueres tú también de una supuración de amor algunas veces

Muerte, que es orgasmo, petite mort. Como en la pintura daliniana, la simbología onírica y surrealista enmascara el teatro de operaciones de la sexualidad.

En cambio, el deseo no sólo se simboliza mediante la sombra y la oscuridad. También el amor es luz cuando significa unidad, unidad entre el cuerpo de los amantes y unidad entre el cuerpo individual y el cuerpo cósmico, el todo. En este caso, erótica significa totalidad. El amor luminoso es el que se expresa en el poema escrito en 1948 titulado «Canciones de despedida» ${ }^{275}$. El amor queda liberado de todas sus ataduras: la culpabilidad, la represión y la frustración. También desaparecen la simbólica siniestra y ahora asistimos a la plena unidad amorosa que trasciende el mero contacto de los amantes y conlleva a su vez la unidad de lo interior y de lo exterior. Unidad que supone una relación de armonía de los sujetos amantes con la realidad, la perfecta integración en el todo cósmico.

Tumbo los ojos primero en el limbo

Después origino la luz del encuentro

\title{
$[\ldots]$
}

La culpa expulso de mi frente

Nunca a la lluvia se le dice adiós

Frente al amor como oscuridad el poema opone el amor luminoso que reside en la imagen velada del «amor» (A) como «luz»(B).

${ }^{275}$ El poema se publica por primera vez en 1974 por Pont en Poesía abierta, pp. 49-50. 
Pero la luz que vehicula los ojos

Luz que recorre en película interior sube y baja empleando el movimiento que ciencia es la caricia diestra

\section{$[\ldots]$}

Una amistad aquí nos reune y borra

El mundo y el amor antaño disputaron

El amor luminoso supone una erótica que trasciente el propio cuerpo de los amantes y va más allá irradiando su armonía hacia el exterior. No existe oposición entre los amantes y la realidad, el deseo amoroso queda fundido en la realidad como si se tratase de una erótica mística. Si en el poema «Erzulie (icono creolo)» asistíamos a una amor que suponía la adoración de un fetiche:

Erzulie diosa del amor y amante mis besos suben lentos por tus piernas de madera y me postro de rodillas

Ahora tenemos frente a nuestros ojos la presencia de una sexualidad sagrada, alquímica, que transforma a los amantes y cuyo símbolo es el «ámbar»:

Y nuevamente en el lenguaje acústico pido un flexible afecto en lo compacto con o sin que el ámbar de ti brote

Amor sagrado, místico, total, luminoso... buscado por el yo amante. En este sentido, encontramos la huella de la sexualidad sagrada del tantrismo. Tanto en el tantrismo clásico de la India, que surgió del hinduismo con el que mantuvo un estrecho contacto, como en el budismo tántrico, se busca la unión con Brahman a través del amor erótico y del placer transgrediendo los códigos de una mística ascética. Para Jean Varenne (1977, 1985: 23) el tantrismo supone un camino hacia la mística que recorre la vía del placer, donde la sexualidad es un medio adecuado para la expansión de la conciencia. Si en la tradición religiosa occidental el triángulo simboliza la divinidad (símbolo cristiano de la trinidad), en el tantrismo el mandala, establecido sobre la cuaternidad ${ }^{276}$, señala el ${ }^{276}$ Sic. 
centro, origen e imagen del universo, cuyo significado apunta hacia la perfección de la realidad en el ahora instantáneo. Y en el centro se halla el triángulo invertido, símbolo de la sexualidad (de la feminidad) ${ }^{277}$. Triángulo que se une al triángulo vertical, la superposición de los dos señala la unión amorosa, la sexualidad sagrada. Imagen que apunta, al fin y al cabo, a la unión de contrarios. En este sentido funciona la simbología del «ámbar», término que apunta a la simbólica de los metales y de las piedras preciosas en la alquimia. En este sentido, el oro, la piedra filosofal, no es otra cosa que la transformación mística (Eliade, 1956, 1974: 50; Jung, 1942, 1989: 45). En el tantrismo, creencia que une hinduismo, budismo y alquimia, el diamante, imagen del semen, simboliza la mística de la unión sexual, la unión entre el Atman y Brahma. Unión que simboliza la iluminación o budeidad en el budismo tántrico (Varenne, 1977, 1985: 148149). En la alquimia taoísta el cinabrio puro o el elixir de la larga vida son símbolos de proceso de trasformación interior (Watts, 1963, 1990: 78-79). Se trata, pues, de un amor sagrado, místico, que afirma desde la experiencia de la unión de los amantes la unidad del universo, la pertenencia al gran océano de la totalidad.

\subsubsection{Hacia un lenguaje experimental}

Otra arista de la provocación postista apunta a la experimentación poética. El carácter lúdico, subversivo y humorístico del Postismo busca un lenguaje que se aleje tanto del lenguaje grandilocuente y clasicista del poder, como del lenguaje realista tan en boga en la posguerra poética. La experimentación postista surge del sentimiento de alegría y gratitud y se transforma en juego. En estos poemas postistas dispersos el poeta parece un niño que disfruta mientras juega con las palabras. Esta actitud poética queda perfectamente expresada en el diario oryano (2004, Vol. I: 36):

\section{4 octubre}

¡Risa! ¡Risa! La risa es todo. La poesía es risa. La vida es risa. Lo profundo es risa. Y la risa es el canto de los órganos. La risa es el canto de la materia... (Imposible expresar nada esta noche).

${ }^{277}$ Mircea Eliade $(1956,1974: 41)$ interpreta el simbolismo del triángulo como la imagen que representa el delta como significado de matriz y fuente. Signo que remite a la vulva. 
En el poema «La virgen del Aprisco» ${ }^{278}$, poema escrito en 1947 , aparecen varios juegos lingüísticos:

La lana de la luna la cieluna

el humo que en la loma se amotina

Aquí las palabras se unen por su similitud de sonido, claro ejemplo de paronomasia: «lana», «luna», «cieluna». Palabra esta última creada mediante la unión de «cielo»y «luna». En el verso siguiente la eufonía se crea mediante sonidos parecidos «umo»y «oma»: «humo», «loma», «amotina». Se crea así un ritmo interno basado en la disonancia. En el poema que se titula «Un verso», escrito en 1954 y que se publica este mismo año en Garcilaso $^{279}$, asistimos al siguiente juego de palabras que tiene la forma de un galimatías:
Coge de mi tacto a tientas
coge todas mis cosas:
helicón heliotropo
la troglodita losa
de mis huesos el uro
de mi sangre la choza
de mis huesos ¡los ojos!
Oh manatial que anochas

En este caso tenemos frente a los ojos aquello de Samuel Levin (1962, 1979: 22) llamó couplings, unas parecidas estructuras que se reiteran. Estructuras sintácticas en el caso de los versos quinto, sexto y séptimo, y estructuras puramente fónicas en otros casos. La similitud de sonido es la operación que une las palabras:

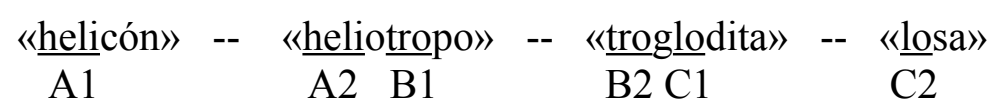

${ }^{278}$ Este poema se publica por primera vez en la revista Dabo, $n^{\circ} 1$, Palma de Mallorca, 1951, p. 9. Con posterioridad se publica en diferentes ediciones: Historia y Antología de la Poesía Española (1951), ed. de Sainz de Robles; Poesía (1954-1969) (1970), ed. de Grande, p. 78; Metanoia (1978, 1990), ed. de Cózar, pp. 138-139; Antología de poesía postista (1998), ed. de Herrero, p. 127; Música de lobo. Antología poética (1941-2001) (2003), ed. de Pont, p. 232.

279 Garcilaso, $\mathrm{n}^{\circ} 28$, Madrid, agosto 1945 , p. central. El poema aparece publicado también en Poesía abierta (1974), ed. de Pont, pp. 20-21. 
El poema escrito en 1948 y titulado «Poema de colores», del que anteriormente ya se han comentado algunos rasgos, supone un ejemplo de este lenguaje lúdico y naïf. En él asistimos a varios procesos que alteran en funcionamiento léxico como la invención de palabras, la práctica de la jitanjáfora o el juego rítmico, tal como ocurre en el siguiente fragmento:

La noche que todos dormimos sin dormir las uvas ríen ríen muchísimo el Jabalitos el Jubalitis el Paltonis el Chunchaluris eran las nubes

Otras palabras inventadas atraviesan el poema como signos, pinceladas, tachaduras o marcas que estructuran el poema y realzan la impronta transgresora de este lenguaje disparatado: «bolita palentúlica», «se encontró / con un jalotis y con un paluchi», «La comarruga de antrofálogos», «jugar al zapatulis», «salacularteno».

En el poema, también comentado anteriormente, «Amigo fuma» asistimos también a este lenguaje marcado por la locura inventada basado en la sintaxis ebria y la proximidad fónica. Existen en él juegos de palabras como «menteloca», «fumamigo»y expresiones como «malucho de ser mucho» $\mathrm{o}$ «el viento anda despacio en su palacio».

En «El hombre de los palomares sucios ${ }^{280}$, escrito en 1947, el lenguaje poético se sustenta en la constante reiteración de estructuras sintácticas, en la rima extraña y en el juego fónico:

¡Qué horribles son sus labios cuando habla! ¡Son horribles sus piernas! ¡Son horribles sus labios! Y sus piernas son sus labios

Aquí esta ese hombre solo en una tabla haciendo gestos ininteligibles llenando a Dios de oprobios y de agravios

Proximidad fónica que une las palabras «aprobios» y «agravios» y extraña reiteración fónica que establece la rima «habla» $\mathrm{y}$ «tabla» o «labios» $\mathrm{y}$ «agravios». En todo caso

280 Aparece en Poesía (1954-1969) (1970), ed. de F. Grande, p. 72 y en Música de lobo. Antología poética (1941-2001) (2003), ed. de J. Pont, p. 230. 
cabe señalar que la repetición de las permutaciones de los sonidos /b/ y /1/ estructuran este fragmento poemático: «horribles», «labios», «habla», «tabla», «ininteligibles»». Lenguaje basado en los diversos couplings fónicos y sintácticos.

En el poema «El rey de las ruinas» ${ }^{281}$, escrito en 1947, Ory recrea mediante ciertos rasgos teatrales, propios de la comedia burguesa, y algunos coloquialismos, una conversación entre la asistenta de la casa y el Yo poético, papel que representa el poeta maldito:

Entro llamo ay ay ¡Señorito! ¡Ay! ¡Ay!

No puede ser así usted no se parece ¡Aparición! ¿Quién soy? Te pido yo una cama para abrigar mis labios con un sueño anticuado No te pongas así no te asustes de mí ¡Ayaymiseñoritoustedyanoeselmismo! Parece usted de veras un cansado harapiento Me da pena su ombligo lleno de soledad Ropa y candela dióme y cené con la vieja con la comadre atónita que mientras reza Riendo yo le explico «Soy el rey de las ruinas» Y ella plasma un quejido «¿Qué es eso señorito»

Este lenguaje nos recuerda al lenguaje empleado en los romances postistas, debido al trasvase de registros lingüísticos y a la voluntad experimental, que transgrede los límites que, como muros de contención, encorsetaban el discurso poético. La óptica lúdica de Ory, que crea versos como «¡Ayaymiseñoritoustedyanoeselmismo!», supone una enorme fisura en el edificio del clasicismo poético.

Estos juegos poéticos, tremendamente fútiles, intrascendentes e irreverentes, significan una apertura hacia una poesía libre, que se sacude la asfixiante normativa poética de la época y traza una línea que fructificará en la futura poesía experimental profesada por la vanguardia de posguerra. En la poesía oryana el juego postista desemboca en el lenguaje experimental donde Ory atraviesa territorios poéticos marcados por el concretismo poético, el letrismo, la poesía visual...

${ }^{281}$ Se publica por primera vez en Pepeles de Son Armadans, $\mathrm{n}^{\circ}$ 164, Palma de Mallorca, noviembre 1969, p. 169. Aparece también en Poesía (1945-1969) (1970), ed. de Grande, p. 76 y en Metanoia (1978, 1990), ed. de Cózar, p. 137. 


\subsubsection{Una poesía metafísica}

La poesía oryana va adquiriendo un sentido metafísico que trasciende la voluntad provocativa del Postismo y va convergiendo con las preocupaciones de signo metafísico, mágico y místico propias de la aventura introrrealista. Entre ambas concepciones no existe un corte radical que las separe, ni tampoco hay una obra que sirva de límite geográfico entre ellas, sino que existen múltiples puentes y diversas puertas que hacen de vías de conexión. La preocupación por la expresión de la interioridad y por el carácter misterioso y metafísico de la poesía se va acrecentando en el postismo poético oryano a medida que pasan los años. Así, sin ninguna agitación, ni ningún cambio brusco, la poética postista desemboca en el introrrealismo poético y queda convertida en método de conocimiento que se dirige hacia lo desconocido.

La preocupación metafísica de la poesía oryana se encuentra presente ya en los poemas publicados en 1945 en la Revista Garcilaso $^{282}$. Esta impronta también puede observarse incluso en la primera poesía oryana, cuyo signo más evidente era la preocupación existencial. Pero, es en esta poesía postista dispersa donde germina la poesía metafísica, mágica y mística. Esta bucea en las concepciones filosóficas de la antigua Grecia, investiga las concepciones sobre la realidad que poseen algunas filosofías orientales y se interesa en los misterios de la alquimia... Todo ello hace que la poesía oryana se desplace hacia el terreno de la heterodoxia y de la marginalidad. Sus referencias las encontramos en Heráclito, Pico della Mirándola, Marsilio Ficino, Paracelso, Novalis, Nietzsche, Rimbaud, Baudelaire, Eliot, Pound, Breton... El poema, escrito en 1949, titulado «Necesidad poética» ${ }^{283}$ es una muestra perfecta de esta poesía visionaria y mística que se preocupa por acceder al misterio cósmico y, desde aquí, desvelar la experiencia mística. En él Ory ofrece, mediante su peculiar lenguaje lúdico e irreverente, sus antecedentes: filósofos, maestros, magos, chamanes, poetas visionarios, y artistas inquietos. En definitiva, exploradores del misterio:

César Vallejo lleva el pellejo a cuestas

Eliot triste como unas tijeras

Rimbaud Rimbaud Rimbaud Rimbaud

${ }^{282} \mathrm{n}^{\circ} 28$, agosto 1945. En Poesía abierta (1974), pp. 17-21, Pont presenta tres poemas publicados allí: «Sonata del jardín negro», «Niña envuelta» y «Un verso». En Metanoia (1978), pp. 119-120, Cózar incluye el poema «Poema a tu figura».

${ }^{283}$ Poesía abierta (1974), ed. de Pont, p. 65. 
Los poemas de Klee y de Jean Arp

De Max Jacob de Henri Michaux

Los versos de oro de André Breton

Y claro Paul Eluard con su sabor a viento

Y no olvidas los sonetos de Nerval

No olvido a Baudelaire

Ezra Pound y otros y otros

Maravillosos necesarios

y ciertos sacerdotes clásicos.

Esta poesía acomete la tarea de desvelar el misterio de la existencia, por ello se convierte en una poesía mística que posee varias direcciones: la esotérica, la mágica, la visionaria, la oriental, la metafísica... En este sentido, la primera referencia que aparece en el Diario de Ory se ofrece el 11 de enero de 1947 (2004, Vol. I: 26):

¡Los conceptos son música! ¡Vamos a hacer de conceptos cabales un logogrifo denso, una babel densa y sonora, una poesía ilógica, logomáquica y logomágica! ¡Viva el misterio creado!

Quiero concretar, exhaustivamente, mi noción de misterio. Para esto, necesito estudiar, a fondo, el misterio común.

El Diario ofrece otras referencias acerca de esta concepción mística de la poesía. El uno de octubre del mismo año Ory escribe (2004, Vol. I: 36):

...Y desde los 11 años en que no sólo hacía versos sino que también veía, aunque espantado y sin saber, y sobre todo sin entender, ¿y qué veía? Pero hoy, ¡oh hoy!, veo, veo, veo con la carne y con el espíritu la gran dulzura y el gran tormento de vivir...

Cabe destacar también algunos fragmentos del Diario escritos el día 29 de noviembre del mismo año (2004, Vol. I: 102-104):

Yo me agito en la inmensidad, frente o bajo la inmensidad.

[...]

Ante el Hecho no cabe al hombre sino arrodillarse y no clamar, es decir: no pedir explicaciones a Nadie [...] Lo incognoscible no puede ser explicado jamás. Es inútil entablar querella con los astros. Una ignorancia Total nos invade, respecto a lo Divino, es decir, respecto a las cosas invisibles [...] Y para ir a lo Cierto sólo el hombre debe esforzarse en lograr una conducta noble y duradera: una conducta constante de valor y sinceridad como guardianes eternos en la tierra... 

era Misterio.

Carlyle decía en el Misterio, y todo para él, desde él mismo y el mundo,

«Salimos del Vacío; pasamos como un huracán ante la faz de la Tierra, asombrada, para sumergirnos de nuevo en el Vacío... Pero ¿de dónde, ¡oh profundos Cielos!, y hacia dónde? La Razón nada sabe, la Fe nada sabe, sino que vamos del Misterio al Misterio.»

La poesía, pues, es el método de conocimiento perfecto para profundizar en el misterio. Por eso los poemas oryanos son aperturas hacia este misterio indescifrable y se abisman, como si de una meditación se tratase, en el enigma de la existencia. Por ello la poesía se convierte en mística, pero no una mística instalada en la verticalidad, dirigida a una divinidad trascendente, sino una mística de la inmanencia en la que la divinidad se halla presente en el aquí, en todo lo existente. Ello queda perfectamente expresado en el siguiente fragmento del poema «Pensamientos» ${ }^{284}$ escrito en 1949:

La tierra es tiempo y al mismo tiempo eternidad

La resurrección comienza en este mundo

Cuando la carne nace también nace la muerte

La muerte es vida comenzando en vida

Me subsumo me hundo en Dios

Me asimilo a su savia cósmica

¿Y qué soy yo sino una florecita

una hoja negra una oreja de burro

hijo del polvo?

Presencia de la poesía mística de Juan Ramón y de algunas concepciones del hinduismo, del taoísmo y del budismo. Se trata de una mística inmanente en el sentido en el que Baruc Spinoza concibe la divinidad. Propuesta filosófica que supone una genealogía de la religión en la que lo trascendente queda suprimido y la divinidad queda asimilada a lo inmanente, es decir, a la naturaleza ${ }^{285}$, que es además inagotable. Ciertamente, el punto de contacto entre la mística oryana y las místicas orientales se establece en la concepción de una divinidad inmanente, en el sentido del tat tvam asi, el tú eres eso del hinduismo. Se trata de una mística que considera que el ser humano es parte del universo y el universo parte del ser humano. Se trasciende la oposición entre el ego y aquello que es distinto a él, hecho que implica a su vez la destrucción del ego. La

${ }^{284}$ Poesía abierta (1973), p. 62.

${ }^{285}$ Ver, Onfray, Michel (2007), Les libertins baroques, París, Centre National du Livre; traducción de Marco Aurelio Galvarini, Los libertinos barrocos. Contrahistoria de la filosofía, III, Barcelona, Anagrama, 2009, pp. 245-246. 
divinidad toma forma aquí de totalidad, ya que el ser divino es el cosmos, ilimitado y eterno. Este es el sentido de los versos «Me subsumo me hundo en Dios / me asimilo a su savia cósmica». Si la divinidad es el mundo, y este es eterno, el movimiento que posibilita la existencia es el ritmo de los instantes, el movimiento que implica a todos los seres. Este se presenta en el poema como una incesante danza:

¡Cómo no danzar si veo danzar!

Si siento besos en la noche solitaria

¿cómo no preferir el amor del mundo?

Mas si alguien muere yo quiero morir

Un baile continuo en el que todos los seres participan, en el que la muerte y la vida se dan cita y provocan el movimiento circular de la existencia. En este sentido, el poema actualiza el significado que poseen antiguos símbolos arquetípicos como la savástica hinduísta, el yin y el yan, anfisbena (la serpiente de dos cabezas), eurobos (la serpiente alquimista que se come la cola)... También reactiva la concepción del amor cósmico nerudiana o hernandiana, y sobre todo, la concepción del amor como destrucción de Aleixandre.

La poesía oryana se convierte en un proceso de meditación, en la búsqueda de una lenguaje capaz de trascender el pensamiento racional y la referencialidad pragmática. Ory busca en la mística y en el pensamiento del budismo zen un lenguaje que se acerque al silencio. En el budismo zen, como ya se ha visto, el lenguaje se acerca al silencio, o bien convirtiéndose en un susurro (haiku) o creando una fractura lingüística que hace estallar el lenguaje $(k o a n)^{286}$. Este lenguaje poético trasciende la realidad representacional y apunta a la realidad tangible. La poesía se convierte en una meditación, deja en suspensión el pensamiento racional y se abisma en el silencio. Esto es lo que se expresa en los últimos versos del poema titulado «Préstanos linde» ${ }^{287}$, escrito en 1948:

Callo la boca dificulto el coro de las voces confusas dejo que un gran murmullo de silencio reine 
La poesía está compuesta por palabras de silencio que trasmiten, mediante la evocación, significados ocultos y que permiten que la realidad pueda expresarse por sí misma. El poema «Hoy pienso» ${ }^{288}$, escrito en el mismo año, está cifrado en este lenguaje de silencio:

La soledad tiene rostro muy bello

Derribo el techo de las vanidades

No tengo flores con que festejarme

La poesía falsa me hiere la piel

Y no me gusta la melancolía

Los hombres se despegan con hachas invisibles

Sólo la soledad viviente tiene música

Sólo el silencio no nos encanece

Conciencia augusta sala del espacio

Y todo el resto es cama de hospital

El silencio es el método de conocimiento que ofrece esta poesía oryana que profundiza en el interior del ser y desde aquí intenta una aprehensión de la realidad basada en un lenguaje no racional, en un no pensamiento. Esto es lo que significan expresiones poemáticas como la «soledad viviente», el «silencio» y la «conciencia augusta», una percepción que se aleja de los conceptos religiosos occidentales tradicionales. Poesía significa ahora percepción consciente de lo real desde el silencio de la meditación. Ella trata de ofrecer una sacudida para que el lector perciba lo numinoso, aquello que no se puede expresar con las palabras. Y apunta, en este sentido, a un significado misterioso y sagrado. El poema «Esta hora» ${ }^{289}$, escrito también en 1948, supone una descripción de la meditación oriental: soledad, silencio, respiración, conciencia, aprehensión...

Oh qué cantas infeliz rubio mamífero

a estas horas sempiternas admirables

horas llenas de aires vastos

que respiras con un pecho de palmera

Oh la hora la gran hora principal

en que fundes alhajado de verano

la fecunda miel del verso en áurea chispa

Cara al oro de la aurora en esta hora

288 Poesía abierta (1974), ed. de Pont, p. 43; Metanoia (1978, 1990),ed. de Cózar, p.

${ }^{289}$ Poesía abierta (1974), ed. de Pont, p. 45. 
Aquí el «oro» alquímico se asocia con la iluminación o repentino despertar del budismo, porque, de hecho, en el tantrismo, en el budismo tántrico o en el taoísmo la meditación se considera una alquimia interior. La poesía como meditación es la «(áurea) chispa» o fogonazo que provoca la iluminación, el «oro de la aurora».

Otro ejemplo de esta conciencia de la totalidad lo encontramos en el siguiente fragmento que pertenece al poema «Los ojos y el alma», escrito en $1948^{290}$. Aquí el lenguaje oryano, que estrecha sus contactos con la poesía total juanramoniana ${ }^{291}$, trasciende la oposiciones mentales y representacionales y une los conceptos aparentemente antagónicos de «todo» $\mathrm{y}$ «nada», absoluto y vacío:

Bajo a mi alma y nunca se menean tanto mis ojos de mirar nada Abro el ojo cerrado de la Nada y no veo aunque mis ojos vean

Subo a mis ojos subo y todo es todo Mi alma está llena pero no de alma Mis ojos no ven nada y todo es calma Cierro el alma bellísima del todo

Este lenguaje que surge de la experiencia mística, numinosa, que tiene como finalidad provocar una sacudida en el ser, toma la forma del canto mágico, de la palabra mágica establecida en los ritos mistéricos, del murmullo de los chamanes o de los sonidos meditativos de los mantras. Se trata de un canto órfico ${ }^{292}$ que intenta despertar los oídos al misterio de la existencia y que transmite el éxtasis de la experiencia

${ }^{290}$ Aparece únicamente en Energeia (1978), p. 87.

291 Ver el poema «El otoñado» perteneciente a La estación total (1946), del que presentamos un fragmento:

Correo luz: doro el lugar oscuro, transmino olor: la sombra huele a dios, emano son: lo amplio es honda música, filtro sabor: la mole bebe mi alma, deleito el tacto de la soledad.

Soy tesoro supremo, desasido, con densa redondez de limpio iris, del seno de la acción. Y lo soy todo. Lo todo que es el colmo de la nada, el todo que se basa y que es servido de lo que todavía es ambición.

${ }^{292}$ Ver la intoducción de Ruiz Soriano (2004: 13-32) a su antología de poesía órfica. 
dionisíaca: la fusión del ser en el todo, en una realidad ilimitada en el sentido de que no posee límites que separen ese todo, que es uno, uno sin segundo ${ }^{293}$. El poeta toma la imagen de Orfeo que con su lira va cantando la armonía universal, canto que, como en los misterios eleusinos, suponía un descenso a los infiernos ${ }^{294}$. Imagen que se observa en el poema escrito en 1946 titulado «Un temblor pavoroso» ${ }^{295}$ :

No sólo pienso en cantar recantar

Sobre la acción del poeta dijo alguien

debe ser inocente $\mathrm{Y}$ esta acción

daña al poeta al cabo de los siglos

y aun en su vida El poeta es

culpable de la inocencia

Cuando canto

sufro un temblor pequeño pavoroso

La carne es la que tiembla el alma no

De recantar te gastas vas hiriéndote

Mas sin embargo canto para los que

salís indemnes de este sacrificio

sacudidos de encanto y de pereza

La poesía queda convertida así en una operación chamánica, en un rito mistérico que supone la transmutación humana alquímica, que en todos los casos consiste en conseguir la unión con la divinidad. Para Jung (1939, 1994: 149-169), la alquimia es, en definitiva, la búsqueda de la sabiduría o iluminación mística. La piedra filosofal, el elixir de la vida, la Panacea, el andrógino divino son símbolos cuyo significado que apunta a la conciencia de divinidad como fusión de lo individual y el cosmos divino. Claude Lecouteux ${ }^{296}$ interpreta el descenso a los infiernos realizado por Orfeo en busca

${ }^{293}$ Wilber, Kent (1983), Eye to eye, ed. de 1990, Nueva York, Doubleday; traducción de David González Raga, Los tres ojos del conocimiento. La búsqueda de un nuevo paradigma, Barcelona, Kairós, 1991, pp. 284-300. Wilber interpreta, basándose en la mística perenne, este concepto como la percepción de la realidad sin dualidades: absoluto, Todo, divinidad, vacío, Brahma, cuerpo der Buda, Tao...

${ }^{294}$ Los misterios de Eleusis se celebraban en honor de Deméter, de Perséfone y de Baco. Allí los asistentes tenían una experiencia de realidad alterada. Eliade (1956, 1974: 131) interpreta el significado de los misterios como la transmutación del hombre provocada por el conocimiento de la experiencia de unidad, que implicaba la experiencia de muerte y la de renacimiento.

${ }^{295}$ Poesía abierta (1974), ed. de Pont, p. 28.

${ }^{296}$ Lecouteux, Claude (1988), Fées, sorcières et lous-garoux au moyen age, París, Editions Imago; traducción de Plácido de Prada, Hadas, brujas y hombres lobo en la Edad Media. Historia del Doble, Palma de Mallorca, El Barquero, 1999, pp. 186-187. «No cabe ninguna duda de que la noción de alma separable, de Doble, es un elemento fundamental del chamanismo, cuya influencia en el mundo helénico es manifiesta, y como últimos testimonios de ello tomamos los cultos entusiastas, por ejemplo de Baco; si las bacantes ayunan, danzan, cantan y gritan para llegar al delirio divino, es para liberar de su cuerpo el espíritu-Doble [...] Existe también la leyenda de Orfeo, tras la cual encontramos la estructura del viaje chamánico 
de Eurídice como un símbolo chamánico cuyo significado apunta a un viaje hacia otras realidades. Este viaje por la territorialidad del chamanismo y de las antiguas corrientes herméticas está totalmente patente en el poema «Himno a un poeta» ${ }^{297}$ que Ory escribió en 1947 y que se publicó al año siguiente en la revista Espadaña. En él se hace referencia explícita a Orfeo y a Job, símbolos del poeta y su especial función:

¿Qué se ha hecho de un hombre que cantaba siempre al atardecer un hombre fuera del día y de la noche un gran anillo en el fondo del sol una gran sombra?

¿Qué se ha hecho? Cantaba himnos peánicos Pero era más bien bíblico Ponía un pie en la luminosa Grecia antigua otro en Judea menos luminosa

\section{$[\ldots]$}

¿Qué se hicieron de sus lamentaciones aquellas saturnales funerarias aquellas conflacciones en los muros donde vaciaba su clamor profético?

Lo vi Lo vi $Y$ en sueños erigía su pedestal viviente y en sus ojos fuste de llama comprimida mientras tañendo su dulcémele dormíase<smiles>[CH]1[CH]C=C1</smiles>

Canta canta tu soga es ya bastante Encarnas tú a Orfeo y Job a un tiempo Surte tu empresa de reflujos suaves Yo haré el silencio al deponer mi himno

Cabe señalar las referencias que apuntan hacia la figura del poeta como chamán: el poder para salir del tiempo («un hombre fuera / del día y de la noche»), los símbolos alquímicos («un gran anillo / en el fondo del sol»), los rituales ceremoniales («aquellas saturnales funerarias», «clamor profético»), la iluminación o visión extática («en sus ojos / fuste de llama comprimía») y la presencia del silencio («Yo haré el silencio al deponer mi himno»). Poesía, en todo caso, que activa el lenguaje del silencio, que surge al más allá».

${ }^{297}$ Espadaña, n 33, León, 1948, p. 2. También aparece publicado en Poesía abierta (1974), pp. 37-38 y en Metanoia (1978, 1990), pp.140-141 
de su propio ámbito y se dirige directamente a la realidad. La poesía es, pues, una forma o método de percepción de la realidad, cuya práctica hace necesaria la presencia del silencio. Otra referencia hacia la poesía órfica se realiza en el poema comentado anteriormente «Academia fantástica», en él aparece la figura del poema como mago, chamán, maestro iluminado...:

Con la cabeza vendada de abejas el noble heredero de Orfeo doma el largo caimán

\subsubsection{Una poesía metapoética}

En los poema postistas dispersos encontramos una constante que Ory ya no abandonará más: la metapoesía. No se trata aquí del territorio de la metapoesía establecido por la poesía veneciana de la generación de los 70 o generación novísima. En este caso la metapoesía no supone un estética que exprese sus contactos con el informalismo pictórico o la metapintura (Bousoño, 1979b: 53-56). En la poesía oryana la metapoesía supone una reflexión sobre la concepción específica de la propia poesía. Existe una gran cantidad de poemas donde se teoriza sobre la misma poesía, en ellos la poesía declara su intención meditativa y se ofrece ella misma como una vía de exploración metafísica, un camino que se dirige al misterio que se halla en plena cotidianeidad. La poesía oryana se acerca a lo numinoso. Como perfectos ejemplos de poema metapoético podríamos señalar los siguientes (ver Apéndice III): «Un verso», «Un temblor pavoroso», «Hoy pienso», «Lo exquisito», «Esta hora», «Canciones de despedida», «Academia fantástica», «Necesidad poética», «Dame Dios mío este verso», «Fantasías acerca de mi arte», «Concentración directa» y «Las palabras». Aunque no sean tan evidentes, en muchos otros poemas existen también referencias metapoéticas, pues para Ory la poesía se convierte en metapoesía en cuanto que supone una práctica mística. La metapoesía oryana es el intento de plasmar el sentimiento de armonía con una divinidad inmanente, la expresión del éxtasis ante el misterio existencial.

Una dirección de esta poesía metapoética apunta a la unión poesía y música. La poesía es expresión y reflexión de la música cósmica. No olvidemos que una de las 
propuestas postistas más provocativas consistió en la euritmia, la exploración y el juego con el aspecto fónico y musical de la poesía. La convergencia entre música y poesía toma rasgos órficos, pues la música simboliza el poder metafísico y mágico de la palabra, por ello supone un ejercicio de transmutación interior y expresa la experiencia de unidad cósmica. Si la poesía es música, tal como expresaron los poetas simbolistas, parnasianos y modernistas, la reflexión sobre la música desde la propia poesía se convierte en un ejercicio metapoético, ya que ello supone una reflexión sobre la misma poesía. La poesía teoriza sobre la labor meditativa y transformacional de la música. En el poema titulado «Lo exquisito» ${ }^{298}$, escrito en 1948, la música posee una función mística y toma la forma de un mantra hinduísta.

\section{Oigo ahora que es de noche mi pedazo de ser vivo en mis latidos melodiosos cuántas veces te eres música tú tú \\ Filtro místico ángel máximum venusto candelabro de llamita enternecida Lo exquisito de tu verso de nenúfar}

La poesía es música callada, palabras de silencio que poseen la capacidad de profundizar, como la atención consciente de la meditación, a través de una percepción directa en la realidad. Se trata de una música interior («latidos melodiosos») que posee cualidades chamánicas y alquímicas en cuanto que supone un método de iluminación. En el poema la música se asocia al ceremonial del rito mágico o al de la meditación. Es este el sentido de la simbología establecida por la luz de la llama que posee la capacidad de iluminar la oscuridad («candelabro de llamita eternecida»). Como en la «Noche oscura» de San Juan de la Cruz, se trata de una luz interior que habita en el espacio más profundo del corazón y que ilumina con una potencia (simbólica) superior a la del sol. Luz mística interior, presencia de la divinidad en el interior humano que trasciende los límites de la piel y expande en todas direcciones. Se señala así la unión perfecta entre exterior e interior, experiencia que se transmite mediante la imagen «verso de nenúfar».

La poesía se convierte en meditación, trance, éxtasis, iluminación. Posee la capacidad de despertar, de sintonizar con la energía cósmica que atraviesa todas las cosas y todos los seres, incluido el poeta mismo que experimenta en sí la unidad con el 
cosmos. La concepción órfica de la unión entre música y palabra toma esta dirección meditativa. El poeta órfico es el ser que experimenta el goce permanente de la alegría y de la ebriedad de Dionisos, es el ser que se ha transmutado en un ser divino, que ha convertido para sí la realidad en un incesante éxtasis. Orfeo descendió a los infiernos, escuchó la música de la locura y de la desesperación y luego empredió el regreso a la vida trasformado en ser divino. Su divinidad consiste la experiencia de sentirse partícipe de la divinidad. Este es el sentido que Ory otorga la imagen mítica de Orfeo. Según aparece en el mito, Orfeo, figura asociada a Tracia y a una reforma del culto de Dionisos durante el siglo VI a $\mathrm{C}$, encantaba con su lira a las rocas, a las plantas, a los animales e incluso a los guerreros tracios. Sus canciones contaban el origen del universo. Orfeo realizó su descenso a los infiernos para recuperar a Eurídice, pero en el viaje de vuelta a la tierra miró hacia atrás y este gesto hizo que regresase al infierno otra vez. Su muerte a manos de las Ménades tracias lo convierten en el símbolo del desmembramiento sacrificial de los ritos dionisíacos y de las corrientes herméticas y alquímicas. En los misterios eleusinos la experiencia psicodélica funcionaba como experiencia de descenso a los infiernos, una experiencia de muerte y resurrección, de viajar a otros mundos y luego regresar (Eliade, 1956, 1974: 132-133). La imagen mítica del desmembramiento posee el significado de romper con los límites del propio ego y expandirse en el océano de la realidad. Ya hemos comentado anteriormente que, para Nietzsche (1872, 1973: 56-60), Dionisos, dios de la desmesura, expresa la ausencia de límites y por tanto simboliza el gran todo. Ello marca otra de las direcciones de la metapoesía oryana: la relación entre la música y la locura. En este sentido funciona la imagen del poeta órfico oryano que desde la locura se coloca en el espacio de la heterodoxia para rechazar plenamente los valores apolíneos de la cultura racionalista y los valores de la sociedad burguesa ${ }^{299}$.

En «Concentración directa» ${ }^{300}$, escrito en 1948, se ofrece una reflexión en clave metapoética sobre el lenguaje de la ebriedad. El poema, que se estructura mediante la comparación de poesía y pintura, muestra un movimiento hacia dentro que lo convierte en el punto de referencialidad. El poema se pliega sobre sí rehuyendo las referencias exteriores:

${ }^{299}$ Esta es la imagen del poeta órfico que nos traza Francisco Ruiz Soriano (2004: 29$30)$ sobre la poesía de Leopoldo María Panero (2004: 29-30), que también sería extensible a la de la poesía de Carlos Edmundo de Ory.

300 Poesía abierta (1974), ed. de Pont, p. 53; Metanoia (1978,1990), ed. de Cózar, pp. 148-149; Música de lobo. Antología poética (1941-2001) (2003), ed. de Pont, p. 294. 
Cómo dormir si este poema me dibuja

en el papel tranquilo silenciario

Y sin embargo en el papel encuentra alpiste

no azúcar como los caballos

Este poema nace por los pies

aunque cae de cabeza mi milagro

Un poema me da de vivir

En la siguiente estrofa aparece el concepto de la poesía como música al citar la palabra «arpa» en el interior de una visión de base surrealista: «Escribo con mi arpa». Además, el poema trasmite la función visionaria y curativa de la poesía, lo que supone un exorcismo o una experiencia chamánica extensible a un rito de purificación o de trasformación:

Tanto poema como dibujos el caso es gastar minutos nuevos

Escribo con mi arpa y pinto con dedidos $^{301}$ de colores

Mancho mi corazón aquí solo

Solo y mudo recorro mi sueño

con mi ojo de niño en la llanura

de nieve con mi mano maniática

El final de la estrofa presenta la clave del discurso de la ebriedad y de la locura, que queda plenamente desarrollado en la estrofa siguiente. La referencia a la pintura de Kandinsky muestra el contacto de esta poesía interior humana con el expresionismo pictórico que pretendía expresar paisajes y realidades interiores, radiografiar el interior humano. De otro lado, la presencia del lenguaje de la ebriedad señala el paralelo de la poesía oryana con la práctica de un nuevo lenguaje libre y desbocado, lunático y ebrio, practicado por los poetas y narradores de la literatura americana beat.

En la cama escribo dibujos borracho de Kandinsky por cierto también de vino voy borracho en mi noche de anonimato Pinto en la noche descomunal todo vértebras todo culebras

${ }^{301}$ Sic. Así aparece en todas las ediciones. 
La metapoesía expresa la idea de la poesía como la práctica del discurso de la locura, discurso que sitúa esta práctica poética en el flujo en el que se entretejen todos los discursos en el espacio de la marginalidad. Para Foucault $(1970,1973: 14)$ el discurso de la locura soporta la exclusión del terreno cultural incluso la propia prohibició en algunos ámbitos. Esto es así porque:

Desde la más alejada Edad Media, el loco es aquel cuyo discurso no puede circular como el de los otros: llega a suceder que su palabra es considerada nula y $\sin$ valor $[\ldots]$ en cambio suele ocurrir que se le confiere, opuestamente a cualquier otra persona, extraños poderes como el de enunciar una verdad oculta (1970, 1973: 16).

En este sentido, el discurso de la locura, como práctica poética, pasa a ser el discurso del bufón y el poeta su símbolo. Ello es la imagen que trasmite «Fantasías acerca de mi arte ${ }^{302}$ escrito en 1948. La metapoesía expresa la concepción de la poesía como operación interior que excluye al poeta de los espacios culturales centrales. Operación voluntaria de alejamiento en la periferia, en la marginalidad y en la heterodoxia:

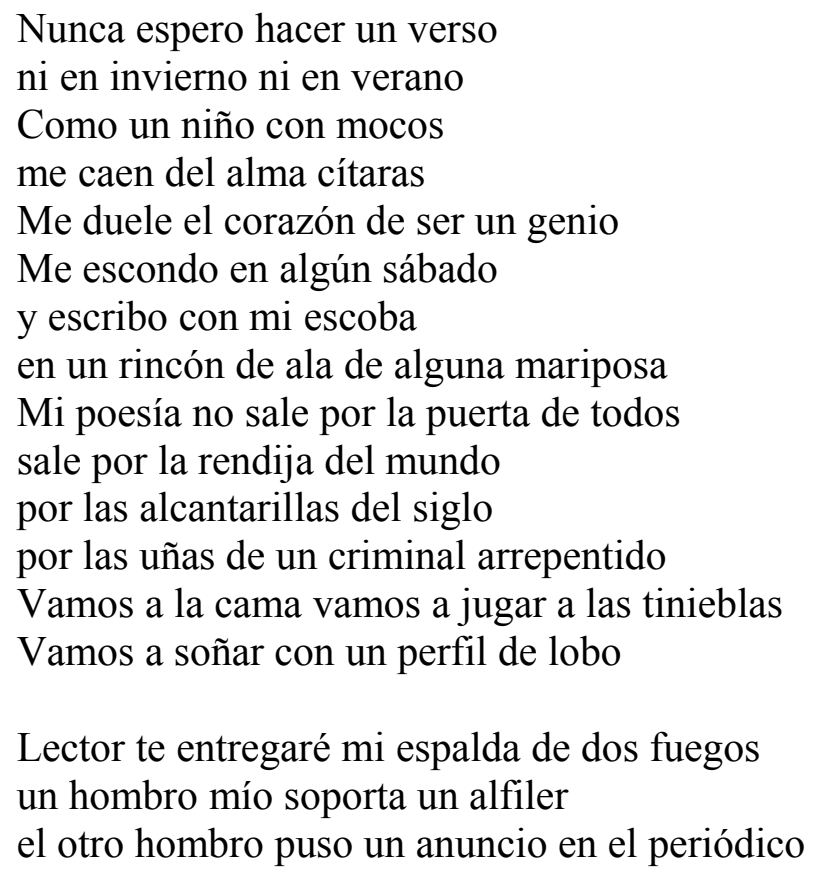

La imagen del poeta se compara con la inocencia de un «niño» sensible a los hechos más insignificantes pero, a la vez, más misteriosos de la realidad tangible. El poeta, además, es un ser marginal y oscuro que penetra en los misterios de la noche y del 302 Poesía (1945-1969) (1970), ed. de Grande, 86; Metanoia (1978, 1990), ed. de Cózar, p. 145. 
sufrimiento, es el ser antitético del personaje anodino y burgués que representa el orden social. Este es el sentido que se desprende del símbolo poemático del «lobo», recurrente en la trayectoria poética oryana. La imagen del poeta como «lobo» cabe interpretarla en el sentido del ser marginal: arlequín, payaso, cíngaro, marinero, mendigo, sabio... La semántica de esta figura está intertextualmente conectada con la novela Der Stepnwolf, escrita en 1927 por Herman Hesse. El lobo estepario significa, en la obra de Hesse, el ser que se aparta de la manada, símbolo perfecto de la sociedad burguesa, para buscar en la soledad la práctica de una experiencia vital más intensa y genuina. Cabría citarse, además, la conexión mística que se establece entre el discurso de Hesse y el de Ory.

La práctica de la metapoesía se convierte en una reflexión sobre el lenguaje en el largo poema titulado «Las palabras» ${ }^{303}$, escrito en 1949. El poema, que se divide en siete partes, se presenta como una continua definición sobre la función, la esencia, el poder y la voluntad de la poesía. En él se ofrecen planteamientos que serán retomados en 1951 en Nuestro tiempo: Poesía $a^{304}$, texto considerado como el manifiesto del Introrrealismo poético. Así aparece descrita la poesía órfica:

palabras de ángel y de signos ebrios unas veces oscuras otras blancas epifanías órficas o píticas siempre libres hollando la vorágine

O la poesía como una alquimia interior:

Raíces cosidas a la luz de un símbolo hechas plata de abismo y misterio hechas oro de místico aparejo hechas hierro de lenguas sempiternas hechas coral de costas imposibles hechas carbón de vívidos destellos hechas miel hechas brasas hechas cobre

${ }^{303}$ Revista Centauro, n 3, Lima, p. 4, abril 1950; Revista Poesía Española, n 38, febrero 1955, pp. 3-6; Antología de la Poesía Española, 1954-1955 (1955), ed. de Rafael Millán, pp. 117-119; Poesía (1945-1969) (1970), ed. de Grande, pp. 92-95; Revista Cuadernos Hispanoamericanos, $\mathrm{n}^{\circ}$ 245; mayo 1970, pp. 319-323; Revista Norte, $\mathrm{n}^{\circ} 240$, México, marzoabril 1971, pp. 74-75; Metanoia (1978), ed. de Cózar, pp. 155-160; Música de lobo. Antología poética (1941-2001) (2003), ed. de Pont, pp. 300-305.

${ }^{304}$ Obra cit. 
También se definine la poesía como una forma de explorar el interior humano y de ahondar en el dolor existencial:

Esas palabras de hambre y de martirio todas van hacia abajo y hacia arriba hojas de una garganta y nada dentro Aquí las nombro regias como escudos colgando como andrajos de esa almena siempre humana del hombre y de su boca

De otro lado, el poema supone también una actividad metapoética porque nos va señalando el proceso de la propia creación poética. Asistimos, pues, a una reflexión sobre el lenguaje poético y su práctica:

Palabras que se arrastran y pululan Palabras que arden y que van despacio sobre las cosas removiendo el légamo quebrando cimas y asumiendo estrofas

Una serie de marcas nos indican que el poema posee un referencialidad interna. Este se repliega hacia y elimina la referencialidad externa, habla de sí mismo y se dirige hacia sí. Estas marcas serían comparables a las que establece el discurso pictórico informalista, matérico ${ }^{305} \mathrm{o}$ pop. Pensemos en la pintura de Antoni Tàpies, existen en ella marcas pictóricas (como tachaduras, líneas no borradas, flechas u otros trazos) que nos revelan detalles de la estructuración de la obra concreta o que nos ofrecen significados sobre el propio proceso creador. En el poema oryano hallamos estas mismas marcas autorreferenciales que tienen la particularidad de ofrecer las claves de su construcción y de provocar la sensación de que el lector asiste al acto creador y que participa en él como si el poema se estuviese construyendo en su presencia:

¡Papeles blancos! Tumbas del poema

¡Papeles misteriosos! Tumbas tumbas paredes mudas que abarcáis sonantes superficies de letras oficiosas letras y letras carros suculentos por hormigas armónicas guiados y por moscas de máximos valores y por sirenas que se llaman frases

${ }^{305}$ Sic. 
lazos del pensamiento entre murciélagos

La superficie rectangular del poema se recorta sobre el silencio representado por el blanco de la página, en él se van dibujando las estructuras laberínticas creadas por las palabras, representaciones de sonidos, que se arrastran agrupándose en constelaciones mayores, sintagmas y oraciones, y forman a su vez otras constelaciones de signos como versos y estrofas («hormigas», «moscas», «sirenas»). De modo que el poema desvela el funcionamiento del discurso poético y lo aplica al propio poema:
Ahora se rompe la palabra tímida que trae consigo certidumbres fónicas Ahora se rompen y en belleza fulgen como acentos cargados de inminencias como pulpas de olor ligero y cálido como una rosa convertida en música como un tesoro de perlada orgía $\mathrm{y}$ hace irreal el juicio que la indujo y hace del pensamiento que la atrajo una cadena pura del lenguaje que ata y desata legendarias voces remedos y expresiones de otros astros de planetas y etéreos laberintos donde la voz no vive y sólo vive la palabra mortal madre del canto

Se trata de una definición de la práctica poética que surge de la transgresión del valor comunicativo del lenguaje y se convierte en mecanismo de autoexploración y conocimiento íntimo. Discurso intertextual que se nutre de otras prácticas en las que se enreda y, por ello, las actualiza. En esta reflexión sobre la textura poética se ofrecen varias definiciones del hecho poético. Entre ellas cabe señalar el componente irracional del discurso poético, marcado sobre todo por tratarse de un lenguaje cuyo significado es emocional:

La poesía es un vuelo de palabras tibiamente enlazada al sentido $\mathrm{y}$ al son mago del vívido prestigio de ese sentido irracional ilógico poético tan sólo y sin sosiego 
De otra parte, este poema oryano supone también una teorización sobre la funcionalidad poética. Únicamente la lectura supone la puesta en práctica de la poeticidad, el discurso poético solamente existe en tanto que hay una lectura que lo posibilita y lo activa. La lectura codifica y reactiva los signos poéticos ${ }^{306}$. La creación poética es también, a su vez, la lectura de otros signos poéticos anteriores, reactivados en el poema que se escribe:

La poesía es palabra tras palabra palabra muerta con palabra viva palabra que arde y flota eternamente hasta que muere en la matriz del vuelo y muere para arder debajo de ella y para ser resucitada un día por hombres por un hombre por el poeta

306 Ver Eco, Umberto (1965), Apocalittici e integrati, Milán, Bompiani, traducción de Andrés Boglar, Apocalípticos e integrados, Barcelona, Lumen, 1968, p. 125; y Jauss, Hans Robert (1970), Literaturgrschichte als Provokation, Frankfurt, Suhrkamp Verlag, traducción de Juan Godo Costa, La literatura como provocación, Barcelona, Ediciones Península, 1976, pp. 192-192. La recepción literaria completa la obra al ofrecer nuevos significados aportados a través de la óptica del receptor. De modo que la obra siempre queda abierta a posibles significados futuros que la contextualizan nuevamente, así a lo largo del tiempo una obra va adquiriendo nuevas lecturas. 
4. POESÍA NÓMADA 


\subsection{POESÍA DEL DOLOR}

Tal vez en unos años podamos volver a ver si al fin los pájaros azules se repiten.

Rafael de Cózar

Anteriormente hemos visto que la poesía nómada recoge la producción poética oryana desde el introrrealismo íntegro hasta, más o menos, finales de la década de los setenta del siglo pasado. Esta poesía se halla estructurada en una serie de obras de las que cabe mencionar como más importantes Técnica y llanto, La flauta prohibida, Lee sin temor o Miserable ternura - Cabaña. Sus signos más destacados son la conciencia de pertenencia a un espacio cultural periférico y marginal, la voluntad de indagar en la tradición heterodoxa de la cultura occidental y el acercamiento al pensamiento de culturas lejanas. Esta poesía supone una verdadera convergencia con las nuevas realidades culturales surgidas en las décadas de los años sesenta y setenta: el posestructuralismo, la cultura pop, la importancia de las filosofías orientales, la contracultura, el underground...

\subsubsection{Acercamientos al expresionismo}

La aparición en 1969 de Poemas supone la certificación del acercamiento definitivo de la la poesía oryana al expresionismo. No existe un punto exacto que separe la poética postista oryana de la poesía introrrealista, más bien ambas se solapan y confluyen en su interés metafísico, pues la poesía postista llevaba ya impresa una impronta mística. Carlos Edmundo de Ory, desde sus mismos inicios poéticos, se planteó ya la actividad poética como una vía de conocimiento de las profundidades humanas y de los misterios que esconde la existencia. Aunque Poemas se publique en 1969, presenta un segmento de la poesía oryana escrita entre 1946 y 1969. Por ello representa la transición de la poesía provocativa del Postismo hacia la poesía introrrealista, una poesía más visceral y humana, enteramente vivencial e interior, cercana al expresionismo. Se trata también de una poesía descentrada, cuyos intereses 
no coinciden con los intereses poéticos y culturales de la poesía coetánea peninsular. Y supone también un rechazo del espacio poético central y un deseo de explorar nuevas geografías periféricas. En ella, aparte de conectar con espacios poéticos marginales como los establecidos por Cirlot o Brossa, existe un deseo de exilio y de rechazo frontal de los presupuestos poéticos generacionales. Emparentada con Poemas, se halla la obra Técnica y llanto, formada por poemas escritos entre 1969 y 1970 y publicada en 1971. En ella la poesía se configura como una meditación sobre el dolor, un dolor que toma la forma del quejío cósmico y existencial expresado en el cante jondo, cuya convergencia más evidente se hallaría en el cuadro El grito (1895) de Munch. Joaquín Marco (2012: 12-13), director de la colección Ocnos en la que se publicó la obra, nos ofrece sus claves. Por un lado, la encuadra en la línea poética de experimentación efectuada por la poesía de los años setenta y, de otro, señala tres líneas temáticas importantes: la erótica, el existencialismo y el dolor. Podríamos, pues, decir que Técnica y llanto, como toda la poesía introrrealista, supone, en cierto modo, la expresión del discurso de la crueldad ${ }^{307}$, cuyos antecedentes resultan ser André Breton, Antonin Artaud o Georges Bataille. Así lo expresan las siguientes palabras del Diario de Ory correspondientes al 31 de septiembre de 1950 (2004, Vol. I: 93):

¡Introrrealismo íntegro! Darnos en espíritu, en vibración, en fiesta, y claro que también el dolor, a la realidad inconfundible, antirromántica, cruda y tan dulce de nuestra vida [...] ¡La vida!, ¡La vida! No digo que no haya dolor. Tal vez todo es dolor...

Son palabras que proponen una poesía metafísica interior que escapa a la vieja concepción humana separadora entre cuerpo y mente. Una óptica paralela se expone en el concepto de atletismo afectivo de Antonin Artaud (1938, 2011: 171-181). El teatro metafísico de Artaud concuerda perfectamente con el introrrealismo oryano. Se trata de un teatro del cuerpo, una ceremonia que penetra el cuerpo en toda su profundidad, un teatro dirigido a la globalidad del ser ( $\sin$ separaciones ni abstracciones que oponen lo corporal a lo mental). Por ello citamos estas palabras de Artaud (1938, 2011: 171):

${ }^{307}$ El discurso de la crueldad equivale a la adopción de un lenguaje que se allá más allá del racionalismo, que transgrede la palabras y su significado conceptual (Artaud, 1936, 2011: 133): "La palabra crueldad debe ser tomada en un sentido amplio, no en el sentido material que se le da habitualmente. $Y$ reivindico así el derecho a romper con el sentido usual del lenguaje, de quebrar de una vez la armadura, de hacer saltar el collar de hierro, de regresar, en fin, a los orígenes etimológicos del lenguaje». 
El actor es como el atleta físico, pero con una sorprendente diferencia: su organismo afectivo es análogo, paralelo al organismo del atleta, su doble en verdad, aunque no actúe en el mismo plano.

El actor es una atleta del corazón [...]

Los movimientos musculares del esfuerzo físico son como la efigie de otro esfuerzo, su doble, y que en los movimientos de la acción dramática se localizan en los mismos puntos.

El punto en que se apoya el atleta para correr es el mismo en que se apoya el actor; pero en la carrera del actor se ha vuelto hacia el interior.

También forma parte de esta poesía introrrealista Órgano constante, poemario que se ofrece al púbico con la aparición en 1978 de Energeia. En él aparecen poemas escritos entre 1951 y 1953, repartidos en dos obras, una de título homónimo y otra titulada Genitalia.

Esta poesía de signo metafísico explora las realidades interiores y se erige como una meditación existencial ofrecida desde la óptica del dolor. Se trata de una reflexión sobre el dolor cósmico donde se aúnan existencialismo, expresionismo y la herencia más telúrica del surrealismo. Sus referencias son ahora la poesía visionaria de Novalis, la mística interior de Juan Ramón Jiménez, la concepción del dolor existencial de Arthur Schopenhauer, el vitalismo de Fiedrich Nietzsche, la existencia como absurdo de Franz Kafka, el existencialismo de Martin Heidegger y de Sören Kierkegaard, la exploración de los misterios del interior humano de Antonin Artaud y de Georges Bataille, la expresión del dolor de Georges Trakl, de Edward Munch o de Alfred Kubin y el pesimismo escéptico, corrosivo y radical de Cioran. Se trata de una poesía visionaria que trata de desvelar las imágenes que estructuran el interior humano, una poesía destinada a hacer visible lo invisible. Esta propuesta poética desemboca en una poesía paralela a la poesía de la beat generation americana, a la llamada poesía del mayo francés o a ciertos ámbitos de la poesía novísima de la generación del 70 del siglo $\mathrm{XX}$. Una poesía que busca espacios marginales como son el conocimiento de las filosofías orientales, la filosofía perenne, el chamanismo o la hermética. Como resultado de todo ello, esta poesía queda convertida en una poesía mística que trata de expresar un conocimiento más allá de las palabras y que lleva impresa una voluntad de transmitir la sensación de integración en un cosmos divino. Poesía que expresa el sentimiento humano de ser partícipe de una totalidad cósmica. Dolor y erótica son los dos ejes sobre los que gravita esta poesía interior. 


\subsubsection{Dolor existencial.}

La poesía introrrealista oryana queda configurada como un viaje a través de la noche, ella es el espacio donde se experimenta internamente el dolor de la existencia. Poesía que supone una mirada desde el dolor y una meditación sobre el dolor. En el artículo «Las ratas en la poesía alemana» ${ }^{308}$ (1991: 189) Carlos Edmundo de Ory define perfectamente la poesía expresionista como una poesía de hospital, en la que los cisnes se convierten en ratas. La poesía intorrealista conecta totalmente con el expresionismo poético. Se trata, en cierto sentido, de una poesía de la repugnancia que ofrece la descripción de los paisajes más devastados de la existencia humana. Una poesía abisal que explora la noche cósmica a través de una mística del dolor y que nos recuerda la mística negativa, doliente y ascética, extática, de San Juan de la Cruz. El ser se halla inmerso en la sombra más cruel de la existencia, en una niebla que lo atrapa en la espesura del dolor y en la viscosidad de una angustia telúrica, entre los ladridos y los alaridos de las bestias y bajo los rayos amenazantes de los astros. El poeta se erige como ser doliente que experimenta en sí el dolor existencial emanado de la energía cósmica, un ser convertido en explorador de la noche siniestra. Ello se nos muestra en los fragmentos siguientes:

Oh noche poderosa ya han entrado tus ojos Ya puedes ser madura como un dolor perfecto Oh lamento perdido ya entrado tus reyes al pie de las anónimas y enfermas oquedades

Sí mi noche sí quiero maldecir de ti misma Porque pareces casa y sin embargo es aire Es viento y torbellino mi corazón y el tuyo Oh poderoso envío de límbicas regiones

Estos son mis poderes oh mística alma mía Para ti no parece la noche sino tumba

$$
\text { («Poderes», Poemas) }
$$

Negras sombras os hablo con boca amarga y dura Negras y libres sombras cual piernas de algo grande

Tal vez seréis los signos milenarios de un surco

${ }^{308}$ Cuadernos Hispanoamericanos, n 185, Madrid, mayo 1965. 
Tal vez es Dios quien hace tanta sombra en la sombra

(«Siento ropas», Poemas)

Obscura es también mi intensidad

Maldigo yo las alucinaciones

Tortura me torturo y hago esfuerzos

Sobrehumanos por desdesesperar

(«Negros de sufrimiento mis ojos», Técnica $y$ llanto)

En la noche telúrica el ser siente el dolor cósmico. En cierto sentido, la poesía oryana se acerca al discurso de la locura representado por la pintura de Vincent Van Gogh y continuado por la literatura de Kafka o por las concepciones teatrales de Artaud. La noche del insconciente, la noche telúrica, fue representada por Van Gogh a través de su óptica de la locura en La noche estrellada (1889). Esta noche primordial es también la noche que, teñida de esquizofrenia, envuelve a los animales de la pintura de Franz Marc. Noche que es símbolo del dolor existencial y en ella se ofrece una ceremonia del dolor, en la que el sufrimiento supone la ligazón del ser humano con esa divinidad cósmica y telúrica :

ENTRAN gritos veloces y muchos. La noche:

Ese peso grabado en las tristes pupilas

Ya me encuentro incluido en los pálidos ayes

En los perros del hombre me instalo

Y del viento del viento se borra confuso

mi terrible y costoso ladrido

Oigo solo. Allá lejos hablándome sin nadie

Solo escucho la gubia en los cortes del alma

Oh del alma en la noche del alma sus breves sonidos

$\mathrm{Y}$ en el cielo maquinan los astros

(«Hay un increible rumor llorando», Poemas)

El ser humano en su sufrimento habita entre los ladridos, los aullidos y las dentelladas de las bestias (buhos, gaviotas, cuervos, perros, lobos, ratas...). Se necesita agotar el sufrimiento para expresar la vida en toda su complejidad, invertir la mirada hacia adentro para sentirse partícipe del dolor cósmico, de ese mar eterno, de ese océano cuyas gotas son los hombres. El símbolo del mar sustituye, en ocasiones, al de la noche: 
Me abandonan los hechos sobre el desierto pico

de una roca no exenta de materia. Felices

los sabios peces cerca de nosotros.

Sienta bien a mi alma el mar eterno.

(«Cuadro de mi alma», Poemas)

Otros símbolos del dolor empleados son el bosque, el desierto y el abismo.

Ahora habito mi bosque edificado

en el palacio de mi sola música

$$
\text { («¿Quién?», Técnica y llanto) }
$$

Esta poesía supone una meditación sobre la realidad surgida desde el mismo dolor. El poeta debe abismarse en la tristeza y, desde aquí, celebrar el hecho de estar vivo. De la misma manera que la alegría supone la gratitud ante la participación de la realidad, también la tristeza puede erigirse como vía mística, en este caso negativa, y proceso de transformación. El poema «El mundo es danza vieja», que pertenece a Poemas, muestra esta mística del samsara ${ }^{309}$ :

El mundo es viejo danza vieja y el fiero pecador del alma y cabellos puro entiende la noche Todas las aves cantan secretas en la antigua lejanía

En Técnica y llanto se agudiza la soledad humana, la existencia se siente como una herida íntima que debe ser experimentada. El poeta explora y agota todas las llagas del dolor y para ello rehúsa toda anestesia que pueda ofrecer la cultura y la sociedad:

Soy una herida sonora que ríe

Soy el dolor echando humo

Soy como el hombre soy lo que no tengo

${ }^{309}$ El budismo hinayana trataba de abandonar el samsara o rueda de la existencia mediante el acceso al nirvana. El budismo mahayana, en cambio, pone el acento en el samsara, pues si existe un nirvana, éste sólo puede experimentarse en el mismo samsara. 
Miseria antigua ser herida permanente

(«Soy lo que no tengo»)

Me quiero ir de vuestro lado

Me quiero ir

Toda lepra os conmueve

Todo lloro os espanta

$[\ldots]$

Aquí me faltan los gritos de las gaviotas

El rumor de las ondas espumosas me falta aquí

Yo digo grito y la palabra grito

es silenciosa y sombra de un reflejo

La escritura no habla como yo

Yo grito y hablo de él la boca muda

Mi dolor no es contagioso

Pero quiero

inocularos mis angustias

Os escupe mi alma

$[\ldots]$

Yo conozco en infierno

Superior a mi talento es mi ser

Estoy tarado de sueño y locura

(«Plenitud del desastre»)

El rechazo del rebaño convierte al poeta en un lobo que aúlla alejado de la manada. Presencia aquí de la heterodoxia cultural: Hesse, Nietzsche, Nerval, Blake... El grito oryano es el grito dionisíaco y órfico que clama a martillazos, la nietcheana voluntad de poder que se despliega en todo acontecer y que marca el ritmo fluido y orgánico de la vida (Nietzsche, 1987, 1972: 88-98). Voluntad de poder que es, en suma, voluntad de vivir. Ory trata de liberar su existencia y su poesía de la esclavitud de los prejuicios sociales y de los diques racionalistas que encorsetan el conocimiento. La poesía oryana trata de romper con el lenguaje racionalista y se ofrece como una vía de conocimiento más allá de los conceptos. Este conocimiento parte del interior humano y busca, a través del dolor metafísico, la experiencia de totalidad, la unidad inseparable de todos los seres. El poeta se presenta como vidente de su propia existencia que, como Blake, limpia las puertas de su percepción. 
Si las ventanas de la percepción fuesen limpiadas, cada cosa aparecería al hombre como verdaderamente es, infinita.

Pero el hombre se ha recluido en sí mismo hasta tal punto que sólo ve las cosas a través de las grietas estrechas de su caverna ${ }^{310}$.

La expresión de este dolor existencial sólo puede ser libre, revulsiva, visionaria; y su lenguaje no puede ser otro que la poesía. La poesía se convierte, pues, en reflexión existencial y en expresión idónea de la propia existencia. Como consciencia de ello, toma la forma de la metapoesía:

¡Dios mío calma al fin el huraño gemido!

Criatura de volcán y de caligrafía

(«Este poema como», Poemas)

En mi poesía no hay estado mórbido

Ni tampoco soy un poeta maldito

No soy un esteta en su torre de marfil

Estoy en las tinieblas del alma humana

(«Confesión de poeta», Técnica y llanto)

\subsubsection{Las ratas.}

Las ratas representan en nuestro inconsciente colectivo la expresión más vívida del horror y de la repulsión. La asepsia cultural establecida desde siglos atrás rechaza como elemento tabú todo aquello que tiene que ver con el excremento, pues este suponía un verdadero foco de infección y el elemento transmisor de enfermedades por antonomasia. De hecho, aquello que primero se reprime en el ser humano es la relación con el excremento y con la desnudez ${ }^{311}$. En la esfera más íntima y vivencial del ser queda de este modo asociado asco y excremento, vergüenza y desnudez. En este sentido funciona el simbolismo de las ratas, a ellas se asocian todo tipo de sensaciones desagradables: viscosidad, oscuridad, insalubridad, asco, miedo, pánico, terror... Culturalmente las ratas se hallan asociadas al ámbito de las tinieblas, a lo apocalíptico, a

${ }^{310}$ Blake, William (1793), The marriage of heaven and hell; en Cazamian, M. L. ed., William Blake, traducción de Marie-Chistine del Castillo, Abelardo Linares y Cristóbal Serra, Madrid, Júcar, 1984, p. 165. «Tápate».

311 Una de las primeras frases que se dirigen al niño suelen ser: «Eso caca» o 
la pura catástofe. Las ratas son, de forma individual o consideradas colectivamente en forma de aterradora manada, el símbolo perfecto de la inmundicia humana. Las ratas apocalípticas se encuentran en las imágenes infernales de la pintura de El Bosco ${ }^{312}$, entre los monstruos de Bruegel ${ }^{313}$ o en las criaturas maléficas de Durero ${ }^{314}$. Más tarde regresan en los grabados de Goya... Las ratas, como paradigma de las criaturas de la noche y símbolo de la existencia más siniestra del ser humano, pueblan toda la literatura del horror desde $\mathrm{Poe}^{315}$ a la narrativa de la actualidad, pasando por Villiers de L'Isle-Adam, W.W. Jacobs ${ }^{316}$ o H.P. Lovecraft ${ }^{317}$. En la expresión poética, las ratas inundan los arrabales de la ciudad de París en Les fleurs du mal (1857) de Charles Baudelaire y se convierten en símbolo del malditismo y de la putrefacción cultural. La rata, como símbolo decadentista, encarna la demencia poética y la angustia más repugnante. En el expresionismo alemán, la rata se convierte en visión de pesadilla en la poesía de Trakl y, sobre todo, en la novela Die Andere Seite. Ein Phantasticher Roman (1909). Las ratas expresionistas aparecen también en la novela expresionista barojiana instaladas en el inmundo extrarradio madrileño de La busca (1904) y en el esperpento de Valle-Inclán. El horror representado por las ratas se instala en el existencialismo de Albert Camus, cuya expresión más patente se muestra en La peste (1947).

La poesía oryana del dolor debe insertarse en el interior de esta estética expresionista, que persigue la representación del horror más siniestro. Es la poesía lo que permite la convivencia con las ratas, la valentía, la osadía y el rechazo de los anestéricos sociales. Las ratas funcionan aquí como símbolo del ángel caído, condenado por su acto de rebeldía. Este es el símbolo perfecto que representa la arriesgada heterodoxia de la propuesta poética oryana. Poesía que arraiga en el territorio habitado por un malditismo combatiente que se separa totalmente de la manada social. Se trata de la expresión de un poeta maldito que encarna el dolor cósmico en su interior, que se siente partícipe, a través del dolor y de la angustia, de la unidad oceánica de todas las cosas:

${ }^{312}$ Las tentaciones de San Antonio (hacia 1500), Lisboa, Museo Nacional de Arte Antiga; El juicio final, Viena, Akademie der bildenden Künste.

${ }_{313}$ Dulle Griet (1562); Triunfo de la muerte (hacia 1562). En el segundo cuadro los ejércitos de esqueletos parecen manadas de ratas enfurecidas prestas a atacar.

${ }^{314}$ Adan y Eva (1504), grabado, Nuremberg, Germaniches Nacional Museum.

315 «El pozo y el péndulo» (1942).

${ }^{316}$ "The Monkey's Paw», The Lady of the Barge (1902).

317 «The Rats in the Walls» (1923), In the Vault (1925). 
Me estoy solo en completo silencio y carne viva

$\mathrm{Y}$ amo la oscuridad fuente de dicha

Demoníacos ratones estallan en mi espíritu

y las vanas y blancas mariposas se pudren

en mi cabeza de gran poeta

Únicamente yo reconozco el terror

que iza en la honda noche su bandera

cuando cierro los ojos o tristes los manejo

ante el divino cuerpo en su columpio

(«Blanco nocturno», Poemas)

CLIMA de ratas es la noche

El hombre huyendo y solo la tortuga

del mal lo alcanza con sus pobres ojos

Motores de la vida y de la noche

tu cazador iluminado grita

pues soy yo mismo

(«Clima de ratas es la noche», Poemas)

Las ratas son las criaturas de la sombra, los ángeles demoníacos que representan aquella zona territorial sagrada y socialmente maléfica que Ory no quiere abandonar. Por ello el poeta toma la apariencia de un ser doliente que se abisma en una herida cuya geografía quiere explorar.

Un plagado único dolor perdido acude a la desierta esfera blanca de los misterios

La sed santa la fe secreta roza el ánimo

¡Me asisten seres de fatales alas!

(«Ven triste ve tu», Poemas)

El poeta, mediante una operación de terrible alquimia interior a modo del sufrimiento experimentado en los ritos iniciáticos, conjura los demonios y es capaz de conjugar sombra y luz. Así encuentra, para decirlo de algún modo, la divinidad en el infierno.

En el poema «Plenitud del desastre» de Técnica y llanto, las ratas adquieren otra simbología. Aquí son representación de personas especiales, en este caso el poeta Félix Grande, su esposa de Francisca Aguirre y el joven Alberto. Son ratas porque se trata de 
personas distanciadas de los engranajes de la dinámica social y, por ello, ratas queridas, humanas, «inocentes»:

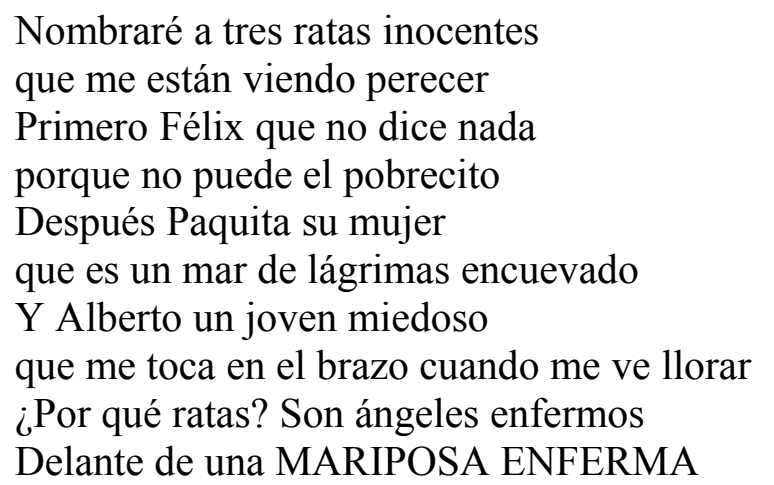

También las ratas representan a los amantes en el juego de un amor repulsivo. Amor como mal, que se alimenta de odio y soledad. El amor expresado en esta poesía oryana es un amor doliente que recoge en sí la dolorosa energía telúrica. Los amantes están conectados de manera automática e inexorable a la energía cósmica, por ello sienten el dolor y la sombra dentro de sí:

Los más amados henchidos de quietud Miran algo en las sombras y se engarzan de odio Bajo sus falos itifálicos Pasan las ratas del infierno En sus cráneos se quiere cavar un azadón Miran algo en las sombras del bosque del hastío Y no se alarman por el plan del mal

Sus manos han sonado como sus lenguas secas («Ratas», Técnica y llanto)

Erótica de la sombra, de la putrefacción y del excremento. En este sentido, Ory explora la senda abierta por André Breton y continuada, sobre todo, por Georges Bataille que consiste en desvelar el escenario interno del deseo amoroso. El poema anterior nos presenta una escena del teatro grotesco y apocalíptico del infierno de El Bosco. Para Bataille (1957, 1985: 366-367), el amor se mueve en la línea que trenza el placer y el horror. El éxtasis amoroso necesita la presencia de la muerte como telón de fondo, pues este es el espacio desde el que se percibe el goce. Para Georges Bataille (1957, 1985: 367): 
No llegaremos al éxtasis más que en la perspectiva de la muerte, y en la perspectiva de lo que nos aniquila.

Un hombre difiere de un animal en que ciertas sensaciones lo hieren y lo liquidan en lo más íntimo. Estas sensaciones varían según el individuo y según las maneras de vivir. Pero la vista de la sangre y el olor a vómito, que suscitan en nosotros el horror de la muerte, nos dan a veces a conocer un estado de náusea que nos alcanza aún con mayor crueldad que el dolor. No soportamos estas sensaciones vinculadas al vértigo supremo.

Bataille define perfectamente las constantes de la erótica oryana, instalada sobre el escenario del amor: una herida que supura.

Te amé con cualidad y con hojas mis manos

A ti que no eres lluvia y te arañó mi tigre

Envuelto en mi vestido de besos grité

mi cara que camina por sendas de terror

Te amé con luces lava y nervios montañosos

A ti que no eres rosa hospitalaria

Con lágrimas y esperma pinté tus nubes negras

Y con sangre de poeta tu invierno empapelé

Todo ha sido un extraño drama de rotos días escupiendo los vómitos enfermos del amor Quise siempre poner mi dulzura en tu cráneo

Quise llenar de estrellas tu boca degollada

Enterré mi lenguaje de rocío en tus ojos porque tú no leías mi nieve de pasiones

Para ti eran mis sueños cuervos y para mí el árbol de tu odio una torre tristísima

(«Los amantes dolientes», Técnica y llanto).

Esta erótíca desafiante tiene su paralelo en la pintura expresionista de Egon Schielle, cuyos signos son la representación de la locura, la plasmación descarnada de la geografía genital femenina, la plástica de una práctica erótica prohibida. Desde su circunstancia social, la erótica de Schielle fue considerada como la plasmación de una sexualidad perversa. Esta erótica de la perversión queda reflejada en la presentación pictórica de escenas de lesbianismo, de exhibicionismo, de masturbación... 


\subsubsection{Una alquimia interior.}

Mircea Elíade (1956; 1974: 90) señala el paralelismo que en la antiguedad existía entre el herrero, el mago y el poeta. El herrero trabajaba con el poder que le confería el arte de la forja, el mago operaba en la geografía del cuerpo mediante el poder de las ciencias ocultas (magia, sanación, chamanismo...) y el poeta era el orfebre del canto y de la danza. Sus utensilios eran los sentimientos. La poesía oryana pretende rescatar los poderes antiguos que poseía el poeta: la alquimia y el chamanismo. Por ello la poesía introrrealista supone una operación alquímica, pues toda alquimia consiste en una transformación interior. La alquimia supone una imagen de la mística; sus símbolos y operaciones son metáforas que apuntan a conceptos y procesos místicos. Así ocurre con el elixir de la larga vida, la morada de los inmortales (Eliade, 1965, 1974: 103107) y la flor de oro de la alquimia taoísta ${ }^{318}$, con la serpiente Kundalini del yoga tántrico (Varenne, 1977, 1985: 194-197), con la piedra filosofal de la alquimia europea (Jung, 1942, 1989: 46) y toda la simbólica hermética. La alquimia o filosofía hermética tiene su origen en el panteón de las divinidades egipcias, el dios Tot griego se convierte después en el Hermes Trimegisto griego ${ }^{319}$. Más tarde la hermética aparece transformada por el cristianismo. En este sentido Jung (1942, 1989: 45) añade:

La alquimia contenía ya desde los más antiguos tiempos una docrtrina secreta, o directamente lo era. Las concepciones paganas no desaparecieron de ningún modo por la victoria del cristianismo bajo Constantino; continuaron vivas en la curiosa terminología arcana y en la filosofía de la alquimia. Su principal figura es Hermes, es decir, Mercurio, en su notable doble significado de mercurio y alma del mundo, acompañado por el sol (el oro) y la luna (la plata). La operación alquímica consiste esencialmente en una separación de la prima materia, del llamado Caos, de lo activo, es decir, el alma, y lo pasivo, el llamado cuerpo; los que volverán a reunirse personificados en una figura, la llamado coniunctio, la «boda química»; la coniunctio es alegorizada como Hieros Gamos, como boda ritual de sol y luna. Esta unión surge del llamado filius sapientiae o philosophorum, Mercurius transformado, que como signo de su acabada perfección era pensado como hermafrodita. El opus alchymicum, a pesar de su aspecto químico, siempre fue pensado como una especie de acción ritual, entendida en el sentido de un opus divinum; por eso pudo ser representada por

${ }^{318}$ Ver Jung, Carl Gustav y Wilhem, Richard (1928), Das Geheimnis der Goldenen Blûte, Olten, Walter-Verlag AG; traducción de Roberto Pope, El secreto de la flor de oro, Barcelona, Paidós, 1991, pp. 40-41.

${ }^{319}$ Ver Renau, Xavier (1999), Textos herméticos, obra cit., pp. 8-12. Hacia el siglo II a. C. se traducen al griego algunos de los tratados egipcios de magia, astrología y alquimia que fueron acogidos con gran expectación. Este contacto entre la filosofía griega y la cultura egipcia marca el inicio del pensamiento hermético y de su literatura. 
Melchior Cibinensis, al comienzo del siglo XVI, como una misa, ya que mucho antes el filius, o lapis philosoforum, había sido concebido como allegoria Christi.

Las operaciones alquímicas, metáforas evidentes de estados místicos y mapas mentales que representan una orografía de la trasformación interior, tienen como finalidad una experiencia de muerte, de sentir la interioridad que ofrece el regreso al origen, al antes y al después de la vida. Esta es la nigredo, el retorno al útero, a la madre tierra. Se trata pues de un rito de renacimiento como lo eran los misterios de Eleusis o de Mitra, cuyo fin suponía una experiencia de integración en el fluir eterno del cosmos. En otras culturas ello equivale a la experiencia del despertar: experimentar la divina unidad de todo lo existente, sentir la energía cósmica en el interior del ser, anular las barreras que separan el cuerpo del resto de la realidad, provocar la desaparición del ego que separa y encierra al individuo en un ser atomizado, notar la presencia de la divinidad en el alma... Descripciones todas que evidencian una experiencia mística. La alquimia muestra cuatro estados que el experimentador debe atravesar (Eliade, 1956, 1974: 142-143). La nigredo supone la experiencia de la pérdida el ego, la desaparición de los límites corporales y mentales que separan al ser individual de la realidad. Se trata de una metáfora del infierno, una verdadera experiencia de muerte y de regreso a la profundidad de la tierra, experiencia, pues, de putrefacción. La fase siguiente es albedo, la obra blanca o experiencia de resurrección. Es el regreso de los infiernos, el renacimiento y la constatación de la experiencia de la unidad y de la totalidad mística. Las fases posteriores intensifican la nueva consciencia adquirida mediante la iniciación. Estas son la citrinitas y la rubledo. La rubledo podría describirse como la percepción de la divinidad o la unión mística, se trata de la obtención de la piedra filosofal. En este sentido, Juan Eduardo Cirlot $^{320}$ asocia el oro, símbolo de la piedra filosofal, con la inmensa felicidad que proviene de la luz divina que surge del centro del todo. La imagen del centro se revela como la conjunción de los opuestos, imagen que tiene su paralelismo en el ser andrógino. El oro es para Cirlot «el sol subterráneo apareciéndose en la profundidad del atanor ${ }^{321}$.

En la poesía oryana encontramos la presencia del rito alquímico, en ella se ofrece una meditación sobre el dolor. En este caso, meditación no equivale simplemente

${ }^{320}$ Cirlot, Juan Eduardo (1958), Diccionario de símbolos tradicionales, Barcelona, Luis Miracle; Diccionario de símbolos, Madrid, Siruela, 1997, $3^{\text {a }}$ ed., p. 34.

${ }^{321}$ íbid. 
a una divagación intelectual, sino a una experiencia psicosomática, a una percepción consciente del dolor existencial. Se trata, pues, de una experiencia de la noche, de la sombra, que coincide con la nigredo de los alquimistas. El Diario de Ory contiene numerosas referencias a la magia, la alquimia y a su proceso trasformativo. El día 15 de mayo de 1952, Carlos Edmundo de Ory escribe en Madrid:

Yo no soy nada porque nací. No seré nada porque vivo. ¿Morir? No es nada. El Universo es grande. Yo no soy ni siquiera pequeño. No soy nada. Y en cuanto a la Historia, ¿qué es la Historia? La Historia no es nada para el Universo. El hombre (que es comido por la tumba) quiere ser comido por Dios. Quisiera estae dentro de la boca de Dios. Sentir que Él me masca, me traga, me engulle. Vivir dentro de Dios como Jonás dentro de la ballena (que le ${ }^{322}$ depositó en Cádiz).

El ego sólo está rodeado de basuras, de las más bajas basuras. El ego es odioso y maloliente. El ego es una mosca enviscada en la suciedad de las pasiones y del sensorio (2004, Vol I: 199).

El 22 de marzo de 1953, desde París, Ory añade:

El hombre debe olvidarse de su yo, que es mezquindad. El hombre debe abrirse al mundo, a todas las cosas, con la ternura de su alma, y no cesar en esta tarea. Debe impregnarse del mundo natural y divino. Porque todo lo natural es divino. El hombre tiene la obligación de educarse hasta la muerte (2004, Vol. I: 253).

Este fragmento data del día 10 de septiembre de 1968:

Mi vida sangrienta está en mis poemas.

$$
[\ldots]
$$

No quiero que nadie venga a curar mis llagas. No tienen que ser curadas. Que se trasformen algún día en joyas (2004, Vol. II: 209).

Y el 28 de julio de 1972, Ory traza un decálogo de su proceso de iluminación. En él aparecen referencias a la alquimia, a la magia, al chamanismo... así como a las filosofías orientales como el hinduismo, el taoísmo y el budismo:

No soy místico ni ocultista. Tampoco mago o chamán. Sin embargo, he estudiado todas las principales religiones del mundo. Soy budista, o más bien aspiro al estado de Buda.

${ }^{322}$ Sic. 
Yo he vivido largas soledades, descritas en mis numerosos diarios. Y he gozado con ellas contemplando mi sufrimiento y mis sufrimientos. El dolor siempre me ha deparado bienes [...]

No tengo teorías sino reglas. Como cuando tengo apetito, duermo cuando tengo sueño. Estoy preparado para vivir así. No soy un héroe ni un santo. Ni vivo milagrosamente. Decidí un retiro para poner un orden en mis «pensamientos almacenados».

Estos pensamientos me acompañan, así como el ejemplo de los grandes místicos del «sendero directo». Mis pilares son el Tao, el Zen y el Vedanta.

También me inspiran y me enaltecen los profetas del Antiguo Testamento y la Kábala. He estudiado el ocultismo en sus obras más difícil acceso $[\ldots]$

He aprendido casi todo lo que me sirve para estar despierto -digo DESPIERTO- [...]

No soy un iluminado ni un alucinado. Soy un hombre simple que circula, forzosamente, en medio de una civilización caótica y confusa, enferma y decadente (2004, Vol. II: 354-355).

El interés oryano por la alquimia forma parte de un proceso individual de iluminación que queda perfectamente reflejado en su poesía, que a su vez se ofrece como su glosario. En ella la alquimia toma un aspecto relevante, pues forma parte del ejercicio de meditación que se realiza a través del dolor. Todo ello queda perfectamente representado en este aerolito:

La poesía es un vómito de piedras preciosas.

(Los aerolitos, 2005)

A través de la noche y de las tinieblas, como si se tratase de un proceso curativo, se traza un viaje hacia la iluminación. Para ello se debe atravesar, como en la mística ascética sanjuaniana, el desierto de la noche oscura, de la tristeza, de la angustia y de la desolación, hasta conseguir rasgar el velo de maya. Romper los sistemas ilusorios creados por el lenguaje y acceder a la realidad primigenia, a la materia prima de los alquimistas. Operación que coincide con el despertar del budismo o el satori del zen:

La poesía es un engendro del dolor desde antes de la época moderna La leyenda de Orfeo el Kalevala todo es allí llanto y más llanto El dolor me pertenece y tengo que responder a él No me importa la felicidad 
sino la vida soberana

lo grandioso, lo abismático

la fiesta el ardor el peligro

la ola santa del corazón

la locura dionisíaca

la beatitud del ser puro

El dolor del hombre sofocleico

(«Confesión de poeta», Técnica y llanto)

Ory llega, a través del dolor, a la percepción del éxtasis ante una realidad beatífica, y esta beatitud es expresada como un rapto dionisíaco ante lo que ocurre en el aquí y el ahora. Tarea preconizada por Nietzsche, la de vivir la realidad bajo la óptica de la ebriedad dionisíaca, negadora de todo límite conceptual. Porque detrás de los conceptos se esconde una realidad sin límites y para acceder a ella se debe, como si se tratase de un proceso alquímico, abandonar el viejo equipaje de las palabras:

Nadie oye mis pasos yo tampoco

Abro y cierro los ojos en tinieblas

Mis pestañas se enganchan al vacío

Mi lujuria en el viento enfermo sangra

Espantado de mortal cansancio

Solamente vigilo mi silencio

Descubro tras la noche la gran puerta

donde el guardián invisible me espera

(«Estoy callado», Técnica y llanto)

Para acceder a la realidad beatífica, el poeta debe someterse a una quirurgia del dolor, cuya finalidad supone sacudir los viejos prejuicios y las antiguas servidumbres que esclavizaban al ser humano, sometido entre los engranajes de una cultura represiva. El rito alquímico representado en la poesía oryana supone abolir el peaje cultural pagado a una entidad social que preconiza, utilizando el lenguaje de Nietzsche, una moral de los esclavos $(1887,1972: 31-38)$.

El fin de la alegría es la salud de la vitalidad (Beethoven) y no la enfermedad de los débiles los eternos débiles enemigos de la vida 


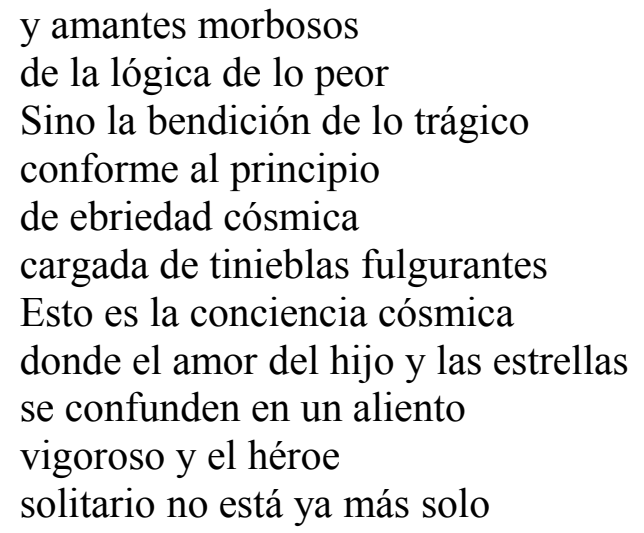

(«Vamos hacia lo mejor», Técnica y llanto)

En un lenguaje visionario y críptico, que recoge la tradición de Blake, Novalis, Rimbaud o Eluard, Ory nos traza el significado último de la filosofía perenne: taoísmo, budismo, zen... que en definitiva es la infinita interconexión de todas las miríadas que forman el cosmos ilimitado. 


\subsection{POESÍA DE PROTESTA}

Pero no hay crecimiento sino demarcación, luz sucia, leche amarga, mierda en los orinales.

Javier Vela

Con la escritura de La flauta prohibida la poesía oryana toma una nueva dimensión: la poesía social. Aunque la obra apareció publicada en 1979, abarca un gran periodo de tiempo, exactamente desde 1947 a 1979. Algunos de sus poemas, tal como figura en el Apéndice XIX, ya se habían ofrecido al público en entregas parciales ${ }^{323}$, pero La flauta prohibida los recoge y los articula en una estructura unitaria. Esta obra cíclica está compuesta por cuatro partes que pueden considerarse obras en sí mismas: Clausi tenebris carcere integra poemas escritos entre 1957 y 1979, El rey de las ruinas contiene poemas escritos entre 1947 y 1969, Todo es una gota de fuego se halla compuesto por poemas escritos entre 1953 y 1967 y Música de lobo presenta poemas escritos entre 1957 y 1969. Como puede observarse, esta obra nos ofrece un período poético dilatado que va desde la poesía postista hasta la escritura de una poesía vanguardista y experimental, pasando por una poesía heterodoxa que discurre paralela a la poesía peninsular de la generación de los setenta. En ella se ofrecen varias direcciones que serán continuadas en otros poemarios posteriores: la poesía experimental, la poesía beat y el acercamiento a las filosofías orientales. Es justamente Música de lobo la apertura que inicia el interés oryano por el viaje a Oriente y su recorrido a través de todas sus geografías culturales.

\subsubsection{Un lenguaje crítico.}

La poesía contenida en La flauta prohibida supone, en cierto modo, una reivindicación de la poesía social. Se trata de una poesía política, que posee una

${ }^{323}$ Apareció una parte de la obra, titulada La flauta prohibida, exactamente 8 poemas, en Papeles de Son Armadans, n 114, Palma de Mallorca,septiembre 1965, separata. También se publicaron 17 poemas pertenecientes a El rey de las ruinas en Papeles de Son Armadans, $\mathrm{n}^{\circ}$ 164, Palma de Mallorca, noviembre 1969, pp. 157-174. Música de lobo se publicó íntegramente en 1970, Madrid, Grupo N.O. 
verdadera voluntad de denuncia y se erige como un grito de indignación frente al fascismo, imperante ahora en los engranajes socioculturales mundiales. Esta actitud se nos desvela como una ataque abierto contra los sistemas dictatoriales universales (sea la dictadura de Augusto Pinochet como el fascismo practicado por los regímenes de signo comunista), como un alegato contra todo abuso de poder. Poesía libertaria, pues supone un claro rechazo a toda forma de poder. Ahora bien, el espacio político recorrido por $L a$ flauta prohibida no coincide con el territorio poético donde surgió la poesía social de las décadas de los cuarenta y los cincuenta en la posguerra española ${ }^{324}$. Aunque la poesía política oryana busca su raigambre en la ética e insiste en establecerse como testimonio sobre la actualidad, rehuye tanto las tesis neorrealistas como la primacía del elemento ideológico. El interés oryano más que centrarse en el cambio social lo hace en desvelar cómo los tentáculos del fascismo se han infiltrado en la maquinaria social. En este sentido, Jaume Pont (1998: 229) señala la expresión de la ideología del yo frente al acontecer histórico.

La óptica realista, representada como un espejo reflector de la realidad, se cambia ahora por una estética, que sin rehuir la mirada mimética, se podría enmarcar en el territorio del pop crítico o estética de la denuncia. Óptica que no consiste simplemente en el realismo fotográfico, sino en la elaboración mediática de los materiales representados sustraidos de la realidad. En la poesía oryana no encontramos el interés por la colectividad, ni el abandono de la estética poética por el interés en el acercamiento a un destinatario mayoritario. El lenguaje poético oryano no va dirigido a la gran mayoría de Celaya o la inmensa mayoría oteriana, sino que se trata de un lenguaje que posee un verdadero interés poético, que supone una gran aventura lingüística, que busca una renovación poética convergente, en ocasiones, con la vanguardia más radical. Se trata pues de un lenguaje que corre paralelo a su temática crítica, un lenguaje libertario que recorre ciertas zonas de lo que literariamente se llama

${ }^{324}$ Luis (1965: 13-20). En la posguerra poética Leopoldo de Luis mantiene que aquello que diferencia la poesía social de la poesía política es el sentido dogmático y panfletario, propiedades exclusivas de la esta última. La poesía social en la posguerra comparte con la poesía civil y con la poesía política el componente realista y la historicidad. Pero, lo que para el autor define plenamente la poesía social es el compromiso con la realidad y el carácter protestatario ante una situación de injusticia humana. Leopoldo de Luis define la poesía social como una conciencia que defiende la igualdad y la libertad de los seres humanos. Definición que englobaría la poesía protestataria y política de Carlos Edmundo de Ory. Pues la óptica oryana excluye siempre cualquier tinte panfletario. 
la poesía experimental, como la poesía concreta, la poesía visiva o la poesía semiótica... El poema titulado «Trípode español» resulta totalmente representativo:

\section{I}

Españoles oles oles ¡olé! olas del mar

Españoles es ser o no ser

pañoles paños puños piñas

Es un es

$$
\text { pañol }
$$

niño en pañales

¡puñales!

\section{II}

Que no me vengan a mí

que no me vengan

con venganzas

Español

espada y gol

Yo andaluz

el que anda con luz

ilumino

el camino

y apago el casino

\section{III}

Yo no pienso en España

(pienso para las vacas)

Yo doy la cara España

y doy la seña

La seña aquí y ahora

¡Señora España!

Este lenguaje crítico, contestatario y libertario, parte, sobre todo, de la poesía de Allen Ginsberg. La publicación en San Francisco, en 1956, de su poema «Howl», incluido en el poemario Howl and Others Poems, significó una verdadera conmoción estética y social. Allí se hallaba un lenguaje improvisado y lunático, profundamente anárquico y totalmente crítico, que atacaba abiertamente todas las dinámicas del sistema 
social americano. Ginsberg presentaba así un lenguaje heterodoxo que condensaba una airada protesta dirigida al dios Moloch, símbolo perfecto del stablismen americano.

Moloch the incomprehensible prison! Moloch the crossbone soulless jailhouse and Congres of sorrows! Moloch whose buildings are judgement! Moloch the vast stone for war! Moloch the stunned governements!

Moloch whose mind is pure machinery! Moloch whose blood is running money! Moloch whose fingers are ten armies! Moloch whose breast is a cannibal dynamo! Moloch whose ear is a smoking tomb!

Este lenguaje crítico, airado y combativo, establecido por Ginsberg, coincide plenamente con el lenguaje oryano practicado en La flauta prohibida. Un lenguaje que persigue una dirección política, que expresa un frontal ataque al fascismo y a la ideología burguesa, cuyo producto es la sociedad posmoderna mercantilista y consumista, paradigma de la tecnocracia capitalista. Este fragmento del poema «Nagasaki Days», escrito en 1978 por Ginsberg, el mismo año en que fueron escritos algunos de los poemas oryanos que forman parte de La flauta prohibida, contiene la misma voluntad de unir vanguardia y conciencia crítica que la propuesta oryana:

2,000,000 killed in Vietnam

13,000,000 refugees in Indochina 1972

$200,000,000$ years for the Galaxy to revolve on its core

24,000 the Babylonian Great Year

24,000 half life of plutonium

2,000 the most I ever got for a poetry reading

80,000 dolphins killed in the dragnet

$4,000,000,000$ years earth been born

(Plutonian Ode. Poems 1977-1980, 1982)

Esta poética crítica, paralela al lenguaje de Ginsberg, se observa en el poema oryano «Heil Hitler»:

Treblinka Treblinka Treblinka

Heil Hitler!

Büchenwald Büchenwald Büchenwald

Heil Hitler! 
Plotzensee Plotzensee Plotzensee

Heil Hitler!

Auschwitz Auschwitz Auschwitz

Heil Hitler!

El lenguaje crítico-político oryano entronca con los flujos lingüísticos que surgen del pop-art más crítico $^{325}$ y de la canción protesta descendiente del folk norteamaricano ${ }^{326}$ que confluyen en el lenguaje de Bob Dylan, amigo de Ginsberg y continuador de su poética beat. Ejemplo de ello resulta el fragmento de la canción homónima del disco publicado en 1965 titulado Highway 61 revisited:

Oh God said to Abraham, «Kill me a son»

Abe says, «Man, you must be puttin' me on»

God say, «No.» Abe say, «What?»

God say, «You can do what yuo want Abe, but

the nex time yuo see me comin' you better run»

Wel Abe says, «Where do you wnat this killin' done?»

God says, «Out on Highway 61.»

Uno de los acercamiento al lenguaje poético crítico se efectúa desde la vanguardia artística y poética. Son los autores de la poesía experimental quienes socialmente mantienen las actitudes más radicales: el lenguaje conceptual de Ben Vautier ligado al grupo Fluxus, la poesía concreta de Decio Pignatary, la propuesta politizada del Paul de Vree surgida a partir del Grupo 70, la poesía-proceso de Moacy Cirne, la poesía pop-art radical de Cavan MacCarty, la poesía visual de José Miguel Ullán y de Guillem Villadot, y, sobre todo, la actitud comprometida de Joan Brossa. El

${ }^{325}$ El arte pop consiste, sobre todo, en la presentación social del lenguaje mediático y publicitario. En este sentido, sólo algunas de sus prácticas poseen la voluntad de desenmascarar los mecanismos industriales de manipulación social. Para Marchán Fiz (1986: 48), la postura de los artistas pop nunca ha sido excesivamente crítica. Su función ha consistido en utilizar los fetiches ofrecidos por las sociedades del capitalismo tardío, en ofrecer la obra de arte como una mercancía industrial. De todos modos, es evidente la existencia de un lenguaje crítico en autores como Robert Rauschenberg, George Segal, E. Kienholz, Kitaj, J. Tilson y en algunas producciones de Andy Warhol. La derivación más política del pop-art es el underground pop. Por otra parte, el arte psicodélico tiene también derivaciones politico-sociales porque surge de la contracultura de los años sesenta y por ello supone un rechazo frontal al sistema.

${ }^{326}$ El folk norteamericano nace de la conjunción de la música de la mayoría racial blanca y la de las pequeñas comunidades indias. De aquí surge la canción protesta, unida a la lucha por los derechos civiles. Los primeros representantes de la protest song son Joe Glazer, Woody Guthrie y Pete Seeger. En la década de los años sesenta del pasado siglo el folk se bifurca en dos direcciones: el folk purista (que luchaba contra la electrificación como signo de distanciamiento de las estrategias del capitalismo) y el folk progresivo o folk-rock, cuyo representante más icónico sería Dylan (Judas para sus enemigos). 
soneto brossiano titulado «Llaor», escrito en 1973, es un ejemplo claro del lenguaje testimonial, urgente y directo, y de la línea política de su poesía:

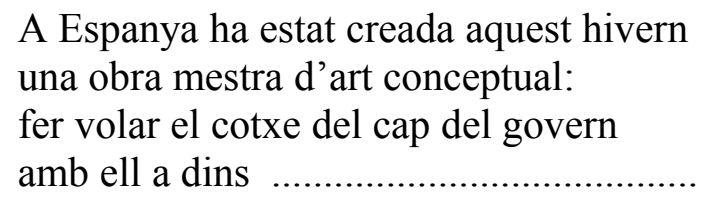

Este lenguaje poético crítico, que contiene una clara carga política, posee una clara intersección con la territorialidad pictórica desde la que surge la obra pop de denuncia social de Josep Guinovart, la pintura protesta de Juan Genovés, la crónica social de signo pop practicada por el Equipo Crónica ${ }^{327}$ y por el Equipo Realidad ${ }^{328}$. Esta actitud crítica, ofrecida en la pintura, se distancia del realismo social en el sentido de que ahora la obra de arte no sólo debe mostrar la realidad más inmediata, sino desenmascarar los mecanismos que articulan la realidad social. El simple testimonio no basta, cabe pues desarticular los engranajes de la manipulación que ofrece el lenguaje del poder. Desde el informalismo pictórico el grupo El Paso ${ }^{329}$ inicia este gesto de cuestionamiento y de oposición a la cultura oficial. En el segundo Manifiesto (1959) se propone la práctica de un arte permanentemente renovador que surge de unas condiciones históricas precisas y que tiende hacia la intervención social:

${ }^{327}$ Grupo fundado en Valencia en 1964, integrado por Rafael Solbes, Manolo Valdés y Juan Antonio Toledo.

${ }^{328}$ Grupo formado en Valencia en 1966 por Joan Cardells y Jorge Ballester.

329 Grupo creado en 1957 y disuelto en 1969, formado por Antonio Saura, Manolo Millares, Luis Feito, Rafael Canogar, Manuel Rivera, Juana Francés, Antonio Suárez, Martín Chirino, Manuel Viola, Pablo Serrano y por los críticos Manuel Conde y José Ayllón. 
Creemos que nuestro arte no será válido mientras no contenga una inquietud coincidente con los signos de la época, realizando una apasionada toma de contacto con las más renovadoras corrientes artísticas.

Vamos hacia una plástica revolucionaria -en la que estén presentes nuestra tradición dramática y nuestra directa expresión-, que responda históricamente a una actividad universal.

[...]

Nos encaminamos hacia una gran transformación plástica en la cual encontrar la expresión de una «nueva realidad».

Y hacia una anti-academia, en la que el espectador y el artista tomen conciencia de su responsabilidad social y espiritual (Marchán Fiz, 1986: 345).

\subsubsection{Poesía política.}

En La flauta prohibida la poética oryana se ofrece como una poesía de testimonio, que intenta bajo un tono apocalíptico, a la vez que irónico y paródico en ciertas ocasiones, dirigir la atención del lector hacia ciertos aspectos políticos y sociales de la realidad. En este sentido, se trata de una poesía de denuncia y de protesta, cuyo lenguaje rehuye las tesis del realismo poético y converge con la vanguardia poética. Se busca un lenguaje desinhibido y fresco, más acorde con el arte y con la realidad de la posmodernidad. La poesía oryana busca determinadas referencias socioculturales y las activa a modo de iconos pop: las imágenes de Nixon, Gandhi, Hitler, Neruda, la guerra del Vietnam, el imperialismo norteamericano, la guerrilla, el poder militar, el fascismo ruso, el destierro... En el mismo prólogo de la obra Ory nos habla de una «experiencia desgarradora», contextualizada en la cotidianeidad, que no puede rehuir la indiferencia humana. Por ello, se trata de una poesía comprometida hasta el tuétano, que posee sus conexiones con el arte referencial que surge del mayo francés y de la contracultura postpop. La poesía política oryana tiene sus enclaves en la estética narrativa del reportaje social y la estética feísta del schocker $p^{3} p^{330}$.

La poesía política oryana queda configurada como un doble alegato: por un lado contra el fascismo y, por otro, a favor de la libertad personal. Libertad que, a su vez, exige una gran dosis de solidaridad. En ello justamente se observa la admiración de Ory

${ }^{330}$ Ver Marchán Fiz (1982: 65-69). El schocker pop está ligado al undergroud y resalta, bajo una óptica política combativa, las contradicciones y los conflictos sociales, en ocasiones locales y puntuales. En la sociedad norteamericana el schocker pop ofrece un testimonio de la coetaneidad: la guerra vietnamita, el black power, los derechos de las comunidades indias, el feminismo... Esta estética se acerca a la protesta de la nueva izquierda liderada por figuras como Abbie Hoffman, Jerry Rubin o los Panteras Negras. 
por la poesía de Gabriel Celaya. Entre ambos poetas existió una gran amistad que queda reflejada en una estrecha relación epistolar y en un interés compartido por la vanguardia poética. Interés que en el caso de Celaya se tradujo en la obra Campos semánticos (1971). Resulta reveladora la exaltación de la poesía oryana frente a los poetas de la década de los cuarenta que encontramos en algunas cartas de Gabriel Celaya:

Amigo Carlos Edmundo: Tú y Labordeta sois los dos únicos poetas españoles contemporáneos que no me aburren

Esto quizás te parezca poco pero es extraordinario. Influís en mí, me hacéis pensar que me he desviado y que con mis monerías me estoy yendo por los cerros de Úbeda ${ }^{331}$.

Me gusta saber de ti. Eres estimulante. Siempre me das un poco de agua virgen. Nuestros poetas me tienen tan aburrido que a veces me aburro de mí mismo - que al fin y al cabo me parezco a ellos- y entonces me creo triste. No es verdad pero es muy fastidioso ${ }^{332}$.

Una de las direcciones de la protesta poética oryana consiste en erigirse como un permanente alegato contra al fascismo. Muchos poemas son los que presentan un ataque al fascismo, entre todos ellos señalamos el titulado «Beso y mordisco»:

El verbo es para mí la hierba y las ideas son mis dientes Yo que soy beso para la mujer soy mordisco para la invasora sombra del militar tarado Los árboles que aconsejan a Dios son de seda y no de madera y la inocencia angélica se alza con Dios a la cabeza vestido de pirata Entremos a saco de fastidio contra el fascismo

O el poema que se titula «Información»:

En el despacho del infierno las caras de los jerifes pegadas a los teléfonos de oro mientras desnudas muchachas teclean comunicados de última hora Europa tiene cáncer en el culo

331 Carta escrita el 10 de diciembre de 1949. RevistaAtlántica de poesía, $\mathrm{n}^{\circ} 27$, separata, publicación cit., p. 47.

${ }^{332}$ Carta escrita el 30 de febrero de 1952. Ibíd., p. 48. 
El Demonio se ha acostado en su cama de cristal

La referencia al fascismo hitleriano queda mucho más clara en la instantánea poética que supone el poema «El bunker del hambre de Auschwitz», claro retrato de la violencia y el horror causado por las prácticas genocidas:

\author{
El bunker del Hambre de Auschwitz \\ es hoy un santuario \\ es hoy un santuario \\ Le rompían los miembros \\ en la célula de betón \\ y no le daban agua \\ tampoco agua \\ Sin ventana ni nada \\ de betón a betón \\ y hasta Gandhi bebía \\ agua en las huelgas \\ de hambre \\ es hoy un santuario
}

Cabe señalar que el aspecto narrativo de este registro poético, totalmente alejado de la poeticidad habitual del discurso oryano, se acerca a la óptica del reportaje testimonial, cuyo lenguaje resulta mucho más prosaico. La narratividad poética es un registro que recorre toda la poesía social oryana, convirtiéndola en un caleidoscopio de pequeñas intantáneas sociopolíticas. En «Persona non grata» el objetivo de Ory apunta a la realidad del destierro, del exilio y de la marginación:

Le hicieron saber oficialmente

que le será prohibido hablar

y le instan a abandonar el territorio

No dijo nada y sonrió

Estaba mudo

Pasó la puerta despacio

sin sombrero y sin corbata 
La ironía es otro recurso empleado en esta poesía de apariencia prosaica. El poema titulado «Amor a deshora» reproduce, a modo de poesía oral, la conversación entre un guerrillero y su amada. Supone, después de haber penetrado en la opacidad irónica que envuelve al poema, una reflexión sobre la erótica y el compromiso, sobre el amor y la violencia. En todo caso, el poema propone una mirada hacia la violencia institucional militarista y hacia la respuesta violenta de la guerrilla. Aquí la ambigüedad que se establece en el poema acerca a la poesía oryana al arte conceptual ${ }^{333}$ :
Mira querido tenemos que hacer algo
-Pues estoy besando tu boca
Que no es eso quítame allá esas pajas
Es que el mundo se hunde
-Pues di mejor que el mundo se hunde
No seas caprichoso oso miamor ${ }^{334}$
- Ahora no pienso en nada
Es que debes pensar en la guerrilla
-Te juro que estoy presto y predispuesto
Pues vete ya
-Espera que me interesan tus dos pechos

Narratividad, prosaísmo, referencialidad, ironía... son los ingredientes que marcan la experimentación que conlleva esta poesía de signo político y social. En el poema la preocupación política está mediatizada por un lenguaje experimental instalado en la vanguardia poética coetánea. La frialdad que ofrece su semántica puede suspender la expresión de la ira. Frialdad que surge de la distancia entre el objeto representado y el objeto que se observa. La poesía política oryana se apropia de este mecanismo

${ }^{333}$ Entendemos que el arte conceptual supone un desplazamiento del objeto hacia el concepto. Por ello, se trata del arte que juega con el concepto. Pero no se trata de un juego intrascendente porque ello implica una verdadero proceso intelectual y reflexivo. Consiste en una reflexión sobre la práctica artística o sobre el propio arte. En el caso más extremo se tiende a la desmaterialización total del producto artístico, de modo que resulta un arte lingüístico donde la palabra queda separada de todo objeto material. Ello implica una paradoja, ya que el mismo signo lingüístico posee un componente material que hace de soporte del significado, en este caso conceptual. El arte conceptual también puede sustituir el lenguaje por el signo icónico (dibujo, grafismos, fotografía, video...) que actúe como elemento semiótico o narrativo. Por otra parte, en la posmodernidad toda práctica artística exige una teoría, porque el objeto artistico exige una interpretación. Según el concepto del arte como transfiguración de lo cotidiano, propuesto por Arthur C. Danto, sin la teoría la pintura sólo se trataría de colores y nada más.

En el caso de la materialidad del significado lingüístico ver Ángel López García (1980), Para una gramática liminar, Madrid, Cátedra, p. 50. En el caso de la transfiguración ver Arthur C. Danto (1984), Die Verklärung des Gewöhnlichen. Eine Philosophie der Kunst, Fráncfort del Meno, Suhrkamp; traducción castellana La transfiguración del lugar común: una filosofía del arte, Barcelona, Paidós, 2002 y Konrad Paul Liessman (1999), Philosophie der modernen Kunst, Viena, WUV; traducción de Alberto Ciria, Filosofía del arte moderno, Barcelona, Herder, 2006, pp. 169-180.

$$
{ }_{334}^{3} \text { Sic. }
$$


distanciador ofrecido por el pop-art. El juego con las frases hechas, la subversión del lenguaje amoroso, el contraste entre lo individual y lo colectivo hacen que el poema se acerque a la estética de la performance y al happening político ${ }^{335}$.

La poesía oryana nos ofrece también un claro testimonio sobre el maltrato infantil y sobre el maltrato femenino. Como la poesía de Lorca, la poesía oryana traza lazos de solidaridad con los más indefensos y con los más oprimidos. Si en Lorca estos son los gitanos de Andalucía y los negros de Harlem, en Ory son los personajes heterodoxos: poetas, artistas, sabios, mendigos, apátridas, trabajadores... Y entre ellos los personajes más marginados de todos, las mujeres y los niños. Ello queda perfectamente expresado en el poema «Oprimidos»:

La mujer los niños bichos raros en las jaulas de los amos ¿Es que no son las jirafas más grandes que los enanos?

Los niños son subnormales o minusválidos psíquicos Cuando los mimos se olvidan les tratan a palo limpio

Dentro de estas miniaturas se forma la larga fila de negros mujeres niños y los mayores ENCIMA

Parecido mensaje posee el poema vanguardista que tiene como irónico título «Lección de apertura a los cursos de mitologías orientales en la Facultad de Letras de la Universidad de $\mathrm{X} »$ :

\author{
Señor Rector \\ Señor Decano de la Facultad de Letras \\ Señores Cónsules generales \\ Señores Profesores \\ Señoras Señoritas Señores \\ Niños \\ Criadas de servir
}

${ }^{335}$ Una de las direcciones que ha desarrollado el happening ha sido la política. El happening como tal ha supuesto una práctica utilizada como actitud combativa en el espacio público. En este sentido funcionan las acciones de J.J. Lebel, de W. Vostel o de J. Beuys. 
trabajadores obreros

gatos y perros

hormigas

Ahora bien, la ira y la rabia aparecen de una forma más patente cuando el objetivo de la poesía se dirige el poder militar y a sus abusos. El poema titulado «Pablo de Chile» refleja el desprecio más atroz ante el horror producido por la violencia practicada por los militares que, apoyados por el poder de estados Unidos, fraguaron el golpe de estado en Chile. En él se expresa el terror que produjo la terrible represión efectuada a base de asesinatos, torturas, desapariciones y otras humillaciones. El siguiente fragmento, estructurado a modo de una imagen continuada que parte del elemento real A (militares), nos traza una instantánea de la ira sufrida ante tal situación:

Pistolas y fusiles manos negras

Hombres torcidos máquinas de lepra

Enemigos del trigo azote sucio

Basura del veranos universal

Oscurantistas de la luz humana

Asesinos de halos y luciérnagas

Herederos de ciegos y miopes

Bandada de odio duchos en tinieblas

Gente docta en doctrinas maniacas

Turba tentacular señores grises

Jefes de la terrible tierra muerta

Coleccionistas de sangre roja

Funcionarios de la tortura

\subsubsection{Contra España.}

Otra de las direcciones de la poesía política oryana la ofrece la crítica a la sociedad española ${ }^{336}$. Ory presenta una mirada agria y desencantada sobre la realidad cultural peninsular. Esta poesía, escrita básicamente desde su exilio en Francia, ofrece una serie de amargos testimonios sobre los tópicos donde se asienta la ramplonería, el

${ }^{336}$ Cano (1979: 28), García de la Concha (1979: 240; 1987: 576-577). Es Carlos Bousoño quien en la posguerra, rehuyendo las posiciones sociales y políticas, propone una mirada angustiada sobre la realidad española en el poema "Dios sobre España», que apareció en marzo de 1945 el número 23 de la revista Garcilaso. En la primera obra de Bousoño, Subida al amor, aparece este poema que, junto a «Oda a España» y «España sosegada», introduce el tema de España en la posguerra poética. En cierto sentido, Bousoño inicia en la posguerra la óptica del desasosiego respecto a la realidad nacional, gérmen de la crítica sobre la situación social, cultural y política de la realidad española. 
chauvinismo y el atraso cultural de la sociedad de este país ${ }^{337}$. Desde el amplio horizonte del exilio cultural, desde este gran desierto nómada que representa la cultura transpirenaica, se trazan una serie de instantáneas dirigidas al espacio baldío que se ha dejado atrás. La sociedad española, vista en el blanco y negro de la televisión del franquismo, se nos aparece como una inmenso páramo, como una cárcel extensa y como un vasto cementerio. Espacio de asfixia y de opresión, que toma en ocasiones la imagen de un gran ataúd. Imagen esta que es bastante recurrente:

Los nervios (como un ay) se ahogan dentro de un ataúd ¡Cuántas veces me ahogo dentro de un ataúd!

$$
\text { («He entrado en París») }
$$

Y en el agua sucia de las palanganas dejo el pus siniestro de algunas heridas Y me voy cansando de los ataúdes $\mathrm{y}$ de los marquitos pechos de viuda $\mathrm{y}$ de los piojos que tiene la vida

$$
\text { («Oxymoron de la angustia») }
$$

Con tus capas de torero hazme un traje funerario y un sudario de primera $Y$ en mi tumba pon mañana un cocido de garbanzos con chorizo

$$
\text { («España mística») }
$$

Otra de las imágenes asociada a la sociedad española es la de una herida infectada que provoca pus, vómitos y hemorragias. A través de las llagas de sus tópicos socio-culturales supura el dolor causado:

Dentro estoy del enredo involuntario de haber nacido tan pequeño y cuántas enfermedades de mal gusto bien atendidas por más de un par de manos

${ }^{337}$ La crítica sobre la realidad cultural española coincide plenamente con la amarga visión ofrecida por Luís Martín Santos en Tiempo de silencio (1961) y con la óptica apátrida de Juan Goytisolo expresada, sobre todo, en Reivindicación del conde don Julián (1970). Autores que unen crítica y experimentación. 
Las fiebres termométricas y las cucharas que me meten en la boca

De mi país he respirado todos los microbios

(«Odio»)

Nuestro diálogo era escuchado por las moscas que no tienen físico

Comparados con los sabios incendiarios de antaño nuestra ropa de lepra de Madrid oyendo misa en las alcantarillas y todo nuestro altar era un grito miserere

(«Ovario materno»)

Hemos perdido demasiado el tiempo con tristezas perezas y trapitos de patria oyendo las sirenas y el pitido de los trenes y otras hemorragias del corazón en la niñez

(«Reflejos de lugares bis»)

La podredumbre cultural se hace extensible a toda la sociedad occidental. Por ello, lo que se rechaza no es simplemente la cultura represiva del franquismo, sino los mismos engranajes sociales de toda cultura. Frente a la sumisión que propone todo poder social, en su poesía Ory expresa la ruptura de todos los valores represivos, ruptura cuya práctica exige el ejercicio de la libertad. En la poesía oryana no sólo se rechaza España, sino todas las patrias y el concepto de patria en sí. La crítica oryana afecta a toda la dinámica social, su gesto de ruptura es heredero del dadaísmo más cínico:

Ratones pululan en mis interiores

Mis dedos se llenan de miel y manteca

Sangre en las butacas mierda en los pianos

Olí en Inglaterra mil pedos de lores

Me aburrí de Francia en una biblioteca

Salí de la cárcel de España con granos

En todos los puertos me harté de escabeche

Jugué a las barajas con apaches bajos

Jodí con las putas viejas de Marsella

$\mathrm{Y}$ en total el mundo me parece ¡leche!

Brillan más que joyas los escupitajos 
Mi ametralladora fusila a una estrella

(«Oxymoron de la angustia»)

La crítica a España se ofrece mediante la transvalorización de sus signos. El rechazo de los símbolos de una cultura que produce angustia es la óptica que subvierte el lenguaje del poder. La poesía oryana eleva los símbolos que definen la cerrazón cultural española al estatuto de iconos pop: la liturgia católica, los toros, las verbenas, los saraos. Se trata de la subversión de los símbolos oficiales de la cultura franquista.

Como llora una hembra

sobre una mano de hombre

así llorar quisiera

sobre la piel del toro fiera

de mi país toreado

con una velo de viuda

y muerto con la espada

de oro damasquinado de Toledo

(«Como llora una hembra»)

No imagines que ando borracho no que no

Eso pertenece a tiempos otros cuando

las cárceles y las verbenas

me procuraban vómitos alcohólicos

Pero es que yo he amado mucho y ya noamo

(Ahora es cuando amo clamo clavo mi mano)

(«He entrado en París»)

A estas horas de humo y de guitarras

horas de húmedos estambres y liturgias

como hormigas que en invierno

bailan locas en el fuego

del repique atronador de castañuelas

Yo me meto en la cocina con mi gato

Y la noria de la noche filtra el cielo

Y pestañas caen al suelo por segundos

del atroz zapateado y como lluvia

caen del cielo escupitajos

(«España pagana») 
De los muertos muertos de hambre pararrayos de oraciones el ciprés

Tengo sed de alcantarillas y de cerveza bendita Dame prisión de campanas con tus rosarios mohosos $[\ldots]$

Fiesta digna de matracas y cohetes Oh mi España de peluca y de tomate Matricúlame de muerto en la alcaldía y celebra un carnaval de escapularios ese día noche alba o madrugada

(«España mística»)

La exposición crítica de estos signos supone el desprecio radical de las ideología que representan. Este rechazo forma parte de la voluntaria aceptación de una heterodoxia permanente. Para ello Ory sigue el modelo ofrecido por Henry Miller, cuyo gesto literario y vital significó una ruptura total con los valores establecidos de la sociedad que le tocó vivir. La ruptura de Miller traza un paralelismo perfecto con la ruptura social de la vanguardia histórica. Ello queda reflejado en el Diario oryano el día 1 de agosto de 1974. Ory toma prestadas algunas palabras de Hery Miller para definir su propia heterodoxia individual (2004, Vol II: 392):

Leyendo un libro de Henry Miller, en traducción francesa: «Virage à quatre-vingts». Temas que conciernen vitalmente a mi propia concepción de la existencia [...] Dice Miller: «La risa del sabio sube de las tripas, de las profundidades; la risa del predicador -y él ríe poco- tuerce el rostro del lado malo».

Y esto: «Al verdadero sabio y hasta el mismo santo nada importa la moral. Está por encima y más allá de esa clase de consideración. Es un espíritu libre».

Y también esto, que aplico totalmente: «Nunca he pertenecido a ninguna organización, religiosa, política o lo que sea. Nunca. Nunca en mi vida he votado. Desde la adolescencia, nunca he dejado de ser un anarquista filósofo. Soy un exiliado voluntario que en todas partes se siente en casa menos en la suya». 


\subsection{POESÍA DE VANGUARDIA}

el yo intacto

la adición vendrá

a añadir a la letra el uso de la bondad

José Miguel Ullán

Toda la producción poética oryana realizada desde las primeras publicaciones postistas puede considerarse como una poesía de vanguardia. Se trata de una poesía que parte de las tesis renovadoras expuestas en los documentos que conforman el aparato teórico del Postismo. La impronta vanguardista acompañará a la poesía oryana a lo largo de todo su recorrido temporal. La euritmia, el juego fónico del lenguaje o la poética visual se radicalizan alejando el discurso poético oryano de la significación lógica, lo que propicia un lenguaje libre que se abandona al oleaje del sonido y transgrede la codificación sintáctica. Esta poética, de signo dadaísta, se acerca en ocasiones al letrismo francés y a la poesía visiva y supone la creación de un lenguaje ebrio y alucinado que asocia las palabras aleatoriamente por la proximidad fónica, que destruye la estructura misma de las palabras mediante la convergencia y la transmutación de los sonidos y que juega deliberadamente con las arritmias y la cacofonía. Esta dirección vanguardista es una de las aristas que ofrece la poesía poliédrica de Ory, precisamente es ella el punto de unión entre la vanguardia poética anterior a la guerra civil y la poesía experimental que se desarrollará años más tarde.

Aunque la óptica vanguardista articula toda la poesía oryana, la poesía experimental queda centrada solamente en algunas obras, estas son Arte de la fuga o rig (1973-1976), Tambor de sicomoro (1975-1977), Lee sin temor (1976), La flauta prohibida (1979) y Miserable ternura (1971-1972). Arte de la fuga o rig y Tambor de sicomoro son obras que permanecieron inéditas hasta que Ory publicó su propia antología en 1978, Energeia. Miserable ternura se editó junto a otro poemario en 1981 con el título Miserable ternura - Cabaña. 


\subsubsection{Antipoesía.}

La dirección vanguardista de la poesía oryana, mediatizada por los presupuestos postistas, supone una reafirmación de los postulados futuristas, representados por el Manifiesto futurista (1909) de Marinetti y Una bofetada a la opinión pública (1912) de Vladimir Maiakovsky y Víctor Klebnicv, como de los postulados dadaístas y surrealistas, representados por el Manifiesto del señor Antipirina (1918) o el Manifiesto Dadá (1918) escritos por Tristan Tzara y por el Manifiesto del surrealismo (1924) de André Breton. De aquí recoge Ory el rechazo de cualquier elemento retórico y la voluntad de destruir los modelos poéticos tradicionales. Estos presupuestos quedan instalados en la geografía poética de la posguerra y en ella esta poética queda configurada como búsqueda de una antipoesía que confluye, por una parte, en una poesía visual, y ,por otra, en un acercamiento al lenguaje coloquial. La poesía oryana es, por tanto, heredera de los experimentos de Guillaume Apollinaire, quien desde las páginas de Alcools (1918) o Calligrammes propuso una poesía cercana a la oralidad para plasmar en ella las peculiaridades del discurso oral y del lenguaje coloquial. En ella Apollinaire trató de reproducir fragmentos de conversaciones, monólogos interiores y ensayó diversos juegos lingüísticos y experimentos fónicos. En la búsqueda de una antipoesía, Ory contacta con la poética romántica de Wordsworth y de Blanco White, que abrió un espacio heterodoxo al rechazar el lenguaje poético clásico y sustituirlo por un lenguaje común (Paz, 1987: 119), mucho más próximo al lenguaje usual. Esta poesía antipoética, a la manera de Nicanor Parra, entronca también, como ya se ha mencionado de manera superficial, con los experimentos futuristas de Joan Salvat-Papasseit, con la poesía vanguardista y visual de Joan Brossa y con los experimentos poéticos de Juan Eduardo Cirlot.

Como ya hemos visto, con Brossa la poesía oryana presenta numerosas convergencias. La primera, el interés por el surrealismo, que en el caso de Ory articula su lenguaje en toda su dilatada trayectoria y en el de Brossa deriva hacia la escritura automática en sus imágenes hipnagógicas. Estas conforman sus primeros sonetos, Poemes hipnagògics ${ }^{338}$. La bola i l'escarbat (1940-1943) es un claro ejemplo del soneto surrealista. El interés por el soneto es otra de las convergencias que se establece entre estos dos autores. Fue el poeta surrealista catalán J.V. Foix quien apremia a Brossa en la

${ }^{338}$ Poemes hipnagògics, R. Salvo Edicions, Barcelona, 1995. 
renovación del soneto. En Fogall de sonets (1943-1948) el soneto se torna experimental. Otra de las convergencias es el interés compartido por los dos poetas por la poesía lúdica y experimental. En el caso de Brossa la experimentación desemboca en la poesía visual, práctica de arte conceptual que juega entre la relación de la imagen y el signo lingüístico. También Ory posee una serie de collages y de poemas visuales ${ }^{339}$ en los que poesía y artes plásticas se unen. En ellos los lenguajes mediáticos, como el cine, la publicidad..., se deconstextualizan y parodian, quedando abiertos a la plurisignificación poética. La poesía vanguardista oryana corre paralela a la brossiana y se acerca a la poesía fonética. La poesía oryana parte de la euritmia postista y la de Brossa surge de los juegos colectivos planteados por el surrealismo como el azar objetivo, el cadáver exquisito y las palabras en libertad, este último de herencia dadaísta. A su vez, como ya se ha visto con anterioridad, también el Postismo significó una reactivación de las experiencias de la vanguardia anterior. Ambos poetas practican una poesía experimental cercana al letrismo o el espacialismo, movimientos que significan el inicio de la experimentación literaria de la segunda mitad del siglo $\mathrm{XX}^{340}$. En ella la palabra poética cede cierto espacio al material plástico, lo que implica una nueva estructuración del espacio poético. La obra de ambos poetas muestra una convergencia más: la utilización de la poesía popular y el interés por el romance. Los Romancets del dragoli (1948), incluidos en la obra brossiana Poesía rasa (1970), suponen una actualización de la poesía popular contenida en las rondalles y en las auques de la cultura catalana. Esta dirección de la poesía de Brossa entronca perfectamente con los romances postistas oryanos, Laocoonte y la luna, y los escritos junto a Eduardo Chicharro, Las patitas de la sombra.

La poesía vanguardista oryana ofrece un paralelismo evidente con la poesía de Juan Eduardo Cirlot, el poeta surrealista que mantuvo correspondencia con André Breton. Entre Ory y Cirlot también existió una relación epistolar que manifiesta perfectamente una gran amistad. Además del interés de ambos por el surrealismo francés, comparten también la importancia de la cercanía entre poesía y música y de las capacidades sonoras del poema, la investigación de la simbología de los arquetipos y de

${ }^{339}$ Ver Metanoia, obra cit., pp. 327-334, El desenterrador de vivos, obra cit., pp. 48-49, $52,55,56,58,61,62,64$. La obra visual está catalogada en el Apéndice XI y algunos collages se muestran el el Apéndice XI.

${ }^{340}$ Cabe señalar, en este sentido, la labor realizada por Ángel Crespo, poeta integrante del movimiento postista, como director de la revista Deucalión, que introdujo la poesía concreta al plasmar las experiencias de Decio Pignatari y del grupo Noigandres de Brasil. 
las imágenes culturales, el interés por la pintura y la expresión de una poesía experimental. El siguiente fragmento de Cirlot, perteneciente a La doncella de las cicatrices (1967), podría pasar por uno de Ory:

se mueve casi en la oscuridad

recta

puede morir

morirá

una noche era otra-ella

ella.

En el poema se observa el juego fónico de las palabras, tan practicado por Ory. El segmento poético «otra-ella» sustituye a la palabra estrella. Su proximidad fónica es, pues, evidente. La poética de la antipoesía, practicada por Cirlot, Brossa, Ory, Chicharro, Labordeta... converge totalmente con los antipoemas de Nicanor Parra. Mirada que supone la total desmitificación del lenguaje poético ${ }^{341}$.

La práctica de la antipoesía se observa perfectamente en el poema escrito en 1959, incorporado a Los sonetos, titulado «Satán al aparato». Aunque ya ha aparecido en la página 230, lo volvemos a ofrecer debido a su especial relevancia:
¿Quién está al otro lado que no entiendo su voz tan sorda tan oscura tan cavernosa que más mi oído tiendo menos entiendo? ¡Diga! — Soy Satán
¿Quién dice ser? ¡Repita! No le entiendo Habla usted como un trueno un huracán como un ciclón un torbellino horrendo y no le entiendo. ¡Diga! — Soy Satán
¿Cómo ha dicho? ¡Por Dios, hable más bajo! ¿Con quién hablo? Le escucho Presto oreja Ahora su voz se aleja se me pierde

${ }^{341}$ El interés por la plástica y su interrelación con la poesía une las poéticas de Cirlot, de Brossa, de Ory y de Parra. Existe un claro paralelismo entre la poesía combinatoria de Cirlot, los poemas visuales y los poemas objeto de Brossa, los artefactos de Parra y los poemas-collage de Ory. 
—Soy Sa... ¿SA QUÉ?... tan tan ¿TAN QUÉ? ¡No atajo!

—Digo que soy Satán iSu voz se aleja!

Repita se lo ruego ¡quién es? —MERDE

En él aparecen los juegos fónicos, las posibilidades sorpresivas del lenguaje y la cercanía a la oralidad. Se conjuga, a la manera de Joan Brossa, la estructura del modelo poético clásico, el soneto, con la experimentación. Se mantiene la rima clásica del soneto y al mismo tiempo se juega con la sonoridad a base de la repetición recurrente de varios sonidos. Se trata pues de un atentado y, al mismo tiempo, de un homenaje al soneto. El poema desecha la retórica estética y se acerca al registro lingüístico coloquial, por ello posee la falsa apariencia de un poema vulgar. Lo que existe en él es un delicado proceso de elaboración que pone de manifiesto toda su poeticidad. Pues, el lenguaje se retuerce, se exprimen sus posibilidades humorísticas, se juega y se experimenta con él. El poema adapta el lenguaje coloquial al discurso poético, de hecho el poema representa una conversación telefónica. Ahora bien, se trata más de un monólogo que de un diálogo, ya que la voz que aparece por el auricular apenas lo hace en la textualidad:

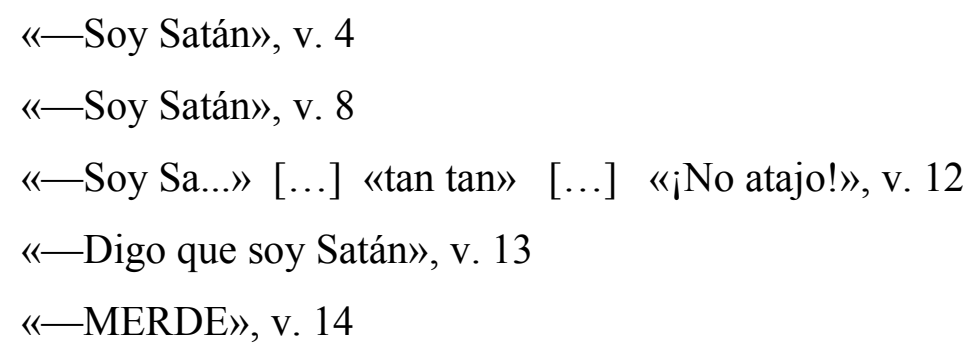

El lector interpreta las claves de la situación comunicativa plateada en el texto, pues en él, como texto escrito, se activa otro texto. De modo que el primer texto se desdoble en un segundo texto, o intertexto, de carácter oral.

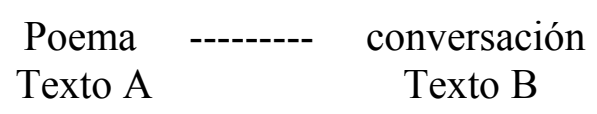

Por otra parte, la óptica humorística posibilita el absurdo situacional de este proceso comunicativo irreal. El intercambio de papeles entre emisor y receptor (el diablo y el yo poético) incrementa el absurdo, pues es el sujeto poético quien responde a la llamada de teléfono del diablo. Y es precisamente el diablo quien se impacienta de la torpeza 
mostrada por su interlocutor. El ruido, la obturación del canal distorsiona la comunicación entre los sujetos del enunciado. La falta de fluidez del proceso comunicativo provoca la respuesta agresiva del diablo, lo resalta mucho más debido a la imposibilidad del otro sujeto poético. De otro lado, es evidente el juego sonoro, la proximidad fónica de las palabras y la repetición de unos mismos sonidos:

Ahora su voz se aleja se me pierde

—Soy $\underline{\mathrm{Sa}} \ldots$... ¿ $\underline{\mathrm{SA}} \underline{\mathrm{QUÉ}}$ ?... $\underline{\tan } \underline{\tan }$ ¿TAN QUÉ? ¡No atajo!

$$
\text { a1 } \frac{\mathrm{a} 2}{\mathrm{~b} 1} \quad \frac{\mathrm{c} 1}{\mathrm{c} 2} \mathrm{c} 3 \mathrm{~b} 3
$$

El poema «Fonenoramas», escrito en 1963, que aparece por primera vez en 1970 en la antología realizada por Félix Grande, Poesía (1945-1969), supone también un claro ejemplo de la antipoesía oryana:

Si canto soy un cantueso

Si leo soy un león

Si emano soy una mano

Si amo soy un amasijo

Si lucho soy un serrucho

Si como soy como soy

Si río soy un río de risa

Si duermo enfermo de dormir

Si fumo me fumo hasta el humo

Si hablo me escucha el diablo

Si miento invento una verdad

Si me hundo me Carlos Edmundo

En este poema se muestra la práctica de la experimentación poética basada en un lenguaje abandonado a su propio oleaje fónico, donde las palabras estructuradas en una pretendida libertad se asocian según su sonoridad. Sintácticamente el poema es un claro ejemplo de coupling, un reiterado paralelismo de estructuras sintácticas:

Conj. («Si») + Verb. + Verb. («soy») + SN

A partir de esta estructura, que sufre una modificación a partir del séptimo verso donde se sustituye el verbo «soy» por otras formas en presente, las palabras se unen mediante una doble dirección: el significante y el significado. En el primer caso es la similitud del sonido el eje estructurador. Así «canto» se une con «cantueso» (v. 1), «leo» con «león» 
(v. 2), «emano» con «mano» (v. 3), «amo» con «amasijo» (v. 4)... Podríamos establecer el siguiente esquema:

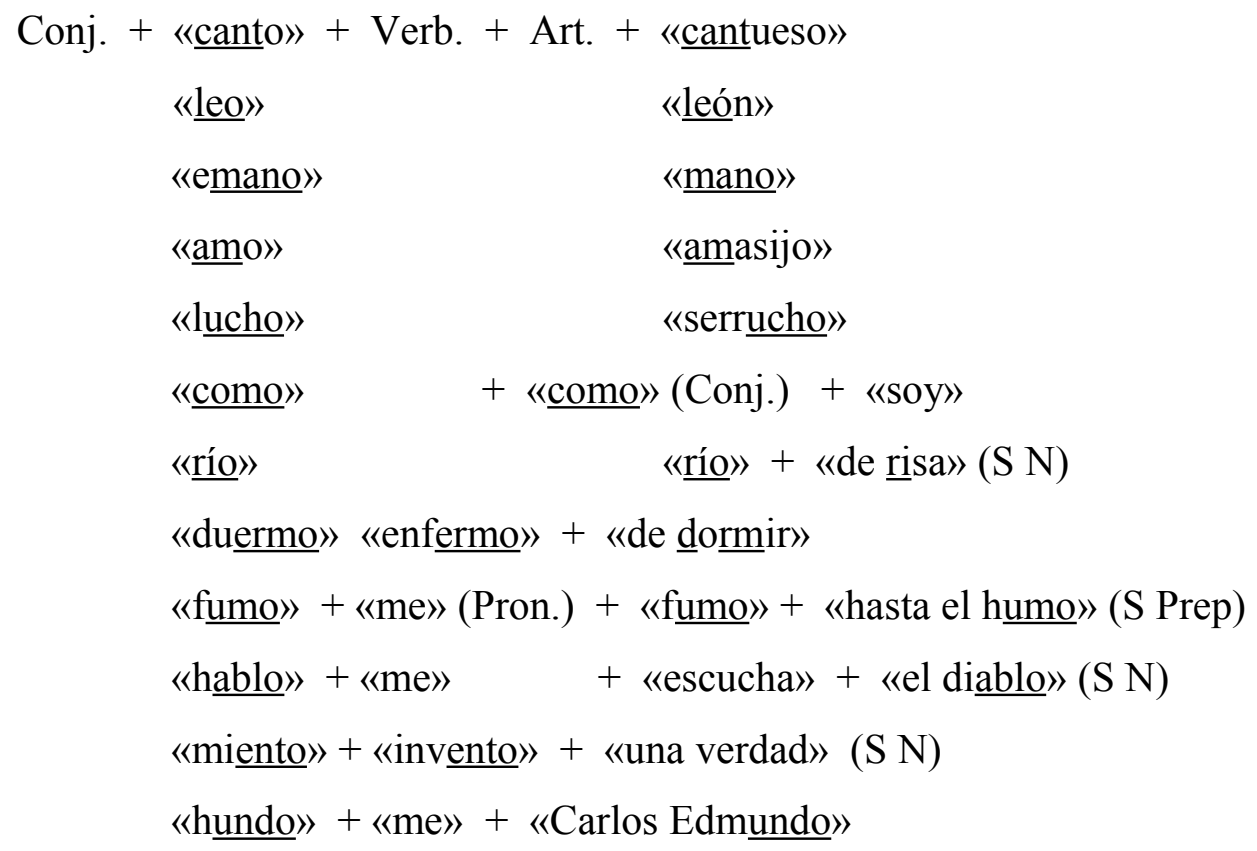

En el plano del significado, el poema supone un verdadero ejercicio de arte conceptual. Aquí las palabras toman en unos casos significados contrastivos, en otros adquieren nuevos significados o agrandan, como en el caso de la poesía conceptista, su espacio semántico. En el segundo verso la relación semántica que establecen los términos «leo»y «león» se basa totalmente en la ambigüedad y en la plurisignificación. El término león resulta ambivalente, pues podemos interpretar basándonos en la proximidad fónica con el término anterior que se refiere, transgrediendo la normativa lingüística, a una persona que lee, o a un ávido lector. Ahora bien, este significado lleva impreso también la huella connotativa de animal de la selva poderoso y libre. Por ello, en el contexto poemático asociamos las lectura con la significación de poder y libertad.

$$
\text { «león» }=\text { sdo } 1-\text { lector }+ \text { sdo } 2-\text { poder, libertad }
$$

El penúltimo verso supone una paradoja. Este podría considerarse por sí mismo como un aerolito, un aforismo, una greguería ramoniana o un koan zen. El significado emocional, radicalmente irracional y absurdo, juega con los significados de la invención y de la creación literaria o artística, o incluso del conocimiento representacional. Aunque los términos «miento» $\mathrm{y}$ «verdad» son totalmente antitéticos, la creación 
supone la invención de realidades, de verdades que son mentiras. Por ello, la mentira como invención exige la presencia de una verdad. Lo interesante es el ejercicio intelectual que nos lleva a realizar una reflexión acerca del conocimiento, la invención y la creación en cuanto a su relación con la realidad. ¿Es la mentira una traición a la realidad? ¿Lo puede ser también la verdad? O ¿la traición puede ser cualquier representación de lo real? El lector se halla atrapado, de forma inconsciente, en estas fluctuaciones, que tienen la labor de hacer consciente lo inconsciente. Es decir, el material poético presenta desde la inconsciencia un escenario para la reflexión. Por último, el verso final del poema supone la transgresión de las estructuras semánticas y sintácticas, juega con el lenguaje como si se tratara de un palíndromo: «Si me hundo me Carlos Edmundo».

La práctica de la antipoesía recorre, en cierta medida, la poesía escrita por Ory en las décadas de los sesenta y de los setenta del siglo XX. Encontramos su presencia en Lee sin temor (1976), La flauta prohibida (1979) y Miserable ternura-Cabaña (1981). Presentamos aquí algunos ejemplos:

Te amo tanto que duermo con los ojos abiertos

Te amo tanto que hablo con los árboles

Te amo tanto que como ruiseñores

Te amo tanto que lloro joyas de oro

Te amo tanto que mi alma tiene trenzas

Te amo tanto que me olvido del mar

Te amo tanto que las arañas me sonríen

Te amo tanto que soy un jirafa

Te amo tanto que a Dios telefoneo

Te amo tanto que acabo de nacer

(«Hipérbole del amoroso, Lee sin temor»).

Estimo urgente

que no falten alas ni alimento

Estimo urgente

el pensamiento libre como liebre

Estimo urgente

abrir la calle al primero que no calle

Estimo urgente

el destete en las tetas etiquetas

Estimo urgente

el respeto a la vida mental y elemental 
Gente de todos los días

sin ideologías

Gente de todas las noches

sin coches

Gente de todas las horas

sin mecedoras

Gente de todos los minutos

sin lutos

(«Estimo urgente», La flauta prohibida).

En mi poesía no hay sitios

No hay malavez ${ }^{342}$ nombres ni años añoranzas tiempos

pasados pisados puentes

ni acueductos ni calles

En mi poesía no hay anales

tampoco tramas o temas

ni banderas ni oficinas

En mi poesía no hay público

ni sermones ni discursos

ni ruedan trenes y no hay

luna en mi poesía ni países

En mi poesía no hay fines

para entretener o sonar

con palabras cadavéricas

En mi poesía hay fulgor

(«En mi poesía no hay», Cabaña).

En todos ellos los juegos lingüísticos resultan muy evidentes. La repetición fónica retuerce y la expresión en la que el sonido es el punto de unión de las palabras, que, utilizadas en contextos extraños, adquieren significados sorpresivos. Una muestra de ello puede observarse en los siguientes segmentos poemáticos: «lloro joyas de oro», «no faltes alas ni alimento», «el pensamiento libre como liebre», «el respeto a la vida mental y elemental», «años añoranzas tiempos / pasados pisados puentes / ni acueductos ni calles»...

${ }^{342}$ Sic. 


\subsubsection{Poesía visual.}

Una de las vertientes de la poesía de vanguardia de Carlos Edmundo de Ory se acerca a la poesía de signo visual. La poesía visual parte de las experiencias de la poesía de la vanguardia histórica que pretendían romper con la poesía clásica y sus moldes y con el estatuto de referencialidad. La vanguardia poética desecha pues el modelo poético sonoro en favor del componente poético visual. La ruptura dadaísta y el simultaneísmo cubista descubren nuevas posibilidades poéticas que acercan la poesía a la plástica. Si en la pintura asistimos a la ruptura de la mirada realista, cuyo axioma consistía en captar la realidad pictórica mediante un único punto de vista, la poesía también busca la multiplicidad de perspectivas espacio-temporales. De modo que el poema se resquebraja mediante la dispersión de la ópticas. Es el caligrama el punto de unión de entre palabra y dibujo, entre texto y figura ${ }^{343}$. En él el acento recae en la grafía, así el poema se hace figura ${ }^{344}$. El desarrollo de esta poética se dirige hacia una poesía que se configura como experimento y que trata de unir poesía y arte: música, plástica, cibernética, publicidad... La poesía experimental se configura como una experiencia totalizadora que intenta aunar todas las expresiones artísticas y sus lenguajes. Lo que define a la poesía experimental de la segunda mitad del siglo XX es su elemento colectivo (Millán y García Sánchez; 1975: 16), por ello rechaza la relación íntima que se establecía entre poeta y receptor y propone una experiencia colectiva.

En la poesía oryana existe un acercamiento, desde las tesis postistas, a varios presupuestos y a determinadas prácticas de la poesía experimental. Por una parte, existen convergencias hacia la poesía como expresión del arte conceptual; por otra, convergencias con la poesía concreta y con el letrismo. Esta poesía visual o visiva se puede encontrar, sobre todo, en obras como La flauta prohibida, Arte de la fuga o rig y Tambor de sicomoro. Una de las direcciones de La flauta prohibida supone la reactivación de los experimentos poéticos. La poesía concreta se halla en poemas como «Trípode español» ${ }^{345}$, ya visto anteriormente, que queda estructurado a modo de caligrama en una triple representación, tal como si fuese un tríptico. Se observan en él

\footnotetext{
cit. 344 Foucault (1973, 1981: 33). Para el autor el caligrama tiene una función triple: «compensar el alfabeto; repetir sin el recurso de la retórica; coger las cosas en la trampa de una doble grafía».

${ }^{345}$ Ver p. 403.
}

343 Ver Cózar (1991), obra cit., y Zarate, Armando (1976), Antes de la vanguardia, obra 
rasgos del espacialismo ${ }^{346}$ como la transmutación de las palabras y grafías que se van repitiendo:

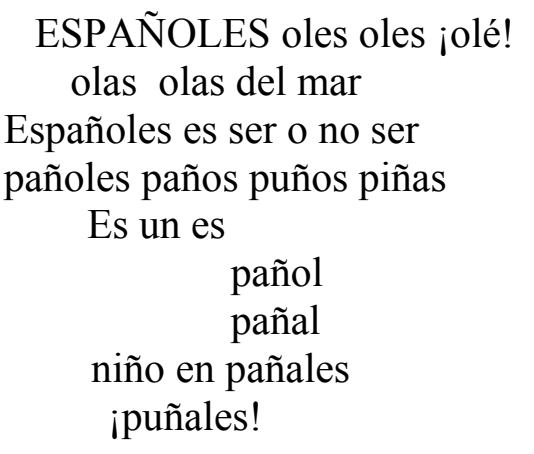

Señalamos gráficamente la asociación de sonidos, que a su vez conecta significados alejados y produce significaciones sorpresivas y sorprendentes.

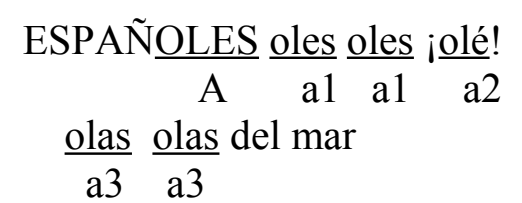

Españoles es ser o no ser

$\mathrm{B}$

pañoles paños puños piñas

b1 $\quad$ b2 $\quad$ b3 $\quad$ b4

Es un es
pañol
b5
pañal
b6

niño en pañales

b7

¡puñales!

b8

La creación de contextualizaciones diversas y plurales hace que las palabras cambien de significación y presenten una significación diversa. A medida que discurre el poema, cambian pequeñas unidades de sonido y ello posibilita que unos significados vayan enganchándose con otros. Tenemos así una expresión poética fluctuante y metamórfica, en la que sonido y sentido están poéticamente imbricados y no se someten a las normas reguladoras del lenguaje comunicativo.

346 Movimiento poético que parte de Pierre e Ilse Garnier que posee un concepto totalmente visual de la poesía basado en la repetición de palabras. 
Otro ejemplo de la experimentación poética se encuentra en el poema «Heil Hitler ${ }^{347}$, que consiste en la mera repetición de una misma secuencia sintáctica variando simplemente sus elementos paradigmáticos. Citamos solamente unos versos en los que se intercalan los nombres de campos de concentración entre los saludos nazis:

\title{
Treblinka Treblinka Treblinka
}

Heil Hitler!

\section{Büchenwald Büchenwald Büchenwald} Heil Hitler!

Por último, podríamos señalar el poema titulado «Nuitard» que está estructurado de una forma muy parecida al anterior:

\author{
NUITARD \\ (homenaje a Armand Robin) \\ Restera sur ces ans \\ L'homme ayant osé le pas le plus avant.
}

\begin{abstract}
A.R.
Te encontré voyeur de Dios en los árboles

Te encontré cantor de la calle y los pájaros

Te encontré mendigo de imágenes y nómada

Te encontré fugitivo enmielado en la noche

Te encontré a ti sin cama acompañando al viento

Te encontré general de guerra sin cuartel

Te encontré en una era de odio y propaganda

Estoy solo en mi cuarto con tus gritos prohibidos

Estoy solo en mi cuarto con tu espina dorsal

Estoy solo en mi cuarto con tu pureza humana

Estoy solo en mi cuarto con tu conocimiento

Estoy solo en mi cuarto con tu voz de guerrero

Estoy solo en mi cuarto con tu trabajo justo

Estoy solo en mi cuarto con tu inocencia escándalo

En un mundo destruido guardaste la Belleza

En un mundo destruido guardaste la sonrisa

En un mundo destruido guardaste un gran silencio

En un mundo destruido guardaste el mundo entero

En un mundo destruido guardaste el infinito

En un mundo destruido guardaste el rostro abierto
\end{abstract}

${ }^{347}$ Ver pp. 404-405. 
En un mundo destruido la muerte te guardó

El arte de la fuga o rig es la obra oryana se halla más cercana a la poesía concreta. En ella se ofrecen convergencias con el Postismo y con el espacialismo, pero la importancia dada al espacio gráfico como agente estructural marca la cercanía con el concretismo. De las experiencias postista hallamos la presencia de la euritmia y del espacialismo la constante reiteración de segmentos poéticos. Ello se observa en el poema titulado «26.VII.75»:

ME duelen los hombres

Me duelen los hombros

Me duelen las sombras

Me duelen las cumbres

Me duelen las ubres

Las permutaciones de sonidos unidos al segmento fonético «/mbr/» van alineando las palabras, de manera que de las mismas vamos pasando a otras mediante variaciones mínimas:

$$
\text { hombres --- hombros } \underline{\underline{s}} \text {--- sombras } \underline{\text { som }} \text {--- cumbres }
$$

Las variaciones de sonidos, a modo de permutacions, van asociado significados específicos.

Como en la poesía concreta, el signo poético opera simultáneamente en el sonido, en el significado y en la grafía. El poema titulado «Per jocum» es claro ejemplo de esta técnica en que el texto poético en funciona como espacio fónico, semántico y visual. El contexto creado liga estas tres direcciones y funciona como nexo que une las palabras:

¡arre! ¡arre! ¡arre!

¡arrepiéntete! 
El poema «5.XI.73» está basado en la asociación de las palabras en base a su significante, de modo que ello queda establecido como si se tratase de una metáfora fónica fundamentada en la homonimia, como si se tratase de un calambur.

PARA mí

el paramo

Me digo

mendigo

El fundamento, o equivalente, en el que reside la asociación de los términos es muy evidente:

$\mathrm{A}(\underline{\mathrm{PARA}} \underline{\mathrm{mi}})=\mathrm{B}(\underline{\text { páramo }})$

$\mathrm{A}(\underline{\mathrm{Me}} \underline{\text { digo }})=\mathrm{B}(\underline{\text { men }} \underline{\text { digo }})$

El poema titulado «17.X.73» es el que más se ajusta a la poesía concreta:

$\begin{array}{llll}\text { ab } & \text { in } & \text { in } & \text { no } \\ \text { so } & \text { fi } & \text { tan } & \text { ser } \\ \text { luto } & \text { nito } & \text { gible } & \\ \text { absoluto } & & & \\ & \text { infinito } & & \\ & & \text { intangible } & \text { no-ser }\end{array}$

En él encontramos la disposición geométrica o la matemática poética propias de las experiencias de Gomringer y del Grupo Noigandres.

\subsubsection{Un lenguaje ebrio.}

La poesía de Ory pretende radicalizar los lenguajes poéticos de signo vanguardista, para ello intenta hacer estallar el lenguaje, llevarlo a un callejón sin salida donde este queda situado frente a la extrema paradoja. En este territorio, las palabras abandonan sus espacios referenciales conocidos y se aventuran entre la arena movediza de las significaciones traslúcidas y extrañas. El lenguaje estalla en mil aristas y cristales 
rotos, así las palabras se deshilvanan, se deshacen, transmutan con el intercambio de unos sonidos con otras. Se crea así una extraña red de términos raros, surgidos mediante las asociaciones de sonidos. De manera que este lenguaje se convierte en una hilaridad de despropósitos lingüísticos y de metáforas fónicas que lo convierten en un lenguaje ebrio, que se aleja del manido lenguaje poético subvertiendo sus normas y sus usos para transitar espacios totalmente ajenos a la poesía. Este lenguaje se desprende de las significaciones y fluye en el aire como un mantra, convertido en una vibración de vibraciones, donde los sonidos convergen y se trasmutan. Se trata de un lenguaje extremo, violento, ebrio, que rompe con la referencialidad de los términos para crear espacios contextuales donde las palabras establezcan sus contagios con otras y adquieran nuevos valores, extrañas alianzas, contactos sorpresivos... Carlos Edmundo de Ory juega con el lenguaje de las misma manera como René Margritte jugaba con los objetos pictóricos, manifestando sus diferencias y sus similitudes y empujándolos hacia un paisaje radical donde la referencialidad queda totalmente subvertida ${ }^{348}$.

Este fragmento del poema, que pertenece a La flauta prohibida, titulado «Negro spirituals» es un claro ejemplo del lenguaje ebrio oryano:
AyJesús AyJesús
Mi llanto hecho con perlas
madre mía madrépora
padre mío padréporo
vuestro hijo es un botijo
que llora en línea recta
AyJesúsyMaría

Otro ejemplo viene dado por el poema titulado «Homofonía inmódica» que pertenece a Lee sin temor:
Entre lejos allí
Lo lejos que se aleja lejándose
El lejanía lejanosidad
Tu lejano lejar de alejadez

${ }^{348}$ En este sentido, las siguientes obras de Magritte son especialmente reveladoras: Le modèle rouge (1937), donde unos pies acaban transmutados en botas; La reproduction interdite (Portrait d'Edward James) (1937), donde la cabeza y la espalda del sujeto quedan reflejadas en el espejo de manera totalmente ilógica; Golconde (1953), que asocia las gotas de lluvia con grises ciudadanos vestidos con gabardina y sombrero; Les vacances de Hegel (1958), que subvierte la relación entre el paraguas y el vaso de agua. 
Te lejó lejosistro

Ojos lejos alejanía

Lejos es rojo

Y se arrodilla un lejos

Me lejos yo de ti los ir

E ir montado en un lejos

Piensa enlejamortiz

Lejosanto

Lejalá alejasiénteme

Una queja de lejos se silla

Lo lejos otra vez mi lejos

Nosotros acerca lejosle

Es El arte de la fuga o rig la obra en donde más presente se halla el lenguaje ebrio oryano, totalmente libre y experimental. El primer poema de esta obra supone un claro ejercicio de palabras en libertad, aquí las palabras se estructuran libremente a base de rupturas en el código y mediante engarces de diferentes perspectivas a modo de collage y de caligrama:

ESTOY sentado solitario chu pándome el dedo gordo

Es un hecho que ya estoy pensan

do re mi fa sol la si

Busco sonidos fugas

bacanal vaca anal

Ansiedad Así es la edad

Ory nos ofrece pistas en sus poemas acerca de la naturaleza de su lenguaje ebrio, pistas que en este sentido funcionan como ejercicios de metapoesía en cuanto son una reflexión sobre la propia poesía y su especificdad discursiva. Pues lo que Ory trata de clarificar es la distancia que toma el lenguaje poético respecto al lenguaje usual e incide en que esta distancia se hace posible gracias al aspecto informal y lúdico de la poesía, que supone per se una transgresión del código establecido en el lenguaje comunicativo. En este caso lo que se busca es la similitud fónica, lo que a su vez supone la ruptura de la lógica del discurso.

$$
\begin{aligned}
& \text { «bacanal» }=\text { «vaca anal» } \\
& \text { «Ansiedad» }=\text { «Así es la edad» }
\end{aligned}
$$


Por otra parte, el termino fracturado «pensan» (el íntegro sería «pensan / do») introduce la escala musical:

«pensan( $\underline{\text { do }}) »-----~ « \underline{\text { do }}$ re mi fa sol la si»

En el poema titulado «Res nullius», cosa de nadie en derecho, las palabras se deshilvanan, se deshacen y metamorfosean. Es el intercambio de sonidos el agente de tal transmutación:

ESTRELLAS sin dueño

lejánicas cosas

Profesor de forma sin caña de pescar pesco el nadir de nadie

Trabajo lo de abajo

Saco todo el arriba

Soy múgico soy másico

soy lótico soy mísgico

El poema queda convertido en una permanente hilaridad de metáforas fónicas, pues los términos se asocian por el sonido:

«el nadir de nadie»

«trabajo lo de abajo»»

Palabras como «múgico», «másico», «lótico» y «mísgico» se crean mediante la destrucción de los términos habituales y el trasvase de sonidos de unos a otros. Así el primer par de términos opera de la siguiente manera:

$$
\begin{aligned}
& \text { «má + gico - «mú + sico» } \\
& \text { A B } \\
& \text { «mú + gico» - «má + sico» } \\
& \text { b1 a2 a1 b2 }
\end{aligned}
$$

La misma operación se utiliza para crear el otro par de términos: 


$$
\begin{aligned}
& \text { «ló + gico» - «mís + tico» } \\
& \text { C D } \\
& \text { «ló + tico» - «mís + gico» } \\
& \begin{array}{llll}
\text { c1 } & \text { d2 } & \text { d1 } & \text { c2 }
\end{array}
\end{aligned}
$$

El poema «Ortografia ebria» define perfectamente este lenguaje violento, alucinado y espasmódico de esta poesía radical. Se trata, en cierta mediada, de un lenguaje psicodélico en el sentido de que nos abre la mente, pues las asociaciones de sonidos nos llegan como un fogonazo que explota en nuestra mente:

TABIOS míos tabios que bebíanse

las tágrimas tan tristes

Conozco la relleza de llorar

$\mathrm{Y}$ aquí pienso en los meyes

y las meinas y en los

bríncipes y las brincesas

que también alguna vez lloraron

de apores y de peseos

mojando con sus tágrimas el trono

y sus tabios de olo

Aquello que posee la capacidad de sorpresa es la transgresión de la normativa lingüística, este es uno de los signos de este lenguaje ebrio, que por su parte nos ofrece otros sentidos. De este modo, mediante su significado contextual, sabemos que «tágrimas» significa lágrimas tristes. La sustitución de un sonido por otro destruye las palabras momentáneamente y las vuelve a constituir, operación que agranda el campo significativo de los términos. Así «relleza», «meyes», «meinas», «bríncipes», «brincesas», «apores», «peseos», «tágrimas», «tábios», «olo» son términos poéticos en los que se ha alterado un sonido. Hipotéticamente deberían leeerse, siguiendo la corrección, de la siguiente manera: belleza, reyes, reinas, príncipes, princesas, amores, deseos, lágrimas, labios y oro:

$$
\text { «relleza» ----- } \underline{b} e l l e z a
$$

El parecido con realeza es evidente, de aquí se desprenden los tres términos siguientes:

«meyes» ----- reyes 


$$
\begin{array}{lll}
\text { «meinas» } & ----- & \text { reinas } \\
\text { «bríncipes» } & ----- & \text { príncipes }
\end{array}
$$

El térnimo «tágrimas» queda asociados a la esfera léxica del dolor cuyo significado últerior apunta al círculo semántico del amor:

$$
\text { «ágrimas» ----- lagrimas }
$$

De él se desprenden los términos siguientes:

$$
\begin{array}{lll}
\text { «apores» } & ----- & \text { amores } \\
\text { «peseos» } & ----- & \text { deseos }
\end{array}
$$

Y de aquí las palabras apuntan al cuerpo, parodiando y subvertiendo los tópicos poéticos del petrarquismo y del preciosismo aristocrático de signo modernista :

$$
\begin{array}{lll}
\text { «tabios» } & ----- & \text { labios } \\
\text { «olo» } & ----- & \text { oro }
\end{array}
$$

Otro poema donde se destaca el aspecto lúdico del lenguaje poético es el titulado «14.X.74», que toma la forma del puro juego lingüístico:

$$
\begin{gathered}
\text { MENTE desgraciada } \\
\text { desgraciadamente } \\
\text { Grecia desgraciada } \\
\text { desgraciada gracia } \\
\text { Dado desgraciado } \\
\text { desgraciado dedo } \\
\text { Dime Dimensión }
\end{gathered}
$$

El poema toma la apariencia de un juego de niños en el que a partir de unas mínimas variaciones de sonidos se van sucediendo palabras diferentes. La inclusión de un sonido establece un nuevo derrotero a seguir. De «gracia» se derivan otras palabras como «desgraciada», «desgraciadamente», «desgraciado», «Grecia». De «MENTE» se activa «desgraciadamente». De «Dado» se desprenden «dedo», que a su vez la «d» introduce la palabra «Dime» y esta activa «Dimensión». El poema se edifica sobre la práctica de 
la repetición de términos, pertenecientes unas mismas esferas léxicas, y de la intersección fónica. Más o menos podemos esquematizar el proceso seguido mediante el cual unos sonidos se enganchan con otros.

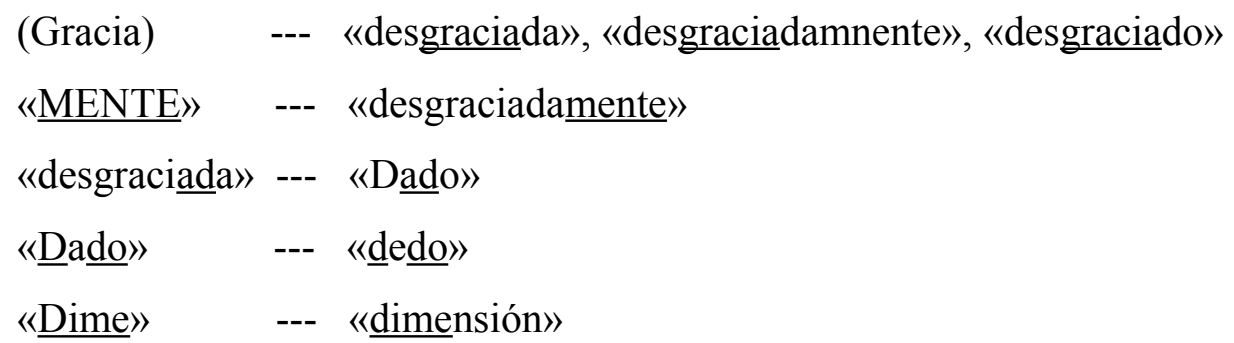

Este lenguaje alucinado aparece también en obras posteriores como Miserable ternura - Cabaña y en Tambor de sicomoro. Además su signo queda impreso en la expresión oryana tanto en los aerolitos como en toda la dilatada obra poética. El juego con el sonido, constituido a base de proximidades y de trasvases fónicos, la ruptura del código y la semántica libre se hallan presentes en el poema «Tristal cristeza», que pertenece a Miserable ternura:

\section{TRISTAL CRISTEZA}

En nombre de mi alma genero ondas sonoras Lingüística del silencio sintónico poético amo sus piros y amo mis terios fonológicos Sin duda soy un lo un co un malabárico desatando las sílabas lavadas en música Nochemente en primera persona oigo yorar $\mathrm{y}$ en el arrullo del silencio discrimino los timbres inauditos de mi acústica estética Tristoy tristestoy por eso hablo increíble como un ángel borracho de onomatopeyas Nunca el gastar palabras sellará lo sentir No miento el sentimiento con voces mundanales ni soy pico de oro ni poeta gramático Todo soñar sonoro trae sorpresa y prodigio y basta con llamar las cosas por sus cumbres Mi cristeza me dicta fonemas suficientes Hace ya mucho tiempo que mi alma es de tristal Hoy reflejo los dichos de la lírica breve La expresión de un ser vivo se inventa cada vez 
El poema es otro ejemplo de metapoesía reflexiva y, por ello, toma la forma de la teoría. Aparece aquí la figura del poeta como «un ángel borracho de onomatopeyas» y la poesía como un misterio de la música: «las sílabas lavadas en música», «Todo sonar sonoro trae sorpresa y prodigio». Pero el poema es, sobre todo, una práctica del lenguaje ebrio oryano. En él encontramos trasvases fónicos en términos como «tristal»y «cristeza», palabras creadas a partir de cristal y tristeza:

«tristal» ----- cristal

La consonante $c$ del término cistal es sustituida por la $t$ de tristeza. $\mathrm{Y}$ en el caso inverso se sustituye la $t$ de tristeza por la $c$ de cristal:

«cristeza» ----- tristeza

Existen también transgresiones lingüísticas como «Tristoy» y «tristestoy» o como «sus piros», «mis terios», o «un lo» y «un co», cuyo referente lingüístico de los dos últimos sería un loco. Encontramos asimismo una imagen fónica en el siguiente segmento poemático: «y basta llamar a las cosas por sus cumbres». La palabra «cumbres» sustituye a «nombres», el fundamento fónico de la asociación reside en el segmento fónico «mbres»:

«cumbres» ----- nombres

Ahora bien, desde la óptica del significado el término «cumbres» queda asociado a la extrañeza y a la magia del lenguaje poético, sustituto del prosaico lenguaje usual.

El poema «Carmen», que pertenece a Cabaña, queda configurado como otra práctica del lenguaje ebrio basado en la creación de palabras extrañas que resultan de la asociaciones entre distintos términos, morfológicos y léxicos:

Di algo Suena Tañe

Gargantabla Ojomírame

Andagime Lloramía

Lauradime Dijujéame

Escarmenta Carmentina 
Yo te digo higo higo

Laumecarlos Ellameama

Somosnoche Besosomos

Tetenemos Ahlamiga

Venquevengas Oquescribas

y que vivas esta vida

vidalita

Mi mamita

Carlossoy

El siguiente fragmento del poema titulado «Para Cló», que figura en el mismo poemario, supone una muestra más de esta poética ebria que enlaza sus segmentos mediante sus proximidades fónicas y sus similitudes semánticas. La secuencias lingüísticas quedan unidas por las conexiones que establece el sonido y extrañeza del los significados alterados.

Tú comprendes que yo tenga

que estar solo que estar alto

en castillo de cobalto

con mi espada ensangrentada

con mi odio con mi amor

y el tambor de mi almamía

y la cítara de mi

silenciocio

y el orgullo de ser gallo mañanero

ojiabierto siemprevivo

vivaracho de ser macho

con mis ojos siempre rojos por insomnio

y magníficos a vere

los cojones de mi ser

Cló mujera compañera

de mi amigo como trigo

quiéreme émemé y víveme

con tu gana palpitana

Cló mi hermana

Esto escribo vivo vivo

con dos pies en el estribo

del Amor

Este lenguaje en libertad, de algún modo, supone la deconstrucción del código y se configura como una práctica lingüística dislocada, creadora de una expresión ampulosa y extravagante, de signo barroco, expresionista. Ory propone un lenguaje muy 
próximo a los retruécanos del juego poético barroco. La desmesura de la poética del Barroco, tanto de signo conceptista como culterana, se halla en la base del lenguaje poético oryano, tal y como se muestra en el poema «Dulzura colosal» perteneciente a Miserable ternura:

Dulce mi miel de besos siemprevivos Alma de almíbar y masosusurros Te amoro terriblesco de gozo fugitivo Todo se acaba y somos melarquía Nos amamos nos manos nos imamos Másmás en la lactancia ambrosiaca drogadictos de mostos suculentos Seres labiales ningún otro opio no nos satisfará la boca calda

Junto a la experimentación, consistente en la deconstrucción del código y en la total lejanía respecto del lenguaje referencial, se halla una expresión de signo cultista basada en la perfecta elaboración del material lingüístico. Al fin y al cabo, se trata de la práctica de una actitud lúdica frente a la sistematización del lenguaje. Aparente juego lingüístico que subvierte la mecánica lingüística y que apunta a un escepticismo radical frente al lenguaje y a sus valores comunicativos y estructuradores de la realidad. La transgresión del lenguaje muestra una nueva faz de lo real, así los mecanismos poéticos que desestructuran el lenguaje funcional suponen una vía de acceder a una realidad oculta, más sensible y poética. 


\subsection{POESÍA BEAT}

llueve en el invierno, la oscuridad es un círculo por el laberinto de la máxima destrucción

Leopoldo María Panero

\subsubsection{Una generación beatífica.}

Como ya hemos visto, con el nombre de Beat generation nos referimos a un grupo de escritores estadounidenses que mantuvieron en las décadas de los cincuenta y los sesenta del pasado siglo un actitud rebelde, bohemia y subversiva frente a los modelos socialmente establecidos de la época. Los límites que demarcan la geografía literaria de estos autores son imprecisos, algunos autores consideran que Timothy Leary, Hunter S. Thompson o Charles Bukowsky (Duval, 2012, 2013) también forman parte del grupo. William Burroughs, autor que conocía a todos los escritores que integraron el grupo desde un principio, nunca quiso considerarse miembro integrante. El núcleo del grupo beat queda formado por los personajes más conocidos: Allen Ginsberg, William Burroughs, Jack Kerouac y Neal Cassady. Aunque este último sólo posee una obra escrita, El primer tercio (1981), los otros tres son escritores con una dilatada producción. A estos se suman otros escritores que formaron el primer grupo: Philip Lamantia, Philip Whalen, Gary Snyder, Michael McLure, Kenneth Rexroth, Lew Welch, Gregory Corso y Lawrence Ferlinghetti. Este último es el creador, junto a Peter D. Martin, de la librería y mítica editorial City Lights en San Francisco. Otros escritores que se suman al grupo con posterioridad son Ken kesey, Ken Babbs o LeRoi Jones, que cambia en 1966 su nombre por el de Amiri Baraka debido a sus creencias islámicas y a su actitud combativa a favor de la comunidad negra. Existen además las mujeres beats, escritoras como Diane Di Prima, Leonore Kandel, Jan Kerouac, Joanne Kyger, Janine Pommy Vega o Anne Waldman. Así pues, la beat generation queda formada por un heterogéneo grupo de escritores, novelistas algunos y la mayoría poetas.

La génesis del grupo se halla en el año 1944, cuando Burroughs conoció a Kerouac y a Ginsberg los animó a ser escritores. En 1945 Burroughs y Kerouac, 
entonces dos jóvenes advenedizos y desconocidos, escriben And the hippos were boiled in their tanks, novela corta que permaneció inédita hasta $2008^{349}$. En ella se narra el crimen que dio origen a los beats, el asesinato en 1944 de David Kammerer a manos de Lucien Carr, quien después de apuñalar a su obsesivo amigo arrojó su cadáver al río y contó lo sucedido a Kerouac y Burroughs. De todas formas, se considera que el inicio de la Beat generation viene trazado por dos acontecimientos: la lectura de Allen Ginsberg, junto a otros poetas beat, del poema «Howl» ${ }^{350}$ en la Six Gallery de San Francisco en 1956 y la publicación de la novela On the road de Jack Kerouac en 1957. Novela escrita en un rollo de teletipo de cuarenta metros que nadie quería editar. En ella se transcribe de una menera totalmente novedosa, entre la escritura automática, la improvisación naïf y la ruptura del realismo, el viaje que realiza su autor en 1951, bien de modo solitario o junto a Neil Cassady, de un extremo a otro de los Estados Unidos. Se trata de un viaje hacia ninguna parte que inaugura todo una dinámica vital: la actitud contracultural. De esta primera etapa surgen importantes obras como: Junkie (1953), Naked lunch (1959) de Burroughs, The Dharma bums (1958) de Kerouac, Kaddisch and other poems (1961), Reality sandwiches (1963) de Ginsberg, Gasoline, the vestal lady on Brattle and others poems (1958) de Corso...

A partir de 1964 se inicia la segunda época de la generación beat, más contestataria, política y comprometida. Esta supone la entrada en la verdadera contracultura. Los nuevos ideólogos son ahora Ken Kesey y Timothy Leary, dos intelectuales preocupados por la percepción alterada mediante el L.S.D. y por sus implicaciones socio-culturales. Son los continuadores de los experimentos psicodélicos realizados con la mescalina en 1954 por Aldous Huxley y publicados dos años más $\operatorname{tarde}^{351}$. En 1963 Timothy Leary y Richard Alper son expulsados de la Universidad de Harvard por su experimentación con el L.S.D., a partir de aquí Leary se convirtió en un gurú de la experiencia psicodélica y dirigió viajes de ácido lisérgico para audiencias masivas. Kesey formó en 1964 el grupo The Merry Pranksters que realizó el viaje beat en autobús recorriendo Estados Unidos de costa a costa. Al volante del autobús estaba Neal Cassady, en Nueva York contactan con Kerouac y Ginsberg, también visitan a

349 Burroughs, William y Kerouac, Jack (2008) And the Hippos Were Boiled in Their Tanks, Nueva York, Grove Press; traducción de Fernando González Corugedo, los hipopótamos se cocieron en sus tanques, Barcelona, Anagrama, 2010.

350 Ginsberg, Allen (1956), Howl and Other Poems, San Francisco, City Lights; traducción de Rodrigo Olavarría, Aullido Barcelona, Anagrama, 2006.

${ }^{351}$ Huxley, Aldous (1956), Doors of perception. Heaven and Hell, obra cit. 
Leary en Millbrook Farm. Un uño más tarde crean los kool-Aid Acid Test en la Costa Oeste. Todo ello queda registrado por Tom Wolfe en The electric Kool-Aid Acid Test Farrar (1968). Por otra parte, Ginsberg se convierte en un agente político que apoya todas las protestas contraculturales: la oposición a la guerra de Vietnam, la psicodelia, la liberación homosexual, la actitud vital hippie... Otro agente beat fue Bob Dylan, músico muy unido al grupo beat y, sobre todo, a Allen Ginsberg. Dylan llevó el lenguaje poético beat, inconsciente, improvisado, surrealista, hermético y vibrante, a la canción. Superada su época folck, Dylan supuso, en los años sesenta, la trasformación de la música pop mediante la unión de música y poesía ${ }^{352}$. La Beat Generation significó la antesala de la contracultura.

Los beatniks son los bohemios descendientes de los existencialistas que reivindican la radicalidad combativa del Dadaísmo y la actitud rebelde de los poetas malditos. Personajes marginales que se aglutinan en los cafés y tugurios del Nort Beach de San Francisco y en los clubs de jazz del Greenwich Village de Nueva York y que mantienen la misma actitud de rechazo social que los hipsters, aquellos oscuros nihilistas, blancos y negros, que en los años cincuenta iban en busca perpetua de la orgiástica del instante presente. El hispster, cuya imagen icónica más conocida sería Charlie Parker, es el rebelde subterráneo que rompe radicalmente con la ética social y se refugia en una existencia privadamente marginal, marcada por la marihuana y la heroína. Los beats parten del rechazo los valores del American way of life. Como los hipsters utilizan los estados alterados de percepción para crear un nuevo lenguaje y buscar una experiencia mística en el aquí, inmanente. Sus obras están inspiradas por varias sustancias psicodélicas. En las novelas, sobre todo, encontramos multitud de situaciones donde los personajes las utilizan o se hallan bajo sus efectos. En ellas aparece el alcohol, la marihuana, la benzedrina (anfetamina), la heroína, el ácido lisérgico... Por otra parte, la rebeldía y la oposición a la normativa social se muestra en el rechazo de los roles sociales como la premura, el trabajo, la sexualidad y las relaciones familiares. Esta actitud rebelde tuvo sus encontronazos con la sociedad y sus

${ }^{352}$ Duval (2012, 2013: 44-45). En una entrevista realizada por este autor a Ginsberg, este último manifiesta que Dylan es el poeta norteamericano más importante de la segunda mitad del siglo XX y lo incluye dentro del grupo de los poetas beat. 
conexiones con la delincuencia y el delito ${ }^{353}$. La Beat generation inagura un estilo de vida libre y protestatario, totalmente alejado de los engranajes sociales.

\subsubsection{Una poesía libre y rebelde.}

El concepto Beat Generation fue acuñado por Kerouac en 1948. El término beat significa, de un lado, la libertad y la improvisación de los ritmos bohemios y salvajes del jazz, sobre todo del be-bop $p^{354}$. Y por otro, la expresión viene de visión beatífica. Parámetros ambos que definen el espacio abierto de la poesía beatnik. Poesía que parte, paralelamente a la poética postista, de la demolición del discurso racionalista burgués. Se trata de una poesía radicalmente alucinada, salvaje y libre, que se acerca a la inocencia de la niñez y escapa de la restricción de la normativa retórica. Kerouac la define, en Los orígenes del gozo en poesía como un grito, el grito primario, jovial y alegre de un niño o de un sabio (1973: 7):

La nueva poesía norteamericana en tanto que tipificada por el Renacimiento de San Francisco (lo que quiere decir Ginsberg, yo, Rexroth, Ferlinghetti, Mc Lure, Corso, Gary Snyder, Philip Lamantia, Philip Whalen, supongo) es una especie de nueva-vieja poesía lunática zen, escrita tal y como entra en la cabeza según va viniendo; poesía que regresa a su origen, al niño bardo, autñenticamente ORAL como dijo Ferling, en vez de grises palabrerías académicas. Poesía \& prosa hace largo tiempo que han caído en las falsas manos de lo falso. Estos nuevos poetas puros se confiesan públicamente por el simple placer de confesarse. Son NIÑOS. También son homeros infantiles de barba gris cantando en la calle [...] La de San Francisco es la poesía de una nueva

${ }^{353}$ Ovejero (2011: 102-121). Este autor estudia las relaciones entre los integrantes de la Beat generation y el delito. Burroughs y Kerouac, acusados de complicidad, tuvieron problemas con la justicia en el caso Kammerer en 1944. Jack Kerouac pasó unas semanas en la cárcel. En 1951 Burroughs marchó de Luisiana a México para escapar de una condena por posesión de drogas, allí mató accidentalmente (se supone) a su mujer de un tiro mientras quería ensartar la bala en la manzana que ella tenía sobre su cabeza. De aquí marchó a Tánger aprovechando su libertad bajo fianza. Neil Cassady en su juventud fue detenido infinidad de veces y pasó por varios reformatorios y por varias prisiones, su delito más frecuente fue el robo de cohes. Gregory Corso pasó su infancia y adolescencia en reformatorios y cárceles. Allen Ginsberg no estuvo en la cárcel, pero sí en el psiquiátrico. Lawrence Ferlinghetti fue detenido en 1956 acusado de provomer la obscenidad por publicar Holw and others poems de Ginsberg. Ken Kesey pasó también alguna temporada en prisión acusado de posesión de drogas. En 1970 Timothy Leary, acusado de posesión de marihuana, estuvo en la cárcel, de donde escapó y se fugó a Europa. Se emitió una orden de detención internacional contra él, lo que le llevó a ingresar unos pocos días en una cárcel de Suiza.

${ }^{354}$ El be-bob es una derivación vanguardista del jazz que se desarrolla en la década de los cincuenta y se basa en la inspiración momentánea, en la total improvisación, en la libertad suprema y en la rebeldía social. Algunos músicos conocidos representantes de esta tendencia son Charlie Parker, Thelonius Monk, Hampton Hawes, Art Pepper, Chet Baker... 
Locura Santa como la de tiempos pasados ( $\mathrm{Li}$ Po, Hanshan, Tom O Bedlam, Kit Smart, Blake) aunque también tenga esa disciplina mental tipificada por el haiku (Basho, Buson), es decir, la disciplina de señalar las cosas directa, pura, conretamente, sin abstracciones ni explicaciones, wham wham el auténtico canto triste del hombre.

La poesía beat, en su avidez por transgredir los límites de los códigos poéticos caducos, se acerca, en cierto sentido, a la poesía experimental que se desarrolla en la cultura posmoderna. De hecho, la gran ruptura en la poesía americana se produce con la aparición de la obra de Allen Ginsberg, cuya estela ha sido de una importancia capital en la poesía posterior. Indian Journals (1971) supone un total acercamiento a la poesía concreta, de signo visual, donde palabra poética y artes plástica quedan unidas. También la obra de Lawrence Ferlinghetti atraviesa el territorio poético experimental con obras como Love is no stone on the moon (1971) o Open Eve, Open Heart (1973). El siguiente poema de Jack Kerouac, titulado «From OLD ANGEL MIDNIGHT», publicado en 1959 en Beetitood y recogido posteriormente en 1971 en Scttered poems, es un clara práctica de este lenguaje poético experimental.

54.

peep
peep the
bird tear the
sad bird drop heart
the dawn has slung
he aw arrou drape

to sissyfoo \& made eastpink

dink hte dimple solstice men crut and so the birds go ttleep and now bird number two three four five six seven and seven millions of em den dead bens barking now the birds are yakking \& barking swinging Crack! Wow! Quiet! The birds are making an awful racket in the Row twep? tswip! creet! clink! crack! Ding dong the bell rope bird of bread of day Okay birds
please

you birds robins

black \& blue birds redbreasts \& all 
sisters,

my little parents

have the morning

by the golden balls

And over there the sultan forgot

El lenguaje beat busca una escritura fluida, no mediatizada por el intelecto y alejada de toda posible abstracción. Una escritura que surge de la propia experiencia, improvisada y libre, dejando que las imágenes se acoplen por sí mismas, como el lenguaje adoptado por los músicos de jazz. En este sentido se persigue un verso que se armonice con el ritmo de la respiración. Los poetas beat reivindican la poesía profética, desmesurada y libre de Walt Whitman, como Withman el poeta beat quiere cantar la existencia, celebrar el hecho de existir en el aquí y en el ahora. Precisamente de Withman la poesía beat toma el verso largo y deshilvanado, tremendamente antirretórico. La esccritura beat es fluida y dinámica, rápida y digresiva, descentrada. Se trata de una escritura que representa la velocidad. La narrativa beat, inaugurada por Kerouac en On the road y Cassady en The first third, supone un continuo monólogo interior, una escritura primitiva y elemental, impulsiva y subjetiva, enormemente desordenada que intenta rechazar toda elaboración e intromisión del pensamiento. Se trata de una escritura automática que parte de la experiencia. La crítica ha comparado la escritura beat con la forma de conducir de Neil Cassady, que intentaba tocar el freno lo menos posible para imprimir más velocidad al viaje. Los puntos establecidos en un fragmento beat equivalen al frenazo, así el texto adquiere el máximo dinamismo posible. La rapidez de esta escritura improvisada se halla en la influencia de la benzedrina, droga que más tarde toma el nombre de anfetamina ${ }^{355}$. La poesía de Ginsberg toma este lenguaje de verso largo y electrizante ${ }^{356}$, lenguaje que conecta con la poesía oryana, extraña y rara, totalmente excéntrica y marginal. En obras como $L a$

${ }^{355}$ Ver Cunnel, Howard, «Esta vez deprisa: Jack Kerouac y la redacción de En la carretera», en Howard y otros (2007, 2010: 35-41); Shapiro, Harry (2003), Waiting for de man, traducción de Valeria Marcó del Pont, Historia del rock y las drogas, Barcelona, Ed. Robinboock, 2006, p. 121-122.

${ }^{356}$ Allen Ginsber escribió en 1959 kaddish, su segundo poemario que toma la forma del rito mortuorio judío dedicado a su madre, después de pasar la noche del sábado en casa de un amigo escuchando música de Ray Charles. Allí tomó morfina y metanfetamina. Al amanecder llegó a su casa y se puso a trabajar en el poema desde las seis de la mañana hasta las diez de la noche sin descanso. Las dosis de dexedrina (un tipo determindo de anfetamina) fue aquello que mantuvo despierta su concentración. Ver Kaddish y otros poemas (1958-1960), ed. definitiva del 50 aniversario, traducción de Rodrigo Olavarría, Barcelona, Anagrama, 2014, pp. 205-208. 
flauta prohibida, Tambor de sicomoro o Lee sin temor existe una presencia muy marcada de este lenguaje, descentrado y fluido, de ascendencia beat. El siguiente fragmento del poema «Apoteosis de la esperanza» que pertenece a Tambor de sicomoro es un claro ejemplo:

Os pido que séais luces atravesando el túnel del mundo tan podrido / la tiniebla podrida No olvidéis la oración ululante en la noche Meditar y soñar y durante la noche no dejéis que se apague el brasero del mundo entero y verdadero / hay que enviar flechazos por cuenta propia y sagrados salibazos contra estátuas y fantasmas Entrammo a ritornar nel chiaro mondo Hermanitos la cabaña es pequeña pero cabe la música grande y las siete trompetas Quiero que un billón de jóvenes / del mundo entero y verdadero / venga a besasrme el occipucio Pero no van a caber el el peristilo Por eso me quedo con una muchacha siempre solo y nos quedamos solos poniendo discos negros de auténticos negros autodidactos

También el siguiente fragmento del poema, que pertenece a la misma obra, «Variación sobre un viejo tema» está escrito en este lenguaje beat:

Soy un viento mirándote dormir bajo la disciplina de la felicidad Entré en el terciopelo y frecuenté la urdidumbre y visité la fábrica salvaje de la miel viviendo una experiencia de mutismo binario atravesando largos corredores violetas Y la respiración de colores / el sueño con su casa sin puertas es una antigua casa Azul muralla de cristal / regia muñeca viva mojada de licor en esa noche egipcia

Todavía se observa de una manera más clara este lenguaje improvisado de signo narrativo, a la manera de Ginsberg, en el siguiente fragmento:

¿Quién está ahí? ¿Qué luz es esa? ¿A qué vienes tú?

-A consolaros y a traeros felices nuevas

He sido otras veces un muchacho y una muchacha 
una garza y un pájaro y un pez mudo sobre el margaritas

Dormía y soñaba que le ponían un anillo en el dedo

¡Aguárdame! No tardaré en reunirme contigo en ese hondo valle

¡Uh... uh... uh... uh...! ¿quién se acuerda del caballito?

Bien dicho topo viejo

La noche es una casa inmensa

El loco dice locuras

¿Qué fastidio comenzar todas las mañanas la vida!

No deseo el sufrimiento de cosa alguna viva

¡Vivir es estar profundamente solo!

Habla Golod ven sentémonos aquí Inioldo

Mi vida era bella espléndida y pura

¿Quien viene? ¿Quién me llama? Nadie...

El hombre es el sueño de una sombra

(«Exterius», Lee sin temor)

El Diario supone la certificación del interés de Ory por la Beat Generation, en él aparecen referencias hacia William Burroughs (2004, Vol. III: 22), Jack Kerouac (2004, Vol. III: 56), Gary Snyder (2004, Vol. III: 56, 58), Harold Norse (2004, Vol. III: 92). Ahora bien, el poeta beat con quien Ory se siente más identificado, y que con posterioridad surgirán mutuas colaboraciones, traducciones y amistad, es con Allen Ginsberg. El Diario es testigo de ello: (2004, Vol. II: 375), (2004, Vol. III: 13, 294-295, 297-298, 302, 310-311, 337). Como en Ginsberg, la poesía oryana siempre ha poseído una impronta combativa y transgresora, tanto de los códigos estéticos como de los sociales. Howl supuso un verdadero desafío frente a los cánones socio-culturales de la época, de hecho la obra estuvo censurada y su editor, Ferlinghetti, fue llevado a los tribunales acusado de promover la obscenidad. De forma paralela, la poesía oryana desafió, desde los postulados postistas y desde el espacio marginal que ocupa su producción poética posterior, todas las normas de la poesía de posguerra. Ory fue el gran heterodoxo, el más raro de los poetas que escribían en castellano. En todo caso, es el poeta español que más proximidad tiene con el lenguaje libre instalado por Ginsberg. $\mathrm{Su}$ poesía nómada y errabunda rechaza toda pertenencia a cualquier patria $\mathrm{y}$, como Kerouac, instaura en su poética el viaje perpetuo a ninguna parte, en el que la meta es el propio camino y en el que se celebra toda experiencia acerca del existir. En el siguiente fragmento del poema «Miserable ternura», que pertenece al poemario homónimo, encontraños las referencias que apuntan hacia la imagen del vagabundo del Dharma instaurada por Kerouac: 


\begin{abstract}
¡Abandonado abanadonado abandonado!
Sin carta sin teléfono sin besos

Me fui a una isla solo y desolado

Viví entre rocas de imponentes pesos

$[\ldots]$

En medio del camino de mi vida

ebrio de vida y como siempre yendo

al galope y el viento como brida

y un no sé qué que quedan balbuciendo

Corro hacia donde nunca nada no

y sin llegar jamás a donde he ido
\end{abstract}

La mística del viaje, que introdujo kerouac al reinterpretar el budismo $z e n^{357}$, queda aquí trasladada al lenguaje inefable de la mística occidental de San Juan de la Cruz. En su Diario (2004, Vol. II: 276) Ory traza (tal como lo hizo Kerouac en sus novelas) desde Amiens, el día 2 de septiembre de 1971, el decálogo de eterno viaje:

La idea culminate de separación, de abandono. Hacia otra cosa. No torcer los ojos al pasado. Lo vagabundo. Holganza y ocio. Siempre fue un tema central de mi disponibilidad creadora (expuesto en este Diario, hace años). Por qué no tengo casa nunca. Mi necesidad de no hogar. Lo viajero en mí. Ciudades, capitales, caminatas sobre la superficie del planeta, solo. Huida de España, París, Londres, Marruecos, Europa (Bruselas, Venecia, etc.), y más tarde (el año pasado), Estambul, y solo por las calles de Lisboa, el 10 de agosto de este año, hace veinticuatro días, y Lima, y mis días -años, desde 1967- en Amiens. Como mi caminata de esta noche.

Hacia el futuro, mi desprecio a las fronteras.

Vida sedentaria, sede de parásitos. Odio lo cerrado, lo sentado, lo inactivo.

Ory, al igual que Ginsberg, Ory se empapa de todas las filosofías marginales que conforman la contracultura, cuyos postulados defiende con una actitud combativa frente a la cultura central del posmodernismo. El interés oryano queda fijado en las culturas

357 Wilber (1983, 1990: 249), obra cit. Este autor considera que el zen-beat no coincide con la mística austera del zen: «Las disciplinas verdaderamente auténticas no tienen nada que ver con el no hacer nada, con la baetitud bobalicona, con el zen beat, con los vagabundos del dharma o con el fluir con el aquí y el ahora». Dejando de lado la posición de Wilber, Kerouac es uno de los introductores del budismo zen en norteamérica y su idea del zen va mucho más allá del ingenuo fluir dictado por impulsos y sentimientos. Alan Watts (1958, 1992: 77) se muestra menos crítico con el zen beat, aunque considera que el acercamiento al zen por parte de la Beat generation llevó al rechazo de las reglas tanto artísticas como sociales. Hecho que se halla más allá del zen. 
periféricas. Desde su exilio en Francia, Ory entra en contacto con todas las corrientes underground y defiende mantiene una actitud libertaria y de ferviente oposición a la cultura del poder. En este sentido, Ginsberg (como la mayoría de los autores beat) trasladó a su obra el interés por la psicodelia. Drogas como la marihuana, las anfetaminas, la ayahuasca, el peyote, el L.S.D., la morfina... se hallan en la génesis de sus poemarios. Sustancias tomadas como forma de experimentar la percepción de la realidad y como método creatívo. La poesía oryana, en cierta medida, también aparece sustentada por ciertas sustancias, las más frecuentes son el tabaco, el café, el alcohol y el hachichs. Tabaco y alcohol aparecen como motivo poemático en numerosos paisajes poéticos, pero la sustencia psicodélica oryana por excelencia es el hachichs. La proximidad de Cádiz con la costa africana hace que esta sustancia se haya extendido desde tiempo inmemorial por la geografía andaluza. Además cabe contar los constantes viajes de Ory a Marruecos, sus visitas a la zona del Rif. De todas formas el cannabis se halla presente en la poesía oryana:

¿Qué son esas criaturas moviéndose en las redes del espacio encantado si se puede saber? Son alucinaciones que pudiera tejer una araña borracha de hachís por las paredes

$$
\text { («Lo que el ojo miró», La flauta prohibida) }
$$

Por una carretera llena de baches irregulares a una velocidad apetente zumba un Diamond rojo conducido por el hombre más peinado Tú y yo subidos en un coche de «La Valenciana» desde Tetuan a Xaüen por un sendero accidentado Yo fumaba kif y tú estabas mal del vientre Ahora en mis cartas te hablo de los caminos árabes Pero aún nos queda mucho por recorrer Mucho nos queda por recorrer Por recorrer por recorrer

(«Reflejos de lugares», La flauta prohibida)

Oh Cádiz mío calla calla fumador de mi Cádiz con kif

$\left(« O v a r i o\right.$ materno» $\left.{ }^{358}\right)$

${ }^{358}$ Publicado por primera vez en Diario de Cádiz, 25 de abril, 1972. 
El interés oryano por la psicodelia le lleva a la lectura sobre la literatura del peyote, tal como muestra la introducción a Energeia (Poesía 1940-1977) titulada Sueño de la poesía (1978: 15):

\begin{abstract}
Algunos se han escapado hacia el misticismo, o hacia «el sueño de la razón». Bien me digo yo que ambas soluciones contradictorias producen mostruos por separado. ¡Qué lejos estoy del Tibet y de la montaña tarahumara! No obstante, envidio la suerte de Artaud entre aquellos indios o la de Castaneda tras la ruta que conduce a Ixtlán.
\end{abstract}

Ory hace referencia en este fragmento al viaje a México realizado por Antonin Artaud en 1936, allí asiste a los ritos del peyote o mitotes celebrados por los indios tarahumara. Todo ello queda registrado por el autor en la obra Los Tarahumara ${ }^{359}$. La otra referencia a la literatura del peyote apunta a la obra Viaje a Ixtlán escrita por Carlos Castaneda. Castaneda, un antropólogo de la U.C.L.A. que viaja a México para realizar un estudio sobre las plantas psicodélicas utilizadas por los indios yaquís, conoce a Don Juan Matus, un brujo chamán, y acaba convertiéndose en aprendiz. En su iniciación Castaneda prueba el peyote, la psilocibina contenida en los hongos y la datura inoxia. Pero son las experiencias vividas y las explicaciones de Don Juan las que realizan la demolición de las estructuras mentales racionalistas de Carlos Castaneda, largo proceso que le lleva a convertirse en el nagual de un grupo chamánico ${ }^{360}$. Una cita de Castaneda incicia la introducción escita por Ory para la edición de Energeia (1978: 14):

-¡Allí! ¡La eternidad está allí! -dijo, señalando el horizonte. Luego apunto hacia el cénit.

Carlos Castaneda, Relatos de poder.

359 Artaud, Antonin (1971), Les Tarahumaras, París, Gallimard, ed. 1979 aumentada; traducción de Carlos Manzano, Los Taraumara, Barcelona, Seix Barral, 1985.

${ }^{360}$ Ver Castaneda, Carlos (1968) Las enseñanzas de Don Juan, obra. cit; (1971); Una realidad aparte, obra cit.; (1972) Viaje a Ixlán, obra cit.; (1974) Relatos de poder, obra cit.; (1977) The second ring of power, Nueva York, Simon \& Schuster, El segundo anillo de poder, Barcelona, Pomaire, 1979; (1981) The eagles gift, Nueva York, Simon \& Schuster, traducción de José Agustín, El don del águila, Madrid, Eyras, 1982; (1984) The fire from within, Nueva York, Simon \& Schuster, traducción del autor, El fuego interno, Madrid, Swan, S.L.. Avantos \& Hakeldama, 1984; (1987) The power of silence, Nueva York, Simon \& Schuster, traducción del autor, El conocimiento silencioso, Madrid, Swan, S.L.. Avantos \& Hakeldama, 1988; (1993) The art of dreaming, Nueva York, Harper Collins, traducción de Nayely Tycho Thal, El arte de ensoñar, Barcelona, Seix Barral, 1993; (1998) The active side of infinity, Nueva York, Barror International, traducción de Brandon Scott, El lado activo del infinito, Barcelona, Ed. B.S.A., 1999. 
Otra cita de Castaneda abre el poema titulado «Metanoia», que pertenece a la antología homónima realizada por Cózar (1978: 311):

-¿Cree usted que he cambiado? -pregunté.

Tras un titubeo, soltó la carcajada.

-Eres el mismo idiota de siempre -dijo-. Y sin embargo no eres el mismo.

¿Ves lo que quiero decir?

Carlos Casteneda, Relatos de poder.

\subsubsection{Poesía como meditación}

La poesía beat converge también con la poesía oryana en cuanto que ambas plantean la práctica poética como una meditación. Poesía, en ambos casos, de signo metafísico, visionaria a la manera de Blake, ebria y mágica a la manera de Withman. Los poetas beat reivindicaron la gran tradición del taoísmo y de la poesía zen, propuesta poética paralela a la poesía oryana y su interés, ya desde sus posiciones postistas e introrrealistas, por la poesía como proceso de iluminación. Jack Kerouac fue uno de los introductores, junto a Alan Watts y Daisetz T, Suzuki, del budismo zen en la cultura norteamericana. Su novela The dharma bums (1958) supuso, de algún modo, un catálogo divulgativo del paisaje zen. A partir de esta obra el budismo zen se convirtió en fenómeno mediático. Ginsberg también estuvo interersado por el zen y practicó la meditación zezen, método básico del budismo zen. Ginsberg fundó en 1974, junto al maestro Chögyam Trungpa, el Naropa Institute en Boulder, Colorado, instituto dedicado al estudio y a la divulgación del budismo. En el seno de esta institución Ginsberg creó junto a Anne Waldman la Jack Kerouac Scholl of Desembodied Poetics, que se dedica a la difusión de la literarura beat incorporada en el marco filosófico del budismo. Gary Snyder, personaje que Kerouac incorpora en The darma bums con el nombre de Japhy Ryder, vivió doce años en un templo budista zen de Kioto. A su regreso a California se instaló en una cabaña en las Montañas Rocosas para vivir el silencio. Gregory Corso, Michael McClure y Philip Whalen también practicaron la meditación zen, de hecho este último se convirtió en maestro zen en San Francisco. Todos los poetas beat, en mayor o menor medida, han realizado el viaje cultural a Oriente: hinduismo, taoísmo, budismo, zen... 
En la poesía oryana encontramos también este interés por el budismo, y muy claramente por el zen, pero también por el taoísmo, el hinduismo, el tantrismo, incluso por el sufismo o el chamanismo. Territorios todos ellos que configuran los mapas mentales del interés por las creencias o religiones. La poesía oryana queda convertida, ya desde el introrrealismo íntegro, en pura meditación y en la práctica de la búsqueda de la iluminación. Alan Watts, Suzuki, Tomas Merton o Sri Aurobindo son los intermediarios. Ory descubre la meditación como método de transformación, el pensamiento zen como método de conocimiento no conceptual, el tantrismo como sexualidad sagrada, el taoísmo como lenguaje del vacío. La poesía incorpora las enseñanzas de los viejos maestros como Lao-Tse o Chang-Tzu y la inmediatez de $z a$ zen. La poesía oryana queda convertida en samadhi, en una mística de la inmanencia y expresa el éxtasis ante la experiencia de totalidad, donde asistimos a la percepción directa de la realidad que se ofrece como un océano ilimitado de vibraciones divinas.

No hay lenguaje idóneo para nada Sólo el silencio como cero único Participa del todo y todo impregna $\mathrm{O}$ ver un rostro humano tal cual es

Frente a lo elemental qué inútil es la frase sistemática y no cuenta la moneda que corre en el mercado de las palabras feria de sonidos

Entonces ser silente es retornar a los desiertos o los grandes valles Profundidad de no poder hablar Esto es renuncia al lenguaje espurio

(«Cero único», Tambor de sicomoro).

La poesía de Carlos Edmundo de Ory explora otros territorios de la mística como los cultos mistéricos y la alquimia. Se concibe pues como una mística sincrética, tal como muestra el siguiente fragmento del poema «Apoteosis de la esperanza» de Tambor de sicomoro. En él se utiliza la imagen de un cóctel para mostrar este sincretismo religioso:

Lejos de la histeria y de la historia de soldados / entre sonajas sagradas 
y gatos y arañas / entre tabaco y juego entre gonsis y risa / música y kundalini entre mandala y besos / il vento odo lo único de que habla de verdad $\mathrm{Y}$ estoy bebiendo mis licores mezclados mi sangría con ron

Mezclo vedanta con vudú mezclo arriba con abajo mezclo vivas con silencioso ebrio de soma y de soda ebrio de ascesis y de agni ebrio de loas y de rishis ebrio de espumas y de fosfenos ebrio de Tao y de théo ebrio de ternura y de catarsis lejos de Cádiz / lejos de mis novias buscando con la mirada águilas

La poesía oryana se instala en la continuación de la línea subterránea que atraviesa la zona crítica del pensamiento occidental: Blake, Nietzsche, Nerval, Carlyle, Baudelaire, Rimbaud, Lautréamont, Whitman, Tzara, Breton, Éluard, Vian, Jung, Reich, Hesse, Bataille, Artaud, Michaux, Deleuze, Norman O. Braun, Ginsberg, Castaneda... 


\subsection{POESÍA ORIENTAL}

La posesión del límite que encierro hacia un espacio sin final me lanza.

Jaime Siles

El interés de Ory por la mística no es nuevo. Desde los años cuarenta del pasado siglo la poesía es para él un método para expresar lo numinoso, para percibir lo que está más allá de las palabras. Encontramos en su poesía la existencia de una mística inmanente que no busca ninguna divinidad trascendente, sino que certifica el hecho divino del estar, el hallarse, en el aquí y el ahora. A su vez, ella expresa el sentimiento de unidad con el todo, de eterna totalidad cósmica. Pero el interés por el pensamiento oriental se intensifica, sobre todo, a partir del conocimiento de la obra de Alan Watts. Junto a Suzuki o a Lin Yutang, Watts fue el gran intermediario entre la cultura racionalista occidental y la paradójica sabiduría milenaria oriental. Su obra supone la divulgación de las filosofías orientales (taoísmo, hinduismo, budismo, tantrismo...) en Occidente, su labor reside en explicar y actualizar el pensamiento paradójico a los seres occidentales, perfectamente lógicos, cartesianos y unidireccionales. Watts vivió y experimentó en sí los conocimientos y los estados de la sabiduría oriental. La tarea de trasladar estas vivencias a la sociedad occidental supuso para él un radical cambio de paradigmas en el espacio social que le llevó al rechazo del academicismo y a la negación de los valores culturales imperantes. A su vez, ofreció a la sociedad toda una nueva geografía mental que, de algún modo, cambió sus rígidos parámetros culturales. Por todo ello, Watts está considerado como uno de los padres de la contracultura. Entre muchas de sus aportaciones cabe destacar la idea de la inexistencia de un ego consciente controlador del ser humano ${ }^{361}$. Esta ficción es aquello que separa y aisla al ser humano de la realidad, convirtiendo a los humanos en corpúsculos solitarios e infelices. Por otra parte, Watts parte de que el conocimiento mental es limitado, pues la realidad es mucho más vasta y sabia que la pura racionalidad, causante del miedo y del desasosiego. Para este autor, el pensamiento no sólo es una pura actividad mental, sino que se piensa también con las vísceras y los huesos. Y precisamente este pensamiento emocional es knowing who you are, obras cit. en la bibliografía. 
aquello que puede reconectar al hombre con la realidad. La actitud de Watts supuso la readmisión cultural del cuerpo, territorio secuestrado en la cultura de nuestra geografía occidental desde el cristianismo medieval. Como puede observarse, existe una total convergencia de las tesis de Watts con las preocupaciones metafísicas oryanas, pues la poesía de Ory intenta situarse más allá de las palabras. El interés de Ory por la obra de Watts queda reflejado en varios parajes de su Diario. El 5 de junio de 1977 puede leerse:

Sigo adentrado en las cosas de Alan Watts. Me las apropio, como estudiante de orientalismo, y no como sabio. Esto diría él de sus propios saberes, considerándose más bien como un vulgarizador del zen, del vedanta y del taoísmo. O que le consideran otros, no sin hacer notar que a menudo deforma los hechos a fin de acordarlos con sus teorías. ¿Cómo no hacerlo así? Es el método hermenéutico creativo. Es el fondeo fáustico. La mirada múltiple. Trabajo de buzo. Tender la vasta red del pensamiento sintético y sincretista [...]

Y Alan Watts dice, a propósito de los cotejos teoréticos, que son los suyos particulares, aplicados a términos básicos de la metafísica oriental: «Por eso, aunque se hayan burlado de mí, por haber establecido un paralelismo fácil entre el nirvana budista y el moksha hindú, o entre el sunyata de Nagarjuna y el Brahman de Shankara, puedo muy bien demostrar la exactitud de tales asimilaciones» $[\ldots]$

Esto es, en puridad, la complexio oppositorum, el abrazo de los contrarios, aligamento de antípodas, una «religio» de las bodas del cielo y del infierno. Es «la divina unión» de San Juan de la Cruz y de la Verdad hermética: Así de arriba como de abajo. Como en el cielo, así en la tierra. (2004, Vol III: 55-56)

Ory encuentra en la filosofía oriental la confirmación de las corrientes heterodoxas que surgieron al amparo del pensamiento occidental: misticismo, alquimia, hermetismo... Saberes que culturalmente se reactivan ante la nueva mirada ofrecida por el underground.

Jaume Pont (1974: 12-13) en el prólogo de la antología sobre Ory, Poesía abierta, observa rasgos que evidencian en la obra postista e introrrealista la presencia de algunos conceptos pertenecientes a las filosofías orientales. Ahora bien, es Música de lobo la apertura definitiva hacia la sabiduría oriental. Para Pont (1989: 187-191) este poemario está escrito en clave hermética ${ }^{362}$ y supone una expresión de todas las

${ }^{362}$ Pont interpreta el significado de la obra como un profético viaje a los infiernos, resultado de una experiencia ritual iniciática órfica y chamánica. La mirada de Ory se inscribe en la tradición de la visión dionisíaca, revitalizada sobre todo por Nietzsche. El lenguaje onírico y visionario es el eje vertebrador de la transmisión de la experiencia del horror más profundo. Experiencia de muerte y renacimiento. 
concepciones heterodoxas respecto al pensamiento racionalista y científico imperante en la cultura occidental ${ }^{363}$. La poesía oryana queda configurada en esta obra como una mística cósmica totalizadora que reformula la perfecta armonía entre sujeto y cosmos y muestra, a su vez, la presencia de la energía cósmica en el interior de los seres. Esta impronta mística intenta explorar el misterio de la existencia desde una óptica poliédrica donde todas las experiencias místicas quedan conjugadas: ritos mistéricos, filosofías dionisíacas, orfismo, magia, alquimia, chamanismo, hinduismo, budismo, taoísmo, zen... El poemario toma la forma de rito, de una experiencia extática. En algunos momentos parece que se trate de un diálogo con la figura de un maestro. Por ello, la obra supone una experiencia directa que trasmite el contacto con la divinidad, presente en el cuerpo humano. Experiencia que, desde otras ópticas, queda continuada en Lee sin temor y Miserable ternura - Cabaña y que, años más tarde, reaparece en Melos Melancolía (1999).

\subsubsection{El hinduismo y la no dualidad}

El hinduismo es uno de los centros de interés visitado por la atención oryana. Varios conceptos y referencias de la poesía oryana remiten a la tradición védica o Vedanta $^{364}$, a las Upanisads ${ }^{365}$, al yoga ${ }^{366}$, a la Bhagavadgita ${ }^{367}$ y a la filosofía de

${ }^{363}$ En este sentido cabe señalar la presencia de la imagen del lobo, hallada en el título, que reactiva tanto la interpretación realizada por Herman Hesse en Der Steppenwolf (1927) como la de Ginsberg en Holw (1956). En todo caso, se trata del símbolo por excelencia de lo heterodoxo, del ser que se aparta de la manada en busca de una experiencia vital más genuina e intensa. Símbolo que significa todo un ataque a los postulados de la civilización burguesa.

${ }^{364}$ El Vedanta, de tradición oral en su origen, comprende escritos situados entre los años 1400 y 400 a.C. Entre ellos cabe destacar las colecciones de Vedas: el Rigveda, el Samaveda, el Yajurveda y el Atharveda. En ellos se encuentran himnos a los dioses del panteón hinduista, los ceremoniales y los rituales (Eliade y Couliano, 1991, 1994: 167-169).

${ }^{365}$ Las Upanisads, escritas entre los años 700 y 500 a.C., muestran las enseñanzas de los maestros. En ellas aparece la teoría del karma. Es la ignorancia, avidya, la base del sufrimiento cósmico y existencial. Sólo la gnosis, jnana, puede liberar al ser del engaño tras el que aparece el dharma (Eliade y Couliano: 1991, 1994: 169-170). Otro de los conceptos básicos de las Upanisads es el de una divinidad inmanente o el de una realidad divina, donde Brahman es la realidad. Raimon Panikkar (1997: 72) interpreta la frase ahan brahma asmi («yo soy Brahman») no como la unión del ego y la divinidad, sino como que la frase, y por extensión el lenguaje, solamente puede pertenecer al atman, al yo humano. En este sentido, la reencarnación o metempsicósis toma otra óptica. Quien se reencarna no es el ego, sino Brahman en las innumerables miríadas de los seres.

${ }^{366}$ El yoga como conjunto de técnicas y soporte filosófico fue codificado por primera vez por Patanjali en el Yogasutra en siglo II a.C. Ver Eliade, Mircea (1962), Patáñjali et le yoga, París, Editions du Seuil; traducción de Juan Vañmard, Patañjali y el yoga, Barcelona, Paidós, 1987.

${ }^{367}$ El Canto del bienaventurado o Bhagavadgita pertenece a una obra clave de la literarura épica, el Mahabharata. En la Bhagavadgita, poema escrito en el siglo II d.C., Krishna 
Sankara. Partiendo de la óptica advaita de Sankara, Raimon Panikkar (1989: 68-70) rechaza todo dualismo de la mirada hinduista, desde esta perspectiva no existe separación alguna entre lo divino y la realidad, entre atman y Brahman. El atman individual, que busca la unión con el Brahman divino, en realidad no se diferencia en nada de él. Siempre ha estado unido a Brahman, lo que implica que no existe ningún ego diferenciado:

Lo que el advaitin reconoce no es su nada que se revela $a$ él sino la Plenitud que se revela en sí misma. No hay por tanto lugar para un ego que puede tener esa experiencia. La experiencia es y eso es todo. Todo retorno a un ego anularía la experiencia advaita. Es inefable porque no existe ningún ego para describirla o dar testimonio de ella. (Panikkar, 1989: 68-70)

Panikkar, al referirse a la experiencia mística, ofrece el ideario clave del hinduismo, que por otra parte aparece en la fórmula sánscrita utilizada para señalar la unidad sin fisuras entre el individuo y la realidad cósmica y divina: tav twam asi, tú eres eso (Huxley, 1945, 2010: 19-21).

En el poema «La tierra tiembla», perteneciente a Lee sin temor, mediante un lenguaje exhortativo Ory trasmite la experiencia de unidad cósmica:

La tierra habla

El hombre está solo

La Naturaleza es naturaleza

El hombre es anormal

Perdido el hilo de lo antiguo

Estatua del Devenir

La tierra habla desde siempre

Y desde siempre el silencioso

está nuevo

Torna a él

Al silencio nuevo y lo solar

En lo bajo y en lo alto

El hombre está solo

Espiando espiándose

Hipnotizado

Sal del sueño

ilusorio

Entra

en el alud de oro caliente

expone ante el guerrero Arjuna, desencantado y desfallecido ante la inminente batalla, las claves de la práctica del desapego y de la acción desinteresada. 
Pasea en aires de polvo

fuera de tu cuerpo

Entre varias cuestiones referentes al hinduismo, el poema presenta en su final, bajo la dinámica de una orden, la unidad a experimentar entre el yo humano y la realidad divina. Encuentro del ego y el eso, unidad del atman y Brahman. Para ello el ego debe destruir la ignorancia, despertar del «sueño ilusorio» y ser consciente de su verdadera realidad. El poema activa aquí el concepto hinduista de la ruptura del velo de maya que enmascara la verdadera realidad tras la representación de las ilusiones, tal como anteriormente hemos tratado de una manera superficial. Maya, producto de la ignorancia humana, supone el aspecto ilusorio del mundo creado por el pensamiento reperesentacional que se muestra incapaz de percibir lo real como caos. La representación, al intentar ordenar lo caótico, impone los límites y las separaciones. Pero la realidad, caótica e ilimitada, es envolvente como un nudo sin fin. Por ello, no existe, según las tesis del hinduismo, separación posible entre el individuo y lo real, entre el atman y Brahman. Es maya, el condicionamiento cultural, quien crea la ilusión (traducida como red conceptual que estructura la realidad) de la distancia. Las Upanishads proponen rasgar el velo de maya para poder percibir de forma consciente la verdadera realidad, indivisa, que se manifiesta como totalidad. El ser humano, «hipnotizado», debe trascender la ignorancia mediante la gnosis y acceder a la verdadera realidad, vista en el poema como «alud de oro caliente». Es maya quien provoca en el ser humano la sensación de soledad y aislamiento. Soledad que queda asociada a la tristeza, la angustia... el dolor existencial, signos de tribulación y opacidad ante la confusión generada por maya.

En este sentido, el concepto hinduista conecta con el símbolo de la noche oscura establecido por la mística negativa y ascética de San Juan de la Cruz, influida a su vez por la mística sufí ibérica y andalusí (Eliade y Couliano, 1991, 1994: 200-202). Pues la noche oscura, que se atraviesa después de un periplo de rechazo y sufrimiento, queda convertida en noche dichosa, en noche de luz, pues la presencia íntima del amado convierte la mística negativa en una experiencia unitaria. Experiencia que en la poesía mística sanjuaniana puede traducirse como la presencia de Dios en el alma. 
En la Noche dichosa, en secreto, que nadie me veía, ni yo miraba cosa sin otra luz y guía, sino la que en el corazón ardía.

Aquesta me guiaba más cierto que la luz del mediodía, a donde me esperaba quien yo bien me sabía, en parte donde nadie parecía.

Maya se halla presente en varios escenarios de la poesía oryana, su ruptura equivale al despertar, a la iluminación, cuyo símbolo es la luz. Luz que se transforma en sabiduría, consciencia de la unión con la divinidad:

El mundo de los necios abandono transformado porque se ha desgarrado para mí el velo del engaño

(«Huyo del aplauso miserable», Música de lobo)

Otro concepto hinduista que aparecía en el poema comentado anteriormente «La tierra tiembla» es el de la eternidad. Eternidad que se establece en el tiempo y en el espacio, pues la realidad no comprende límite alguno, sino que es una espiral sin fin. Movimiento eterno que se dirige hacia afuera, hasta las distancias cósmicas, y, al mismo tiempo, microscópicamente hacia el interior. De modo que los planetas son células de otros mundos ilimitados y nuestras células universos en sí mismos.

Perdido el hilo de lo antiguo

Estatua del Devenir

La tierra habla desde siempre

(«La tierra tiembla», Lee sin temor)

Esta idea del infinito viene mostrada por dos conceptos del hinduismo: el avatar y la teoría de los ciclos cósmicos. La teoría del avatar, o manifestación terrestre del Visnu, aparece en la epopeya hindú, en los Puranas, escritos entre el año 300 y el 1200 de la era cristiana, y en la literatura de Harivamsa, perteneciente al siglo IV d.C. En estas obras se muestra la genealogía de Visnu, que reaparece bajo la figura de un pez, Matsa; 
de una tortuga, Karma; de un jabalí, Varaha; de un hombre-león, Narasimha; de un enano, Vamana; de Rama del hacha, Parasurama; Rama, Krihsna, Buda y Kalki (Eliade y Couliano, 1991, 1994: 172). Lo que transmiten estos textos es la misma teoría de los ciclos cósmicos, que viene resumida en la idea del tiempo infinito. El período de tiempo más pequeño es el yuga o edad, un ciclo cósmico o mahayuga comprende cuatro edades de duración desigual, el krtayuga, el tretayuga, el dvaparayuga y el kaliyuga. Mil edades o mahayugas comprenden un kalpa o período cósmico marcado por el intervalo temporal de un día de la vida de Brahman. Deidad que a su vez vive cien años de trescientos sesenta días y noches cósmicos, es decir más de trescientos mil millones de años terrestres. Esto es, un mahakalpa, que equivale a un parpadeo de Visnu, la divinidad suprema. Para el budismo, la imagen del tiempo también toma la forma del ciclo infinito o, lo que es lo mismo, la ausencia de límites. El tiempo queda establecido en una serie incontable de eones, que equivalen también, como en el hinduismo, a un simple parpadeo de Buda (Eliade, 1951, 1974: 112-115). Espiral infinita donde cada línea es, a su vez, una vuelta más de un ciclo de ciclos. La imagen hinduista que, por excelencia, traduce este concepto es la svastica, cuyo paralelo taoísta sería el círculo completo que representa el yin y el yang. Imagen del ritmo orgánico de la vida, de la conexión de los contrarios, unidad intrínseca y polar de vida y muerte. Pues es la muerte el alimento de vida.

Bien sé que no hay que nacer sino renacer

Esto es muerte pero nunca lúgubre

Lo bello existe en alguna parte sin polvo

(«Nadie viene», Lee sin temor)

Oh estrellas dibujos iguales por nadie pintados

Oh cuánto infinito se encierra en la Nada vacía

Oh ideas de dioses nonatos miriadas de dioses

Oh tiempo invencible mirando sin rostro a los hombres

Oh cosas pensadas que nunca se llegan a veredictos

Oh tantos fugaces instantes naciendo y muriendo

Oh seres que sufren en vano pidiendo consuelo

$[\ldots]$

(«Exclamatorio», Lee sin temor)

Alan Watts (1963, 1990: 94) aclara el significado de esta danza cósmica: 
El principio y el final, el nacimiento y la muerte, la manifestación y la renuncia siempre se implican [...] Si el nacimiento implica la muerte, la muerte implica el renacimiento, y del mismo modo, la destrucción del mundo implica su recreación.

Parecido significado queda expresado en el poema «Correspondencia», escrito en 1975 y publicado en 1981, perteneciente a Cabaña:
Y ayer me escribirás Lo has hecho ya
Porque también mañana hemos estado
juntos en parte alguna con espacio
El infinito es un dibujo chino
Y las arañas mismas que soñamos
en nuestras pesadillas de nocheros
no son distintas de las que veían
los babilonios en los sueños suyos
Nadie se libra de este cabestraje
cual buey de ley que mansos así somos
Flotamos en la charca del espacio
Agradecer al sueño su absoluto

Si tiempo y espacio no tienen límites, todo puede ser reversible: «ayer me escribirás», «mañana hemos estado», «juntos en parte alguna» ${ }^{368}$. Sin límites, sin asideros, «flotamos en la charca del espacio», sin nada sobre la cabeza ni nada bajo los pies. Presencia del karma, esta es la ley de la existencia; pues «nadie se libra de este cabestraje».

Por otra parte, debido a la ignorancia, extraviarse en los laberintos de maya es, para Ory, la condena que pesa sobre el ser humano. Este, ignorante ante la realidad divina, no es capaz de deshacerse de su ego, lo que para Watts (y aquí Ory sigue la misma estela) equivale a la noción de pecado $^{369}$. Pecado que, en este caso, se trataría de la desviación del curso natural de las cosas, del estado unitario de la realidad. Por ello el ser humano, en cuanto ego controlador, se siente atrapado en una cápsula que lo separa y aísla de la realidad. Este es el sentimiento de separatividad, la confusión que permite

368 Nótese que los siguientes segmentos poéticos funcionan como trasposiciones temporales. Ver Bousoño (1952, 1976: 389-392).

369 Watts, Alan (1973), Cloud-Hidden, whereabouts unknown; traducción de Rolando Hanglin, El futuro del éxtasis, Barcelona, Kairós, 1990, p. 14. 
al ser distanciarse de lo que en definitiva es una unidad sin costuras, aquello que el hinduismo denomina Brahman y que todo lo incluye. La impronta racionalista, atomizada en lo pensante como control sobre lo real, hace que el ser humano sólo se perciba como agente observador y no como participante, indistinto, de la realidad. Este concepto queda reflejado totalmente en el siguiente fragmento del poema de Lee sin temor, «La nada divina»:

No hay más que un pecado el «Yo»

Mi ética es la ética de la compasión

de la catarsis de la purgación

de la completa liberación del ego

La Nada divina

Unidad y separatividad se encuentran reflejados en el siguiente poema sin título, perteneciente al mismo poemario, que forma parte de Silencio:

Una estrella y un árbol

Ni arriba ni abajo

Yo veo que están juntos

Y no hay otro ejemplo

Porque el hombre y el hombre

ni juntos ni separados

Divididos viven y mueren

El sentimiento de unidad, expresado en la poesía oryana, queda plasmado en la respuesta que Krishna le ofrece al desfallecido guerrero Arjuna en el segundo capítulo de la Bhagavad-gita:

¡Oh, Dhananjaya! Nada hay superior a Mí. Por mi acción, todo lo que existe se enlaza como un collar de perlas, sobre el hilo de un collar.

Yo soy el sabor de las aguas, Yo soy la luz del sol y de la luna, Yo soy la sílaba Aum de los Vedas, el sonido en el éter y la virilidad en los hombres.

Yo soy fragante perfume en la tierra y energía de luz en el fuego; Yo soy la vida en todos los seres que existen, Yo soy la fuerza ascética de quienes la practican.

¡Oh, hijo de Pritha! Yo soy el germen eterno de todos los seres existentes, Yo soy la inteligencia en el ser inteligente y la energía en el ser enérgico. ${ }^{370}$

${ }^{370}$ Bhagavad-gita o el canto del bienaventurado, ed. de José Barrio Gutiérrez, Madrid, Edaf, 1996, p. 62. 
El hinduismo, como toda las concepciones religiosas orientales, supone una mística de la experiencia, una gnosis, donde el ser experimenta en sí el contacto con la divinidad, su presencia. Para Antonio Escohotado ${ }^{371}$ la palabra mística proviene de Mystes, el nombre que, según Aristóteles, recibían los iniciados en los ritos mistéricos de Eleusis. Ritos donde los participantes experimentaban profundamente y humanamente el sentido de estar vivos, verdadera experiencia existencial. La poesía oryana muestra la experiencia totalizadora del yo que ha transformado su conciencia a través de un rito. Música de lobo queda configurado como la certificación de esta experiencia mágica. En este sentido, la práctica yóguica está considerada por Ory como experiencia mágica, chamánica y como método de transformación. En el primer poema de Té, integrado en Música de lobo, se hace referencia al pranayama, ejercicio que marca la respiración en el yoga, como práctica de un ritual mistérico:

Los antiguos aconsejaban colocar una mano sobre las espinas de los cedros jóvenes con el fin de que el Prana condensado penetrase por las yemas de los dedos

Los antiguos bebían en los cráneos de sus terribles enemigos los cálices para sus rituales sagrados se hacían del hueso sincipital ${ }^{372}$ de la coronilla

Los antiguos solían señalar los días malos Así se recordaban las secuencias de los manvaratas y pralayatas aunque aplicado al existir terreno

Los antiguos llamaban al sentimiento la forja del poder El Maestro vigila los fuegos Los fuegos que ilumina el aura Y que además habitan el espacio De ahí la importancia de los fuegos

El poema toma, pues, la forma de un ritual trasformador, donde aire y fuego juegan un papel fundamental porque son percibidos de manera interna como parte integrante del ser humano. El «Prana» del tercer verso es el aire, el hálito, el pneuma occidental que da vida al ser. Ahora bien, el hinduismo, a diferencia de la concepción occidental

${ }^{371}$ Escohotado, Antonio (1991), El espíritu de la comedia, Barcelona, Anagrama, p. 59. 372 Sic. 
monoteísta de herencia platónica y judeo-cristiana, no concibe la oposición entre alma y cuerpo, espíritu y materia, instinto y razón o cielo y tierra. Por ello aire y tierra son por igual componentes del cuerpo humano, que, a su vez, es parte integrante del universo, de la realidad cósmica que todo lo incluye. Por ello, incluso los gusanos y los excrementos son elementos sagrados. Igual trato ofrece el hinduismo a las pulsiones y la sexualidad. El pranayama es la respiración pausada, abdominal, que se realiza en los ejercicios de yoga y en la meditación. Se trata de una disciplina de hálito que consiste en ralentizar al máximo, de modo consciente en un primer momento, la respiración para luego dejar que ello suceda de forma automática. Según Eliade (1962, 1987: 50-51), en el pranayama se armonizan los tres momentos respiratorios: inspiración (puruka), espiración (réchaka) retención (kúmbhaka). La respiración correcta, automática y natural, es el elemento base en cualquier tipo de meditación oriental y es una práctica que consiste en ser consciente de ser, de pertenecer al cosmos que, de esta forma, se experimenta en el cuerpo al respirar sin respirar. «Prana», en el poema, está visto como un ejercicio practicado en un rito efectuado en el hinduismo en el que se utilizaba una sustancia enteógena. Esta es el soma, según Huxley ${ }^{373}$, la droga más antigua de la que se tiene noticia y que se cita en el Rigveda. Huxley usó su nombre para designar a la sustancia psicodélica citada en la novela futurista Brave new world (1932), la droga de la felicidad. El rito, al que el poema se refiere, es el agnihotra, ceremonia relizada en torno al fuego y ofrecida a él. En ella la ebriedad jugaba un papel fundamental en la transformación personal del participante. Este es el sentido del siguiente fragmento que pertenece a la misma obra:

Alguien escucha voces lejanas Alguien se convierte en luminoso Alguien caminó sobre las aguas Alguien caminó entre llamas

Alguien fue levitado

Alguien ingirió veneno sin daño

Alguien no ha necesitado dormir

Alguien no ha necesitado comer

${ }^{373}$ Huxley, Aldous (1980), Moksa, ed. Michael Horowitz y Cyntia Palmer, Londres, Chattu \& Windus; traducción de Eduardo Goligotsky, Moksa, Escritos sobre psicodelia y experiencias visionarias 1931-1963, Barcelona, Edhasa, 2007, p. 55. 
El pranayama aparece en otros escenarios de la poesía de Ory que toman la imagen del yoga y la meditación como método de trasformación:

\author{
Cansado ya de todo \\ Agotado de amar \\ No tengo más que un modo \\ de existir respirar \\ $[\ldots]$ \\ Perseguí como ciego \\ tres cosas sin piedad \\ RESPIRACIÓN y luego \\ PLACER y OSCURIDAD
}

(«Tres cosas», Lee sin temor)

\begin{abstract}
Tú no sabes que el lenguaje es inhumano
Sólo el grito del ser habla con lengua viva

Un eco suyo es la salmodia hindú

No oigas más que las voces profundas

y la inocencia del deseo
\end{abstract}

En estos versos que pertenecen a un poema sin título de Lee sin temor, Ory se refiere a las cualidades místicas y sagradas del sonido que poseen los mantras. En ellos, como en las salmodias religiosas occidentales, el sonido se abandona a sí mismo y se despega del significado referencial, terapia que provoca tranquilidad y relajación y que consiste a su vez en una de las vías idóneas para la meditación. La sílaba sagrada $O M$ está compuesta de vibraciones luminosas que en el hinduismo tántrico quedan asociadas al diamante, a la irradiación (Varenne, 1977, 1985: 180-181) y a la luz brillante del conocimiento interno.

\title{
4.5.2. La sexualidad sagrada: el tantra
}

La imagen del amor como fuego, utilizada, como hemos visto anteriormente, en la poesía erótica oryana ya desde sus inicios, se asocia ahora a lo sagrado. Lee sin temor y Miserable ternura - Cabaña pueden leerse como la plasmación de una serie de experiencias cósmicas, donde eros es el punto de conexión del individuo y el cosmos. 
Unión entre sexualidad y mística, trascendencia de la sexualidad como apertura hacia el exterior, conexión entre la alcoba y los espacios estelares. El amor es un rito que abre la conciencia del participante hacia lo externo y conecta la realidad exterior con su interioridad más íntima. Rafael Ramírez Escoto ${ }^{374}$ señala el acercamiento de la poesía de Ory al tantrismo. Para este autor es la conciencia creativa individual del poeta la que se funde con la totalidad del cosmos en una danza dionisíaca. Unidad, en definitiva, entre interior y exterior. $\mathrm{Y}$ es justamente el amor uno de los puntos de contacto entre esta aparente doble realidad, cuya división es en definitiva inexistente.

El tantrismo es un sistema de pensamiento que surge del hinduismo y se desarrolla también en el interior del budismo como una de sus direcciones, el vajrayana o vehículo del diamante. El tantrismo hinduista, cuya literatura se remontaría hasta las Upanishads (Varenne, 1977, 1985: 15), ofrece las claves de esta filosofía que se convertió en una cultura masiva a partir del siglo IV de nuestra era en la geografía hindú y de aquí irradió hacia otras latitudes (Eliade, 1962, 1987: 109). En China el tantrismo se funde con la alquimia taoísta y se fundamenta en el mito del elixir de la inmortalidad, imagen que posee un trasfondo totalmente místico. Del hinduismo provienen las deidades tántricas, Siva y su $S a k t i^{375}$. La primera designa la existencia de los seres y apunta al ámbito masculino que toma el nombre del dios hindú, la otra es la energía cósmica femenina comparable a la imagen de la madre tierra, divinidad femenina oceánica. Tal y como advierte Raimon Panikkar (1997: 122-123), no debe confundirse tantra con tantrismo. El tantra es un sistema que tiene, en cierto sentido, relación con el yoga, el hinduismo y el tantrismo. Este último supone una tradición religiosa particular mientras que el tantra se refiere a una manera de entender la realidad más allá de cualquier aspecto doctrinal. De todas formas, en ambos casos se trata de una visión cósmica y religiosa de la realidad donde la materialidad se diviniza. La palabra tantra, cuya raíz es tan, significa extensión, desarrollo (Eliade, 1962, 1987: 108-109), por lo tanto sería interpretable el tantrismo como método que extiende o incrementa el conocimiento. Panikkar (1997: 122) relaciona su significado con tender, tensar, y lo

374 (2001), «La ascensión de Kundalini: el misticismo de Ory», en Pont y Fernández Palacios (2001: 319-322).

375 (Eliade, 1962, 1982: 87) La visión del tantrismo se basa en la unión de estos principios polares y de la trascendencia de los contrarios. Principio masculino y principio femenino que se dan en la práctica del amor, como queda perfectamente expresado en palabras de Eliade: «El bindu es Siva, el rajas es la Sakti; el semen es la Luna, el rajas es el Sol». 
interpreta como proyectar el conocimiento más allá de sus límites. Tanto en el tantrismo hinduista como en el tantrismo budista, el ser humano está indisolublemente conectado con el cosmos, de manera que se constituye como parte integrante del mismo. A su vez, el cuerpo humano reproduce el cosmos en sí y se concibe como un cosmos viviente.

Algunas concepciones tántricas rechazan el proceso de meditación, tanto ascética como especulativa, y subvierten sus métodos porque creen que el cuerpo en sí ya contiene a la divinidad y que en la pura espontaneidad se halla la liberación que otras personas quieren alcanzar mediante prácticas y teologías. En este sentido los llamados tántricos de la mano izquierda, de herencia hinduista, basan sus creencias en la experiencia del gozo existencial. La carne, el vino y el amor erótico, utilizado en sus rituales, son la clave para obtener la unidad intrínseca con la divinidad. Es la satisfacción del deseo aquello que funde al ser humano con lo divino (Eliade, 1962, 1982: 112). El éxtasis vital, sea sexual o de cualquier otro tipo, es éxtasis divino. El tantrismo budista, vajrayana o tantrismo del diamante, propone la sexualidad como un medio para alcanzar la liberación o budeidad. Según sus tesis, esta también puede alcanzarse mediante la práctica del placer.

El amor es en el trantrismo la vía de acceso a la divinidad. Esta concepción sagrada del erotismo queda impresa en la poesía oryana, su impronta es una erótica cósmica. El amor es una energía expansiva y unificadora, pues la concepción tántrica rehuye la asociación, tan cristiana, de erotismo y pecado. La mujer representa la energía cósmica que emana de la madre tierra, la Sakti, y que forma parte también del ser humano. El cuerpo de la mujer es escenario sagrado, imagen de las deidades hinduistas y budistas: Laksmi. Durga, Tara... Subvirtiendo siglos de tradición occidental, el cuerpo femenino está totalmente alejado de lo demoníaco. La mujer amada es la extensión de la tierra, la atmósfera etérea y, a la vez, los cuerpos celestes. Este cuerpo femenino es el receptáculo del éxtasis, de la celebración de la existencia donde la alcoba es el universo y los amantes seres que se funden en él:

Perfecta es la dulzura de esta noche natal

Caricias lentas en tu cara y soy silencio

Amo esta flora viva y subjetiva única

Y desnuda en la alcoba cargada de fosfenos

Dibujo glauco de mis ojos eres dos 
una te da unidad otra entra en mi órbita

Soy olfato además te averiguo oceánica

El bajío y las algas me anuncian tus axilas

Ya te miro completa criatura gigantesca

mientras caricias tardas en tu seda nos tejen

invisibles velámenes

(«Invisibles velámenes», Miserable ternura)

Existen en el poema los ecos de la erótica panteísta de Vicente Aleixandre:

Cuerpo feliz que fluye entre mis manos

rostro amado donde contemplo el mundo

(«Unidad en ella», La destrucción o el amor, 1933)

El poniente sin mancha quiere besarme desde tus mejillas inocentes Un cándido corpiño encierra la gloria dulce de un mediodía prisionero

(«El desnudo», Sombra del paraíso, 1944)

Amada cósmica, unidad perfecta entre divinidad y cuerpo femenino. El tú poético femenino es el cosmos divinizado, cuerpo ilimitado e infinito, eterno.

He conocido ya tus huesos de laúd y mis caricias hechas de música animal cubren de arena fina tu epidermis sin fin

Te estoy amando hasta nacer de nuevo

(«De nuevo nacer de nuevo, Miserable ternura»)

Se trata, pues, de una amor sagrado, místico, que lleva a los amantes a trascender su ego particular y a sentirse partícipes de la realidad. Seres divinos, ya que son integrantes de la realidad divina. Y esta, a su vez, toma la imagen de una danza gozosa donde todos los seres se aman a la vez, conectados a esa energía cósmica que es el amor.

$\mathrm{Y}$ sin reliquias ya radiantes indivisos

animales hondísimos de obediencia amorosa

afines de salud y de silencio afines 
el torrente de la dicha nos abisma

(«Soledumbre», Miserable ternura)

En esta concepción del amor, este queda equiparado a un método de meditación. Meditación que conlleva tensar el arco perceptivo del ser, experimentar la identidad interna entre ser y el océano de la realidad. Por ello, para el tantrismo la sexualidad es sagrada, pues queda perfectamente integrada en el espectro de lo natural como una de las funciones de la vida cotidiana. Se trata de una sexualidad holística, porque está totalmente conectada con la red de relaciones que forma la realidad. El amor ofrece, en la poesía oryana, consciencia de la unidad de los dos amantes y de su fusión en un todo indisoluble:
Amar y ser amado
Y cada uno es ambos
Esto es pureza Vida
Conciencia cristalina
Amantes en un mismo
abrazo diamantino
Los dos se están de molde
Con el deseo santo

(«Sahaja», Lee sin temor)

La experiencia amorosa es mística porque tiene la facultad de trascender el ego, por ello los amantes se funden en un único ser que se funde, al mismo tiempo, con el ser de la realidad divina. Divinidad cuya imagen es Brahman, el cuerpo de Buda...

Y juntos de la mano los dos igual vestidos de negra ropa y blancos los espíritus pasaremos por estos instantes de unidad con la soberanía lenta de las caricias

(«Hablando a solas contigo en la noche», Miserable ternura)

La práctica del amor es en el tantrismo el acto mágico que conecta el ser individual con el ser total, cósmico. La sexualidad es la energía cósmica que reside en el 
cuerpo humano, su imagen ha sido representada en la India por la serpiente llamada Kundalini, símbolo del despertar ${ }^{376}$, que podemos encontrar en la poesía de Ory:

Carlos te habló de los centros

Carlos te habló de levitación

Carlos te habló del Ahora

$$
\text { («Enseñanza 1», Lee sin temor) }
$$

Carlos te habló de Kundalini

Carlos te habló de rayos y magnetos

Carlos te hablo de Continuidad

Carlos te habló de Conciencia

Carlos te habló de crecimiento en AHORA

Carlos sabe beber AGUA

\section{(«Enseñanza 2», Lee sin temor)}

Kundalini es la imagen de la energía cósmica que se manifiesta en el cuerpo humano, surge de los genitales y va activando los centros de energía que Ory cita en el fragmento de «Enseñanza 1», hasta llegar al cerebro. En el mito tántrico (Varenne, 1977, 1985: 194-197), que ilustra el concepto asociativo entre cuerpo humano y mundo, la serpiente Kundalini se halla en el muladdhara, chakra que está situado en la zona del cuerpo humano donde se halla el ano. Este es el espacio perteneciente el microcosmos humano que se corresponde, según las mitologías hindú y budista, en el macrocosmos con guhá, nombre de una caverna situada en la base del monte Meru. Según Varenne (1977, 1985: 194), el monte Meru, que se trata un axis mundi ${ }^{377}$, es la imagen de un lingam $^{378}$. De modo que queda patente la total identidad entre cuerpo y mundo, espacios

${ }^{376}$ Nótese la diferencia de significado que adquiere la serpiente en la mitología hindú respecto a la simbología de la serpiente en la tradición bíblica.

377 Eliade, Mircea (1973), Fragments d'un journal, París, Gallimard; en El vuelo mágico, ed. de Victoria Cirlot y Amador Vega Madrid, Siruela, 1995, p. 164. «Es significativo el hecho de que Brancusi reencontrara en la Columna sin fin un motivo folklórico rumano, La Columna del Cielo (columna cerului) que prolonga un tema mitológico atestiguado ya en la prehistoria y que además estuvo muy extendido por todo el mundo. La Columna del Cielo sostiene la bóveda celeste; en otros términos, es un axis mundi, del que se conocen numerosas variantes: la columna Irminsul de los antiguos germanos, los pilares cósmicos de las poblaciones norasiáticas, la Montaña central, el Árbol cósmico, etc. El simbolismo del axis mundi es complejo: el eje sostiene el cielo y asegura a la vez la comunicación entre cielo y tierra. Cerca del axis mundi cuya situación se concibe en el Centro del Mundo, el hombre puede comunicarse con las potencias celestes».

${ }^{378}$ El lingam es, en el lenguaje tántrico, el símbolo del órgano sexual masculino y el yoni el símbolo del órgano femenimo. Ambos términos significan también la masculinidad y la feminidad, energías polares que tienen su paralelo en el taoísmo en el yin y el yang. 
donde irradia la energía de Kundalini. La energía cósmica, simbolizada por esta serpiente, surge del muladhara y asciende por el interior de la columna vertebral y va activando los demás chakras: el sadishtana que se sitúa en los genitales, el manipura que reside en el ombligo, el anahata que se halla en el corazón, el vishudha que está en la garganta, el ajna que se ubica en la frente y el sahasrara, el último de todos, que se sitúa en la cabeza y representa, bajo la imagen de un loto color diamante con mil pétalos, el absoluto, la totalidad más allá de cualquier indiferenciación (Varenne, 1977, 1985: 196). Podríamos definir los chakras como centros que regulan las funciones psicosomáticas y emocionales del cuerpo humano.

Para el pensamiento tántrico, la culminación del amor, el coito, despierta la energía latente en el cuerpo humano y, de este modo, Kundalini inicia su ascenso. El éxtasis erótico se convierte en éxtasis místico y el amor erótico en amor sagrado. Esta idea sagrada del amor tiene su paralelismo en el amor cortés provenzal nacido del gnosticismo cátaro. Para Martí de Riquer ${ }^{379}$, el amor expresado en la poesía trovadoresca es un amor erótico espontáneo y alejado de la normativa convencional, el matrimonio. No se trata pues de un juego vacío o de un mero divertimento, sino de un amor erótico divinizado, cuyo signo es la armonía. Watts (1958: 182-183) señala la presencia de elementos tántricos en el catarismo, entre ellos la idea del amor como deseo sagrado, la del erotismo como elemento transmutador del ser humano y la del amor como elemento de la vida contemplativa. También existe un paralelismo entre cortesía amorosa y galantería sexual que manifiesta el contacto entre la karezza $a^{380}$ y el amor cortés. La dilatación del deseo, practicada por los adeptos del amor cortés, conducía a la identificación del éxtasis erótico y del éxtasis místico.

En la poesía de Carlos Edmundo de Ory se observa cómo el amor se convierte en un ritual. Práctica que nos recuerda a los ritos amorosos tántricos en los que los amantes se manifestaban como encarnaciones de la divinidad y la energía sexual suponía una toma de conciencia de la percepción de la energía cósmica. Kundalini, en este sentido, es la energía cósmica que se halla presente en el interior del cuerpo

${ }^{379}$ Riquer, Martí de y Comas, Antoni (1964), Història de la iteratura catalana, Vol. I, Barcelona, Ariel, $3^{\text {a }}$ ed. corregida, 1982, pp. 34-35.

${ }^{380}$ La Karezza, práctica del amor tántrico que excluye la eyaculación de la relación sexual, puede entenderse como la práctica del erotismo sin finalidad. Al desligar sexo y orgasmo, la percepción amorosa queda abierta hacia la realidad, de modo que se trata de una relación más consciente. 
humano, porque cuerpo y cosmos están conectados. Este rito de amor aparece en el poema de Miserable ternura titulado «Amic e amasía». En él se dan varias referencias que apuntan al amor cortés y al sufismo ${ }^{381}$ :

Sin brújula y sin mapas errando en descampado persiguiendo la fresa silvestre ávidamente jamás pudo pensar que el país del amor condujera a la ruta secreta de aquel rostro

Los versos que dirán del amigo y la amiga tan sólo estas palabras de un encuentro al azar de intrincados senderos dando rostro con rostro hasta que se abismaron a la par en sus noches

Y el amigo con dedos somníferos la palpa nocturnamente táctil amoroso y descubre que ya no sueña más y que es dueño de todo lo que estaba en la nada engañando los sueños

En un cuarto los dos se miran irreales mientras sanguíneas sombras crepitan en la hoguera Son sus cuerpos a un tiempo sacrificando besos en un extraño altar de ritos extremados

Aparecen en el poema varias de las ideas tántricas: el amor como método de liberación del engaño ilusorio ofrecido por Maya, la presencia del fuego como símbolo del amor y la práctica del amor como rito sagrado. El amor es un rito de fuego donde arden los amantes fundiéndose los dos en una misma unidad, rito que transmuta a los amantes acercándoles a la divinidad. El fuego de la pasión queda convertido en la «luz» del conocimiento, tal como se expresa en el fragmento del poema «Sábanas» ${ }^{382}$, perteneciente al mismo poemario:

${ }^{381}$ La influencia del pensamiento sufí se encuentra en la obra de Anselm Turmeda, en el Llibre d'amich e amat de Ramon Llull, en El Collar de la paloma del poeta andalusí Ibn Hazm y en la poesía trobadoresca. En el sufismo el amor se concibe como una energía emocional que irradia del cuerpo del ser enamorado hacia el exterior y carga de significación e intensidad cada pliegue de la cotidianeidad hasta los hechos más anodinos e insignificantes. El sufismo rechaza, en cierta medida, los preceptos del islam al considerar que el sujeto posee una unión íntima con la divinidad. Los sufís rehusaban peregrinar a La Meca porque, según sus concepciones, la Kaaba daba vueltas sobre ellos en todo momento.

Ver Racionero, Luis (1977), Las filosofías del underground, obra cit., pp. 105-115; Alberto Cardín (1997), Contra el catolicismo, Barcelona, Muchnik Editores, pp. 242-245; Eliade y Couliano (1991, 1994), obra cit. en la bibliografía, pp. 197-203.

${ }^{382}$ Este poema está formado por cinco fragmentos, escritos durante el 6 y el 7 de marzo de 1972, que funcionan como poemas por sí mismos (Miserable ternura, pp. 47- 51). 
Yo siempre hundí mis manos en el fango

de tórridas pasiones y saqué

cabellos muchas veces de melenas de miel

pestañas y vedija ensortijada

Oh yo fui poderoso por tenaz

y el único testigo de mis ansias

Apuntala mi rostro con tus besos

Gritando sombra me musico luz

El amor es una celebración de la realidad divina, la experiencia amorosa lleva a los amantes percibir que ambos forman parte del cosmos divinizado. En cierto sentido, se trara de un amor dionisíaco que se transforma en experiencia extática:

¿Qué se hizo del rito nupcial de miel y lodo? ¡evohé! ¡evohé! las ninfas de los bosques y las bacantes ríen y lloran exiliadas Evoco la espantosa sapiencia de Sileno el padre de los sátiros y el coro dionisíaco y a la voluptuosa Milytta la gran madreselva entre falsas mujeres y mancebos pintados Pongo el grito en el cielo por el divino Eros malherido en los grandes mercados del deseo las fábricas de eunucos las clínicas de orgasmos donde parecen tantos parias del dulce lecho ¡Más oscura que nunca es la palabra Amor! Ya no se canta y baila con locura davídica ejemplar de la lírica fálica de otros tiempos y el errabundo erótico es un triste Tristán

(«Divino Eros», Miserable ternura)

En un lenguaje totalmente nietzscheano, Ory propone una erótica de la embriaguez, que se convierte en un ritual sagrado en cuanto que la práctica amorosa supone la experiencia divina de sentirse arrastrado por el éxtasis de la realidad. La experiencia amorosa es un culto al antiguo dios Eros. Análogo sentido poseen las esculturas tántricas que ornamentan la arquitectura tradicional de la India, en cuyas construcciones aparece una multitud de cuerpos enroscándose unos sobre otros y realizando el acto sexual en diversas posturas yóguicas como si se tratase de un Kamasutra colectivo. Esta erótica grupal, cósmica, se observa en la iconografía de varios templos budistas e hinduistas. Entre ellos cabe destacar los templos erigidos en Khajuraho (el Paraswanath 
levantado en el siglo XI, el Khandariya Mahadeva construido en el siglo XI y el Vishvanath en el XIII) y en Konarak (el templo Surya que data del siglo XIII).

La poesía erótica de Ory es una poesía escrita desde el cuerpo y manifiesta una corporeidad que se aleja del universo de las abstracciones, pues los sujetos poéticos participantes en el ritual amoroso, ritual sagrado por excelencia, se funden abrazados un un cuerpo único que recibe la energía que el cosmos irradia. En el sacramento del amor, que equivale a una experiencia numinosa, desaparecen nombres y entidades conceptuales quedando sólo los cuerpos en un abrazo místico:

Entramos en la cama como en una iglesia entra un par de monjas por costumbre

$[\ldots]$

Obispo de amor mi tiara

es un falo de palisandro

No podíamos salir de estar pegados

como un silencio a otro silencio

(«Ambos», Cabaña).

En el altar del amor los conceptos pierden relevancia, pues en el amor vida y muerte son inseparables, como también lo son placer y sufrimiento. En este sentido, la vida es un orgasmo permanente, cuyo signo es el fuego de la constante combustión. Fuego que se transmuta en luz:

Tu cabeza y la mía se amansan en el amor y pesan como espuma quietas están unidas en la luz son flor y piedras musicales

Como un sol es perfecto en su alto trono así fulgen estas dos efigies tocando tierra con sus rayos de oro manos y dedos improvisan gamas

(«Imágenes mágicas», Miserable ternura). 
4.5.3. El budismo y la imagen de la vacuidad

La relación de Carlos Edmundo de Ory con el budismo viene de muy lejos. La preocupación por el dolor existencial, que define uno de los postulados del Introrrealismo, coincide plenamente con la visión budista. En su Diario encontramos numerosas reflexiones que se solapan con determinados aspectos del pensamiento budista. El día 28 de noviembre de 1949 Ory escribe (2004, Vol. I: 70-71):

¡Qué consuelo más ímprobo, cada noche las páginas de mi Diario! Pero todo dolor nos hace cobardes, y si toda nuestra vida es dolor no dejaremos nunca de sentir miedo. ¿Qué el dolor sino el miedo metafísico? Miedo de más dolor. De nuevo dolor y también seguridad de súbita dicha, repentina felicidad que ha de venir a suplatar nuestro eterno disgusto humano.

Contemplar la tristeza como si fuera un espectáculo.

En las páginas correspondientes al 29 de noviembre de 1950 aparece una referencia a Carlyle que supone un acercamiento al concepto budista de la vacuidad (2004, Vol. I: 103-104):

Carlyle decía en el Misterio, y todo para él, desde él mismo y el mundo mismo, era Misterio.

«Salimos del Vacío; pasamos como un huracán ante la faz de la Tierra, asombrada, para sumergirnos de nuevo en el Vacío... Pero ¿de dónde, ¡oh profundos Cielos!, y hacia dónde? La Razón nada sabe, la Fe nada sabe, sino que vamos del Misterio al Misterio».

Este mismo año, un domingo de diciembre, sin fechar, Ory escribe el siguiente fragmento (2004, Vol. I: 105):

...Sé muy bien que no estoy dentro del catolicismo. Estoy dentro de la religiosidad infinita del dolor que no pregunta ni pide consolación. Ni pide cielo ni pide infierno. No pide nada. Pide estar sola, como toda religiosidad pide estar sola.

Y el 18 de enero de 1951 las siguientes palabras (2004, Vol. I: 113):

No busques la Verdad. Besa el pecho del mar y mira el sol. El sol te da la vida, es decir, el ímpetu de la vida. Y, de noche, la luna te llama para fortalecerte con su fósforo. 
No busques la Verdad. Besa una piedra, aunque esta piedra tenga extremos cortantes. Y, si te clavas uno de sus picos, chupa la sangre de tu labio $[\ldots]$

No me deis el pan de la Verdad, si me quitáis el hambre de la vida. No quiero vuestras migajas de reflexión, ni el frío pan abstracto de vuestros ideales. ¡Quiero la vida!

Estos fragmentos muestran claramente la distancia que Ory mantiene respecto a las coordenadas por donde trascurría la poesía española de la época, anclada entre un catolicismo oficial y un ateísmo combativo. El pensamiento oryano converge con la visión que el budismo ofrece sobre la realidad. El budismo supone el rechazo de la ascética de la mortificación y de la especulación abstracta, por ello acepta la vía del medio como forma de alcanzar la liberación: la meditación, la consciencia, la experiencia. El budismo rechaza el concepto platónico de idea y su traducción cristiana, el alma, y propone el no apego al mundo y la idea de que nada permenece, o finitud de los seres y de las cosas individuales. La supresión del dolor se conseguirá mediante la supresión del deseo, íntimamente ligado al ego. Frente al sistema racionalista, el budismo propugna una concepción orgánica de la realidad en la que todo es proceso, por ello no existe el ser permanente, el sujeto, sino el fenómeno solamente ${ }^{383}$. Este último fragmento del Diario de Ory, que hemos expuesto, nos recuerda la parábola del Buda histórico que trata del hombre herido por una flecha. En ella se rechaza la especulación abstracta en favor de la acción directa, señalando de paso el absurdo de los edificios creados por la mente. En ella lo primero que realizó el hombre herido fue dejarse arrancar la flecha y no preguntar por el nombre de quien lo hirió, el nombre de sus padres, su casta y su país. Frente a la abstracción, el budismo preconiza la experiencia directa ${ }^{384}$. Para Alan Watts, el último tramo de Ótuple Sendero, llamado Samyak-samadhi, es la conciencia sin dualismos (1945a: 75):

Esta conciencia consiste en una viva atención hacia la propia experiencia directa, al mundo tal y como se lo percibe inmediatamente, a fin de no ser descarriado por nombres y rótulos. La última sección del sendero es la perfección de la conciencia pura, por lo cual ya no hay dualismo de cognoscente y conocido.

383 Ver Coomaraswamy, Ananda (1916), Buddha and the gospel of buddhism; traducción de Enrique A. Franchi, Buddha y el evangelio del budismo, Barcelona, Paidós, 1989, pp. 67-80; Borges, Jorge Luis y Jurado, Alicia (1976), Qué es el budismo, Madrid, Alianza Editorial, 2000, pp. 65-69; Rahula, Walpola (1959), What the Buddha Taught; traducción de Gilberto Lachassagne, Lo que el Buda enseñó, Buenos Aires, Kier, 1965, pp. 32-44.

${ }^{384}$ Borges y Jurado (1976), obra cit., p. 48; Rahula (1959), obra cit., p. 30. 
La vacuidad budista, sunyata, supone que la realidad no se aferra a ningún asidero, principio o normativa (Watts, 1958a, 1971 : 86-87). Nagarjuna propuso en el siglo I d.C. una óptica radical al rechazar la esencia de todas las cosas. La vacuidad supone el vacío desde donde surgen todas las miríadas de las presencias, los fenómenos. Frente al vacío, nada hay a lo que aferrarse. Una referencia a la vacuidad budista la encontramos en el siguiente fragmento del poema «Manos humildes» de Miserable ternura:

\section{Esto soy una llama material llama que ama como el aire ama el vacío vacío de sombras y tan sólo lleno de oscuridad lleno de luz}

La óptica radical de Nagarjuna ejerce una demolición de las creencias y de los pensamientos, pues si los fenómenos no tienen naturaleza propia, menos aún la tienen los conceptos. «Oscuridad» $\mathrm{y}$ «luz», «aire» $\mathrm{y}$ «vacío» no pueden separarse porque en el gran vacío, que constituye el universo, no hay limitaciones que disgreguen.

Podemos distinguir varias direcciones de la concepción budista: el budismo hinayana, el budismo mahayana, el budismo tántrico, el budismo tibetano, el budismo chino o taoísta y el budismo zen. El interés de Ory se centra, sobre todo, en el budismo mahayana y en el budismo zen. Este último lo trataremos en otro apartado. El budismo hinayana pone el acento en el nirvana. Alcanzar el nirvana, mediante un proceso de samhadi o meditación, equivale a despertar, a reconocer que el ser humano posee la naturaleza de Buda, llamada budeidad. El nirvana es alcanzado por el ser cuando este destruye la idea del ego personal. No se trata, según Walpola Rahula ${ }^{385}$, de destruir el yo, sino de la aniquilación de la falsa idea del yo. Por ello el nirvana queda asociado con la libertad absoluta, porque consiste en liberarse de la tiranía de los conceptos: dualidad, tiempo, espacio. El nirvana supone la imagen del infinito en el tiempo y en el espacio. Se trata, en el fondo, de la extinción de la ilusión, proclamada por Buda a sus discípulos. De una forma bastante lúdica y jovial, Carlos Edmundo de Ory reflexiona sobre el abandono del ego y sobre la iluminación en el siguiente poema, perteneciente a Lee sin temor, que no posee título: 54.

${ }^{385}$ Rahula, Walpola (1965), Wat the Buddha taught, obra cit., ed. en castellano, 2002, p. 
Yo yo yo

Para mí

Lo mío

Sí sí yo quiero

No no yo no quiero

He aquí la semilla de la cual

saldrá el Buda

Desde los parámetros del budismo, es el deseo quien ofrece al hombre la falsa idea de su yo, y es la imagen del yo la causa del sufrimiento existencial humano. Sufrimiento que es causado por la ignorancia, pues únicamente mediante el samadhi, proceso de meditación, el ser humano puede alcanzar la iluminación, la verdadera naturaleza de Buda. El budismo mahayana, llamado también el gran vehículo, intercambia la perspectiva al negar la oposición entre nirvana y samsara, pues la budeidad o naturaleza de Buda, que potencialmente posee cada ser humano, únicamente puede alcanzarse aquí en el samsara. De hecho, la misma realidad, percibida aquí y ahora, es el propio nirvana. En definitiva, el ser humano vive ya inmerso en esa realidad divina. Por lo que el intento de alcanzar el nirvana supone un total disparate, tratar de encontrar algo que nunca se ha perdido supone un absurdo total. El budismo mahayana propone el abandono de la idea de búsqueda, ya que paulatinamente todos los seres forman, conforman, el cuerpo de Buda:

Y sufrimos

Damos vueltas y más vueltas en nuestro lecho de miseria Y debajo de este lecho está el cielo y no lo sabemos

(«Y sufrimos», Lee sin temor)

En lenguaje oryano, podría decirse que el hombre es un ser divino pero no se da cuenta de ello. Ignora su verdadera realidad. Este desconocimiento se traduce en sufrimiento, pues el ser humano ignora que habita en el nirvana. Sólo la conciencia de ello, de saberse instalado ya en el nirvana, trasforma el dolor en dicha. Ello queda expresado mediante el lenguaje paradójico y típico del misticismo cristiano y sufí:

Mira hacer revivir las cosas Todo

mira no has aprendido a revivir 
Tanto tanto tanto cosas tú y tú y tú Mucho no es nada No cojas nada

Ten lo que viene y va Ten el aire

El asombro no se asombra del asombro

Después del éxtasis hay un después

Ningún después es antes o después

Que el asombro suceda al éxtasis

Lo maravilloso no parece maravilloso

La piedra que encuentro no es piedra que busco

Busca hasta no encontrar Encuentra

lo nunca buscado y eso es nuevo

Nuevo es el Ser Es sonrisa

Oro y agua de cristal

Sala sin puertas en el desierto

$\mathrm{Y}$ el desierto tiene puertas

Todo tiene puertas sin puertas

Mira ya has pasado No estás

(«Escrito increíble», Lee sin temor).

La realidad es, pues, éxtasis permanente. Este sentimiento extático solamente puede ser expresado mediante un lenguaje de signo paradójico, como queda claramente expresado en el poema oryano. Esta es la filosofía de Nagarjuna, basada en la identidad de nirvana y samsara: cuando cesa el empeño humano por alcanzar la iluminación, sobreviene el éxtasis del nirvana. Idea cuya traducción al lenguaje cristiano sería encontrar el paraíso en la tierra. Puesto que ya estamos en él, debemos abandonar la idea de búsqueda, ya que esta liga el ser al ego humano. El siguiente poema que no lleva título, perteneciente también a Lee sin temor, asocia el ego, producto de la ignorancia, a la enfermedad:

Cuando el tercer ojo está enfermo no puedo hacer el ver directo en la natura de Buda y debe haber en mis dos ojos ordinarios una cierta manera de mirar que me valdrá la visión de mi propia natura

En este sentido, recordemos que el pensamiento es para Erich Fromm (1955, 2012: 18 25) la enfermedad básica del ser humano, aquello que lo distingue de los demás seres. Únicamente el hombre es un ser que piensa en su vida y que sabe que va a morir. Esta enfermedad que se llama cultura. Y, ¿cuál es la «propia natura» que aparece en el último verso del poema de Ory? Como contestación citamos otras palabras de Ory: 
«Flotamos en la charca del espacio», verso del poema «Correspondencia», que pertenece a Cabaña. Desde la óptica negativa de Nagarjuna, la naturaleza de los seres es el vacío. Para la escuela Yogacara del budismo mahayana, seguidora de la óptica negativa, el mismo universo es una construcción mental y por ello no cabe asignarle entidad de realidad, ni siquiera ilusoria. En este sentido la definición de la «propia natura» resulta más complicada. En el Diario (2004, Vol. II: 372) Ory nos deja el 26 de octubre de 1972 una aproximación a esta definición:

Es no ser nada, la experiencia de no ser simplemente nada. Cuando el hombre no es nada, está con TODO.

Omnipresencia, flores y pájaros y eso soy yo.

\subsubsection{El taoísmo y el budismo zen}

En su expansión hacia Oriente, el budismo mahayana llegó a China de la mano de Bodhidharma en el siglo VI, allí confluyó con el taoísmo y se transformó en lo que se conoce como budismo zen. Bodhidharma es el primer patriarca del budismo Ch'an, tal como se denominó en China, y del budismo zen en Japón. Podría decirse que la visión del Tao queda expresada en el Tao te king, escrito por Lao-Tsé, personaje contemporáneo de Confucio, que vivió entre el 570 y el 479 a. C. Ahora bien, los orígenes del taoísmo se remontan al I Ching o Libro de las mutaciones, obra de adivinación que puede situarse entre los años 3000 y 1200 a. C. y que se encuentra en la base del pensamiento chino. El Tao puede considerarse como el ritmo natural, armónico y desinteresado de la existencia. Este se opone a la creación, es el fluir espontáneo, sin esfuerzo, de todo cuanto existe en la realidad. El taoísmo se opone también a la acción personal y forzada del ego, verdadero punto de contacto con el budismo mahayana, génesis del zen. El taoísmo y el zen rechazan plenamente el sistema conceptual humano, pues consideran que el pensamiento humano es incapaz de captar una realidad pluridireccional y poliédrica. Este es el punto de partida del Tao te king: «El Tao que se puede enunciar no es el verdadero Tao ${ }^{386}$. El zen, por su parte, propone la experiencia directa, sin concepto, como forma de conocimiento.

${ }^{386}$ Lao-Tsé, Tao-Te-King; prólogo de Luis Racionero, traducción de Gloria Peradejordi, Barcelona, Ediciones Obelisco, 1986. «El principio que puede ser enunciado no es aquel que fue siempre», p. 12. 


\subsubsection{El silencio}

En la poesía oryana, la presencia de este pensamiento posee varias direcciones. Una de ellas es la búsqueda del silencio poético, la adopción de un lenguaje donde las palabras se alejan del ruido producido por la mente o desembocan en un fractura lingüística que conduce al paroxismo del absurdo conceptual, como ocurre sobre todo en los aerolitos, que más adelante comentaremos. En este sentido, la poseía de Ory consiste en un abismarse en el silencio (Mesado, 2013c: 84-87) como si se tratara de una meditación zen. Ory rechaza el valor referencial de la palabra y explora el susurro creado por los enlaces no conscientes que enganchan los segmentos de un lenguaje emocional. Ya hemos analizado el funcionamiento del haiku en la primera poesía oryana. Ory sigue utilizando esta especie de micropoesía y ahora le otorga un valor más metafísico, pues conecta totalmente con el verdadero significado del haiku, que no es otro que ser una expresión de satori (Mesado, 2013c: 87-88), de un instante de budeidad. Por ello transmite el sentimiento de gratitud ante la presencia de la materialidad más cercana.

Estás aquí al lado mío Y arrojas pétalos de rosas en las aguas sagradas de mi cara

$$
\text { («A una mujer», Técnica y llanto) }
$$

Al lado estaré siempre de los árboles contigo quieto estanque de mi amor

(«Quieto estanque», Miserable ternura)

Los pies llenos de lágrimas la cabellera enorme del silencio sobre la almohada

(«Urna diurna», Tambor de sicomoro)

La otra dirección que conduce hacia el silencio y que atraviesa todo el discurso de Carlos Edmundo de Ory es la fractura lingüística: el koan. Este hace estallar el lenguaje proyectando la conciencia más allá del lenguaje. En este sentido, la poesía 
oryana (Mesado, 2013c: 95) está más próxima al koan que al haiku, pues la paradoja articula ya el discurso oryano desde su impronta postista. La poesía postista significó la adquisición de una semántica ilógica, lúdica, extraña y absurda, que en su momento condujo a la subversión de los postulados del realismo poético. Esta dirección, marcada profundamente por el koan, desemboca en los aerolitos, que en definitiva son verdaderos ejercicios de arte conceptual. Mostramos algunas marcas que este discurso paradójico ha dejado en la poesía oryana:

Pero el secreto me venda la cabeza para que no vean que ilumino

Húyeme de mi me elevo desde lo alto hacia lo bajo Y ellos no comprenden Vena continua de oro riquísimo Y sangre y saliva

(«Misterio y tormento», Lee sin temor)

Corre despacio hacia No hay caminos

ningún camino Etapas Ilusiones

Fantasmas

(«Veo Leo», Lee sin temor)

Palabra rara

de la boca muda

Redes de palabras

en continuo repique

(«Mundo ardiente», Lee sin temor)

Y debajo de este lecho

está el cielo y no lo sabemos

(«Y sufrimos», Lee sin temor)

Humanos son los pájaros también

(«Poemas interminables», Lee sin temor). 
¿No ves en mi corazón un higo?

¿No ves en mi cara un panal?

(«Racimo», Miserable ternura)

Ory nos señala la paradoja desde la que se edifica este lenguaje de silencio: «Palabra rara / de la boca muda» que se opone al lenguaje representacional, símbolo por excelencia de la actividad mental, que toma aquí la forma de la red, «Redes de palabras / en continuo repique». La red, cuya estructura es lingüística, atrapa a nuestro pensamiento en las celdillas de las palabras. Ory busca un lenguaje de silencio, que señale directamente a los objetos y no a los conceptos, por eso se dirige a los agujeros de la red. Es decir, al silencio. Pues el silencio supone la captación de la realidad sin lenguaje, que es la verdadera actividad del zen:

\section{CERO ÚNICO}

NO hay lenguaje idóneo para nada Sólo el silencio como cero único participa del todo y todo impregna $\mathrm{O}$ ver un rostro humano tal cual es

Frente a lo elemental qué inútil es la frase sistemática y no cuenta la moneda que corre en el mercado de las palabras feria de sonidos

Entonces ser silente es retornar a los desiertos o a los grandes valles Profundidad de no poder hablar Esto es renuncia al lenguaje espurio

\section{(Tambor de sicomoro)}

Hay un largo discurso en el silencio No dice nada y dice cosas que hacen pensar al aire Ningún silencio llora ni no ríe

$$
\text { («...», Cabaña) }
$$

Y no comienzo nada que rasguño el silencio nutrimental simiente de la guzla y la quema 
Un agujero en el silencio es mi utopía

(«Silencio música tenaz», Cabaña)

Instantánea es la Naturaleza
El Universo majestuoso
No oye tus palabras
No conoce el Bien y el Mal
Época $^{387}$ falta de silencio

(«Mundo ardiente», Lee sin temor)

La inspiración directa viene del silencio

Aquí no acaba este poema

(«Alteraciones de las corrientes», Lee sin temor)

\subsubsection{La experiencia directa}

El budismo zen rechaza la especulación mental y propone un pensamiento más allá del pensamiento, una experiencia de la realidad sin palabras. Taisen Deshimaru nos lo plantea así (1974, 2002 : 22-23):

El secreto del Zen consiste en sentarse, simplemente, sin finalidad alguna ni espíritu de provecho, en una posición de gran concentración.

Esta forma desinteresada de sentarse se llama za-zen; za significa sentarse y zen meditación. La enseñanza de la posición, que es transmisión de la esencia Zen, tiene lugar en el $\operatorname{dojo}^{388}[\ldots]$ El Zen no puede enmarcarse en un concepto, ha de ser practicado; es, esencialmente, una experiencia. No se subestima la inteligencia, sólo de busca una dimensión más allá de la conciencia no ceñida a una visión unilatertal de los seres y de las cosas. El sujeto está en el objeto y el sujeto contiene al objeto. Se trata de sobrepasar, con la práctica, todas las contradicciones, todas las formas de pensamiento [...]

La idea clave es Aquí y Ahora; lo que importa es el presente. La mayoría de las personas tienden a pensar, angustiadamente, en el pasado o en el futuro, en vez de estar completamente atentas a los actos, palabras o pensamientos que se suceden en el momento. Estar presente en cada gesto, concentrarse Aquí y Ahora, ésta es la lección del Zen. A ella podemos añadir la fórmula sentarse (shikantaza) simplemente, gratuitamente, sin fin determinado ni espíritu de provecho (mushotoku).

\footnotetext{
387 Sic.

${ }^{388}$ Espacio en el que se prectica la meditación zen.
} 
La práctica del zen cabe inscribirse en lo que se llama una vía de transformación, que en el imaginario y en el lenguaje del budismo consiste en llegar a alcanzar la naturaleza de Buda. Concepto que, para Deshimaru (1974, 2002: 23), equivale a un regreso al origen, a la vacuidad:

Naturaleza de Buda significa la condición más normal que pueda darse: la natural, origen de nuestro espíritu [...]

Si abrimos las manos podemos poseerlo todo. Si estamos vacíos podemos contener el Universo entero. Vacuidad es la condición del espíritu que a nada se anuda.

El budismo zen, sobre todo en la rama Soto zen o escuela Soto (aunque también ocurre algo análogo en el zen Rinzai), pretende barrer la especulación intelectual y, como consecuencia, toda concepción metafísica. Por ello, la filosofía del zen, si es que existe, va totalmente ligada al zazen, a la práctica de la meditación. El zazen consiste en sentarse en la postura del loto, sin motivo ni finalidad, en armonizar la respiración y, por decirlo de algún modo, abismarse en el silencio suprimiendo el pensamiento. El zazen consiste en ser testigo de aquello que sucede, en concentrarse en lo que está ocurriendo aquí y ahora sin quedar atrapado en el curso de los pensamientos. Según Taisen Deshimaru (Deshimaru y Ikemi, 1985, 1990: 126), Maestro Soto zen, en el zazen se alcanza de manera natural, inconsciente, automática e instantánea, el satori o naturaleza de Buda; pues este es el estado propio del ser humano. De modo simbólico se explica Deshimaru (Deshimaru y Ikemi, 1985, 1990: 127):

Nuestra vida es, sin cesar, contradictoria. Oscilamos entre el satori y la ilusión, el espíritu de Buda y el espíritu del demonio, el bien y el mal. Pero no debemos cometer el error de categorizar en exceso y aislar el satori de las ilusiones, puesto que nuestros errores se convierten en la sustancia de nuestras virtudes. La vida no es posible sin la energía de los deseos y de las ilusiones. De esta manera hemos de entrar en el satori sin cortar voluntariamente los deseos, purificar la raíz de la ilusión y no cortarla. Querer abandonar el espíritu demoníaco para no conservar más que la santidad es una empresa arriesgada. Pero practicar el zazen es estar más allá de la ilusión y de la santidad, captar que el demonio y el Buda tienen la misma cara, hacer real el verdadero satori inconscientemente, natural y automáticamente.

En el zazen el individuo se siente, de manera inconsciente, partícipe de la energía cósmica y experimenta que esta se halla en su interior. Para Masao $\mathrm{Abe}^{389}$,

${ }^{389}$ Abe, Masao (1987), La naturaleza de Buda según Dogen, introducción a Dogen, en La naturaleza de Buda; traducción de Félix E. Prieto,Shobogenzo, Barcelona, Ediciones 
profesor de filosofía budista en la japonesa Universidad de Nara e intérprete de las enseñanzas que el maestro Dogen (1200-1253) transmitió en el Shobogenzo, la naturaleza de Buda no es potencialidad, no es algo que deba ser alcanzado, sino que es inherente a la cotidianeidad del ser humano. Desde el punto de vista de Dogen, no puede existir una naturaleza de buda separada del aquí y del ahora.

Esta óptica paradójica, totalmente antiascética, queda recogida en innumerables espacios de la poesía oryana. En «La infelicidad del poeta», poema que pertenece a Lee sin temor, se rechaza tanto la actividad intelectual especulativa como la terapia ascética. Y frente a ello se propone la elementalidad, la inmediatez y la experiencia directa que el zen supone:

\section{Respirar ver oír dormir} ¡Qué simple es todo eso!

Fragmento que nos recuerda la poética extasiada contenida en Cántico (1928) de Jorge Guillén:

Ser, nada más. Y basta.

Es la absoluta dicha.

(«Más allá»)

Soy, más, estoy. Respiro.

Lo profundo es el aire.

(«Más allá»)

Ningún primor: ni voz ni flor. ¿Destino?

¡Oh absoluto presente!

(«Desnudo»)

Al igual que Guillén, Ory propone una experiencia directa de la realidad y en ella encuentra el éxtasis en el instante presente:

Obelisco, 1989, pp. 30-31. 
¡Qué paz qué paz!

-fuente informal del ser

No hago nada

atención sin defecto

La cabeza en las llamas

(Lee sin temor)

El satori en la filosofía zen se ha definido siempre como el repentino despertar, como un rayo, instantáneo y automático. Es la súbita comprensión que se produce en el aquí y en el ahora. Nos dice Suzuki $(1959,2002: 149)$ que el satori consiste en hacer consciente lo inconsciente, por ello se experimenta el misterio que está más allá de las palabras. Para Suzuki, cuando el satori es expresado de forma artística, crea obras que vibran. Este ha quedado traducido en los haikus, en los jardines japoneses, en los trazos minimalistas de la pintura paisajística taoísta, en las líneas abstractas de la caligrafía... En la poesía de Ory todo ello hace que esta, a grandes rasgos, se configure como búsqueda y expresión del misterio infinito e inmediato de la existencia. De una manera más delimitada, la poesía oryana ofrece diversas instantáneas de satory. Así ocurre en el siguiente fragmento del poema titulado «Otra cosa», de Lee sin temor:

Me vino a la conciencia como una luz de cerca

No tengo nada en lo que arrodillarme

Ya nada compraré ni venderé nada

He descubierto que existir es existir

Conozco la vida directamente

No hay iniciación sin iluminación

En un cielo desnudo soy estrella

Mi soledad es profunda y en su centro

comunico con lo íntimo irradiando

En él el satori toma la forma de luz, una luz que ilumina al despejar la nube de conceptos que empañan la mirada directa sobre la realidad. En el poema «Metalenguaje», que forma parte del mismo poemario, Ory utiliza la imagen del relámpago:

Mira este verso si lo puedes oír Escúchalo en tus dedos si son labios

Pero no beses la poesía que arrasa como un religioso relámpago 
El poema, como la propia poesía, es fruto del satori, es experiencia de iluminación, cuyo signo es la dispersión de los conceptos que enturbian la mirada. De modo análogo, aparece el relámpago en el poema «Trono de la claridad» que también forma parte de Lee sin temor:

\author{
Veo la mano que pregunta por la flor \\ Ella misma la que había \\ la que había puesto en mí \\ plateado misterioso \\ Mano del conocimiento \\ y la experimentación \\ en relámpagos \\ Criatura sonriente niñecida \\ Sabélo
}

En el poema «Racimo», que pertenece a Miserable ternura, el satori toma la imagen de la luz, una luz que irradia una inmensa gratitud ante el hecho de estar vivo. En él se expresa la experiencia de ser parte integrante («gota») del engrudo cósmico llamado realidad, cuya imagen es el océano:
De una infinita plenitud de luz
y una profunda felicidad
gota tras gota te lluevo oceánico
y para ti son mis palabras

Como luz se manifiesta el satori en el poema «Plenitud pura» que pertenece al mismo poemario:

\author{
¿Y tú? que eres testigo de mi más \\ Te nombro Intensidad de un más extremo \\ hasta el límite tenso de mi llama \\ de pura plenitud pulmón de luz
}

Luz interior, que ilumina al ser, pues este está en perfecta concordancia con una realidad que también es luz. Una luz que se respira y no se piensa. Esta luz sacude los conceptos y expresa visiones que son trasuntos de experiencias. En este sentido, Ory se acerca a la visión de satori expresada por William Blake en el poema «Augurios de la inocencia»: 
To see a World in a Grain of Sand

And a Heaven in a Wild Flower

Hold Infinity in the palm of your hand

And Eternity in a hour

El más allá con forma de dedal

Y mi hogar en un grano de arena

El polvo y el vacío dialogan en vano

(«Sub vesperum», Cabaña)

Por último, debemos comentar el símbolo surgido en la cultura taoísta, que desde tiempos innumerables ha expresado la imagen de una realidad dinámica y divina: el yin y el yang. Anteriormente hemos analizado este símbolo comparándolo con la svástica, la espiral o la cinta de Moebius, pues todos ellos expresan la circularidad de un tiempo infinito. Análogo significado posee la imagen del río de Heráclito y, en cierto modo, la de Jorge Manrique. Watts (1963, 1990: 70) añade además el simbolismo del fylfot y el signo zodiacal de piscis. El símbolo taoísta señala la infinitud de una realidad no creada, una realidad que se halla más allá de los conceptos y supone la vacuidad, el gran vacío de donde surgen los fenómenos. En este el ser y el no ser surgen mutuamente, no existe la separación conceptual, únicamente la unidad sin fisuras. Uno de los poemas que mejor muestran el significado que transmite este símbolo es el siguiente:

\section{DOBLE FIDELIDAD}

No hay más que sima y cimas espanto y maravilla

No hay más que horror y éxtasis heridas y laureles

No hay más que afán y nada desafío y diamantes

No hay más que estrellas y algas azur y sexo

No hay más que dicha y ruinas mieles y males

No hay más que bajo y alto nubes y lotos

No hay más que angustia y fiesta ANGUSTIA Y FIESTA 
5. POESÍA DEL RECUERDO 


\subsection{VIAJE A LA GRAN CIUDAD}

Gods dance on their own bodies

New flowers open forgetting Death

Allen Ginsberg

La poesía oryana del recuerdo es una poesía de madurez, en ella se instalan todos los microespacios visitados con anterioridad para formar una nueva territorialidad. Esta poesía se configura como un nuevo viaje a través de la tradición heterodoxa e intenta actualizar sus símbolos como si de una hermenéutica se tratara. Por otra parte, como ocurre en toda la poesía oryana, confluye con el hermetismo poético, continuador de la poesía simbolista por el hecho de rechazar plenamente el discurso lógico. Al igual que la poesía hermética que se inició a principios del siglo $\mathrm{XX}$ y fue practicada por autores como T. S. Eliot, Ezra Pound, W. H. Auden, Dylan Thomas, Paul Valéry, Reiner Maria Rilke, Giuseppe Ungaretti, Konstantinos Kavafis, Fernando Pessoa, Juan Ramón Jiménez, Jorge Guillén o Vicente Aleixandre, la poesía oryana se concibe como un ejercicio de reflexión sobre la realidad que se vive. Intelectualismo, meditación y esteticismo son otras características de esta poesía hermética, de raíz metafísica. En cierto sentido se trata de un retorno al origen: tradición cultural, tradición poética y tradición vital.

Esta poesía del recuerdo se centra en las tres últimas obras publicadas: Sin permiso de ser ángel, Melos melancolía y La memoria amorosa. En ambas la poesía toma la forma del viaje, a la gran ciudad, a la tradición y a la vida pasada. El recuerdo es quien marca la deriva de esta poesía que se ofrece como un retrospectiva de instantes vividos, instantes instalados en el tiempo, cercano o lejano, del autor y en el tiempo histórico de la humanidad. La primera de estas obras, Sin permiso de ser ángel, queda establecida como un viaje a la gran ciudad, a Nueva York. La obra surge del viaje realizado por Ory y Laura Lachéroy de Ory para visitar al amigo poeta Allen Ginsberg, visita que desde el recuerdo se transforma en poema. 
Llevábamos tres flores en la noche tres crudos corazones escarlata parecían lechugas muertas de vergüenza Ricorda $^{390}$ esos tus gritos en la calle ALLENNNNN ALLENNNNN ALLENNNNN engarzados en la lámpara del oxígeno Te equivocas de casa de poeta Te llevas el teléfono a la boca hasta que un rayo de luz en el ombligo nos enciende camino de los campos Mentí cuando me decía:

«Acaso no hay poetas?

No no los hay

Como busco mujeres los busco»

Estaba chez lui nos echó un calcetín

Nos recibió muy quieto en su cocina

Nos enseñó las aguas y los vientos

Allí los tres a bordo de su hogar y sacaste tú fotografías

A Allen Ginsberg mi amigo

ansí le dedico mi libro azul

él me hizo un poema días antes y hoy me regala songs

(«Vistanoche a Allen Ginsberg»)

Ginsberg dedicó a Ory («él me hizo un poema días antes») el poema titulado «Proclamation», que fue publicado junto a «Visitanoche a Allen Ginsberg» en Diario 16 en el suplemento «Culturas» el día 3 de octubre de 1992. En 1996 «Proclamation» aparece publicado en francés en la obra de Ginsberg Cosmopolitan greetings ${ }^{391}$ (Pont, 1998: 235).

\subsubsection{Instantes junto a Ginsberg}

Angel without a permit, obra breve que consta únicamente de ocho poemas, se editó en Nueva York en 1988 como una traducción inglesa efectuada por Edith Crossman y Allen Ginsberg sobre poemas que Ory escribió en 1987. La afinidad de

390 Sic.

${ }^{391}$ Ginsberg, Allen (1996), Cosmopolitan greetings, Évreux, Chistian Bourgeois Editeur, pp. 72-73. 
Carlos Edmundo de Ory con el patriarca de la poesía beat puede rastrearse desde finales de los años sesenta. La impronta de Ginsberg, sobre todo Howl and Other Poems, está muy presente en la poesía oryana desde Música de lobo. Ory coincide en adoptar esa poesía de verso largo y libre a la manera de Walt Witman, su poesía converge también con la de Ginsberg en la actitud rebelde, heterodoxa y combativa frente al poder. Pero el primer encuentro entre ambos poetas no se produjo hasta 1987, cuando coincidieron en una lectura de poemas que Carlos efectuó en Gas Station, en el East Village de Nueva York, el 31 de octubre. En el Diario de Ory (2004, Vol. III: 302) existen alusiones a este encuentro. E1 7 de enero de 1994 Ory escribió lo siguiente:

Copio aquí un párrafo de una carta que me escribe Jesús Fernández Palacios, fechada en Cádiz, 26.12.93, a propósito de un recital de Allen Ginsberg en Madrid, últimamente:

«José Ramón fue al recital de Madrid y me contó que estuvo interesantísimo. Ya te contará Ripoll: hablaron y J. R. R. le enseñó la Revista ${ }^{392}$ y le dijo que íbamos a publicar tus traducciones. Le gustó la Revista y dijo que tú eras el único, el mejor poeta beat de España. Estuvo simpático».

Con que yo, poeta beat. No está mal la definición. Eso me recuerda lo que a mí me dijo el mismo Ginsberg en Nueva York, después de escuchar mis poemas en un recital que di en Gas Station, la noche del 31 de octubre de 1987. Me dijo: - Tenemos el mismo élan (creo que me dijo élan, significando arranque o impulso, o ímpetu, o entusiasmo). Luego, me comparaba con su propia poesía.

Ambos somos aventureros espirituales buscadores de la «X» mística. Holísticos, tántricos, budistas y gestaltistas del «totalismo místico»...

No se rían de nosotros porque creemos en los ángeles y en las cosas invisibles, percibidas de algún modo metaóptico.

A partir de entonces, tras visitar la casa del poeta americano, surgió la traducción al inglés del poemario oryano por parte de Ginsberg y además una cómplice amistad poética. Ambos poetas compartían la afición por los ángeles y la creencia, también compartida, en su existencia real. En el Diario oryano (2004, Vol. III: 294) existe otra referencia acerca del primer encuentro con Ginsberg:

Cuando fuimos por primera vez a Nueva York, en 1987 (octubrenoviembre), conocí personalmente a Allen Ginsberg. Nos encontramos dos veces, primeramente en una de mis lecturas de poemas en Gas Station, en el East

392 J. R. R. Es José Ramón Ripoll, periodista y poeta discípulo de Ory y la revista mencionada es RevistAtlántica de poesía, de la que Ripoll era su director. 
Village, la segunda la noche del 31 de octubre. Otra noche fuimos a su casa con el amigo Osvaldo ${ }^{393}$ y le llevamos tres flores exóticas, color carmín, de largos tallos, llamadas anthuriums.

Esta visita queda registrada también en el poema, cuyo fragmento hemos ofrecido con anterioridad, titulado «Visitanoche a Allen Ginsberg».

Ginsberg es el alma gemela de Ory al otro lado de océano. Como ya se ha dicho, los dos poetas convergen en unos mismos referentes poéticos y en el interés hacia el budismo. El segundo encuentro se produjo el 16 de mayo de 1993 con motivo de la lectura de poemas efectuada con dos días de anterioridad por Carlos en el Graduate Center de Nueva York. Este nuevo contacto afianzó totalmente el mutuo interés, que existió hasta el final del camino de cada uno. Ambos tradujeron y difundieron los poemas del otro. La amistad entre estos dos poetas vagabundos ha quedado convertida en poesía.

Brincas y brincas me punzeas me loqueas

Me atas la frente al espíritu

Me organizas hasta la aurora boreal

Pónesme en mi un arco iris

Ten cuidado no te cojas los dedos

en la cerradura de la Poesía

¡Ay la poesía es archidifícil!

Íbamos por las calles tal cigüeñas

Vestidos de cocido y yo te dije:

«Negréame un poema».

(«Visitanoche a Allen Ginsberg»).

Sin permiso de ser ángel es el documento que certifica la convergencia entre las poéticas de estos dos poetas insumisos que rechazaron de pleno los cánones socioculturales en los que ellas se desarrollaron. Se trata, pues, de dos rebeliones paralelas, una la del poeta americano que rompió con todos los modelos de conducta que se le ofrecían y halló un lenguaje poético tremendamente intuitivo y espontáneo. Muy pronto se declaró homosexual, tuvo experiencias con las drogas psicodélicas al buscar nuevas formas de conocimiento, vivió la vida bohemia beat, participó activamente en las protestas antibelicistas, mostró su apoyo a los movimientos contraculturales, mantuvo

${ }^{393}$ Se trata de Osvaldo Gomariz, viejo amigo argentino residente en Francia. Carlos Edmundo de Ory y Laura se hospedaron durante su estancia en Nueva York en casa de Osvaldo y Janine Neble. 
siempre un interés activo por el budismo y por otras formas orientales de religiosidad... La otra, es la rebelión del poeta gaditano que agitó los aires viciados de la caduca cultura castiza del franquismo con sus postulados surrealistas. Frente a la marginalidad propuesta por Ginsberg, Ory optó por un gesto totalmente radical: su exilio voluntario. Rechazó una realidad opresiva para buscar, alejado de patrias potestades, la libertad expresiva que ofrece una existencia apátrida, dinámica, acorde con una realidad concebida sin patrones. Su interés por la mística y por atrapar el misterio de la existencia lo encontramos ya en algunas declaraciones efectuadas en los escritos postistas, en las proclamas introrrealistas y en toda la extensión de su dilatada y poliédrica poesía.

Nueva York es el espacio físico y cultural testigo de la convergencia de estos dos poetas disfrazados bajo la apariencia de dos ángeles. Por sus calles y avenidas, sobrevolando escombros y basuras, planean las alas de otros ángeles como Burroughs, Kerouac, Neil Cassady, Peter Orlovsky, Hart Crane, Emerson, Yukio Mishima, Alberti, Lorca o Leonard Cohen, que asisten a esta cita para celebrar entre las ruinas de la civilización la amistad de estos dos poetas.

$¡ Y$ has abierto las puertas para que entre DIOS!

No era EL No era EL

(Dijo Emerson:

«La poesía es pintura oral

la pintura es poesía muda»)

Terminada la cita lo damos por sentado

Entonces ciérrala entonces ciérrala

(«Secreto del arte»)

Vos que sos mi tutela en la sancta basura

de avenida en avenida séasme abuelo

(Si no pude ver a Hart Crane

sí que pude ver a Allen Ginsberg)

Me cabroneas me espoleas

$[\ldots]$ 
A ti amigo te regalo regaliz

y pasas de Corinto y más venenos

confina estos versos en tu paladar

de comunista del entusiasmo

(Se pone pálido cuando telefonea

a Yukio Mishima)

Frases cortadas con serrucho

frases como tablas

(«Taller de frases»)

La amistad entre los dos poetas la encontramos también reflejada en el Diario de Ory (2004, Vol. III: 337-338). En él aparecen algunos fragmentos inéditos que su autor rompió. En el que corresponde al día 26 de noviembre de 1996 se rescata el texto siguiente dedicado a Allen Ginsberg:

De escritos sobre mis encuentros en Nueva York con Allen Ginsberg. Fragmentos.

No se le escapa nada. Acecha, mira, observa lo que le pasa delante, detrás (con el ojo de la nuca), a su alrededor como si temiese ser atacado de pronto por unos enemigos imaginarios. Lo noté estando él sentado a mi lado durante la cena de una noche. Hablábamos y sus ojos de lechuza funcionaban sin cesar.

John Giorno, que le tenía hincha, dijo a propósito de la perspicacidad animal de Allen: «Salta con el ruido de un alfiler». Me he podido dar cuenta de ello, en varias ocasiones, conversando con él. Y ya digo, esa noche, sentados juntos a la mesa para comer, escuchándome mientras mira el plato no se le escapaba nada.

Le estoy hablando de una editorial de Barcelona que publico hace diez años, en dos volúmenes, todas las entrevistas de «Gay Sunshine» bajo el título Cónsules de Sodoma. De súbito, vuelve la cabeza hacia mí, me mira fijamente y sonríe.

Le hizo gracia el título publicitario. No lo sabía. Sin duda la noticia le interesó por ser él mismo uno de los doce homosexuales entrevistados, entre los años 1973-1977.

Y Allen me enteró de la publicación en América de una antología de poetas gays, donde iban poemas suyos, titulada más dulcemente Angel of the Lyre.

He aquí los doce sodomitas consulares: Allen Ginsberg / John Giorno / Chistopher Isherwood / Roger Peyrefitte / Ned Rorem / Tennessee Williams / William Burroughs / Jean Genet / Lou Harrison / John Rechy / Gore Vidal / Winston Leyland. 


\title{
5.1.2. Paisaje mágico
}

Sin permiso de ser ángel expresa la experiencia íntima producida a través del contacto con el paisaje de la gran urbe, símbolo de toda una civilización. Por ello la ciudad de Nueva York no puede dejar de aparecer bajo una mirada culturalista, ya que en lo que importa es el impacto emocional que la urbe produce. Para Pont (1998: 235) la óptica de Ory, consciente de que se trata de un espacio totalmente intertextualizado, literaturizado y mitificado, deriva hacia la intimidad, hacia el instante preciso que se instala en la cotidianedidad personal. Su atención queda centrada en la esfera de lo que Pont (1998: 235) llama «un espacio eminentemente personalizado y doméstico». Aunque el escenario del poemario sea el paisaje urbano de la gran ciudad, en realidad se trata de un paisaje interior donde se ofrecen una serie de instantáneas, a modo de microespacios, de la intimidad. En este sentido, es también un espacio mínimo, o minimal, porque lo anecdótico sucede en el interior de la piel. El paisaje urbano de Nueva York es ahora el escenario donde se representa el acto, cotidiano y gratuito, de la celebración de la gratitud ante los instantes vividos. Ory celebra cada momento que pasa ante la presencia de su amigo poeta.

\author{
me traes espejos con tripas de violines \\ y llamas por teléfono al conserje de los dioses \\ Oh confitero de las vibraciones \\ Tocas el piano de mi corazón \\ Tú que me llevas con tus doce dedos \\ me quitas hasta el alma \\ me quitas hasta el lápiz \\ Eres el ángel sin carta de permiso \\ Eres un horno con cara de verano \\ La poesía es energía escarchada \\ Nos juntamos y se arma el acabose \\ La rosa es una risa es una rosa
}

(«Ritornello de Nueva York»)

La obra poetiza el espacio doméstico, el territorio familiar de la casa es trasunto de la intimidad. Las paredes son la piel que delimita el ámbito del ser frente a la ciudad. Este es el espacio donde surge la magia que habita en lo cotidiano y lo transforma en instantes de experiencia mística. Se trata de una mística inmanente que se produce en el 
instante donde realidad y poesía quedan ensambladas sin junturas. El símbolo que transmite la experiencia de estos instantes mágicos es la figura del ángel. Y este es quien se manifiesta, bajo el aspecto de Emerson, en el poema titulado «Secreto del arte», que antes ya hemos mencionado:

En tu casa que tiene las paredes de coco llamaban a la puerta con no sé qué nudillos nos miramos con carne de gallina ¿Quién será? ¿Quién será?

Resuelto diste un paso a pesar de los miedos

¡Y has abierto la puerta para que entre DIOS!

Qué chasco nos llevamos

No era EL No era EL

(Dijo Emerson

«La poesía es pintura oral la pintura es poesía muda»)

Terminada la cita lo damos por sentado Entonces ciérrala entonces ciérrala

Los interiores domésticos estructuran las experiencias donde la poesía es una vivencia mágica:

Yo voy de cuarto en cuarto caballo que relincha

La poesía en mi rostro es una cicatriz

$[\ldots]$

He venido a tu casa de amo delicado para ver el gatito de tu corazón

(«Pincelada de ternura»)

Te equivocas de casa de poeta Te llevas el teléfono a la boca hasta que un rayo de luz en el ombligo nos enciende camino de los campos

(«Visitanoche a Allen Ginsberg») 
Todo se ceremonia a cada paso contado

Tú ibas a escuchar el ruido del lavarropas

y creías oír sonar la flauta de Dios

(«Fiesta del alma»)

El espacio urbano queda trasformado por la presencia de elementos surreales que se insertan en el escenario de la cotidianeidad. Así la ciudad adquiere un aspecto extraño y mágico cuyos fragmentos muestran abiertamente sus referencias hacia lo paradisíaco. Esta aparece como el paraíso en el que dos ángeles deambulan sumergidos en la celebración del éxtasis que ofrecen los instantes.

Ahora bien, este espacio urbano también posee resonancias que apuntan a la mirada que Lorca traza en Poeta en Nueva York. Si el Nueva York lorquiano suponía una crítica mordaz de la realidad y la denuncia atroz de una civilización que desvelaba la hipocresía, la insolidaridad, el odio, el racismo..., la ciudad oryana, transmutada mediante el lenguaje surrealista de signo evidentemente lorquiano, posee un cariz más luminoso, porque se muestra capaz de integrar el aspecto negativo o maldito de la urbe y de restituirlo en paradisíaco. Para decirlo de alguna manera más explícita, hasta la basura de la ciudad forma parte del paraíso. En este sentido existen pasajes que nos recuerdan totalmente la mirada de Lorca:

Miramos el paisaje de la noche que se nos cae a pedazos desde el cielo ¿Dónde has puesto la caña de pescar?

En el tren exquisito de la muerte aguas adentro de nos quema el alma los cabellos mojados en ruinas

$$
\text { («La misa del degüello») }
$$

La calle es un puchero de garbanzos

Anda ponte el gabán de lana negra para tomar a dúo el lenguaje del sol

Vos que sos mi tutela en la sancta basura 
de avenida en avenida séasme abuelo

(«Taller de frases»)

Esta es la tierra de la hierba

del harapo y del oro

Son pocos los que llevan

la llave la llama ¡Oh Vieja York!

(«Taller de frases»)

Al surrealismo lorquiano se le suma la óptica tremendamente profética, enérgica y vitalista de Walt Whitman, para quien, tal como mostró en Hojas de hierba (1885), la entidad individual es universal y paradisíaca. Por ello celebró la vida en todos sus aspectos:

Lo, the most excellent sun so calm and haughty,

The violet and purple morn with just-felt breezes,

The gentle soft-born measureless light,

The miracle spreading all, the fulfill'd noon,

The coming eve delicious, the welcome nigth and the stars,

Over my cities shining all, enveloping man and lan.

\subsection{3. Ángeles en el paraíso}

Igual que André Breton, que plantea que las experiencias vividas en los sueños no quedan registradas en la memoria $(1962,2009: 24-25)$, Ory cree en la realidad de los sueños. Estos forman parte de una «suprarrealidad» ${ }^{394}$ que ignoran aquellos que viven de espaldas a ellos. Los sueños son la puerta de acceso a otros planos de la realidad que

394 Breton $(1962,2009)$. «En el instante en que el sueño sea objeto de un examen metódico o en que, por medios aún desconocidos, lleguemos a tener conciencia del sueño en toda su integridad (y esto implica una disciplina de la memoria que tan sólo se puede lograr en el curso de varias generaciones, en la que se comenzaría por registrar ante todos los hechos más destacados) o en que su curva se desarrolle con una regularidad y amplitud hsta el momento desconocidas, cabrá esperar que los misterios que dejen de serlo nos ofrezcan la visión de un gran Misterio. Creo en la futura armonización de estos dos estados, aparentemente tan contradictorios, que son el sueño y la realidad, en una especie de realidad absoluta, en una sobrerrealidad, si así se le puede llamar», pp. 26-27. 
se superponen a este, tal y como se cree en el chamanismo ${ }^{395}$, significan la entrada a otras dimensiones de lo real (Ory, 2004, Vol. II: 158).

«No hay más que el mundo astronómico», afirma John Cowper Powys. Dice que estamos en contacto con otras dimensiones, con otras capas de la vida. De esto estoy convencido yo también. Cada día es un pasaje, una escala, un movimiento, un vaivén, un estremecimiento de contactos sutiles con la Vía Láctea [...] Todo está ligado a todo, la cuarta dimensión obra en nuestros sueños, y cuando nos creemos despiertos, el sueño diurno nos precipita de nuevo en dimensiones desconocidas por nuestros sentidos enredados entre sí.

De igual modo que existen varios planos de realidad superpuestos, para el chamanismo también existen varios tipos de seres y entidades. Carlos Castaneda utiliza el concepto de seres inorgánicos para denominar otras presencias que no poseen forma humana y que asímismo transitan por el espacio de la realidad. No es raro ver un paralelismo con la figura tradicional de los ángeles. Para Ory los ángeles son entidades que habitan en capas diferentes de la realidad y, por ello, cree en su existencia como seres reales y no solamente imaginarios. Según sus creencias, en los sueños nos visitan seres reales. Para él los seres imaginarios hallados en el folklore y en la tradición simbólica de los mitos poseen entidad real (2004, Vol. III: 39-41).

Los sueños no cesan (este es el diario de los sueños). Sigo encontrándome con visiones de cuerpos vivos y almas de otro mundo; unos están dentro de mí y se pasean dentro de mí, vuelven, no se van; otros dan vueltas a través del demios oneiros, también dentro de mí, en los confines del Okeanos, en la frontera del mundo real. No se sueña; nos visitan sueños; imagines mortuorum et lares. Soñando nos llenamos las manos de carbunclos. La madre noche es Nyx, ¿qué tiene en sus dos brazos sino sus dos hijos gemelos? El sueño y la muerte -Hypnos y Thanatos-. Hasta ella desciende Morfeo llevando en una mano un cuerno humeante y en la otra un huso de marfil. Son los dos símbolos claros de las dos especies de sueños: los falsos y los verdaderos.

El sueño de la razón produce mónstruos (Goya).

El sueño creador produce músicas y danzas.

${ }^{395}$ Recordemos que Carlos Edmundo de Ory fue un ferviente lector de la obra de Carlos Castaneda. En ella Don Juan separa los conceptos de tonal y nagual, el primero se trata del mundo tal como es organizado por la representación humana y el segundo está formada por unos filamentos luminosos de energía que nuestra mente no logra organizar. Dos universos paralelos que existen en el aquí y que son el reverso de la misma realidad. Para acceder al nagual los brujos cambian su percepción variando la posición del punto de encaje que es el lugar donde el sistema perceptivo se alía con las vibraciones y emanaciones que provienen del engrudo energético de la realidad eterior. Ver Castaneda, Carlos (1974), Relatos de poder, obra cit., pp. 157-195; (1984) El fuego interno, obra cit., pp. 129-149. 
Hay mundos sobre mundos

La puerta misteriosa.

$[\ldots]$

Vienen ángeles de allí hasta aquí, donde duermen los elegidos, como cuando dormía Mahoma entre las colinas de Safa y de Al-Ma'va, y de allí vino entonces el Ángel Gabriel.

Quien pudo ver ángeles en sueños, ése es un nabï, simple profeta; quien puede verlos despierto y escuchar lo que dicen. ése es un profeta enviado o nabi morsal. Uno y otro reciben la visión y la palabra, pero de distinto modo.

El mundo de lo imaginal conserva su realidad en la imaginación activa. No es un mundo de ningún modo irreal. La conciencia imaginativa penetra en ese mundo de realidad interna, que no es, sin embargo, una ilusión como puede creerse. «Guardémonos de confundir esta potencia imaginativa con la fantasía» (H. Corbin).

Lo extramental se objetiviza en el soñador visionario espiritual. Algunos han visto el mundo imaginal con sus paisajes y siluetas perfectamente reales, conservando su «identidad». Exploración y creación son idénticos en el mundo onírico imaginal.

Después de leer estos pasajes de tinte junguiano y esotérico del Diario, que nos hacen pensar por qué algunos autores le llamaban a Ory el loco, podemos entender la creencia de Ory en la existencia real de los ángeles. La imaginación para Ory es también realidad. Otro pasaje del Diario (2004, Vol. III: 218) nos habla del naturaleza borrosa de los entes de la realidad. Esta es dinámica y cambiante, fluida y líquida en la que nada permanece estático. Pues es el vacío quien une las partículas de lo real:

Cada objeto es objeto de la conciencia que lo capta. Ondas, ondas, ondas, ¡qué ilusión! ¡qué cosquilleo sensible! En verdad no hay nada estático, ¡Oh cosas, oh átomos, electrones y protones, girando y vibrando sin cesar!

Diariamente acuden los objetos a la cita de la luz.

Se sostienen en vilo, flotantes e inseguros, como telarañas.

Esta existencia líquida es el punto de contacto entre los ángeles y la realidad. Ahora bien, para observar a los ángeles se precisa la mirada del chamán, que puede ver aquello que el hombre percibe cotidianamente sin darse cuenta, sin dar importancia, aquello que los ojos miran pero no ven. La capacidad de percibir al ángel es un ejercicio de consciencia, no de mirar sino de ver. En este sentido, las aureolas de los ángeles simbolizan, a la luz de la filosofía perenne, su existencia sutil. 
No es de extrañar, pues, que Sin permiso de ser ángel se convierta en la certificación del encuentro entre dos ángeles. No se trata de la encarnación de dos ángeles, sino de que los dos poetas han alcanzado lo que denominaríamos su cuerpo sutil, el estatuto de ángeles. Para Pont (1998: 237) la «personalización de lo angélico» es el símbolo que expresa la unión de poesía y amistad, y relaciona la representación del ángel con Alberti y su obra Sobre los ángeles, en la que estos plasmaban anécdotas personales y cotidianas. Ciertamente el poemario oryano se edifica sobre el territorio albertiano, pues los ángeles de Alberti, surgidos de la unión entre la irreverencia surrealista y la religiosidad pasionaria y siniestra de la tradición iconográfica andaluza, son arquetipos de lo humano. Para Bodini (1963, 1982: 61-62) son imágenes que expresan el misterio que habita tanto en los sueños como en la realidad, y sobre todo en el interior humano:

Esos ángeles que podemos encontrar ascendiendo en una cueva o entrando en una habitación vacía, en la basura, en las pizarras o en los sueños oxidados, son las raíces cuadradas del misterio que rodea nuestros sueños más humanos.

A diferencia de otros ángeles aparecidos en la poesía: Juan Ramón, Larrea, Lorca..., los ángeles de Alberti, tanto los buenos como los malos, los tristes y los pesarosos, son todos terriblemente humanos.

No en las calles, en todo, indiferente, necio, me lo encuentro.

$¡ E l$ ángel tonto!

¡Si será de la tierra! -Sí, de la tierra sólo.

(«El ángel tonto»)

Al igual que los ángeles de Alberti, los ángeles que aparecen en Sin permiso de ser ángel son ángeles humanos. Los poetas, transmutados por la amistad, se han convertido en ángeles y Nueva York es la metáfora del paraíso donde estos deambulan a través de un paisaje de ensueño, edénico: 
En la seda furiosa de los días nosotros dos ciclistas dos ciclistas zigzageando ${ }^{396}$ con sus dos bufandas

El infinito y su collar de perlas se nos mete en la boca respirando La vida extraordinaria nos menea

(«La misa del degüello»)

Te llevas el teléfono a la boca hasta que un rayo de luz en el ombligo nos enciende camino de los campos

(«Visitanoche a Allen Ginsberg»)

Eres ángel sin carta de permiso Eres un horno con cara de verano La poesía es energía escarchada Nos juntamos y se arma el acabóse

(«Ritornello de Nueva York»)

La fantasía y sus raíces de cristal nos hace centinelas de bellos dientes blancos

He venido a tu casa de amos delicado para ver el gatito de tu corazón

(«Pincelada de ternura»)

Blancura, cristal, luz... son los signos de la energía desprendida con que se revisten estos ángeles. Aunque, como en el caso de Alberti, también se trata de ángeles furiosos, armados con espadas de fuego:

vestido de almirante malherido a ti te corto el cuello con mi espada

(«La misa del degüello»)

En otros casos, la figura del ángel no se centra en los dos poetas. Este es un ente exterior que, como ángel vigilante, habita en el aire. En el poema «Secreto del aire» el ${ }^{396}$ Sic. 
ángel llama a la puerta de la casa de Ginsberg y pronuncia la frase de Emerson, a la que ya nos hemos referido con anterioridad:

llamaban a la puerta con no sé que nudillos

nos miramos con cara de gallina

¿Quién será? ¿Quién será?

Resuelto diste un paso a pesar de los miedos

$¡ Y$ has abierto la puerta para que entre DIOS!

Qué chasco nos llevamos

NO era El No era EL

(Dijo Emerson:

«La poesía es pintura oral

la pintura es poesía muda»)

La voz del ángel aparece también en el poema titulado «Diálogo del perro y el ángel», diálogo que toma la forma del juego postista, ejercicio de poesía conceptual creado a base de transposiciones cualitativas tan utilizadas por Ory:

El perro le dijo al ángel: «yo te beso»

el ángel le dijo al perro: «yo te muerdo»

el perro le dijo al ángel: «yo te canto»

el ángel le dijo al perro: «yo te ladro»

el perro le dijo al ángel: «yo te alabo»

el ángel le dijo al perro: «yo te meo»

el perro le dijo al ángel: «yo te leo»

y el ángel: «¡cállate que me estropeo!»

La gran urbe queda convertida en paraíso, en una realidad distinta y asombrosa, donde cada acto y cada pequeño gesto se convierten en una experiencia gozosa. Nueva York es el escenario del asombro de dos seres mágicos, ángeles, ante los detalles más insignificantes de la realidad, que celebran una existencia que aúna poesía y amistad.

\subsubsection{Surrealismo radical}

Como nos indica Jaume Pont (1998: 236-237), la poesía de Sin permiso de ser ángel activa la poética surrealista de signo bretoniano practicada por su autor en Los poemas de 1944. A ello cabe añadir la huella lorquiana impresa en Poeta en Nueva York 
y la impronta, surrealista también, de la poesía beat. Con todos estos referentes, la poética utilizada en este poemario toma la forma del surrealismo radical. Lo que queda alterado, respecto los referentes poéticos anteriores, es el signo de la mirada. Mientras que Lorca y los poetas beat ofrecían una mirada crítica y negativa, deprimente y claustrofóbica, de la gran urbe, la poetica oryana supone una óptica eufórica, en la que todo lo observado se convierte en goce y éxtasis. Cambia también el signo del surrealismo oryano respecto del surrealismo practicado en la poesía postista. La soledad, patente también en la obra lorquiana, queda sustituida por la compañía y la amistad. Y, como resultado de ello, la obra ofrece una experiencia extática ante los instantes vividos:

¿Por qué pasas tan deprisa

las páginas de tus nervios?

Todo se celebra a cada paso contado

$(«$ Fiesta del alma»)

Se trata, pues, como en la poesía de Whitman, de la celebración del hecho de estar vivo y ello queda traducido en la sensación de asombro ante cada instante percibido. Esta extrañeza se nos transmite a través de su lenguaje más adecuado, el surrealismo radical, que, en este caso, revaloriza la magia invisible que se halla impresa en cada parcela de la realidad. Las asociaciones inesperadas y las imágenes visionarias, propias de este lenguaje absurdo, realzan el ámbito mágico de la realidad representada.

Estrujas con tus ojos mi cara soñadora y yo cojo con pinzas de monje jorobado el bañador del ser humano $[\ldots]$ cada día niquelas la mañana

$$
\text { («Ritornello de Nueva York») }
$$

Yo voy de cuarto en cuarto caballo que relincha La poesía en mi rostro es una cicatriz

Ahora tengo las manos metidas en el sueño depósitos totales de locos sobresaltos Estoy extenuado 
de apuntar la pasión con los ojos de buzo

(«Pincelada de ternura»)

Ory utiliza un lenguaje extraño, repleto de imágenes visionarias de tinte onírico, en el que sus términos se enlazan de modo irracional o automático. Todo ello se observa en expresiones como: «La poesía en mi rostro es una cicatriz», «Ahora tengo las manos metidas en el sueño» o «Estoy extenuado / de apuntalar la pasión con los ojos de buzo». La poesía es una corriente que en su fluir va enganchando unas imágenes con otras como si fuese un ejercicio de poesía automática.

Anda ponte el gabán de lana negra para tomar a dúo el lenguaje del sol

\section{$[\ldots]$}

Pongo mi lira de rodillas

al servicio de todas las pestañas

Trabajar en la mina de ondas frescas

para saciar el hambre canina de belleza

(«Taller de frases»)

En ocasiones el lenguaje se acerca de un modo más directo a la poesía de Lorca:

Me besas mis crepúsculos

me traes espejos con tripas de violines

y llamas por teléfono al conserje de los dioses

(«Ritornello de Nueva York»)

Cuyo tono se aproxima bastante a los siguientes versos lorquianos:

Hay muy pocos ángeles que canten, hay muy pocos perros que ladren, mil violines caben en la plama de mi mano.

(«Casida del llanto», Diván del tamarit, 1940) 
Por otra parte, encontramos también ecos del surrealismo postista, sobre todo, en lo que respecta a los juegos de palabras y a la sintaxis descentrada y subvertida, de herencia barroca. Esta última queda totalmente presente en el siguiente fragmento, que posee el aroma del hipérbaton.

El hombre que me echando carbón un triángulo de papel en el alma tenía

(«Taller de frases»)

El juego con el lenguaje de signo postista, caracterizado por la cacofonía y la proximidad fónica, se observa perfectamente en el poema «Diálogo del perro y el ángel»:

el perro le dijo al ángel: «yo te leo» y el ángel: «cállate que me estropeo»

Este lenguaje lúdico y travieso aparece además en multitud de fragmentos y de expresiones:

· «mi cara soñadosa»

- «miocaballero»

- «La rosa es una risa es una rosa»

(«Ritornello de Nueva York»).

· «séasme abuelo»

$\cdot$ «te regalo regaliz»

- «Son pocos los que llevan / la lleve la llama ¡Oh Vieja York»

(«Taller de frases»).

- «me punzas me loqueas»

· «Pónesme en mi cuello»

- «Negréame un poema»

(«Visitanoche a Allen Ginsberg»). 


\subsection{DESDE LA MADUREZ}

veo que el mar persiste, insobornable, relevando a la sombra derrotada.

Amador Palacios

\subsubsection{Geografías recordadas}

Melos melancolía, obra publicada en 1990 y ampliada con un nuevo poema en 2013, es una obra escrita desde la conciencia de la madurez. Para Pere Gimferrer (2012: 25) se trata de una obra que se concibe como una recapitulación final de la poesía del autor. En este sentido tenemos una poesía que se configura como una retrospectiva hacia la existencia pasada del autor, que recupera diversos instantes de su itinerario vital y traza vislumbres lejanos de su infancia. Ana Sofia Pérez Bustamante (1012: 14) señala el aspecto testamental de la obra, hecho que marca otra dirección de la mirada poética de Ory: la reconstrucción de diversos territorios recorridos por la poesía oryana. Ambas direcciones, la que apunta a la existencia del poeta y la que se dirige a la obra, marcan la impronta autorreferencial de la obra. Una tercera dirección recupera varias geografías propias de la tradición cultural universal que va desde la historia clásica a las filosofías más herméticas y heterodoxas. Melos melancolía gravita retrospectivamente sobre estas tres direcciones: la existencia del autor, la poesía y la tradición simbólica de la humanidad. Esta poesía de madurez posee las constantes poéticas anteriores, se trata de una poesía metapoética, visionaria, metafísica y mística que busca desvelar el misterio que acecha en cada instante, presente y pasado, de la existencia.

\subsubsection{La infancia y el mar}

Entre los instantes recuperados Melos melancolía dirige la mirada hacia la infancia. Mirada trazada por la madurez y la sabiduría que otorga la experiencia vivida. Desde la atalaya de la edad se evocan diferentes instantes de la infancia, que queda asociada al mar, al Océano Atlántico que baña de luz las costas de Cádiz: 
Tomé asiento en la costa de mis días primeros y empezaron las olas a sonar en mi ser

El corazón que tengo se lo debo a Neptuno

(«Canto criaturial»)

Fui un rey en el balcón perfecto

de unos brazos

cuando supimos ser antiguos como el mar

recibiendo los ojos celestes del espacio

Robé una piedrecita en la playa cercana

Allí el viento paseaba

con sus piernas terribles músculos de belleza

(«Pupitre»)

El mar de Cádiz aparece como el origen de la vida, tanto del ser existencial, que ahora ya no es joven, como de la vida misma. Origen y símbolo de la existencia, pues el mar aparece como espacio infinito y divino, porque la divinidad toma forma de océano cósmico que integra todas las individualidades.

He aquí la historia en limpio del papel que jugué

bajo el sol y la luna las nubes y los pájaros

desde que descendí de la nave infinita

y tomé ser pisando la costa de mis días

$[\ldots]$

Y empezaron las olas a sonar en mi alma

cuyo modelo tuvo que ser el mar indócil

Harto conozco mi anfibio corazón

que se bañó en las aguas natales y heme aquí

más hambriento de vida que de pan contemplando

destellos de distancias en mi memoria de oro

(«Imágenes»)

El mar representa lo ilimitado, lo que no posee costuras ni muros de contención, ni símbolos ni significados. El mar es la realidad sin conceptos ni territorios, símbolo de la existencia apátrida del poeta y de su rebeldía ante las normas de lo establecido, tanto vitales como poéticas. Recordemos que esta poesía es sobre todo autorreferencial y metapoética. Por ello trata sobre la existencia del autor y la de su discurso. 
Alma y dedos a tierra velámenes y anclas

En adelante zumbos me escucho en caracola abandonado en el pesebre del insomnio

junto a las tiernas rocas mis almohadas empetro

la sombra del océano centinela durmiente

de los sueños la senda solitaria me valga

Ahí mi corazón novicio pilotó

a pique mis pies místicos dando vueltas

eran playas enormes donde no había cosas

y entonces se mojaba los ojos el gran ciego

(«Desembarcadero»)

El mar toma el simbolismo de la existencia dinámica, del movimiento continuo sin dirección ni fin establecidos. Mar que es existencia, viaje al absoluto, y es símbolo del gran cosmos. En este sentido, el mar oryano converge con la imagen expectante y eterna de mar juanrramoniano, que observa desde su eternidad las existencias de los seres que forman el acontecimiento cósmico:

¡Mar fuerte, oh mar sin sueño, contemplador eterno, y sin cansancio y sin fin, del espectáculo alto y solo del sol y de las estrellas, mar eterno!

(«Mar despierto», Diario de un poeta recién casado, 1917)

En la poesía oryana el mar queda asociado a la infancia y esta se halla mediatizada desde la perspectiva de la vejez, a modo de una continua transposición temporal. El pasado de la infancia se inserta, como si se tratase de un injerto, en el presente.

¡Mira! ¡Mira! no acaba tu insomnio acuérdate que has dormido otras veces siendo un cuerpo precioso aunque ya nada sabes de tu noche pequeña Medita en la nodriza admirable acunándote la antigua lavandera de climas soleados

Reconozco estos símbolos que luzco en la memoria levantando la lumbres de remotas ternuras Las manos de mi padre poniéndome el babero y no olvidas tampoco que tuviste una abuela que te quiso muchísimo y espiaba con lástima los arrebatos de tu melancolía Hazte un recuerdo de esos honores recibidos 
en los láricos tiempos en los láricos tiempos

cuando calladamente andabas sin saber

lo que haría de ti la religión del llanto

(«Vestigios»)

La óptica distanciada de la mirada oryana queda perfectamente situada en el presente de la vejez:

El cuerpo mío piensa igual que un jazminero voz y oreja avisados del don personalísimo Ahora ya soy un viejo rapsoda terrenal

$(«$ Poeta $)$

Experto en la vivencia existencial sientas piedra de escándalo con los cabellos sueltos

(«Arcanum»)

Hace ya mucho tiempo que baje del bajel

(«Adonai Adonai»)

Esta poesía autorreferencial traza una cartografía de los territorios existenciales y culturales del poeta: la infancia, la rebeldía de la juventud, el exilio permanente, las culturas antiguas con sus mitos y sus símbolos, las filosofías cósmicas y místicas... Y supone una vía de acercamiento al interior sentimental del poeta.

\subsubsection{La experiencia mística}

Uno de los territorios más transitado por la poesía de Melos melancolía es la experiencia mística y su expresión poética. Como ya hemos visto anteriormente, la mística oryana se acerca, sobre todo, a las tradiciones religiosas que se han preocupado por acceder al misterio de la existencia y que conciben la imagen de una que divinidad reside en el ser humano. Sus conceptos y expresiones son utilizadas como vía de conocimiento y de comprensión del retrato humano que la obra traza. En este sentido 
encontramos acercamientos al hinduismo y a la teoría del avatar, teoría que manifiesta el concepto de reencarnación, de renacimiento experimentado en cultos solares y de eternidad de la existencia humana:

Lloro el embarcadero alejado de mí y lloro los escollos de mi nuevo avatar al borde las aguas sintiéndome mirado por los ojos de Eolo como si fuera un héroe

(«Canto criaturial»)

En el embarcadero lejos de mí dejé la cama de mi voz mi camita de cantos aquel brizo columpio de los sueños que meció la sirena cuyo rostro no vi Pero los escollos de mi nuevo avatar al borde de las aguas sintiéndome mirado por los ojos de Eolo como si fuera un héroe

(«Imágenes»)

Nótese que ambos poemas están configurados atendiendo a la técnica postista del enderezamiento, por ello muestran una apariencia casi idéntica. La imagen del ser humano que aparece en estos fragmentos es la de una presencia eterna que forma parte de un tiempo infinito, que toma la forma de una espiral que nunca acaba. Hombre que es eterno, instaladado en un tiempo eterno. El ser humano, como ser eterno que es, se presenta como múltiples encarnaciones individuales. Esta idea de circularidad temporal se ofrece en el siguiente fragmento:

Estas son las palabras escritas en la arena infinita del tiempo por demás infinito

Todo empezó en el mar que está en mis tuétanos

(«Arcanum»)

También existen varias referencias que afectan al carácter ilusorio del mundo, concepto que en el hinduismo queda expresado en el concepto de maya, tal y como ya se ha visto en apartados anteriores. En este sentido, los símbolos de la noche, la tristeza, el dolor... son en realidad símbolos de la tribulación existencial y de la opacidad 
humana ante la confusión generada por maya. Concepto que expresa la ignorancia que impide ver que el ser humano es, en realidad, un ser divino y que habita en una realidad divina.

Con ojos tristes de bebé contemplo el mundo bañado en tinieblas

¡Ah pliega ya la vieja red!

Me apetece ahora mismo escudriñar mi alma

Si me arrimo a las cosas desusadas

sabré también que crezco renovado

Terriblez de la tierra

Hemos sangrado a cuerpo vivo

Sí la noche ha llegado

¡Y qué importa la angustia!

Ahí búscalo todo con un salto mortal

Busca el castalio chorro y olvídate del rictus

de la mueca caduca del santo día humano

que se escurre transido de sudores de espejos

(«Tenebrae»)

El fragmento anterior funciona como símbolo de la caída en la noche, o existencia. En este sentido, la noche supone la apariencia equívoca de maya, un reflejo que se asocia a una imagen inexistente. La noche u oscuridad ha de ser vivida y experimentada para que el ser se trasforme y disipe sus tinieblas conceptuales, porque el ser humano siempre ha habitado en una realidad hecha de luz. Ya hemos comentado anteriormente la función trasformadora de los antiguos ritos iniciáticos.

Coloco mi tienda una vez más en la isla en la isla ${ }^{397}$ posible mientras viva y a lo largo del toldo la noche de la luz me dé la mano el viento que es mi mejor amigo bajo la eternidad constelada de ampos

(«Pupitre»)

Conceptos análogos aparecen tomados del budismo, sobre todo del budismo mahayana, considerado como gran vehículo. Como ya se ha visto, el mahayana basa sus concepciones en la ruptura entre la distinción de nirvana y samsara y sus derivaciones. Melos melancolía presenta el absurdo que conlleva considerar la existencia de nirvana.

${ }^{397}$ Sic. 
Como en el mahayana, Ory concibe que únicamente existe el samsara, por ello irónicamente la poesía expresa la divinidad del ser que vive un una realidad divina. De modo que cualquier modificación o intento por conseguir un cambio en su existencia, intentando alcanzar el nirvana, supone un absurdo existencial.
El olvido es un destino y uno no busca camino No se va a ninguna parte
Muchas veces yo me creo a las puertas del nirvana ¿entro? ¿no entro? antes de darme un paseo

(«Canturria de la amnesia»)

El yo poético toma la imagen de maestro, del ser que ha recuperado la memoria (original) y, por ello, sabe que es un ser divino y que no hay más divinidad que el aquí. En el poemario también la noción de vacuidad, el gran vacío de donde surgen las miríadas de las cosas, sin naturaleza propia, sustancia o esencia. El samadhi, percepción que ofrece la meditación más allá de los conceptos, posibilita ser consciente de ser parte del cuerpo de Buda, tal como manifiesta el budismo. En este sentido, el yo poético, reflejado en el tú especular, adquiere el status de sabio iluminado, del ser consciente de la vacuidad existencial:

En el fondo de ti vuela la mariposa personal ¡Salta en el vacío!

Nada suplanta la experiencia diestra ¿Qué haces en la ribera lamentándote? Momento piloto del ser monumento Estar en el espacio santísimo y divino las dos pupilas diarias y el órgano pineal Y mirar las estrellas con ojo terco

En la época dorada saber poner las manos sobre la Nada no coger ya nada

La mixtificación no te rodea

(«Nihilismo») 
También son numerosas las referencias que apuntan hacia el budismo zen, a la meditación za-zen y el concepto de satori. En este sentido, el silencio es la imagen que transcribe el estado de la repentina iluminación, llamada también conciencia de la budeidad:

Yo sé que alguna vez dije más en silencio riendo bellamente de mí por fin maduro porque no es a través del verbo como puede mirar el alma su paisaje chino

$(«$ Arcanum»)

He aquí la otra página que divulgo a los vientos Pues entonces hagámoslo ciertamente al socaire de labios misteriosos acostumbrados a las enormes palabras mudas del corazón y que me oiga alguien que adora la tristeza Por decente que sea siempre alabo los dones que profeso por ser una natura extraña tocando las campanas terribles de mi ser como cuando mantengo largas conversaciones con un compatriota del alma que se hospeda en la misma posada que yo y me da pábulo al rompimiento de mi gran silencio $[\ldots]$ Sabrás que cifro arcanos y que consulto a solas ecos de ecos viniendo de pozos insondables y en el poema engarzo las perlas del silencio

(«Monostrofe»)

Se trata del lenguaje del silencio, propio del zen, basado en la destrucción del lenguaje y sus conceptos. Por otra parte, es el viento («vientos», «socaire»), símbolo perfecto del cambio constante y perpetuo, quien barre los significados conceptuales y hace posible la experiencia sin lenguaje:

Yo que me iba hacia la mujer el mugir del viento y a mi lado me estaba mirando el mundo a mí mientras toco los cables de alta tensión y toco el fondo del crepúsculo hasta encontrar la perla

(«Ruinas luminosas») 
La poesía de Melos melancolía, gravita, de otro lado, hacia la sexualidad y el erotismo. Recordemos que el erotismo ha sido uno de los vértices que han marcado profundamente la poesía de Ory. En la obra existen numerables referencias que apuntan a la concepción del erotismo como una verdadera religión. Como ya hemos visto, el amor es un amor sagrado que exige una práctica concebida como una forma de meditación. Eros queda configurado como una mística, cuyo símbolo más claro está representado por kundalini, la serpiente tántrica, símbolo del despertar.

Ileso al otro lado de la sombra me entretuve lanzando una ojeada a este rostro difícil que me vió ${ }^{398}$ quieto en el infinito poderoso La serpiente del ser inmoble su ojo y el pensamiento mío redondeándome cayéndome los pétalos del alma en el silencio oscuro de la nada

$(«$ Never more»)

El erotismo adquiere la forma de un rito de resurrección, ya que el amor es un fuego que quema y abrasa como ocurre en la ceremonia de la cremación. El fuego, exponente del dolor, transforma al ser en cenizas divinas. La ceniza, pues, es símbolo de cambio y trasformación que conlleva la conciencia de pertenencia a un cosmos divino. El amante se transforma porque es consciente de que no está solo y de que forma parte del ser amado $\mathrm{y}$, en última instancia, de todos los seres que son sus amados y que conforman una misma unidad que ama. El yo poético, instalado ahora en plena madurez vital, es el ser que ha adquirido conocimiento a través de la práctica erótica, que ha profesado la religión del amor. La poesía de Melos melancolía supone la certificación del aprendizaje de ese otro yo que el yo poético fue en el pasado. Por ello expresa la constatación de un proceso de iluminación:

Tripulante del mundo fue rey de la locura goloso de mujeres locas de puerto en puerto y al pairo se quedó con los brazos cruzados como quien ya no sabe qué hacer con sus pasiones Rompió la costumbre de sentir el marullo y se muerde los labios de pena y echa baba Pocos son los que beben sangre de la belleza

398 Sic. 
sabiendo que no pueden alcanzar el olvido

Entre ratas y éxtasis como el hermano Trakl

otro monje parece artista del crepúsculo

estudiante hechizado de sombras ominosas

leyendo su alma aprende a estar solo en silencioso

(«Pasiones»)

El fuego del amor remite a los ritos eleusinos de trasformación, al renacimiento a través del dolor. La poesía es la expresión de esta alquimia amorosa.

No quiero ni pensarlo al fin me envenenó la poesía esa hetaira mi máxima lujuria Medio loco de ideales profundos y silentes recogiendo pepitas de oro en el abismo

$[\ldots]$

Chupé el espejo negro de la belleza nula con la leña del sexo incendié mi osamenta y luego la apagué con agua de mujeres Allá mi frente absurda jubila en las alcobas ante sendos pudores de vírgenes y ángeles ¿Dónde estarán agora las sempiternas hembras oh rostros fugitivos cohetes de una fiesta? Notas de un corazón al azar de catástrofes campanadas de vida goces sin paralelo La ceniza de ondinas tras la quema de besos

(«Agenda»)

La mística oryana es una mística sincrética que abarca todas las tradiciones que ha vivido la humanidad. Mística inmanente que queda plasmada en el siguiente fragmento que pertenece a La memoria amorosa:

Miro alrededor mío y no me asusta nada. Soy todo lo que estoy mirando. Estoy enamorado del universo: el aire ondulado. Y oigo el trino de los pájaros (2011: 99).

Este pasaje nos recuerda la imagen de la vida, melancólica y eterna, que presenta el poema titulado «El viaje definitivo» de Juan Ramón Jiménez, poema que integra perfectamente vida y muerte en la realidad existencial, en el ritmo dinámico de la vida: 
... Y yo me iré. Y se quedarán los pájaros

cantando;

y se quedará mi huerto, con su verde árbol, y con su pozo blanco.

Todas las tardes, el cielo será azul y plácido y tocarán, como esta tarde están tocando, las campanas del campanario.

(«El viaje definitivo», Segunda antolojía poética, 1922)

\subsubsection{La música divina}

Una de las propuestas de la literatura postista fue la euritmia, práctica que conllevaba la idea de convergencia entre poesía y música. Ya hemos visto con anterioridad cómo la música tiene para Ory un aspecto mágico, cómo la poesía posee la magia de las palabras y su poder transformador. La música es un elemento órfico que supone un método de conocimiento y un acceso a un estado del ser que lleva a la percepción primigenia y mágica de la realidad. La concepción de la poesía como música exige una metapoética, puesto que la poesía se convierte en reflexión sobre sí misma. En Melos melancolía la poesía expresa su aspecto metafísico y místico, se convierte además en un meditación, a modo de trance, y expresa el éxtasis frente a la realidad.

La poesía

Sonido canto y palabra más allá de la letra

Porque la letra es asesina una espada de dos filos

El pensamiento escrito trae engaño agazapado pues no hay persona que habla sino pergamino muerto Las palabras se enfrían como cadáveres

(«Viva vox»)

Ory apela a la tradición primigenia de la poesía, cuando esta era canto oral, palabra órfica acompañada por los sonidos de la lira. De ahí, la palabra lírica. Poesía, que como música, tiene un poder trasformador y se acerca al silencio porque intenta prescindir de los conceptos que quedan establecidos en los significados: 
Que la tierra llora por mis ojos

Salgan en mi defensa

los maestros primaverales

Ellos vienen al lado de los sueños que tengo

trayendo los tambores del silencio

$[\ldots]$

Escúchalos con la tercera oreja

como cuando habla el viento

y a ti te dice cosas increibles

(«Melinea»)

La poesía, como la música, posee la capacidad de sintonizar con la magia de la existencia, con la energía cósmica que atraviesa a todos los seres y posibilita la experiencia de sentir la perfecta unidad con un cosmos que adquiere rasgos de divinidad. La poesía, como ya hemos visto anteriormente, se convierte en un lenguaje de silencio.

Sangra la mente en blanco y sintonizo náufrago en el bajío del lenguaje

$[\ldots]$

Ante todas las cosas que estallan agonizo

Contemplo el templo mudo del salitre

Arrodillo mi frente en el secano

(«Saloma»)

La poesía, como música órfica, está ligada a la experiencia alquímica, dionisíaca, de transformación. En este sentido en ocasiones queda asociada a la locura, hecho que ha sido una constante de la poesía oryana. De manera irónica se expresa Ory al respecto, activando la imagen del pasado, cuando la ortodoxia de la primera posguerra quiso excluir su discurso de la territorialidad poética y despectivamente fueetiquetado como Lautréamoncito o el Rimbaud andaluz ${ }^{399}$ :

${ }^{399}$ Así queda certificado en el Diario (2004, Vol. II: 192-193) y en el poema titulado «Vir Obscurissimus», escrito en Amiens el 21 de marzo de 1972, perteneciente a Miserable ternura y publicado en Miserable ternura - Cabaña, Pozuelo de Alarcón, Hiperión, 1981, p. 59:

A mí que me llamaron el rimbaudandaluz

lautréamoncito novokafka novocatulo

- cotejos y mixturas al monje monspermo-

¡Comparadme a la bestia que se lleva su morral! 
Todavía mantengo la música locura

aislado del rebaño leproso de la poesía

(«Agenda»)

Ory, en su vejez, se autoafirma sobre el recuerdo y propone el valor alquímico de la poesía, la «locura poética»:

Porque yo sigo siendo el mismo mudo místico

imbuido de aquellos soplos iniciales

motivando las frases ancianas de los puros

labios de la locura la locura poética

y ellos terminarían por besar la mañana

fraterna de los hombres bajo el eterno soledumbre

¿Quién dirá que grité música en el desierto?

Diabólico es el día de gasoil

El vómito del mundo cayó sobre mis pies

y vi un ángel borracho con un dedo en la boca

Entonces comprendí mi corazón atónito

En la jaula de león de una lágrima sólida

estuve solitario callado mucho tiempo

Garganta noble hija de la angustia

y las canas me muerden las carnes del espíritu

¿Qué es lo que entrará en el ataúd?

El cuerpo mío igual que un jazminero

vos y oreja avisados del don personalísimo

Ahora soy un viejo rapsoda terrenal

$(«$ Poeta»)

Otrora el lento labio del laúd supuró

como si del mugido del ser no hiciera mofa

y mi lengua lamiente imitando la res

con instinto fatal gustó el pus de la llaga

(«Agenda»)

Frente a la música airada, símbolo del vendaval de la heterodoxia, en Melos melancolía se alude también a la música de las esferas, concepto pitagórico reformulado por el neoplatonismo, tal y como ya se ha observado anteriormente al tratar la euritmia. La poesía toma los rasgos de la música y se convierte en receptáculo del movimiento cósmico armónico, cuyas notas quedan traducidas en la danza de los 
planetas. Las vibraciones armónicas de la poesía eternamente emiten armonía y vitalidad a los elementos cósmicos, y así la música se convierte en pasión, dolor, amor o éxtasis.

\author{
Ya musito lo mío \\ favorito como antes \\ mas nuevamente hecho \\ mole concorde al tacto \\ sino polvo de perlas \\ Sea la partitura \\ Y sea poesía de pasiones \\ que en su viejo emitir \\ responda a las claves \\ memorables \\ Aureolas auspicios \\ hagan sitio a la vida \\ en el eidos ahora \\ mientras toco
}

(«Pupitre»)

En este poema Ory activa la imagen neoplatónica de la música de las esferas. De la cítara tañida por el ser divino surge una música que crea el movimiento armónico del universo celeste, inmersos en él los planetas trazan sus órbitas perfectas. El poema establece una conexión muy evidente con la poesía de Fray Luis de León. En la «Oda a Francisco Salinas» y en los siguientes versos de la «Canción de la vida solitaria» la música queda configurada como vehículo de la experiencia mística:

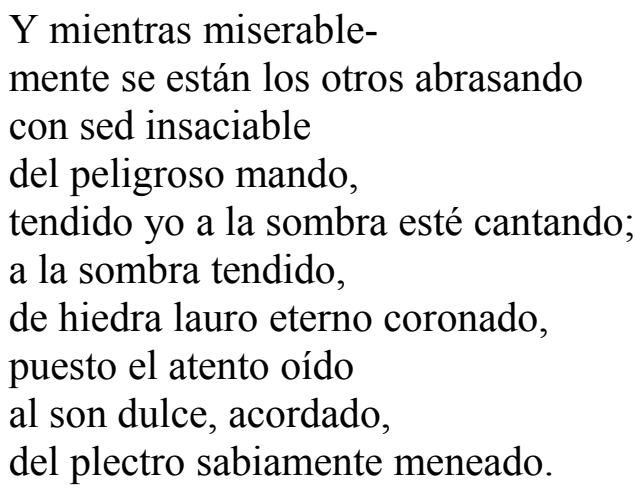

La mística de Fray Luis de León queda establecida en la concepción de la unidad cósmica divina. Idea del gran Uno, que todo lo contiene, de Plotino, concepto que desembocó, a través del pensamiento neoplatónico renacentista, en la idea de un mundo 
divinizado, reflejo de la divinidad de su creador. De este modo cristianismo y hermetismo, egipcio y persa, quedaron unidos y ofrecieron la idea de una divinidad inmanente en la que el ser supremo, Dios, se manifestaba en la realidad ${ }^{400}$.

La poesía oryana, en cierta medida, procede de la lírica órfica, de la música que antiguamente acompañaba a la palabra cuando la poesía era todavía canto. Música primigenia, pues. Para José Ramón Ripoll (2012a: 18), poeta y musicógrafo que estudia la actividad musical en la poesía oryana, Ory cree en una música primordial que antecede a la palabra y que la poesía ha de moldear uniendo matemáticas y metafísica:

Esta música nos habla -apunta Ory-, «de problemas y respuestas, de técnicas y sistemas, de descubrimientos». Y añade: «Esta dialéctica es apasionante». Metafísica y matemáticas juntas [...] La regla de oro de su lírica, que asigna forma y orden a su manantial sonoro, ese que mana agua parlante del centro de la tierra o de los dioses del canto y la poesía (2012a: 18).

Concepción pitagórica de la música cuyas vibraciones quedan establecidas por la combinación matemática, de manera que realidad física, sonido, y construcción mental quedan unidos e imbricados. Unión que además tiene la capacidad de suscitar una emoción. Para Pitágoras la música podía hallarse también en el interior humano y estaba en consonancia con é ${ }^{401}$. La concepción oryana de la música convierte a la poesía en una reverberación de vibraciones, tal como ocurre en los mantras orientales. Ory busca la música del origen, la música que ha existido desde siempre:

Pisando las alfombras terribles de la noche en un ocio mayúsculo guardián de mi dolor toco la lira monocorde de la angustia Infinita es la música del invierno en mi alma Cuánta pasión de lluvias y de nieves mantengo Busco el castalio chorro búscolo

(«Lantamara»)

La «lira monocorde» se interpreta como una referencia al monocordio pitagórico, instrumento que Diógenes Laercio atribuye a Pitágoras y que consistía en una cuerda

${ }^{400}$ Castro, Américo (1972), El pensamiento de Cervantes, obra cit. p. 163.

401 Gómez Pin, Víctor (2015), Pitágoras y el pensamiento presocrático, Madrid, Batiscafo, pp. 89-90. 
tensada sobre una caja de resonancia y un dispositivo que permitía modificar la longitud de la cuerda que se pulsaba para producir la vibración. De manera que la sucesión de notas creaba la frase de sonido. Así quedó establecido que la secuencia matemática era la que producía el sonido melódico.

La música es infinita y se encuentra en todo fragmento del cosmos, música que atraviesa cosas y seres envolviéndolos en su red de sonido:

Oiga el lector un habla que me ensoga entre peces y estrellas queriéndome servir del mejor aire métrico a ras de la marea

(«Trova inefable»)

5.2.2. Figuras en el paisaje

Presentamos aquí algunos motivos o esferas significacionales que, con anterioridad, han sido elementos recurrentes en la poesía de Carlos Edmundo de Ory. Son figuras, imágenes, rostros... vislumbrados ya y que, de manera cíclica, aparecen de nuevo perfilando su sentido, a la vez que adquieren nuevos significados. En este caso se trata de personajes que han adquirido el estatuto de símbolos y, con el tiempo, desarrollan nuevas aristas en su significación poética.

\subsubsection{El vagabundo}

Los primeros versos de Melos Melancolía son estos:

¡Ay del nacido! ¡Ay del trotamundos! Bajo el sol y la luna y las constelaciones entre los infinitos destellos de lo alto todo lo más vecinos ridículos del pájaro que no se posa encima de la cabeza humana nos nostálgicos de cúspides y ápices ${ }^{402}$ pisando limo caminamos hacia donde

${ }^{402}$ Sic. 
La tierra de la miel el humo y la basura

y cuanto exhala el mundo en mi nasal nativo

respiré respiré su perfume y su tufo

apenas descendí de la nave invisible

el iodo y el jazmín milagrosos efluvios

(«Canto criaturial»)

El poemario se inicia pleno origen de la existencia individual y destaca la condición itinerante del ser humano. El yo poético se define como personaje mítico, metafísico incluso, pues el referente más importante de la obra es la existencia. Existencia itinerante que consiste en un permanente viaje a través de una realidad mítica, comunal, en la que no existen espacios propios para los seres. El yo vagabundo es un ser totalmente apátrida. La imagen del poeta como nómada permanente, cuyas máscaras son las del loco, el maestro errante o el sabio vagabundo, ya ha sido estudiada con anterioridad. Cabe mencionar, en todo caso, las referencias poéticas que apuntan a la imagen del poeta como viajero perpetuo, como vagabundo del Dharma establecida por el escritor beat Jack Kerouac en The Dharma bums. En ella la imagen del vagabundo señala a los viejos maestros errantes y pobres del taoísmo y del budismo zen. La poesía de Ory discurre por un tinerario análogo:

Caminante en harapos me encamino seguro al hondo valle donde vivaquean los mílites del crimen con sus gafas ahumadas allí el generalato cocina su cordero Niños sin pan ni leche rodan ${ }^{403}$ in nemoribus seres humanos huyen de las flores Ya no quedan poetas errantes en Europa

(«Garito»)

La realidad es vista desde la óptica descentrada y marginal de la extrañeza. Sentimiento que ofrece la no pertenencia a ninguna zona particular de la realidad, a ninguna tierra y a ningún país. El yo poeta muestra sus señas de pertenencia a la realidad cósmica y ofrece su visión mítica frente a la banalidad surgida de la estrechez de la mente que configura la realidad social alimentada por el ruido de fondo que amansa a los individuos. La imagen trazada del poeta es la del viejo rapsoda órfico que

403 Sic. 
canta el éxtasis ante el remolino indiferenciado de la realidad dionisíaca. La visión mítica queda contrapuesta a la grisáceo escenario social, caracterizado como oscuridad, noche, dolor... En este sentido, la obra toma la forma de un lenguaje hermético que describe un proceso trasformador que lleva al yo poeta más allá de las tinieblas. Transformación que es iluminación, mística inmanente:

Lejos de los escollos lejos de las orillas cantando con dulzura a ras de onda tripulo en el crepúsculo divino

$(«$ Saloma»)

¿Qué hago en esta caverna yo el bebé de las olas?

Acaso no soy más que un polizón atávico

o me jacto de ser eterno marinero

(«Adonaï Adonaï»)

En estos últimos verso existe una clara referencia a la caverna platónica, símbolo de la ignorancia. La «caverna» de Ory establece sus conexiones con el libro VII de La República, en el que Platón se expone el mito de la caverna. El conocimiento experiencial permite que el poeta pueda traspasar la oscuridad y, más allá de la caverna, dirigirse hacia la luz, signo de la conciencia de su integración cósmica.

En el poema «Imágenes» el poeta aparece como un «argonauta anónimo» y un «anacoreta» consciente de su naturaleza divina porque se siente receptáculo y partícipe de la energía cósmica:

Entonces me enamoro del sol y voy descalzo por una playa luenga cuyas arenas vírgenes son amantes del mar y yo su hijo legítimo Por eso mi conciencia visionaria creció y edifiqué mi ética en el espacio abierto

La referencia a la obra de Apolonio de Rodas, Argonáutica, activa el simbolismo del viaje como itinerario existencial, viaje realizado por el héroe mítico Jasón y los argonautas en su expedición a la Cólquida en busca del vellocino de oro. La imagen del poeta como ser itinerante, que viaja a través de una serie de espacios abiertos, alude a la 
escritura rizomática y periférica que queda instalada como nomadismo cultural. Escritura que, como ya hemos visto con anterioridad, hace rizoma con el mundo y se pliega a él (Deleuze y Guattari, 1980, 1988: 16). Si hay alguna escritura de este signo es la de Carlos Edmundo de Ory:

Borracho en el columpio de la vida hace tiempo que soy un harapo portátil

Pisando estuve en el éxtasis mis pétalos y mis ojos

Ya no puedo decir que me acuerdo de mí

Busco mi mascarilla rascándome la sien parezco inmaterial

Me siento pleno de mi nada virgen

(«Torbellinos»)

La experiencia de poeta vagabundo queda plasmada como experiencia budista de la vacuidad. El poeta es un nómada que participa del desfile de la existencia, de la danza de la vida que Shiva realiza. Danza que armoniza todos los contrarios, como ya se ha visto, y que engloba a todas las criaturas en una única espiral eterna que alimenta la energía cósmica que penetra cada miríada de la existencia (Watts, 163, 1990: 94). La vida se renueva en nuevos ciclos de nacimientos y muertes, del mismo modo como Brahman se reencarna a sí mismo en nuevas existencias (Panikkar, 1989: 76-70).

Transeúnte del puente colgante a dónde vas A los grandes teatros del amor y del dolor sin traje de etiqueta acudo a toda hora A mí me bastan mis andrajos de moaré

(«Efigie genesíaca»)

La poesía oryana propone la elementalidad de la realidad frente a la cultura humana y sus derivaciones.

Desprecié las banderas y toda trapisonda a la busca incesante del sentimiento oceánico con fervor de aborigen que naufraga en el éxodo

(«Imágenes») 
Nazcamos y en el acto preciso levantéis de seda negra la bandera únicamente que no haya otra en esta isla al pairo sábete de memoria tu camarote náufrago ex-marinero hombre de pelo en pecho tripulante del mundo hasta morir

(«Trova inefable»)

El vagabundo es el ser que elige vivir la elementalidad, imagen recurrente en toda la obra que va adoptando distintas máscaras: arlequín, payaso, zíngaro, loco, marinero, mendigo, sabio... En todas ellas se trata de un personaje marginal y heterodoxo, reflejo del sujeto poético:

La garganta en hilachas ser harapo de canto vendaje o veste única que tuvo de atavío un mendigo del mundo llevado como manto

(«Cavatina»)

Nunca tuve casa propia

Por eso vagabundeo y me alejo

(«Bajo mi lámpara de trabajo»)

Me tratan de loco en mi casa rezan por mí

Pero no rezan para que yo sea yo mismo sino para que sea como ellos

(«Viva vox»)

Ha bajado la tierra su telón

Pero yo no me quito jamás me quitaré mi mascarilla negra de Arlequín

(«Viva vox»)

Todo un tiempo poseso del numen insondeable mientras llevo consigo la tara de la estirpe Avento el humo negro de mi cabeza hereje

(«Desembarcadero») 
Entre todas las máscaras cabe destacar la imagen del poeta lobo, que ha sido figura constante en la trayectoria poética oryana y que, en primera instancia, remite a su obra Música de lobo (1970). En ella ya se encontraba la referencia intertextual que apuntaba a la obra de Hesse Der Steppnwolf (1927), poeta como lobo estepario que se aparta de la manada burguesa. En este sentido resulta sintomático encontrar el siguiente texto que pertenece a La memoria amorosa, obra posterior a Melos melancolía, que se erige como recordatorio de una serie de instantáneas de su periplo vital:

En la Biblioteca Nacional de Madrid me tomaban por sospechoso. Pedía libros que nadie pedía. Ocurrió un incidente vergonzante. Tuve una vez más la impresión de que la sombra de Torquemada no había desaparecido del país. Un día pedí a la mesa de solicitaciones de libros la novela de Herman Hesse titulada EL LOBO ESTEPARIO. He aquí que me siento en mi puesto y me pongo a leer. Como no podía devorarlo en unas horas, lo devuelvo y retorno al día siguiente para continuar la lectura. Apenas abro páginas cuando se me acerca un empleado, me reclama el libro, más exactamente lo coge de la mesa, lo cierra en las páginas que estaba leyendo y, señalando con un dedo perentorio la cubierta, me designa, debajo del título EL LOBO ESTEPARIO, la extraña frase entre paréntesis: SÓLO PARA LOCOS (2011: 75).

Existe además un paralelismo perfecto entre los territorios culturales que interesaron a Hesse y a Ory: la marginalidad, la música, la cultura oriental y la experiencia mística:

Recuerdo cuando yo era orfebre del abismo acodado en mi ser lobo de la esperanza

(«Agenda»)

\subsubsection{Los dormidos}

Melos melancolía en cierto sentido funciona como un descenso a los infiernos y nos ofrece un retrato dantesco tal como El Bosco o Bruegel mostraron en sus cuadros. En este sentido muestra una descripción de la realidad humana y de la decadencia de un determinado modelo socio-cultural. La imagen que la obra ofrece del ser humano está teñida de cierto pesimismo existencial que posee sus conexiones con la visión del ser humano que ofrecía la poesía surrealista de Vicente Aleixandre, instalada en la impronta de la elementalidad y el panteísmo cósmico. La obra aleixandriana donde se plasma el 
pesimismo humano de una forma más aguda es Sombra del Paraíso (1944), en ella se utiliza el símbolo poético de los dormidos para expresar la realidad angustiosa del ser humano. En la simbología aleixandriana los dormidos son aquellos seres que viven a la sombra del paraíso. Sus signos son el exilio y la caída, pues son seres exiliados y caídos, separado de los demás seres y de la realidad misma. Seres excluidos de una realidad divina porque se hallan atrapados en su propia individualidad, en su ego particular. Hecho que les hace percibir que son corpúsculos inconexos despegados de aquello que les envuelve y por ello se sienten excluidos del fluido orgánico y vital de la realidad, de una realidad que adquiere visos de divinidad. La óptica oryana muestra su paralelismo con la consideración del ser humano de Vicente Aleixandre: ser triste y solitario, aislado en su tristeza y en su angustia, vacío, gris, anodino porque ha perdido la experiencia directa de la realidad, su conexión con la elementalidad del universo. Para Aleixandre, la pérdida de la inmediatez ante lo real deriva de la mediatez conceptual ${ }^{404}$. Las relaciones del ser humano con la realidad están filtradas por la red de símbolos que crea el lenguaje y el pensamiento y ello lo aleja de la energía cósmica, de la experiencia beatífica que los demás seres experimentan y comparten. Así lo expresa Ory:

El pensamiento escrito trae engaño agazapado pues no hay persona que habla sino pergamino muerto Las palabras se enfrían como cadáveres

$$
\text { («Viva vox») }
$$

Los dormidos son únicamente los seres humanos, que se han alejado del movimiento cósmico y han olvidado que forman parte del cosmos divino. Ello queda perfectamente expresado en el poema de Aleixandre titulado «Al hombre» de Sombra del paraíso:

${ }^{404}$ Para Aleixandre la divinidad es cósmica, inmanente, cuyo signo es la naturaleza más elemental e incontaminada por la actividad humana. Si el paraíso queda asociado con lo natural, la luz; la civilización queda asociada al infierno, su sombra:

¡Ah! Amigos, arrojad lejos, sin mirar, los artefactos tristes, tristes ropas, palabras, palos ciegos, metales, y desnudos de majestad y pureza frente al grito del mundo, lanzad el cuerpo al abismo de la mar, de la luz, de la dicha inviolada, mientras el universo, ascua pura y final, se consume. 
Regresa tú, mortal, pura arcilla apagada, a tu certera patria que tu pie sometía.

He aquí la inmensa madre que de ti no es distinta. $\mathrm{Y}$, barro tú en el barro, totalmente perdura.

Barro, sueño, sombra. Barro, pero barro divino. Los dormidos se hallan sumidos en la oscuridad porque aún no han despertado y no han conseguido el estado de iluminación, tal como se denomina en ciertas corrientes religiosas. Son seres que no poseen, por tanto, conciencia de su verdadera realidad y, por ello, viven exiliados del «paraíso», tal como queda manifestado en la poesía oryana:

Mentecatos destruyen de antemano visiones

en las ondas solares del camino

Ha sido siempre así la multitud sellando la conciencia a cada paso

Daños cunden y muchos se equivocan

desde que el bajo suelo está viciado

Pocos son los responsables del tejido

La corteza terrestre lacrimosa

la atmósfera maltrecha

No hay técnicos de eternas lontananzas

Raros son los humanos que algo vieron

(«Tenebrae»)

Parece una visión apocalíptica, una instantánea del descenso a los infiernos. Pues Melos melancolía, en cierta medida, toma la forma del itinerario dantesco. Viaje iniciático, que tiene tiene algunas referencias biográficas, y se dirige hacia territorios culturales alejados como las concepciones presocráticas de la realidad y las filosofías orientales. En todo caso, se trata, a la vez, de un viaje hacía la mística. Esta visión trágica y siniestra del ser humanos coincide con la imagen que Luis Cernuda nos traza: seres oscuros, sombras, seres muertos aunque sigan en vida. Por ello Cernuda los asocia con los fantasmas, los vampiros y los muertos insepultos:

Con vida misteriosa quizá los hombres duermen mientras desiertos blancos representan el mundo; espacios tan pequeños como tímida mano, silenciosos, vacíos bajo una luz sin vida.

Sí, la tierra está sola, bien sola con sus muertos, al acecho quizá de inerte transeúnte 
que sin gestos arrostre su látigo nocturno;

mas ningún cuerpo viene ciegamente soñando.

(«Decidme anoche», Un río, un amor, 1929)

La imagen del ser humano como ser dormido se repite de forma recurrente en Melos melancolía:

¡Ay del nacido! ¡Ay del trotamundos! unos con sus pestañas quemadas otros concentración sus pezuñas de recua más todos trajinando idénticos a máquinas pálidas y nerviosas han perdido la savia han perdido el saber dejados de la mano magnífica del cosmos

(«Imágenes»)

Oscuras claridades a galope circulan cabe la frente mía como hiena que aúlla a las estrellas la cabeza alta y que ni ven el mundo en su palor de sombras Ya decoran la noche mas el hombre insensible duerme a ojos cerrados y los abre despierto sin saber que otro sueño les mueve a dormir

(«Lantamara»)

Ory asocia esta imagen fantasmagórica de los seres humanos con la dinámica de vida burguesa y la hipocresía social:

Lodo y sangre salpican nuestras bocas Me da pena mirar la corbata del mundo Fantasmas con zapatos de charol A cada despertar agoto mis pupilas Encuadernando lágrimas estoy

(«Bajo mi lámpara de trabajo»)

¿Quién va? ¿Son ratas o transeúntes fulminantes?

Solitario paraje de la queja

Los malheridos y aquellos que esconden su dolor

(«Bajo mi lámpara de trabajo») 
Muchos son los que rezan arrodillados

junto a la cama antes de dormirse

Ya está ya cumplí

No quiero estar en deuda con la religión

(«Viva vox»)

Unos cuantos granujas con sangre en las corbatas

afilan sus cuchillos en lingotes de oro

(«Garito»)

Frente a la imagen pesimista del ser humano, frente a los seres dormidos, se opone el ser marginal que se autoexcluye de la normativa social. Este personaje, como ya se ha expresado anteriormente, aparece bajo diversas máscaras y, en todo caso, funciona como símbolo referencial del yo poético, imagen autorrefencial oryana: piratas, marineros, payasos, locos, vagabundos, místicos... Personajes distanciados de la dinámica de la moral social y que, por ello, poseen un compromiso más estrecho con la realidad. En cuando seres excluidos del funcionamiento social, son seres iluminados, capaces de sentir en sí la elementalidad de la existencia, seres conscientes de que forman parte de una realidad infinita, conscientes de ser fragmentos de un cosmos inseparable.

Adiós los ojos míos que vieran lo que vieron

Los antiguos payasos y los locos preciosos

Portentosas farándulas caravanas de cíngaros

antorchas y fogatas en la noche envidiable

¡oh seres milenarios mensajeros de ritmo!

Humanos marginales que supieron beber

el látex de la luna inmemorial

\section{(«Viva vox»)}

La poesía de Melos melancolía expresa de este modo la verdadera realidad del ser humano, la de ser un ser divino, no distinto de la divinidad. Por ello, el despertar de los seres dormidos consiste en considerar que la conciencia humana de separación y de exilio es pura ilusión. La realidad humana consiste en experimentar la beatitud que 
ofrece sentir que el paraíso está dentro de uno mismo. En este caso, en el interior del sujeto poético:

Aquí va el universo poniéndome la piel de la noche como un abrigo de cristal ¿Está la luna fuera o está la luna dentro?

(«Lazareto de los sueños»)

Paraíso perdido derrumban tus vestigios

Luz limpia de las cosas revela el sol antiguo con la llave del alma que no se oxida nunca

(«Adonai adonai»)

Mi alma piafa estoy mirando el cielo Hombre de asombro omnímodo contempla con ojos instintivos de reptil toda luz en el lar infinito Yo mismo reverbero suavemente y asumo en trance síquico el poder inasequible el triunfo nugatorio $[\ldots]$

No te detengas y camina lento hacia el umbral del cosmos pavorido Abandónate a vínculos sin tacha

(«Cojeando por los campos»)

Melos melancolía supone un viaje interior, el viaje que realiza el ser a través del océano de la existencia, viaje que es, al mismo tiempo, una celebración del hecho de existir.:

¡Estoy vivo! ¡Estoy vivo! grita mi corazón conforme con la ley solar de los festines flotando como un corcho en las sombras azules

(«Crepúsculo del batelero») 


\subsubsection{Los seres intermedios}

Melos melancolía profundiza en la cultura sincrética de la antigüedad, en las creencias egipcias, hebreas, griegas, islámicas... Sobre todo profundiza en la sabiduría, hoy olvidada y oculta, que se desprende del lenguaje simbólico y mítico que sustenta la hermética egipcia y su herencia alquímica, las filosofías presocráticas, la mitología antigua y la literatura tradicional. De estos territorios Ory toma concepciones ideológicas y simbología adaptándolas perfectamente a su expresión poética. Por ello, la poesía oryana supone una búsqueda del origen tanto personal como colectivo. Así persigue el origen en el recuerdo particular de la infancia y en el lenguaje humano mítico, arcano y hermético, de signo social. La simbología oryana, escapando de la tiranía de las visiones monoteístas, coloca al ser humano en un espacio mítico habitado por seres divinizados como dioses, semidioses, héroes, ángeles... Seres que son representaciones de escenarios humanos, cuyos símbolos poseen siempre un referente humano muy próximo al sueño y a la poesía. Para Jung (1912, 1963: 50), el mito, como el arte, tiene la posibilidad de hacer consciente lo inconsciente, por ello supone una vía de acceso al origen humano.

\subsubsection{1. Ángeles}

Como ya hemos visto, Ory tiene predilección por los ángeles. El ángel, en la ortodoxia judeo-cristiana, tiene estatuto de ser intermediario, situado entre la divinidad y el ser humano. En este sentido la presencia de los ángeles nos alerta de la deriva destructiva que ha tomado la realidad:

Toda la luz se enciende en apagones y se hace trizas la conciencia laica Viendo estás un inmenso desgarrón Los ángeles ansiosos golpean las aldabas nadie acude al portal han perdido la llave cunde la asebia y triunfa el asesino ¿Quién sabe del espacio cuajado de milagros?

Dios ya no huele a heno en los campos de azufre

\section{$(«$ Garito»)}


Visión dantesca donde los ángeles se hallan prisioneros en el laberinto infernal en el que se ha convertido la realidad. Pero los ángeles, como seres intermediarios, llaman a los hombres y les ofrecen el eco del origen perdido, ya que el ángel es el mensajero entre el ser humano y la divinidad. El lenguaje de los ángeles aparece en varias secuencias de la obra:

Vibra la voz del ángel en el aire incoloro cuando el tambor de luna de la noche infinita colma mi pensamiento de arquetipo sonoro Era la voz que supe todavía no escrita antes de que el dolor fuera bello bordado sobre la seda negra de la frase maldita

$$
\text { («Cavatina») }
$$

Murmullo de criatura tan preciosa que fuera aleteando en su bosque y mírola lamer la oscuridad dañina dándose con la noche Ya el ángel del lenguaje no encabeza el disfrute ya no más medio mudo la sonrisa le aureola

(«Ruinas luminosas»)

La voz del ángel, que surge del aleteo de sus alas, se expande entre el paisaje ruinoso de la realidad. El lenguaje del ángel, símbolo de la poesía, expresa el dolor existencial, porque el ángel, como trasunto humano ${ }^{405}$, es un ser caído que habita en la noche humana.

En el poema «Sacra» Ory cita a los ángeles Serafín y Gabriel como paradigma de seres divinos, conscientes de su propia divinidad:

Nuestros ojos de arcilla frágiles ante el muro no ven la puerta janua que nos franquea el paso adentro de la mina donde se encuentra tope forzosamente entonces chocamos con terror salvo los predilectos que en el in pace aguardan la salida inminente de este mundo soez Materia prima dijo el Ángel de la Escuela refiriéndose al alma también no sólo al cuerpo

${ }^{405}$ Rafael Alberti, como ya se ha visto, trató poéticamente, desde una optica surrealista, la humanidad de la figura simbólica del ángel en Sobre los ángeles (1928). 
mientras que de lo Alto donde la casta especie

habita bellas alas oh beata Seraphim

son ellos los espíritus abrasados de amor

y de luz que elegidos paradisiacamente ${ }^{406}$

sin pasar por el árbol de los siete pecados

conforme a la esperanza de la divina ciencia

con inefable gozo digno de eternidades

contemplan los suplicios de la tierra infernal

Dame leche le dije a mi ángel dame leche

Lo más precioso que conozco es Gabriel

vestido de hombre y llevando tres copas

$\mathrm{Ni}$ el vino ni el agua me has de dar

Quiero el blanco conocimiento

El mundo es la sombra de la Majestad

Sólo aquí el absoluto tiende al negro

que es ala izquierda del gran ángel

y nuestra sola cuna de tinieblas

La angustia es bella y sin embargo y sobre todo

llamo a Gabriel el único señor

de autoridad legítima el seguro

custodio y fénix del ángelus

Hagios que cura los tumores del espíritu

sé mi último médico y primero

El sudor de la mente también has de evitar

Oh modelo perfecto oh Enviado

¿Cuál es mi rango cuál es mi plenitud

que me cobije bajo su ala derecha?

En este poema, escrito con un lenguaje totalmente hermético, el ángel Serafín aparece, representado de forma femenina, como ser de fuego, símbolo pasional del amor y de la alegría. Representa el goce de vivir una existencia sin conciencia de pecado y sin experimentar la angustia humana. Ángel, pues, que representa la conciencia de sentirse ser divino. La literatura hebrea le otorgaba la luz celeste, pues los serafines eran concebidos como seres ardientes, ángeles de fuego o rayos de luz, que pertenecían a la jerarquía más elevada del panteón celeste. En el poema, Serafín aparece como llama, perpetua combustión amorosa, porque es consciente de su unidad infranqueble con la divinidad. Es el ángel del cielo. Por otra parte, el ángel Gabriel ${ }^{407}$ queda asociado al conocimiento y en el poema representa la dirección que lleva a la noche y a la conciencia tenebrosa de la realidad. Para Ory, es el ángel que se instala en la tierra, el ángel de la tierra. En la tradición es símbolo del mensajero, el emisario o agente anunciador. En el cristianismo es el arcángel San Gabriel quien anuncia a María la

406 Sic.

407 Tratado ya por Lorca en el poema «San Gabriel» del Romancero gitano (1928). 
futura llegada de Jesús. En el islam es Gabriel quien revela a Mahoma la palabra divina, por ello queda convertido de este modo en el último de los profetas bíblicos. Gabriel es el intermediario entre el hombre y el dios trascendente, el intérprete del verbo divino que emana del cielo, espacio ocupado por este ser divino superior que no habita en la tierra y, por tanto, no queda en ella contenido. En el poema, la figura del ángel toma el sentido que tenía en el judaísmo. Es el ángel mentiroso, el tramposo que engaña a los hombres y, por ello, queda asociado a la oscuridad, a lo maléfico y a lo demoníaco. Es aquel que esparce las tinieblas sobre la realidad, el que crea la sombra. Como tal, es el ser que confunde al ser humano transmitiéndole la conciencia del exilio y de la caída. Ahora bien, de otro lado, es también el portador de la luz del conocimiento mediante el cual el humano puede abandonar la conciencia habitar en una realidad sombría.

Jaime D. Parra (2001b: 325-333) interpreta, en su artículo «El rumor de las alas de Gabriel: la última poesía de Carlos Edmundo de Ory», la poesía oryana a la luz del sufismo y la relaciona con el tratado titulado El rumor de las alas de Gabriel, escrito por el iraní Shîhâboddîn Yahyâ Shoravardî, seguidor de Avicena. Según el místico sufí, el ala derecha del ángel apunta al cielo, a lo divino; en cambio, la izquierda se dirige a lo humano, a la tierra, a la realidad. Las dos alas simbolizan la luz y la oscuridad. La óptica oryana supone, a nivel simbólico, la convergencia de las dos alas del ángel, encontrar la luz de lo divino en la realidad humana. Por ello la poesía de Ory profundiza en la oscuridad con el fin de deshacer el espejismo creado por las apariencias ilusorias. En el poema anterior Ory busca lo sagrado, representado por el ala derecha de Gabriel, que se halla imbricado, de manera oculta, entre los pliegues de la realidad. Podemos interpretar el significado de la oscuridad como el fondo necesario para poder percibir la luz. La imagen arquetípica de la sombra, cuyo símbolo más extremo son la tiniebla y el infierno, es una faceta más de la realidad sagrada vivida por el ser humano. Diríamos, en el sentido oryano, que el infierno es también parte integrante de la divinidad:

Sólo aquí el absoluto tiende al negro que es el ala izquierda del gran ángel y nuestra solo cuna de tinieblas

Jung (1938, 1949: 98-101) interpreta la imagen de la oscuridad y de lo maléfico asociándolo al arquetipo de la cuaternidad, símbolo de una divinidad que se manifiesta 
en la realidad creada, en la tierra. Frente a ello, la trinidad, símbolo de la realidad celeste, es para Jung la imagen de la cuaternidad sin diablo, cuyas aristas son: Dios, Eva, Adán y el diablo. Para Jung, la interpretación trinitaria, imagen central de la ortodoxia cristiana, consiste en excluir lo maléfico no sólo de la existencia, sino también de la divinidad. Ahora bien, diablo y dios, tiniebla y luz, se hallan totalmente asociados como caras inseparables de una misma moneda, tal como señala Carlos Edmundo de Ory en el poema anteriormente comentado.

\subsection{Héroes, dioses, semidioses}

Melos melancolía es una obra cuyas referencias se dirigen a los orígenes de la tradición simbólica y cultural. En ella encontramos imágenes míticas que pertenecen a la cultura grecolatina, egipcia, persa... y que simbolizan facetas y realidades inherentes al ser humano como deseos, situaciones, problemáticas, cualidades... Aquello que dioses, semidioses, héroes y toda la gama de la imaginería mítica comparten con el hombre es, precisamente, su humanidad. En la obra aparecen varios referentes clásicos como Hermes, Isis, Priapo, Eolo, Neptuno, Venus, Helena, las sirenas y otros seres arquetípicos que reactivan los significados humanos convergentes.

Neptuno, Eolo, Helena, sirenas, nereidas, junto al concepto hinduísta de avatar, tratado ya con anterioridad, aparecen en los poemas «Canto criaturial» e «Imágenes»:

El corazón que tengo se lo debo a Neptuno

Lloro el embarcadero alejado de mí y lloro los escollos de mi nuevo avatar al borde de las aguas sintiéndome mirado por los ojos de Eolo como si fuera un héroe Entre estrellas y cuevas anduve ensimismado bajo la cabellera salada de la noche y avanzando moroso hacía el bajío iba a través del varec y la arena aguanosa Pero perdí mi olfato mágico tierra adentro

(«Canto criatutrial») 
Celebro las nereidas que fueron mis penates

Todo mi corazón se lo debo a Neptuno

[...]

En el embarcadero lejos de mi dejé

la cama de mi voz mi camita de cantos

aquel brizo columpio de sueños

que meció la sirena cuyo rostro no vi

Pero vi los escollos de mi nuevo avatar

al borde de las aguas sintiéndome mirado

por los ojos de Eolo como si fuera un héroe

un argonauta anónimo que pernocta en la rada

y cuántas entidades supe del demiurgo

cuasi criaturas todas ciertamente theoi

sorprendentes palabras concretas y reales

las sed la lluvia el frío el aliento de Helena

y las rocas las rocas almohadas del espacio

(«Imágenes»)

Estatuto de ángeles poseen en ellos dioses y criaturas míticas. Si los ángeles pertenecen a los mundos celestes y, en ocasiones, descienden sobre la tierra haciendo de intermediarios entre ambas realidades, estos personajes se relacionan con el mar. Eolo y Neptuno son dioses, las nereidas y las sirenas son criaturas mitológicas que habitan en el mar y acompañan al héroe en su viaje marítimo, tanto a Ulises como a Jasón. Ambos textos ofrecen la misma imagen existencial: la vida humana como viaje perpetuo. El ser humano, pues, es un marino eterno que se halla inmerso en un viaje infinito. El mar es el espacio abierto de la existencia, una existencia que no acaba con la muerte sino que es apertura hacia otras existencias y realidades. Y no es el mar lugar sombrío, sino espacio de luz:

Entonces me enamoro del sol y voy descalzo por una playa luenga cuyas arenas vírgenes son amantes del mar y yo su hijo legítimo

(«Imágenes»)

Los seres imaginarios no son figuras amenazantes, sino compañeros del viaje a través de la existencia, de esa espiral infinita en el espacio y en el tiempo, que realiza el sujeto del discurso. Son seres interiores porque se trata de un viaje interior, seres que de algún modo residen en la vida íntima del poeta. La música de las sirenas y de las 
nereidas es música metafísica, cuyo signo es la poesía, lenguaje de los sentimientos. Lenguaje interior, cuyo significado emocional es el vehículo adecuado para trasmitir el misterio de la existencia. Viento y mar, Eolo y Neptuno, son símbolos marítimos que remiten al océano, cuyo referente es, en última instancia, la existencia ilimitada e infinita. En ella no hay ningún elemento aislado, porque todos sus componentes, ya sea viento o lluvia, cielo o ser, quedan trasmutados en elementos sagrados, «theoi», miríadas que forman parte de una realidad divina indivisa.

Por otra parte, el poema «Imágenes» alude al «frío aliento de Helena». Helena, la heroína y daimon, semidiosa, ser intermedio que aparece en los cultos micenaicos del siglo VIII a C. Sobre ella existen testimonios en el tratado Sobre los misterios de Egipto escrito por el neoplatónico Jámbico de Celeseria, en la obra Epitalamio de Helena de Teócrito y en la Iliada de Homero. Helena, la hija de Zeus, debido a su extrema belleza era pretendida por muchos héroes. Fue raptada por Paris y ello marcó el inicio de la guerra troyana. Helena, divinizada ya, se refugia en los Campos Elíseos o en la isla de Leuce junto a su marido Menelao. En la Orestiada Esquilo la asocia a lo maligno. Ella es origen de la violencia ciega e imparable que impera por doquier. Para Ory, Helena es divinidad de los cultos ofrecidos a los seres intermedios. Según estos ritos, los hérores, Helena y Menelao en este caso, irradian su poder después de su muerte, su cuerpo queda convertido en talismán y su tumba en centro de peregrinación. El mismo sentido les ha atribuido la tradición católica a las reliquias. De este modo, podemos interpretar el segmento poético «el frío haliento de Helena» como experiencia de muerte y de renacimiento, o muerte sentida y experimentada en uno mismo. Pues, en la poesía oryana la muerte no traza un final, sino que marca infinitos inicios.

En el poema «Pasiones» aparece Venus, la Afrodita griega, hija del mar, diosa del amor y de la pasión, asociada a Venecia. Ciudad rodeada por el mar, símbolo de descenso a los infiernos, espacio de corrupción social y experiencia de degradación individual:

Oh mar de larga fecha que retorna engañoso

¡Ten cuidado hijo mío con las dulces sirenas!

Pero él no hace caso de consejos y vio

vio en los cuerpos que viera otras formas de olas

Tanto erró en la ciudad afrodisíaca tanto 
atravesó los puentes colgantes del deseo que llevaban sus pasos hacia las misteriosas habitaciones de ilusión donde estarían esperándole góndolas esperándole góndolas Corazón alcohólico soportando delirios bajo la maravilla absurda del amor cuando tuvo a su alcance en la cuesta del día los peligros más grandes de todos los poderes ¡Oh Venus oh Venecia de las aguas corruptas!

Venecia es Venus, ciudad que es también hija del mar y ciudad del amor, con sus «aguas corruptas». La figura mítica de las sirenas simboliza el amor femenino, cuyos cantos embelesan y traicionan al héroe viajero. En un principio estas eran seres híbridos, mitad mujer y mitad ave, luego pasaron a representarse como mujeres con cola de pez. Las sirenas tientan y seducen a los hombres con sus encantos, por ello Ory las asocia con la prostitución. Sus cuerpos desnudos se describen como olas marítimas, imagen basada en las ondas de sus senos. Estas viven en la ciudad marítima donde habita Afrodita. También Venus funciona aquí como símbolo de la tentación. Tenemos activado en el poema el arquetipo femenino de la mujer como prostituta. Venus, como diosa del amor, es la mujer prostituta que se ofrece a los hombres, pero es a la vez figura ilusoria porque su feminidad no puede ser apresada por estos. Representa la tentación y el delirio, y también la amenaza y el temor. En cierto sentido se trata de la figura arquetípica de la vagina dentada. Mithu M. Sanyal ${ }^{408}$ señala función represiva que esta imagen significó en el cristianismo. Esta autora ha encontrado esta imagen en muchos textos y representaciones de la antiguedad e incluso en otros mucho más actuales. Aparecen en las leyendas griegas, en la cerámica precolombina, en la épica artúrica... su representación es universal. Para los surrealistas era motivo de fascinación por su belleza extraña. En otros textos el miedo causado por esta vagina con dientes queda transferido a la voz de la mujer ${ }^{409}$. Este es el sentido que en la tradición literaria posee el canto de las sirenas, Homero lo registra en la Odisea y otorga a sus voces un

408 Sanyal, Mithu M. (2009), Vulva, Berlín, Verlag Klaus Wagenbach; traducción de Patricio Pron, Vulva. La revelación del sexo invisible, Barcelona, Anagrama, 2012, pp. 80-81: «Buenaventura no reveló qué temía que sucediera si las mujeres no mantenían a raya sus labios superiores o inferiores y se entragaban a la voluptuosidad labial. Tampoco era necesario, ya que la Iglesia acababa de difundir el argumento de que, con ayuda de la luna y de determinados hechizos, las brujas podían hacer crecer dientes en sus genitales; de hecho, jadeantes fauces vaginales armadas con dientes poblaban ya los cuentos y leyendas de todo el mundo. El mensaje era claro: si las mujeres dejaban hacer a su sexo lo que quisiera, éste castraría invariablemente a los hombres o se los tragaría completamente». 409 íbid. 81. 
permanente caracter de amenaza para el hombre. Vagina o voz, el temor masculino hacia ellas queda perfectamente expuesto en este poema oryano: «Ten cuidado hijo mío con las dulces sirenas»».

En el poema «Crepúsculo del batelero» Isis es símbolo de una erótica femenina que adquiere significados alquímicos de trasformación personal. Isis, diosa egipcia, fue la mujer de Osiris, quien, tras reunir los trozos despedazados del cuerpo de su marido, hizo el amor con él y concibió a Horus. Es la diosa de los misterios romanos. La etapas de iniciación de los ritos dedicados a esta diosa aparecen mencionadas en El asno de oro de Apuleyo. Isis representa el arquetipo de la madre tierra, diosa de la fecundidad y de la maternidad. El poema escenifica un viaje a través del océano de la realidad y expresa la experiencia cósmica de sentirse partícipe del universo divinizado. Viaje que se realiza en barca a través del Nilo:
¿A quién hermana mía dar un beso supremo hasta el estrago y no tocar ya más los remos de la noche? Ahora sin hora sé lo que no supe nunca jamás cuando cruzado de brazos contemplaba holgazán la desnudez de Isis

La presencia de Isis adquiere un sentido mistérico. El yo poético se abisma en la noche como si participase en un rito de trasformación en el que la diosa interviniese. Por ello la erótica adquiere el estatuto de una celebración sagrada. Isis aparece desnuda, buscando los retos desemembrados de su marido con el fin de que este vuelva a la vida y poder hacer el amor con él. El equivalente de esta erótica alquímica es el rito en el que adepto adquiere una experiencia de aniquilamiento y su renacimiento posterior. La experiencia de muerte significa el regreso a la interioridad primera, al origen. Para Mircea Eliade (1956, 1974: 132-133), se trata de una experiencia de la separatio alquímica:

Vi jardines y vi fangales del Nilo las bandadas de patos y de ocas salvajes naneando la noche en un ligero esquife Batelero nacieras con espíritu de ibis y el viento me llevara fácilmente hasta donde van cigüeñas y van las endiabladas nubes 
a la vez que en lo abajo se deslizan crótalos

y la rapaz mangosta y los pies de mujeres

¡Ay cuándo callaré y cuándo bajo a tierra!

No soy escorpión no golondrina soy

mas asumo la mística de todo cuerpo físico

sabiendo que los muertos hijos también del beso

aúllan como canes famélicos ${ }^{410}$ y nadie

ni aquende ni allende consolarán su mal

¡Estoy vivo! ¡Estoy vivo! grita mi corazón

Otra referencia clásica que cabe comentar es la imagen del poeta como héroe fálico o Príapo, significado que se asocia a Hermes Trimegisto y a Dionisos, símbolos ambos de la fecundidad, de la embriaguez, del desorden y de la trasgresión:

A semejanza de Hermes marcho en el laberinto

héroe fálico que franquea mil puertas

Mi voz que era la voz de no se sabe quién

en estado permanente de erección

(«Lazareto de sueños»)

Oh tañedor de arpa el sol se pone

y oyes llorar los pechos de tu amada

He aquí que de nuevo no sé cómo llegar

separado del día y con el falo erecto

(«Crepúsculo de batelero»)

Hermes es el dios egipcio Tot, se le identifica con la luna, es el señor del tiempo y representa la armonía cósmica, es el creador del lenguaje, de las ciencias y de las arte: la magia, la medicina, la astrología y la alquimia. En la época helenística surge la imagen de Hermes Trimegisto como intérprete de la palabra revelada del dios Tot. Para Xavier Renau:

${ }^{410}$ Nótese la referencia que Ory traza sobre el existencial e impresionista atardecer registrado por Antonio Machado en el poema «LXXIX» de Galerías (1907):

Desnuda está la tierra, y el alma aúlla al horizonte pálido como loba famélica. ¿Qué buscas, poeta, en el ocaso? 
No es descartable que el mismo epíteto del Trimegisto sea testimonio de la dialéctica entre la unicidad de Dios y sus manifestaciones, tan típica de la religión egipcia y que heredará el hermetismo ${ }^{411}$.

Resulta pues interesante el significado alquímico y mistérico que adquieren los textos anteriores. La asociación entre Hermes y Príapo señala el matiz trasformador e incluso místico del amor erótico, aspecto que ya se ha visto anteriormente en relación con tantrismo. En este caso, el amor es alquimia interna que trasforma al ser amante. Sexualidad sagrada expresada por Ory una vez más.

Por último, cabe señalar la presencia del mito de la expulsión del paraíso. Adán y Eva aparecen en algunos poemas en los que, además, se activa la imagen arquetípica de la caída. La existencia se manifiesta como una realidad caída, en la que los seres humanos son sombras, fantasmas que viven una existencia oscura y dormida. En este sentido funciona en la obra el mito bíblico:

No sé quién soy por más que hijo de Adán el tonto

Toda la luz se enciende en apagones

y se hace trizas la conciencia laica

Viendo estás un inmenso desgarrón

(«Garito»)

Cada noche una calle abre y cierra su cremallera

La materia orina o es el canto de la lluvia

Ha caído un ruiseñor en el pantano

Respiraciones y tinieblas en el corro de sombras

Oh Eva oh mundo de oxígeno y serpientes

Bajo astros extraños juega el humo humanal

(«Bajo mi lámpara de trabajo»)

Según la tradición bíblica, Adán es el ser humano primordial, primer humano construido por el dios de la tradición hebrea. Ser hecho a imagen y semejanza del ser divino y, como tal, ser divino también, pues en él se hallan las cualidades de su creador. Adán era físico y, a su vez, inmortal, reflejo perfecto de su creador. Según la tradición, dueño del jardín de la creación, donde todos los animales le servían y los frutos lo alimentaban. El mito señala la perfecta integración y armonía del ser humano y la

${ }^{411}$ Renau, Xavier (1999), Textos herméticos, obra cit., p. 11. 
creación, pues el Edén es, a su vez, un reflejo del jardín celeste habitado por Dios. Ahora bien, según el mito, el paraíso no era un reflejo exacto de la realidad celeste porque si en el cielo, según interpreta Watts el Génesis (1968, 1998: 61-62), se hallaba el árbol de la vida, regado por el río de aguas cristalinas que emanaba del trono de Dios, en el paraíso había dos árboles. En mitad del jardín se erigía el árbol de la vida, reflejo del árbol celeste, pero además existía otro árbol, el árbol del conocimiento, el del bien y el mal. En este escenario el dios todopoderoso viendo que su creación más preciada estaba solo entre todas las parejas de animales, decide crear a un ser de segundo grado que sea compañía de Adán. Así, por mediación de él, Dios crea a Eva a partir del propio cuerpo de Adán y se completa la creación del mundo con los dos primeros padres. En el paraíso las criaturas humanas estaban libres de todo conflicto, eran seres inocentes que no conocían la vergüenza porque no eran conscientes de la culpa, de la desnudez, de la separación ni de la infelicidad. Seres inmortales totalmente integrados en escenario divino. Según la tradición, Lucifer, el ángel caído, entró en el paraíso y tomó la forma de una serpiente que se enroscó en el árbol del conocimiento y tentó a Eva para que probase el fruto jugoso del árbol prohibido por Dios. Watts (1968, 1998: 63) interpreta que el árbol del conocimiento es el árbol de la inmortalidad y que la serpiente convenció a Eva para transgredir la prohibición de Dios diciéndole que en realidad Eva no moriría, porque el conocimiento le ofrecería la condición de poseer los mismos atributos que tiene Dios. Eva quiso, pues, conocer lo que era el bien y el mal y comió del fruto prohibido y luego se lo ofreció a Adan, quién también lo probó. Instantáneamente se abrieron sus ojos y fueron conscientes de su desnudez y de la vergüenza que ésta les provocaba, así que cubrieron sus sexos con hojas de higuera. La ira de Dios se traduce en una triple condenación: a la serpiente a arrastrar su vientre por el suelo y a enemistarse perpetuamente con los humanos, a Eva a parir con dolor y a Adán a trabajar para poder comer. La expulsión del paraíso significa la conciencia de la mortalidad, pues la última maldición de Dios supone la condena del hombre a ser un ser mortal. El mito escenifica la caída del ser humano, la quiebra infranqueable de la realidad humana con la realidad divina, la ruptura del ser humano con la tierra. Maldición que alcanza a todo el orden universal y se convierte en una condena eterna. Melos melancolía activa el mito de la caída en el siguente fragmento del poema «Bajo mi lámpara de trabajo»: 
Hubo un varón en tierra de Hus

Y Job dijo: Aburríme no he de vivir eternamente

Déjeme pues mis que mis días son vanos

Me levanto del pan para ganarme la cama

Tengo que comer e ir vestido por las calles

dormir bajo techado en un viejo colchón

a ras del suelo soñar sueños

En este sentido Melos melancolía significa un viaje al origen de la humanidad.

\subsubsection{Atravesar las tinieblas}

La presencia del mito de la caída humana es la óptica que hace que la mirada de Ory se dirija hacia la tierra, dirección señalada por el ala izquierda de Gabriel. En ella pretende, entre las ruinas y la oscuridad, reencontrar el misterio original, la beatitud perdida, la existencia luminosa y edénica. Para ello el sujerto poético debe atravesar las tinieblas, experimentar el dolor y la angustia de sentirse un ser separado y excluido, atomizado en el corpúsculo de su yo y escindido entre paradojas y trampas que le tiende su pensamiento: cuerpo y alma, espíritu y materia, consciente e inconsciente... Imagen de un ser que se halla en una perpetua lucha interior. Ory realiza una operación de alquimia para hallar entre las cenizas y el lodo de la realidad la piedra filosofal que convierte el estiércol en oro, la sombra en luz, pues el paisaje de la tierra está formado por «ruinas luminosas»:

Pon un dedo en el alma y que sus labios sabios hagan de la garganta una página única La batuta a mis pies más fina que un cuchillo desde mi camarote me escondo del espanto Y cueste lo que cueste buscaba y buscaré la isla donde estuve cantándome a la vera del retumbo infinito de las cosas donde estuve junto a ellas cayéndose y también me caía en camino a espalda de los bosques Un enfermero borracho que se rompe la frente Mi cabeza rojiza se llenaba de llanto Tengo razón de irme más cerca de lo lejos para encontrar más pura la locura del canto $\mathrm{Oh}$ ruinas ruinas luminosas no hay musgo 
que cubra la memoria minada de zafiro

(«Ruinas luminosas»)

La poesía es un arte mágico, un rito iniciático. Toma la forma del viaje efectuado por el chamán. En él queda alterada la percepción y este entra en un estado de realidad no ordinaria en el que observa la realidad con otra luz y se siente partícipe de las corrientes de energía que forman el cosmos. Recordemos que no es la primera vez que el sujeto del discurso toma la imagen del chamán:

Nunca jamás el cuervo de la noche que so el alma desciende enseñará otro espejo tan brillante de mí mismo como el que ya contemplo con faz limpia tras el sucio prestigio de los días lejos del fango y lejos de la entusa ${ }^{412}$ Pasando el cuerpo por la telaraña que misteriosamente se quedó intacta y yo quedéme a su compás molde de su molécula geométrica Ileso al otro lado de la sombra me entretuve lanzando una ojeada a este rostro difícil que me vio quieto en el infinito poderoso La serpiente del ser inmoble su ojo y el pensamiento mío redondeándome cayéndome los pétalos del alma en el silencio oscuro de la nada Tuve en sangre la boca de estupor cuando a ciegas la noche me llevaba la cabeza como un humo escultórico alejándome más alejándome más hasta bajar al alba si es que bajo

(«Never more»)

Como el chamán, el poeta adquiere los signos del ser que observa la realidad verdadera, aquella que el ser humano dejó de percibir tras la caída y que su pensamiento ilusorio oculta. Por ello el poeta es el ser mágico que ve lo que los seres corrientes no pueden ver, por más que miren, y que sólo algunos hombres han vislumbrado a lo largo

${ }^{412}$ Sic. 
de la existencia. Ory es el poeta visionario, a modo de Blake ${ }^{413}$, que observa, limpias ya las puertas de la percepción ${ }^{414}$, el eterno paraíso que ofrece sus maravillas ante sus ojos. La poesía se convierte en el lenguaje que vehicula esta experiencia mágica:

Empeñoso andarín de la espelunca estúveme drogado de las grandes maravillas del sueño Y viendo los cangrejos del alba gracias doy a las siete visiones totales del espíritu Oh páramo mortal donde he buscado siempre el ruiseñor la gaviota el asfódelo Tránsfuga enarenado pasajero sumido en este cuerpo extraño llamado a los azules que disfruta la fruta del ser matutinal

$$
\text { («Leulalilias») }
$$

O habiendo conocido el nidal de las águilas que dejara bañado en un eterno éter ¿dónde estuvo más solo y dónde vio más cosas sin máscaras ni lazos de señuelos de sueños? Ya en recuerdos rebeldes y febriles colmado como si hubiera visto el mismo tigre púrpura

(«Demencia poética»)

El poeta es el iniciado que, en su trance, atraviesa la oscuridad del noche, y simbólicamente desciende a los infiernos desde donde regresa como un ser renovado, capaz de percibir el misterio de las cosas y, por ello, expresa su infinita gratitud ante una realidad misteriosa, cambiante, luminosa, paradisíaca y divina.

Ni el búho ni el murciélago ni el cuervo de Poe se abren paso en los campos del espacio luminoso Alto vuela el cóndor y la gaviota nunca vuela en la noche En las alas perfectas del verso consigo un vuelo ancho Volando de árbol en árbol como los gorriones cantores Todo poema es un pájaro libre en los campos del aire

${ }^{413}$ Tal es la visión que nos ofrece su extenso poema «Auguries of innocence» que pertenece a Songs of innocence (1789):

To see a World in a Grain of Sand And a Heaven in a Wild Flower, Hold Infinity in the palm of your hand And Eternity in a hour.

414 Así se expresa Blake en su «A memorable fancy»: «lf the doors of perception were cleansed every thing / would appear to man as it is, infinite». 
Sobre bosques y praderas y valles y montesinos

Sobre el mar y las arenas y sobre el oscuro mundo

de los mortales y sus cadáveres

El duelo y la música de Orfeo

llagan mis labios cantores en la tierra infernal

Los poetas los hijos de la Aurora sellan su júbilo

y las alas del ave surcan abismos

(«Viva vox»)

El poeta, tras atravesar la noche, se convierte en un ser de luz que lleva la luz en su mirada:

Estar en el espacio santísimo y divino las dos pupilas diarias y el órgano pineal Y mirar las estrellas con ojo terco

\section{(«Nihilismo»)}

De poesía al extremo del habla mi conducta reside en alumbrar el candelabro del oro del solitario dormitorio que asumí como si fuera un calabozo del espíritu

\section{(«Monostrofe»)}

Los ojos de Ory perciben la luz que se halla en la realidad, en las ruinas oscuras, mirada que ilumina y muestre las cosas tal como son, resplandecientes:

Paraíso perdido derrumban tus vestigios

Luz limpia de las cosas revela el sol antiguo con la llave del alma que no se oxida nunca

$$
\text { («Adonaï Adonaï») }
$$

La mirada oryana revela que la realidad es la conjunción de los contrarios, tal como se representa perfectamente en la imagen taoísta del yin y el yang. Suma de luz y oscuridad, dolor y gozo, alegría y llanto, noche y día, vida y muerte. 


\subsection{LA EXISTENCIA RECORDADA}

Una chispa en el giro de la Luna

late en esos Universos sin tregua

Marcelo Díaz

La memoria amorosa (2011) es su obra póstuma, la última obra que Carlos Edmundo de Ory escribió, esta fue publicada meses después de su muerte. Se trata, pues, del último edificio poético construido por el autor y, como tal, lleva inscritas todas las líneas e improntas que marcaron la poliédrica poesía oryana. Obra totalmente autorreferencial que confirma la última mirada hacia la existencia, individual, social y cósmica. Tal como indica Jesús Fernández Palacios en el prólogo (2011: 17-19), la obra significa la reconstrucción de la vida a través del recuerdo. Para ello Ory evoca una serie de instantáneas de su pasado ligado a los espacios que trazaron el laberinto de su vida. Según este autor (2012: 10-20), la obra presenta la reconstrucción de la identidad del poeta, identidad que se fragua a base de fragmentos de distintos yoes. Y es el recuerdo el eje vertebrador que articula tal reconstrucción, hecha como un caleidoscopio de evocaciones en el que el autor se busca a sí mismo en los diferentes espacios transitados, desde el origen de su existencia, unido a la luz y al oleaje de Cádiz, a sus postrimerías, recluido en la tranquilidad del campo entre árboles y el canto de los pájaros. Cabe tener presente, como afirma Fernández Palacios (2012: 20), estudioso y amigo de Ory, que se trata de la vida del autor tal y como este la quiso relatar:

En fin, como dije en el prólogo de La memoria amorosa, la biografía de Ory tal vez se pueda contar de varias maneras: yo la esbocé como supe y él la recreó como quiso. Pues bien, la mejor biografía, la más atractiva, es la contada por el propio poeta y por eso es la que recomiendo leer con ojos y oídos frescos, dejando volar la imaginación y, sin prejuicios, jugando y riéndose con Ory al doblar las esquinas de su vida. La vida de un trágico feliz.

La memoria amorosa consta de cincuenta y un textos escritos en prosa poética de distinto signo. Su discurso es plural, ofrece una significativa variedad discursiva que aúna poesía, narrativa, diálogo, monólogo, fantasía, realidad, crítica... Como anteriormente se ha dicho, es el espacio filtrado por el recuerdo el eje articulador de la 
obra. Así se ofrecen cuatro espacios que se asocian a las distintas etapas vitales: «Tarsis», cuyo referente es la infancia pasada frente al mar de Cádiz; «Mayrit», la capital de la España gris de la posguerra que se asocia con la juventud; «Lutecia», el París de la libertad y el conocimiento; y, finalmente, "Amiens-Thézy», la Picardía francesa, el espacio del sosiego de la madurez. La obra muestra una visión particular de la propia vida, donde su autor rescata a la manera de Proust la magia y el misterio del hecho de vivir. Para ello se remonta hasta el origen rescatando emociones, sensaciones, impresiones de instantes perdidos en su lejana infancia que quedaron grabados en la textura más íntima. En otras ocasiones resalta más la impronta crítica o combativa, pues la mirada oryana significa en todo momento un elogio de la heterodoxia, elogio que Ory erigió con su propia trayectoria vital.

\subsubsection{El mar}

La óptica de Ory consiste en reconstruir el recuerdo, porque la memoria capta de forma intuitiva la magia y el misterio que se hallan impresos en cada instante de la existencia de los seres. Magia que se busca en el origen de la existencia particular del poeta y se rescata en forma de emoción. La infancia queda emocionalmente asociada al mar, a la luz y la imaginación, estos son los signos que definen la sensibilidad de la infancia de un yo reconstruido. En el primer texto, titulado La baranda, en tono cósmico Ory identifica su existencia con el espacio habitado:

Encima de mi cabeza, los cielos. Debajo de mis ojos, el mar. Me ponía a inspeccionar el mar. Lo miro, lo huelo y lo degusto hasta que me siento borracho. Allí estoy alelado sin decidirme a caminar.

Partiendo del trasvase de los planos temporales, el texto se sitúa en la Alameda Apodaca, escenario de la infancia donde la familia de Ory tenía su casa. La «baranda» es la alameda que bordea la costa con su muro, a modo de mirador, que termina en el Parque Genovés. Más allá se hallan las rocas y la arena extendida de La Caleta. Este es el espacio de la infancia:

Oh, sí, la baranda decimonónica. Bellísimo balcón de mi adolescencia. 
Territorio emocional, formado por fragmentos de realidad y por retales de la subjetividad, escenario este donde sucede lo mágico. Espacio habitado por seres imaginarios, por toda una zoología misteriosa que se encuentra en los pliegues de la cotidianeidad. Algunos son seres míticos y otros son seres totalmente personales:

No puedo explicarme la atracción visual que ejercen en mi ánimo ciertos animales poco amables [...] Por ejemplo la hiena, adorable hiena. También los reptiles ofidios, de cuerpo largo, las serpientes de distintas especies [...] Y no olvido la rata almizclera de larga cola anillada y escamosa. Otro animal atrayente, verdadero encaje del espacio, es la araña [...] De la zoología mitológica, animales que no han existido nunca, me encanta la serpiente de dos cabezas, la una en su sitio y la otra en la cola.

\section{(«Animalia fascinante»)}

La anfisbena, la «serpiente de dos cabezas», señala aquí el componente imaginario que contagia de subjetividad el espacio de la infancia, en el que sueño y realidad quedan unidos agrandando, como suponían los surrealistas, el concepto de lo real:

Este divertimento de antaño tocaba a manos llenas el juego injugable. Soy tal como fui, ya digo, un lúdico vesánico. ¿Os cuento mi manicomio? Sí, os lo cuento. Se trata en realidad de mis quehaceres de coleccionista de hotentotes o, si queréis llamarlos objetos complejos. No los olvidaré nunca, esos tejemanejes míos de cosas domesticadas a mi capricho. Bueno, he aquí una pequeña lista de mis amados hotentotes:

Una manga de riego pintada de verde debajo de la cama.

Un barril de vino tinto que me servía para fabricar sangre falsa.

Un puñado de uñas llenando tubos de aspirina.

La torre de tapones de corcho que llegaba hasta el techo.

La linterna que me servía para alumbrar la cara de mi madre dormida.

La trenza larguísima de mi hermana que llevaba cosida en la culera del pantalón.

La plancha para planchar papeles de plata.

Los guantes blancos de primera comunión que pinté de colores.

Las sábanas de mi cama que teñí de negro.

Etc, etc, sin ponerme a contar unos pocos hotentotes absolutos como eran:

un compás masónico

una caja de limpiabotas

un colmillo de elefante

una látigo de domador

un maxilar inferior

(«Hotentotes») 
La vida infantil de Ory está impregnada de lo maravilloso, como si habitase en la realidad mágica que se desprende de las páginas de Gabriel García Márquez. Cádiz, en este sentido, sería su Macondo particular, marino y luminoso. En este espacio subjetivizado encontramos la belleza extraña que fascinaba a los surrealistas. En los fetiches oryanos se halla la belleza convulsa, que surge del choque de lo imprevisto y de la extraña atracción hacia lo raro y los perverso, como «la trenza larguísima de mi hermana que llevaba cosida a la culera del pantalón». Esta extraña belleza, que impregna la realidad de la infancia, en cierto sentido, procede del ámbito religioso cuya imaginería y ceremonial cubre toda la superficie del espacio social ${ }^{415}$. Ello queda totalmente de manifiesto en el texto titulado «La misa de los domingos», en el que se nos ofrece la realidad desde la mirada de un niño cuya fascinación queda atrapada por el protocolo ceremonial y por la parafernalia de la liturgia. La estética oryana emana de la ambigua relación de atraccción y rechazo ante la simbología cristiana:

¡El altar! Al presbiterio penetrábamos por la sacristía. Este lugar me impresionaba. Todo tan ordenado ahí, tan limpio y curioso. No había nunca nadie vacío como estaba. Los intrusos se topaban de improviso con el hombre especial que llegaba para revestirse. No hablaba con el muchachito que trajinaba a su alrededor. Era el monaguillo tocando cosas que hubiera querido tocar yo. Se sacaban del armario de tablas paralelas para indumentaria eclesiástica. Se estaba vistiendo el sacerdote. Tenía en las manos una larga estola y se la pasaba por la cabeza; ora un manípulo, ora una casulla. Veía yo cómo sacaba de las alacenas prendas y objetos de culto.

La lógica de la infancia sospecha ante la magia ofrecida en el ritual, porque al sacerdote se le ven los pantalones y tal impostura desenmascara la falsa solemnidad:

Pero lo que más me llamaba la atención eran los pantalones del sacerdote. ¿Lleva pantalones de hombre? Luego es un hombre como todos. Ya no me parecía un cura. Sin embargo pronto se transformaba.

El cura deja de ser figura mágica para quedar reducido a ser humano común, adquiriendo así el estatuto de impostor. El ritual religioso queda reducido a la más pura teatralidad y el sacerdote toma los rasgos del artista figurón que sobreactúa en su escenario:

${ }^{415}$ Estética expresada también por el cine de Luis Buñuel, por la poesía de Alberti en Sobre los ángeles, por la poesía y el teatro de Lorca y por la poesía del grupo Cántico de Córdoba. 
Ropa preciosa que ninguna mujer viste. Sólo los toreros lucen con tanto brillo. Pero qué distintos esos dos. No recuerdo a ningún hombre haciendo algo parecido. Ejecutando los mismos gestos, ajeno por completo a la calamidad del mundo. De vez en cuando vuelve la cabeza, ni por casualidad sonríe y ni mira ni ve a los fieles. Henchido de prestigio, no se deja llevar a hombros como los toreros. Ite, Missa, est.

Por otra parte, el mar conforma este escenario mágico, que es un espacio más instalado en el escenario mágico que es el cosmos. En él todo se metamorfosea de manera mágica, pues, como el mar, la infancia es también metamorfosis constante, como la vida. De ahí la atracción oryana por los escenarios marinos, dinámicos, cambiantes, sugerentes, cargados de misterio y, sobre todo, abiertos a la imaginación:

Mis mejores disfrutes siempre han sido el mar, las playas desiertas y las dunas, y las rocas. Me entusiasma un ancla. Me conmueven los procesos físicos, el hierro oxidado, la herrumbre, lo enmohecido, los musgoso. Todo lo que se enfrenta con las aguas alguna vez hasta perder su uso y queda en la apariencia sólida, aunque en ruina. Ah, las ruinas, itálica famosa.

La alegría diablesca de introducirme en un barco deshabitado para siempre jamás, un barco fantasma, cuya tripulación desapareció del mapa hace mucho. Nadie a bordo; digo personas, pero sí, hambrientas aves y ratas. Visitarlo, desde babor a estribor; meterse en los camarotes, en las bodegas. Desde el puente de mando donde la bitácora y la caña del timón hasta la sala de máquinas con sus engranajes averiados ¿Dónde están los fogoneros? Encontrar allí, bajo un olor a yodo y algas, la resonancia del océano.

(«Las aguas»)

El mar emite las ondas infinitas de la existencia, cuyo oleaje que alcanza a todos los seres. Ahora bien, sólo los seres sensibles, como algunos niños o algunos adolescentes, conectan con sus ondas y son conscientes de ello:

Criaturas en cuyos sistemas nerviosos se instala una telegrafía sin hilos, captan las ondas del infinito. No parecen tener ni presente ni futuro.

(«Espeleólogos existenciales») 


\subsubsection{Eros}

En el laberinto que sobre la tierra trazan los pies del yo recordado, la feminidad está presente ya desde los inicios como constante que atraviesa todos los espacios transitados. En ellos van apareciendo las mujeres más queridas: la madre; Denisse, la primera esposa de Ory; Laura, la compañera de viaje con la que se casó en el año 2000; y otros rostros femeninos. Todos ellos, juntamente, forman el cuerpo colectivo de la feminidad, que juega un papel importante en la trayectoria oryana:

¡Y de qué te sirve explorar las galaxias si no son más bonitas que las mujeres.

$(« \mathrm{Mi} \operatorname{cosmos} »)$

Las mujeres son estrellas instaladas en el aquí, perlas de la tierra, cuerpos del amor. Son los diversos rostros de Eros. La óptica oryana rechaza toda ascesis, toda santidad y toda mística puritana que excluya la erótica, así las mujeres son manifestaciones de la divinidad y, por ello, asumen sus diversas caras. La erótica de Ory, como ya se visto, queda configurada como mística, amor que es religión ante el altar del amor, que es, a su vez, la tierra y no el cielo. Por ello se concibe como un ritual transformador, camino de iluminación personal, misterio y enigma de la existencia. A través de la mujer, Ory experimenta la gratitud del hecho de estar vivo, la mujer es una de las vías que permite experimentar el éxtasis ante la realidad. La piel de la mujer se extiende hasta cubrir toda tierra, los seres, el cielo... el cosmos entero. El amor es el ceremonial en el que se experimenta la unidad de todas las cosas y de todos los seres, cuando la energía cósmica es sentida en el interior del cuerpo. Sus signos son el éxtasis y la gratitud. La escritura de Ory se pliega sobre la sexualidad, concebida esta como actividad sagrada y receptáculo de la energia primordial, del goce de la experiencia existencial:

En cambio, mi Eros habitual, animal y natural de sexos distintos se ha basado siempre en la piel, en la carne, en el cuerpo femenino. La mujer con sus ojos de ágata, la ladina, la tantálica, la fulminatriz, la muy bella y cochambrosa dama del clítoris climatérico [...] ¡Dona! Eres Eros, mi compañera de todos los instantes. No me apartes de tus brazos de brasa, que tú eres la Mujer y te llamas Lilita, Eva, Prima Pandora, Afrodita, divina Astarté, Ersulie negra, Izé Kranile. ¡Ven Venus! ¡Ven, que vengas, virgen loca, hetaira babilónica!. 
Repudio la condensación de la Venusberg, el horror antifeminista de los discípulos de San Pablo y San Agustín, exjodedor empedernido. Deploro el destino de santos y del pobre héroe virginal, el casto loco, la locura de Atys y el arrepentimiento de Amfortas. Todos aquellos que huyen de la basia catulliana como de la peste.

(«Texto del sexo»)

Para Ory, el puritano tiene miedo del cuerpo porque piensa que es un ser caído. Para él la tierra es limo y contaminación, en cambio anhela el cielo porque es paradigma de pureza. En defensa de su alma lucha contra el cuerpo, ya que el alma es platónicamente inmortal e incorrupta. Ory rechaza de pleno todo platonismo y toda supremacía de lo mental sobre lo corporal, ya que el ser humano no es un ser escindido en dos mitades irreconciliables. La erótica, pues, es la experiencia de la unidad de lo corpóreo y la intelectualidad y, además, es experiencia de unidad del ser con los otros seres y con el cosmos todo. Como en el tantrismo, la erótica es para Ory una experiencia mística. La mujer es ser sagrado, diosa; pero no diosa celeste como la donna angelicata o la amada petrarquista.

En La memoria amorosa la mujer, como tal, se presenta ante el yo juvenil oryano como arquetipo de la sexualidad humana, del amor como energía vital. Así aparece en el texto titulado «El caballero Tannhäuser», «Anacha» es la mujer que representa el despertar erótico y posee la imagen de Venus, pero no la Venus púdica representada por Boticcelli, paradigma del recato y el pudor, imagen de pureza que transmite el arquetipo del ángel blanco, cuyo paradigma más visible es la Beatriz de Dante. La feminidad oryana es la Venus impúdica, que se ofrece desnuda cuando sale del mar:

Me dormí sobre la arena inocente y en mi sueño la joven satisfecha sonreía. Cuando me desperté no quise mirarla extrañado como estaba del hundimiento de la barca. ¿Qué hago aquí sin mi Giocasta? Ni eso parece la orilla del mar.

¿Os he hablado de la mujer que muge de amor? La dama que vino vestida de damasco y se desnudó saliendo de las aguas profundas de mi deseo como Venus Anadiómene, hija de Belcebú. ¿Se llamaba Ana? No, no se llamaba Ana a secas. Se llamaba Anacha. No me creyó cuando le dije que estábamos en la isla Citera y que yo era el caballero Tannhäuser. 
El sexo es sagrado, pero separado de la idea cristiana del triunfo del espíritu sobre la carne. La mujer es diosa precristiana, deidad antropomórfica, símbolo de la madre tierra. En el despertar juvenil de Cádiz la figura de la mujer no se ha focalizado todavía en un ser concreto hacia quien dirigir la energía erótica:

No hicimos ningún pacto para andar juntos. Nunca nos separábamos. ¡Qué vitalidad de moza! No lloraba nunca. Gritaba de mil modos, llana ${ }^{416}$ de impulsos imprevistos. La veía correr sin freno y cuando se fatigaba era una leona dormida.

Se lanzaba al mar enloquecidamente y se ponía a nadar en las aguas alejándose hasta perderla de vista, si no fuera por el alga negra de su abundante melena, a lo lejos, flotando en las olas.

Nunca supe su nombre.

(«Nunca supe su nombre»)

En el espacio de la juventud y la algarabía que es Mayrit, la imagen de la feminidad adquiere también el aspecto de diosa, de animal mágico, de divinidad ambigua, mezcla de encanto y peligro, de éxtasis y dolor. Dibujo de la mujer en toda su complejidad:

Te estoy hablando de animales perfumados. Son las mujas o mujaras, criaturas fosforescentes. Aves de paso luciendo el pelo en el aire de las calles. ¡Ay! ¡Ay! ¡Ten cuidado, querubín! No las sigas en los atardeceres opalescentes porque su tacón de gacela trae consigo desgracias sin cuento. Aléjate de sus rostros exquisitos como milhojas.

Mujas, mujaras, mujeriarcas. Ya te digo, hijo mío, mucho ojo con ellas. Porque, a la hora del crepúsculo bajan a las calles y tiemblan sus faldas de seda sangrienta entre las cuales hay boquetes que te engullen; ya no puedes volverte atrás donde respiras aire fresco. Ten mucho cuidado con los agujeros que te conducen a los balcones cerrados de los cuartos oscuros.

$$
\text { («Las mujas») }
$$

Alerta irónica, oscuridad, opresión, miedo... es otra de las aristas de la feminidad, cuyo cuerpo está irónicamente presentado como peligro. Evidente resulta su relación con la imagen de la sirena. En este caso la mujer aparece como arquetipo de prostitución.

416 Sic. 
Frente a esta visión, Ory nos ofrece otra mirada en la que la mujer es ser divino bañado por la luz de la mañana:

Algunas veces, al amanecer, salimos a la calle. Vamos abrazados. Mi risa estentórea suena hasta los altos pisos. Nadie comprende el sonido ni se asoma a los balcones. Únicamente tú, a mi lado, entiendes mi gozo mañanero y te deleitas.

$[\ldots]$

Nuestro lenguaje es semejante al de Adán y Enoch antes de la caída. Creemos en tu dignidad, oh lector, y es por esta razón por lo que te hacemos confesión de la unidad de nuestras vidas cuyo secreto es conservado por la Pléyades.

Solo existe una historia que se puede comparar con la nuestra. La de los esposos reales del antiguo Egipto: Amenonfis IV y Nefertiti. Nefertiti, cuyo nombre significa «La Dama de la belleza ha llegado». Celebrada por los papiros con expresiones de exquisita ternura.

$(«$ Realeza»)

Esta imagen de la mujer transmite la energía amorosa focalizada en el cuerpo femenino, el sentimiento amoroso dirigido a una feminidad sexuada y corpórea, cuyo amor es reflejo del amor cósmico. Pues todos los elementos del cosmos están unidos por una energía amorosa que los atraviesa.

\subsubsection{Inquisiciones}

La memoria amorosa supone, a su vez, una mirada crítica y combativa que contacta con la poesía urgente de La flauta prohibida. Esta queda estructurada en base a una serie de instantáneas del pasado rememorado. En este sentido, «Mayrit», el Madrid de la posguerra, se nos ofrece como cloaca pestilenta cercada por los adalides ideológicos de la dictadura y su prácticas represivas. Ory ataca los cimientos en los que se alza el edificio de la España castiza, anclada en la caduca tradición imperial: la religiosidad castradora, la vieja hidalguía, la cultura sumisa y represiva... Se trata del Madrid gris y mediocre que se compara con un «sórdido garaje de ratones viejos». Tal es la imagen que se ofrece en el texto titulado «Garaje», donde Ory deja muy clara su oposición ideológica ante la nueva cruzada: 
La insolencia señorial de España y la sumisión del indigente respirando un miedoso soplo vindicativo bajo bozal. País de forajidos y de esclavos, de opulencias y de esa inercia del paupérrimo cuerpo sin energías. Arrogancia y dolor demacrado; desierto y jardín, toros y chinches...

La crítica oryana se remonta a la visión machadiana de la vieja España. En el texto se atacan los símbolos que definen el tradicionalismo y la intransigencia de su sociedad. De esta manera Ory recoge los signos de la literatura de los francotiradores: Blanco White, Larra, Clarín...

[...] la España endiosada de Dios desde Isabel la Católica, pasando por Torquemada, hasta los días franquistas. La Guerra Civil con sus muertos contados a dedo por Dámaso Alonso: Madrid es una ciudad de más de un millón de cadáveres.

$[\ldots]$

Más dicotomías. Ricos y pobres; nobles y esquilmados; hidalgos, caballeros y pillos, vagabundos; monjas y anarquistas de Barcelona; el Niño de Oro de Sevilla y el Niño de Vallecas; el inteligente ibero y el Bobo de Coria; Don Panza y Sancho Quijote.

Madrid, sórdido garaje de ratones viejos

En el texto se hallan presentes todos los símbolos culturales y literarios de la cultura meseteña: el catolicismo inquisitivo, la mística ascética, la hidalguía e hipocresía propia del caballero español, la picaresca y la corrupción social, la brutalidad trágica de los toros... La referencia directa a la obra Hijos de la ira de Dámaso Alonso señala aquí el ambiente putrefacto y corrosivo de la sociedad de la posguerra española, pues en 1944 los «cadáveres» de Alonso no apuntaban a los muertos.

En el fragmento titulado «Los anarcopitecos», en el que existen, además de un guiño al anarquismo como teoría política, diversas marcas que señalan las rebeliones portagonizadas por el autor, encontramos una clara referencia al ambiente opresivo de la sociedad. En el texto, que ofrece un paralelismo con la Rusia zarista, el yo discursivo toma el nombre ruso de Ilucha y su interlocutor (compañero de rebeliones y amigo) el de Saschka. Por carta Saschka escribe a Ilucha lo siguiente: 
-En Siguenza cogí un tren de segadores hasta Calatayud. Y tuve que presenciar una terrible escena, que te sintetizo aquí, en espera de ampliarla. Venían los segadores cansados y muertos de calor a pasar el domingo con sus mujeres. Sube un policía y pide a uno de ellos la documentación. «No la tengo; me la he olvidado», contesta el siervo. «Pero sí que tengo el billete», añade mostrando el cartoncillo. El policía, entonces, le da dos enormes bofetadas. «¿Es que te quieres burlar de mí?». Entonces fue cuando el segador sintió que la sangre se le subía al rostro (un aragonés brutal) y cogió las hoces y dijo blasfemado horriblemente que iba a cortarle la cabeza (yo estaba maravillado pensando que iba a rodar una cabeza guillotinada). El policía saca dos pistolas y dice que nos vayamos que va a disparar... Las mujeres salen alucinadas y corriendo. Pero dos curas rurales se interponen entre el policía y el siervo y protegen a éste. El siervo sufre un ataque como epiléptico. El tren llega a Ariza. Sube la Guardia Civil y logra esposar al segador, con mucho trabajo, ya que se retorcía y espumeaba saliva. Y cuando lo dejan esposado, el policía se quita la chaqueta y empieza a pegarle puñetazos. Los curas, y los demás hombres protestan. Los civiles obligan callar a todo el mundo. Huele a espiga y a sangre. Las voces caídas sobre el pecho: todo esto es Ariza.

Este fragmento recuerda totalmente a la óptica crítica de signo neorrealista de narrativa de Ignacio Aldecoa que adquiere ciertos tintes vallinclanescos. Aldecoa fue compañero de Ory en la Pensión Garde en el Madrid de los años cuarenta ${ }^{417}$.

En el texto titulado «Luces del oscurantismo», texto comentado ya acerca de la prohibición en la Biblioteca Nacional de Madrid de la lectura de la novela El lobo estepario de Herman Hesse, se observan las prácticas prohibitivas de un poder autoritario que atenta sobre la información cultural de sus ciudadanos. En él aparecen la labor de la censura y la existencia de funcionarios que arbitrariamente atemorizan a los lectores. El lobo estepario era lectura no recomendable, ni Diario de una camarera de Octavio Mirbeau, tildada de obra escabrosa. Se muestra así la dinámica cultural franquista que negaba el saber al ciudadano por consideralo peligroso:

En aquella España del Generalísimo, cuando no se trataba de ocultar a un Proudhon, eran las obras completas de Nietzsche. Éstas las vi en un estante de una biblioteca popular de barrio atadas con un cordel.

Frente a este clima opresivo y asfixiante, Ory manifiesta su gesto de ruptura en el texto titulado «Destierro», que cierra el apartado dedicado a Madrid, y que representa el exilio voluntario al París de la libertad. Desde la capital francesa, a modo de

417 Ver «Por calles y tabernas con José Ignacio Aldecoa»; Aproximación crítica a Ignacio Aldecoa, a cargo de Drosoula Lytra, Madrid, Espasa-Calpe, 1984; tambien en Carlos Edmundo de Ory (1991), Iconografías y estelas, Cádiz, Diputación, 61-81. 
transposición espacial, Madrid aparece como un laberinto de asfalto gris apartado de la luminosidad radiante y vívida del mar, espacio cerrado, capital del dolor y de la asfixia:

Te amo Madrid. MADRID O MADRIGUERA. Mi cubil, mi cueva, mi juventud encadenada. Bueno, todo lo vivido me lo comí de un trago. Tengo hecha la digestión de muchas habichuelas y de muchos garbanzos. Hoy estoy en París y antes estuve en Madrid. La letra $M$ de tu nombre desentraña sonoras etimologías: Mantua Carpetanorum, luego Majoritum y, al fin, Madritum, más cerca ya de tu nombre definitivo. Urbe, finalmente, habiendo sido una aldea en los tiempos romanos, que toman los moros y butizan Magerit, sitio fortificado.

El ataque más certero al poder inquisitorial se produce en el texto que cierra la obra. La diana de Ory es ahora la intransigencia religiosa de la iglesia cristiana, católica, apostólica y romana. Iglesia, cuyo aparato represor, la Inquisición, mantenía excomulgaciones y prohibiciones, cuya sombra todavía sobrevuela el espacio actual de la sociedad occidental. Ory defiende y la figura de Miguel de Unamuno como intelectual representante de la libertad frente a unos engranajes eclesiásticos que pretendían subyugar a la humanidad bajo la esclavitud mental y material. Ory ataca su excomunión, la inclusión de sus obras en el índice libros prohibidos por la Inquisición. La venta en las librerías de Del sentimiento trágico de la vida y La agonía del cristianismo no fue autorizada. El Anatema contra Unamuno sugirió a Ory la protesta siguiente, que a su vez supone una actualización de la tarea librepensadora de este intelectual:

¡Pobres gentes! ¡Ridículos! También pusieron en el «Index» La vida de Don Quijote y Sancho. El Quijote en bloque al infierno ¿por qué? Porque en esa obra se justifica el comportamiento de una joven maritornes. ¡San Miguel de Unamuno en el infierno! ¡Invicta paradoja! No olvidemos la línea místicocristiana de Unamuno y recordemos lo que él dijo en La agonía del cristianismo: «La pedagogía jesuítica es una pedagogía anticristiana. El jesuita odia la mística». Me sé la página de memoria: «Los jesuitas. Los desgraciados hijos de Íñigo de Loyola, nos vienen con la cantinela esa del reino social de Jesucristo, y con ese criterio político quieren tratar los problemas sociales y económicos. Y defender, por ejemplo, la propiedad privada». Pero él, Unamuno, había acertado cuando pronunció este dístico ferviente: «¡Tú, Cristo del Cielo, / redímenos del Cristo de la tierra». Unamuno se condenó a sí mismo diciendo:

«En Nicea vencieron los idiotas».

Por otra parte, la crítica contra las prácticas fascistas no se circunscribe a la sociedad española. La memoria amorosa contiene la crítica más corrosiva dirigida 
contra el militarismo y la práctica de la violencia, propia de todo fascismo imperante. El texto, que posee verdaderos tintes pacifistas $^{418}$, entronca perfectamente con la mirada política expresada en La flauta prohibida:

En las paredes de mi cuarto he depositado una colección de imágenes plurifacéticas. Son recortes fotográficos y estampas, reproducciones y grabados de mi panorama del mundo. Visiones de la segunda guerra mundial y de la guerra de Corea. Suplicios asiáticos. La China en guerra: un documento de primera mano recogido en las calles de Shangai, una muchacha, huyendo del avance comunista, lleva a la espalda a un niño chino, cae derrengada víctima del frío y del hambre. Otra fotografía: un oficial decapita con su sable a un aviador norteamericano prisionero de guerra, arrodillado en medio del campo y con los ojos vendados. De Tientsin: a bordo del buque Laiteland, un soldado chino, con el cigarrillo en los labios y el dedo en el gatillo de una ametralladora (fabricada en Japón) guarda la cabina donde el capitán Sexton está negociando con los oficiales comunistas de China la libertad del cónsul general norteamericano, $\mathrm{Mr}$. Angus Ward, y de los diecinueve funcionarios que tenía en su oficina de Mukden, Manchuria. Una imagen del ghetto de Varsovia: combates en las ruinas de las calles de Bonifraterska, Kurza, Pawia y Zamonhol. El último grupo de judíos insurrectos penetrando con las armas en las manos en territorio «ario». Un retrato de Rosa Luxemburgo y un esbozo de la calavera de Liebknecht asesinado. Campos de concentración hitlerianos.

(«Imágenes crueles»)

\subsubsection{Mística del instante}

En La memoria amorosa Ory, rehuyendo toda metafísica transcendente circunscrita en el más allá cuyo origen se halla en divinidades antropomórficas, propone una mística del instante que se centra en el aquí. Una experiencia mística basada en el aquí y en el ahora, que señala la pertenencia del ser a una realidad infinita en la que el todo conforma el rostro de la divinidad. Se trata de una mística panteísta en cierto sentido, que recoge la herencia de las filosofías orientales negadoras de una divinidad creadora, en la que dios es el cosmos y el ser humano un integrante más de la

${ }^{418}$ Recordemos que el pacifismo, aunque tiene sus raíces en pensadores lejanos como Ralph Waldo Emerson o Henry David Thoreau y en la actividad de Bertrand Rusell como pionero en la oposición a la Primera Guerra Mundial, se agudizó como movimiento contracultural que se opuso en Estados Unidos a la guerra de Vietnam y a toda práctica militar a nivel internacional. Entre los pensadores más cercanos a la contracultura cabe señalar a Paul Goodman, Norman O. Braun, Herbert Marcuse... Destacamos que la actividad de Ory llevada a cabo en Amiens desde el A.P.O. converge perfectamente con esta línea de pensamiento. 
totalidad divina. En el siguiente diálogo aparece el decálogo de tal metafísica, que, por otra parte, hemos conocido ya a través de la poesía:

-Usted me habló, Carlitos, de su trilogía vital: «conocimiento, amor y revolución». Mucho interés tengo en que me diga si dedicó a una de estas tres cosas su estancia en el campo y cuál fue la que eligió, ya que, como supongo, no compartió sus horas con las tres.

-Seguro que no. Estuve siempre solo. Sepa que no di tregua a la reflexión y a la escritura. A esta exclusividad cabe añadir los paseos solitarios.

-Esto que me dice no puede por menos que alegrarme. ¿Y qué ha reflexionado usted? Fuera de los libros ¿qué ha visto en usted mismo?

-Que me encamino a pasos agigantados hacia el reino de las verdades saladas.

-¿Cree usted que lo conseguirá?

-La tentativa toma cuerpo ¿Cómo? Más allá de la filosofía discursiva.

-¿Escribiendo poemas?

-Tampoco. Más allá de la liricoteca.

¿¿Dejando de ser poeta?

-Dejando de ser Narciso. Más allá del ego. Quiero poner el dedo en la llaga de la metafísica.

-Veamos, Carlitos, la metafísica no tiene llaga.

-Sí que la tiene, amigo mío. Porque se trata de una metafísica inmanente, de la tierra, del hombre. No es una metafísica trascendental. Por lo tanto, implica un supuesto finalista.

-¿Qué entiende usted por «presupuesto finalista»? Suena a gastos o ingresos de una empresa

-La inmanencia plena del ser es la única empresa que nos incumbe. Tiendo al presocratismo.

(«Metafísica campal»)

La mística oryana plantea la inmanencia frente a trascendencia, una divinidad cósmica frente a dioses celestes, el panteísmo frente a cielos y nirvanas. Propone la divinidad del ser humano, la unidad de este con un cosmos divino, la experiencia de 
concebirse como sujeto divino en cada instante y en cada espacio. En definitiva, una mística del aquí, frente a la del más allá. Del texto cabe señalar el rechazo de «la filosofía discursiva», aspecto que debe relacionarse con la mirada directa del zen. El lenguaje discursivo, productor de especulaciones conceptuales, se halla atado al recuerdo y al estatismo propio del pensamiento, y por ello no es el lenguaje apropiado para revelar lo que sucede un una realidad que cambia perpetuamente. Ory, siguiendo a Henri Bergson, propone un lenguaje alejado de la especulación, un lenguaje de signo intuitivo, perceptivo, más acorde con una realidad infinita e indivisa. Este lenguaje expresa la divinidad de cada instante transcurrido y, desde el aquí, manifiesta, como producto de una meditación no discursiva, la sensación de plenitud experimentada en cada momento. O dicho en otras palabras, todo instante es un hecho divino, porque tiempo y espacio son manifestaciones de la realidad divina:

Dicha perfecta y absoluta, he aquí todo. El hombre que busca otra cosa se pierde entre la sombra de los escombros pestilentes.

(«Fue una vez»)

Irónicamente Ory arremete contra la ciencia especulativa y su visión mecanicista del mundo, que busca explicaciones entre modelos del universo que responden a causalidades y finalidades, a principios y desarrollos. Frente a ello, propone la imagen de un cosmos infinito en el espacio y en el tiempo, sin origen:

Del espectograma han salido las últimas teorías sobre el origen y la naturaleza del Universo, pero del corazón no ha salido más que desesperación. ¿De dónde vienes y a dónde vas? ¿Cómo has sido creado? Quizás se acerque el día en que el corazón pueda contestar a las preguntas desesperadas de la inteligencia. Cuando el corazón haya obtenido sus logros.

La mayoría del mundo se asombra de los adelantos a pasos agigantados de la ciencia y de cómo se pueden explorar hoy las galaxias. La instalación en SaintMichel-de-Provence, en Francia, de un telescopio electrónico hace pensar ya que los observatorios de Mont-Wilson y de Palomar tendrán que cerrar sus balcones al cielo. ¡Y de qué te sirve explorar las galaxias si no son más bonitas que las mujeres!

Me acuerdo de una astrónomo que peroraba acerca de los prodigios de la ciencia actual. Fue interpelado por uno de sus oyentes. El orador estaba diciendo que en una alta montaña de California se había instalado un telescopio tan potente que permitía distinguir las cejas de una muchacha situada a mil kilómetros de 
distancia. Entonces fue interrumpido con una pregunta: «¿Quiere usted explicarme para qué sirve una muchacha, por guapa que sea, si se encuentra a mil kilómetros de nosotros?».

$(« \mathrm{Mi} \operatorname{cosmos} »)$

El texto oryano señala, a modo de paradoja o koan, la inutilidad de un pensamiento que únicamente opera en elaboraciones especulativas y que ha perdido la inmediatez de lo real, un pensamiento separado de la realidad del aquí debido a la construcción de modelos de pensamiento de herencia platónica. Ory busca un lenguaje directo atento a la percepción de lo instantáneo, que pulverice antiguas dicotomías y que no separe lo que en la realidad se halla unido: el yo y lo demás, el observador y lo observado, el aquí y el allá. Como aparece en el texto, Ory, aunque sabe que la realidad es infinita en el espacio, se decanta por el universo más cercano, por el universo humano y, a consecuencia de ello, propone una mística del aquí.

Aquí. Allí. Y cuando decimos Allá, suena Más Allá, o sea, el más allá ¿Es eso un sitio donde se pueda estar? Pero nunca decimos el más aquí. Y este aquí es el mundo ante todo, la tierra donde estamos ¡el inmenso aquí!.

(«Sobre un extraño adverbio de lugar»)

La mística del aquí exige tomar conciencia de presenciar, experimentar directamente, infinitamente el milagro de la existencia que se ofrece en cada instante, sin mediación de conceptos. En el texto titulado «Elogio de la nariz» Ory lo expresa de la mejor forma posible: «Respirar es todo». La expresión del texto «Rosas azules», citada ya con anterioridad, condensa totalmente la metafísica oryana: «Soy todo lo que estoy mirando». Ory se identifica con el afuera, ya que no existe ninguna barrera que separa interior y exterior. La piel no encierra al individuo en una burbuja, sino que es punto de conexión con lo exterior. Como queda manifestado en algunos pasajes de la obra, podemos afirmar que Ory es todo lo que ve y todo lo que percibe. Y todo eso es él. Esta es su mística del aquí, mística del instante. 
6. POESÍA LIMINAR ${ }^{419}$

${ }^{419}$ Con el epígrafe de poesía liminar denominamos el discurso oryano que se halla bordeando los límites de lo que se considera poesía. Aquí situamos los aerolitos y la poesía visual, cuyo signo es el collage. 


\subsection{CUANDO EL LENGUAJE ESTALLA: LOS AEROLITOS}

Vuela piedra oscura más allá de la noche

José Ramón Ripoll

Los aerolitos oryanos son segmentos lingüísticos breves e intensos, a modo de sentencias y aforismos, que presentan, desde un significante inconexo y desde un significado paradójico, un instante de lucidez. José Ramón Ripoll (2011: 205) señala su impronta radiante, luminosa y vívida:

Ory llamaba aerolitos a esos fugaces instantes de conciencia representados por frases aparentemente inconexas que, desde el espacio caótico del pensamiento, caen sobre el papel tras un viaje milenario. Son formas perdidas del sueño, experiencias acumuladas de lecturas, luces de la observancia que van configurando en su esparcimiento el extraordinario apriorístico de su poesía.

Los aerolitos oryanos, tal como figura en la bibiografía, están contenidos en varias obras y se hallan también, de modo disperso, en otras publicaciones como revistas y antologías. La primera publicación se realizó en francés en el año 1962 con el título de Aèrolithes y con un prólogo de Marcel Béalu. También en francés y en versión del propio autor, apareció en 1966 otra publicación de los aerolitos en la revista Réalités Secrètes, titulada también Aèrolithes. Las dos publicaciones francesas se editaron en castellano en la revista Cuadernos Hispanoamericanos, la primera en $1965^{420}$ y la segunda en $1969^{421}$. En 1985 los aerolitos se publicaron en castellano en forma de libro en la editorial El Observatorio con el título de Aerolitos. Algunos de estos ya habían aparecido en 1970 en la antología oryana editada por Félix Grande, Poesía 1945-1969 y en 1978, recogidos por Rafael de Cózar, en la antología Metanoia, ampliada en 1991. Posteriormente han aparecido dos ediciones más en la editorial Calambur, una en 2005 y otra en 2011 prologada por Félix Grande. En 1995 Ory publicó un nuevo grupo de aerolitos bajo el título de Nuevos Aerolitos y en 2009 todavía aparreció otra obra más: Novísimos aerolitos. En la antología realizada por Pont y publicada en 2003, Música de

${ }^{420}$ Madrid, $\mathrm{n}^{\circ} 181$, enero 1965.

${ }^{421}$ Madrid, n 230, febrero, 1969. 
lobo. Antología poética (1941-2001) se ofrece una breve selección de los aerolitos y en la antología-homenaje a Ory realizada en 2006, El desenterrador de vivos, se publican varios aerolitos inéditos. Por otra parte, fragmentos de lo que son los aerolitos han aparecido en otras publicaciones ${ }^{422}$.

Pont (1998: 308-309) encuentra los antecedentes de los aerolitos en la literatura postista, lúdica y experimental: las pulgas, los emblemas y los ejercicios de enderezamiento. Todos estos juegos verbales, de los que se ha tratado anteriormente, están documentados en las dos revistas postistas (Postismo y La Cerbatana). Las pulgas y los emblemas son relevantes por su brevedad y su impetuosidad y el enderezamiento por la tarea paródica de subvertir el texto. Pont (1998: 10-11) señala, también, como un antecedente del aerolito las proposiciones establecidas en las publicaciones del Atelier de Poésie Ouverte; aunque estas, fechadas entre 1967 y 1968, son posteriores a las ediciones primeras de los areolitos.

\subsubsection{Hacia una definición del aerolito}

El propio Carlos Edmundo de Ory ofrece, en las ediciones de sus aerolitos (1995: 13; 2005: 7), pistas y referencias acerca del discurso mininal de los areolitos:

Novalis los llama: polen; Rozanov: hojas caidas; Baudelaire: cohetes; Nietzsche: sentencias y dardos; Antonio Porchia: voces; Louis Scutenaire: inscripciones; Cioran: pensamientos estrangulados; André Siniavski: pensamientos repentinos; Malcom de Chazal: sentido-plástico; yo: aerolitos.

En su Diario Ory teoriza sobre la especificidad del discurso de los aerolitos y plantea, desde su particular mirada poética, algunas definiciones:

Sigo haciendo aerolitos de cuando en cuando, cuando me viene la chispa. Son perlas del cráneo llenas de corazón. A ver si tengo tiempo de trasladar a mi Diario los trozos sueltos de texto que escribo con una finalidad temática, y luego no utilizo dejándolos desunidos. Mejor reunirlos en archipiélago, como islitas perdidas en el mar de la escritura (2004, Vol. III:185).

422 Alcance, n 9, León, 1981; Barcarola, n 15, Albacete, 1984; Hora de poesía, n 51 51, Barcelona, 1987; Diario de Cádiz, abril, 1993; Cuadernos Hispanoamericanos, $\mathrm{n}^{\circ} 545$, Madrid, 1995; El ciervo, n 544-545, Barcelona, 1996; La carátula, separata, Elche, 1998; Caleta, n² Cádiz, 1998; RevistAtlántica de poesía, nº 27, separata dedicada a Ory, 2004. 
Resulta muy interesante la definción que ofrece su autor: «Son perlas del cráneo llenas de corazón». Discurso psicosomático, integrador de la totalidad del ser humano, sin escisiones entre cuerpo y mente, que conecta el discurso cerebral, cuyo signo es el concepto, con la visceralidad propia del discurso de la emoción. En todo caso, el aerolito oryano, cuyo referente más alejado se encuentra en la literatura gnómica medieval, se distingue de la máxima y del aforismo en el rechazo del concepto como único punto de interés. No es un puro artefacto conceptual, simple labor de orfebrería inteligible, sino que el aerolito surge de la emoción, del sentimiento y de la experiencia interior. Es un breve paisaje de la interioridad lanzado como un rayo, que ilumina en la noche, hacia el exterior. El aerolito rehúye el discurso intelectual y se sitúa como discurso periférico.Discurso poético, visceral, emocional, onírico, absurdo, paradógico, lúdico y metafísico.

El discurso salta, liberado de la tiranía de una semántica específica que lo atrapa, en el vacío, como los fuegos artificiales iluminan la noche. En este sentido, es un relámpago de luz, símbolo del satori en el budismo zen, que estalla en la mente lectora. En el Diario encontramos diversas claves que pueden acercarnos a una definición del aerolito:

Ante todo, aspiro a la brevedad. Lo lacónico.

Brevis, laconius (gr. Lakônikos).

Mis aerolitos, la frase relámpago, la pompa de jabón.

Quintaesenciar, ser elíptico, discontinuo. Saltos, digresiones. Decir lo indecible: balbucir.

Economía verbal extrema. No verbalización. Gnómica, haikú. Mejor que nada: el silencio. La sentencia wittgensteniana: «De lo que no se puede hablar hay que callar» (2004, Vol. III: 273).

Ory instala los aerolitos en la poética del silencio y los compara con la estética del haiku budista. Son fragmentos mínimos del lenguaje del silencio, para ello Ory cita las palabras de Wittgenstein que cierran el Tractatus logico-philosophicus (1921). Los aerolitos no son máximas, sino mínimas, pequeñas islas en el mar del discurso. Como lo son las palabras, islotes que sobresalen en el océano del silencio, representado por la luz del blanco de la página. 
Ory va ofreciéndonos las referencias precisas de sus aerolitos: Novalis, Nietzsche, Heidegger, Cioran, Kafka, Breton, Friedrich Hebbel... Pero los aerolitos son herederos de la dislocación discursiva de la vanguardia, del dadaísmo, del surrealismo... Por ello las greguerías de Ramón Gómez de la Serna resultan una referencia muy especial debido al juego lingüístico, al componente lúdico, al humorismo inteligente, a la ruptura semántica y a la incongruencia. La presencia de la greguería en la poesía oryana viene de lejos, se efectuó en los años del Postismo ${ }^{423}$. De hecho algunos aerolitos de Ory presentan similitudes con las greguerías. La estética postista se plegaba perfectamente sobre la impronta ramoniana. La risa, el juego y la estridencia se observan perfectamente en los siguientes aerolitos:

\section{Descarta a Descartes}

Platón come plátanos

La gula que estrangula

Un pavo color rosa es una cosa pavorosa

${ }^{423}$ Resulta paradójico, pero Ramón Gómez de la Serna cita a Ory como uno de los herederos de las greguerías, tal como lo testimonia el siguiente fragmento del Diario de Ory:«Releo el Diario de Friedrich Hebbel, en una edición italiana de 1912, que poseo desde abril de 1954, siendo desde entonces uno de mis libros de cabecera, y un espejo de aforismos semejantes a mis Aerolitos.

Leí uno que dice: L'odore e la morte del fiore.

Es un "aerolito" o una "greguería". Y veo que lo cita Ramón Gómez de la Serna en su prólogo a la sexta edición de sus GREGUERÍAS / Selección 1910-1960, publicado en colección Austral, en febrero de 1960. Traducida al español, así como otras perfectas "greguerías" del poeta y dramaturgo alemán, continúa citando autores de todos los tiempos (que greguerizan): "...y las de Hebbel: el perfume es la muerte de las flores, o Las pulgas son los únicos animales que no tienen pulgas, o El hombre únicamente está en éxtasis cuando reza y cuando se afeita."

Y también cita -ino me lo esperaba!- "entre los buenos gregueristas de última hora", cosas de Jacinto Miquelarena y mías, que no sé de dónde las sacara por permanecer inéditas y hasta olvidadas por mí: "Son buenas las de Edmundo de Ory: "El silbido es el esqueleto de la palabra", "La luna es la cáscara del silencio del mundo", "El acordeón de la semana se rompe siempre los domingos"».

Cita esos tres ejemplos de mi cosecha ramonesca, de los años del Postismo, cuando yo acudía a la tertulia del café Pombo, en la calle Carretas, los sábados por la noche. Fui asiduo contertulio de la Sagrada Solana Cripta de Pombo, pero sin Ramón» (2004, Vol. III: 315).

En la Historia del postismo, escrita por Ory y publicada en la antología realizada por Félix Grande, aparece también la misma referencia: «En cuando a Ramón, él hubiera saludado el Postismo sin duda alguna. Lo hubiera saludado por encima o por debajo de su ramonismo. Ya en la selección que hizo de sus GREGUERÍAS (1910-1960), en la Colección Austral, pude ver que me saluda personalmente en la página 41 al pasar revista a sus corifeos: "Son buenas las de Edmundo de Ory: «El silbido es el esqueleto de la palabra», "La luna es la cáscara del silencio del mundo», "El acordeón de la semana se rompe siempre los domingos», y las del escritor argentino Gotardo Croce...» (Grande, 1970a: 267-268). 
Los libros son las hojas del árbol del pensamiento

El hombre es un animal que miente

En Inglaterra los ataúdes están provistos de una campanilla por si los muertos despiertan

Era tan pesimista que creía hasta en Dios

El lobo es un hombre para el lobo

La tortuga lleva la tortura a rastras

Qué horror el honor

De todos los violines el más extraordinario es el extradivario

SOCIEDAD rima con suciedad

La cara más cara es la máscara

La experimentación lingüística es el signo de este lenguaje dislocado, en el que la proximidad fónica articula este lenguaje, sacudiendo la coherencia y la referencialidad. De otro lado, el humor, que surge del enfrentamiento de los significados, es el eje hacia el que gravita este lenguaje deshilvanado. Así se asocian los conceptos en este aerolito. A modo de desplazamiento: «Los libros son las hojas del árbol del pensamiento».

$$
\begin{aligned}
& \text { libros --- hojas --- árbol } \\
& \text { A } \quad \mathrm{A}+\mathrm{B} \quad \mathrm{B}
\end{aligned}
$$

Imagen visionaria: (A) libro $=$ (B) árbol (b1 - pensamiento)

Según los parámetros establecidos por Roman Jakobson, tenemos aquí un lenguaje en plena función poética. Lenguaje que se desvincula del significado puramente pragmático para dirigir la mirada al propio lenguaje como tal, en busca de la poeticidad. Para ello, no sólo se reivindica la atención al puro significante, sino que esta se dirige a la suma de significante y significado. De manera que Ory crea una nueva significación al alterar el significado comunicativo de los signos. La alteración del término «pesimista» se ofrece claramente en la dislocación significativa del aerolito «Era tan pesimista que creía hasta en Dios». Hipérbole significativa, Ory da la vuelta al 
término al alterar el sentido usual y cultural de la expresión «pesimista» al retorcerla y distorsionarla. Si en la cultura occidental católica el pesimista (término cercano a ateo o agnóstico) es quien no cree en la existencia de un dios creador y lo niega rotundamente, Ory asocia «pesimista» al de cristiano creyente. Queda así agrandado y desviado el significado de la palabra pesimismo. El lenguaje oryano se basa en la significación periférica de las palabras y atiende a un significado profundamente emocional, basado en la plurisignificación, en las resonancias connotativas despegadas del significado central denotativo (calambur, retruécano, paranomasia, metáfora...). Juego y deformación, a fin y al cabo, del significado. Las siguientes greguerías de Ramón Gómez de la Serna ${ }^{424}$ podría perfectamente pertenecer a Ory:

El minotauro del minutero.

¿Cuál es la mujer más antigua? Antígona.

Descartes: es el que se descartó de muchas ideas para quedarse sólo con las buenas.

Mentor parece ser el que enseña a decir mentiras.

No sólo el juego, el humor y la experimentación son los ingredientes que definen los aerolitos, el aerolito oryano se configura como un instante de iluminación, como un rayo nocturno que alumbra los paisajes mentales más ocultos y despeja las sombras para que nuevos significados surjan de sus escondites. Los aerolitos oryanos tratan desde cuestiones puramente metapoéticas hasta metafísicas, pasando por referencias sociales, culturales, religiosas... En ellos Ory desvela todo su pensamiento, muestra claramente sus referencias y ofrece su punto de vista particular hacia los autores citados, óptica que en algunos casos supone apropiaciones e identificaciones y en otros exclusiones y ataques. Los aforismos siguientes, que pertenecen al pensador escéptico y pesimista por excelencia E. M. Cioran, poseen totalmente un regusto oryano. Ambos gravitan sobre la paradoja, el contraste y la oposición:

Cada ser es un himno destruido. 1955.

${ }^{424}$ Ejemplos de greguerías tomados de la edición Total de greguerías, Madrid, Aguilar, 
Estamos todos en el fondo de un infierno, cada instante del cual es un milagro. ${ }^{425}$

En todo caso, la definición de los aerolitos se encuentra en ellos mismos. Ory nos la ofrece así:

\section{La poesía es un vómito de piedras preciosas}

Poesía como operación visceral diamantina, como alquimia digestiva o etílica. Si la poesía es joya, lo son también los aerolitos: perlas de sabiduría.

\subsubsection{Identificaciones y exclusiones}

En los aerolitos como en los ensayos y, sobre todo, en el Diario, Ory va estructurando las coordenadas de su viaje cultural. Estos textos son, pues, el cuaderno de bitácora que ofrece la cartografía del extraño laberinto por el que Ory transita. Los aerolitos se configuran como tarea de meditación y de reflexión sobre un territorio temáticamente acotado que responde a la preocupaciones de su autor: metapoesía, metalenguaje, cultura, simbología, metafísica... En ellos Ory ofrece su particular mirada sobre el estado de las cosas, revela su óptica descentrada sobre el panorama cultural y ofrece acercamientos al misterio inefable de la existencia. Ory muestra sus cartas boca arriba y son ellas las que definen su ideario plegándose sobre las referencias ofrecidas. Los aerolitos funcionan como un mapa mental que estructura el territorio mediante una señalización particularmente emocional. Los aerolitos son una vía de acceso intuitiva a la realidad, cuyo interés parte de la interioridad anímica y sentimental y se dirige a la realidad concreta. Se trata, en definitiva, de un acercamiento poético a la existencia.

El aforismo, por sí mismo, posee siempre una carga poética que lo erige, por condensación, en una alquimia de la palabra. Comparado con el discurso narrativo o el informativo, el aforismo, como el lenguaje poético, consiste en una palabra vehemente, de alto octanaje. En este sentido, José Antonio Marina señala en el prólogo a la obra que

${ }^{425}$ Aforismos pertenecientes a El aciago demiurgo (1969), tomados de la antología realizada y prologada por Fernando Savater: Adios a la filosofía y otros textos, Madrid, Alianza Editoral, 1998, pp. 161-162. 
recopila los aforismos dispersos de Max Aub, Aforismos en el laberinto, que los aforismos «suponen a veces un aerolito de poesía en el campo de la prosa» ${ }^{426}$. Ofrecemos aquí algunos aforismos de Aub que ofrecen evidentes paralelismos con los aerolitos oryanos:

Dejar y no dejarse.

Ser molino, no molienda.

Primero fue el silencio.

Todo está por hacer: hagas lo que hagas, nunca se hizo ${ }^{427}$.

Escritura ideológica donde el lenguaje se abre ante el lector mostrando sus resquicios significativos ocultos.

La literatura oryana nunca ha consistido en un juego vacuo e intrascendente, nunca ha sido una impostura snob, sino que en ella todo fragmento lingüístico, por naïf o inocente que parezca, va cargado de un potencial significativo oculto, en ocasiones corrosivo, que hace de esta escritura un texto ideológicamente pregnante, tal como ocurre en los siguientes aerolitos:

El Hombre de Damasco (Pablo)

El hombre vestido de damasco

Existencia oficial del infierno (concilio de 547)

La lluvia, del cielo para abajo, no moja a Dios

Los besos: pecados mortales (Padres de la Iglesia)

Los aerolitos de Ory suponen verdaderos ataques a los sistemas opresivos del ser humano, a sus creencias y a sus prácticas. Existen en ellos verdaderas diatribas contra la explotación material y mental del hombre. Entre los símbolos culturales rechazados se encuentran: San Lucas, San Juan Evangelista, San Mateo, San Agustín, San Pablo, Aristóteles, Descartes, Pascal, Leibniz, Kant, Hegel, Tolstoy, Hitler, Franco, Lenin,

${ }^{426}$ Marina, José Antonio (2003) «Lectura privada de Max Aub», prólogo a Max Aub, Aforismos en el laberinto, ed. de Javier Quiñones, Barcelona, Edhasa, p. 17.

${ }^{427}$ Obra cit., pp. 137-139. 
Stalin... Así Ory acerca su discurso al pensamiento libertario y erige la heterodoxia como símbolo cultural:

DE mis listas de gente interesante: idiotas, enanos, monstruos, payasos, apaches, vagabundos, gitanos, harapientos, amerindios, esquimales, beduinos, lapones, bobos, ufólogos, insumisos

Mi patria es el aire que respiro

Los dardos de Ory apuntan a la misma diana que las afiladas sentencias de Friedrich Nietzsche: al cristianismo cuyos valores fueron los supuestos en los que se edificó la decadence:

No amar más que a uno solo es una forma de barbarie, pues va en detrimento de todos los demás. Así el amor a Dios.

Se ha observado mal la vida, cuando no se observa la mano que, con todos los respetos, mata.. mismo $^{428}$.

En tiempo de paz, el hombre belicoso se hace la guerra a sí

Una decisión peligrosa. La decisión cristiana de encontrar un mundo feo y malo ha hecho el mundo feo y malo ${ }^{429}$.

Como Nietzsche, Ory no sólo ataca al cristianismo como método de subyugamiento, sino también a su sombra, el racionalismo y sus derivaciones políticas: los totalitarismos, tanto de signo capitalista como comunista:

CONCIENCIA comunista: Prohibido el inconsciente en la sociedad soviética

Maud Tabachik, escritora israelita, atormentada por el recuerdo del Holocausto: «Hitler fue seguramente un chiquillo encantador. Pol Pot también»

Otras referencias contra las que se recorta de manera positiva la geografía cultural oryana son: Diógenes, Heráclito, Montaigne, Spinoza, Sade, Schopenhauer,

${ }^{428}$ Nietszche, Friedrich (1886), Más allá del bien y del mal, traducción de Carlos Vergara, Madrid, EDAF, pp. 93-94.

${ }^{429}$ Nietszche (1882: 215). 
Hölderlin, Goethe, Flaubert, Nietzsche, Heidegger, Kiergkegaard, Thoreau, Baudelaire, Rimbaud, Poe, Kafka, Whitman, Valéry, Freud, Jung, Breton, Benjamin Péret, Eluard, Artaud, Wittgenstein, Jorge Guillén, Juan Ramón Jiménez, Lorca, Maiakovsky, Céline, Cioran, Nabokov, Ernest Jünger, Bernanos, Bachelard, Koestler, Hebbel, Pavese, César Vallejo, Konrad Lorenz, Thomas Merton, Krishnamurti, Ginsberg, Castaneda, Malcom Lowry, Lyotard, Lipovetsky... Ory sigue a través de la brecha abierta por Nietzsche y transita recorridos más allá de la dogmática establecida por el conocimiento científico y por el pensamiento sistemático. Se sitúa pues en las coordenadas de un pensamiento borroso que aprehende una realidad líquida y flexible, continuamente dinámica, donde los límites que encierran conceptos y entidades no quedan precisados con rigidez. El Diario oryano nos lo aclara con más nitidez (2004, Vol. III: 286):

Más allá del dominio del conocimiento científico, existe el vasto campo de lo incognoscible y de la nesciencia, desde siempre explorado por la metafísica y por la religión de los misterios. Un más allá que los positivistas llaman «inmensidad»y Freud «sentimiento oceánico», que se apodera del espíritu y lo sumerge.

Los aerolitos muestran vislumbres y resplandores, a modo de intantáneas, de esa zona abierta que desemboca en la metafísica y en el misterio existencial. "Aforismos del espíritu libre» los denomina Ory en el diario (2004, Vol. III: 286) cuya función es desvelar territorios ocultos por la sombra de la razón:

Frases anormales, ondeantes y versátiles, cuanto más ilógicas más mágicas.

Contra el lenguaje tradicional y la palabra declamatoria, registro de ensueños $\mathrm{y}$ de reflejos infinitos, comunicando tonos privativos de la imaginación y del inconsciente (2004, Vol. III: 288).

He aquí aquí varios ejemplos:

La luna es una obra maestra

El tiempo es la respiración del espacio

Con mis manos llenas de curiosidad toco el insecto de lo desconocido

Chocamos contra el muro del infinito

Llueve luego existo

Dios está en la sal y en el azúcar 
Ningún espejo refleja la mismidad del ser

El cosmos no oye la campana de la iglesia llamando a oración. En cambio, oye el zumbido de un mosquito o el roer de un ratón

Los huesos de la respiración

Ama la lluvia como a ti mismo

Se dice el más allá, pero nunca decimos el más aquí

\subsubsection{Más allá del lenguaje}

La poesía oryana queda convertida en un proceso de meditación, en la búsqueda de una lenguaje que trascienda el pensamiento racional y la referencialidad pragmática (Mesado, 2013c: 83-97). Ory busca en el pensamiento del budismo zen, en su lenguaje terriblemente disparatado y absurdo, y a la vez cargado de evocación, la transgresión del pensamiento lógico. En este sentido, el koan, como ya hemos visto, ofrece una fractura lingüística que nos hace saltar más allá del pensamiento. El koan hace estallar el lenguaje, ya que por sí mismo supone una situación sin salida y busca así la experiencia directa, la fluidez inmediata, la ocurrencia repentina, la clarividencia del gesto. El koan se dirige a la realidad, no al pensamiento. Busca el silencio mediante la ruptura del lenguaje. Se trata de la supresión del pensamiento tal como ocurre en la medición zazen.

En el budismo zen japonés se dan dos direcciones: la escuela rinzai y el soto zen. El zen rinzai utiliza el koan como método de ayuda en el proceso de la meditación, samadhi, que trata de alcanzar el satori. El zen soto, en cambio, rechaza el uso del koan por considerarlo un soporte artificial en la búsqueda de la iluminación. Para esta escuela, la práctica del zazen es única vía para alcanzar el satori. De todas formas, el koan impregna todo el pensamiento budista, extraño, paradójico y absurdo. En la literatura zen existe diversas colecciones de koans, en otras ocasiones el koan se ofrece un una situación o en un diálogo ${ }^{430}$. El monje Nansen, cuando su maestro iba a partir con la espada un gato por la mitad, objeto de la disputa de los monjes del monasterio, se puso los zapatos sobre la cabeza. Otro monje visitó a Basho para preguntarle cuál era el

${ }^{430}$ Ver Cleary, Thomas (1993), Zen antics: 100 stories of enlightemment; traducción de Sebastián Vázquez Jiménez Antología zen. Cien historias de iluminación, Madrid, EDAF, 1995. 
principio del budismo y Basho le pegó como respuesta. Existen algunos famosos koans como:

Dime cuál es el sonido de una sola mano.

(Hakuin, 1685-1768)

¿Cuál es el rostro que tenías antes de nacer.

(Hui-Neng / Eno, 638-713)

¿Un perro tiene la naturaleza de Buda?.

(Joshu Jushin / Chao-Chou, 778-897)

Textos que recuerdan, por su lógica paradójica, la radical subversión del racionalismo y de representación icónica realista efectuada por la vanguardia histórica. La vanguardia encuentra en el absurdo una violencia que es, a su vez, una radical provocación frente a una cultura que sustenta un pensamiento estancado, que choca contra el dinamismo ilimitado de la realidad. La violencia del absurdo, el primitivismo y la ingenuidad naïf suponen la ruptura con un todo un sistema cultural que pone diques a la realidad, tanto humana como cósmica. Para Breton, el absurdo supuso un elemento liberador. La siguiente máxima es un auténtico koan (1962, 2009: 61):

Este verano las rosas son azules, el bosque de vidrio.

El lenguaje de silencio de la poesía oryana está más próximo al koan que al haiku, toda ella está atravesada por la lógica paradójica del koan. La poesía postista, surgida de las propuestas programáticas y de las prácticas de este movimiento, supuso una semántica ilógica, lúdica, extraña y absurda que desemboca en el arte conceptual de los aerolitos. Si la poesía basada en el haiku es como la reverberación de las ondas creadas cuando se tira una piedra en un estanque, los aerolitos son como pedradas en la cabeza, relámpagos en la noche que súbitamente iluminan. Ellos intentan subvertir las coordenadas que estructura nuestro pensamiento, su impronta es abrir brechas para que el pensamiento opere en nuevas direcciones. Los aerolitos son chispas que procuran provocar un incendio cerebral, plantean un impasse en nuestras rígidas y acomodaticias 
estructuras mentales que propone un salto mental, un juego que apunta a la terrible paradoja que supone el propio lenguaje. Tal como apunta Allan Watts (1958a, 1971: 2324) en la frase «qué le ocurre a mi mano cuando cierro el puño», el lenguaje se desvela incapaz de representar la realidad ${ }^{431}$. La paradoja, como señalaba ya Zenón de Elea ${ }^{432}$, únicamente existe en la representación, que no se adecúa al funcionamiento de lo real. Los aerolitos se acercan al silencio porque destruyen el lenguaje. Al igual que el koan, hacen estallar el lenguaje y su fractura crea una explosión que provoca un terremoto mental que expande el pensamiento, proyectándolo más allá de las cosas, hacia la percepción directa de la realidad. Tal es el sentido del siguiente aerolito:

Pienso con la yema de los dedos

La fractura lingüística de los aerolitos nos deja las siguientes perlas en el discurso de Ory:

Di algo que no sepas decir

¿De qué color es el silencio?

Ciegos son aquellos que no ven lo invisible

Nunca cambia de sitio el infinito

Un beso no se describe

El silencio tatuado

En el vacío del aire nada es nada. Nadie ha visto los pensamientos

Ningún esqueleto es metafísico

La muerte no se acaba nunca

Acuérdate de ahora mismo

Sin silencio previo las palabras no suenan

431 «Así por convicción científica se decide si un anguila será un pez o una serpiente, y la convención gramatical que determina qué experiencias serán llamadas objetos y cuáles recibirán el nombre de sucesos o actos. Cuán arbitrarias pueden ser estas convenciones se advierte con esta pregunta: “¿Qué ocurre con mi puño -objeto sustantivo- cuando abro la mano?" El objeto desaparece misteriosamente porque la acción estaba disfrazada por una parte de la oración que generalmente designa a una cosa».

${ }^{432}$ Las paradojas de Zenón apuntan a la insostenibilidad de la teoría no al de la realidad, pues Aquiles alcanza a la tortuga. Se trata pues de un impasse conceptual. 


\subsection{LA POESÍA SE HACE IMAGEN: POESÍA VISUAL}

blanc blanc blanc blanc blanc blanc un esvoranc

blanc blanc blanc blanc blanc basqueja i s'enllota

Joan Brossa

La poesía visual queda enmarcada en los límites de la vanguardia poética de la segunda parte del siglo XX y conecta totalmente con los desarrollos de la poesía experimental. Ya Ory, en su etapa postista, había reactivado los presupuestos vanguardistas practicando una poesía totalmente surrealista, de signo francés. A partir del introrrealismo, su poesía se acerca al expresionismo. Pero, sobre todo, la poética oryana supone, junto a la de Brossa y Cirlot, la apertura a la poesía experimental. Una de las aristas de la poesía de Ory consiste en la práctica de la experimentación poética, cuya obra más representativa, Arte de la fuga o rig, transita territorios propios de la poesía visual, del espacialismo y de la poesía concreta. La poesía visual oryana se enmarca en estas coordenadas. Se trata de una serie de obras en las que la imagen sustituye a la palabra, o bien imagen y palabra quedan amalgamadas en forma de poema-collage. No olvidemos la cercanía pictórica que manifiesta la poesía oryana, donde la imagen, visionaria, onírica o grotesca, juega un papel fundamental. Ory, además, participó en las dos exposiciones postistas, ha jugado un papel importante en la crítica artística y ha profundizado en los estudios plásticos tanto en la tradición pictórica como en el arte de vanguardia. Recordemos, en este sentido, que los manifiestos postistas eran verdaderos catálogos sobre las prácticas de la vanguardia histórica como de la historia del arte universal.

Parte de la obra visual oryana está contenida, tal como se especifica en el Apéndice XI, en antologías y otras publicaciones dispersas. En la Fundación Carlos Edmundo de Ory se guardan varios collages representativos de esta poesía visual. En la antología Metanoia, Rafael de Cózar recoge algunos poemas-collage. La antología El desenterrador de muertos (2006) presenta algunas muestras de esta obra gráfica oryana. En la revista Caleta de Cádiz, segunda época, $\mathrm{n}^{\circ} 16$, aparecen varios collages que ofrecen un muestra clara de la obra gráfica oryana que conjuga poesía y plástica. 


\subsubsection{Descontextualizaciones}

La poesía visual oryana, situada entre la obra gráfica y la práctica poética, se edifica sobre el poema-collage. Conjunción de imágenes o poemas hechos con imágenes, plásticos, fotográficos. En todo caso prevalece la mirada poética, esta es la que articula un discurso que integra diversos elementos icónicos y diferentes códigos: la pintura, la fotografía, el cine, la publicidad, la televisión... de la contemporaneidad. Esta propuesta converge con algunos desarrollos de la poesía visual como la poesía visiva de Michele Perfetti, integrante del Grupo 70, del Grupo Techne o del Grupo de Lucha poética; la poesía semiótica de Fernando Millán, de Guillermo Deisler o de JeanFrancois Bory; la poesía conceptual de Joseph Kosuth; los grafismos poéticos pop art de Robert Indiana... Los poemas-collage titulados ...et maintenant y Operation été midi que aparecieron en la revista Voratosc $^{433}$ son un claro ejemplo de poesía visual oryana, muy cercana al espacialismo y a la poesía concreta, ambos basados en la poesía gráfica que sustituye el verso por el ideograma y en la yuxtaposición no discursiva de sus elementos. Se trata de un collage de mensajes lingüísticos dispares sacados de diversos textos mediáticos como periódicos, revistas... a modo de los juegos tipográficos de la poesía futurista y dadaísta.

Ory recoge la herencia del collage de la vanguardia histórica: cubismo, dadaísmo y surrealismo, sobre todo. En la mayoría de sus collages se suprime la palabra para dejar que sea la imagen la que provoque las asociaciones significativas. Ory descontextualiza las imágenes tomadas de diversos discursos culturales y mediáticos y las coloca en nuevos contextos que articulan aquellos signos, dotándolos de nuevos significados o desvelando significados que permanecían ocultos. En los poemas-collage cabe destacar la presencia del collage plástico de autores dadaístas como Raul Hausmann, de Johanes-Theodor Baargeld o de Kurt Schwitters, de los cuadros-collage del cubismo analítico de George Braque o Pablo Picasso. Pero es el surrealismo el movimiento que posee una impronta más vehemente en el collage oryano. Son los collages de Max Ernst quienes, en cierto sentido, marcan las coordenadas en las que transita esta poesía de la imagen de Carlos Edmundo de Ory. En el collage más conocido de Ernst, La pubertad cercana o las Pléyades ${ }^{434}$ (1921) se ofrecen las claves

${ }^{433}$ Voratosca. Papers literaris d'Olot Mision, Olot, $\mathrm{n}^{\circ} 10$, pp. 84-85.

${ }^{434}$ Collage, partes de fotografías retocadas, aguada y óleo sobre papel sobre cartón, París, colección particular. 
de esta poética visual. Ernst amalgama pintura, fotografía y palabra en esta obra y ofrece un espacio visual cuyo acceso viene mediatizado por la poesía. El texto situado en la base de la obra, enmarcándola en la parte inferior coloreada del cartón, contextualiza las imágenes: el desnudo femenino sin rostro extraído de una fotografía que se recorta sobre un fondo azul suspendido sobre las olas del mar. De este fondo azul, donde flota el cuerpo femenino, se desprende una piedra y un fragmento de adoquín. El texto poético cohesiona estos elementos dispersos ofreciendo un nuevo contexto: «La pubertad cercana no ha arrebatado todavía / su gracia a las Pléyades / La mirada de nuestros ojos llenos de sombras se dirige hacia el adoquino que caerá / Todavía no existe la fuerza de la gravedad de las olas». Es la poesía la que dicta sus normas en esta nueva realidad que no ofrece ningún punto de contacto con lo real: poesía, sueño, deseo, extrañeza... subversión de la tiranía de la realidad social. En algunos collages, como Naufragio o Homenaje a Novalis, Ory utiliza el grabado decimonónico como material icónico siguiendo los pasos de Ernst en sus novelas, en las que la narrativa se apoya en el grafismo fotográfico ${ }^{435}$, paradigma total del collage.

Esta primacía, enteramente, poética que contextualiza los elementos icónicos, sean pictóricos o fotográficos, es deudora de algunas obras de Joan Miró. La mirada artística mironiana es profundamente poética, pero en algunas obras se agudiza aún más por el hecho de incorporar el fragmento poético a la obra. En Estrellas en los sexos de los caracoles $(1925)^{436}$, el título aparece en el vértice superior izquierdo del cuadro como si fuese un verso o un micropoema. Lo mismo ocurre en el cuadro titulado Este es el color de mis sueños $(1925)^{437}$, donde el texto queda incorporado a modo de poema visual. Cabe recordar que Miró, como Ory, no concebía ninguna separación entre pintura y poesía. Otro pintor surrealista del que el collage oryano es deudor, por sus imágenes oníricas y sus asociaciones inesperadas, es René Magritte. En algunas de sus obras sustituye los objetos pictóricos por palabras, o bien desliga la palabra, como pura etiqueta, del objeto que representa. Este último es el caso de la obra La llave de los sueños $(1927)^{438}$, en la que aparecen cuatro objetos señalados por cuatro palabras y sólo uno de ellos coincide con la palabra que lo representa. En El mundo perdido (1929) ${ }^{439}$

${ }^{435}$ La femme 100 têtes (1929), Rêve d'une petite fille qui voulut entrer au Carmel (1930), Une semaine de bonté ou les sept éléments capitaux (1934).

${ }^{436}$ Óleo sobre lienzo, Düsseldorf, Kunstsammlung Nordrhein-Westfalen.

${ }^{437}$ Óleo sobre lienzo, colección particular.

438 Óleo sobre tela, Múnich, Pinakothek der Moderne.

439 Óleo sobre tela, Milán, Galería Milano. 
Magritte señala la absurda relación entre el objeto visual y las palabras que lo representan. En el cuadro el lenguaje sustituye a los objetos, ello expresa una dislocación porque la relación entre palabra y cosa resulta incoherente. La palabra «cheval» se corresponde con una mancha de pintura negra. En el cuadro, que ha quedado como una imagen icónica pregnante, La traición de las imágenes (Esto no es una pipa) (1929) $)^{440}$, el fragmento poético dispuesto bajo el objeto representado, la pipa, señala la función metartística de la frase, cuyo referente es la imagen pictórica y no la realidad objetual. De modo que la pintura se convierte en metapintura. Pintura que reflexiona sobre sí y queda desligada de la realidad objetual ${ }^{441}$.

Si Magritte sustituye en sus cuadros la imagen por la palabra, Ory realiza la operación contraria y en la imágenes visionarias manifiestadas en sus collages sustituye la palabra por la imagen. Así en Mentón-culo (1972), que aparece en el Apéndice XII, Ory presenta la imagen de un militar armado en formación, de su mentón surge la fotografía de unas nalgas y de su frente y de su cabeza surgen, a modo de casco, dos culos más. Tenemos aquí varias imágenes poéticas:
(A) mentón $=(\mathrm{B})$ nalga
(A1) frente $+(\mathrm{A} 2)$ cabeza $=(\mathrm{B})$ culo

Se trata una de las estrategias pictóricas de Salvador Dalí, en la que diversos objetos forman por sí mismos otra figura poética diferente. Así ocurre en el retrato de Voltaire, que aparece en Mercado de esclavos con la aparición del busto de Voltaire (1940) ${ }^{442}$. El busto de Voltaire, que reposa sobre una pequeña peana, está formado por dos figuras vestidas de negro, cuyas cabezas se corresponden con los ojos, que se difuminan entre las demás figuras humanas.

En el collage, que no tiene título ni fecha, que se encuentra en la página 316 de la revista Caleta, tal como se indica en el apéndice XI y puede observarse en el Apéndice XII, aparece la fotografía de una desierta estación de metro donde las vías

${ }^{440}$ Óleo sobre tela, Los Ángeles, County Museum.

${ }^{441}$ Michel Foucault (1973, 1981: 31-45) estudia los mecanismos que intervienen en el modelo representativo de Magritte y señala las perversiones efectuadas por el autor en la relación entre imagen y lenguaje. Tanto la imagen como el texto son puras representaciones, por ello no hay ningún objeto («pipa») en el espacio artístico.

${ }^{442}$ Óleo sobre tela, Cleveland, Ohio, Colección Reynols Morse. 
férreas acaban en la oscuridad de un túnel. En la parte inferior y franqueada por las imágenes fotográficas de dos parejas sumidas en juegos eróticos, aparece la fotografía de unas piernas y unas nalgas femeninas. Se establece aquí otra imagen encadenada:

$$
\begin{aligned}
& \text { (A1) estación }=\text { (B1) culo de mujer } \\
& \text { (A2) túnel }=\text { (B2) ano }
\end{aligned}
$$

De signo totalmente surrealista es también el poema-collage, sin titulo ni fecha, que aparece en la página 322 de la revista Caleta. En él aparece un rostro femenino, seguramente extraído de algún texto publicitario. Los ojos abiertos, que miran hacia arriba, poseen unas grandes pestañas postizas. Entre los carnosos labios pintados surgen una serie de pececillos viscosos que se cuelan por los orificios de la nariz. Los ojos de los peces siembran su cara como si fueren granos o perlas. Del collar que recorta la garganta surgen estos peces que se enredan en las orejas de largos pendientes y en el pelo. Totalmente surrealista se nos presenta el titulado Pesadilla sexual o Araña (1973), contenido en el Apéndice XII, que de algún modo nos recuerda a ciertas imágenes de Un chien andalou (1929), aquellas que asociaban el sexo (la mano, imagen de la masturbación) con las hormigas, la culpabilidad. Ory aquí asocia, bajo la imagen onírica de la pesadilla, el deseo sexual femenino con las arañas. En este collage unas arañas sobrevuelan el cuerpo erotizado y desnudo de una joven que, con las piernas abiertas, enseña impúdicamente los labios de su sexo rasurado mientras oprime con sus manos sus pechos. Las arañas intentan coger con sus largas patas peludas unas piedrecitas o lágrimas que reposan sobre el vientre desnudo de la mujer.

El collage de Ory, en cuanto descontextualización de los lenguajes mediáticos, muestra sus convergencias con el pop art, desde los cuadros de Robert Rauschenberg o el famoso cuadro de Richard Hamilton (que en sí mismo es un collage) ¿Qué es lo que hace que los hogares de hoy sean tan diferentes, tan agradables? (1956) ${ }^{443}$, hasta las obras de Martial Raysse, de Peter Phillips, de Wolf Vostel o de Martial Raysse, donde la descontextualización es el eje articulador de la obra. El collage pop deconstruye la iconografía social contemporánea para construir artefactos fragmentarios cuyo punto de unión consiste en una extraña coherencia interna. Es esta mirada extraña la que

${ }^{443}$ Colección Georg Zundel. 
amalgama a las diferentes imágenes dotándolas de un sentido plural, que modifica la semántica particular de cada una de ellas, descontextualizándolas, para dotarlas de otro contexto significativo. La crítica al consumismo del cuadro anteriormente citado de Hamilton reúne en sí toda la iconografía pop: la marca publicitaria, la comida envasada, el cine, los electrodomésticos, la televisión... Por ello constituye un ataque a la sociedad capitalista y a sus tópicos: el culto al cuerpo, la seducción del cuerpo femenino, la sonrisa publicitaria, el estilo de vida acomodaticio, el excesivo confort...

El collage de Ory, como el Martial Raysse, dirige sus referencias a algunos fragmentos de la plástica clásica. Así la obra artística se pliega sobre el mismo arte y desvía la mirada hacia sí para evitar posarse sobre otras realidades no representacionales. Así Ory representa lo anteriormente representado, a modo de intertextualidad explícita, y ofrece nuevos contextos que articulan aquellos signos de la tradición cultural. Se trata de dirigir la imaginación sobre lo imaginado, las referencias sobre antiguos referentes, de un juego de espejos entre el original y la copia. Raysse construye su collage, titulado Made in Japan (1965) ${ }^{444}$, sobre las figuras de las bañistas de Ingres. En la nueva contextualización, el material que ha sido tomado prestado, los desnudos femeninos de Ingres, se convierte en paradigma del mal gusto, pero también en crítica del arte decorativo de consumo y de las técnicas de producción masiva. En Oro y carne, collage que aparece en la página 56 de El desenterrador de vivos, Ory toma, mediante disposición fotográfica, los elementos gráficos de la pintura y de la escultura clásica. Una clásica figura femenina al óleo, desnuda, abraza una de las tres reproducciones de la Venus del Milo. El collage titulado San Sebastián, que aparece en la página 52 de El desenterrador de vivos, intercala la figura de una chica que pasea con minifalda y peinado pop en el óleo renacentista de Antonello de Messina, San Sebastiano $(1476)^{445}$, que representa a un San Sebastián atravesado por las saetas. La chica lleva una mariposa a modo de palmito con la que se cubre parcialmente el rostro, desvelando sus ojos. Esta figura femenina aparece en el escenario solamente como espectadora, con lo que todo adquiere un nuevo sentido, mucho más ambiguo y crítico. El collage, que se halla en la página 62 de la misma antología y que se titula Apocalipsis, está estructurado mediante la superposición de varias imágenes extraídas de la pintura religiosa.

${ }^{444}$ Colección particular.

445 Óleo sobre tabla, transportado a tela, Driesde, Gemäldegalerie. 


\subsubsection{La feminidad como mercancía}

Ory ofrece una mirada naïf, pop, fresca y desenfadada en apariencia, pero irónica y subversiva frente al funcionamiento de la imagen social. Mirada que va dirigida, sobre todo, al cuerpo femenino y que descubre los engranajes ocultos que estructuran la mirada social. La obra gráfica de Ory se alimenta del lenguaje icónico de la sociedad mediática y se transforma en representación irónica de los mecanismos socioculturales que mercantilizan el objeto femenino representado y lo transmutan en mero reflejo económico. En ella se observa la destrucción del cuerpo individual, reducido a la mera superficialidad al quedar instalado en escenarios puramente virtuales y abstractos, como lo son los que presentan los medios informativos y publicitarios. Este proceso trasformador del cuerpo femenino desvela la superficie y el vacío que se esconden tras el objeto y devuelve la mirada, como un espejo, ante los mismo ojos del espectador. Esta mirada especular refleja aquello que cotidianamente observan los ojos del individuo social, ya sea en la bidimensionalidad del papel impreso, de los muros y las vallas de las ciudades o del espacio eléctrico de las pantallas. Ory muestra la pérdida de dimensión humana, cultural y social a la que los humanos estamos sometidos, pero además certifica la mercantilización a la que la feminidad se halla sometida, los mecanismos sociales que utilizan en cuerpo de la mujer como territorio acotado, como propiedad, y lo someten al poder del sistema económico. La mirada oryana descontextualiza el cuerpo femenino para presentarlo como mera mercancía, golpeado por la mirada del espectador y convertido en valor de cambio, en mero objeto de consumo.

El collage titulado Desnudo roto, publicado en la página 319 de Caleta, muestra tres fragmentos, troceados a modo de rasgaduras, de la fotografía en blanco y negro de un desnudo femenino que posa de rodillas sobre una tela. Ory ha suprimido la cabeza de manera deliberada, además el espacio visual adquiere la apariencia de una fotografía ajada y rota en tres pedazos. Se representa así la imagen de la mujer suprimida, quebrada, fragmentada, cuyo único valor es la representación erótica en el mercado social. Otro collage que instala el cuerpo femenino en el escenario mercantil es el que aparece en la página 328 de Metanoia y se titula Elle en rêve que des belles robes et des plaisirs. En un paisaje indeterminadamente devastado, recortado por lo que parece una pancarta vertical donde se hallan impresos unos ideogramas alfabéticos chinos, el 
cuerpo femenino erotizado se muestra de manera impúdica a los ojos del espectador. Aunque la figura femenina no muestra demasiadas geografías de su cuerpo, es la actitud de las manos, la pose de seducción, la mirada deseante y los labios oferentes aquello que hipersexualiza su cuerpo convirtiéndolo en mercancía y objeto de consumo. El rostro femenino pierde relieve humano para acercarse a la textura fría y superficial de la muñeca. Mujer convertida en objeto, cuerpo a quien va dirigido, como un dardo, el deseo social del espectador. La transmutación del cuerpo femenino en una operación mercantil, enmascarada por la seducción premeditada de los códigos publicitarios, viene señalada por el título, que funciona como slogan perfecto que define a la mujer objeto. Ory representa la típica imagen de la mujer ofrecida por los canales mediáticos de la sociedad occidental en la segunda mitad del siglo XX y que se globaliza a medida que la cultura se filtra por los escenarios telemáticos. En este contexto la frase que titula el collage, Ella sólo sueña en ropas bonitas y en los placeres, queda convertida en denuncia del machismo imperante en una sociedad mediática que frivoliza la feminidad para que la mujer, una vez deconstruida por el discurso publicitario, ocupe su lugar acorde al proceso de banalización social efectuado por los discursos mediáticos y mercantiles.

La hipersexualización del cuerpo femenino convierte a la mujer en simple objeto mercantil, la desposee de su cuerpo para crear un cuerpo artificial. La mujer, despojada de su subjetividad, acaba convertida en muñeca, tal como ocurre en las esculturas del surrealista Hans Bellmer. Mujer monstruo, inconscientemente perversa y fetichista, capaz de esclerotizar su sexualidad en infinitas articulaciones. En su obra La muñeca $(1945)^{446}$, la erotización convierte el cuerpo de la mujer en una masa deforme, en un mecanismo de infinitas articulaciones sexuales. Los collages de Ory muestran la imagen de una mujer que hipostasia sus rasgos femeninos. Una mujer troceada, fragmentada, sensualizada, erotizada... Una mujer cuyo cuerpo resulta, en última instancia, vacío, despojado de todo signo de individualidad: labios pintados, senos neumáticos, rostros alegremente inexpresivos... Este es el lenguaje cosificado de Tom Weesselman, Allen Jones, Roy Lichtenstein, Meter Phillips, Mel Ramos, James Rosenquist o Helmud Newton. El cuerpo femenino pop-art desvela, parodiando a la publicidad, la imagen de la mujer observada a través de la mirada social masculina. Cuerpo femenino socialmente pervertido, cuerpo fetichista objeto de transacción.

${ }^{446}$ Madera pintada, pelo, calcetín y zapato, París, Centre Pompidou. 
La fotografía de Newton muestra una mujer profundamente erotizada, enérgica, casi masculina en su feminidad. En Big Nude III, la modelo, vestida únicamente con zapaton de tacón, se tapa el sexo con las manos a modo de las representaciones clásicas. Pero, en este caso, ha perdido la inocencia y el pudor de la Venus de Botticelli, ahora la mujer exhibe impúdicamente su cuerpo desnudo. La Venus de Newton no está desnuda, su desnudo resulta enormemente fetichista. Los zapatos de tacón alto ofrecen una actitud desafiante. Esta es la gran aportación de la modernidad: el fetiche. Newton (al igual que hicieron los artistas Salvador Dalí, René Magritte, Man Ray, Hans Bellver, Paul Delvaux...) sitúa el erotismo alejado del cuerpo femenino. Traslada la erótica a los zapatos de tacón y, sin pretenderlo, muestra la tiranía de la ortopedia sobre el cuerpo de la mujer. Bien mirado, el zapato de tacón resulta un instrumento de tortura que, a su vez, funciona como elemento de seducción. Es una prenda absurda que no tiene ninguna finalidad práctica, sólo señala la morbidez del fetiche. El fetichismo es aquello que aleja a la Venus de Helmut Newton de la de Botticelli. La mirada de Newton lleva impregnada, como signo inherente, la tortura del cuerpo femenino, sus modelos aparecen siempre en posturas impúdicamente forzadas, contorsionadas. Su fotografía representa la tiranía de la seducción, el sometimiento del cuerpo femenino a sus dictados. Para Óscar Tusquets ${ }^{447}$, el tacón de aguja y la posición del cuerpo femenino con las piernas simétricamente abiertas son los dos signos de la representación femenina posmoderna. Es este erotismo hiper lo que aporta el arte posmoderno: el cuerpo de la mujer hipererotizado y representado desde la tiranía de la mirada fetichista masculina. Cuerpo femenino regido por la dinámica mercantil del consumismo.

Ory desvela en sus collages los mecanismos publicitarios que, en cierta medida, incorporan a su discurso la radicalidad y la provocación, propia del amour fou de los surrealistas, sometida ahora a los cánones del discurso económico. La representación del inconsciente suponía, desde los postulados de la Vanguardia histórica, la ruptura de los tabúes sexuales y el surrealismo se concebía como un método de liberación humana con una verdadera incidencia social, liberación que afectaba inevitablemente a la mujer. El cuerpo de la mujer era el depositario del misterio más escondido, en él se conjugaban todas las fuerzas telúricas reprimidas. A su vez, suponía una territorialidad liberada, un espacio capaz de hacer aflorar los sentimientos sumergidos. En este sentido, la primera subversión contra el orden establecido consistió en hacer estallar toda barrera capaz de

${ }^{447}$ Tusquets Blanca, Óscar (2007), Contra la desnudez, Barcelona, Anagrama, p. 236. 
constreñir la feminidad, sobre todo aquella que reside en la interioridad afectiva, sensual, sensitiva y erótica. Ory muestra la imposibilidad liberadora de la feminidad, cuyas antiguas rebeliones son asimiladas por el capitalismo social, que en la posmodernidad sigue sometiendo el cuerpo femenino bajo la tiranía de las normas sociales en sus redes culturales. El collage, desprovisto de título, representado en la página 315 de Caleta, muestra el desnudo de una mujer que mira fijamente al objetivo de la cámara y que con sus manos tapa la vellosidad de su sexo, lugar de donde surge un candelabro que sostiene la fotografía de cintura para arriba de otra mujer en miniatura, como si fuese una muñeca, vestida con sujetador y que se tapa los ojos con el antebrazo. La imagen muestra el juego lúgubre que la publicidad realiza con el erotismo, operación de simple valor de cambio que funciona como dique edificado para someter la feminidad instalada en una sociedad regida por valores monetarios. Para Ory el erotismo ha sido secuestrado por los valores económicos y sociales imperantes, banalizándolo al presentarlo en los escenarios masivos y convirtiéndolo en simple objeto prefabricado:

La semipornografía de cierto erotismo estampado sumerge los instintos en un baño de rosas necio, ni frío ni caliente. Nuestra época, fundamentalmente óptica, enemiga del misterio material, sabe codificar la antigua divinidad demoníaca en el insinuante fetiche sexual prefabricado ${ }^{448}$.

El cuerpo femenino, como en las obras de Tom Wesselman, queda diluido en el acto de mirar. La feminidad se exhibe en un discurso dirigido a una sociedad masculina que recrea sus deseos, puramente mentales, transfiriéndolos, a la manera del voyerismo, a los cuerpos de la feminidad que se ofrecen a la mirada. Wesselman suprime el cuerpo femenino en favor de la señalización del código erótico. En Bathtub 3 (1963) ${ }^{449}$, el cuerpo que posa de una forma forzada y totalmente impúdica en la bañera queda suprimido para resaltar, como accidentes geográficos, tres paisajes del territorio erotizado: los labios, los pezones y el vello púbico. Se trata de un erotismo sin cuerpo, en el que la hipererotización femenina, transmitida por los medios, despoja al ser humano de su cuerpo en una operación que supone un sucedáneo de la experiencia sexual. La sexualidad, para Ory, supone un misterio sagrado que se manifiesta en los

448 Ory, Carlos Edmundo de (1968), «Erotismo y civilización», Cuadernos Hispanoamericanos, Madrid, $\mathrm{n}^{\circ}$ 221, mayo; en lconografías y estelas, Cádiz, Servicio de Publicaciones de la Diputación, 1991, pp. 217-218.

449 Óleo sobre lienzo, plástico, diferentes objetos, Colonia, Museum Ludwig. 
rituales eróticos corporales, una experiencia que irradia del interior hacia el exterior, proyectándose sobre todos los seres. El erotismo es así una mística sagrada. Como tal aparece en el collage realizado en 1977 que se encuentra en la página 329 de Caleta. En él se manifiestan, en la semioscuridad que ofrece un candelabro con nueve velas, un seno recortado y un negro pubis que se realza en el claroscuro formado por las sombras de unas piernas de mujer. Intencionadamente esta imagen recuerda, a modo de intertextualidad evidente, al cuadro pintado con total realismo ginecológico por Gustave Courbet que se titula El origen del mundo $(1866)^{450}$. En él se muestra el cuerpo desnudo de una mujer que las piernas separadas enseña sus labios vaginales enmarcados por un enérgico vello púbico ${ }^{451}$. Sexualidad que es origen, conexión y permanencia en una realidad amorosa.

450 Óleo sobre tela, París, Museo d'Orsay.

451 En abril de 2014 la artista de Luxemburgo Deborah de Robertis realizó una performance en el Museo d'Orsay de País consistente en sentarse y enseñar su sexo, abierto con las manos, frente al cuadro de Courbet. La acción se completó con el siguiente texto oral: "Yo soy el origen, soy todas las mujeres, quiero que me reconozcas, virgen como el agua creadora de esperma». La reacción del público se tradujo en aplausos y risas, y la respuesta del Museo fue su prohibición. www.abc.es/abci-sexo-desnudo-courbet-performance201406051014 
TERCERA PARTE

HERENCIA ORYANA 


\section{LA ESTELA ORYANA EN LA POESÍA CONTEMPORÁNEA}

\section{POETAS (MÁS O MENOS) ORYANOS}

Tal vez aún no comprendo la verdadera hondura de las plantas.

Mercedes Escolano

Los poetas que recogen directamente la impronta poética establecida por Carlos Edmundo de Ory se hallan ligados de alguna manera a la trayectoria poética y vital (que en este caso resulta ser indivisa) del poeta maestro. Nacidos entre 1942 y 1959, han transitado por trayectos diversos en el intrincado laberinto de la poesía oryana. Son poetas cuya expresión ha quedado marcada por las huellas de los relieves del sello poético de Ory: la libertad creadora, la alquimia verbal, la transgresión normativa, la aventura experimental, la conciencia heterodoxa... Se trata de autores que, como Ory, unen los segmentos más separados de la diáspora poética: vanguardia y tradición. Sus poéticas, profundamente culturalistas e intelectualizadas, herméticas, bucean en la tradición con la voluntad de ir más allá. De hecho, se dirigen a las instancias más urgentes de la modernidad y de la vanguardia poética, buscan artefactos poéticos que se plieguen totalmente con los relieves culturales de la sociedad posmoderna y se diluyan en el flujo de sus discursos. Son coetáneos de los novísimos, inician sus trayectorias en la década de los años setenta bajo el signo de la ruptura del realismo y se sumergen radicalmente en los nuevos parámetros culturales de una sociedad abierta a una conciencia pop y cosmopolita, que sacude los viejas estructuras anquilosadas de la 
carpetovetónica cultura hispana, trasformándolas y transgrediéndolas sin abandonarlas ni perderlas de vista.

Hablamos de poetas que conocieron directamente a Ory y declararon su devoción, que lo han reconocido como maestro y han interiorizado la mayoría de los presupuestos de su poesía. Sus poéticas han quedado instaladas en el territorio de una voluntad poética independiente, heterodoxa y libre, comprometida con la soledad, con el lenguaje y con la autenticidad de las vivencias. Estos poetas practican una poesía que escapa de los territorios aclamados por modas y mayorías.

\subsection{Herencia directa}

Los poetas que primeramente surgieron de la estela dejada por la poesía oryana son, evidentemente, aquellos que más próximos se sintieron a la impronta marina y cósmica de la poesía oryana. Poetas ligados al núcleo geográfico de Cádiz, o bien porque allí han nacieron, o porque allí viven o mantienen con esta ciudad otro tipo de vinculación. En todo caso, al margen del poeta catalán Jaume Pont, cuyos estudios oryanos lo atan rígidamente a Cádiz, los demás poetas nacieron o vivieron en Andalucía. Por ello su poesía supone una reactualización de los territorios poéticos andaluces convergentes con la vanguardia: Alberti, Lorca, Cernuda, Ory. De todos ellos la huella que ha quedado impresa con más relieve es la de Carlos Edmundo de Ory. Tres de estos poetas, Jesús Fernández Palacios, Rafael de Cózar y José Ramón Ripoll, pertenecieron al grupo Marejada de Cádiz, surgido en 1971 y del que ya se ha tratado con anterioridad. Marejada enlaza con la poesía gaditana de posguerra, de la que se siente heredera. El punto de conexión lo establece la revista Platero, que fue dirigida en Cádiz por Fernando Quiñones entre 1951 y 1954. Estos tres autores, junto a Antonio Hernández, son los cuatro jinetes oryanos ${ }^{452}$.

La obra de Jesús Fernández Palacios es deudora de la poesía oryana en muchos sentidos. Su poesía surge de los territorios poéticos de la marginalidad más radical: el interés por el underground y por la Beat generation. Su voluntad de libertad le lleva a

${ }^{452}$ Así los llamó Carlos Edmundo de Ory, Los cuatro jinetes, título de su introducción a la antología, Nueva Poesía 1: Cádiz. Obra cit. 
una poética libre, que rompe con la tiranía de los encorsetados modelos poéticos de la posguerra y propone un regreso a la vitalidad de los lenguajes establecidos en la vanguardia: fragmentarismo, eclosión inconexa de imágenes enganchadas, automatismo, distorsión léxica, alteración gramatical, ruptura de todas las normativas:
Nuestro asunto es testimonio
por mi boca pocas rocas
de la playa sonajera
tu mano será viajera
en el vientre de la foca
por antiguo matrimonio
Hoy jamás la vida puedo
y nunca mi desaliento
en la nostalgia mantengo
Cada camino "tristeza"
venite oremus Sakina
"cuérpame tu cuerpecito
piel de piélago bajito
cascabel de la sardina
que me suena en la cabeza"

(«Coplas para vivir físicamente», Coplas de Israel Sivo, 1982$)^{453}$.

El punto de contacto de esta poesía libre y la vanguardia poética es la obra de Carlos Edmundo de Ory. Fernández Palacios rescata la subversión postista y la erige como proclama de su poesía, que se reafirma en recuperar las aventuras y las rebeldías efectuadas a lo largo de la tradición. Esta libertad poética implica un doble compromiso, con el lenguaje y con la realidad. No en balde otro de los referentes de su poesía es César Vallejo, cuyo lenguaje libre quedó adaptado a la preocupación humana y a su interés por los signos de la cultura indígena de la que se sintió partícipe. La experimentación poética supone una reactivación del surrealismo y del Postismo que lleva a su autor a una poética esencial de la palabra, que busca la extrañeza semántica y la sorpresa. Las palabras se enhebran unas a otras como si se tratase de una cadena de vibraciones. Nótese cómo el siguiente fragmento toma la forma de un extraño mantra alucinado:

${ }^{453}$ Las Coplas de Israel Sivo se publicaron en Cuadernos Hispanoamericanos, $\mathrm{n}^{\circ} 383$, Madrid, mayo 1982. En esta edición sólo aparecen las seis primeras. En Poemías, Sevilla, Ediciones En Huida, 2012, se añaden cuatro más. 
Extasiado estoy como un sueño irreal

La vida en el éxtasis de los sueños

Sueños mis uñas rotas rotos los ojos

Necio me desenvuelvo en mí mismo

Agito y levanto la ira y la violencia

Me exalto funciono a destiempo

Me hago anacrónico anatema polvoriento

Me deslizo vuelvo egoísta

Me superegoísto me superoigo soy Yo

No resisto la tentación de desvestiros

Succionaros el jugo de vuestros cuerpos

Y el libre calor de vuestras mentes

Vuelvo a nacer y me suenan los oídos

Interpongo mi razón compongo vano

Triste compongo sutiles armas

Resuelvo una suposición contra vosotros

Al fin me debilito pido culpas y lloro

(«Vigilia», Poemías, 2012). ${ }^{454}$

La práctica poética de Fernández Palacios surge de una necesitad afectiva y vivencial. Por ello, gravita lo cotidiano y, desde una óptica netamente sentimental, reflexiona, rehuyendo imposiciones y solemnidades, sobre la experiencia. Entre sus obras cabe destacar Poemas anuales (1976), El ámbito del tigre (1978), Coplas de Israel Sivo (1982), Signos y Segmentos 1971-1990 (1991), Los poemas de Sakina (1997), Signos y segmentos. Segunda antología (2007) y Poemías (2012), obra que rescata poemas publicados de modo disperso, ofrece otros inéditos y reescribe algunos publicados en obras anteriores.

Otro autor que recibe directamente la herencia oryana es el poeta, pintor, novelista y crítico Rafael de Cózar, antólogo y estudioso de la poesía de Ory. Sus estudios sobre la poesía visual le han llevado a reconstruir toda una tradición silenciada y reprimida, marginal, que surgió desde tiempos inmemoriales y cristalizaron en la poesía experimental. Este empeño crítico liga su poesía, de un lado, a la práctica de la poesía visual $\mathrm{y}$, de otro, a la adopción de una poética de signo vanguardista $\mathrm{y}$ trasgresora, que desecha la tradición inmediata para abrazar la tradición de la marginalidad: juegos literarios, laberintos, artificios, simbolismo, surrealismo, expresionismo... Una poesía que, como la oryana, se nutre de la experiencia humana y

${ }^{454}$ Poema publicado en Cuadernos Hispanoamericanos, n 283, Madrid, enero 1974. En Poemías aparece totalmente retocado. 
exige un discurso libre, simbólico y, como tal, visionario. En todo caso, revelador del interior humano.

La soledad es la edad del sol, la soledad es un pájaro de cobre, la soledad es hacer el amor con la nada, la soledad es un trazo de noche en la garganta, la soledad es un diálogo con el aliento, la soledad es el azul pisotón de la tarde, la soledad es una carta de tinta invisible, la soledad es el carné de identidad del infinito, la soledad es la uña de la huella y ella un goterón de lluvia entre los dedos, una bocanada de nube, las piernas invertidas de la uve o el sabor de un buzón vacío.

Por eso la soledad es solo eso: el sol de cobre, la nada garganta, el aliento de la tarde, el invisible infinito de la huella, los dedos de la nube, la uve desolación de un buzón vacío...

la edad del sol. solo eso:

(«La soledad», La copa de los ecos, 2011) ${ }^{455}$

Totalmente evidente resulta la huella que la poesía de Ory ha dejado en este poema. La poesía de Cózar intenta desvelar zonas ocultas del ser y hacer visible lo invisible, consciente lo inconsciente. Para ello utiliza el método becqueriano de la elaboración del instante poético, captado por la inspiración. En Cózar, el proceso poético articula las emociones de la experiencia vivida dejadas en la memoria, de modo que el sujeto del discurso no es el sujeto de la experiencia, sino el de la poesía. Esta, situada en una zona abierta que bascula entre la realidad, la sensación y la evocación, rehúye todo sentimentalismo al transmutar el sentimiento en imagen. Su poesía aparece en antologías y publicaciones dispersas y en tres obras importantes: Entre Chinatown y River Side (1987), Ojos de uva (1988) y Los huecos de la memoria (2011).

Otro jinete oryano es José Ramón Ripoll. Su poesía incorpora la música como elemento esencial, tanto es así que resulta imposible y absurdo separarlas. Se trata de

${ }^{455}$ Pertenece a Los huecos de la memoria, Sevilla, Ediciones En Huida, 2011. Incluye poemas escritos entre 1977 y 1980, estructurados en dos poemarios: La copa de los ecos y Sombras de tus ecos. Además ofrece una muestra de la poesía visual del autor, coétanea a los poemas. 
una poesía que surge de lo íntimo y se dirige a lo humano. En cierto modo, siguiendo el modelo de la poesía oryana, reflexiona sobre la metafísica de la cotidianeidad: la circularidad temporal de la existencia, la realidad y la representación, la búsqueda del origen, la integración del ser en la totalidad humana y cósmica, el reconocimiento y la asimilación del devenir y de la muerte...

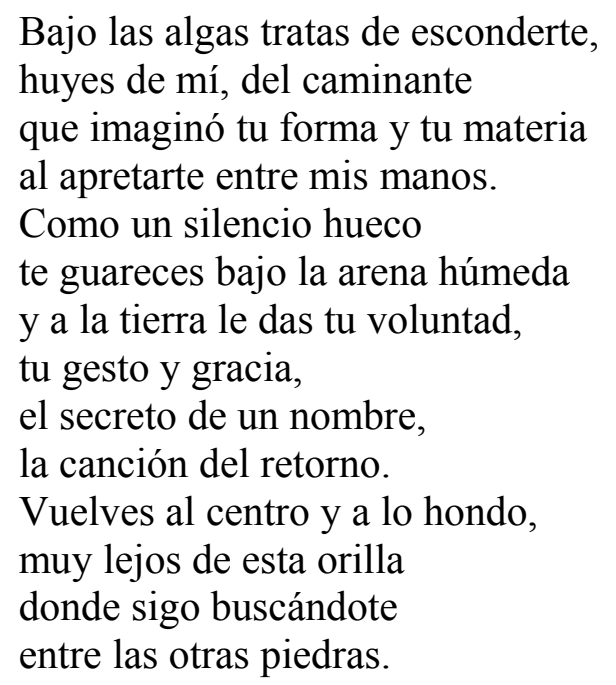

(«Huida», Piedra rota, 2013)

En este fragmento se nota totalmente la preocupación oryana por desvelar el misterio encerrado en la realidad vivida. Otra arista de la poesía de Ory, presente en el discurso poético de Ripoll, es la dinámica del silencio. Silencio que es inherente a la realidad y que se articula como lenguaje de la existencia, espacio desde donde surgen los signos de los seres y las cosas. Respecto a sus compañeros de herencia, la poesía de Ripoll desarrolla una óptica menos rupturista, basada más en la cadencia y en la presencia del silencio que en la transgresión. En su obra poética, notablemente dilatada, destacan La tarde en sus oficios (1978), Sermón de la barbarie (1981), El humo de los barcos (1984), Las silabas ocultas (1991), Niebla y confin (2000) y Piedra rota (2013).

Jaume Pont ni es andaluz, ni publica en ninguna antología gaditana. Es más, es un poeta que escribe en catalán. Ahora bien, Pont es el crítico que posee la obra teórica más extensa sobre el Postismo y Carlos Edmundo de Ory, por ello resulta fácil imaginar la huella impresa que Ory ha dejado en su poesía. Pont sitúa su poesía en plena territorialidad vanguardista a la sombra de J.V. Foix, Joan Brossa y, como no, Ory. Resulta, pues, evidente el sustrato surrealista que recorre toda la poesía de Pont: 
Es mou

la llengua de la nit.

Com una serp li muda

la pell a dins la teva boca ${ }^{456}$.

(«Larva sobre larva», Enlloc, 2007)

Pero también resulta clara la ascendencia vanguardista que liga esta poesía con el compromiso con el lenguaje y la sitúa en un espacio marcado por la concreción del minimalismo poético, la libertad semántica y el poder de la sugerencia. Aquí se nota presente la sombra de Ory, que significó una apertura hacia el lenguaje extraño y paradójico utilizado por los maestros del budismo zen. En Pont hallamos la influencia del lenguaje de silencio, presente tanto en el haiku como en el koan. Su poesía discurre por las geografías del extrañamiento conceptual de los aerolitos oryanos, de manera que resulta una poesía intensa y depurada, de verso corto y brillante, cuyas estructuras crean atmósferas donde se amplía notablemente el poder sugerente de las palabras. Como la poesía oryana, la de Pont supone una vía para explorar el misterio que encierra la realidad. Por ello es una poesía visionaria y hermenéutica, que intenta ampliar los límites del conocimiento y para ello estudia los significados escondidos en los símbolos y las imágenes míticas de la tradición. Pont quiere recuperar la sabiduría olvidada y marginada por la ortodoxia occidental. De este modo, esta poesía supone, desde la red de representaciones que forma la cultura mediterránea, una apertura a otros horizontes culturales. En ella quedan imbricadas perfectamente la cultura andalusí, la árabe, el taoísmo o el zen. Como obras importantes cabe citar: Límits (1976), Els vels de l'eclipsi (1980), Jardí bàrbar (1981), Vol de cendres (1996) traducida en castellano (Vuelo de cenizas, 2008), Llibre de la frontera: de Musa Ibn-Al-Tubbi (2000) y Enlloc (2007). Resulta especialmente interesante la poesía apócrifa presentada en el Llibre de la frontera donde Pont inventa diversos discursos poéticos de poetas fingidos, con sus realidades vitales e históricas propias. Esta poesía, que se configura como escritura a la manera de, entronca con la poesía heterónima de Fernando Pessoa y con la poesía paródica de autores inventados por Max Aub en su Antología traducida (1963).

${ }^{456}$ Se mueve / la lengua de la noche / Como una sierpe que cambia / la piel dentro de tu boca. Traducción mía. 
Antonio Hernández (1943) es el cuarto poeta antologado Nueva Poesía 1: Cádiz, el cuarto jinete tal y como Ory lo denomina en el prólogo. Poeta andaluz que en los años setenta abogaba por una nueva poesía social comprometida con la realidad andaluza y, al mismo tiempo, abierta a las diferentes territorialidades culturales. Rehuyendo siempre todo elemento regionalista y costumbrista, la poesía de Hernández se ha erigido como reivindicación de la Andalucía oculta y marginada. Su tono comprometido no transita los límites establecidos por el realismo poético, sino que brota del surrealismo comprometido andaluz: Alberti, Lorca y, en cierto sentido, Ory. La impronta oryana se encuentra en la supresión del color local y de la estampa típica, en el compromiso con el lenguaje, la plasmación de la luz, la recuperación de la memoria, la mística telúrica, el registro paradójico y el humor. Rasgo este último poco frecuente en la poesía de la época. La visión enamorada y a la vez crítica de la realidad andaluza presenta también la huella de Ory. La poesía de Hernández posee un tono narrativo y sosegado, adecuado para convertirse en una reflexión intimista sobre la cotidianeidad. En cierto sentido, se trata de una poesía plural, como la oryana, en la que se amalgama, totalmente imbricada, una serie de registros dispares: discurso poético, narrativo, cinematográfico, periodístico...

Entre su extensa obra poética cabe destacar el poemario Metaory (1979) configurado como un homenaje a la poesía de Carlos Edmundo de Ory. En él se ofrece una visión fragmentaria, a modo de caleidoscopio de recuerdos, de la realidad andaluza. Realidad que toma una forma mítica:

Carlos Edmundo, te hablo de un lugar desolado, picado por la espuela del cieno y la avaricia, de un pueblo que es el río de las contemplaciones, donde si no me miro comienzo a ser nada. Allí están las vides y ofrecen la conducta de quienes las podaron, sus ejemplos de salmo, los trigales creadores 
de la oración, las largas

caravanas de olivos

que no son más que abrazos.

Antonio Hernández no es un continuador de la poesía la poesía oryana, pero su admiración por ella y por la situación vital del autor junto a las convergencias de algunas de sus propuestas poéticas hacen que su poesía pueda concebirse dentro del radio de acción de la diáspora oryana.

\subsection{Parientes y allegados}

Estos autores, de algún modo, son deudores del legado poético de Carlos Edmundo de Ory, bien por la cercanía de sus presupuestos o porque su obra gravita de manera próxima sobre zonas propias de la geografía oryana. Sus poéticas pueden encuadrarse en el territorio acotado por Luis Antonio de Villena (1986) y etiquetado como poesía postnovísima, pues sus primeras obras fueron publicadas a finales de los años setenta y a principios de los ochenta del pasado siglo. Desde estas coordenadas, sus poéticas van trasmutando alargándose hasta la actualidad.

La poesía de Alberto Porlan (1947) es deudora de la poesía oryana debido a la voluntad de indagar en lo incomprensible y a su componente heterodoxo, apátrida y, en ocasiones, libertario. Se trata de una poesía fluida, que rehuye el artificio y se dirige a lo humano. Como muestra de ello basta señalar obras como Pájaro (1981), Perro (1997), Peña (1999) o País (2009).

Andrés Sánchez Robayna (1952) celebra también la disidencia literaria de Ory y declara su pertenencia al magisterio oryano ${ }^{457}$. Su poesía supone una meditación sobre la luz y sobre la realidad, que continúa la senda trazada por Ory en sus acercamientos al silencio y a la meditación del budismo zen. La poesía de Robayna se centra en el instante presente que se percibe, en su representación abierta sin límites conceptuales, a modo de pensar no pensando. Entre sus obras destacamos Clima (1978), Tinta (1981), La roca (1984), Palmas sobre la fosa fría (1989), Fuego blanco (1992), Sobre una

${ }^{457}$ Sánchez Robayna, Andrés, «En la muerte de Carlos Edmundo de Ory», Cádiz, Caleta, Segunda época, no 16, marzo 2011, p. 67. 
piedra extrema (1995), El libro, tras la duna (2002), La sombra y la experiencia (2010) y Variaciones sobre el vaso de agua (2015).

También ha manifestado su atracción hacia de poesía de Ory la poetisa Rosa Lentini (1957), quien en 2001 preparó junto a Ricardo Cano Gaviria una antología de su poesía $^{458}$. En su poesía se encuentran impresos algunos relieves de la huella oryana: la consideración de la poesía como forma de autoconocimiento y de aprehendizaje de la realidad, la importancia del sueño y el estudio de las imágenes culturales míticas. La poesía de Lentini es una poesía del recuerdo, que es, a su vez, una indagación en la propia existencia emocional. El pasado se recupera para construir el presente. Como la oryana, la poesía de Lentini supone la desnudez íntima de la autora, que incorpora el silencio y el sosiego como únicos espacios posibles para la escucha de ese lenguaje oculto que brota cuando caen las máscaras. Su producción poética es más tardía que la de otros poetas oryanos, de hecho hasta 1994 no publica ninguna obra. De ella cabe citar: La noche es una voz soñada (1994), Cuaderno de Egipto (2000), El Sur hacia mí (2001), Las cuatro rosas (2002), El veneno y la piedra (2005), Transparencias (2006) y Tuvimos (2013).

Otro poeta, en este caso más cercano al Cádiz de Ory, es Juan José Téllez (1958), periodista, crítico, narrador y biógrafo. Tal y como se muestra en la correspondencia electrónica mantenida conmigo que figura en el Apéndice XIII, desde su adolescencia se quedó prendado de la originalidad, de la musicalidad y de la rebeldía de la poesía de Ory. La actitud oryana se ha mostrado en su faceta de agitador cultural, llevada a cabo desde colectivos con voluntad contracultural. Fue miembro del grupo Jaramago. Su poesía, que discurre entre los límites del intimismo y de la crítica social, recoge la impronta heterodoxa de Ory, su humor lúcido y ácido, su ideario nómada y libertario, tan presente en los aerolitos. La actitud crítica liga su poesía con la denuncia que Ory, de una manera totalmente imaginativa y novedosa, imprimió a su obra La flauta prohibida. La poesía de Juan José Téllez busca la insensatez y el misterio frente a la plasmación tangible de lo real. El siguiente poema es un ejemplo de las convergencias estéticas e ideológicas de ambos poetas: obra cit.

${ }^{458}$ Cano Gaviria, Ricardio, y Lentine, Rosa, ed. de Carlos Edmundo de Ory, Antología, 
No pongas banderas, ningún himno suene: yo fui un meteorito, un reflejo en el agua, un beso robado, un país de silencios, un hombre sin sombra, una hoja de otoño, el sueño que amanece, y no es poco.

(«Antiguo testamento», Las grandes superficies, 2010)

De su actividad poética hay que mencionar obras como Crónicas urbanas (1979), Ciudad sumergida (1985), Bambú (1988), Daiquiri (1989), Las causas perdidas (2005) o Las grandes superficies (2010).

El poeta y crítico Amador Palacios (1954), cuyos estudios han gravitado sobre el Postismo y las poéticas de Carriedo y Crespo, no siente, como queda expuesto en el Apéndice XIII, que la poesía oryana haya dejado una influencia manifiesta en su obra poética. Aún así, pueden observarse algunos puntos de contacto como la irreverencia, el humor, la poética del silencio del haiku, la expresión de un paganismo reflexivo opuesto al monoteísmo, el sentimiento de comunión con la inmediatez de la realidad campestre y la mística panteísta. De su dilatada obra poética cabe citar Ejercicios de versificación (1979), La cúspide y la sima (1987), Enemigo admirable (1994), Estancias (2005), Licencias de pasaje (2007) y Bajo véspero (2014).

La poesía del trasmundo rural de Rafael Adolfo Téllez (1957) marca también unas precisas convergencias con la territorialidad poética de Ory. Entre sus precedentes, como lo son Vallejo, Borges o Félix Grande, hay que incluir a Ory por sus herejías y por la óptica misteriosa desde la que se erige su realidad poética. Como contactos podemos señalar la incesante presencia del misterio en la cotidianeidad, la magia de lo insignificante, la circularidad temporal, la reescritura del infinito y la celebración mística de la existencia. La poética de lo rural de Téllez se acerca a la vivencia de totalidad experimentada por Ory en su cabaña y en el retiro de ThezyGlimont. En ambos casos se trata de concepciones y expresiones poéticas que parten de una total libertad, experimentadas en soledad, totalmente vívidas y viscerales, que rehuyen normativas y cánones. Ello puede observarse en obras como Si no regresas al portón oscuro (1988), Quienes rondan la niebla (1993), Los adioses (1996), Muertes y 
maravillas (2004), Los pasos lejanos (2007) o Los cantos de Josph Uber (2011). Obras que contienen una poética que no avanza en línea recta, sino que de modo circular planea sobre un mismo espacio: lo rural cotidiano que se muestra como zona abierta donde se citan vivos y muertos y en la que, sin tragedia, la muerte queda insertada en la vida.

Otro autor, cuya actitud poética, ética y vital está muy próxima a la de Ory, es Uberto Stábile (1959), poeta y agitador cultural. Su poesía surge de los parámetros culturales vividos en el tardofranquismo con una voluntad heterodoxa y contracultural. En este sentido, Ory fue uno de los puntos de afirmación de la poesía rebelde de Stábile, como lo son también los poetas de la Beat generation, Bob Dylan, Leonard Cohen o Lou Reed. Resulta muy fácil observar los contactos que existen entre las poéticas, marginales, descentradas y periféricas, de los dos autores: la lejanía de los espacios trazados por la oficialidad, la huella impresa por Allen Ginsberg y los autores beat, el interés por la cultura libertaria que sustentó el undrground y las filosofías heterodoxas, la transgresión de los códigos poéticos y el alejamiento de la sensibilidad pretendida y de lo previsible en favor de una poesía de la imaginación permanente. Como Ory, Uberto Stábile también es un poeta de la sentencia, del aerolito, pariente cercano del graffiti y de la pintada.

sé mi libro, líbrame de escribirte

(Afterhours, 2013)

Entre sus poemarios destacamos: Distrito maritimo (1981), En torno a un mar (1986), Las edades del alcohol (1995), Perverso (1997), Los días contados (2000), La línea de fuego (2008) y Aftherhours (2013). 


\section{OTROS POETAS BAJO EL SIGNO DE ORY}

En el viejo salón de baile del cosmos, la noche eternamente gira

Pablo Acevedo

\subsection{Más allá de la Modernidad}

Históricamente estos poetas están más desvinculados de las coordenadas temporales en las que Ory le tocó vivir. Algunos de ellos tuvieron la suerte de conocerlo ya en su vejez, otros lo conocieron sólo a través de su literatura, sobre todo a raíz de la lectura de Metanoia, antología donde encontraron una poesía atípica, escrita a contracorriente. Entre ellos y Ory existe una fuerte conexión, ya que el pensamiento oryano es tremendamente actual y rejuvenecedor. La rebeldía de su actitud, la voluntad herética y culturalmente insumisa no cedió con los años. Ory fue un poeta totalmente independiente, que supo mantenerse alejado de los espacios propios que la oficialidad y el poder, con variadas prebendas, dedican a la intelectualidad. Siempre reaccionó contra ello, nunca fue un artista decorativo, orgánico en el sentido gramsciano ${ }^{459}$, más bien una figura incómoda que jamás traicionó los postulados que edificaron su particular óptica de concebir la realidad. Incómoda, sobre todo, para la crítica, ya que no ha podido ser encasillado bajo la etiqueta de una corriente o alguna tendencia. La autenticidad de su independencia y su compromiso con la poesía son los puntos de reivindicación de los poetas más jóvenes, algunos de los cuales ven en él una imagen de permanente coherencia y un icono de recalcitrante búsqueda y experimentación. Es el aspecto de poeta vagabundo y eterno ser errante aquello que seduce a los poetas que, desde unas circunstancias temporales totalmente diferentes a las que vivió, intentan trazar su camino fijándose en la estela impresa que ha dejado su poesía.

En la mayoría de los casos, se trata de autores cuyas poéticas libres rehúyen el encasillamiento en grupos, modas y otro tipo de cánones. Poetas que, aunque compartan

${ }^{459}$ Ver Gramsci, A (1967), La formación de los intelectuales, México, Grjialbo. 
los presupuestos culturales generacionales con los poetas coetáneos, no subyugan sus poéticas a la rigidez de la normativa grupal. Todos ellos son herederos de una poesía vibrante y renovadora, de signo vanguardista que, sobre todo, revaloriza los hallazgos del surrealismo y los convierte en el territorio familiar en el que se enraizan sus poéticas. Se trata de poetas que tratan de desvelar el misterio que se oculta en aquello que posee la apariencia de lo normal y que procuran hacer visible lo invisible. Su poesía, evidentemente, tiende hacia el interior humano vivencial, la indagación metafísica y, sobre todo, el compromiso con el lenguaje. Estos poetas, plenamente instalados en el ocaso de la Modernidad, han experimentado el descrédito de las viejas utopías y los proyectos fraguados en torno a la idea de progreso. Ellos han crecido en el hipermercado de las sociedades capitalistas y saben que la poesía se ha convertido en una operación de marketing; por ello rechazan el comercio de la poesía y huyen de los espacios mediáticos para buscar la poesía en el espacio íntimo de la soledad, en la vivencia e incluso en la emoción. Como Ory, son poetas que escriben con las vísceras. En este sentido, cabe resaltar la presencia poética de la feminidad, pues el discurso femenino, incluso feminista, es uno de los nuevos paradigmas que define el espacio de la Posmodernidad ${ }^{460}$.

\subsection{Poetas fin de siglo}

Se trata de poetas que, más o menos, nacieron en la década de los sesenta del pasado siglo, o en los primeros setenta (toda división aquí resulta más que arbitraria) y se sienten de algún modo deudores de la obra de Ory. Temporalmente se hallan en una situación cercana, un tanto posterior en algunos casos, a lo que se llama la generación poética de los ochenta o los postnovísimos. Como se ha enunciado antes, son poetas transmodernos, que han vivido el fracaso y la desilusión ante los proyectos de la Modernidad. Por ello, no existe en ellos una batalla generacional para desbancar a la generación anterior, la de los novísimos. Son poetas que no se sienten seducidos por el dogma del progreso ni por la etiqueta de lo moderno. No se sienten partícipes de la generación de los ochenta ni de la del 2000. Son poetas descentrados, que intentan distanciarse de credos y colectivos, su signo más característico es la pluralidad.

${ }^{460}$ Ver Owens, Craig, «El discurso de los otros: Las feministas y el posmodernismo», en Baudrillard, Jean y otros (1983, 1985: 93-124) 
A diferencia de los poetas coetáneos, no sienten ninguna atracción por el realismo poético, ni reivindican ninguno de sus postulados, ni siquiera el realismo meditativo o la poesía de la experiencia, signos que definen algunas zonas de la poesía posnovísima (Villena, 2010: 8-11). Sí que se reivindica, en algunos casos, la minimalista poética del silencio, llevada a cabo por José Miguel Ullán o el propio Ory. Algunos de estos poetas se sienten herederos, a distancia, de la vanguardia histórica y de sus desarrollos posteriores. La estética vanguardista, como el surrealismo o la poesía experimental, ha pasado a convertirse en lenguaje cotidiano para ellos. Saben que la actitud vanguardista ha perdido capacidad de provocación, pero saben también que la voluntad de renovación es vital en sus poéticas. Son hijos de una sociedad hiper, la del hipermercado, post-pop y mediática que ha institucionalizado la rebelión artística ${ }^{461}$. La vanguardia ha sido asimilada y mercantilizada, transformada para ser consumida por el público masivo como mero objeto de deglución. Por ello estos poetas abren brechas contra la banalización social e intentan construir obras arriesgadas porque saben que estas se instalan en los territorios de la periferia cultural.

La impronta de Ory ha quedado totalmente impresa en la poesía radical de Ángel Petisme (1961), «cantante, poeta y ministro de la felicidad», tal como se define su $\mathrm{web}^{462}$. Poeta y músico de pop-rock, cantante comprometido de protesta y agitación. Luis Antonio de Villena lo incluye en 1986 en su antología Postnovísimos. Su poesía coincide con la oryana en su actitud combativa y en la provocación. Su radicalismo frente a la situación social queda ligado a la protesta política realizada por Ory en $L a$ flauta prohibida, actitud que unía poesía social y vanguardia expresiva, estética renovadora y compromiso ético. Entre sus poemarios cabe destacar Constelaciones al abrir la nevera (1996) cuyo prólogo viene firmado por el propio Ory.

La poesía de Juan Vicente Piqueras (1960), sencilla según él, incorpora sin estridencias los juegos lingüísticos y los laberintos fónicos postistas:

Aquí es donde estoy yo.

Esté donde esté

461 Ver Lipovetsky, Gilles (1983), L'ère du vide. Essais sur l'indivdualisme contemporain, París, Éditions Gallimard; traducción de Joan Vinyoli y Michèle Pendanx, La era del vacío. Ensayos sobre el individualismo contemporáneo, Barcelona, Anagrama, 1986, pp. 105-106.

${ }^{462} \mathrm{Https}$ ://petisme.wordpress.com 
yo siempre estoy aquí donde me ves.

Esta casa, estas caras, estas cosas

cansan, porque aquí cansa.

(«Adverbios de lugar», Adverbios de lugar, 2004)

Se trata de una poesía de la emoción basada en la sugerencia, que gravita sobre la nostalgia y el desasosiego. Carlos Edmundo de Ory la define como escritura errante en el prólogo a La edad del agua $(2004)^{463}$.

Ana Sofía Pérez-Bustamante (1962), cuya actividad crítica sobrevuela los territorios poéticos establecidos por los poetas gaditanos, es una poeta que mantiene diversas convergencias con la poesía de Ory. En su poesía de signo metafísico, intelectualista y, en ocasiones, visionaria y visceral, hallamos un lenguaje renovador, donde la palabra adquiere libertad plena, que entronca con la experimentación poética oryana. Abundan las asociaciones libres y las enumeraciones caóticas, en ocasiones su discurso bordea el automatismo. Pérez-Bustamante hereda de Ory y de Cirlot la profundización en la simbología de las corrientes herméticas y en las imágenes arquetípicas de la tradición. De signo oryano resulta también la expresión de una mística inmanente que conlleva la experiencia de totalidad cósmica, del sentimiento de unidad del ser con cada microespacio de la realidad. Oryana es también la conciencia de la sexualidad, en esta caso desde la óptica de la feminidad, como celebración de lo sagrado y como elemento de aprehensión de lo real:

soy su hombro, su brazo, la plancha, soy el áspero

lienzo limpio, el tablero y la manta, soy el aire poroso, estremecido, la luz de la media tarde, la habitación, la casa y el silencio: una espiral de gozo que fluye de la piel de la cabeza, que recorre los vellos verticales, que agita remolinos en el sexo y desde el sexo gira, gira, gira esparciendo hacia abajo y hacia arriba océanos de anémonas que ríen, ríen, ríen la tranquila sorpresa del placer infinito.

(«Caduceo de Hermes (Feérica)», Mercuriales, 2003)

${ }^{463}$ La edad del agua, Lucena, Ayuntamiento, 2004. 
En su obra poética destaca el poemario Mercuriales (2003).

Heredera de Ory es también la poeta Mercedes Escolano (1964), incluida como representante de la emergente feminidad poética en la antología Diosas blancas $(1985)^{464}$. Oryana es, sobre todo, la primera etapa de su poesía, transgresora de los códigos poéticos tradicionales, vanguardista y experimental, irracionalista y simbólica, representada magistralmente por obras como Las bacantes (1984), La almadraba (1986) o Felina calma y oleaje (1986). La presencia oryana se nota en la adopción de los postulados de la poesía postista: el juego lingüístico, la semántica extraña, la ruptura sintáctica, la eliminación de elementos conectores y signos de puntuación. Como Ory, la poesía luminosa de Escolano explora el simbolismo del espacio marítimo, telón de fondo en el que se articula su erótica profunda, vital, casi metafísica. Surrealismo, erótica y la presencia del mar son los signos que ligan las poéticas de ambos autores. A partir de la segunda mitad de década de los ochenta, la poesía de Mercedes Escolano se aleja de los presupuestos del Postismo y se acerca a la poesía de la experiencia. Poética urbana que se fragmenta en microespacios colectivos periféricos, desolados al estilo del pintor Edward Hopper: terrazas, barras de bar, hoteles de carretera...

Otro autor gaditano, cuya poesía converge con territorios oryanos, es Rafael Ramírez Escoto (1961), poeta, crítico y novelista. Su poesía fantástica, esotérica, es heredera de Cirlot y de Ory, una poesía que atraviesa zonas oryanas heterodoxas como el chamanismo, la magia, la alquimia, los ritos mistéricos, la hermética, el budismo, el hinduísmo. Siguiendo la estela de Ory o Cirlot, la poesía de Ramírez Escoto queda articulada como una hemenéutica, un estudio de los símbolos y de las imágenes arquetípicas de la tradición cultural universal. Poesía fantástica, misteriosa, que se desdobla en dos planos a la vez, magia y realidad. Entre su obra poética cabe destacar Trobar clus (2000) y Ziggurat (2008).

José Manuel García Gil (1965) es otro de los críticos que reivindica la importancia de la obra de Carlos Edmundo de Ory. Su poesía, como la oryana, posee una impronta íntima que surge del instante vivido. Poesía que se concibe como vívida sacudida y se pliega sobre la realidad, trasformándola en emoción. Proceden de Ory las

${ }^{464}$ Diosas blancas. Antología de la joven poesía escrita por mujeres, ed. de Ramón Buenaventura, Madrid, Hiperión, 1985. 
rebeldías frente a la tradición, la voluntad trasgresora, la concepción lúdica del hecho poético y la práctica de una escritura que es constante creación. Su poesía huye de los lugares comunes y de las retóricas superfluas y se instala en los espacios periféricos de la heterodoxia. Poesía intimista, donde se halla impresa la huella del surrealismo, que explora y desvela los misterios de la cotidianeidad. Es autor de obras como El salón de los eclipses (2005), Aguas prohibidas (2009) o Una hora sin cámaras (2011).

Guadalupe Grande (1965), hija de poetas, forma parte de esta herencia oryana por el compromiso con el lenguaje, signo definitorio de su poesía, y por una concepción vívida y activa de la poesía, permanentemente creativa, que se asume como método transformador interno. Su poesía responde a una inquieta voluntad de renovación, de superar los códigos impuestos. Se trata de una poesía que limita con elementos periféricos de lo que se considera poético, una poesía de versículo largo y abundante, de tono meditativo, donde confluyen registros diferentes y opuestos: la narrativa, la reflexión, la imaginación poética... Bajo la apariencia de un lenguaje engañosamente naïf se ofrece un cierto automatismo que abandona el lenguaje a su propia deriva. La deliberada ausencia de las marcas del autor posibilitan que el lenguaje se exprese por sí mismo. El silencio del autor, autora en este caso, acerca este discurso a la inmediatez del zen, a la captación de instantes de éxtasis, en los que se celebra de modo gratuito el mismo hecho de estar vivo. Con Ory converge la actitud metafísica de esta poesía meditativa que se dirige a lo cotidiano, a lo instantáneo, que intenta recuperar el pasado, transformado, para proyectarlo sobre el único plano temporal existente, el presente:

Huir quisiera ser pez abisal que ha llegado a la superficie después de tanto oscuro, de tantos siglos anegado en la profundidad, brillan las primeras gotas de luz sobre su lomo albino de criatura castigada.

(«La huida», Libro de Lilit, 1995)

En su obra cabe mencionar Libro de Lilit (1995), La llave de la niebla (2003) o Hotel erizos (2010).

La poesía de Migue Ángel García Argüez (1969) también lleva impresa la impronta de Ory. García Argüez es un ser poliédrico, escritor, poeta, músico de rock, 
agitador cultural y social. Forma parte, junto a José María Gómez Valero y David Eloy Rodríguez, del proyecto La Palabra Itinerante, colectivo de poesía en acción cuyos montajes se configuran como arte total, donde poesía, música, imagen y artes escénicas quedan perfectamente integradas. También dirige en Cádiz la Escuela de las Palabras, auténtico laboratorio de experimentación pedagógica y literaria. Ambas actividades poseen la actitud trasgresora, experimental y combativa del A.P.O. dirigido por Ory en Amiens y su intento de llevar la poesía a la calle, a la escuela, a la fábrica... Desde una conciencia libertaria, apátrida y radicalmente heterodoxa, surge una obra atrevida, valiente y desafiante. La poesía de García Argüez, íntimamente relacionada con la canción y con la faceta musical de su autor, queda instalada en la periferia cultural actual, enraizada entre el pop más reivindicativo y el underground. Converge con la poesía de Ory en la actitud provocativa, en el interés por la cultura de la marginalidad, en el rechazo de modas, etiquetas y normativas, en la libertad como paradigma creativo, en la transgresión y en la extrañeza. Extrañeza que se traduce en cierto expresionismo o estética feísta y en la adopción de un lenguaje que mezcla (bajo la sombra de Quevedo) lo crudo con lo poético:

He introducido en tu coño todas las miserias de este mundo, huracanes, bosques, música, carritos de la compra, páginas de la Biblia, terrones de azúcar, borrachos, lunas, tripis, demonios

(«Penetración», Ecce Woman, 2001)

Como la oryana, la poesía de García Argüez resulta una poesía de signo experimental, que propone y ensaya nuevos paisajes poéticos, pero que tampoco renuncia a la tradición. En este sentido, igual que Ory o Brossa, este autor experimenta con el soneto como modelo. En su obra poética destacan Cambio de agujas (2005), Los días del maíz (2010) o Danza caníbal (2012).

Forma parte también de herencia oryana quien esto escribe. Se trata de poesía que se halla bajo el signo de Ory por su interés por el budismo zen y las filosofías heterodoxas de la antigüedad: hermética, chamanismo, sufismo, hinduismo, taoísmo... 
Su poesía posee una raíz profundamente metafísica y se instaura como expresión de una mística de la totalidad, producto de la meditación za-zen. Además supone una reflexión sobre el movimiento incesante y fluido de la realidad expresado en la antigüedad por algunas de las imágenes arquetípicas como el mandala, el yin y el yang, la svástica, la espiral, la anfisbena... Se trata de una poesía, que como la oryana, celebra el misterio de la realidad y su ritmo armónico, orgánico e infinito.

El riu de l'infinit tornarà a començar i seré una vegada més gra de sorra, arrel, cuc de seda.

Aigua que devalla per cims i barrancs.

I em banyaré una vegada més en el riu constant de la realitat, el l'oceà de cada fulla, en cada filagarsa del pols. Per a ser novament aigua, terra, cuc de seda ${ }^{465}$

(«Cosmologies», Samsara, 1012)

Poesía que converge con la oryana por ser una poesía libre, cuyas referencias se hallan en el pensamiento heterodoxo: Breton, Jung, Huxley, Ginsberg, Watts, Kirshnamurti... Aunque próximo a Aleixandre, también resulta oryano el lenguaje poético surrealista abandonado a su propio vaivén, las imágenes oníricas y las asociaciones inesperadas. Mucho más oryano, y experimental, es el poemario Laberintos, inédito aún.

\subsection{La cybergeneración del nuevo milenio}

Bajo este título se hallan los poetas de lo que se podría llamar la generación del 2000, pertenecientes a la posmodernidad tardía, poetas que han crecido junto al hiperdesarrollo tecnológico y son hijos de los nuevos escenarios telemáticos y de sus nubes virtuales. Para Agustín Fernández Mallo ${ }^{466}$, poeta y científico, aquello de define el nuevo territorio mediático, y por lo tanto cultural, no es el tiempo sino el espacio. La

${ }^{465}$ El río del infinito volverá a comenzar / y seré una vez más grano de arena, raíz, gusano de seda. / Agua que desciende por cimas y barrancos. / Y me bañaré una vez más / en el río constante de la realidad, / en el océano de cada hoja, en cada hilacho / de polvo. Para nuevamente ser / agua, tierra, gusano de seda. Traducción del autor.

466 García Mallo, Agustín, "Tiempo topológico, hippies digitales», Les tecnologies digitals en la producció literària, ed. de Germà Colón y Santiago Fortuño, Castellón, Universitat Jaume I, 2014, pp. 30-33. 
nueva sociedad se instaura como una cultura sin tiempo, sin historia, la red proyecta sus estrategias hacia la realidad cambiando las relaciones que se establecen entre los productos culturales. El punto de conexión entre los diversos textos culturales, según Mallo, queda establecido en el puro espacio, en este se producen las relaciones conceptuales que hacen del espacio una territorialidad abstracta, conceptual ${ }^{467}$. Este nuevo punto de intersección, desde donde surge el flujo de los textos, posibilita una dispersión de ópticas que multiplica y relativiza las pluralidades. Todo ello queda traducido en un mayor eclecticismo. Luis Antonio de Villena (2010: 23) establece que el punto de ruptura de esta nueva generación sobre la anterior lo marca el definitivo abandono de la óptica realista. Frente al realismo implícito en la poesía de la experiencia, los nuevos poetas proponen una poesía intelectualizada, metafísica en algunos casos, fruto de la inteligencia. Poesía, en todo caso ecléctica, donde convive la meditación de signo realista con el surrealismo más visionario.

Diversos autores de esta generación reivindican la figura de Ory como radical libre y se identifican con su propuesta poética a contracorriente, solitaria, genuina, lúdica, experimental y perpetuamente innovadora ${ }^{468}$. Autores que sienten la obra de Ory como una poética próxima, incluso más contemporánea que la de algunos poetas más próximos en la edad. Entre los poetas cuyo lenguaje está próximo al surrealismo podemos citar a José Luis Rey (1973), que incorpora poderosas imágenes visuales de profundo signo irracional y visionario. Define su poesía, de signo culturalista y metafísico, como realismo visionario por su voluntad de acercarse a lo trascendente desde lo más cotidiano.

El surrealismo crítico de Antonio Lucas (1975) también es de herencia oryana; su poesía significa, como lo fue el Postismo, un rechazo de las convenciones poéticas y la adopción de una poética en libertad claramente irracional con convergencias con el surrealismo de Paul Éluard y el simbolismo de Rimbaud. En Los desengañados (2014) la poesía de Lucas muestra una actitud crítica frente a la realidad social y asume la perspectiva del ciudadano.

\footnotetext{
467 Ibíd., p. 33.

${ }^{468}$ Ver el artículo de José Ramón Ripoll «Una nueva mirada» (2012b: 21-25). En él poetas jóvenes de la actualidad como José Luis Rey, Goretti Ramírez, Antonio Lucas, Ana Isabel Conejo y Javier Vela, declaran aceptar plenamente la vigencia de la poesía oryana y reivindican su actitud como actividad precursora de la poesía contemporánea.
} 
Goretti Ramírez (1971), poeta incluida por Sánchez Robayna en la antología sobre el grupo Paradiso de Tenerife titulada Paradiso, siete poetas (1994), celebra la independencia tenaz y la voluntad heterodoxa de la poesía oryana. Heredera de ella resulta su concepción de la poesía como gnosis, como experiencia sagrada y método de conocimiento del enigma que se oculta bajo los pliegues de la realidad. De signo oryano es su poesía enraizada en el sufismo, la hermética y las filosofías heterodoxas de la humanidad. Converge también con Ory su poética del silencio, presente en El lugar (2000) y en La llamada (2004), interesada por la palabra mínima y austera, de tradición zen, que a través del silencio trata de expresar la música interior.

José María Gómez Valero (1976) es poeta integrante de La Palabra Itinerante y del Circo de la palabra itinerante, proyectos dedicados a la poesía escénica y multidisciplinar, prácticas de activismo cultural paralelo al del A.P.O., que proponen expandir la poesía a territorios más inhóspitos y frecuentados por los lectores. Llevar la poesía a la calle para que, de modo rizomático, se enrede con la vida y se comprometa con ella y la transforme. Oryana es también la concepción de la poesía como método de conocimiento y práctica que amplía los límites de la conciencia. La poesía Gómez Valero significa un intento por desvelar lo invisible, aquello que queda escondido en los más cercano e insignificante o en lo más lejano e inaprehensible. Para ello propone adelgazar la palabra hasta hacerla transparente, actitud totalmente cercana a la poética del silencio, sobre la que tanto peso ha tenido la impronta del haiku:

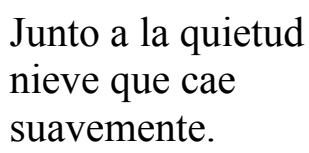

(«La representación», Los augurios, 2011)

También resulta oryana la concepción órfica de la poesía y la del poeta como ser mágico, hechicero, augur...

Otro miembro del colectivo La Palabra Itinerante es David Eloy Rodríguez (1976), para quien la poesía es el signo creador que irradia y fluye integrándose en las demás prácticas artísticas. Por ello propone una práctica poética multidisciplinar y poliédrica. En obras como Asombros (2006) y Desórdenes (1014), se observa una 
poesía, que como la oryana, explora la realidad oculta y se interesa por captar la fluidez y la libertad de la existencia, sin ataduras ni esquemas que la aprisionen. Pues para este poeta, estos son fruto del miedo a la pérdida, a la muerte y, también, a la libertad y a todo lo que no puede ser asido:

Habría que nacer, darse a nacer

tener la audacia

de aquiestar ${ }^{469}$ este mundo,

probar a lo que sabe algo sin nombre,

apoyar las dos manos en su vértigo

Sólo somos si somos aventura

Sólo lo fugitivo permanece

(«Apariciones fugaces de prodigiosa duración», Asombros, 2006)

Su poesía converge con Ory en la voluntad transformadora, que puede cambiar de manera colectiva al ser humano, pero sólo desde su interior. Esta actitud comprometida, al igual que lo hizo Ory, se lleva a cabo desde una estética experimental que transgrede los postulados del realismo. Poesía que, además, se configura como magia y revelación, aventura que expresa el misterio que anida en lo caótico y sus derivaciones.

Carmen Camacho (1976) también está relacionada con La Palabra Itinerante y con la acción poética. El proyecto Poesía escénica Toma de Tierra aúna poesía, interpretación, danza, cante y música. Con Ory converge su activismo cultural y su labor agitadora, el territorio vanguardista y experimental donde instala su poesía, la pluralidad de discursos y la diversidad de prácticas artísticas que ofrece, el minimalismo poético que incorpora el lenguaje del silencio, la libertad que presupone una poesía auténtica y vital, que desvela los enigmas interiores y aquellos que quedan ocultos en los pliegues de la realidad menos visible, la ironía de un lenguaje apartado de normativas grupales. Este lenguaje, mínimo, rechaza los artificios para expandir los resortes de la sugerencia. Lenguaje que recupera la antigua oralidad popular. Minimás (2008) y Letra pequeña (2014) son poemarios cercanos al silencio, a los cantares, al haiku, pero también al koan y al aerolito. Los siguientes fragmentos tienen un sabor oryano, pero sin perder la impronta de su autora, sugerente y sensible:

${ }^{469}$ Sic. 
Los estampados curiosos de los vestidos avisan de la lluvia

El pez volador quiere vivir en la grieta que hay entre el cielo y el mar

(Minimás, 2008)

Cabe decir que las mínimas de Carmen Camacho suponen el desarrollo directo de los aerolitos de Ory, su continuación. Ellas se acercan al lenguaje de los sueños, a la ingenuidad de la infancia, a las anodinas expresiones de la calle, a las pintadas de los muros urbanos... Sortean el lenguaje comunicativo y se dirigen a la paradoja, agitan el lenguaje desligando los significantes de la tiranía de la razón para acercarlos a una significación basada en la emoción ${ }^{470}$.

En la poesía de Pablo Acevedo (1977) se observa la huella dejada por Ory, su heterodoxia, su mirada descentrada y crítica, surgida de la soledad y distanciada de tendencias y etiquetas. La poesía de Acevedo es una poesía vivida, que surge del fondo de ser y sacraliza lo cotidiano, su magia y su misterio, y a la vez desvela la radical soledad del ser social. En Los oficios (2012) la poética asume la otredad en diversas perspectivas, instaladas en la marginalidad, desde las que se pluraliza la mirada sobre la realidad, ejercicio efectuado bajo la óptica del extrañamiento. La poética de Acevedo, como la oryana, es una poética comprometida, sobre todo, con el lenguaje. Un lenguaje libre, que subvierte la semántica referencial para erigirse en signo paradójico, próximo a los postulados postistas, donde las palabras se acercan caprichosamente por la similitud del sonido:

Rimo y, pese a todo

remo,

con mi cara de payaso eterno,

rimo,

con mi historia bondadosa.

(«Remero de imágenes», Los oficios, 2012)

${ }^{470}$ Ver, Mesado, Rafael, «Más allá del lenguaje. Los aerolitos de Carlos Edmundo de Ory», en prensa. Comunicación presentada en las Jornades de Foment de la Investigació, Universitat Jaume I, Castellón, 2015. En trámite. 
Este fragmento parece entresacado de un poema de Ory. Acevedo concibe la escritura como aventura que explora espacios abiertos en la expresión poética.

Para finalizar esta nómina, cabe mencionar a Javier Vela (1981), director de la Fundación Carlos Edmundo de Ory y poeta ligado a la poesía oryana por su concepción del erotismo poético como una reflexión no racionalista sobre la existencia humana. La erótica es para Vela una actividad sagrada que consiste en la celebración de todas las existencias habidas desde la génesis del ser. En Hotel Origen (2015) el amor privado se funde con la colectividad, trasciende las paredes del dormitorio y se expande a través de la realidad hacia las galaxias:

Sigo la nervadura de tus brazos.

La breve línea en la que se remanga

-elástica visión - la eternidad.

El amor, al negar la linealidad de los instantes y suprimir el transcurso, dilata su espacio temporal en una circularidad que abarca desde el pasado más pretérito al futuro más lejano. Oryana resulta la actividad meditativa de la poesía de Javier Vela, actividad que transmuta la conciencia en poesía, ampliándola mediante la percepción sensible. La poesía revela aquello que pasa desapercibido a la lógica. Oryano es, sin duda, su lenguaje libre, alejado de la vanguardia más estridente, pero imaginativo y personal. En Ofelia y otras lunas (2012) la poesía de Vela se aproxima muchísimo a la poesía oryana, de ascendencia whitmanniana, una poesía de largo aliento, donde el lenguaje se halla dejado a su propio fluir siguiendo la tradición beat, desbordado, siguiendo los cauces del surrealismo, sin ataduras:

Cruzas el arco de la librería como una osa lunar que se guarece bajo la nieve sucia del recuerdo. Allí todo es seguro, y hay banderas, $\mathrm{y}$ hay guantes de mendigo colgando de un paraguas.

(«Canción del cosmonauta», Ofelia y otras lunas, 2012)

Estas son algunas de las poéticas herederas de la impronta que Ory ha dejado en la poesía posterior. No se pueden citar a todos los poetas influidos por la autenticidad, la coherencia y la libertad de la propuesta poética oryana porque su importancia se 
extiende sobre la territorialidad de la poesía actual definida, entre otras acracterísticas, por la independencia y el rechazo de los cánones establecidos. 


\subsection{En la poesía.}

La impronta que ha dejado la poesía de Ory en el territorio de la poético ha sido reconocida de manera lenta, casi a cuentagotas. Poco a poco, han sido los poetas quienes de modo paulatino han manifestado, bien de manera pública mediante sus textos críticos o de modo más privado en sus propios poemas, el interés por la poesía oryana. En muchas ocasiones, el reconocimiento aparece como una huella impresa que el autor ha querido resaltar ante la mirada de todos, o como una marca, o guiño sutil y cómplice destinado al lector, ofreciendo a sus ojos el reconocimiento a la tarea poética realizada por Ory. En algunas ocasiones, la huella oryana aparece bajo el signo del homenaje. En todo caso, es la práctica de la intertextualidad la estrategia utilizada por los poetas para mostrar las referencias oryanas de su poesía, sus convergencias y sus conexiones. La cita, el guiño, la contrafactura o la clave velada son algunas de las marcas que muchos autores han insertado en su escritura. Son marcas poéticas que manifiestan abiertamente la conexión y la adhesión a una propuesta poética creadora, independiente, rebelde, cuyo primer compromiso ha sido el compromiso con el lenguaje y con la propia existencia del autor, en la que vida y poesía han quedado perfectamente unidas e imbricadas. Estas marcas, en cierto sentido, tienen su correspondencia en los 
trazos y en los iconos culturales que utilizan algunos pintores en sus obras y que delimitan una serie de coordenadas culturales e ideológicas en las que se inscriben su producciónes artísticas.

\subsubsection{Cercanías}

En la recepción de la poesía de Carlos Edmundo de Ory han tenido una labor especial los poetas reunidos bajo el grupo Merejada, podría decirse que casi inaugural. Es evidente, como ya se ha señalado antes, que Ory fue uno de los poetas reivindicados por la generación de los novísimos. Pero es Marejada el grupo que manifiesta de una forma más activa su devoción por la figura del maestro Ory. Sus integrantes declaran abiertamente su voluntad de erigirse como discípulos. En la Orygénesis (1973), montaje teatral sobre la poesía y la vida de Ory del que se ha hablado con anterioridad, se leen cuatro poemas dedicados a Ory: «Carlos E. de Ory tiene 50 años» de Jesús Fernández Palacios, «Soneto para un Mundo lleno de Ed» de José Ramón Ripoll, «Carlos Edmundo de Ory» de Alberto Porlan y «A Carlos Edmundo de Ory» de Gabriel Celaya.

Ahora bien, es Antonio Hernández, el cuarto jinete oryano, el primer poeta cuya escritura poética ofrece marcas de señalización que manifiestan la conexión con el territorio poético de Ory. En la antología compartida con los tres integrantes de Marejada, Nueva Poesía 1: Cádiz, publicada en 1976, ofrece textos poéticos de lo que será su obra Metaory, que aparece años más tarde, en 1979. Estos formaban parte de lo que entonces tenía como título Epístola Andaluza a Carlos Edmundo de Ory. Las marcas más evidentes se hallan en el fragmento que exponemos a continuación:

Carlos Edmundo, te hablo

de un lugar desolado, picado por la espuela

del cieno y la avaricia

$[\ldots]$

Carlos Edmundo, te hablo

de un paraíso en grietas.

(Del libro en prensa «Epístola a Carlos Edmundo de Ory».) $)^{471}$

${ }^{471}$ Obra cit., pp. 161-162. 
Evidentemente, la poesía de los miembros de Marejada siempre ha manifestado de modo muy claro tanto la pertenencia a la territorialidad oryana como sus conexiones con ella. Jesús Fernández Palacios selecciona los poemas más oryanos de su obra y los concentra en la antología Poemías (2012), prologada por propio Ory y a quien va dirigida como si se tratase de un homenaje. La obra se inicia con la siguiente dedicatoria:

\section{A Carlos Edmundo de Ory, en mi memoria amorosa.}

Claro guiño cuyo referente apunta a la Memoria amorosa, última obra oryana publicada de manera póstuma, cuya edición corre a cargo de Jesús Fernández Palacios y que responde a una petición que le hizo Ory poco antes de morir. Las marcas poéticas que establecen las relaciones intertextuales son múltiples. Forman parte, en cierto modo, de la poesía culturalista de su autor, que pliega de modo evidente sus textos poéticos sobre los de otros autores mostrando así las líneas transversales que los conectan. El segundo poema, titulado «Réquiem en descomposición», dedicado también a Ory, contiene numerosas marcas relacionales que funcionan como evidentes guiños que no escapan al lector interesado en la poesía oryana. Todo él está construido sobre los motivos del exilio voluntario y de la ruptura con la sociedad española, que en el caso de Ory se manifestaron en su gesto insumiso que le llevó al exilio y a la voluntaria marginalidad. El poema, del que ofrecemos el siguiente fragmento, se erige además como crítica atroz del modelo social tiránico y represor vivido bajo el franquismo:

\section{Para Carlyundo de Ory}

Pavoroso he visto construir el Muro de la Vergüenza y la mano de un niño empujando su inocencia.

En la casa de Madame Bernard vive Ory su destierro, como un rey de las ruinas con su flauta prohibida.

Los hombres son hedonistas y allí convive un ángel, en la humilde buhardilla de esa casa apartada.

He visto a los ascéticos y nihilistas derrumbarse abatidos en el Muro de la Vergüenza. A los ángeles también los detienen y los reyes no son sabios de capirote. En Amiens se cuecen las habas con miel y en el Muro de la Vergüenza se desangran los hombres se desangran 
En el poema titulado «Al visitante oportuno» también aparecen marcas que relacionan el pasaje poético con la figura de Ory. En este caso los trazos poéticos, como de balizas de señalización, apuntan a Cádiz, ciudad en la que vive Fernández Palacios, y a la que Ory viajaba con frecuencia desde Francia. El poema, modificado para su publicación en Poemías, ya había aparecido en 1976 en la antología Nueva Poesía 1: Cádiz ${ }^{472}$.

Por la magia de camareros trasnochados la voz del sacerdote nos llega limpia con sus anotaciones en el margen de la tierra y la punta del acero clavada en la cabeza.

Aquí vivió serenamente el devorador de flores, visitante de balcones y funerarias, funámbulo volatinero de la historia, descrito tantas veces economista de las heces, los comicios, la censura, amigo íntimo que era.

Pasó para anotarse en los lomos de los libros y en las despensas de los arcanos abuelos, comedido escribano, sepulturero sórdido, huracán sin viento ni violencia: era tímido barredor de las trompas de los ángeles, enorme y provisto o viceversa que vivió escasos meses alados en la ciudad. Al visitante, minutos de silencio en el poema.

A modo de poesía metapoética, el texto ofrece una imagen caleidoscópica de diversas instantáneas oryanas. De otro lado, queda totalmente claro que el poema titulado «La cabaña del poeta» ${ }^{473}$ se refiere al ático de Amiens donde vivían Ory y Laura Lachéroy:

Mi brazo un ascua que se extiende, en las afueras de la ciudad un sitio, una cabaña en el ático de la casa

${ }^{472}$ Obra cit. pp. 107-108.

${ }^{473}$ Este poema, que aquí aparece debidamente modificado, se publicó por primera vez en la revista sevillana Gallo de vidrio. También fue incluido en la antología Nueva Poesía 1: Cádiz, pp. 120-121. En ella el poema se titulaba «La decadencia de Occidente o la manera de intuir una fisiología musical que conduzca sólo al retorno de la verdad». Como se ha dicho anteriormente, este se leyó en la Orygénesis, obra recogida en el libro Marejada (Lanz, Juan José y Téllez, Juan José, 1996: 227-267). 
y dos seres demoníacos que se aman:

Carlos Laura Carlos Laura Carlos.

Otro poema que muestra una intextualidad manifiesta con la poesía oryana es el titulado «Ory tiene cincuenta daños». En él se presenta un imaginativo lenguaje en el que los significados se acoplan mediante relaciones basadas en la sorpresa. Jesús Fernández Palacios se muestra como un maestro y funambulista de la sorpresa, tal como Ory también lo fue:

\section{Para Carlos al cumplir 50 años}

Porque no puedo respirar como quisiera

Porque Andalucía tiene dueño

Porque el mar queda lejos de su casa

Porque la vida es un corazón

Porque su muerte será la muerte

Porque causa tristeza a la tristeza

Porque su garganta es como un beso

[...]

Porque la vida es liturgia

Porque abril ha vuelto a nacer en su memoria

Verdadero ejercio de escritura el realizado por su autor en este poema, que supone una manifiesta recreación de la poesía de signo experimental de Ory. Otro trazo que delimita otra intertextualidad con la poesía oryana se halla en el poema «El amor en una mesa de vidrio». En él se cita una obra poética concreta de Ory:

Sakina es un viejo camaleón
en el camerino de los obispos,
donde busca locamente su peine de plata
y recita a viva voz los Cantos de Malintzí.

Evidente resulta la relación que el poema que cierra Poemías mantiene con Ory. El poema, titulado «Leucemia», está dedicado a él («Para Carlos Edmundo de Ory, il mio fratello») y se trata de la despedida de un discípulo ante el viejo maestro, enfermo, al que en breve sobrevivirá:

¡Venga ya, no te asustes!

que aquí estamos nosotros, 
tus hermanos pequeños, con los glóbulos sanos que faltan al poeta, al querido maestro del que tanto aprendimos en las horas confusas.

A diferencia de la poesía de Fernández Palacios, la de Rafael de Cózar, poeta oryano y crítico literario reivindicador de la poesía de Carlos Edmundo de Ory, no es proclive a establecer de modo directo sus referencias y convergencias con los territorios poéticos con los que se halla enlazada. Aún así, el poema «La soledad», que pertenece a La copa de los $\operatorname{ecos}^{474}$, traza un guiño, a modo de marca territorial, que señala su procedencia del código poético oryano. En el fragmento siguiente, expuesto ya anteriormente, la impronta oryana se halla impresa de manera dedicida:

La soledad es la edad del sol, la soledad es un pájaro de cobre, la soledad es hacer el amor con la nada, la soledad es un trozo de noche en la garganta, la soledad es un diálogo con el aliento, la soledad es el azul pisotón de la tarde, $[\ldots]$

La poesía de José Ramón Ripoll también deja constancia de la importancia que la huella oryana ha imprimido en ella. Una muestra de ello, que actúa como marca o señal, se observa en la cita empleada al inicio de la primera parte, titulada «Encuentro», del poemario Piedra rota (2013). La cita, que acompaña a su título, es un verso del poema oryano «Bajo mi lámpara de trabajo» que pertenece a Melos melancolía: «Vino una piedra ayer a visitarme».

Por su parte, Jaume Pont marca su poesía con trazos evidentes que señalan su conexión con la poesía oryana. El poema «Postscriptum (El poeta)», que pertenece al poemario escrito en catalàn Limit(s) (1976), está dedicado a Ory y se inscribe en la estética minimalista tan propia de su autor:

${ }^{474}$ La copa de los ecos y Sombras de tus ecos recogen poemas escritos entre 1977 y 1980 y que aparecen publicados en 2011 en Los huecos de la memoria, obra cit. 
Lluny
més lluny
fràgil com la gola del porc
transparent
com la mort
més lluny
que la dent corcada del cel

mut carnisser

del no-res

En la antología L'altra llum (Poesia 1976-2011) (2014), el poema titulado «Les paraules» lleva impresa una marca intertextual oryana, concretamente se trata de una cita del autor:

\author{
Te mira ojo a ojo Te \\ pide no sé qué Te \\ mata \\ (Carlos Edmundo de Ory)
}

\title{
1.1.2. Oryanos a distancia
}

No sólo son los poetas más cercanos a Ory aquellos que únicamente muestran en su poesía marcas de reconocimiento y señales que territorializan su poesía sobre el inmenso espacio de la poesía oryana. Multitud de poetas manifiestan en sus propios poemas el interés patente en mostrar sus conexiones con la poesía oryana.

Jaime Siles ha dedicado un poema a Ory, extenso poema que aparece de forma inédita en la revista Campo de Agramante ${ }^{475}$, titulado «Apoteosis de Carlos Edmundo de Ory». Escrito tras la muerte de Ory, queda convertido en homenaje y despedida. Transcribimos el siguiente fragmento por lo elocuente que resulta:

Adiós, Carlos Edmundo, mientras deja el relente mecidas en la orilla las flores de tu frente

${ }^{475}$ Campo de Agramante, Jerez de la Frontera, n 19, diciembre 2013, pp. 132-134. 
racimos de poemas

de perlas esplendentes,

collares, diademas

flotando en la corriente

del único lenguaje

donde la luz del fondo

suena fosforescente

y hace de Ory oro

y de los aires, ejes

para que las palabras

sean incandescentes

y suban por la lluvia

$\mathrm{y}$ alcancen lo celeste.

Luis Eduardo Aute, poeta y músico ligado a Ory por ser admirador de su poesía, por haber puesto música a algunos de sus poemas y por su cercana amistad, ofrece un notable protagonismo a Ory en su obra Animalhada. Libro que aúna pintura y poesía y en el que Ory escribe prólogo y epílogo. En el primero, titulado «¡Volemos juntos montando escoba!», Ory en un tono directo agradece a Aute, entre juegos de palabras, su tarea artística que liga extrechamente la pintura con la poesía y que, en la obra, se organiza en torno a la representación artística de la sexualidad y de la erótica. El libro finaliza con el epílogo oryano («Luz lúbrica») en el que, continuando con el mismo tono del prólogo, reivindica la figura del ángel como ser sexuado y como verdadero paradigma de una sexualidad sagrada. Sagrada precisamente por lo humana que es y porque significa la celebración del hecho de vivir. En la parte titulada «Animalario», Aute, para señalizar su territorio estético, entre palabras de Jung, Ionesco, Unamuno, Huxley, Pessoa y otros, utiliza la siguiente cita de Carlos Edmundo de Ory. Cita que, aunque forma parte del poema «Rosa mía» ${ }^{476}$, puede funcionar por sí mismo como un verdadero aerolito:

La física nuclear no me sirve para comprender por qué lloro por amor... ${ }^{477}$

En cierta forma, Aute dedica a Ory toda la parte titulada «Somática semántica», basada esta en la representación erótica. Bajo el título indica: «motivado por C. E. de O.». En la

\footnotetext{
${ }^{476}$ Poema musicado por Aute en El desenterrador de vivos, obra cit., p. 21. Pertenece a Lee sin temor, obra cit., p. 40.

477 Temática desarrolada también por el escritor y novelista, creador del Grupo Nocilla, Agustín Fernández Mallo.
} 
página anterior, situados en el margen izquierdo se leen los siguientes textos del autor, escritos a la manera de Ory:

\author{
Sôma Sêma: \\ el cuerpo es tumba. \\ Y cuando el cuerpo \\ pide rumba, \\ somos semen.
}

El último libro publicado por Aute, El sexto animal (2016), mantiene también una extrecha relación con Ory. La obra presenta fotos y dibujos de temática erótica y, de otro lado, una colección de textos breves conectados totalmente con los aerolitos oryanos. Su autor los denomina poemigas. Citamos uno de ellos que posee un sabor toalmente oryano por el cuidadoso trabajo lingüístico, por el juego conceptual y por su misterioso significado filosófico:

\title{
Cuando alumbra
}

la penumbra, la oscuridad deslumbra.

Por otra parte, Juan Vicente Piqueras encabeza el poema titulado «Nublao» del poemario Aldea (2006) con una cita de Ory:

\section{En la aldea de mi alma a solas con la lluvia Carlos Edmundo de Ory}

En su libro Atenas (2013), algunos poemas de difícil encaje, son verdaderos homenajes a Ory. Entre ellos descatamos «Gracias a Grecia», «Perdices», «Batalla» o «El mar en Kalamata».

Andrés Sanchez Robayna en su obra reciente, Variaciones sobre el vaso de agua (2015), dedica un poema a Ory, «El vaso de agua». Cada poema, o lo que es lo mismo cada vaso de agua, está dedicado a un autor y va precedido de un discurso teórico en el que reflexiona sobre la representación poética a partir de la metáfora del vaso de agua. En el texto titulado «15» se habla de la poesía oryana como del agua misteriosa, desconocida y amenazadora que transforma y abre la puerta a la existencia humana más extraña. 
Hay más poetas que aceptan esa herencia oryana y, sin embages, la manifiestan en su obra. Juán José Téllez dedica a Ory el poema titulado «La forja de un rebelde» en su libro Daiquiri (1989), título que nos recuerda a la novela de Arturo Barea. Mercedes Escolano le dedica también «Paso del Ecuador», poema perteneciente a Felina calma y oleaje (1986) que posee numeras referencias eróticas. Como cita introductoria lleva el título de un conocido poema oryano: «Amo a una mujer de larga cabellera». José Manuel García Gil también homenajea a Ory con el poema todavía inédito «La caja número 998». Carmén Camacho marca sus mínimas, herederas directas del aerolito, con un trazo intertextual oryano:

\section{Carlos Edmundo \\ Ory pro nobis}

(Minimás, 2008)

Estos son algunos testimonios. Podrían aportarse muchos más que muestran las marcas en la poesía de autores que, mediante ellas, quieren resaltar, enseyando las cartas boca arriba a la manera de las imágenes icónicas en la pintura, los territorios poéticos oryanos de los que su poesía se nutre. Ello significa una muestra de la importancia de la poesía oryana y su desarrollo en la territorialidad de la poesía actual.

\subsection{Como personaje literario e icono cultural}

Debido a su dilatada obra, a su larga trayectoria vital y a su combativa voluntad heterodoxa, la imagen de Carlos Edmundo de Ory ha quedado impresa en la textura emocional de nuestra cultura como símbolo de rebeldía, de insumisión, de independencia y de autenticidad. Su asumida voluntad de situarse en la periferia cultural, tanto en el franquismo como en su posterioridad, ha representado la marca más visible de su expresión como símbolo cultural. Como objeto cultural ha sido motivo de diferentes acercamientos. Entre ellos podemos destacar algunos que nos parecen muy significativos. Ory ha logrado ser un icono en la cultura postpop, una imagen referente de lo que nunca pierde actualidad y como tal figura en diversos discursos artísticos y culturales. Exponemos aquí algunas miradas que enfocan a Ory como personaje literario, y, por lo tanto, ficticio. 
En 1994, Carmen Martín Gaite publica Esperando el porvenir con motivo del veinticinco aniversario de la muerte de Ignacio Aldecoa. La obra surge de una serie de conferencias ofrecidas en la Fundación Juan March e intenta recuperar la memoria de aquellos años vividos y ahondar, de algún modo, en la imagen literaria Aldecoa. Entre las figuras que pueblan el paisaje descrito aparece, de forma constante, la figura de Carlos Edmundo de Ory. En el escenario de la cotidianeidad del Madrid de la posguerra Ory surge entre la masa gris como personaje extravagante y llamativo:

Era extremadamente menudo, unos cuarenta y cinco kilos, trataba a las mujeres con mucha gracia, llevaba una bufanda enorme, y era lo más vanguardista que paseaba por Madrid, si exceptuamos a Mayra O'Wisiedo, que también tenía lo suyo $^{478}$.

El Postismo aparece como una especie de surrealismo ibérico insurrecto con el que, de manera ética y estética, contactó Aldecoa. La obra pretende recordar la amistad y la convivencia de ambos escritores, estrechada sobre todo en la pensión que compartieron. En ella se escenifican las aventuras de la noche madrileña junto a Rafael Santos Torroella, Ángel Crespo, Pedro Bueno o Juan Arboleda. Resulta interesante la aparición de Eduardo Chicharro en su estudio de pintura: «Ch. H., como se le nombraba en los textos postistas ${ }^{479}$. La mirada de Matín Gaite se focaliza en la antesala literaria de Aldecoa, espacio donde la influencia de Carlos Edmundo de Ory fue decisiva.

Personaje literario vuelve a ser Ory en las páginas de Tiempo de guerras perdidas (1995), primer volumen de las memorias escritas por Juan Manuel Caballero Bonald, cómplice literario y amigo de Ory. En él relata su llegada a Madrid y su introducción en los ambientes artísticos, literarios y nocturnos. Allí coincidió con Ory y con las insurrecciones del Postismo, movimiento que queda representado como una propuesta frívola que se sustentaba de una total sacudida de preceptos de la pacata moral de sagrario de la época:

Ory ya había conseguido cierto desordenado renombre con sus tejemanejes humanos y poéticos a propósito del postismo, un credo que se quedaba a menudo en el mero lucimiento efectista, en alguna que otra frívola pirueta estética, pero que también supuso el único arriesgado programa de desentumecimiento de aquella generalmente recalentada y monocorde lírica de devocionario. Era al menos una opción saludable y transgresora, una

${ }^{478}$ Martín Gaite, Carmen (1994), Esperando el porvenir, Madrid, Siruela, p. 27.

479 Ibíd., p. 29. 
desobediencia muchas veces pueril y pocas inane frente a la sumisa oficialidad de la poesía ${ }^{480}$.

Ory aparece observado a través de varias instantáneas de admiración que han ido adquiriendo mayor consistencia con el tiempo: como personaje que en su juventud iba fraguando una de las obras más interesantes de la segunda parte del siglo XX. Poeta visionario, oficiante de la sagrada poesía, anacoreta de la palabra... esta es la imagen transmitida desde estas páginas. En Oficio de lector (1013), obra que intenta subvertir los límites que separan la novela del ensayo, Cabellero Bonald traza otra mirada sobre la figura de Ory. Este aparece aquí como el maestro de la desobediencia y de la transgresión:

El aspecto de Ory se correspondía con el de un rebelde vocacional o con el del fugitivo de algo, es decir, que se diferenciaba a simple vista de aquella tribu de poetas acogidos a la inmediata etiqueta de garcilacistas [...] Sabía por lo pronto, que la obra y la vida de Ory iban juntas y que su condición de prófugo de la oficialidad artística imperante lo dotaba de un cierto prestigio literario. No me defraudó cuando lo conocí; al revés, me proporcionó un buen acopio de seducciones adicionales, muy bien situadas entre la inteligencia y el disparate. Anoté entonces que tenía voz de huérfano y mirada de alquimista. Lo de la mirada aún se le nota. Pero sobre todo se parecía mucho a un insumiso situado en la cuerda floja que enlaza la anarquía con la inocencia ${ }^{481}$.

La mirada que Caballero Bonald traza sobre Ory se completa con el elogio de una propuesta poética que, desde el exilio, sacraliza la actividad poética, que crea realidades desconocidas y que significa un constante ejercicio de sorpresa y de una desbordante imaginación.

Una mirada diferente nos ofrece Jesús Ferrero en su novela Balada de las noches bravas (2010). Su óptica consiste en dar entidad ficticia a Ory convirtiéndolo en personaje narrativo. La novela, además de situar parte de la historia contada en el espacio del París de finales de la década de los sesenta y de parte de los setenta del pasado siglo, supone un homenaje a determinados personajes que tuvieron gran importancia en el escenario de la cultura occidental, cuya huella ha quedado impresa como icono cultural. Entre sus páginas desfilan Jean Paul Sartre, Roland Barthes,

${ }^{480}$ Caballero Bonald, Juan Manuel (1995), Tiempo de guerras perdidas, Madrid, Alfaguara, ed. de 2004, p. 284. 402-403.

${ }^{481}$ Caballero Bonald, Juan Manuel (2013), Ofico de escritor, Barcelona, Seix Barral, pp. 
Jacques Lacan, Louis Althusser, Michel Foucault, Gilles Deleuze, Richard Lester, Audrey Hepburn, Julio Cortazar, Agustín García Calvo, José Ángel Valente, Alfonso Costafreda y, entre ellos, Carlos Edmundo de Ory, que aparece como un chamán visionario en su cabaña de Amiens:

Ory vivía en la buhardilla de una casa que entonces se hallaba a las afueras de la ciudad y sus ventanas daban al campo. Cuando llamé a la puerta de su casa, Ory estaba todavía en la cama, pero se levantó para abrirme en compañía de una mujer de unos veintidós años, de un rubio tan claro que parecía albino.

Ory me indicó un asiento y me pasó un libro de magia negra para que me entretuviera un poco mientras ellos se aseaban. Toda la casa estaba abuhardillada y reinaba un amable desorden jalonado de objetos sorprendentes. Parecía al mismo tiempo la casa de un bohemio y la cueva de un chamán.

Ory tenía entonces cincuenta y seis años, la barba y los cabellos blancos, la mirada intensa y sufriente, y por lo pude ver ese día, vestía ropas ajadas y en la más estricta tradición bohemia ${ }^{482}$.

En la novela, el Ory personaje realiza un extraño ritual para celebrar al eternidad del instante presente y el hecho de los seres pertenezcan al fluido cósmico de la existencia.

En la novela El azar y viceversa (2016), a la vez recreación intertextual de la picaresca narrativa clásica y homenaje a Andalucía, Felipe Benítez Reyes ofrece de manera autobiográfica un viaje de ida y vuelta por los escenarios del pasado: Rota, Cádiz, Sevilla, Jerez de la Frontera. En el mosaico de espacios, algunos de ellos cercanos a la marginalidad y a la delincuencia, otros asociados a trabajos y ocupaciones, algunos poetas gaditanos pueblan el microespacio propio de las inquietudes culturales. Entre ellos, Carlos Edmundo de Ory o José Ramón Ripoll aparecen con entidad narrativa de personajes reales, citados con su nombre.

Para finalizar este apartado, que aporta varios testimonios literarios que autentifican la importancia de la figura de Ory como referencia cultural en el panorama de la actualidad, nos centramos en el libro, citado ya con anterioridad, Escaramuzas de Antonio Martínez Sarrión que posee dos referencias importantes acerca de la figura de Ory:

${ }^{482}$ Ferrero, Jesús (2010), Balada de las noches bravas, Madrid, Siruela, p. 193. 
Es rara y de alabar, la comparecencia en los medios de Carlos Edmundo de Ory, pese al lado histrión del poeta. Me gusta saber, en una de ellas, reciente, que sigue bien vivo, bien alerta, a los ochenta años. Dice, por ejemplo: «Sólo me interesan Irak, Israel, los horrores. Pero tampoco veo que los poetas se ocupen mucho de eso». O: «No hay poesía sin silencio. La poesía viene del silencio para regresar a él, es una isla». Y remata de esa imperial manera, citando uno de sus «aerolitos»: «La poesía es un vómito de piedras preciosas», que me trae a la memoria la mejor definición del «surrealismo» a cargo de peruano César Moro: «El surrealismo es la esmeralda de Nerón». ¡Perfecto! ${ }^{483}$

Con este brío y esta rabia escribe ahora mismo Carlos Edmundo de Ory, el más joven de todos los poetas españoles:

Unos cuantos granujas con sangre en las corbatas afilan sus cuchillos en lingotes de oro,

o:

Pienso en los tercos de tantísima estrellada

coronando la marcha minada de la turba.

¡Qué consuelo! ${ }^{484}$

Antes de acabar, cabe citar dos hechos artísticos más. Por un lado, el cortometraje dirigido por el portugués Jesús Graván, El que anda con luz ${ }^{485}$, que se presentó en septiembre de 2015 en Cádiz en el docuexpress ALCANCES, edición 47. En él, el actor Bruto Pomeroy encarna a Ory, quien, gracias al permiso del dios Neptuno, surge desnudo del mar porque se ha enterado de que un director de cine está rodando un corto sobre su vida en el que no consta la importancia que ha tenido el mar en su poesía. Ory decide llevar un frasco de agua de mar y entregárselo en el festival. El proyecto supone la génesis de un largometraje sobre la vida del autor. En el corto aparecen entrevistas con Laura Lachéroy, viuda del poeta, Jesús Fernández Palacios, José Ramón Ripoll, Juan José Téllez, Ana Sofía Pérez-Bustamante, José Manuel García Gil y Fernando Lobo. El rodaje está localizado en la playa de Cádiz, en el colegio San Felipe Neri, en la Fundación Carlos Edmundo de Ory, en la Alameda Apodaca donde se halla la Gorieta Carlos Edmundo de Ory, situada frente a la casa natal. Allí Ory observa su

\footnotetext{
p. 8 ${ }^{484}$ íbid., p. 116.

${ }^{485}$ Director: Jesús Graván; guión: Jesús Gravan, fotografía: Gabriel Pinal; reparto: Bruto Pomeray, Andrés Janín, María Espejo; producción, Andrés Janín. Puede verse en https://www.youtube.com/watch?v=EfDLJHiUdko
}

${ }^{483}$ Martínez Sarrión, Antonio (2011), Escaramuzas (Dietario III), Barcelona Seix Barral, 
propia estatua, que ha abandonado el pedestal para ir en busca del mar. El documental ofrece, de manera imbricada con la ficción, breves retazos de la importancia de la obra de Ory en el ámbito cultural.

El segundo hecho que cabe mencionar, es la exposición realizada en el Centro Reina Sofía de Madrid, desde el 27 de abril hasta el 26 de septiembre de 2016, sobre el arte de posguerra. Titulada Campo Cerrado. Arte español de posguerra y comisariada por María Dolores Jiménez-Blanco, incluye una sala dedicada a Carlos Edmundo de Ory y al Postismo, la que se corresponde con el apartado IV. «La irrupción de lo irracional. El Postismo». En esta se muestran diversos materiales cedidos por la gaditana Fundación Carlos Edmundo de Ory. Entre ellos se pueden observar las dos revistas postistas, Postismo y La Cerbatana, las tarjetas de presentación de los tres agentes postistas, el Tercer Manifiesto del Postismo, el manuscrito de Las patitas de la sombra escrito en 1944, fragmentos de la correspondencia de Ory, los catálogos de las dos exposiciones de Pintura Postista... La exposición reivindica la propuesta del Postismo como movimiento impulsor de la vanguardia en la década de los cuarenta, cuando las tendencias artísticas de este país se habían distanciado del resto de Europa. Entre poetas y literatos como Max Aub, Ramón Gómez de la Serna, José Moreno Vila, Luis Rosales, Juan-Eduardo Cirlot o Joan Brossa aparecen los escritores postistas Eduardo Chicharro, Carlos Edmundo de Ory, Silvano Sernesi, Francisco Nieva y Miguel Labordeta. En pintura se muestran obras de Chicharro, Nanda Papiri, Mathías Goeritz, Benjamín Palencia, Gregorio Prieto que representan la estética postista y sus territorios más cercanos como contribución a la vanguardia pictótica y sus desarrollos, mostrados por obras de Salvador Dalí, Pablo Picasso, Josep Renau, Maruja Mallo, Eduardo Chillida, Jorge Oteiza, Manolo Millares, Antonio Saura, Antoni Tapies, Modest Cuixart... 
CONCLUSIONES 


\title{
1. LA IMPRONTA ACTUAL DE LA ESCRITURA NOMADA DE ORY
}

\author{
Me dormí llorando \\ soñé con peces \\ Carmen Camacho
}

Este proyecto de tesis surgió del deseo de reivindicar la existencia, en plena posguerra, de una poesía de signo vanguardista comprometida con el lenguaje y con la tradición irracional, que extendía sus contactos con las poéticas renovadoras y que estaba en plena vigencia en las poéticas primeras que surgieron en el panorama poético tras la guerra. Esta era una poesía menos ensimismada en su cercanía territorial y más abierta a espacios poéticos exteriores, dedicada, sobre todo, a explorar las parcelas menos visibles de la realidad. Una poesía que en la década de los cincuenta rechazó de pleno las normativas del realismo poético y se acercó a lo real desde una mirada mágica. Entre los poetas pertenecientes a esta línea poética, periférica, marginal y marginada, destaca Carlos Edmundo de Ory. Por su dilatada obra, este poeta adquiere una importancia vital en el panorama poético de la segunda mitad del siglo XX y su presencia se hace totalmente notoria en la poesía de la actualidad.

Para ello, hemos estudiado la territorialidad poética de la posguerra española, analizando cada espacio particular para señalar la génesis y la transformación de esta poética vanguardista y mágica, de signo visionario, sus derivas y desarrollos y contextualizarlos en los fluidos poéticos coetáneos. Esta labor de arquitectura nos ha servido como estudio de la capa freática en la que aparece edificado el andamiaje postista y como atalaya desde la que observar sus movimientos e intersecciones en la textura de las poéticas posteriores. Delimitado el espacio poético de la posguerra, se ha situado en él el movimiento postista y se han analizado en profundidad sus propuestas: los materiales programáticos y sus teorías artísticas, sus contactos con la vanguardia histórica, sus prácticas literarias y sus desarrollos. 
1.1. El Postismo como discurso de la posmodernidad

El movimiento Postista surgió en lo que hemos definido como la segunda etapa de posguerra, aquella que se establece, desde nuestro punto de vista, a partir de $1945 \mathrm{y}$ que acaba en 1952 con la publicación de la Antología Consultada y el advenimiento de la poesía de signo social. Es en este intervalo temporal en el que aparecen las directrices que estructuran las futuras líneas poéticas que surcan todo el espacio poétio de la posguerra. La primera posguerra, caracterizada por el escaso interés de una poesía oficialista, acaba en 1944 con un enorme hachazo, que marca un claro límite en su dinámica poética. Por una parte, la publicación de Sombra del paraíso de Vicente Aleixandre cierra de una forma brillante toda una línea poética, el irracionalismo de signo surrealista, cuya continuación se produce de forma marginal. Por otra, la aparición de Hijos de la ira de Dámaso Alonso inaugura una nueva poética centrada en la importancia de lo humano, en la que la poesía dirige la mirada hacia la realidad más inmediata. Ambas obras marcan la poseía surgida a partir de 1945 y significan el inicio de las líneas poéticas desarrolladas en posguerra: la poesía existencial, la poesía social, la poesía de la realidad interior, la poesía esteticista y la poesía de la marginalidad. El Postismo supone, con la publicación en 1945 de las revistas Postismo y La Cerbatana, el inicio de esta última, cuyas derivas son la poesía de signo surreal y la poesía de signo experimental.

El Postismo significó en las coordenadas artísticas de su época una reivindicación de una práctica artística que recuperaba la transgresión y la voluntad combativa de los movimientos de vanguardia como un ataque total a la sociedad impulsada por las ideologías que el franquismo imponía. Frente al clasicismo poético y a la voluntad trasformadora de la poesía realista, el Postismo rescató la provocación y la radicalidad del dadaísmo, convitiéndose en un movimiento de agitación cultural. Del surrealismo se apropió del valor del automatismo como vehículo para el acercamiento a una poética del insconsciente, de la investigación de los sueños como acceso a una realidad mágica y misteriosa, capaz de ser plasmada en las prácticas artísticas, y de la belleza extraña y convulsa, signo de una poética de la fascinación y no del buen gusto. El Postismo revindicó además la estética deformadora y caricaturesca enraizada en estética ibérica y plasmada, sobre todo, en el esperpento vallinclanesco. Conjugó la estética propia del carnaval, que se encuentra en la pintura de El Bosco o Bruegel, con 
la estética de hospital propia del expresionismo alemán. Pero el Postismo, como tal, no sólo supuso la reactivación de las anteriores propuestas, sino que reivindicó otros postulados estéticos como el primitivismo artístico, el acercamiento a un arte organicista en consonancia de una realidad fluida, la búsqueda de la estética paradójica del budismo zen... Por ello, cabe señalarse el paralelo existente en el tiempo entre los hallazgos postistas y la rebeldía, la voluntad de ruptura con la dinámica social y la estética fluida e improvisada que proponían los autores americanos de la Beat generation. El Postismo, basado en la exaltación violenta y libertaria de la imaginación y en la práctica de la provocación, significó una bofetada a las políticas culturales y a los presupuestos estéticos de la época. Ello resultó posible al aceptar la distancia frentre a la oficialidad, por ello el Postismo surgió, en cierto modo, del concepto de marginalidad voluntaria y de la ocupación de un espacio periférico en el territorio cultural. Marca, por tanto, el punto de partida del arte de vanguardia de la segunda mitad del siglo en nuestro país. De las prácticas poéticas postistas, como hemos dicho anteriormente, surgen dos líneas en la poesía marginal de la posguerra.

La primera, de signo surrealista, mágica, que toma en ciertos momentos tintes esotéricos o místicos ${ }^{486}$, atraviesa subterráneamente toda la posguerra, desemboca en el underground y llega a nuestros días. Bajo el sol de la posguerra brillaron las islas de la poesía de Brossa, Cirlot o Ory. En su ocaso la poética surrealista fue reivindicada por los poetas de la generación de los novísmos y en la actualidad vuelve a brillar en autores con Antonio Lucas o José Luis Rey, poetas representativos de la generación del 2000. La segunda, que surge de la experimentación poética propia de los juegos postistas, se dirige a la poesía experimental. Esta, de modo solapado, atravesó también el páramo de la posguerra poética bajo actividad difusora de Ángel Crespo desde las revistas Deucalion y Revista de cultura brasileña para afianzarse con la llegada de la décadas de los sesenta y de los setenta con la labor de Julio Campal, Fernando Millán, el grupo Zaj, José María Montells, Alfonso López Gradolí, Ignacio de Liaño, Felipe Boso y José Miguel Ullán que conectaron activamente con todos los experimentos poéticos que se realizan en el exterior como la poesía visiva, la poesía concreta, la poesía fónica, el espacialismo, la poesía semiótica... Esta es una línea poética totalmente abierta al exterior y que, en contacto con las artes plásticas, escénicas y audiovisuales, nos llega a

${ }^{486}$ En este sentido cabe citar a autores como Cirlot, Crespo o el propio Ory. 
la actualidad bajo numerosas persepctivas: la poesía como interacción artística, la agitación poética, la poesía escénica, la poesía visual, el libro objeto...

Por todo ello, el Postismo anuncia el ocaso de los proyectos propuestos por la modernidad y, sobre todo, constata el fin de las ideologías creadas bajo la óptica del racionalismo. Debido a las especiales circunstancias de la sociedad española, el Postismo significa un rechazo del proyecto político y el papel de la poesía y el arte como agentes claros para una transformación de la realidad. Desde la óptica postista, la incidencia sobre la realidad se realiza de un modo que enlaza con los discursos posmodernos, desordenando el discurso y señalando sus paradojas, tales como verdad racional, proyecto político, idea de progreso, utilidad del arte... Como señala Octavio Paz (1965: 209), la labor del discurso posmoderno no es inventar sino explorar, esta es precisamente la tarea realizada por el Postismo, operar sobre la realidad del lenguaje, porque este ,asimismo, es el mundo.

\subsection{Una poética permenentemente nómada}

Vista la importancia del Postismo en el panorama artístico posterior, hemos centrado nuestro trabajo en la sistematización y el análisis de los presupuestos que han ido sustentando a lo largo del tiempo la poesía de Ory. De algún modo, el Postismo significó la toma de conciencia poética, social y cultural de Carlos Edmundo de Ory. La poesía oryana adopta la concidión de ser una poetica periférica y descentrada, alejada y repudiada no sólo por las instancia políticas sino también por las dogmáticas imperantes en la centralidad poética. La poesía oryana sufrió el desprecio tanto por los poetas clasicistas como por los poetas que combatían desde una poética humana y realista la realidad social. Ory ocupó de manera voluntaria el espacio de la heterodoxia más intempestiva. Sus preocupaciones humanas le llevaron a romper con la atmósfera cultural asfixiante de este país y su rechazo le llevó en 1955 al exilio voluntario. En el territorio de la heterodoxia nació una poesía surgida de la reflexión solitaria y de la experiencia vivida, una poesía visceral y consciente de su autenticidad, experimentada a contracorriente. Una poesía nacida de sus estudios y meditaciones que acercaron su interés a filosofías, que en varias décadas e incluso hoy mismo, son consideradas como pensamiento periférico. Sus preocupaciones intelectuales lo acercan al pensamiento 
mágico, hermético y místico generado en toda la diáspora humana, desde el sufismo islámico al budismo zen, pasando de la mágia y el chamanismo a la alquimia y los arquetipos religiosos de la antigüedad. Esta voluntad heterodoxa le llevó a contactar con las nuevas propuestas estéticas y vitales surgidas en los espacios de la bohemia contracultural y del pensamiento libertario: la Beat generation, el underground, la literatura psicodélica, los movimientos de la contracultura como el pacifismo, la apatría... Poesía que surge del rechazo de lo establecido y se coloca en los espacios de la marginalidad.

La producción poética oryana, poliédrica y dilatada, puede sistematizase en una serie de aristas. Cabe decir que no se trata de una poesía que sigue un línea temporal evolutiva, sino que responde a un movimiento circular en el que preocupaciones y temáticas son retomadas cíclicamente a lo largo del tiempo. La poesía oryana es una reflexión, humana, existencial, que toma la forma de la espiral. En todo caso pueden señalarse una serie de constantes que la vertebran en diferentes sistemas.

La primera poesía escrita por Ory es una poesía crepuscular, una poesía adolescente producida entre 1937 y 1943, que con varias modificaciones se publicó de manera tardía en Poesía primera (1986). Se trata de una poesía que no se ajusta a los engranajes poéticos de su tiempo, que mira hacia un pasado poético que se halla en el ocaso, y que, por ello, resulta mucho más renovadora que la poesía coetánea de signo clásico e imperial. En ella Ory reactiva la tradición simbolista, de signo visionario, y sus desarrollos como el modernismo, el impresionismo y el decadentismo. Desde esta herencia la poesía oryana se acerca a la vanguardia poética a través de la estética cubista planteada por el creacionismo y el ultraísmo, explora el componente neopopular de autores como Juan Ramón Jiménez, Federico García Lorca o Rafael Alberti y propone un surrealismo de herencia hispánica, cercano al de Lorca y Luis Cernuda, que se configura como antesala de la poesía postista. Cabe destacar en ella dos constantes que atraviesan toda la extensión de la poesía oryana: una mística de signo inmanente y el acercamiento al lenguaje de silencio de tradición zen.

A partir de 1945 Ory produce su poesía postista, bien en poemas dispersos aparecidos en revistas y antologías, bien en formato de poemario como Versos de pronto (1945), Los poemas de 1944 (1973) o los romances, escritos junto a Chicharro, 
contenidos en Las patitas de la sombra (2000). La poética postista puede definirse como surrealismo de signo bretoniano más experimentación poética basada en el valor lúdico del lenguaje. En los romances aparece además la deformación expresionista, caricaturesca, de tradición hispánica que los liga a la estetica espenpéntica del carnaval, tan presente en Quevedo, Goya o Valle-Inclán.

Con la escritura, junto a Darío Suro, de Nuestro tiempo: Pintura / Nuestro tiempo: poesía (1951), texto considerado el manifiesto de introrrealismo íntegro, la poesía oryana rechaza totalmente las coordenadas que delimitan el espacio central de la cultura española y, agudizado este hecho por el autoexilio impuesto de su autor, se desplaza a terrenos totalmente periféricos y heterodoxos. Esta es la poesía nómada, escrita entre $1946^{487}$ y 1979. En ella Ory propone unos parámetros poéticos totalmente plurales que abarcan los territorios más alejados de la ortodoxia cultural, desde la expresión alucinada del dolor existencial, al interés por la magia y la alquimia, pasando por el chamanismo, la protesta política, la experimentación poética, la rebelión beat, el pop-art, el underground, las filosofías presocráticas y herméticas, el sufismo y la mística oriental. Resulta interesente la profundización en las filosofías orientales, de ellas toma la conciencia de una mística del instante presente, cuya idea de totalidad queda expresada en la igualdad entre ser y cosmos y en el rechazo de la conciencia como eje vertebrador del ser humano. Así el nomadismo oryano explora el hinduismo y su conciencia no dual, el tantrismo como expresión de una mística sagrada centrada en la sexualidad, el budismo y el concepto de vacuidad, el budismo Mahayana y la idea de la divinidad del universo (el Samsara), el taoísmo y el proceso orgánico de la realidad. Sobre todo, la poesía oryana está impregnada del budismo zen, del lenguaje del silencio contenido en la minimalista estética del haiku, de la lógica paradójica del koan, del intento de establecer una aprehensión de la realidad más allá del pensamiento, de la meditación sin finalidad, de la experiecia de percibir la energía cosmica de manera automática, natural y directa... La presencia de Oriente en la poesía oryana se observa ya desde sus inicios, tanto en la presencia de una mística cósmica como en el interés por la poética del silencio. También impregna el edificio postista, tanto en las concepciones sobre el movimiento orgánico y metamórfico como por la extraña estética paradójica.

${ }^{487}$ Nótese que desde 1946 a 1949, como ya indicamos con anterioridad, coinciden en el tiempo la poesía postista y la poesía nómada. De hecho son direcciones distintas de la plural poesía oryana. Poemas (1969), primer poemario publicado desde la distancia establecida con la poética postista y obra que inicia la poesía nómada, está compuesto por poemas escritos entre 1946 y 1969. 
Pero es en obras como Lee sin temor (1976) o Miserable ternura / Cabaña (1981) donde se condensa este pensamiento que discurre más allá de la lógica.

A partir de los años ochenta del pasado siglo, Ory escribe una poesía de madurez que se instala en el recuerdo, este es el eje estructurador de los útimos poemarios. Sin permiso de ser ángel (1988) reorganiza los instantes pasados durante dos visitas realizadas al poeta Allen Ginsbarg en su vivienda de Nueva York. Melos melancolía (1999) supone una verdadera retrospectiva de la existencia del poeta, de su poesía y de su pensamiento. De manera que, a su vez, configura un viaje a través de la tradición simbólica más heterodoxa. En la obra se recuperan muchas de las constantes de la poesía oryana: la presencia del mar, la poesía como música divina, la mística oceánica, la eternidad e infinitud de la existencia, la imagen del ser humano como dormido... En La memoria amorosa (2011), obra póstuma, es el recuerdo quien articula las diversas instantáneas que, escritas en prosa poética, organizan la mirada del autor, que esta vez dirige los ojos sobre sí, espacio donde exterior e interior se igualan y en el que la metafísica, la mística y la poesía poseen entidad de realidad.

Existe, además, una poesía liminar que se halla en la zona limítrofe de lo que se entiende por poesía, esta la establecen los aerolitos y la poesía visual. Por una parte, los aerolitos son textos breves a modo de sentencias y aforismos que se hallan entre la greguería, la poesía y el koan. Como este último, presentan una logica paradójica que los convierte en un relámpago, cuyo fuego es capaz de provocar un incendio cerebral que proyecta el pensamiento más hallá del lenguaje, hacia la acción directa sobre la realidad. En los aerolitos se halla de forma muy patente la impronta de zen, que persigue una experiencia directa, sin lenguaje ni pensamiento. Por otra, la poesía visual oryana se halla en el poema-collage y en el collage. En ella la poesía se convierte en imagen, en obra gráfica, siguiendo la tradición de la poesía visiva de Michele Perfetti, de la poesía semiótica de Fernando Millán o del grafismo pop de Robert Indiana. En ella, aunque creada a base de diversos códigos icónicos como la pintura, la fotografía, el cine o la publicidad, prevalece la mirada poética.

Como hemos visto, la práctica poética oryana transita por una serie de territorios sin que ninguna voluntad de pertenencia se ate a ellos, por eso se trata de una poesía apátrida, nómada. La tarea de Ory es la del explorador que se halla en todo 
momento en páramos extraños y en terrenos extranjeros. No se trata en absoluto de la tarea del colono, que edifica su poética limitando el espacio de su propiedad con vallas demarcadoras. La poesía oryana se pliega sobre los estratos culturales coetáneos más extraños y heterodoxos y transita atravesando todos los paisajes.

1.3. La huella de una escritura errante, descentrada y libre

Esta poesía, de signo marginal, surge y se alimenta de las preocupaciones vitales y de las posiciones intelectuales adoptadas por el Ory humano. Poesía en la que poeta y ser humano quedan inseparablemente fundidos, en la que vida y obra quedan perfectamente imbricadas, cuyos límites se difuminan de manera líquida. La vida se convierte en obra y la obra se vive intensamente y queda convertida en vida. La poesía oryana resulta un ejemplo total de poesía rizomática, aquella escritura que para Gilles Deleuze y Félix Guattari (1980, 2008: 9-29) hace rizoma con la vida. La poesía es la certificación de los instantes vividos y la vida la poesía experimentada en cada instante de la realidad, una poesía orgánica sin aristas ni construcciones que ha sido capaz de plegarse sobre el ritmo fluido de la existencia del Ory humano, en la que sujeto y objeto de la escritura han desaparecido y sólo quedan líneas y multiplicidades, ramificaciones. Se trata de una escritura nómada que no empieza ni acaba en cada obra y que atraviesa constantemente múltiples espacios sin establecerse en ellos, acotar su territorio y reclamar derechos de propiedad. Escritura errante, al fin y al cabo ${ }^{488}$, que se pliega sobre los territorios culturales, simbólicos, poéticos, los atraviesa y se enraiza en ellos sin erigirse como edificio ni instaurar su poder sobre ellos. Sin colonizarlos.

Es esta escritura, abierta, inmediata, multidireccional, vivida en la soledad y en la incomprensión multitudinaria, periférica y marginal, es la que resulta para muchos poetas de la actualidad enormemente valorada. La impronta poética de Ory ya fue reivindicada por los poetas de la década de los años setenta del siglo pasado, en su poesía celebraron el humor y la heterodoxia. Entre estos poetas cabe señalar de forma

${ }^{488}$ (Deleuze y Guattari, 1980, 2008: 16-17): «Sabiduría de las plantas: incluso cuando tienen raíces, siempre hay un afuera en el que hacen rizoma con algo: con el viento, con un animal, con el hombre (y también un aspecto por el que los animales hacen rizoma, y los hombres, etc)». La escritura rizomática es una escritura orgánica, que crece como lo hacen los seres de forma constante, natural e inmediata, hecha de ramificaciones sin dirección premeditada. 
explícta a Antonio Martínez Sarrión, Gillermo Carnero, Pere Gimferrer o Luis Antonio de Villena. Rosa María Pereda (G. Moral y Pereda, 1979, 1982: 16-17) señala a Ory como uno de los autores influyentes en la poesía novísma debido a su poesía vanguardista, que aúna surealismo y dadaísmo, a su voluntad marginal, a su humorismo críptico y a sus contactos con el underground. La poesía oryana es nuevamente valorada en la actualidad poética; muchos poetas son los que aclaman a Ory como uno de los maestros de la poesía actual junto a Vicente Aleixandre, Jaime Gil de Biedma o Claudio Rodríguez. Son poetas que pertenecen a generaciones dispares, algunos de ellos se declaran abiertamente discípulos de Ory, otros reconocen su labor de magisterio y reivindican su vigencia. En todo caso, todos ellos señalan la huella que la poesía oryana ha dejado impresa en sus poéticas, lo que se traduce en una serie de marcas y trazos evidentes en la propia textualidad, como lo son las citas, las dedicatorias o las diversas intertextualidades, tanto implícitas como explícitas.

De los poetas que se configuran como herederos directos de Ory, cabe señalar a los integrantes del grupo Marejada de Cádiz, Jesús Fernández Palacios, Rafael de Cózar y José Ramón Ripoll, a ellos hay que sumar otro poeta, amigo, y crítico oryano, Jaume Pont. Son poetas cuya actividad se inició en la década de los setenta del pasado siglo. Otros poetas, más o menos coetáneos, incluso algo posteriores, que aceptan la herencia oryana son Alberto Porlan, Andrés Sánchez Robayna, Rosa María Lentini, Juan José Téllez, Rafael Adolfo Téllez o Uberto Stábile. Algunos de los poetas de fin de siglo, disconformes con ser etiquetados por Luis Antonio de Villena como postnovísimos y que rechazan pertenencias y sentimientos grupales, reclaman la parte de herencia oryana que les corresponde. Entre ellos cabe citar a Juan Vicente Piqueras, Mercedes Escolano, Rafael Ramírez Escoto, José Manuel García Gil, Guadalupe Grande y algunos más. Otros poetas más actuales, pertenecientes ya a la cybergeneración del nuevo milenio, se sienten, a su vez, herederos de la poesía oryana y reivindican la impronta de una poesía libre, auténtica, independiente y absolutamente moderna. Entre ellos cabe destacar a autores como José Luis Rey, Antonio Lucas, Goreti Ramírez, Pablo Acevedo, Carmen Camacho o Javier Vela ${ }^{489}$.

${ }^{489}$ En el Apéndice XIII quedan recogidos algunos testimonios de algunos de los artistas citados reconociendo, a través de mi correspondencia virtual con ellos, su pertenencia a la herencia oryana. También algunos poetas jóvenes expresan sus deudas con Ory en las páginas del número que la revista Insula dedicó en 1012 a Ory (Ripoll, 2012b). 
Como hemos visto, la poesía oryana sigue vigente en el estado poético de la actualidad y es aclamada por algunos poetas para los que les resulta más vanguardista y actual que la de muchos poetas de ahora. La poesía de Ory sigue viva mientras que la de otros poetas, considerados más importantes, no poesee una huella tan profunda como la suya en el panorama poético de la actualidad. Además la imagen de Ory ha quedado impresa, a modo de icono, en el territorio cultural. Así, como objeto de la ficción, aparece en novelas y productos cinematográficos. 


\section{BIBLIOGRAFÍA}

\section{BIBLIOGRAFIA PRIMARIA}

1. Obra de Carlos Edmundo de Ory

\subsection{Poesía}

- Versos de pronto (1945), Madrid, Fantasía, Semanario de Invención Literaria, nº 19, julio de 1945.

- Aèrolithes (1962), traducción de Denise Breuil, prólogo de Marcel Béalu, Imprimerie Rougerie; Aerolitos, Madrid, Cuadernos Hispanoamericanos, $\mathrm{n}^{\circ} 181$, enero de $1965^{490}$.

- Los sonetos (1963), Madrid, Taurus, Col. Palabra y Tiempo.

- Diez poemas (1964), Madrid, Cuadernos Hispanoamericanos, $\mathrm{n}^{\circ} 170$, febrero, pp. 229-237.

- El amo del amor (1964), Madrid, Cuadernos Hispanoamericanos, n 177, septiembre, pp. 373-380.

- Poemas reunidos (1965), Madrid, Cuadernos Hispanoamericanis, $\mathrm{n}^{\mathrm{o}}$ 182, febrero, pp. 238-245.

- La flauta prohibida (1965), Palma de Mallorca, Papeles de Son Armadans, $\mathrm{n}^{\circ}$ 114, septiembre, separata.

- Aèrolithes (1966), París, Les Réalités Secrètes, n 28-29, diciembre; Aerolitos, Madrid,

Cuadernos Hispanoamericanos, no 230, febrero 1969.

- Cartas a Malintzi (1966), Madrid, Cuadernos Hispanoamericanos, nº 198, junio, pp. 497-500.

- El musiquero de las manos fecundas (1967), Madrid, Cuadernos Hispanoamericanos, $\mathrm{n}^{\mathrm{o}} 215$, noviembre, pp. 288-296.

490 Incluyo los aerolitos en el discurso poético debido a su plasticidad lingüística y a la voluntad experimental. De este modo, Ory sigue la senda poética trazada por Ramón Gómez de la Serna en sus greguerías, que a su vez traza el camino marcado por Nietzsche o Baudelaire. 
- Poemas (1969), Madrid, Cuadernos Hispanoamericanos, no 230, febrero, pp. 302310.

- El rey de las ruinas (1969), Palma de Mallorca, Papeles de Son Armadans, nº 164, noviembre, pp. 157-174.

- Poemas (1969), Madrid, Rialp, Col. Adonais (1944-1968).

- Música de lobo (1970), Madrid, Grupo N.O. (1957-1969).

- Poesía (1970), Madrid, Cuadernos Hispanoamericanos, n 245, mayo, pp. 315-337.

- Técnica y llanto (1971), Barcelona, Llibres de Sinera, Col. Ocnos (1969-1970).

- Los poemas de Karl Borromaüs y Poema dantesco (1983), Puerto Rico, Río Piedras, Revista de la Facultad de Humanidades, Universidad, nº 2, marzo, pp.149-153.

- Los poemas de 1944 (1973), Madrid, Joaquín Giménez-Arnau, Col. Aguaribay de Poesía.

- Anual poemas (1974), Madrid, Cuadernos Hispanoamericanos, $\mathrm{n}^{\circ}$ 284, febrero, pp. 259-266.

- Lee sin temor (1976), Madrid, Editora Nacional, Col. Alfar (1970-1971).

- 18 poemas (1976), Tudela, Caja de Ahorros de Navarra, Publicaciones de la Sala de la Cultura, febrero.

- La flauta prohibida (1979), Madrid, Zero/Zyx (1971-1972).

- Miserable ternura - Cabaña (1981), Madrid, Hiperión (1968-1975).

- Nabla (1982), Dos Hermanas, Sevilla, Entregas Andaluzas de Literatura, Junta de Andalucía, Consejería de Cultura.

- Arte de la fuga o Rig (1983), Granada, Pliegos Literarios, n 49, Curso de Estudios Hispánicos, Universidad (1973-1976).

- Las hojas de la vida (1984), Málaga, Torre de las palomas, $n^{\circ}$ 43, Imprenta Dardo.

- Aerolitos (1985a), Madrid, El Observatorio.

- Aerolitos y mínima (1985b), Madrid, Cuadernos Hispanoamericanos, $\mathrm{n}^{\circ}$ 418, abril, pp. 31-34.

- Poesía primera (1940-1942) (1986), Cádiz, Fundación Municipal de Cultura.

- Soneto vivo (1988), Barcelona, Anthropos (1941-1987).

- Lazareto de sueños (1988), Madrid, Cuadernos Hispanoamericanos, $\mathrm{n}^{\mathrm{o}} 462$, diciembre.

- Sin permiso de ser ángel / Angel without a permit (1988), traducción de Ginsberg, Allen y Grossman, Edith, Nueva York, Vanguardo Editions/Gas Station.

- Nuevos Aerolitos (1995), Madrid, Ediciones Libertarias. 
- Melos melancolía (1999), Montblanc, Tarragona, Ígitur; $2^{\mathrm{a}}$ ed. ampliada, 2003.

- Historia del lagarto (1999), Málaga, Poesía Circulante, Unicaja Obra Cultural. Pertenece a la obra inédita El caballero, la muerte, el diablo, escrita en 1944.

- Las patitas de la sombra (2000), en colaboración con Eduardo Chicharro, ed. a cargo de Pérez Lasheras, Antonio y Saldaña, Alfredo, Zaragoza, Mira Editores, inédito de 1944.

- Poesía en la Residencia (2004a), lectura de poemas, 24 febrero, Madrid, Residencia de estudiantes.

- Los Aerolitos (2005), Madrid, Calambur.

- La obra en marcha (2008), Málaga, $\mathrm{n}^{\circ}$ 4, dedicado a Carlos Edmundo de Ory, abril, Centro Cultural del 27.

- Novísimos aerolitos (2009), Madrid, Fundación César Manrique.

- La memoria amorosa (2011a), Madrid, Visor.

- Los aerolitos (2011b), prólogo de Félix Grande, Madrid, Calambur.

\subsubsection{Antologías particulares}

- Poesía (1945-1969) (1970), ed. de Félix Grande, Barcelona, Edhasa.

- Poesía abierta (1945-1973) (1974), ed. de Jaume Pont, Barcelona, Barral, Col. Ocnos.

- Energeia (1940-1977) (1978), ed. del autor, Barcelona, Plaza y Janés.

- Metanoia (1944-1977) (1978), ed. de Rafael de Cózar, Madrid, Cátedra.

- Ory: Antología (1983), ed. de Manuel José Ramos Ortega, Cátedra Municipal Cultura Adolfo de Castro, Cádiz.

- Metanoia (1990), ed. de Rafael de Cózar, Madrid, Cátedra.

- Antología (2001), ed. de Ricardo Cano Gaviria y Rosa Lentine, Barcelona, Nuevas Ediciones de Bolsillo.

- Música de lobo. Antología poética (1941-2001) (2003), ed. de Jaume Pont, Barcelona, Galaxia Gutenberg.

- El desenterrador de vivos (2006), 14 poemas cantados por Luis Eduardo Aute y Fernando Polavieja, D.V.D. Apuntes de un encuentro con Carlos Edmundo de Ory, documental, Álbaro Forqué, Barcelona, Galaxia Gutemberg. 
1.1.2. En otras antologías

ALBI, JOSÉ y FUSTER, JOAN, Antología del surrealismo español, Alicante, Rev. Verbo, $\mathrm{n}^{\mathrm{o}} 23-24-25$.

ÁlVAREZ, J. D.; COLINAS, ANTONIO; MARÍN ALBALATE, ANTONIO y VILLAR, MONTSE (2014), Poesía amiga y otros poemigas para Aute, Madrid, Neverland Ediciones.

ARIAS DE LA CANAL, FREDO (1997), Primera antología homosexual, los arquetipos orales de veneno, fango, punción, mutilación y devoración, México D.F., Frente de Afirmación Hispanista A.C.

ASÍS DE, M. D. (1980), Antología de poetas españoles contemporáneos, II: 1936-1970, Madrid, Narcea.

AZCOAGA, ENRIQUE (1953), Panorama de la poesía moderna española, Buenos Aires, Periplo.

BERNATÁN, M. R. y GARCÍA SÁNCHEZ, J. (1974), Poesía erótica castellana, Madrid, Júcar.

BLESA, TÚA y PALLARÉS, ELENA (1994), Sumido-25. Homenaje a Miguel Labordeta, Zaragoza, Dep. de Cultura, Gobierno de Aragón, abril.

CANO, JOSÉ LUIS (1974), Lírica española de hoy. Antología, Madrid, Cátedra.

CARO ROMERO, JOAQUÍN (1973), Antología de la poesía erótica de nuestro tiempo, París, Ruedo Ibérico.

CORBALÁn, PABLO (1974), Poesía surrealista en España, Madrid, Ediciones del Centro.

CORREA, GUSTAVO (1980), Antología de la poesía española, 1900-1980, 2 Vol., Madrid, Gredos.

DÍEZ BORQUE, JOSÉ MARÍA (1977), Poesía erótica siglos XVI-XX, Madrid, Siro.

FORTUÑO LLORENS, SANTIAGO (1992), Primera generación poética de posguerra. Estudio y Antología, Madrid, Ediciones Libertarias. (2008), Poesía de la primera generación de posguerra, Madrid, Cátedra.

GARCÍA POSADA, MIGUEL (1979), 40 años de poesía española, Madrid, CincelKapesluz.

GONZÁlEZ, JOSÉ RAMÓN (2013), Pensar por lo breve. Aforística española de entresiglos. Antología, 1980-2012, Ediciones Trea. 
GULlÓN, GERMÁN (1981), Poesía de la vanguardia español. Antología, Madrid, Taurus.

HARVEY, SALLY (1989), Spanish Poetry, 1939-1989, Special of ANTIPODAS, Auckland (Nueva Zelanda), Journal Hispanish Studies of the University of Auckland.

JIMÉNEZ MARTOS, L. (1964), Antología de la poesía española, 1963-1964, Madrid, Aguilar.

LÓPEZ ANGLADA, L. (1972), Antología de poetas gaditanos del siglo xx, Oriens, Madrid.

LÓPEZ GORGÉ, JACINTO y SALGUEIRO, FRANCISCO (1978), Poesía erótica en la España del siglo XX, Madrid, Taller de Poesía Vox.

LÓPEZ GARCÍA, J. R. (2009), Antología poética, Barcelona, Teide.

MARTÍNEZ FERNÁNDEZ, JOSÉ ENRIQUE (1989), Antología de la poesía española (1939-1975), Madrid, Castalia.

MEDINA BAÑÓN, RAQUEL (1997), Surrealismo en la poesía española de posguerra (1932-1950), Madrid, Visor.

MILÁN, EDUARDO y otros (2002), ed. y prólogo, Las ínsulas extrañas. Antología de poesía en lengua española (1950-2000), Barcelona, Nueva Galaxia Gutenberg.

MiLlÁN, RAFAEL (1956), Antología de la poesía española, 1955-1956, Madrid, Aguilar.

MOLINA, ANTONIO (1966), Poesía española contemporánea. Poesía cotidiana: 1939-1964, Barcelona, Alfaguara.

PARIENTE, ÁNGEL (1985), Antología de la poesía surrealista en lengua española, Madrid, Júcar.

PELEGRÍN, ANA (2007), Raíz de amor. Antología poética, Madrid, Alfaguara, Serie Roja.

PÉREZ ESTRADA, RAFAEL (1985), Del goce y de la dicha (Poesía erótica), 2 vol., Torremolinos, Litoral, $\mathrm{n}^{\circ}$ 151-153 y no 154-156.

RUBIO, FANNY y FALCÓ, JOSÉ LUIS (1982), Poesía española contemporánea (1939-1980), Madrid, Alhambra.

RUIZ SORIANO, FRANCISCO (2004), Poetas órficos, Madrid, Huerga y Fierro editores.

SAINZ DE ROBLES, FEDERICO CARLOS (1951), Historia y Antología de la Poesía Española, Madrid, Aguilar. 
SOLNER, G. L. (1982), Poesía española hoy, Madrid, Visor.

STRAHAN, BRADLEY (1996), Visions, 51, Internacional Poetry Periódical, Nueva York, Black Buzzard Press.

VELILLA, RICARDO (1977), Poesía española 1939-1975, Tarragona, Tarraco.

VVAA. (1955), Antología poética del amor, Madrid, Libros de vacaciones «El Grifón», Ediciones y Publicaciones S.A.

1.2. Narrativa

- El Bosque (1952), Santander, Col. Hordino, relatos.

- Kikiriquí-Mangó (1954), Madrid, Imprenta Saez, Col. El Grifón, relatos.

- Una exhibición peligrosa (1964), Madrid, Taurus, relatos.

- El alfabeto griego (1970), Barcelona, La Esquina.

- Mefhiboseth en Onou. Diario de un loco (1973), Las Palmas de Gran Canaria, Inventarios Provisionales, novela.

- Basuras (1975), Madrid, Júcar, relatos.

- Diario (1944-1956) (1975), Barcelona, Barral, Col. Ocnos ${ }^{491}$.

- Eunice Fucata (Diarios, 1976-1984) (1984), Málaga, Begar Ediciones.

- Historia del lagarto (1999), Málaga, Poesía Circulante, relato.

- Noches dantescas (2000), Cuenca, El Toro de Barro, relato.

- Cuentos sin hadas (relatos completos) (2001), 2 vol., Cádiz, Ayuntamiento, Fundación Municipal de Cultura.

- Diario (1944-2000) (2004), 3 vol., ed. de Jesús Fernández Palacios, Cádiz, Diputación, Servicio de Publicaciones.

1.2.1. Antologías y libros de relatos

BENEYTO, ANTONIO (1971), ed. de Narraciones de lo real y lo fanástico, Barcelona,

Ediciones Picazo; Barcelona, Bruguera, 1977.

(1973), ed. de Manifiesto español o una antología de narradores, Barcelona, Marte.

${ }^{491}$ Incluyo los diarios en el discurso narrativo por ser un relato pormenorizado de la cotidianeidad presente. 
CÓZAR, RAFAEL DE (1981), ed. de Narradores andaluces, Madrid, Legasa Literaria.

FRAILE, MEDARDO (1986), ed. de Cuento español de postguerra, Madrid, Cátedra; $6^{\mathrm{a}}$ ed. corregida, 1996.

GARCÍA PAVÓN, FRANCISCO (1966), ed. de Antología de cuentistas españoles contemporáneos, 1939-1966, Madrid, Gredos.

SHOEMAKER, WILLIAM H. (1959), ed. de Cuentos de la joven generación, Edited by University of Illinois. Henry Holt and Company.

\subsection{Ensayo, crítica y teoría}

- Los nuevos prehistóricos (1949), junto a Mathías Goeritz, Madrid, Galería Palma.

- Nuestro tiempo: Pintura / Nuestro tiempo: poesía (1951), junto a Darío Suro, Madrid,

Edición de los autores, Imprenta Fareso.

- Camus o el ateísmo "in extremis” (1964), Madrid, Editora Nacional, Col. Ateneo.

- Lorca (1967), traducción al frances de Jacques Deretz, París, Editions Universitaires.

- Proposiciones, Taller de poesía, Jungla música, La guitarra, La pintura hoy: un

lienzo con manchas de sangre, Elogio de Xenaquis, Todos somos extranjeros

(1968), extraídos y traducidos de la Revue Maison de la Cultura, Amiens, entre

1968 y 1971, incluidos Carlos Edmundo de Ory, Poesía (1945-1969), ed. de

Félix Grande, Barcelona, Edhasa, 1970.

- Historia del postismo (1970), incluido en Carlos Edmundo de Ory, Poesía (1945-

1969), ed. de Félix Grande, Barcelona, Edhasa, 1970.

Iconografias y estelas (ensayos 1946-1983) (1991), Cádiz, Diputación, Servicio de publicaciones. $^{492}$

492 Contiene: «Chicharro Hijo a rajatabla», Madrid, El Español, no 181, 13 abril 1946; «Música y vida de Bach en Leipzig», Madrid, Correo Literario, $n^{\circ} 5.1$ agosto 1950; «Victor Brauner, el desdichado», Madrid, Indice, $\mathrm{n}^{\circ}$ 177, octubre 1963; "Veinte años de Kafka en Francia», Madrid, Cuadernos Hispanoamericanos, n 175-176, julio-agosto 1964; «El «Nuevo Testamento» de la risa: Kafka - obras completas -», Madrid, Indice, $\mathrm{n}^{\circ}$ 194, marzo 1965; «Chicharro y el Postismo», Madrid, Cuadernos Hispanoamericanos, $n^{\circ}$ 295, enero 1975; «Por calles y tabernas con José Ignacio de Aldecoa», Aproximación crítica a Ignacio Aldecoa, Madrid, Espasa-Calpe, 1984; «Pequeño museo de cera wagneriano», Jerez de la Frontera, Fin de siglo, n 6-7, diciembre 1983; «Marinetti y el futurismo», Jerez de la Frontera, Fin de siglo, $n^{\circ}$ 6-7, diciembre 1983; "Reflexiones acerca de Bahia, cuadro de una película (O Pagador de Promesas», Madrid, Revista de cultura brasileña, ${ }^{\circ}$ 2, 1962; «Robert Desnos y Federico García Lorca», Madrid, Indice, julio 1963; "Camus y el Ateísmo in extremis», Madrid, Editora Nacional, 1964; "Las marionetas del Wayang Kulit de Java», Madrid, Indice, $n^{\circ}$ 183, abril 1964; «El surrealismo de par en par», Madrid, Indice, $n^{\circ}$ 187-188, julio-agosto 1964; «Las ratas en la poesía expresionista alemana», Madrid, Cuadernos Hispanoamericanos, $n^{\circ} 185$, mayo 1965; "Oscurantismo y honor», Madrid, Indice, n 197, junio 1965; "Nosotros decimos: mujer», Madrid, La Estafeta Literaria, n 388, enero 1968; «Erotismo y civilización», Madrid, Cuadernos 
- Sobre el Postismo hoy (2000), incluido en Eduardo Chicharro y Carlos Edmundo de Ory, Las patitas de la sombra, ed. de Antonio Pérez Lasheras y Alfredo Saldaña, Zaragoza, Mira Editores.

\subsubsection{Prólogos, introducciones y epílogos}

- Prólogo a Gregorio Prieto (1948), Toro-mujer, Barcelona, Ed. Cobalto, Col. Entretén.

- Prólogo Eduardo Chicharro (1966), Algunos poemas, Cuenca, El Toro de Barro.

- Prólogo al número dedicado a Eduardo Chicharro, selección de textos y notas de Gonzalo Armero y Mario Hernández, Madrid, Trece de Nieve, $\mathrm{n}^{\circ}$ 2, invierno 1971-1972.

- «Los cuatro jinetes» (1976), introducción a la antología de los autores José Ramón Ripoll, Jesús Fernández Palacios, Rafael de Cózar y Antonio Hernández, Nueva poesía 1: Cádiz, Bilbao, Zero-Zyx.

- «Sueño de la poesía» (1978a), introducción a Energeia (1940-1977), obra cit.

«No leer, peligro de vida» (1978b), prólogo a Algunos poetas de Barcelona, Barcelona, La Cloaca.

- «Pensum» (1981), prólogo a Eelvina Astrada, Mujer arrebatada, Barcelona, Ámbito Literario (edición bilingüe Death of the run, South Carolina, Spanish Literatura Publications Company York, 1987).

- «Prólogo a un poema sin título» (1989a), prólogo a Manuel San Martín, La luna en babia, Cuenca, El Toro de Barro.

- «Prefacio esdrújulo» (1989b), prólogo a Inma Marcos, Málaga, Bailando en la oscuridad.

- «Demonio Petisme» (1996), prólogo a Ángel Petisme, Constelaciones al abrir la nevera, Madrid, Hiperión.

- «El amigo de la tristeza» (1998), prólogo a Cirlot, Juan-Eduardo Cirlot, El libro de Cartago, ed. de Victoria Cirlot, Taragona, Igitur.

- Prólogo a Crespo, Ángel (1998), Poema en prosa (1965-1994), Taragona, Igitur.

- Prólogo, junto a José Hierro, a Piqueras, Juan Vicente (1999), La latitud de los caballos, Madrid, Hiperión.

- Prólogo a Piqueras, Juan Vicente (2004), La edad del agua, Lucena, Ayuntamiento.

Hispanoamericanos, $\mathrm{n}^{\circ}$ 221, mayo 1968 y «Salvador Rueda y García Lorca», Madrid, Cuadernos Hispanoamericanos, n² 255, marzo 1971. 
- «iVolemos juntos montando escoba!» (2005), prólogo a Luis Eduardo Aute, Animalhada, Madrid, Siruela.

- «Luz Lúbrica» (2005), epílogo a Luis Eduardo Aute, Animalhada, Madrid, Siruela.

- Prólogo a Carreño, Alfonso (2009), 101 poemas, una antología, Murcia, Tres Fronteras.

- «Honra tu herencia herética, poeta» (2012), prólogo a Jesús Fernández Palacios, Poemías, Sevilla, Ediciones En Huida.

2. Sobre el Postismo

2.1. Revistas postistas

- Postismo, no 1 y único, Madrid, enero de 1945.

- La Cerbatana, no 1 y único, Madrid, abril de 1945.

- Postismo y La Cerbatana, presentación de Rafael de Cózar, ed. facsímil, Sevilla, Renacimiento, 2011.

\subsection{Manifiestos}

CHICHARRO, EDUARDO (1945), Primer Maniesto de Postismo, Rev. Postismo, Madrid, enero de 1945, pp. 4-5, 12-13.

Tambien se encuentra en:

- GRANDE, FÉLIX (1970), ed. de Carlos Edmundo de Ory, Poesía 1945-1969, Barcelona, Edhasa, pp. 279-287.

- CHICHARRO, EDUARDO (1974), Música celestial y otros poemas, Madrid, Seminarios y Ediciones, Trece de Nieve, pp. 273-283.

- Rev. Poesía, separata, no 2, Madrid, agosto-septiembre 1978.

- PONT, JAUME (1987), El Postismo. Un movimiento estético-literario de vanguardia, Barcelona, Edicions del Mall, pp. 247-260.

- HERRERO, RAUL (1998), Antología de poesía postista, Zaragoza, Biblioteca Golpe de Dados, pp. 365-384. 
CHICARRO, EDUARDO; ORY DE, CARLOS EDMUNDO y SERNESI, SILVANO (1946) Segundo Manifiesto del Postismo, Madrid, Rev. La Estafeta Literaria, $\mathrm{n}^{\mathrm{o}}$ extra.

También se encuentra en:

- GRANDE, FÉLIX (1970), ed. Carlos Edmundo de Ory, Poesía 1945-1969, obra cit., pp. 288-299.

· CHICHARRO, EDUARDO (1974), Música Celestial y otros poemas, obra cit., pp. 275-289.

· PONT, JAUME (1987), El Postismo. Un movimiento estético-literario de vanguardia, obra cit., pp. 261-279.

· HERRERO, RAUL (1998), Antología de poesía postista, obra cit., pp. 385413.

CHICHARRO, EDUARDO (1947), Tercer Manifiesto del Postismo, Madrid, El Minuto, suplemento del periódico La Hora, nº 1 .

También se encuentra en:

- GRANDE, FÉLIX (1970), ed de Carlos Edmundo de Ory, Poesía 1945-1969, obra cit., pp. 300-306.

· CHICHARRO, EDUARDO (1974), Música Celestial y otros poemas, obra cit., pp. 301-309.

- PONT, JAUME (1987), El Postismo. Un movimiento estético-literario de vanguardia, obra cit., pp. 280-29.

- HERRERO, RAUL (1998), Antología de poesía postista, obra cit., pp. 415431.

CHICHARRO, EDUARDO (hacia 1947), Cuarto Manifiesto del Postismo.

Se encuentra en:

· CHICHARRO, EDUARDO (1974), Música Celestial y otros poemas, obra cit., pp. 311-312.

- PONT, JAUME (1987), El Postismo. Un movimiento estético-literario de vanguardia, obra cit, pp. 291-293.

- HERRERO, RAUL (1998), Antología de poesía postista, obra cit., pp. 433437. 
Todos los manifiestos se encuentran agrupados en:

- CHICHARRO, EDUARDO; ORY DE, CARLOS EDMUNDO y SERNESI, SILVANO (2008), La mano en la espalda. Cuatro manifiestos postistas, México D.F., Colección sin nombre.

\subsection{Crítica}

ALCAIDE SÁNCHEZ, JUAN (1945a), «Al postrer ismo literario», Valdepeñas, Balbuena, $\mathrm{n}^{\mathrm{o}}$ 4, junio.

(1945b) «Carlos Edmundo de Ory. Versos de pronto», Valdepeñas, Balbuena, $\mathrm{n}^{\circ}$ 5 , otoño.

ALDECOA, IGNACIO (1946), «Carta de un estudiante a otro estudiante sobre materia postista», Madrid, El Español, nº 188, junio.

CARRIEDO. GABINO-ALEJANDRO (1949), «Postismo, postistas y filopostistas», Ciudad Real, Lanza, 27 de octubre.

CASANOVA DE AYALA, FÉLIX (1964), «Anecdotario y teoría del Postismo», Palma de Mallorca, Papeles de Son Armadans, $\mathrm{n}^{\circ}$ 106, noviembre.

(1989), «Surrealismo-Postismo: 1935-1945», Madrid, Insula, no 511, junio.

CASANOVA DE AYALA, FÉLIX y CARRIEDO, GABINO-ALEJANDRO (1949),

En serio sobre el Postismo, Madrid, Radio S.E.U, hora: 15'50', 9 de agosto.

CIRLOT, JUAN-EDUARDO (1949), «Postismo», en Diccionario de los ismos, Barcelona, Argos.

CRESPO, ÁNGEL (1946), «Alcalde y el postismo», Ciudad Real, Lanza, 6 de febrero. (1949), «Postismo: animal de fondo con lo altivo intacto», Ciudad Real, Lanza, 9 de septiembre.

CHICHARRO, EDUARDO (1945), «Carlos Edmundo a machamartillo», Madrid, El Español, 10 de noviembre.

CHICHARRO, EDUARDO y SERNESI, SILVANO (1946), «¿Dónde está la estética? Historia de treinta años», Madrid, El Español, nº 194.

(1945 o1946), «El arte antiguo y el arte moderno en Italia (logomaquia)», en Jaume Pont, El Postismo. Un movimiento estético-literario de vanguardia, obra cit, pp.459-468. 
CHICHARRO, EDUARDO y ORY, CARLOS EDMUNDO DE (1946), «El ciempiés de la poesía (Bucólico anatomaquia bosquejo de un boscaje)», Madrid, $L a$ Estafeta Literaria, $\mathrm{n}^{\circ} 40$.

D’ORS, EUGENIO (1945), «Novísimo Glosario», Madrid,Arriba, 16 de abril.

FUSTER, JOAN (1948), «El surrealismo y lo demás», Alicante, Verbo, julio-agosto.

GONZÁLEZ RUANO, CÉSAR (1945), «Los postistas», Barcelona, Crítica, nº 6, abril.

NIEVA, FRANCISCO (1950), «El Postismo», Lima, Centauro, Revista de Artes y Letras, $\mathrm{n}^{\mathrm{o}}$ 9-11, octubre-diciembre.

(1984), «El Postismo una vez más», Madrid, $A B C, 22$ de julio.

ORY, CARLOS EDMUNDO DE (1946), «Chicharro Hijo a rajatabla», Madrid, El Español, 13 de abril.

(1948), «Valor y lógica del postismo», Madrid, La Hora, n 82, 7 de mayo.

(1949), «Geografía del postismo», Ciudad Real, Lanza, 8 de septiembre.

(1952), «Surrealismo ibero y apertura de polémica», Madrid, Correo Literario, $\mathrm{n}^{\circ}$ 50, 15 de junio, p. 5.

(1975), «Chicharro y el Postismo», Madrid, Cuadernos Hispanoamericanos, ${ }^{\circ}$ 295 , enero.

POL GIRBAL, JAIME (1958), «El postismo: historia de mil duros», Barcelona, Revista de Actualidades, Artes y Letras, $\mathrm{n}^{\circ} 310$, marzo.

SERNESI, SILVANO (1945), «El futurismo visto desde el postismo», Madrid, El Español, $\mathrm{n}^{\circ}$ 119, 3 de febrero.

TRENAS, JULIO («EL SILENCIOSO») (1944a), «Un poeta maldito... a medias», Madrid, La Estafeta Literaria, $n^{\circ} 13,25$ de septiembre.

(1944b), «Psicosis de celebridad», Madrid, La Estafeta Literaria, n 18,15 de diciembre.

(1945a), «El Postismo», Madrid, La Estafeta Literaria, $n^{\circ}$ 18, 1 de enero.

(1945b), «Más post-ismo», Madrid, La Estafeta Literaria, n 20, 30 de enero.

(1945c), «Ni son todos los que están...», Madrid, La Estafeta Literaria, no 30, 10 de julio.

(1945e), «A ponernos serios, Carlos Edmundo», Madrid, La Estafeta Literaria, ${ }^{\circ}$ 39, 30 de diciembre.

VARELA, JOSÉ LUIS (1945), «Tornton Wilder en Madrid o un diálogo en Recoletos», Madrid, El Español, 7 de abril. 
2.4. Obra literaria

Se trata de la obra postista sensu stricto, que puede enmarcarse dentro de las coordenadas literarias trazadas por el Postismo.

\subsubsection{Discurso poético}

ALCAIDE SÁNCHEZ, JUAN (1993), Poesías completas, Ciudad Real, Biblioteca de Autores y Temas Manchegos, Diputación.

ALDECOA, IGNACIO (1947), Todavía la vida, Madrid, Gredos.

(1949), Libro de las algas, Madrid, Gredos; Pamplona, Diputación Floral de Navarra, 1981.

ARRABAL, FERNANDO (1998), Mis humildes paraísos. Sonetos pánicos, Zaragoza, El último Parnaso.

CARRIEDO, GABINO-ALEJANDRO (1948), La piña sespera, en Nuevo compuesto descompuesto viejo (1948-1979), Madrid, Hiperión, 1980; también en Poesía, Palencia, Diputación, 2006.

(1949), La flor de humo, en Nuevo compuesto descompuesto viejo, obra cit.; también en Poesía, obra cit.

(1951), Los animales vivos, Cuenca, El Toro de Barro, 1966; también en Nuevo compuesto descompuesto viejo, obra cit., y en Poesía, obra cit.

(1952), Del mal, el menos, en Nuevo compuesto descompuesto viejo, obra cit.; también en Poesía, obra cit.

CASANOVA DE AYALA, FÉLIX (1946-1948a), El paisaje contiguo, en Conquista del sosiego, Santa Cruz de Tenerife, Goya, 1959.

(1946-1948b), La vieja casa, Guadalajara, col. Doña Endrina, 1953; también en Conquista del sosiego, obra cit.

CIRLOT, JUAN-EDUARDO (1945), En la llama, Barcelona, Argos. (1946), Donde los lirios crecen, Barcelona, Helikon. (1946), Susan Lenox, Barcelona, Helikon.

(1949), Elegía sumeria, Barcelona, Librería Clann; también en Obra poética, ed. de Clara Janés, Madrid, Cátedra, 1981.

CRESPO, ÁNGEL (1945-1946), Loco de atar, en Primera antología de mis versos, Ciudad Real, Ed. Jabalón, 1949. 
(1945-1948), Música celestial, en Primera antología de mis versos, obra cit.

CHICHARRO, EDUARDO (1971-1972), selección de trextos de Gonzalo Armero y Mario Hernández, Prólogo de Carlos Edmundo de Ory y epílogo de Francisco Nieva. Número dedicado a Eduardo Chicharro, Trece de nieve, $\mathrm{n}^{\mathrm{o}}$ 2, Madrid, invierno1971-1972.

(1945-1947), La plurilingüe lengua, en Música celestial y otros poemas, obra cit. (1947-1958), Música celestial, en Música celestial y otros poemas, obra cit.

(1940-1950), Tetralogía, en Música celestial y otros poemas, obra cit.

(1950-1960), Cartas de noche, en Música celestial y otros poemas, obra cit.

(1965), Algunos poemas, selección y prólogo de Ángel Crespo, Cuenca, El Toro de Barro.

(2002), 13 sonetos (1945-1947), ed. Jaume Pont, Cuenca, Cuadernos del Mediterráneo, $\mathrm{n}^{\mathrm{0}}$ 21, El Toro de Barro, marzo. Dos sonetos inéditos.

CHICHARRO, EDUARDO y ORY DE, CARLOS EDMUNDO (1944), Las patitas de la sombra, obra cit.

FUERTES, GLORIA (1954a), Aconsejo beber hilo, Madrid, Arquero; también en Obras incompletas, Madrid, Cátedra, 1984.

(1954b), Antología y poemas del suburbio, Caracas, Lírica Hispana.

GARCÉS, JESÚS JUAN (1945), Poemas primitivos para ángeles, Madrid, La Cerbatana, $\mathrm{n}^{\circ} 1$, publicación cit.

ORY, CARLOS EDMUNDO DE (1944), Los poemas de 1944, obra cit.

(1945), Versos de Pronto, obra cit.

(1945-1948), Doblo Hablo, introducción de Eduardo Chicharro, en Energeia, obra cit. Contiene Cinco poemas edmundianos (también aparecen en Poesía (1945-1969), ed. de Félix Grande, obra cit. y en Música de lobo. Antología poética (1941-2001), ed. de Jaume Pont, obra cit.) y Laocoonte y la luna, romances postistas (que aparecen en las revistas postistas y en Poesía (19451969), ed. de Félix Grande, obra cit.).

(1969), Poemas, obra cit. Contiene obras fechadas entre 1946 y 1960.

2.4.1.1. Panorámicas y antologías.

ALBI, JOSÉ y FUSTER, JOAN (1952), Antología del surrealismo español, Alicante, Verbo, núms. 23-24-25. 
CHICHARRO, EDUARDO; ORY, CARLOS EDMUNDO DE y SERNESI, SILVANO (1945), Liricoteca, Madrid, Postismo, no 1, pp. 8 y 9, publicación cit. Se trata de la primera antología de poesía postista.

FORTUÑO LLORENS, SANTIAGO (1992), Primera generación poética de posguerra. Estudio y Antología, Madrid, Ediciones Libertarias. (2008), Poesía de la primera generación de posguerra, Madrid, Cátedra.

HERRERO, RAUL («CLAUDIO») (1998), Antología de poesía Postista, Zaragoza, Bilioteca Golpe de Dados.

MARTÍNEZ FERNÁNDEZ, JOSÉ ENRIQUE (1989), Antología de la poesía española (1939-1975), Madrid, Castalia.

RUBIO, FANNY y FALCÓ, JOSÉ LUIS (1982), Poesía española contemporánea (1939-1980), Madrid, Alhambra.

2.4.2. Narrativa.

BORRÁS, TOMAS (1945), Botellas viejas y mujeres viejas, cuento, Madrid, Postismo, $\mathrm{n}^{\mathrm{o}} 1$, publicación cit.

CHICHARRO, EDUARDO y SERNESI, SILVANO (1945), Un hombre poco común o el hombre de los pañuelos, cuento, Madrid, Postismo, $\mathrm{n}^{\circ}$ 1, publicación cit.

CHICHARRO, EDUARDO; ORY, CARLOS EDMUNDO DE y SERNESI, SILVANO (1945), Tres cuentos cortos, microrrelato, Madrid, La Cerbatana, publicación cit.

ORY, CARLOS EDMUNDO DE (1945), La mujer de los tres trapos, cuento, Madrid, La Cerbatana, $\mathrm{n}^{\mathrm{o}}$ 1, publicación cit.

(1973), Mephiboseth en Onou. Diario de un loco, novela empezada en 1945, obra cit. El texto «Venus supernegra» apareció en Postismo, $\mathrm{n}^{\circ}$ 1, publicación cit.

SERNESI, SILVANO (1945), Casi casi nos casó Voronof, cuento, Madrid, Postismo, $\mathrm{n}^{\mathrm{o}} 1$, publicación cit.

2.4.2.1. Novela inédita

CHICHARRO, EDUARDO:

- Las tres esposas turcas de Patamala.

- Las pluricelestiales. 
- Ícaro caído en el jardín de Astaté.

- Los jeroglificos del caballo o El caballero, la muerte y el diablo. ${ }^{493}$

ORY, CARLOS EDMUNDO DE:

- El caballero, la muerte y el diablo.

- La vida sin bondad. ${ }^{494}$

2.4.3. Obras teatrales.

CHICHARRO, EDUARDO (1930), Madrid, Abededonys, Rev. Fantasía.

CHICHARRO, EDUARDO; ORY, CARLOS EDMUNDO DE y SERNESI, SILVANO, $\left(1954^{\mathrm{a}}\right)$, La lámpara, comedia inédita. ${ }^{495}$

(1945b), Historia natural, comedia breve en dos actos, rev. Postismo, publicación cit.

El teatro ensayado por los postistas supone el germen del teatro pánico de Fernado Arrabal ${ }^{496}$ y del teatro furioso de Francisco Nieva ${ }^{497}$. Estas propuestas escénicas poseen tantas convergencias con la estética del movimiento que pueden considerarse parte integrante de la dramática postista:

ARRABAL, FERNANDO (1952), Los soldados, primer título; (1957) Pic-Nic, versión definitiva; en Ángel Berenguer ed., Pic-nic, El Triciclo, El Laberinto, Madrid, Cátedra, 1977.

${ }^{493}$ Pont (1987: 22).
${ }^{494}$ Pont (1998: 426).
${ }^{495}$ Pont (1998: 426).

496 Ruiz Ramón, Francisco (1970); Berenguer, Ángel (1977). Ruiz Ramón, aunque considera que el teatro arrabaliano surge inevitablemente del rizoma literario y cultural español, silencia las conexiones de este teatro renovador con el Postismo (pp. 435-436). De otro lado, sí que instala perfectamente esta propuesta en la vanguardia teatral. Berenguer, en cambio, señala la influencia de la transgresión del discurso realista y la práctica de la provocación que supuso el Postismo como territorio central en el que se edifica el teatro de Fernando Arrabal ( $p$. 44). Para este autor Arrabal comparte con el Postismo el interés por la vanguardia, por la literatura extranjera y por el humor. Tanto los autores postistas como él sufrieron la marginalidad y la exclusión del aparato cultural del sistema franquista (pp.49-50).

${ }^{497}$ Ruiz Ramón, Francisco (1970: 569-570). En el caso del teatro de Nieva, este autor sí que lo relaciona con el Postismo como movimiento germinal de la estética teatral de vanguardia: «En dicho movimiento se adelantaban ciertos fenómenos tan conocidos hoy, como el fenómeno lonesco, el realismo fantástico o el pop art.». 
(1953), Los hombres del triciclo; titulada finalmente El triciclo; en Ángel Berenguer (1977).

(1955), Fando y Lis.

(1956), Ceremonia para un negro asesinado, en Primer Acto, $\mathrm{n}^{\circ} 74$.

(1956), El laberinto; en Nuevo Mundo, $\mathrm{n}^{\mathrm{o}}$ 15, septiembre 67 y en Ángel Berenguer (1977).

(1956), El cementerio de automóviles.

(1957), Oración, en Primer Acto, no 39.

NIEVA, FRANCISCO (1949-1968), Malditas sean Coronada y sus hijas; Malditas sean Coronada y sus hijas, Delirio del amor hostil, Ed. de Antonio González, Madrid, Cátedra, 1980.

(1952), El rayo colgado.

(1953), El combate de Opalos y Tasia.

(1953), Tórtola, crepúsculo y ...telón, en Escélicer, nº 723, 1973.

(1955), La Pascua negra.

(1961), El fandango asombroso.

(1961), El Aquelarre de Pitiflauti.

(1962), Pelo de tormenta; en Primer Acto, no 153, 1973.

(1966), Es bueno no tener cabeza; en Primer Acto, nº 132, 1971.

(1971), La carroza de plomo candente.

(1973), Coronada y el toro; Madrid, Pipirijaina, 1974. 


\section{BIBLIOGRAFÍA SECUNDARIA}

ACEVEDO, PABLO (2015), Ironía, humor y juego en los discursos estéticos de la Modernidad: una mirada a través del Postismo, Tesis Doctoral, dirigida por Francisca Rubio Gámez, Madrid, Universidad Complutense.

ADES, DAWN (1974), Dada and Surrealism, Londres, Thames and Hudson Ltd.; traducción de Marcelo Covián, El dadá y el surrealismo, Barcelona, Labor, 1975.

ALBI, JOSÉ y FUSTER, JOAN (1952), Antología del surrealismo español, Alicante, rev. Verbo, n'. 23-24-25.

ALARCOS LLORACH, EMILIO (1956), La poesía de Blas de Otero, Oviedo, Universidad de Oviedo; 2a ed. Salamanca, Anaya, 1966. (1976), Ensayos y estudios literarios, Madrid, Júcar.

ALONSO, DÁMASO (1952), Poetas españoles contemporáneos, Madrid, Gredos.

AMORÓS, AMPARO (1982), «La retórica del silencio», Oviedo, Los Cuadernos del Norte, $\mathrm{n}^{\mathrm{o}} 16$, noviembre-diciembre 1982.

(1988), «Dos tendencias características de la poesía contemporánea: la crítica del lenguaje y la poética del silencio», en VVAA, Mis tradiciones (Poéticas y poetas andaluces), III Encuentro de poetas andaluces, Córdoba, Publicaciones del Ayuntamiento.

ARTAUD, ANTONIN (1938), Le tëâtre et son double, París, Gallimard; traducción de Enrique Alonso y Francisco Abelenda, El teatro y su doble, Barcelona, Edhasa, 2011

AYUSO, CÉSAR AUGUSTO (1995), El realismo mágico (un estilo poético en los años 50), Carboneras de Guadazaón, Cuenca, El Toro de Barro.

AZNAR SOLER, MANUEL (1980), ed., Juan Gil-Albert, Mi voz comprometida (19361939), Barcelona, Laia.

BATAILLE, GEORGES (1957), L'erotisme, París, Les Editions de Minuit; traducción de Antoni Vicens, El erotismo, Barcelona, Tusquets, 1979.

BATLlÓ, JOSÉ (1968), Antología de la nueva poesía española, Madrid, Ciencia Nueva. 
BARNATAN, MARCOS RICARDO (1970), Antología de la Beat Generation, Barcelona, Plaza y Janés.

BARTHES, ROLAND (1982), L'obvie et l'obtus. Essais critiques III, París, Editions du Seuil; traducción de C. Fernández Medrano, Lo obvio y lo obtuso. Imágenes, gestos, voces, Barcelona, Paidós, 1986.

BAUDRILLARD, JEAN y otros (1983), The anti-aesthetic: essays on postmodern culture, ed. de Hal Foster, New-York, Bay Press, 1983; traducción de Jordi Fibla, La posmodernidad, Barcelona, Kairós, 1985.

BELTRÁN, JOSÉ-CARLOS (1999), ed., Poesía Visual Española ante el nuevo milenio, Vitoria-Gasteiz, Arteragin.

BENJAMIN, WALTER (1969), «El surrealismo. La última instantánea de la inteligencia europea», traducción de Jesús Aguirre, Iluminaciones, Vol. I, 1980, Madrid, Taurus.

BERENGUER, ÁNGEL (1977), ed. de Fernando Arrabal, Pic-nic, El Triciclo, El laberinto, Madrid, Cátedra.

BLASCO PASCUAL, FRANCISCO JAVIER (1982), Poética de Juan Ramón Jiménez, desarrollo, contexto y sistema, Salamanca, Ediciones Universidad de Salamanca. (1988), ed., Juan Ramón Jiménez, Antología poética, Madrid, Cátedra.

BLESA, TÚA (2001), «Últimos coletazos del pez soluble», VVAA, Surrealismo y literatura en España, ed. de Jaume Pont, Lleida, Edicions de la Universitat de Lleida, pp. 323-338.

BODINI, VITTORIO (1963), I poeti surrealista spagnoli, Turín, Giulio Einaudi editore, S.p.A.; traducción de Carlos Manzano, Poetas surrealistas españoles, Barcelona, Tusquets, 1982.

BORDONS, GLORIA (1988), Introducció a la poesía de Joan Brossa, Barcelona, Edicions 62.

BOUSOÑO, CÁRLOS (1952), Teoría de la expresión poética, Madrid, Gredos; $6^{\mathrm{a}}$ ed. 1976.

(1956), La poesía de Vicente Aleixandre, Madrid, Ed. Insula; 4ª ed., Madrid, Gredos, 1977.

(1979a), Superrealismo poético y simbolización, Madrid, Gredos.

(1979b), «La poesía de Guillermo Carnero», prólogo, Guillermo Carnero, Ensayo de una teoría de la visión, Pamplona, Hiperión. 
(1984), Poesía postcontemporánea. Cuatro estudios y una introducción. Gijón, Júcar.

BRETON, ANDRÉ (1962), Manifestes du surréalisme, París, Jean-Jacques Pauvert Éditeur; traducción de Andrés Bosch, Manifiestos del surrealismo, Madrid, Visor, 2009.

(1964), Nadja, París, Gallimard.

(1966), Anthologie de l’humor noir, París, Jean-Jacques Éditeur; traducción de Joaquín Jordá, Antología del humor negro, Barcelona, Anagrama, 1991.

BRIHUEGA, JAIME (1979), Manifiestos, proclamas, panfletos y textos doctrinales (Las vanguardias artísticas en España: 1910-1931), Madrid, Cátedra.

CABALLERO BONALD, JOSÉ MANUEL (2004), «Construcción de destrucciones», Cádiz, RevistaAtlánticadepoesía, nº 27, pp. 30-31.

(2011), «De las desobediencias de Ory», Cádiz, Caleta, segunda época, nº 16, pp. 29-31.

(2015), «Carlos Edmundo de Ory, un arquetipo», Jerez de la Frontera, Campo de Agramante, $\mathrm{n}^{\mathrm{o}}$ 23, otoño-invierno, pp. 9-13.

CANO, JOSÉ LUIS (1957), Antología de la nueva poesía española, Madrid, Gredos; $2^{\mathrm{a}}$ ed., 1966.

(1974), Lírica española de hoy. Antología, Madrid, Cátedra.

(1977), Poesía española contemporánea. Las generaciones de posguerra, Madrid, Guadarrama.

(1979), El tema de España en la poesía española contemporánea, Madrid, Taurus.

CANO BALLESTA, JUAN (1971), La poesía de Miguel Hernández, Madrid, Gredos. (1972), La poesía española entre pureza y revolución (1930-1936), Madrid, Gredos.

(1983), ed., Miguel Hernández, El hombre y su poesía, Madrid, Cátedra.

CAÑAS, DIONISIO (1986), ed., José Hierro, El libro de las alucinaciones, Madrid, Cátedra.

CARNERO, GUILlERMO (1976), El Grupo Cántico de Córdoba. Estudio y Antología. Madrid, Editora Nacional.

(1978), «Poesía de postguerra en lengua castellana», Madrid, Poesía, nº 2, agosto. (1989), Las armas abisinias, Barcelona, Anthropos. 
CASANOVA DE AYALA, FÉLIX (1964), «Anecdotario y teoría del Postismo», Palma de Mallorca, Papeles de Son Armadans, $n^{\circ} 103$, noviembre.

CASTELLET, JOSEP MARÍA (1960), Veinte años de poesía española (1939-1959), Barcelona, Seix Barral; $2^{\mathrm{a}}$ ed. aumentada, 1962.

(1965), Un cuarto de siglo de poesía española, Barcelona, Seix Barral. (1970), Nueve novísimos poetas españoles, Barcelona, Seix Barral.

CERNUDA, LUIS (1957), Estudios sobre poesía española contemporánea, Madrid, Guadarrama.

CHICHARRO, EDUARDO (1945), «Carlos Edmundo a machamartillo», Madrid, El Español, 10 de noviembre de 1945. En Pont, El Postismo. Un movimiento estético-literario de vanguardia, Barcelona, Llibres del mall, 1987; también en VVAA, Carlos Edmundo de Ory. Textos críticos sobre su obra, ed. de Jaume Pont y Jesús Fernández Palacios, Cádiz, Servicio de Publicaciones de la Diputación, pp. 17-36.

CLOTAS, SALVADOR y GIMFERRER, PERE (1971), 30 años de literatura en España, Barcelona, Kairós.

COLLAZOS, ÓSCAR (1970), Los vanguardismos en la América Latina; ed. de 1977, Barcelona, Península.

CÓZAR, RAFAEL DE (1975), Teoría y praxis literaria de un movomiento estéticoliterario de postguerra, Tesis de Licenciatura, Universidad de Sevilla. (1977), Prólogo a Nueva Poesía 2: Sevilla, Bilbao, Zero-Zyx. (1978), ed., Carlos Edmundo de Ory, Metanoia (1944-1977),Madrid, Cátedra; $2^{\circ}$ ed. aumentada, Carlos Edmundo de Ory, Metanoia, Madrid, Cátedra, 1990. (1986), «Heterodoxos españoles, la poesía experimental», VVAA., DadaSurrealismo: precursores, marginales y heterodoxos, de. a cargo de Lola Bermúdez, Inmaculada Díaz Nanrbona, Claudine Lécrivain y Estrella de la Torre Giménez, Cádiz, Universidad, Servicio de Publicaciones, pp. 102-110. (1991), Poesía e imagen. Formas difíciles de Ingenio Literario, Sevilla, Ediciones El Carro de la Nieve. Tesis Doctoral, Universidad de Sevilla. (2001a), «Carlos Edmundo de Ory: evolución hacia el interior», VVAA, Carlos Edmundo de Ory. Textos Críticos sobre su obra, ed. de Jaume Pont y Jesús Fernández Palacios, Cádiz, Servicio de Publicaciones de la Diputación, 2001, pp. 137-149. 
(2001b), «Postismo y surrealismo: la vanguardia como distinta tradición», VVAA., Surrealismo y Literatura en España, ed. de Jaume Pont, Lleida, Edicions de la Universitat, pp. 231-243.

(2005), «El Postismo: Revistas Postismo y La Cerbatana», VVAA., Revistas literarias españolas del siglo XX (1919-1975), al cuidado de Fanny Rubio, Vol. II, Madrid, Ollero y Ramos, pp. 109-118.

(2011), «Carlos Edmundo de Ory y la vanguardia», Cádiz, Caleta, segunda época, $n^{\circ} 16$, octubre, pp. 193-196.

(2014a), «Aerolitos», Rev. Madreselva, 21 de marzo.

(2014b), «Palabra y música: Carlos Edmundo de Ory como vehículo entre la tradición y el OULIPO», Coordenadas, Cádiz, Fundación Carlos Edmundo de Ory, p. 15-46.

CRESPO, ÁNGEL (1946), «Alcalde y el Postismo», Ciudad Real, Lanza, 6 de febrero, p. 3.

CUNELL, HOWARD y otros (2010), traducción de Antonio-Prometeo Moya, Kerouac en la carretera. Sobre el rollo mecanografiado y la generación beat, Barcelona, Anagrama. También en KEROUAC, JACK (2007), On the road. The original Scroll, Nueva York, Penguin.

DALÍ, SALVADOR (1963), Le myhe tragique de «l'Angélus» de Millet, Paris, Société Nouvelle des Éditions Jean-Jacques Pauvert; traducción de Joan Vinyoli, El mito trágico de «El Ángelus» de Millet, Barcelona, Tusquets, 2002.

DELEUZE, GILLES y GUATTARI, FÉLIX (1972), L'Anti-Oedipe. Capitalisme et schizophénie, París, Les Éditions de Minuit; traducción de Francisco Monge, El Anti Edipo. Capitalismo y esquizofrenia, Barcelona, 1985, Paidós.

(1980), Mille plateaux (capitalismo et schizophénie), París, Les Éditions de Minuit; traducción de José Vázquez Pérez, Mil mesetas. Capitalismo y esquizofrenia, Valencia, Pre-Textos, 1988.

DESHIMARU, TAISEN (1974), La practique su Zen, París, Éditions Seghers; traducción de Nieves Samblancat y Pere Rovira, La práctica del Zen, Barcelona, RBA, 2002.

(1979), The Voice of the Valley. Zen Teachings, Nueva York, The Bobbs-Merrill Company; traducción de David Rosenbaum, La voz del valle. Enseñanzas Zen, Barcelona, Paidós, 1985. 
(1983), L’Anneau de la Voie, Paris, Evelyn de Smedt; traducción de Sandra Garzonio, El anillo de la vía, Barcelona, Editorial Ibis, 1991.

DESHIMARU, TAISEN y IKEMI, YUJIRO (1985), Zen et self-control, París, Éditions Retz; traducción de Ramón Badía Vidal, Zen y autocontrol, Barcelona, Kairós, 1990.

DÍAZ-PLAJA, GUILLERMO (1979), Tesoro breve de las letras hispánicas. Serie Ultramar III. Literatura hispanoamericana: pensamiento, realismo $y$ modernismo. Madrid, Magisterio Español.

DIEGO, GERARDO (1947), «La última poesía española», Madrid, Arbor, nº 24.

DUVAL, JEAN-FRANÇOIS (2012), Kerouac et la Beat Generation, París, Presses Universitaires de France; traducción de Francesc Rovira, Kerouac y la generación beat, Barcelona, Anagrama, 2013.

ELIADE, MIRCEA (1951), Le mythe de l'eternel retour. Archétipes et répétitions, París, Gallimard; traducción de Ricardo Anaya, El mito del eterno retorno, Madrid, Alianza Editorial, 1972.

(1956), Forgeons et alchimistes, París, Flamarion; traducción de E. T., Herreros y alquimistas, Madrid, Alianza editorial, 1974.

(1962), Patánjali et le yoga, París, Editions du Seuil; traducción de Juan Valmard, Patanjali y el yoga, Barcelona, Paidós.

(1969), The Quest, Chicago, University de Chicago; traducción de Alfonso Colodrón, La búsqueda, Barcelona, Kairós, 1999.

ELIADE, MIRCEA y COULIANO, IOAN P. (1991), Dicctionaire des Religions, París, Plon; traducción de Isidro Arias Pérez, Diccionario de las religiones, Barcelona, Paidós, 1994.

FANÉS, FÈLIX y otros (1990), Dali escriptor, Barcelona, Fundació Caixa de Pensions. FERNÁNDEZ PALACIOS, JESÚS (1984), «Soy un rey sentado en un retrete», entrevista a Carlos Edmundo de Ory, Oviedo, Los Cuadernos del Norte, ${ }^{\circ}$ 23, enero-febrero 1984, pp.119-124.

(1986), «Carlos Edmundo de Ory y el A.P.O.»; VVAA, Dadá-Surrealismo: precursores, marginados y heterodoxos, Cádiz, Universidad, Servicio de Publicaciones, pp. 99-101; también en VVAA, Carlos Edmundo de Ory. Textos críticos sobre su obra, ed. de Jesús Fernández Palacios y Jaume Pont, Cádiz, Servicio de Publicaciones de la Diputación, 2001, pp. 189-198. 
(2004a), ed. y prólogo, Carlos Edmundo de Ory, Diario 1944-2000, 3 vol., Cádiz, Servicio de Publicaciones de la Diputación.

(2004b), «Ory, punto y aparte», Cádiz, RevistaAtlánticadepoesía, no 27, pp. 3-4.

(2011a), Prólogo, Carlos Edmundo de Ory, La memoria amorosa, Madrid, Visor.

(2011b), «Carlos Edmundo de Ory, calígrafo de la vida», Cádiz, Caleta, segunda época, $n^{\circ} 16$, octubre, pp. 197-203.

(2012), La memoria amorosa, Barcelona, Rev. Insula, nº 189, septiembre, pp. 19-

20.

FERNÁNDEZ PALACIOS, JESÚS y PONT, JAUME (2001), ed., Carlos Edmundo de Ory. Textos críticos sobre su obra, Cádiz, Servicio de Publicaciones de la Diputación.

FORTUÑO, SANTIAGO (1983), «Poética y poesía de Carlos Bousoño», Oviedo, Los Cuadernos del Norte, $\mathrm{n}^{\mathrm{o}}$ 21, septiembre-octubre, pp. 84-89.

(1989), «Carlos Bousoño: elegías a Vicente Aleixandre», Oviedo, Los Cuadernos del Norte, $\mathrm{n}^{\mathrm{o}}$ 54, abril-mayo-junio, pp. 102-104.

(1992), Primera generación poética de posguerra. Estudio y Antología, Madrid,

Ediciones Libertarias.

(1998), «La poesía de la otra generación del 27 (Edgar Neville, Jardiel Poncela y López Rubio)», Vanguardia y Humorismo. La otra generación del 27, ed. de María Luisa Bruguera y Santiago Fortuño, Castelló, Publicaciones de la Universitat Jaume I.

(2008), Poesía de la primera generación de posguerra, Madrid, Cátedra.

(2010), ed. y prólogo de Ildefonso-Manuel Gil, Poesía (1950-2001), Zaragoza, Letra Última, Diputación.

(2011), «Humor al servicio de la metafísica», Humor y Literatura. Ridentem dicere verum, ed. de Germà Colón y Santiago Fortuño, Castelló, Publicacions de la Universitat Jaume I.

(2015), ed. de Carlos Bousoño: estudio y antología poética, Oviedo, Real Instituto de Estudios Asturianos.

FLYS, MIGUEL J. (1968), La poesía existencial de Dámaso Alonso, Madrid, Gredos.

FOUCAULT, MICHEL (1966), Les mots et les choses, une archéologie des sciences humanes, Paris, Editions Gallimard; traducción de Elsa Cecilia Frost, Las palabras y las cosas. Una arqueología de las ciencias humanas, Madrid, Siglo XXI, 1968. 
(1970), L’Ordre du discours; traducción de Alberto González Troyano, El orden del discurso, Barcelona, Tusquets, 1973.

(1973), Ceci n'est pas une pipe, Montpellier, Fata Morgane; traducción de Francisco Monge, Esto no es una pipa. Ensayo sobre Magritte, Barcelona, Anagrama, 1981.

FREUD, SIGMUND (1900), Die Traumdeutung; traducción de Luis López Ballesteros, La interpretación de los sueños, 3 Vol., Madrid, Alianza Editorial, 1966.

(1923), Das Ich und das Es; traducción de Ramón rey Ardid y Luis López Ballesteros, El yo y el ello, Madrid, Alianza Editorial, 1973.

(1930), Das Unbenhagen in der Kultur; traducción de de Ramón Rey Ardid y

Luis López Ballesteros, El malestar en la cultura y otros ensayos, Madrid, Alianza Editorial, 1970.

FROMM, ERICH (1951), The Forgotten Language, Nueva York, Henry Holt; traducción de Mario Cales, El lenguaje olvidado, Barcelona, Paidós, 2012.

(1955), The sane society, Nueva York, Rinehart \& Co; traducción de Florentino M. Torner, Psicoanálisis de la sociedad contemporánea, México, Fondo de Cultura Económica, 1956.

(1956), The Art of Loving, Nueva York, Harper and Brothers; traducción de Noemí Rosenblatt, El arte de amar, Paidós, Buenos Aires, 1979.

FUSTER, JOAN (1955), «Ory, loco de una sola pierna», Valencia, Levante, 3 de abril.

GAMONEDA, ANTONIO (2015), «Carlos Edmundo de Ory en mi mala memoria», Jerez de la Frontera, Campo de Agramante, nº 23, otoño-invierno, pp. 15-21.

GAOS, VICENTE (1971), Claves de literatura española, Madrid, Guadarrama.

GARCÍA DE LA CONCHA, VÍCTOR (1969), «Espadaña (1944-1951), biografía de una revista de poesía y crítica», Madrid, Cuadernos Hispanoamericanos, $\mathrm{n}^{\circ}$ 236237, agosto 1969, pp. 380-397. También en VVAA., Época contemporánea: 1939.1980, ed. de Domingo Ynduráin, Historia y Crítica de la Literatura española, al cuidado de Francisco Rico, Vol. VIII, Barcelona, Editorial Crítica, 1980, pp. 150-154.

(1971), La poesía española de posguerra. Teoría e historia de sus movimientos, Madrid, Prensa Española.

(1987), La poesía española de 1935 a 1975. De la poesía existencial a la poesía social 1944-1950, Vol. II, Madrid, Cátedra. 
GARCÍA JAMBRINA, LUIS (2009), La otra generación poética de los 50, Madrid, UNED.

GARCÍA MORAL, CONCEPCIÓN y PEREDA, ROSA MARÍA (1979), Joven poesía española, Madrid, Cátedra, 1982.

GARCÍA-POSADA, MIGUEL (1984), «Poesía de la generación de 1927: Federico García Lorca y Rafael Alberti», VV.AA, Época contemporánea: 1914-1939, ed. de Víctor García de La Concha, en Historia y Crítica de la Literatura Española, al cuidado de Francisco Rico, Vol. VII, Barcelona, Editorial Crítica , pp. 367368.

GIMFERRER, PERE (1999), Proemio, ed. de Carlos Edmundo de Ory, Melos melancolía, Montblanc, Igitur.

(2012), «Merlín: funámbulo y asceta», Barcelona, Insula, $\mathrm{n}^{\circ} 789$, septiembre 2012, pp. 24-25.

GÓMEZ BEDATE, PILAR (2011), «El pensamiento mágico en la poesía española a mediados del siglo XX», Jerez de la Frontera, Campo de Agramante, nº 15, abril, pp. 29-50.

GRANDE, FÉLIX (1970a), ed., Carlos Edmundo de Ory, Poesía 1949-1969, Barcelona, Edhasa.

(1970b), Apuntes sobre poesía española de posguerra, Madrid, Taurus.

GRANEL TRÍAS, ENRIQUE (2001), «La no novia: los poemas-collages de Carlos Edmundo de Ory», en Carlos Edmundo de Ory. Textos críticos sobre su obra, ed. de Jaume Pont y Jesús Fernández Palacios, Cádiz, Servicio de Publicaciones de la Diputación , pp. 249-257.

HERNÁNDEZ FERNÁNDEZ, MARÍA TERESA (1971), Carlos Edmundo de Ory y el Postismo, Tesis de Licenciatura, Universidad de Murcia.

HERRERO, RAUL («CLAUDIO») (1998), Antología de poesía Postista, Zaragoza, Bilioteca Golpe de Dados.

HUXLEY, ALDOUS (1945), The perennial Philosophy; traducción de C. A. Jordana, La filosofía perenne, Barcelona, Edhasa, 2010.

ILLIE, PAUL (1968), Los surrealistas españoles, Madrid, Taurus, 1972.

JUNG, CARL GUSTAV (1938), Psychologie und Religion, Zurich, Rascher \& Cie. A.G.; traducción de Ilse T. M. de Brugger, Psicología y religión, Barcelona, Paidós, 1949; ed. 1994. 
(1942), Paracelsica, Zurich, Rascher \& Cie. A.G.; Paracélsica, Barcelona, Kairós, 1989.

(1950), Gestaltungen des Unbewussten, Zurich, Rascher \& Cie. A.G.; traducción de Roberto Pope, Formaciones de lo inconsciente, Barcelona, Paidós, 1982.

(1951), Symbole der Wanlung, $4^{\mathrm{a}}$ ed. revisada de Wandlung und Symbole der Libido, 1912; supervisión y notas de Enrique Butelman, Símbolos de transformación, Barcelona, Paidós, 1963.

JURADO MORALES, JOSÉ (2011), «Los pasos encontrados de Carmen Martín Gaite e Ignacio Aldecoa», Madrid, Insula, no 769-770, enero-febrero, pp. 26-27.

KANDINSKY, VASILI (1912), Ubre das Geistige in der Kunst, Munich, R. Piper \& Co.; traducción de Genoveva Dietterich, De lo espiritual en el arte, Barcelona, Paidós, 1996.

KEROUAC, JACK (1973), Scattererd Poems, San Francisco, City Lights; traducción de Mariano Antolín Rato, Poemas dispersos, Madrid, Visor, 2011.

LANZ, JOSÉ LUIS y TÉLLEZ, JUAN JOSÉ (1996), Marejada. Historia de un grupo literario, Cádiz, Quorum Libros Editores.

LAPESA, RAFAEL (1977), Poetas y prosistas de ayer y hoy, Madrid, Gredos.

LECHNER, J. (1975), El compromiso en la poesía española del siglo XX, Vol. II, Leiden, Universitaire Pers, pp. 66-84; también en VVAA, Época contemporánea: 1939-1980, ed. de Domingo Ynduráin, Historia y Crítica de la Literatura Española, al cuidado de Francisco Rico, Vol. VIII, Barcelona, Editorial Crítica, pp. 213-231.

LEVIN, SAMUEL R. (1962), Linguistic Structures in Poetry, N. V. Uitgverij Mouton \& Co.; traducción de Julio Rodríguez-Puértolas y Carmen C. de RodríguezPuértolas, Estructuras lingüisticas en la poesía, Madrid, Cátedra, 1979.

LUIS, LEOPOLDO DE (1965a), Poesía española contemporánea. Antología (19391964), Madrid, Alfaguara.

(1965b), Poesía social española contemporánea. Antología; $3^{\text {a }}$ ed., Madrid, Júcar, 1982.

(1974), ed., Miguel Hernández, Poemas de amor, Madrid, Alianza Editorial.

(1976), ed., Vicente Aleixandre, Sombra del paraíso, Madrid, Castalia.

(1992), Prólogo, Santiago Fortuño, Primera generación poética de posguerra.

Estudio y antología, Madrid, Ediciones Libertarias. 
MAINER, JOSÉ CARLOS (1975), La Edad de Plata (1902-1939), Barcelona, Los Libros de la Frontera.

MARCHÁN FIZ, SIMÓN (1972), Del arte objetual al arte de concepto (1960-1974), Madrid, A. Corazón, Comunicación; $3^{\text {a }}$ ed., Torrejón de Ardoz, AKAL, 1988.

MARCO, JOAQUÍN (1972), Nueva literatura en España y América, Barcelona, Lúmen/Palabra seis.

(1980), «La poesía», VVAA., Época contemporánea 1939-1980, ed. de Domingo Ynduráin, Historia y Crítica de la Literatura Española, al cuidadado de Francisco Rico, Vol. VIII, Barcelona, Editorial Crítica, pp. 109-138.

(2012), «Relectura de Técnica y llanto, de Carlos Edmundo de Ory», Barcelona, Insula, $\mathrm{n}^{\mathrm{0}} 789$, septiembre, pp. 12-13.

MARTÍNEZ FERNÁNDEZ, JOSÉ ENRIQUE (1989), Antología de la poesía española (1939-1975), Madrid, Castalia.

MARTÍNEZ SARRIÓN, ANTONIO (1980), ed. de Carriedo, Gabino-Alejandro, Nuevo compuesto descompuesto viejo (poesía 1948-1979), Madrid, Hiperión.

MESADO, RAFAEL (2011a), «Abismos y mesetas, territorios radicales de la poesía de Carlos Edmundo de Ory», Jerez de la Frontera, Campo de Agramante, $\mathrm{n}^{\circ}$ 15, pp. $15-26$.

(2011b), «Un vagabundo del Dharma nacido en Cádiz», Cádiz, Caleta, segunda época $\mathrm{n}^{\mathrm{o}} 16, \mathrm{pp} .227-231$.

(2012), «Miradas retrospectivas sobre el Postismo y la poesía de Carlos Edmundo de Ory», Castellón, Universidad Jaume I, Fòrun de Recercan $\mathrm{n}^{\mathrm{o}}$ 16, REVISTA ELECTRÓNICA FÒRUN-RECERCA, pp. 397-413.

www.uji.es/CA/pub/edicions/forum.thtml.

(2013a), «Postismo y La Cerbatana, inicio de la poesía de vanguardia en la posguerra», Castellón, Universidad Jaume I, Fòrum de Recerca ${ }^{\circ}$ 17, REVISTA ELECTRÒNICA FÒRUM-RECERCA, pp. 669-683.

www.uji.es/CA/pub/edicions/forum.thtml.

(2013b), «A través del laberinto. Biografía (interna) de un transeúnte (cósmico)», POEMAD Revista de poesía, $n^{\circ}$ 4, 30 de julio, www.poemad.com/carlos edmundo de ory

(2013c), «Ory: poesía y silencio», Coordenadas, Cádiz, Fundación Carlos Edmundo de Ory, pp. 83-97. Conferencia impartida el 9 de octubre de 2013, Coordenadas, III Jornadas en torno a Carlos Edmundo de Ory. 
(2015), «Carlos Edmundo de Ory, poeta beat», Jerez de la Frontera, Campo de Agramante, $\mathrm{n}^{\circ}$ 23, pp. 51-63.

(2016), «La alargada geografía accidentada de la poesía visual», Azharanía, Rev.de poesía, Castellón, El Almadar, nº 10, febrero, pp. 24-25.

(2016), «Más allá de lenguaje: los aerolitos de Carlos Edmundo de Ory», Castellón, Universitat Jaume I, Fòrum de Recerca (en trámite).

MILLÁN, FERNANDO y GARCÍA SÁNCHEZ, JESÚS (1975), La escritura en libertad. Antología de poesía experimental, Madrid, Visor.

MILÁN, EDUARDO y otros (2002), ed. y prólogo, Las ínsulas extrañas. Antología de poesía en lengua española (1950-2000), Barcelona, Nueva Galaxia Gutenberg.

MINGOTE, PILAR EUGENIA (1973), Vida y obra de del poeta Carlos Edmundo de Ory, Tesis de Licenciatura, Universidad de Oviedo.

NAVAS OCAÑA, MARÍA ISABEL (1997), El movimiento postista. Teoría y Crítica, Almería, Grupo de Investigación «Teoría de la Literatura y Literatura Comparada de la Universidad». (2000), El Postismo, Cuenca, El Toro de Barro.

(2001a), «La producción teórica y crítica de Carlos Edmundo de Ory. Un esbozo», VVAA, Carlos Edmundo de Ory. Textos críticos sobre su obra, ed. de Jaume Pont y Jesús Fernández Palacios, Cádiz, Servicio de Publicaciones de la Diputación, pp. 153-162.

(2001b), «El surrealismo y la crítica española», VVAA., Surrealismo y literatura en España, ed. de Jaume Pont, Lleida, Edicions de la Universitat de Lleida, pp. 339-359.

NIETZSCHE, FRIEDRICH (1872), Tragödie ans dem Geiste der Musik, Leipzig, Verlag Von Fritzsch; traducción de Andrés Sánchez Pascual, El nacimiento de la tragedia, Madrid, Alianza Editorial,1973.

(1882), Die fröhliche Wissenschaft («la gaya scienza»); traducción de José Mardomingo Sierra, La gaya ciencia, Madrid, Editorial Edaf, 2002.

(1887), Zur Genealogie der Moral: Eine Streitscherift; traducción de Andrés Sánchez Pascual, La genealogía de la moral. Un escrito polémico, Madrid, Alianza Editorial, 1972.

ORTEGA Y GASSET, JOSÉ (1925), La deshumanización del arte e Ideas sobre la novela, Madrid, Revista de occidente; $2^{\mathrm{a}}$ ed, La deshumanización del arte y 
otros ensayos de estética, Madrid, Revista de Occidente en Alianza Editorial, 1983).

ORY, CARLOS EDMUNDO DE (1972), «Surrealismo es España», Madrid, Cuadernos Hispanoamericanos, $\mathrm{n}^{\circ}$ 261, marzo, pp. 579-583.

(1976), Los cuatro jinetes, introducción, Nueva Poesía 1: Cádiz, Bilbao, Zero S.A.

(1978), Energeia (1940-1977), Barcelona, Plaza y Janés.

(2004), Diario (1944-2000), 3 Vol., ed. y prólogo de Jesús Fernández Palacios, Cádiz, Servicio de Publicaciones de la Diputación.

OVEJERO, JOSÉ (2011), Escritores delincuentes, Madrid, Alfaguara.

PALACIOS, AMADOR (1991), Jueves postista, Ciudad Real, Diputación-Area de Cultura.

(2001), «Una meditación desde el Postismo», VVAA. Carlos Edmundo de Ory.

Textos críticos sobre su obra, ed. de Jaume Pont y Jesús Fernández Palacios, Cádiz, Servicio de Publicaciones de la Diputación, pp. 177-185.

(2014), «Dos "raros" en el contexto de la poesía española: Eduardo Chicharro y Carlos Edmundo de Ory», Coordenadas, Cádiz, Fundación Carlos Edmundo de Ory, pp. 157-179.

(2015a), La poesía española durante el franquismo, Guadalajara, El Alambique, $\mathrm{n}^{\circ} 10$, separata, abril.

(2015b), «Reacción post postista (el paso de Carlos Edmundo de Ory del Postismo al realismo», Jerez de la Frontera, Campo de Agramante, $\mathrm{n}^{\mathrm{o}}$ 23, otoñoinvierno, pp. 91.101.

PANIKKAR, RAIMON (1989), La Trinidad y la experiencia religiosa, Barcelona, Ediciones Obelisco. (1997), La experiencia filosófica de la India, Madrid, Trotta.

PARRA, JAIME D. (2001a), «El surrealismo en la poesía de Juan Eduardo Cirlot», en VVAA, Surrealismo y literatura en España, ed. de Jaume Pont, Lleida, Edicions de la Universitat de Lleida, pp. 267-288. (2001b), «El rumor de las alas de Gabriel: la poesía última de Carlos Edmundo de Ory», en Carlos Edmundo de Ory. Textos críticos sobre su obra, de. A cargo de Jaume Pont y Jesús Fernández Palacios, Cádiz, Servicio de Publicaciones de la Diputación. 
PAULINO AYUSO, JOSÉ (1979), ed., León Felipe, Versos y oraciones del caminante (I y II), Drop a star, Madrid, Alhambra.

PAZ, OCTAVIO (1987), Los hijos del limo, Barcelona, Seix Barral.

PEÑA DE LA, PEDRO J. (1982), Juan Gil-Albert, Madrid, Júcar.

PÉREZ-BUSTAMANTE, ANA SOFÍA (2012), «Melos melancolía: Carlos Edmundo de Ory en su leyenda dorada», Barcelona, Insula, no 789, septiembre 2012, pp. 14-16.

(2015), «Memoria de un cuento azul: Carlos Edmundo de Ory y Juan Eduardo Cirlot», Jerez de la Frontera, Campo Agramante, n 23, pp. 151-166.

PÉREZ LASHERAS, ANTONIO y SALDAÑA, ALFREDO (2000), ed., Eduardo Chicharro y Carlos Edmundo de Ory, Las patitas de la sombra, Zaragoza, Mira Editores.

PÉREZ ZÚÑIGA, ERNESTO (2015), «El oro de Ory», Jerez de la Frontera, Campo Agramante, $\mathrm{n}^{\circ}$ 23, pp. 23-27.

POLO DE BERNABÉ, JOSÉ MANUEL (1977), «El postismo como aventura del lenguaje en la poesía de posguerra en España» Actas del VI Congreso Internacional de Hispanistas, Toronto, del 22 al 26 de agosto de 1977; Toronto, University of Toronto Press, 1980, pp. 579-582.

(1978), «El universo poético de Carlos Edmundo de Ory y el Postismo», Madrid, Cuadernos Hispanoamericanos, $\mathrm{n}^{\circ}$ 335, mayo de 1978; también en VVAA, Carlos Edmundo de Ory. Textos críticos sobre su obra, ed. de Jaume Pont y Jesús Fernández Palacios, Cádiz, Servicio de Publicaciones de la Diputación, 2001, 165-174.

PONT, JAUME (1972), La poesía de Carlos Edmundo de Ory, Tesis de Licenciatura, Universidad de Barcelona.

(1974), ed., Carlos Edmundo de Ory, Poesía abierta (1945-1973), Barcelona, Barral Editores, Col. Ocnos.

(1977), La poesía de Carlos Edmundo de Ory, Tesis Doctoral, Barcelona, Universidad de Barcelona.

(1987), El Postismo, un movimiento estético-literario de vanguardia, Barcelona, Edicions del Mall.

(1990), La letra y sus máscaras. De Villiers de l'Isle-Adam a José Ángel Valente, Lleida, Sección de Lengua y Literatura del Departamento de Filología de l'Estudi General de Lleida. 
(1998), La poesía de Carlos Edmundo de Ory, Lleida, Pagés Editors, Universitat de Lleida.

(1999), «El anillo de Ory», epílogo, Carlos Edmundo de Ory, Melos melancolía, Montblanc, Igitur/poesía.

(2001), «El Postismo como post(surreal)ismo», VVAA., Surrealismo y Literatura en España, ed. de Jaume Pont, Lleida, Edicions de la Universitat de Lleida, pp. 245-266.

(2003a), ed., Carlos Edmundo de Ory, Música de lobo. Antología poética (19412001), Barcelona, Galaxia Gutemberg.

(2003b), «La poesía de José Ramón Ripoll: Hoy es niebla», Barcelona, Insula, $\mathrm{n}^{\circ}$ 682, octubre, pp. 20-24.

(2004), «La poesía de Carlos Emundo de Ory», RevistaAtlánticadepoesía, n 27 , Cádiz, pp. 19-21; también en Espejo y laberinto, Lleida, Pagés Editors, 2012, pp. 235-239.

(2009), «Poesía e imagen insular en la lírica de Andrés Sánchez Robayna», Principios modernos y creatividad expresiva en la poesía española contemporánea, ed. de Elsa Dehennin y Chistian Paepe, Rodopi, AmsterdamNueva York, 2009, pp. 317-385.

(2011), «El sueño del lobo (la obra literaria como autobiografía espiritual)», Cádiz, Caleta, segunda época, no 16, pp. 185-191.

(2012), «Ory», Barcelona, Insula, n 789, pp. 2-4.

(2014), «José Ramón Ripoll: la poesía de la memoria del origen», Barcelona, Insula, $\mathrm{n}^{\mathrm{0}} 815$, noviembre 1014 , pp. 38-40.

(2015), «Carlos Edmundo de Ory y Eduardo Chicharro: luces y sombras de una amistad imborrable», Jerez de la Frontera, Campo de Agramante, no 23, pp. 135149.

POZANCO, VÍCTOR (1976), Nueve poetas del resurgimiento, Barcelona, Ámbito.

RAMOS ORTEGA, MANUEL (2004), «Poesía primera y antecedentes», Cádiz, RevistaAtlántica de poesía, $\mathrm{n}^{\circ} 27$, pp. 13-16.

(2012), «Ory(génesis): la bliblioteca modernista», Barcelona, Insula, $\mathrm{n}^{\circ}$ 789, septiembre, pp. 6-7.

REICH, WILHEM (1948), The Discovery of the Orgone. The Function of the Orgasm, Nueva York, Orgone Institute Press; traducción de Felipe Suarez, La función del orgasmo, Barcelona, Paidós, 1995. 
REY, JOSÉ LUIS (2015), «Carlos Edmundo de Ory o el espíritu en las ruinas», Jerez de la Frontera, Campo de Agramante, nº 23, otoño-invierno, pp. 81-89.

RIBES, FRANCISCO (1952), Antología consultada de la joven poesía española. Valencia, Prometeo, 1983. (1963), Poesía última, Madrid, Taurus.

RIERA, CARME (1988), La escuela de Barcelona, Barcelona, Anagrama.

RIPOLL, JOSÉ RAMÓN (2004), «La memorya oryental», Cádiz, RevistaAtlánticadepoesía, $\mathrm{n}^{\mathrm{0}}$ 27, pp. 23-29.

(2011), «El último aerolito», Cádiz, Caleta, segunda época, nº 16, octubre, pp. 205-214.

(2012a), «La fuente de Castalia (Música y poética en Carlos Edmunde de Ory», Barcelona, Ínsula, no 789, septiembre 2012, pp. 16-19.

(2012b), «Una nueva mirada», Insula, n 789, septiembre 2012, pp. 21-24.

(2015), «Pensamiento y poética en Carlos Edmundo de Ory», Jerez de la

Frontera, Campo de Agramante, no 23, otoño-invierno, pp. 31-39.

RUBIO, FANNY (1976), Las revistas poéticas españolas (1939-1975), Madrid, Turner. (1988), «Federico García Lorca y la poesía española de primera posguerra», Valoración actual de la obra de García Lorca, Madrid, Coloquio Hispano-Francés, 1988, Actes du colloque tenu à la Casa de Velázquez, 13 y 14 demarzo de 1986.

RUBIO, FANNY y FALCÓ, JOSÉ LUIS (1982), Poesía española contemporánea (1939-1980), Madrid, Alhambra.

RUIZ RAMÓN, FRANCISCO (1970), Historia del teatro español. Siglo XX, Madrid, Cátedra, $3^{\circ}$ ed. ampliada, 1977.

RUIZ SORIANO, FRANCISCO (2004), Poetas órficos, Madrid, Huerga y Fierro editores.

SALDAÑA, ALFEREDO (2015), «Amor y muerte a la luz de "Amo a una mujer de larga cabellera"», Jerez de la Frontera, Campo de Agramante, n 23, otoñoinvierno, pp. 65-79.

SÁNCHEZ ROBAYNA, ANDRÉS (2010), «En la muerte de Carlos Edmundo de Ory», Madrid, Cuadernos Hispanoamericanos, $\mathrm{n}^{\circ}$ 726, pp.11-16; también en Caleta, segunda época, nº16, Cádiz, octubre de 2011, pp. 63-69.

SAMPIETRO, JOSÉ LUIS (1978), El hecho poético en Carlos Edmundo de Ory, Universidad de Montpellier. 
SEGOVIA, TOMÁS (1973), Contracorrientes, México, Universidad Nacional Autónoma.

SENABRE, RICARDO (1972), ed., Miguel Labordeta, Obras completas, Zaragoza, Javalambre.

SILVA, ASUNCIÓN (1988), heterónimo de Jesús Fernández Palacios, «Carlos Edmundo de Ory: Las nostalgias de un rebelde», Madrid, Culturas, Diario 16, 4 de junio.

SILVER, PHILIP (1970), «Tradition as originality in Hijos de la ira», Bulletin of Hispanic Studies, XLVII; «La tradición como originalidad en Hijos de La ira», VVAA., Época contemporánea: 1914-1939, ed. de Víctor García de la Concha, Historia y Crítica de la Literaturta Española, al cuidado de Francisco Rico, Barcelona, Editorial Crítica, 1984, pp. 514-517.

SUZUKI, DAISETZ TEITARO (1934), An introduction to zen Buddism, Kyoto, Eastem Buddhist Soc.; Introducción al Budismo Zen, Bilbao, Mensajero, 1992.

(1959), Zen and Japanese Culture, Nueva York, Bollingen Foundation Inc.; traducción de María Tabuyo y Agustín López, El Zen y la cultura japonesa, Barcelona, RBA, 2002.

TALENS, JENARO (1975), El espacio y las máscaras, Barcelona, Anagrama. (1981), «(Desde) la poesía de Antonio Martínez Sarrión», prólogo, Antonio Martínez Sarrión, El centro inaccesible, Madrid, Hiperión.

TZARA, TRISTAN (1963), Sept manifestes Dada, París, Jean-Jacques Pauvert Éditeur; traducción de Huberto Haltter, Siete manifiestos Dada, Barcelona, Tusquets, 1972.

TUDELILLA, CHUS (2015), «Sobre las cartas que escribo y que me escriben. Correspondencia de Carlos Edmundo de Ory y Mathias Goeritz», Jerez de la Frontera, Campo de Agramante, $\mathrm{n}^{\circ}$ 23, otoño-invierno, pp.167-179 .

VALVERDE, JOSÉ Ma (1977), Introducción, Gabriel Celaya, Poesías completas, tomo I, Barcelona, Laia.

VARENNE, JEAN (1977), Le Tantrisme, la Sexualité transcendé, París, Cal-Sofedis; traducción de Javier Troncoso, El tantrismo o la sexualidad sagrada, Barcelona, Kairós, 1985.

VELA, JAVIER (2015), «El lenguaje perdido: juego y conciencia lírica en la poesía de Carlos Edmundo de Ory», Jerez de la Frontera, Campo de Agramante, $\mathrm{n}^{\mathrm{o}}$ 23, otoño-invierno, pp. 41-49. 
VELÁZQUEZ, JOSÉ IGNACIO (1987), ed., Guillaume Apollinaire, Caligramas, Madrid, Cátedra.

VILLENA, LUIS ANTONIO DE (1975), La revolución cultural (desafio de una juventud), Barcelona, RTVE, Planeta.

(1982) «Contracultura: no sólo un momento en el tiempo», en SAVATER, FERNANDO Y VILLENA, LUIS ANTONIO DE, Heterodoxias $y$ contracultura, Barcelona, Montesinos.

(1986), Postnovísimos, Madrid, Visor,

(1996), «El postismo en los días de Venecia», Albacete, Barcarola, $\mathrm{n}^{\circ}$ 50, pp. 227-238.

(2007), El fervor y la melancolía. Los poetas de "Cántico” y su trayectoria, Sevilla, col. Vandalia, Fundación José Manuel Lara.

(2003), La lógica de Orfeo, Madrid, Visor.

(2010a), La inteligencia y el hacha (Un panorama de la Generación poética de 2000), Madrid, Visor.

(2010b), «Carlos Edmundo de Ory, genio del postismo», Madrid, El Mundo, 12 de noviembre; también en Caleta, segunda época, nº 16, Cádiz, pp. 81-83.

VV.AA. (1976), Nueva Poesía 1: Cádiz, Bilbao, Zero S.A.

(1980a), Época contemporánea: 1914-1939, ed. de Víctor García de la Concha, Historia y crítica de la literatura española, al cuidado de Francisco Rico, Vol. VII, Barcelona, Editorial Crítica.

(1980b), Época contemporánea: 1939-1980, ed. de Domingo Ynduráin, Historia y crítica de la literatura española, al cuidado de Francisco Rico, Vol. VIII, Barcelona, Editorial Crítica.

(2001a), Carlos Edmundo de Ory. Textos críticos sobre su obra, ed. de Jesús

Fernández Palacios y Jaume Pont, Cádiz, Servicio de Publicaciones de la Diputación.

(2001b), Surrealismo y literatura en España, ed. de Jaume Pont, Lleida, Edicions de la Universitat de Lleida.

(2004), Documentos Carlos Edmundo de Ory, RevistaAtlántica, $\mathrm{n}^{\mathrm{o}} 27$.

(2005), Revistas literarias españolas del siglo XX, al cuidado de Fanny Rubio, Vol. II, Madrid, Ollero y Ramos Editores.

WATTS, ALAN (1958a), The way of zen; traducción de Juan Adolfo Vázquez, El camino del zen, Barcelona, Pocket-Edhasa, 1971. 
(1958b), Nature, man and woman, Nueva York, Pantheon Books; traducción de José Martín Arancibia, Naturaleza, hombre y mujer, Barcelona, Kairós, 1988.

(1960), This is it; traducción de Enric Tremps, Esto es eso, Barcelona, Kairós, 1992.

(1963), The two hands of God; traducción de Darryl Clark y Carletto Carbó, Las dos manos de Dios, Barcelona, Kairós, 1990.

(1966), The Book On the Taboo Against Konwing Who You Are; traducción de Rolando Hanglin, El libro del tabú, Barcelona, Kairós, 1972.

YURKIEVICH, SAUL (1976), Celebración del modernismo, Barcelona, Tusquets.

ZARATE, ARMANDO (1976), Antes de la vanguardia, Buenos Aires, Rodolfo Alonso Editor.

ZORZO, MARÍA A. (2008), «Una experiencia de silencio», en VVAA, Veintinueve maneras de concebir el silencio, ed. a cargo de Mary Farell y Manolo Dos, Castellón, Servicio de Publicaciones de la Diputación. 


\section{EN LA RED}

1. Sobre Carlos Edmundo de Ory

· www.fundacionory.com

(Fundación Carlos Edmundo de Ory, Centro Cultural Reina Sofía, Paseo de Carlos III, 9, $2^{\circ}$ planta, 11003 Cádiz, tel. 956221680, fax. 956220723).

·www.poemad.com/carlos_edmundo_de_ory.

(POEMAD. Revista de poesía, $n^{\circ}$ 4, dedicada a Carlos Edmundo de Ory, con textos de Pont, Cózar, Gimferrer, Carnero, Fernández Palacios, Vela, Mesado y pinturas de Laura Lachéroy. Se encuentra el artículo «A través del laberinto. Biografía (interna) de un transeúnte (cósmico)» de RAFAEL MESADO, 30 de julio de 2013).

- www.diazmartinez.wordpress.com/.../carlos-edmundo-de-ory-amigoymaestro

· ubiku.blogspot.com.es/2013/01/carlos-edmundo-de-ory.html

- web.udl.es/Dep./filef/ory

(Universitat de Lleida, dirigida por JAUME PONT).

· www.insula.es/Articulos/INSULA_789,html

(PONT, JAUME, «La ínsula de Ory», Insula, nº 789, septiembre 2012).

· UJI.es/bin/publ/edicions/jfi16/filolog/2.pdf

(MESADO, RAFAEL, «Miradas retrospectivas sobre el Postismo y la poesía de

Carlos Edmundo de Ory», Universitat Jaume I, Castelló, 2012, www.uji.es/CA/pub/edicions/forum.thtml, REVISTA ELECTRÒNICA FÒRUM-RECERCA).

· http://www.uji.es/CA/pub.

(MESADO, RAFAEL, «Postismo y La Cerbatana, inicio de la poesía de vanguardia de posguerra», Universidad Jaume I, Castellón, 2013, www.uji.es/CA/pub/edicions/forum.thtml, REVISTA ELECTRÒNICA FÒRUM-RECERCA).

·www.uned.es/centro-investigacion_SELITEN@T/pdf

(ROMERA CASTILLO, JOSÉ, «Jirones autobiográficos y literarios de Carlos Edmundo de Ory en el epistolario al pintor Ginés Liébana», en Scripta 
Philologica in honorem Juan M. Lope Blanch, México, UNAM, 1992, tomo III, pp. 441-453).

· www.circulodepoesia.com/nueva/.../carlos-edmundo-de-ory.segun-marco-fronz $(27 / 04 / 2013)$.

- www.revistade letras.net/el-lugar-de-carlos-edmundo-de-ory/

(VILA, FÁTIMA, «El lugar de carlos Edmundo de Ory», Crónicas, 18/11/10).

· http://miboquitapresta.blogspot.com

(Blog de FÁTIMA VILA).

- www.youtube.com/match?v=ngvdLUnmbb. UCA Homenaje póstumo al poeta CARLOS EDMUNDO DE ORY...

(Video que recoge el acto titulado La Memoria Amorosa, homenaje al poeta recién fallecido, celebrado el 20 de diciembre de 2010 en la Facultad de Filosofía y Letras de Cádiz).

· www.youtube.com/watch?v=JjYx- jhew

Entrevistas:

- Entrevista a Carlos Edmundo de Ory, antecultura.

- Tesis. Carlos Edmundo de Ory, cedecom.

- Literarias: Carlos Edmundo de Ory, videos UCA (junto a Jesús Fernández Palacios).

- De viva voz, Biblioteca Virtual de Andalucía, Carlos Edmundo de Ory, biblioteca virtuland (con Fernando Polavieja y Rafael de Cózar).

- Carlos Edmundo de Ory, bibbru.

· http:/librodenotas.com/poeticas/Archivos/005270.html

(Entrevista).

· www.cervantesvirtual.com

(Biblioteca Virtual Miguel de Cervantes, Instituto Miguel de Cervantes):

- El musiquero de las manos fecundas, pdf. (2011), extraído de Cuadernos Hispanoamericanos, $\mathrm{n}^{\mathrm{o}} 125$, nov. 1967.

- Salvador Rueda y García Lorca, pdf. (2011), extraído de Cuadernos Hispanoamericanos, $\mathrm{n}^{\mathrm{o}}$ 255, mar. 1971.

- Emerson en Europa pdf. (2011), extraído de Cuadernos Hispanoamericanos $\mathrm{n}^{\mathrm{o}}$ 257-258, may-jun. 1971.

- ¿Surrealismo en España?, pdf. (2012), extraído de Cuadernos Hispanoamericanos, nº 261, mar. 1972. 
- Tres apuntes sobre poesía, pdf. (2012), extraído de Cuadernos

Hispanoamericanos, $\mathrm{n}^{\mathrm{o}}$ 269, nov. 1972.

- www.escritores.org/ory.html

(Biografía, bibliografía, enlaces).

· https:/sites.google.com/sites/edmundodeory

(Biografía, bibliografía, poemas).

· http://amediavoz.com/ory.htm

(Poemas).

·http://www.garcianieto.com/carlos_edmundo_de_ory1.htm

(Correspondencia a José García Nieto: cartas y poemas dedicados).

• http://javierbarreiro.wordpress.com/2015/09/01/loa-aforismos-de-carlos-edmundp-deory-una-teoria-poetica-

(bARREIRO, JAVIER, «Los aforismos de Carlos Edmundo de Ory: una teoría poética»).

· http://www.youtube.com/watch?v=EfDLHiUdko

(Cortometraje El que anda con luz, director Jesús Graván).

2. Sobre el Postismo

·www.upv.es/intermedia/.../miguel_molina_la_performance_avant.pdf

(MOLINA ALARCÓN, MIGUEL, «La performance española avant la lettre: del ramonismo al Postismo (1915-1945)», Conferencia realizada el 15 de noviembre de 2007 en Chámalle X. IV Xornadas de Arte de Acción da Facultade de Bellas Artes de Pontevedra, coordinación de Carlos Tejo. Un extracto del texto se encuentra en VVAA. (2008), Chámalle X. IV Xornadas de Arte de Acción da Facultade de Bellas Artes da Universidad de Vigo, Servicio de Publicaciones).

·www.zurgal.com/PDF/061992032.pdf

(MARTÍN, SABAS, «Félix Casanova de Ayala en el Postismo (o viceversa)»).

· www.raco.cat/index.php/Scriptura/.../142445

(PONT, JAUME, «El Postismo, génesis, teoría y obra», pdf.).

· www.insula.es/Articulos/INSULA_789,html

(PONT, JAUME, «La ínsula de Ory», Insula, nº 789, sepiembre 2012). 
- www.elcultural.es/version_papel/LETRAS/143212/Postismo_la_brujeria_de_la_palab ra

(PONT, JAUME, «La brujería de la palabra», El Cultural, 27/06/1999, pdf.)

· www.ucm.es/info/especulo/numero31/chichar.html

(PALACIOS, AMADOR, «La soledad como ámbito del poeta», pdf, 2005.

Espéculo, Revista de estudios literarios, Universidad Complutense de Madrid).

- www.biblioteca.org.ar/libros/133209. pdf

(HOOFT, ANDREU, Eduardo Chicharro Briones. La obra en verso. Estudio y Análisis, Universitat de Lleida, Servei de Publicacions, Tesis Doctoral. También se encuentra en www.bib.cervantesvirtual.com, Biblioteca Virtual Miguel de Cervantes).

·www.prometeodigital.org/.../PDF195_CEPEDA_FDEZ_ARROYO.doc

(CEPEDA, NATIVIDAD, El camino andado de José Fernández-Arroyo, Prometeo, pdf.)

· www.blogelsignodelibra.blogspot.com/.../el-postismo

$\cdot$ http://eprints.ucm.es/33880/

(ACEVEDO, PABLO, Ironía, humor y juego en los discursos estéticos de la Modernidad: una mirada a través del Postismo, Tesis Doctoral, Madrid, Universidad Complutense, 2015).

- cvc.cervantes.es/literatura/tradicion_rupturas/garcia.htm

(GARCÍA-PAGE, MARIO, Algunas notas sobre la estética del Postismo, Uned). 
APENDICES

685 
APENDICE I. POEMAS POSTISTAS COMUNES EN LAS EDICIONES DE VERSOS DE PRONTO Y LOS POEMAS DE 1944

Existen cuatro poemas pertenecientes a Versos de pronto (1945), escritos en 1944, que aparecen en la edición, publicada en 1973, Los poemas de 1944. Estos son «Lamentación del amor que llega», «Bajo fondo», «Amiga» y «Oda a una extraña mujer», que cambia de título en la segunda obra por el de «Oda a una mujer extraña». Cabe señalar que en Los poemas de 1944 quedan suprimidos los signos de interrogación, en ocasiones los poemas sufren modificaciones pequeñas, en otras los cambios son mucho más drásticos. En este caso el poema ha quedado reescrito y actualizado, lo que supone un ejercicio contrafactual, en el que la vieja estructura es abandonada y sustituida por otra basada en ella. Exponemos a continuación los cambios presentados. Para ello debemos presentar las dos escrituras. En el caso de que las dos disposiciones poématicas no contengan grandes variaciones y siempre que sea posible, señalaremos los cambios en cursiva en la segunda escritura, mientras que las supresiones figurarán entre corchetes en la primera versión ${ }^{498}$.

1. «Lamentación del amor que llega»

1.1. Versos de pronto, rev. Fantasía, p. 18:

LLEGA con un fondo de amor y de suspiro, llega amando las rosas, llega como dormido. [Oh, cómo ama, ] ¡cómo abre en su mano un grito polvoriento! [y amanece abierto en cruz sobre una mancha.] Socorro de pureza[,] cuitado llanto sin planta, llora como aire triste [de paloma o de cuervo, como una especie nueva de dulzura.]

[De] [i]oh[!] de dulzura pácífica intemperie

498 Ver Blecua, A (1990), Manual de Crítica Textual, Madrid, Castalia. Aunque no utilizamos el mismo procedimiento, lo seguimos muy de cerca. 
y bosque del vacío por donde tú cabalgas.

Ya tan vaga penumbra vuelve a tu paso. Llega.

Como mares que arrastran son los brazos

¡los brazos del amor pueden con árboles!

[y los llevan y dejan en las orillas tintas.]

Llega como terrible desperezo de ánima

de arcángel en lo oscuro posado por la espalda.

Convida a besos a pestañas de besos

[que creosotan los poros y amargan la saliva

¡maldito licopodio de los huesos!

Mentira, grande signo de falsedad, mentira.

Solo toro de luz, toro de las estrellas

Persiguiendo a la corza caliente de la médula pisando puras sangres y simientes de fósforo.

¡iY tenerte, tenerte que recibir llorando!!

Tú que nos enfrías los pies del hombre

tú que pasas contrarios dientes en un minuto]

tú que raptas

mejillas por la noche. ¡Oh borracho del mundo

oh potente y ateo duende de un ojo solo

pequeñito niño a tientas con un sapo en la boca!

[Y tenerte que recibir llorando.]

Llega, tú llegas siempre cuando el viento se para

cuando se duerme pensando en pocas cosas,

cuando no hay dentro nadie, sino un perfume enano,

una pluma mojada de inocentes colores,

una espuma mansísima que no duele en la nuca.

Y llega, llega lo que tú traes de pronto

y tira por la ventana papeles, sedas, conchas.

Y el corazón se precipita y amaneca en volcán

$\mathrm{y}$ en un hermoso monte sin yerba ni manzana.

[Luego sobre la frente nos escupes, nos besas,

¡fenómeno brutal! ¡siempre junto a las yemas!

Y sabemos tu nombre con la garganta caída.]

1.2. Los poemas de 1944, pp. 67.68 :

Llega con un fondo de terciopelo azul ${ }^{499}$

Llega como extasiado de rosas hasta mí

¡Cómo abre en su mano un alarido dulce!

Socorro de pureza cuidado con el llanto

Llora como uva triste

Oh la dulzura en este bosque natural

Tan vaga es la penumbra que lame su presencia

Y llega

¡Como mares que arrastran son sus brazos!

${ }^{499}$ Como hemos dicho, señalamos los cambios en cursiva. 
Llega como terrible desperezo de hada conmovido en lo oscuro nos convida la noche a juntar las pestañas

Tú que raptas mejillas en los ajuares núbiles ¡oh potente y ateo borracho de la vida! Llega el amor con un sapo en la boca Tú llegas siempre cuando cuando el viento vomita cuando se duerme un árbol pensando en sus hormigas cuando un perfume de melón embriaga el aire Una pluma mojada de inocentes colores Una espuma muy mansa que no hace daño a nadie Y llega

Llega lo que tú traes de pronto en tu canasto y arroja margaritas como confetis crudos El corazón se agita y amanece en volcán Es ya un hermoso monte alfombrado de astros Pero yo me lamento corrompido de flores Qué bienestar me ofrece tu fina luz de arrobo y tu delicadeza de ciega desnudez Por los oscuros salmos de la lluviosa noche Ven Ven ven y ven te llamo te amo $Y$ ven por todo porque eres igual que la paloma que se parece a $t i$ Seré tuyo echando humo humo sangriento y tú perdonarás mi olor del que ama que conoces sólo la paz no tiene olor Amiga galopante Amo besar la flor en el silencio de tu mejilla caliente en la lluviosa noche tus pies fríos tan lejos de las puntas de tus dedos.

$Y$ amo tus orejas donde me lluvio yo ${ }^{500}$

Como se ha podido observar, el poema se ha alargado y ha tomado una nueva disposición. Recordemos que Los poemas de 1944 se publica en 1973, de modo que este y los demás poemas incluidos en Versos de pronto, así como todos los que conforman este poemario, sufren un proceso de reescritura. Se observa de este modo la radicalización de las imágenes y el lenguaje onírico de esta poesía, que toma la forma de la escritura automática.

${ }^{500}$ Parece que este fragmento forme parte de este poema. Podría ser así, ya que la óptica lúdica del autor funciona en este sentido. Pero una lectura más atenta nos indica que forma parte del poema "Amiga» y que se trata de un error tipográfico. Por lo tanto, respeto aquí la disposición de Poemas de 1944, p. 68. 
2. «Bajo fondo»

2.1. Versos de pronto, rev. Fantasía, p. 19:

QUIEN canta desde dentro de una garganta? ¿y quién besa ebrio una rosa maquinal con cinturas de ceniza y de carne? ¿Qué luz se apaga casi sin luz en esta hora de opio y brea y creosata? Locos[,] locos[,] oh locos cuerpos de nuca y venas y fósforo y nostalgia[.] Zumbidos bajan[,] suben desde cortezas sórdidas que vacilan, que injertan gérmenes impolutos[.] Vírgenes en la aurora y muchacha entre zarza[:] [¿me conocéis?, ¡decidlo!] Ya corrompidas ánimas[,] voraces[,] desteñidas oscuramente oblicuas. [iQué viscoso silencio las envuelve y estría como elocuente droga máxima, como sépalos en la piel, como lepra! Y desvanece al mundo, contra el amor depura,] alcaloide postremo [de cereal, de barro, vertiginosamente.] Por dentro de las casas hora de sangre y perro[:] ópalo de pecado los ojos de nepenta[;] buhardilla con su humo deshumano y humano [por manos que destilan y abren dulces mareas. $]^{501}$ Hombres clavados[,] sordos[,] sujetando paredes[,] pusilánimes[,] íncubos[,]

${ }^{501}$ Nótese la escritura psicodélica, coetánea a las experiencias de la generación beat americana. 
libres, enfermos, crueles

[con anillos de hielo

y con linternas secas.]

(Mineros de la carne[.])

Mujeres boca abajo

sin puntas en los senos,

con herrumbre en los muslos.

Maniatadas[,] hurtadas

como velos nocturnos

y no reveladores.

2.2. Los poemas de 1944, p. 64 :

¿Quién canta desde dentro

de una garganta? ¿Y quién besa ebrio una rosa

maquinal con cinturas

de ceniza y de carne?

¿Qué luz se apaga oasis

sin luz en esta hora

de opio y brea y creosata?

Locos locos oh locos

cuerpos de nuca y venas

y fósforo y nostalgia

Zumbidos bajan suben

desde cortezas sórdidas

que vacilan que injertan

gérmenes impolutos

Vírgenes en la aurora

y muchacha de bar

Ya corrompidas ánimas

voraces desteñidas

oscuramente oblicuas

alcaloide postremo

Por dentro de las casas

Hay hambre de perro

ópalo de pecado

los ojos de nepenta

buhardilla con su humo

deshumano y humano

Hombres clavados sordos

sujetando paredes

pusilánimes íncubos

libres enfermos crueles

(Mineros de la carne)

Mujeres boca abajo

con herrumbre en los muslos

sin puntas en los senos 
maniatadas nocturnas

en calles de aguaza!

3. «Amiga»

3.1. Versos de pronto, rev. Fantasía, p.18:

[QUE adivinado viento pasa quieto en tus ojos y qué caído mundo con carácter de sombra?

Busca un rápido bosque de esperanza,]

busca un labio [cubierto de manzana.]

Se mueve

como un pequeño bulto de cristal mi corazón[.]

Muevo dentro de mí

mis manos como frutas de arena.

En la vida del viento se ahogan tus ojos dulces.

Si pudiera decirlo

con un verso perfecto, con anegada huella

o si acaso cantarlo

[iicantarlo!!

¿Hay palabras?, ¿hay labios con palabras?, arroyos

de espuma en la garganta ¿hay o no hay?

Pero canciones, himnos, nocturnos coros suaves

para alzar en tu nombre celestes humaredas

sí hay. Yo quisiera cantarlo.

$\mathrm{Y}$ bendecir el alba que levanta tu carne

y los tristes pasos puros de tu alma en mi rostro.

Sonata de tu amor, como milagro amor.

Tu amor, oh tu amor entreabierto en la frente,

lánguido y vaporoso como un pastor que tiembla

en su traje de pana y soledades.]

Qué favor me hace tu fina luz de arrobo

y tu ciega delicadeza de amiga entre los tilos.

Por los oscuros salmos de la noche[,] ven

$\mathrm{y}$ ven porque te llamo y ven por todo,

porque eres igual de tibia que una inmóvil paloma.

Seré tuyo como un enloquecido humo de la sangre.

tuyo entre dolor y paz de lejana cintura.

Amo lo que no se besa, la flor en el silencio.

tu mejilla de noche como vaso olvidado,

tus pies fríos tan lejos de las puntas de los dedos[,]

amo tus orejas donde se duerme mi caído amor. 
2.2. Los poemas de 1944 , p.69

Como podemos observar, el poema sufre tantas modificaciones que casi no se reconoce el modelo original:

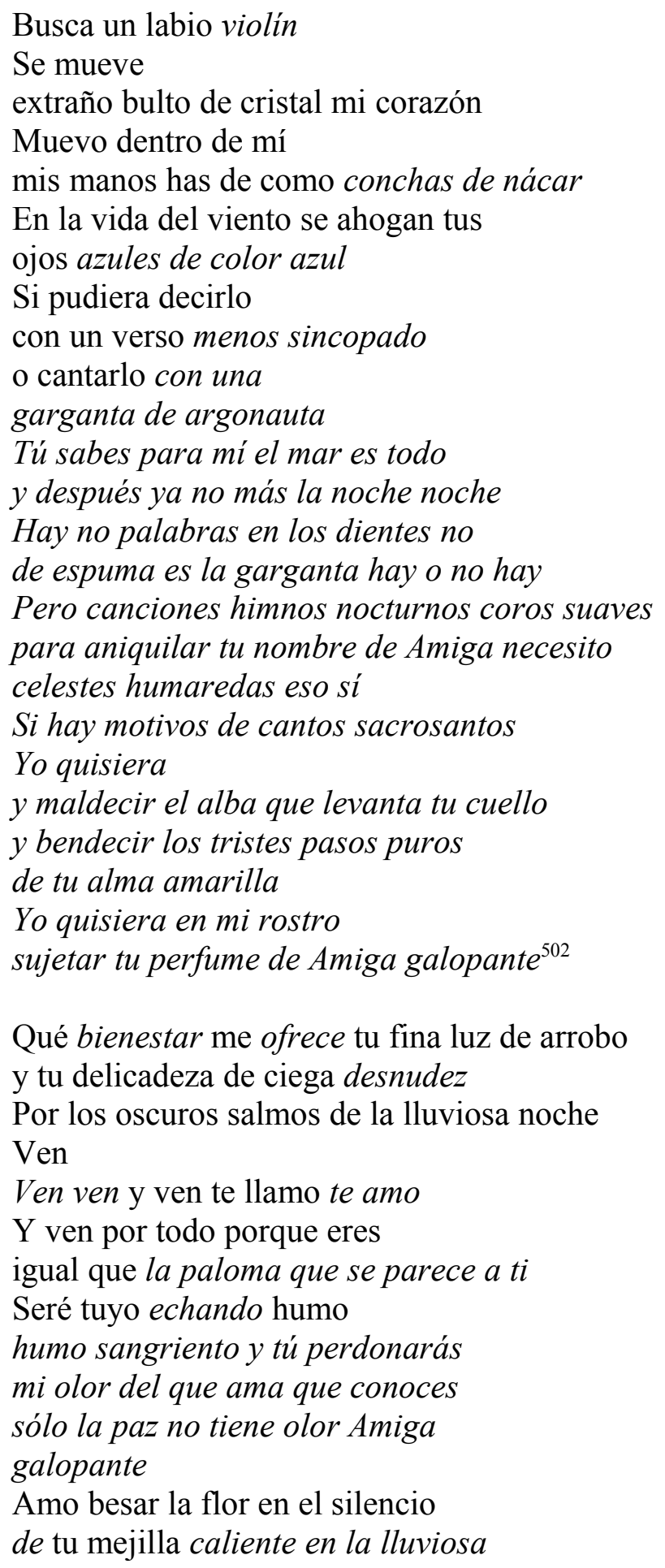

${ }^{502}$ En Los poemas de 1944 existe un error en la impresión y este poema ha quedado incompleto. A partir de aquí el poema figura en la página anterior, la 68. Parece que esta parte del poema se adscriba al poema anterior "Lamentación del amor que llega», pero en realidad se trata de un fragmento de "Amiga». Ello puede observarse mediante la comparación de las dos ediciones del mismo poema. 
noche

tus pies fríos tan lejos de las puntas de tus

dedos

Y amo tus orejas donde me lluvio yo

3. «Oda a una extraña mujer»

3.1. Versos de pronto, rev. Fantasía, p. 20:

NO huyas bajo álamos caricia presentida[,]

no dejes en el cielo vagar tu incendio de gacela,

no olvides[,] oh[,] no huyas del borde de mi cuerpo[.]

Hay un país que baja de tu voz para morir en el sueño.

Hay un océano de espaldas en tus ojos golpeados

por plumas de la vida contra cicutas de la muerte.

No sabes que te quiero[,]

que dentro de mi breve corazón te has posado

rápida voz extraña de muchacha.

Viejos líquenes de esperanza navegan por tu llanto[,]

has abierto una lágrima con un fondo de polvo

[como de un libro sale cargado de añoranza

el lejano jazmín y el rizo de la muerta.]

[i]No sabes que te adoro con sencillo deseo

[como inconsciente dios sobre un buey de tristeza?]

Responde con una luz o una mujer curvada

fija entre dos espejos de hermosura y deseo

con un perdido olor a paisaje en la tierra.

Me parece que te has dormido por detrás de mi alma,

[que tienes una hora de acecho entre mi hombro,]

[i]dulce, dulcísima carne de criatura

y de sutiles pasos navegante[!]

Te quiero[,] pero no huyas[,]

no quites el tiempo de tu rodilla[,]

no te turbes en tu lecho de infinito relumbre[.]

Habla[,] debes venir a decirme cómo piensas,

la mujer se bifurca con los labios cerrados,

la mujer cuando ama es un vuelo ruidoso

[y un cónclave de ardores.]

No dejes en mis manos el gamo de tu sombra.

Ama[,] como era antaño la fuente de tus venas.

[Ama, como cuando sin amor.]

3.2. Los poemas de 1944, p. 70 :

En el título existe un pequeño cambio: «Oda a una mujer extraña». 
No huyas bajo álamos caricia inmantenida

No asumas enn el aire tu incendio engacelado

No olvides oh no huyas del imán de mi cuerpo.

Hay un país que baja de tu voz somniforme

Hay un brillo de espaldas en tus ojos topacios

por plumas de la vida contra cicutas de la muerte

No sabes que te quiero mucho

que dentro de mi imberbe corazón te has movido

rápida voz extraña de muchacha rapaz

Líquenes de esperanza navegan por tu manto

Has abierto una ropa con silueta de loto

No sabes que te adoro con inocentes señas

Responde común luz o escúcheme mujer

dentro de mis espejos de belleza y deseo

Te has dormido inaudita sobre mi espalda muda

dulce dulcísima carne de criatura

$\mathrm{y}$ de sutiles pasos navegante

Te quiero pero no huyas

No quites el tiempo de tu rodilla

No te turbes en tu lecho de infinito relumbre

Habla debes venir a decirme en qué piensas

La mujer se evapora con los labios cerrados

La mujer cuando ama es un vuelo en un sueño

No dejes en mis manos el gamo de tu sombra

Ama como era antaño la fuente de tus penas

4. «Fábula»

4.1. Versos de pronto, rev. Fantasía, p. 19:

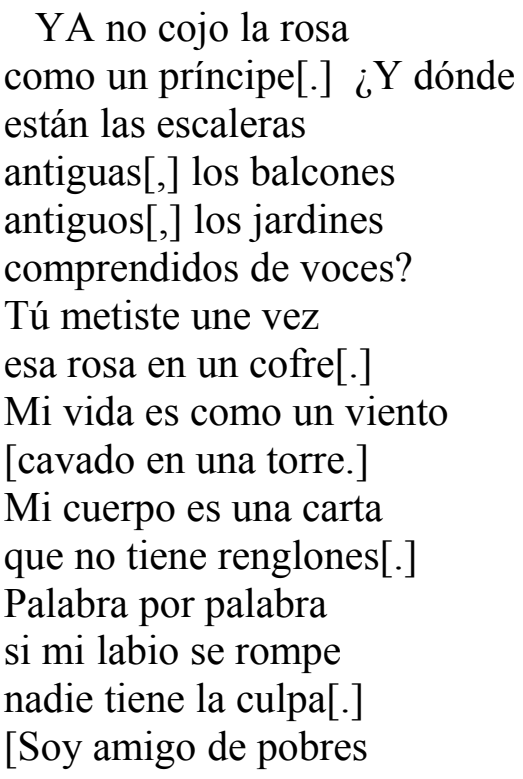


más que de ricos. Do re mi fa sol la... Se goza ...si do... bajo relojes, se goza con los jazmines y con opio. Mi nombre no lo digo. Se tienen muchísimos amores] y mujeres dormidas en cada mano[.] [Noches... noches... ¡lo mismo son que los días!] Los hombres pasan con el amor como un carro sin norte.

[iOh beso que no damos] y la sangre conoce[!] [Hay que vivir viudo detrás del horizonte. ¡Cuánto me canso! Y corro como un conejo doble.]

4.2. Los poemas de 1944, p. 63.

Su título es ahora «Inventos»:

Yo no cojo la rosa como un príncipe ¿Y dónde están las escaleras antiguas los balcones antiguos los jardines comprendidos de voces? Tú metiste une vez esa rosa en un cofre Mi vida es como un viento de cinco dimensiones Mi cuerpo es una carta que no tiene renglones Palabra por palabra si mi labio se rompe nadie tiene la culpa de que invente la noche Desnudos en la cama con el coma de amores Hay mujeres dormidas en cada mano El hombre lleva sacos de amor siempre de noche al monte Un monte es la mujer lo sabe quien no es monje $y$ no es tampoco tonto 
Como puede observarse, existe un proceso de reescritura que actualiza el poema y lo reincorpora a su nuevo contexto. Suponemos que Ory reactualizó estos poemas escritos en 1944 para la edición publicada en 1973 de Los poemas de 1944. Se trata de una labor de estilización y reconstrucción poética. En este sentido la tarea poética funciona suprimiendo algunos segmentos poéticos, alterando otros mediante algunos cambios de palabras y añadiendo algunas expresiones nuevas. En algunos casos se cambia un mero sonido, como ocurre en este último poema. Se sustituye la palabra «venas» por «penas» en el verso de nuevo poema o el verso «Ama como era antaño la fuente de tus penas» que sustituye al inicial «Ama, como era antaño la fuente de tus venas». En otros casos el cambio afecta a toda una palabra como ocurre en los versos siguientes: «No huyas bajo álamos caricia presentida» $\mathrm{y}$ «No huyas bajo álamos caricia inmantenida». Estos cambios mínimos alteran el poema original, pero sin perderlo de vista. Se trata, pues, de un ejercicio de deconstrucción y reconstrucción del poema original. Tarea que se realiza mediante el método postista del enderezamiento. De este modo, el nuevo poema no puede desligarse del original y crea un texto adosado a él. Ory abandona el texto original para quedarse con el texto adosado, que pasa a ser un texto sustitutivo. La actualización de los poemas es una tarea de destilación y de condensación poéticas, operación que consiste en suprimir los segmentos poéticos accesorios. 
APENDICE II. ROMANCES POSTISTAS QUE APARECEN EN LAS REVISTAS POSTISTAS

Los romances postistas contenidos en Las patitas de la sombra fueron escritos entre 1944 y 1945 por Eduardo Chicharro y Carlos Edmundo de Ory creando una escritura simbiótica. Algunos de ellos se escribieron a medias, otros de forma individual por uno de los autores y posteriormente fueron sometidos a un proceso de reelaboración común. Hay romances que aparecieron en la revista Postismo y en la antología que Félix Grande ${ }^{503}$ realizó sobre la obra de Ory antes de que se publicara la obra en el año 2000. Algunos romances escritos únicamente por Ory, editados posteriormente en Laocoonte y la luna, formaron parte también de las publicaciones postistas. En estos casos los poemas fueron reelaborados.

1. Romances aparecidos en Postismo:

1.1. «Romance de Laocoonte y la luna»

\subsubsection{Rev. Postismo, p.8}

Este poema, escrito por Ory, apareció contenido en la sección titulada Liricoteca, primera antología de poesía postista.

Fueron dulces epígones ${ }^{504}[$,
con un lugar y un libro
reminiscente y nuncio
de un inconcuso olvido[,]
y un moroso caballo
azul de vidrio en vidrio
Amanece llorando[,]
sin cama, en unos sitios
de alacranes [.] Cayéndole

${ }^{503}$ Obra cit.

${ }^{504}$ Sic. 


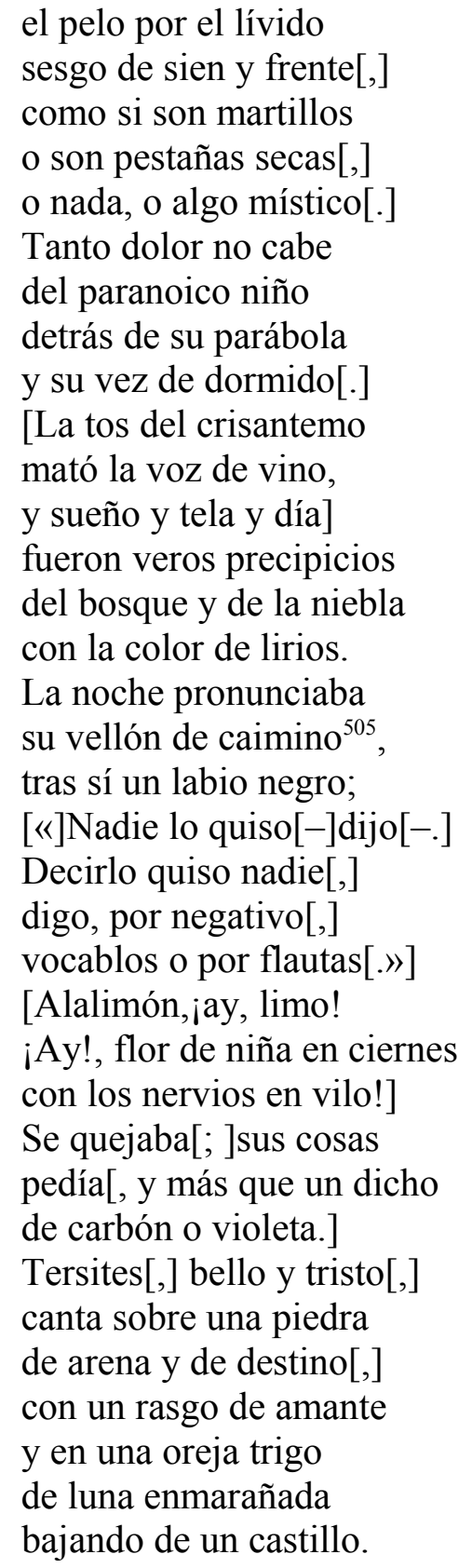

1.1.2. Laocoonte y la luna, en Poesía (1945-1969), ed. de Grande, pp. 243-244

El poema sufre algunos pequeños cambios como el alargamiento de la frase en el verso nueve, la sustitución de varios versos, la supresión o adición de algunas palabras y la eliminación (rasgo distintivo del discurso oryano postista y posterior) de los signos de puntuación y otras señales ortográficas. En otras ocasiones se modifica parte sustancial del texto. Para no repetir otra vez el texto, sólo presentaremos los versos que resultan modificados

${ }^{505}$ Sic. 
La luz de lo profundo

ahogó el dorado sueño

resina de los siglos

del abisal precipicio

que en un bosque nimbado

diera término a un lirio

La noche pronunciada

su sermón matutino

tras sí de una voluta

nadie lo quiso dijo

decir lo quiso nadie

Vio un báculo y un filtro

(v. 32)

Se quejaba sus cosas

Pedía y los destinos

quisieron defreudarle

Tersites bello y triste

canta sobre un tamujo

de una ruina al filo

Tiene un rasgo flotante

y en una oreja un vivo

resplandor de luna

que baja de un castillo.

1. 2. «Romance del ronquido del niño»

\subsubsection{Rev. Postismo, p. 8}

El poema apareció firmado únicamente por Carlos Edmundo de Ory en Liricoteca .

Como un huso pequeño ronca el niño pequeño, ¡ay, por Dios, qué pequeño! ¡sí, sí, sí, qué pequeño! Es que sierra una sierra con aserrín de huevo[,] de huevo y de natillas en su lugar enredo.

Hay un duende en la noche, con la noche pequeño y encendiendo cerillas en su murmuradero... ¡Ay qué bueno es el aire 
que le sale del pecho

y se le sube dúctil

por los dos agujeros!

¡Anda, eso es el ronquido,

y lo coge de vuelo!

[iQué loco, ay, que loco,

qué loco es el abuelo!]

El niño sueña un támbor ${ }^{506}$

que le haga el ronroneo.

Esto es lo más bonito

desde Carlyle a Asuero;

mientras su madre duerme[,]

el niño está durmiendo.

\subsubsection{Las patitas de la sombra, pp. 51-52}

En esta edición la autoría es compartida con Eduardo Chicharro y en ella el poema sufre pequeños cambios. En el título se suprime la palabra romance: «El ronquido del niño».

Como un huso pequeño

ronca el niño pequeño.

¡Ay, por Dios, qué pequeño!

¡Qué loco, ay, qué loco

qué loco es el abuelo!

por los dos abujeros!

Algunos versos se han trasladado de lugar y se ha producido alguna supresión. Ahora bien, cabe señalar la sustitución de la palabra «agujero» de la primera edición por el vulgarismo «abujero» en la segunda.

1.3. «El amigo sangriento»

\subsubsection{Rev. Postismo, p. 9}

El poema está firmado por Carlos Edmundo de Ory.

Lava este amor perdido

con una suelta seña

para que yo entre lanas

me crea ser la oveja

${ }^{506}$ Sic. 
que mana en la fontina

su sueño de marea[.]

[Déjame así, tú que eres

desde el monte la muerte

alma mía enterrada

que sube y baja y besa

los trinos del trasmundo

y el corazón de la tierra.

Los pasos de sus codos

sin verdad y sin lengua

desmonta aquella música

que se quedó en tu oreja.

Vengo a decirte, madre:

¡que él es malo y me pega!

ique me insulta y me rompe

mi garganta tremenda

con un golpe de sitio

la pelleja de almendra!

Es malo, es malo, es triste

que tengo la Tristeza...,

que tengo la Tristeza...;

De noche, por las colchas

de sangre de mi letra,

le escribía romances

que eran de amor si eran.

¡Pero nada, él es fiero

que parece una fiera...,

que parece una fiera!...

No venga ahora, no

a dar consuelo a esta

muchedumbre de llanto

que en mi mejilla aterra.

¡Adiós, dios de los truenos;

un trueno en mi cabeza

me hila hilo de halos

y me endiosa las crenchas!

...que parece una fiera.]

3.1.2. Laocoonte y la luna, en Poesía (1945-1969), ed. de Grande 247-248

En esta edición el poema se alarga y modifica, prácticamente casi se reescribe en su totalidad. De hecho, aparte de la semántica, ambos poemas sólo comparten los versos inciales. El título cambia también por «Romance del amigo sangriento»:

Lava este amor perdido

con una suelta seña

para que yo entre lanas 
me crea ser la oveja

que mana en la fontina

su sueño de marea

Lava este amor perdido con una suelta llama

para que yo encubierto

ascua parezca de oro

Amigo el más liviano

el de salaces musas

Déjame si te inspiro

un episodio íntimo

De aquellos cuantos raptos

cuantos pillajes y obras

vio el cielo que te oía

jurar con salvajismo

La memorable infamia

los inmutables labios

- la panza de la gloria

enseño todavía-

en el pecado de ellos

Tú que besaste el doble

lado de la muralla

que se rompió a la postre

$Y$ mi profunda madre

la madeja en tus dedos

me despertó esa noche

La noche que se omite

en todas tus palabras

en tu propia risa

cilíndrica y chinesca

la que proyecta el énfasis

de tu esternón de muerte

No quiero más efectos

ni veredictos tuyos

Pésete la caricia

Pésete la balanza

Pésete el surco abierto

de la rizada época

¿Quién nos privó del cuasi

sin arbitrio y rumores

solos y embalsamados

del pandemonio dentro

lastre de la celada

vértice del escrúpulo

órbita de la vuelta

de todos los misterios?

Al día siguiente y siempre

tus manos contumaces

qué difíciles eran

qué frágiles estaban 


qué juguete se hacian
en aquel circunloquio
síntoma de locura
iAdios inexistencia!
iÁngel estropeado!
Recuerda bien el gesto
que puse en un principio
Recuerda bien la brújula
del atril del verdugo
iAdios tiempo y amigo
no puede hablar mi alma!
Mi lengua estéril llora
el augur de las puertas
y el soplo de la luna
No dudes de los usos
eternos de mis sueños
No dudes de mi imagen
de la sutil elipsis
Duda de la retráctil
mácula de los halos
pues estamos malditos
y pendientes de un hilo.

2. Poemas aparecidos en La Cerbatana:

2.1. «Soneto paranoico»

\subsubsection{Rev La Cerbatana, p. 7}

Sólo en el mundo con mi media oveja ${ }^{507}$ y una cortada flor en el semblante bajo la mina honda del diamante que no tiene raíz ni tiene reja.

Mas como soy del odio tenue abeja manada de algún duende nigromante peinaré de mi espaldda el monte amante y con heces de concha de la almeja.

Mi paranoia de Iolao y Averno, ¡hola, pato de oro; hola, marea donde la mar merece su medusa!...

$\mathrm{Y}$ creo que de cebra tengo un cuerno $y$ de llama una pata panacea que se gasta en mi alma y que se usa.

${ }^{507}$ En este caso la cursiva no es nuestra. El poema aparece así en la edición original. 
2.1.2. Laocoonte y la luna, en Poesía (1945-1969), ed. de Grande, p, 243:

Solo en el mundo con mi media oreja y una cortada flor en el semblante bajo la mina honda del diamante que no tiene raíz ni tiene reja.

Mas como soy del odio tenue abeja manada de algún duende nigromante peinaré de mi espalda el monte amante y con heces de concha de la almeja.

Mi paranoia de Iolao y Averno ¡hola pato de oro hola, marea donde la mar merece su medusa!...

Y creo que de cebra tengo un cuerno y de llama una pata panacea que se gasta en mi alma y que se usa.

Aparte de la supresión de los signos de puntuación y de la letra cursiva, el único cambio significativo es la sustitución en el primer verso de la palabra «oveja» por «oreja». 


\section{APÉNDICE III. POEMAS POSTISTAS EDITADOS EN OTRAS PUBLICACIONES}

Puede considerarse postista la producción poética escrita por Ory entre 1945 y 1949. La mayoría de ellos no forman parte de los poemarios oryanos, se trata de poemas que se publicaron en revistas literarias o permanecieron inéditos hasta que diversas antologías $\mathrm{u}$ otras obras recopilatorias ofrecieran sus espacios para otorgarles una difusión más amplia. Ofrecemos una panorámica establecida por orden de aparición en las diversas antologías y obras recopilatorias.

1. Antologías realizadas por otros autores

1.1. Poesía 1945-1969, ed. de Grande

- «Vuelven los entes de ficción» (1946), p. 58.

• «Oración nocturna» (1946), p. 59.

- «A Concha Coca Codina-Chedd» (1946), p. 60.

• «Tres misterios» (1947), pp. 61-63.

• «Viejo» (1947), p. 64.

- «Poemas de mi Diario» (1947), pp. 65-66.

• «Canción de Dillinger» (1947), p. 67.

- «La casa muerta» (1947), p. 68.

- «Trabajo de amor» (1947), p. 69.

- «Poema ${ }^{508}$ (1947), p. 70.

- «Del derecho internacional» ${ }^{509}$ (1947), p. 71.

- «El hombre de los palomares sucios» (1947), p. 72.

• «Muerta pagana ${ }^{510}(1947)$, p. 73.

- «A un muerto loco» (1947), p. 74.

${ }^{508}$ Acanto, $\mathrm{n}^{\circ} 4$, abril 1947.

${ }^{509}$ Lanza, 1948.

${ }^{510}$ Almanaque «El Grifón», Madrid, Ed, y Publicaciones S.A., 1955, p. 260. 
- «Soneto a Greta Garbo» (1947), p. 75.

- «El rey de las ruinas ${ }^{511}$ (1947), p. 76.

• «Último poema» (1947), p. 77.

• «La virgen del Aprisco» ${ }^{512}$ (1947), p. 78.

· «El santurrón» (1948), p. 79.

- «Soneto escrito en la taberna» (1948), p. 81.

- «Vientos de invierno» (1948), p. 82.

- «Poema escrito con el torso desnudo» (1948), p. 84.

- «Hypocrite lecteur» (1948), p. 85.

- «Fantasías acerca de mi arte» (1948), p. 86.

- «Sobre el invierno agonizo» (1948), p. 88.

- «Velocidad del recuerdo» (1948), p. 89.

- «Ejercicios respiratorios» (1948), p. 90.

• «Utilidad de un muerto» (1948), p. 91.

- «Las palabras ${ }^{513}$ (1949), pp. 92-95.

- «Poema escrito para Carolina» (1949), p. 96.

• «Serenata» (1949), p. 98.

• «Canto irreal» (1949), pp. 99-101.

1.2. Poesía abierta, ed. de Pont

• «Sonata del jardín negro» (1945), p. 18.

• «Niña envuelta» (1945), p. 19.

• «Un verso» ${ }^{514}$ (1945), pp. 20-21.

• «Llamada fúnebre» (1946), p. 25.

• «No sé» (1946), p. 26.

- «Serenata votiva» (1946), p. 27.

- «Un temblor pavoroso» (1946), p. 28.

· «Falta suelo» (1947), p. 31.

- «El hombre nunca es tarde» (1947), p. 33.

- «Mucho te tapas lo que miras» (1947), p. 34.

• «Bifurcación del mundo» (1947), pp. 35-36.

511 Papeles de Son Armadans, n 164, noviembre 1969, p. 169.

512 Dabo, Pliegos de Poesía, n 1, 1951.

${ }^{513}$ Centauro, n 3, Lima, abril 1950.

${ }^{514}$ Este poema y los dos anteriores aparecieron en Garcilaso, n ${ }^{\circ} 28$. 
- «Himno a un poeta» ${ }^{515}$ (1947), pp. 37-38.

- «Recurro a un fuego» ${ }^{516}$ (1948), p. 41.

- «Cuando no cante más» (1948), p. 42.

• «Hoy pienso» (1948), p. 43.

- «La locura» (1948), p. 44.

- «Esta hora» (1948), p. 45.

• «Lo exquisito» (1948), p. 46.

- «Ah el animal con gran olfato» (1948), p. 47.

- «Concordia del bienestar» (1948), p. 48.

- «Canciones de despedida» (1948), pp. 49-50.

• «Préstanos linde» (1948), p. 51.

- «Labios azules» (1948), p. 52.

- «Concentración directa» (1948), p. 53.

- «Amigo fuma» (1948), pp. 54-55.

$\cdot$ • «oema» (1948), p. 56.

• «Espasmo» (1949), p. 59.

- «Mi amigo Don Francisco Frío» (1949), p. 60.

- «¿Me oís o no me oís?» (1949), p. 61.

• «Pensamientos» (1949), p. 62.

- «Academia fantástica» (1949), pp. 63-64.

• «Necesidad poética» (1949), p. 65.

\subsection{Metanoia, ed. de Cózar}

- «Poema a tu figura ${ }^{517}$ (1945), pp.119-120.

- «Robar el mundo» ${ }^{518}$ (1946), p. 121.

- «Oda a las muchachas» ${ }^{519}$ (1946), p. 122.

- «Dame Dios mío este verso» ${ }^{520}$ (1946), p. 123.

- «Inspirado en un retrato de jec» ${ }^{521}$ (1946), pp. 123-124.

- «Homenaje en honor del poeta Camilo José Cela» (1946), pp. 124-126.

${ }^{515}$ Espadaña, n 33, 1948.

${ }^{516}$ Papeles de Son Armadans, n 164, noviembre 1969.

517 Garcilaso, $\mathrm{n}^{\circ} 28$.

${ }^{518}$ Nubis, octubre 1946.

${ }^{519}$ Acanto, $\mathrm{n}^{\circ} 7$, julio 1947.

${ }^{520}$ Lanza, 1946.

${ }^{521}$ Nubis, octubre 1948. 
- «Sobre unos fantasmas que asustaron a Ana» ${ }^{522}$ (1946), p. 126.

· «Oración nocturna» (1946), pp. 127-128.

- «Tres misterios» (1947), pp. 128-130.

- «La casa muerta» ${ }^{523}$ (1947), pp. 130-131.

- «Poema» ${ }^{524}$ (1947), p. 132.

- «Del derecho internacional» ${ }^{525}$ (1947), pp. 133-134.

• «Muerte pagana» ${ }^{526}$ (1947), p. 134.

- «Soy a tu lado» ${ }^{527}$ (1947), p. 135.

- «Cabeza de silencio» ${ }^{528}$ (1947), pp. 135-136.

• «Soneto a Greta Garbo» (1947), P. 136.

• «El rey de las ruinas» ${ }^{529}$ (1947), p. 137

• «Último poema», (1947), P. 138.

- «La Virgen del Aprisco» ${ }^{530}$ (1947), pp. 138-139.

- «El hombre nunca es tarde» (1947), p. 139.

- «Himno a un poeta ${ }^{531}$ (1947), pp. 140-141.

- «Poemas de colores» ${ }^{532}$ (1948), pp. 141-143.

- «Vientos de invierno» (1948), pp. 143.144.

- «Fantasías acerca de mi arte» (1948), p. 145.

- «Recurro a un fuego» ${ }^{533}$ (1948), p. 146.

• «Cuando no cante más» (1948), p. 146.

$\cdot$ • «oy pienso» (1948), p. 147.

• «La locura» (1948), p. 147.

• «Lo exquisito» (1948), p. 148.

• «Concentración directa» (1948), pp. 148-149.

- «Amigo fuma» (1948), pp.149-150.

$\cdot$ • Poema» (1948), 150.

• «Espasmo» (1949), p. 151.

${ }^{522}$ Acanto, julio 1947.

${ }^{523}$ Acanto, marzo-junio 1948.

${ }^{524}$ Acanto, n 4, abril 1947.

${ }^{525}$ Lanza, 1948.

${ }^{526}$ Almanaque «El Grifón», Madrid, Ed. y publicaciones S.A., 1955, p. 260

${ }^{527}$ Halcón, nº 13, 1949.

${ }^{528}$ Ibíd.

${ }^{529}$ Papeles de Son Armadans, $\mathrm{n}^{\circ}$ 164, noviembre 1969.

${ }^{530}$ Dabo, Pliegos de Poesía, $\mathrm{n}^{\circ} 1,1951$.

${ }^{531}$ Espadaña, $\mathrm{n}^{\circ}$ 33, 1948.

${ }^{532}$ Verbo, marzo-abril 1949.

${ }^{533}$ Papeles de Son Armadans, n 164, noviembre 1969. 
- «Discursos del sacerdote ${ }^{534}$ (1949), pp. 151-152.

$\cdot$ «El payaso» (1949), p. 154.

- «Las palabras ${ }^{535}$ (1949), pp. 155-160.

1.4. El Postismo. Un movimiento estético-literario de vanguardia, Pont

- «Vuelven los entres de ficción» (1946), pp. 351-352.

- «Soneto a Greta Garbo» (1947), p. 353.

- «Recurro a un fuego» (1948), p. 354.

· «Amigo fuma» (1948), pp. 355-356.

• «Academia fantástica» (1949), pp. 357-358.

1.5. Antología de poesía postista, ed. de Herrero

• «Vuelven los entes de ficción» (1946), pp. 122-123.

- «Homenaje en honor al poeta Camilo José Cela» (1946), pp. 123-125.

- «Soneto a Greta Garbo» (1947), p. 126.

• «La Virgen del Aprisco» (1947), p. 127.

- «Vientos de invierno» (1948), pp. 127-128.

• «Hypocrite lecteur» (1948), p. 129.

- «Utilidad de un muerto» (1948), pp. 129-130.

1.6. Antología, ed. de Cano Gaviria y Lentine

- «La casa muerta», p. 14.

· «Poema» (1948), p. 51.

• «Academia fantástica» (1949), pp. 52-53.

1.7. Música de lobo. Antología (1941-2001), ed. de Pont

• «Erzulie (icono creolo)» (1947), p. 228.

- «A Greta Garbo» ${ }^{536}$ (1947), p. 229.

- «El hombre de los palomares sucios» (1947), p. 230.

- «La casa muerta» (1947), p. 231.

- «La Virgen del Aprisco» (1947), p. 232.

- «No podré continuar en este trance» (1947), p. 293.

${ }^{534}$ Platero, $n^{\circ} 23$, enero 1954.

${ }^{535}$ Centauro, no 3, Lima, abril 1950.

${ }^{536}$ Éste es el título con el aparece el poema en esta edición. 
• «Concentración directa» (1948), p, 294.

• «Cuando no cante más» (1948), p. 295.

· «Vientos de invierno» (1948), pp. 296-297.

• «Amigo fuma» (1948), pp. 298-299.

- «Las palabras» ${ }^{537}$ (1949), pp. 300-305.

• «Serenata» (1949), pp. 303-307.

• «Espasmo» (1949), p. 308.

· «Academia fantástica» (1949), pp. 309-310.

2. Antologías y obras recopilatorias realizadas por el propio autor

\subsection{Los sonetos}

- «Sobre una voz melodiosa» (1945), p 66

- «Ser luminoso» (1946), p. 33

- «La clave de lo mago» (1946), p. 35

- «Inspirado en un poema de jec» (1946), p. 93

- «La Virgen del Aprisco» (1947) p. 14

- «La casa muerta» (1947), p. 34

- «Del derecho internacional» (1947), p. 39

- «El hombre de los palomares sucios» (1947), p. 43

• «Muerta pagana» (1947), p. 50

• «Oración» (1947), p. 57

- «A un muerto loco» (1947), p. 58

- «Mal toco» (1947), p. 60

- «Pozo calabozo» (1947), p. 62

- «Hice a unos ojos» (1947), p. 73

- «Soneto a Greta Garbo» (1947), p. 88

- «Erzulie (icono criollo)» (1947), p. 90

- «La mano que ata» (1948), p. 30

• «Amo el sueño» (1948), p. 38

- «No duermo nunca» (1948), p. 40

- «Aguanto el mar» (1948), p. 61

- «Abracadabra» (1948), p. 70

${ }^{537}$ Centauro, n 3, Lima, abril 1950. 
- «Los ojos y el alma» (1948), p. 71

• «El santurrón» (1948), p 99

\subsection{Energeia}

- «La clave de lo mago» ${ }^{538}$ (1946), p. 78

• «Versos rimados» (1946), p. 79

• «Dice Leopardi» (1947), pp. 79-80

- «Mal toco» (1947), p. 48

- «Hice a unos ojos» (1947), pp. 81-82

- «Lo que siempre digo» (1947), p. 83

• «A un montón de muertos» ${ }^{539}$ (1947), pp. 84-85

- «Soneto de mi diario» (1948), p. 86

- «No duermo nunca» (1948), pp, 86-87

- «Los ojos y el alma» (1948), p. 87

- «Aguanto el mar» (1948), p. 88

· «Trozos» (1948), pp. 88-89

- «Los días como brazos de mujer» (1949), pp. 89-90

- «A unos creyentes que me invitaron a tomar el té» (1949), pp. 91-92

• «Canto de un corazón» (1949), pp. 92-94

- «Costumbres orgánicas» (1949), p. 95

· «Estudio de estética» (1949), p. 96

\subsection{Soneto vivo}

• «Sobre una voz melodiosa» (1945), p. 123

- «Inspirado en un retrato de jec» (1946), p. 124

$\cdot \ll$ Ser luminoso» (1946), p. 125

- «La clave de lo mago» (1946), p. 126

• «Del derecho internacional» (1947), p. 127

- «Muerta pagana» (1947), p. 128

- «A un muerto loco» (1947), p. 129

$\cdot$ «Pozo calabozo» (1947), p. 130

538 Estos ocho primeros poemas se insertan en Negruras (1946-1950), pero no aparecen en la edición de Poemas (1969)

${ }^{539}$ Los siguientes nueve poemas, incluido éste, pertenecen a Los lejanos lejanos, pero tampoco se incluyen en la edición de Poemas. 
• «Erzulie (icono creolo)» (1947), p. 131

· «Oración» (1947), p. 132

- «Mal toco» (1947), p. 133

• «A Greta Garbo» (1947), p. 134

- «El hombre de los palomares sucios» (1947), p. 135

- «La casa muerta» (1947), p. 136

- «Hice a unos ojos» (1947), p. 137

- «La Virgen del Aprisco» (1947), p. 138

· «El santurrón» (1948), p. 139

- «Aguanto el mar» (1948), p. 140

• «Amo el sueño» (1948), p. 141

- «No duermo nunca» (1948), p. 142

· «Los ojos y el alma» (1948), p. 143

- «Abracadabra» (1948), p. 144

· «La mano que ata» (1948), p. 145

Como puede observarse, la poesía postista oryana consta de una serie de poemas dispersos y de aquellos que forman parte de otras obras editadas con posterioridad. Estos últimos fueron, por ello, reelaborados para ser insertados en unas coordenadas poéticas diferentes a los presupuestos postistas. Este proceso de publicación dispersa y de posterior reescritura y reinserción de los poemas es frecuente en la mayoría de los poetas coetáneos a Ory. 
Con la publicación de Energeia, Ory amplia sus obras con nuevos poemas. Tanto Negruras como Los lejanos lejanos formaban parte junto a El musiquero de las manos fecundas del libro Poemas, publicado en 1969. Negruras contiene poemas que se escribieron entre 1946 y 1962, Los lejanos lejanos está formado por poemas escritos entre 1946 y 1964. Sólo El musiquero de las manos fecundas formaba, cuando se publicó, una unidad orgánica completa. Esta obra consta de poemas escritos entre 1967 y 1969. Cabe señalar también que, en Energeia, su autor fecha los poemas de Negruras y de Los lejanos lejanos entre 1946 y $1950^{540}$. Suponemos por ello que esta datación sólo atañe a los poemas que la antología añade a estas dos obras. Estos son los poemas que Ory añade a estas obras en Energeia:

\subsection{Negruras}

- «La clave de lo mago» (1946), p. 78

- «Versos rimados» (1946), p. 79

· «Dice Leopardi» (1947), pp. 79-80

- «Oración» (1947), p. 80

- «Mal toco» (1947), p. 81

- «Hice a unos ojos» (1947), pp. 81-82

- «Erzulie (icono creolo)» (1947), p. 82

- «Lo que siempre digo» (1947), p. 83

${ }^{540}$ Pont (1998: 177) fecha los poemas de Negruras y de Los lejanos lejanos, siguiendo con las indicaciones que su autor ofrece en Energeia, entre 1946 y 1950. En cambio, en la antología Música de lobo. Antología poética (1941-2001) algunos de estos poemas presentan una datación posterior. Ello mismo ocurre en las antologías realizadas por Grande (1970) y por Cózar (1978). 


\subsection{Los lejanos lejanos}

- «A un montón de muertos» (1947), pp. 84-85

- «Soneto de mi diario» (1948), p. 86

• «No duermo nunca» (1948), pp. 86-87

- «Los ojos y el alma» (1948), p. 87

- «Aguanto el mar» (1948), p. 88

• «Trozos» (1948), pp. 88-89

- «Los días como brazos de mujer» (1949), pp. 89-90

- «A unos creyentes que me invitaron a tomas el té» (1948), pp. 91-92

· «Canto de un corazón» (1949), pp. 92-94 


\section{APÉNDICE V. POEMAS PUBLICADOS EN LA PRIMERA EDICIÓN DE EL MUSIQUERO DE LAS MANOS FECUNDAS}

Originalmente El musiquero de las manos fecundas se editó en la Revista Cuadernos Hispanoamericanos ${ }^{541}$ en 1967 con el título de «El musiquero de las manos fecundas» y otros poemas. En él se publicaron diecisete poemas, de éstos sólo ocho se adscriben a la obra que aparece en Poemas. En la relación que detallamos a continuación, el número de página de la primera edición se acompaña, en letra cursiva, del número de página que corresponde a Poemas (1969).

1. Poemas que forman parte de la obra tal como se editó en Poemas

• «Este poema como», p. 288

- «Hoy tiembla mi cabeza», p. 288

- «Sentado en el cohete», p. 289

- «Los pájaros y el pan», p. 289

- «Los paisajes majestuosos», pp. 289-290

• «Mira este sueño», p. 290

- «En mi naturaleza», p. 290

· «Añoro las pupilas», pp. 290-291

2. Poemas que no forman parte de la obra

- «Pon pereza», p. 291

· «Tocando al ocio», p. 291

- «Nazco piedra», pp. 291-292

$\cdot\left\langle\right.$ El musiquero ${ }^{542}$, p. 292

· «Los poetas», pp. 292-293

· «Edificios invisibles», p. 293

${ }^{541}$ Cuadernos Hispanoamericanos, no 125 , Madrid, noviembre 1967, pp. 288-296.

${ }^{542}$ Aparece en Poesía 1945-1969, ed. de Grande, p. 109. 
- «Arrojo vida», p. 294

$\cdot\left\langle\right.$ No creo en nada ${ }^{543}$, p. 295

$\cdot \ll$ Gran tesis ${ }^{544}$, p. 295

3. Poemas que forman parte de El musiquero de las manos fecundas y no aparecieron en la edición original

- «Tanto quise», p. 57

- «Félix, Félix» ${ }^{545}$, p. 59

$\cdot$ «Finis lagrimae», p. 63

Como puede observarse, estos tres últimos poemas se añadieron a la obra en la edición de Poemas, poemario que se publicó en 1969. El musiquero de las manos fecundas aparece, tal como resultó editado en Poemas, aparece publicado de manera íntegra Música de lobo. Antología (1941-2000), ed. de Pont, pp. 85-88. Este autor lo fecha en 1968.

${ }^{543}$ Ibíd., p. 120 aparece con el título de «No creo nada» y en Metanoia, ed. de Cózar, pp. 173-174.

${ }^{544}$ Aparece en Poesía abierta, ed. de Pont, p. 83.

${ }^{545}$ Aparece en Poesía (1945-1969), ed. de Grande, pp. 226-227; en Metanoia, ed. de Cózar, pp. 256-258; en Antología, ed. de Cano Gaviria y Lentine, pp. 27-30 y 


\section{APÉNDICE VI. POEMAS PERTENECIENTES A LOS POEMARIOS QUE APARECEN EN LAS DIVERSAS ANTOLOGÍAS}

Presentamos aquí los poemas de los diversos poemarios oryanos ordenados según las antologías en las que aparecen. El número de página es el de la antología, el que aparece en cursiva es el del poemario original.

1. Poesía primera (1940-1942)

1.1. Energeia (Poesía 1940-1977)

1.1.1. Sombras y pájaros

- «Hombre», p. 27

p. 50

- «Pájaros», p. 27

p. 49

- «Paisaje», p. 28

p. 36

- «Ocaso lento», p. 28

p. 35

- «Pájaro», p. 29

p. 51

- «Dios», p. 29

p. 50

- «Ser», p. 29

p. 51

- «Madre», p. 30

p. 49

$\cdot$ • Signo», p. 30

p. 39

1.1.2 Poemas de adolescencia

- «Quimera», p. 31

p. 53

- «Invierno», pp. 31-32

p. 169

• «En mí», p. 32

p. 180

- «Luna», p. 33

p. 172

• «Y», pp. 33-34

p. 181

• «Niño», p. 34

p. 172 
- «Angustia», pp. 34-35

- «Era como», p. 35

- «Ángelus», p. 36

p. 179

· «Oración», pp. 36-37

p. 173

- «La tristeza amarilla», p. 37

p. 176

- «Besos en la floresta», p. 37

p. 177

- «Todo es puente», pp. 38-39

p. 174

· «Otro puente», p. 39

p. 175

\subsubsection{La canción meditada}

- «Voz lejana», p. 40

\subsubsection{Canciones amargas}

- «Como Chatterton», p. 43

- «Nocturno I», p. 42

p. 157

- «Imagen», p. 42

p. 162

- «Canción del ocaso», p. 42

p. 16

1.1. Música de lobo. Antología poética (1941-2001), ed. de Pont

\subsubsection{Poemas de adolescencia}

- «La tristeza amarilla», p. 225

p. 176

2. Versos de pronto

2.1. Poesía 1945-1969, ed. de Grande

• «Un verso más», p. 53

p. 16

• «Tres liras a Emilia», p. 54

p. 21

2.2. Metanoia, ed. de Cózar

- «Lamentación del amor que llega», p. 105

p. $18^{546}$

- «Elegía de mi mano», p. 107

p. 18

• «Un verso más», p. 109

p. 16

\footnotetext{
${ }^{546}$ Aparece la versión modificada en Los poemas de 1944.
} 
- «La estudianta», p. $110 \quad$ p. 18

- «Cantando a ella», p. $111 \quad$ p. 18

• «Oda a los jardines», pp. 111-113 p. 19

• «Tres liras a Emilia», pp. 113-114 p. 21

• «Esposa mía», p. 114

- «Dos sonetos», p. 115 p. 21

- «Insomnio», p. $116 \quad$ p. 22

• «Los llantos», pp. 116-117 p. 22

• «Para algunas sensibilidades», pp. 117-118 p. 15

\subsection{Energeia (Poesía 1940-1977)}

- «La garganta canta», p. 48

p. $15^{547}$

- «Cabía yo en el mundo y en tu mano», p. 49 p. $16^{548}$

- «Soy un pecado», pp. 49-50 p. $17^{549}$

- «Como antes», p. $50 \quad$ p. 21

- «Lamentación del amor que llega», $51 \quad$ p. $18^{550}$

• «Amiga», pp.52-53 p. $18^{551}$

- «Oda a una extraña muchacha», pp. 53-54 p. $20^{552}$

• «Bajo fondo», pp. 54-55 p. $19^{553}$

• «Inventos», pp. 55-56 p. $19^{554}$

2.4. El Postismo, un movimiento estético-literario de vanguardia, Jaume Pont

• «Tres liras a Emilia», p. $343 \quad$ p. 21

${ }^{547}$ Aparece una versión modificada, esta es la que se publica en Los sonetos, p. 81. Ver apéndice VII.

${ }^{548}$ En este caso también hay modificaciones. Se sustituye el cuarto verso del primer cuarteto de la edición original («para ti y para mí como un hermano») por este otro: "para los dos en un momento vano». Cambian también los versos tercero y cuarto de segundo cuarteto. En el soneto original éstos figuraban de la siguiente manera: «que yo mi sed para tu sed partía / como la partiré para el gusano». Quedan sustituidos por: "sed con sed más sedientos todavía / hasta que al fin se consumó el desgrano».

${ }^{549}$ También hay variaciones en este poema, ya que ésta es la versión corregida que se publica en Los sonetos, p. 82. Ver apéndice VII.

${ }^{550}$ Aparece la versión de Los poemas de 1944.

551 Ibíd.

552 Ibíd.

${ }^{553}$ Ibíd. de 1944

${ }^{554}$ Ibíd. En Versos de pronto su título era «Fábula». Aparece la versión de Los poemas 
2.5. Antología, ed. de Cano Gaviria y Lentine

• «Un verso más», p. 7

p. $16^{555}$

- «La estudianta», pp. 8-9

p. 18

- «Oda a una mujer extraña», p. 45

p. $20^{556}$

2.6. Música de lobo. Antología poética (1941-2001), ed. de Pont

• «Tres liras a Emilia», p. 343

p. 21

- «Lamentación del amor que llega», p. 50

p. $18^{557}$

3. Los poemas de 1944

3.1. Metanoia, ed. de Cózar

· «Tránsito sombrío», p. 103

p. 20

• «Material de los sueños», pp. 103-104

p. 22

- «Balada del amor muerto», p.104

p. 23

$\cdot$ • $\mathrm{E} 1$ silencio», 106

p. $83^{558}$

\subsection{Energeia}

• «Oscuro mar del sueño», p. 57

p. 16

- «Oda al dolor», p. 58

p. 17

- «Oda a la sangre», p. 59

p. 18

• «Otra oda más», p. 60

p. 19

- «Trenes de roja noche», p. 61

p. 21

3.3. El Postismo, un movimiento estético-literario de vanguardia, Pont

- «Trenes de roja noche», pp. 335-336

p. 21

$\cdot$ • «He de decir mi nombre a las columnas», p.339

p. 43

$\cdot$ «Los vasos», p. 340

p. 52

${ }^{555}$ El poema muestra variaciones. Éstas afectan a los versos segundo, tercero y cuarto. En la edición original éstos figuran de la siguiente manera: «y un paso más y un llanto más que cabe / que si me ven vivir tan poco grave / sepan que es porque vivo todavía» y en la antología tienen la forma siguiente: «y un paso más y un llanto más si cabe / Pues que al verme vivir tan poco grave / digáis que es porque vivo todavía».

${ }^{556}$ El poema aparece adscrito a Los versos de 1944 y contiene su nueva versión con el título cambiado, p. 70.

${ }^{557}$ Pont adscribe el poema Los poemas de 1944, ya que aparece con la versión modificada, p. 67.

${ }^{558}$ Aparece en Garcilaso, n 11, marzo 1944. 
• «Loplop», p. $341 \quad$ p. 71

- «Canto a la muerte», p. $342 \quad$ p. 75

3.4. Antología de poesía postista, ed. de Herrero

• «Loplop», p. 214, p. 71

3.5. Antología, ed. de Cano Gaviria y Lentine

• «Oscuro mar del sueño», p. $41 \quad$ p. 16

- «Material de los sueños», p. 42 p. 22

- «Sinfonía de la muerte», p. $43 \quad$ p. 26

- «A veces alguien dice mi nombre...», p. $44 \quad$ p. 37

• «El silencio», p. $47 \quad$ p. 83

3.6. Música de lobo. Antología poética (1941-2001), ed de Pont

- «Oda a la sangre», p. $41 \quad$ p. 18

- «Trenes de roja noche», $42 \quad$ p. 21

• «Todo cae», $43 \quad$ p 27

- «He de decir mi nombre a las columnas», p $44 \quad$ p. 43

• «Conmigo vas y no lo sabes...», $45 \quad$ p. 45

• «De mis sueños», p. $46 \quad$ p. 50

- «Los vasos», p. 47 p. 52

- «Lo muerto», p. $48 \quad$ p. 53

- «Himno noche», p. $49 \quad$ p. 61

- «Canto a la muerte», p. $51 \quad$ p. 75

- «Se me levanta un toro», p. $52 \quad$ p. 78

• «A mi madre», p. $53 \quad$ p. 79

4. Doblo-hablo

4.1. Poesía 1945-1969, ed. de Grande

- «Soneto paranoico», p. $243^{559}$

- «Cinco poemas edmundianos», pp. 55-56 luna.

${ }^{559}$ La Cerbatana, p. 7, publicación cit. Queda adscrito en esta edición a Laocoonte y la 
· «Laocoonte y la luna», íntegro, pp. 243-260

\subsection{Energeia}

- «Texto postista», pp. 65-66

- «Cinco poemas edmundianos», pp. 67-69

- «Una cuneta en el malecón una nave», p. 69

- «Soneto págame la tarde», p. 71

- «Canto magnífico a los pastores béticos», pp. 72-73

- «Los pinceles puados», pp. 74-75

• «Romance del loco chillón», pp. 75-76

4.3 . El Postismo, un movimiento estético-literario de vanguardia, Pont

- «Soneto paranoico», p. 344

- «Romance de Laocoonte y la luna», pp. 345-346

- «Romance al poeta Silvano Sernesi», pp.347-348

• «Los pinceles puados», pp. 349-350

4.4. Antología de poesía postista, ed. de Herrero

- «Cinco poemas edmundianos», pp. 115-117

- «Soneto paranoico», pp. 117-118

- «Romance de Laocoonte y la luna», pp. 118-119

- «Romance al poeta Silvano Sernesi», pp. 120-121

4.5. Música de lobo. Antología poética (1941-2001), ed. de Pont

- «Texto postista», pp. 57-58

· «Cinco poemas edmundianos», pp. 59-61

- «Soneto paranoico», p. 62

- «Romance al poeta postista Silvano Sernesi», pp. 63-64

$\cdot$ •Los pinceles puados», pp. 65-66

5. Poemas

5.1. Poesía 1945-1969. ed. de Grande

- «Ven triste ve tú», p. 80 
- «Siento ropas», p. $83 \quad$ p. 21

- «Aprende hijo quimérico», $87 \quad$ p. 20

• «Manida música», p. 107 p. 29

• «El dolor», p. 145 pp. 33-34

- «Aprendizaje de desdicha», p. $172 \quad$ pp. 10-11

• «Pesadas nostalgias», p. 184 p. 35

- El musiquero de las manos fecundas, íntegro menos

«Tanto quise»y «Finis lagrimae», pp. 220-222 pp. 49-56

• «Félix Félix», pp. 226-227 2 pp. 59-62

\subsection{Metanoia, ed. de Cózar}

- «Ven triste ve tú», pp. 144-145 p. 15

• «Poderes», p.153 pp.12-13

• «Hay un increíble rumor llorando», pp. 154-155 pp. 27-28

- «El mundo es viejo danza vieja», pp. 178-179 pp. 43-44

- «Dame», pp. 188-189 p. 14

• «El dolor», pp. 200-201 p. 33

• «Negruras», pp. 202-203 p. 18

- «Cuadro de mi alma», p. $205 \quad$ pp. 39-40

• «Pferdefuss», pp. 210-211 p. 36-38

- «A ti la que me inspira obedezco y deseo», p. 212 p. 18

- «Blanco nocturno», p. $213 \quad$ p. 30

- «Apredizaje de desdicha», p. $221 \quad$ pp. 10-11

- «Clima de ratas en la noche», p. $226 \quad$ p. 32

• «Cada noche», pp. 236-237 p. 17

• «Amo», p. $243 \quad$ p. 45

• «Félix Félix», pp. 256-258 pp. 59-62

5.3. Antología, ed. de Cano Gaviria y Lentine

$\cdot$ «Siento ropas», pp. 17-18

pp. 21-22

• «Añoro las pupilas», p. 19

p. 56

$\cdot$ • Finis lagrimae», p. 20

p. 63

${ }^{560}$ En la edición de Grande no está incluido en El musiquero de las manos fecundas. 
- «A ti la que me inspira obedezco y deseo» ${ }^{561}, 26 \quad$ p. 18

- «Félix Félix ${ }^{562}$, pp. 27-30 p p. 59-62

5.4. Música de lobo. Antología poética (1941-2001), ed. de Pont

- «Ven triste ve tú», p. 69

pp. $15-16$

- «Poderes», p. 70

p. 12

- «Siento ropas», p. 71

pp. 21-22

- «Aprende hijo quimérico», p. 72

p. 20

- «El mundo es viejo danza vieja», p. 73

p. $43-44$

- «Pferdefuss», pp. 74-75

pp. $36-38$

• «El dolor», pp. 76-77

pp. 33-34

- «A ti la que me inspira obedezco y deseo», p. 78

p. 18

· «Banco nocturno»,

- «Clima de ratas es la noche», p. 80

p. 32

- «Amo», p. 81

p. 45

- «Félix Félix», pp. 82-84

pp. 59-62

- El musiquero de las manos fecundas ${ }^{563}$, p. 85-88

pp. 49-56

\section{Técnica y llanto}

\subsection{Metanoia, ed. de Cózar}

- «Los poetas», pp. 253-254

pp.62-63

- «Los amantes», pp. 262-263

p. 21

- «Ensenada en mis besos lagartijas» ${ }^{564}$, p. 263

- «Mas lagri», p. 265

- «Gritos interiores lacónicos», p. 265

p. 31

- «Horrible boca», p. 266

p. 32

- «Cansancio del placer», p. 266

p. 34

• «¿Quién?», p.267

p. 46

${ }^{561}$ Los autores de la antología no atribuyen este poema a Poemas, lo recogen de la antología de Félix Grande, Poemas 1945-1969.

562 lbíd.

563 También Pont, siguiendo el criterio de Grande, excluye los poemas «Tanto quise», «Félix Félix» y «Finis lagrimae» de la obra.

564 Este poema fue censurado para la publicación de Técnica y llanto. Aparece en Antología de la poesía erótica española de nuestro tiempo, ed. de J. Caro Romero, París, Ruedo Ibérico, 1973, p. 90. 
- «Dijo esto el poeta», p. 269

- «Confesión del poeta», pp. 269-270 pp. 55-56

$\cdot$ «La mujer», p. $271 \quad$ p. 57

\subsection{Energeia}

• «El mármol no es mi amigo», p. $178 \quad$ p. 15

- «Tengo una fuerza», p. $179 \quad$ p. 16

• «Negros sufrimientos mis ojos», pp. 179-180 p. 20

6.3. Antología, ed. de Cano Gaviria y Lentine

• «El mármol no es mi amigo», p. $33 \quad$ p. 15

- «Los amantes», p. 34 p. 21

- «Los amantes dolientes», p. 35 p. 28

- «Si tuviera un caballo», p. $36 \quad$ p. 43

- «Dijo esto el poeta», 37 p. 51

6.4. Música de lobo. Antología poética (1941-2001), ed. de Pont

- «Ya no está conmigo», p. 117

p. 14

• «El mármol no es mi amigo», p. 118

p. 15

• «Tengo una fuerza», p. 119

p. 16

- «A una mujer», p. 120

p. 19

- «Los amantes dolientes», p. 121

p. 28

- «Las trompetas de la nada», p. 122

p. 39

- «Si tuviera un caballo», p. 123

p. 43

- «Estoy callado», p. 124

p. 44

- «No te he amado a ti sólo», 125

p. 45

· «La separación de los amantes», pp. 126-129

pp. $47-50$

- «Dijo esto el poeta», p. 130

p. 51

- «Trova», pp. 131-132

p. $53-54$

- «Confesión de poeta», pp. 133-134

p. $55-56$

- «La mujer», p. 135

p. 57

- «Biografías», p. 136

pp. 64-65 
7.1. Metanoia, ed. de Cózar

- «Tres cosas», pp. 263-264

p. 13

- «No saber hacer sufrir», p. 267

p. 15

- «La infelicidad del poeta», p. 268

p. 16

• «Maniluvio», pp. 271-272.

p. 22

- «Misterio y tormento», pp. 272-273

p. 23

- «Niveles en el espacio», pp. 273

p. 25

- «Conóceme tu...», p. 274

p. 32

- «Sabiduría loca», p. 275

pp. $57-58$

- «La mujer azul», p. 276

p. 61

- «Doble fidelidad», p. 277

p. 63

• «Poema», p. 277

p. 65

- «Nunca», p. 278

p. 115

- «Homofonía inmódica» ${ }^{565}$, pp. 278-279

p. 125

- «Entre astros y murallas», p. 279

p. 130

- «Todo mi cuerpo es beso vacío», p. 279

p. 132

- «Mi abismo en mis mudanzas», pp. 280-281

p. 134

- «Hipérbole del amoroso», p. 281

p. 77

$\cdot$ «Exclamatorio ${ }^{566}$, p. 281

p. 157

- «Sagrada poesía ${ }^{567}$, p. 282

p. 163

- «¿Por qué estamos todos así tan mal tan mal?», pp. 282-283

p. 173

- «Esperando Satori lejos de Satori», p. 283

pp. 178-179

- «Lo que yo leo lo que yo pienso lo que yo hago», p. 284

p. 182

- «Empecé a gritar en la noche», p. 284

p. 183

- «Y cuando uno es lego no puede asir el hilo», p. 285

p. 185

- «Frase no eres culpable», p. 285

p. 190

\subsection{Energeia $^{568}$}

- «Acción escrita continua», pp. 181-182

pp. $19-20$

${ }^{565}$ Este poema y los tres siguientes son fragmentos del poema extenso «Homofonía inmódica», perteneciente a Los poemas de Karl Borromaüs, Río Piedras, $n^{\circ} 2$, Puerto Rico, marzo 1973, pp.. 149-150.

${ }^{566}$ Ibíd., p. 151.

${ }^{567}$ Ibíd., p. 163 
- «Mundo ardiente», p. 182

p. 30

· «Entre la locura y el sueño», p. 183

p. 35

- «Amar amar», p. 184

p. 59

- «Manos de mono», p. 185

p. 64

• «Tú...», pp. 185-186

p. 70

- «Cuando ando dormido dos oh sí»», p. 187

p. 113

· «Apocalipsis», p. 187

p. 123

- «Oscuridad», p. 188

p. 142

- «Nadie viene nadie viene nadie viene», pp. 189-190

pp. 176-177

- «Oh ya no lloro más ya estuvo bien», p. 190

p. 191

· «Entre el santón jainita y el chamán», p. 191

p. 192

7.3. Antología, ed. de Cano Gaviria y Lentine

· «Sabiduría loca», p.p. 159-160

pp. $57-58$

$\cdot$ • Filadiz», p. 61

p. 96

- «Hablando un oscuro lenguaje», p. 62

p. 164

• «Contra Escaligero», p. 63

p. 195

7.4. Música de lobo. Antología poética (1941-2001), ed. de Pont

- «Acción escrita continua», p. 139

pp. $19-20$

- «Maniluvio», p. 140

pp. 21-22

• «Niveles en el espacio», p. 141

p. 25

• «Conóceme tú», p. 142

p. 32

· «Y sufrimos», p. 143

p. 39

- «Música muda», p. 144

p. 47

- «Estoy que amo», p. 145

p. 50

- «Estoy malo», p. 146

p. 51

- «Manos de mono», p. 147

p. 64

• «Tú...», p. 148

p. 70

· «Monólogo», p. 149

p. 78

- «Carta a Eduardo con contestación», pp. 150-151

pp. $85-86$

· «Lírica absoluta», pp. 152-153

pp. $98-99$

${ }^{568}$ En esta antología, preparada por el propio autor, la obra Agni, a la que pertenecen los tres primeros poemas, está excluida de Lee sin temor. 
- «Un místico un Tristán un errantómano», p. 154

p. 119

- «Homofonía inmódica», p. 155

p. 125

- «Los colores de Wen Yi To Ory», p. 156

p. 139

- «Sabes tú...», p. 157

p. 145

- «Sagrada poesía», p. 158

p. 163

· «Hablando un oscuro lenguaje», p. 159

p. 164

- «Tengo poema encarcelado en el oído», p. 160

p. 193

- «El viento que yo amo es el viento...», p. 161

p. 221

\section{La flauta prohibida}

8.1. Poesía 1945-1969, ed. de Grande

- «Hipocrite lecteur», p. 85

p. 101

- «Fantasías acerca de mi arte», p. 86

p. 102

• «El niño psíquico», pp. 114-115

pp. 121-122

- «Estuve en el cine», p. 116

p. 120

- «En un café», p. 133

p. 119

- «Y», p. 141

p. 147

- «Conjuro», p. 155

p. 130

• «Botija para André Breton», 174

p. 153

• «España (camafeo)», p. 176

p. 129

• «España mística», p. 178

p. 90

· «España pagana», p. 179

p. 91

· «Yo no soy el amo del amor», p. 193

p. 149

- «Soneto», p. 199

p. 98

- «Sacando punta a los dedos», p. 201

p. 107

• «Sollozos», p. 202

p. 151

· «Rumba del ghetto», p. 203

p. 35

- «El bunker del hambre en Auschwitz», p. 204

p. 36

• «Heil Hitler», p. 205

p. 37

8.2. Poesía abierta, ed. de Pont

· «Lengua para los poetas jóvenes españoles», p. 99

p. 123

· «Ovario materno», p. 109

p. 108 
$\cdot$ «Cuatro chillidos», p. 127

- «El poeta no consuela ya más», p. $145 \quad$ p. 43

• «Cesar Vallejo», p. $147 \quad$ p. 48

\subsection{Metanoia, ed. de Cózar}

- «Discurso del sacerdote ${ }^{569}$, pp. 151-152

• «El niño psíquico», pp. 171-172

pp. 121-122

${ }^{569}$ El título con el que este poema figura en la edición de Cózar se cambia por «Discurso sobre el problema inefable». También el poema adquiere una nueva disposición. En Metanoia aparece así:

La honda del enfermo y el horror del tejedor de la catapulta en puente mordido en las oraciones

La úlcera tierna me fatiga y la traquilla escala temo por todas partes los navíos de las moscas y del horror

Verla empleada sin descanso verla pero no mirarla calor de carne y de trigo calor de odio el puente hinchado del dueño del templo

Al pie de los muros los gatos y las mujeres que arrancan taladros y cables dulces estuvieron formulando estuvieron alternativos viendo en recaimiento fiero de la serpiente de la serpiente

Elijo la furiosa carrera y la ola barbuda del abismo el polvo que flota y forma una varonil noche humana

Oh ceremonia cautelosa aumentativo y fresco lago cuando la noche se hace paja y vestidos llenos de pelo pálido amo del amor $y$ de embeleso irrevocable

Cuando el gallo avaro cante dame muchas muchas cenizas dame muchas muchas cenizas ahora que acudí al pontífice que llora a fondo en la taberna y come en la diurna cuadra tribus de nubes y detritus 
· «Estuve en el cine», p. 172.

p. 120

- «En un café», p. 185

p. 119

- «Delicado delirium», pp. 189-190

p. 112

· «Carta», pp. 208-209

pp. 76-77

• «Conjuro», p. 209

p. 130

· «Escitas», p. 216

p. 34

- «Arrojadme un ataúd negro», p. 217

p. 144

- «Botija para André Breton», pp. 222-223

p. 153

• «España (camafeo)», pp. 223-224

p. 129

- «Discurso sobre el problema inefable», p. 227

p. 94

· «España mística», p. 228

p. 90

- «España pagana», p. 229

p. 91

· «Ovario materno», pp. 229-230

pp. 108-109

- «Autoelegía», p. 231

p. 146

- «Yo no soy el amo del amor», p. 238

p. 149

- «La tierra», pp. 238-239

p. 113

- «La tierra es de mis caricias», pp. 239-240

p. 114

- «Argumento para un gran grito», pp. 240-241

pp. $83-84$

- «Sacando punta a mis dedos», p. 242

p. 107

• «Amo», p. 243

p. 117

de incienso y grita con fuerza y llama a las llamas. cambios.

En La flauta prohibida el poema toma una forma reducida y se efectúan algunos

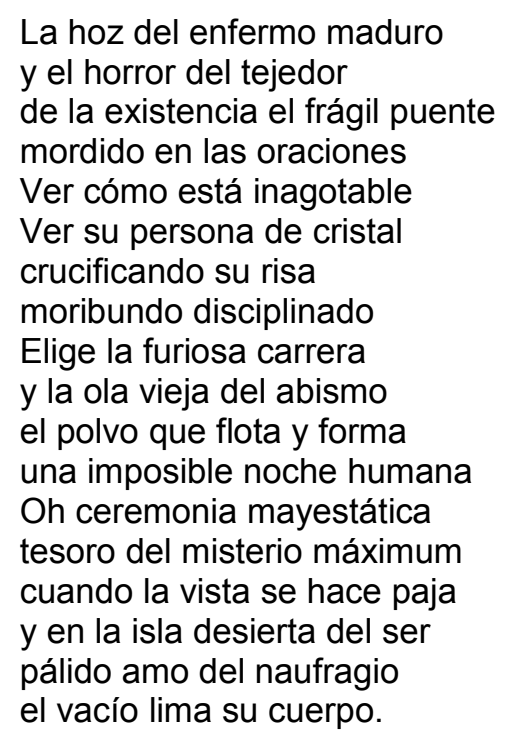


- «Antiguo anticuario», pp. 243-244

- «Rumba del ghetto», pp. 245-246

p. 35

- «El bunker del hambre en Auschwitz», p. 246

p. 36

• «Negro spirituals», pp. 246-247

p. 89

- «Lo mismo soy sublime que grosero», p. 248

p. 97

- «Sueños demóticos de mujer», p. 249

p. 173

- «Himno a Dios», p. 251

p. 96

· «Cristo / Saint-Just», pp. 254-255

p. 33

- «La sacudida inmensa», p. 255

p. 150

• «César Vallejo», p. 298

p. 48

- «Esto», pp. 298-299

p. 41

- «Leche para todos los niños de Chile», p. 299

p. 39

• «Persona non grata», p. 299

p. 38

- «Amor a deshora», p. 302

p. 40

- «Lección de apertura a los cursos de mitologías...», p. 302

p. 47

- «Pablo de Chile», pp. 302-303

pp. $49-50$

8.4. Energeia.

$\cdot\langle\text { Sentencias }\rangle^{570}$, p. 128

p. 117

- «Odio», pp. 131-132

pp. 65-66

• «Hombre en las calles», pp. 132-133

pp. 67-68

- «Carta a un discípulo», p. 134

p. 69

- «Estrofas de golpe», p. 135

p. 72

- «He entrado en París», pp. 135-137

pp. 70-71

• «Oxymoron de la angustia», pp. 137-138

pp. 73-74

- «El caballero de los pies de polvo», p. 139

p. 176

- «El jóven cristo de palabras», p. 140

p. 177

- «El joven aventurero vestido de capa», pp. 140-141

p. 175

- «Así como los caballos olfatean y sienten», p. 141

p. 178

- «El numenius arquatus...», p. 142

p. 179

- «Nunca es tarde», p. 143

p. 162

• «Lapis Lazurius I», p. 144

p. 165

· «Las borracheras», pp. 144-145

p. 128

${ }^{570}$ En esta antología Ory no incluye el poema en La flauta prohibida. 
· «Instantánea», p. 145

p. 127

• «París», p. 146

p. 157

- «Ultradestino», pp. 146-147

p. 158

• «El asesino de una flor», p. 147

p. 160

- «Mi rabo», p. 148

p. 161

- «Catorce veces que», pp. 148-149

p. 159

- «Domingo de ramos», p. 149

p. 164

• «Un siete en la frente», p. 150

p. 163

- «Te aconsejo dormir», p. 150-151

p. 85

• «Que» ${ }^{571}$, pp. 151-152

• «Trípode español», pp. 152-153

pp. 134-135

8.5. Antología, ed. de Cano Gaviria y Lentine

- «Ultradestino» ${ }^{572}$, p. 13

p. 158

• «Sentencias» ${ }^{573}$, pp. 69-70

p. 117

- «César Vallejo», p. 73

p. 48

- «Hombre en las calles», pp. 74-75

pp. 67-68

- «Te aconsejo dormir», p. 76

p. 85

$\cdot \ll$ El asesino de una flor», p. 77

p. 160

8.6. Música de lobo. Antología poética (1941-2001), ed. de Pont

- «El rey de las ruinas», p. 201

p. 92

- «Recurro a un fuego», p. 202

p. 81

- «Hypocrite lecteur», p. 203

p. 101

- «Fantasías acerca de mi arte», p. 204

p. 102

• «Sonido del miedo», p. 205

p. 118

· «Sentencias», p. 206

p. 117

- «Examen de poesía», p. 207

p. 115

- «Carta», pp. 208-209

pp. 76-77

• «Hombre en las calles», pp. 210-211

pp 67-68.

${ }^{571}$ Poema no incluido en la obra, pero integrado en esta antología realizada por el propio autor. Evidentemente queda conectado con el poema "Catorce veces que».

572 Los autores de la antología no lo adscriben a La flauta prohibida, sino que lo recogen de Los sonetos.

${ }^{573}$ Tampoco este poema queda adscrito a la obra, los autores de la antología lo recogen de Energeia, p. 128. Aquí Ory lo adscribe a Órgano costante. 
- «Lingua para los poetas jóvenes españoles», p. 212

p. 123

· «Ovario materno», pp. 213-214

pp. 108-109

- «España mística», p. 215

p. 90

- «Argumento para un gran grito», pp. 216-217

pp. 83-84

- «Tu escritura de guante solitario», p. 218

p. 79

- «César Vallejo», p. 219

p. 49

• «Persona non grata», p. 220

p. 38

- «Delos», p. 221

p. 55

- «Pablo de Chile», p. 222

pp. 49-50

- «Conjuro» ${ }^{574}$, p. 319

p. 131

\section{Miserable ternura / Cabaña}

9.1. Poesía abierta, ed. de Pont

- «Colores originales», p. 121

p. 98

- «Lecturas», p. 122

p. 99

- «Dos palabras», p. 123

p. 101

- «Ambos», p. 124

p. 102

- «Mi circo de pasiones», p. 125

p. 100

- «Sin fecha», p. 126

p. 89

- «Dios dio ordenes», p. 128

p. 103

· «Oh yo allí»», p. 129

p. 106

- «De noche cuando estoy dormido», p. 130

p. 108

- «10 cosas pensando en Anacha», p. pp. 131-133

pp. 113-115

- «Poema», p. 134

p. 116

- «Tengo aspecto de amor», p. 135

p. 121

- «Completa oscuridad», p. 136

p. 122

• «Soy...», p. 137

p. 125

- «Cuando mandrágoras», p. 138

p. 126

• «Tuve miedo...», p. 139

p. 127

- «Iza la intensidad», p. 140

p. 128

· «Dos versos inmortales», p. 141

p. 129

${ }^{574}$ Pont no integra este poema en la obra. 
9.2. Metanoia, ed. de Cózar

• «El mudo», pp. 287-288 p. 31

- «Tres estrofas fervientes», p. $288 \quad$ p. 38

• «Ambos», pp. 288-289 p. 102

- «Vere Gostra» ${ }^{575}$, pp. $289-230 \quad$ p. 105

- «Hay un largo discurso en el silencio», p. $290 \quad$ p. 109

- «Niñería es vivir sin gozar», p. $290 \quad$ p. 111

- «Mi boca es una llaga ya», p. $290 \quad$ p. 112

- «10 cosas pensando en Anacha», pp. 291-291 p. 113-115

- «Tengo aspecto de amor», p. $293 \quad$ p. 121

- «Completa oscuridad», p. $293 \quad$ p. 122

- «Iza la intensidad», p. $293 \quad$ p. 128

- «Dos versos inmortales», p. $294 \quad$ p. 129

• «¿Habréis agradecido bastante?», p. 294 p. 130

• «Con sus manos de plata», p. $297 \quad$ p. 137

\subsection{Energeia}

- «Para Clo», pp. 154-155

pp. 90-91

- «Agua», pp. 156-162

pp. $81-85$

- «Definición de esta noche» ${ }^{576}$, p. 162

p. 85

$\cdot$ «Carmen toda hojas», p. 163

p. 92

- «Carmen», pp. 163-164

p. 93

- «A Carmen la llorona leona», p. 164

p. 94

- «Wagner pregunta a Bakunin», p. 165

p. 96

- «Numinosum», pp. 165-166

p. 97

- «La sed confusa», p. 166

p. 104

- «Nubes y rosas», p. 166

p. 107

- «Silencio música tenaz», p. 167

p. 110

- «Paladar exquisito», p. 167

p. 118

· «Humanismosis», p.168

p. 119

· «El mago simple», pp. 168-169

p. 120

• «Connubium», p. 169 
- «Casablanca con Laura», p. 170

p. 132

· «Anasebo», pp. 170-171

pp. 133-134

- «Trakliana-Oryana», p. 171

p. 136

- «Llorar sobre un ángel», p. 172

p. 138

• «En mi poesía no hay», pp. 172-173

p. 141

- «A Laura que se llama Laura», p. 173

p. 142

• «El árbol de cristal», p. 174

p. 143

· «Helicónides», pp. 174-175

p. 144

• «Juvenir», pp. 175-176

p. 146

- «Correspondencia», p. 176

p. 147

• «Incendio», p. 177

p. 148

- «Krisis», p. 192

p. 45

· «Oro de aire», p. 193

p. 46

- «Palabra tú eres acto o cállate», p. 194

p. 48

- «Tal como fue como fue el sumo encuentro», pp. 194-195

p. 49

- «Desde muy adolescente en Cádiz», p. 195

p. 50

- «Nacer de nuevo», p. 196

p. 52

- «De nuevo nacer de nuevo», pp. 196-197

p. 53

· «Vir obscurissimus», p. 197

p. 59

- «Huí de la mujer», p. 198

p. 62

• «Sobrevivientes», pp. 198-199

p. 64

- «Rosa brutal», p. 199

p. 66

• «Dulzura colosal», p. 200

p. 69

9.4. Antología, ed. de Cano Gaviria y Lentine

- «Tristal cristeza», p. 81

- «Agua», p. 82

p. 82

9.5. Música de lobo. Antología (1941-2001), ed. de Pont

· «Imágenes mágicas», p. 165

p. 11

- «Shivoham», p. 166

p. 12

- «Solitudo saudade», p. 167

p. 33

- «Krisis», p. 168

p. 45

• «Oro de aire», p. 169 
- «Desde muy adolescente en Cádiz», p. 170 p. 50

- «De carne y hueso que soy», p. $171 \quad$ p. 51

- «De nuevo nacer de nuevo», p. 172 p. 53

- «Estarcontigo», p. $173 \quad$ p. 58

• «Fuga», p. 174 p. 60

- «Tristal cristeza», p. $175 \quad$ p. 65

• «Soledumbre», p. $176 \quad$ p. 68

• «Dulzura colosal», p. 177 p. 69

- «Miserable ternura», pp. 178-179 pp. 73-74

- «Adios reina», p. $180 \quad$ p. 75

- «Sin fecha», p. $183 \quad$ p. 89

• «Dos palabras», p. $184 \quad$ p. 101

- «Dios dio órdenes», p. $185 \quad$ p. 103

• «Silencio música tenaz», p. $186 \quad$ p. 110

- «Mi boca es una llaga ya», p. $187 \quad$ p. 112

- «10 cosas pensando en Anacha», pp. 188-190 p. 113-115

• «Connubium», p. $191 \quad$ p. 131

- «Trakliana-Oryana», p. $192 \quad$ p. 136

- «Con sus manos de plata acaricia un perfume», p. $193 \quad$ p. 137

- «En mi poesía no hay», p. $194 \quad$ p. 141

- «Me vas a dejar triste otra vez como anoche». P. $195 \quad$ p. 145

• «Juvenir», p. $196 \quad$ p. 146

• «Incendio», p. $197 \quad$ p. 148

10. Sin permiso de ser ángel

10.1. Música de lobo. Antología poética (1941-2001), ed. de Pont.

- «La misa del degüello», p. 255

pp. $20-23$

- «Taller de frases», pp. 256-257

pp. $24-27$

• «Visitanoche a Allen Ginsberg», pp. 258-259

pp. $38-31$

- «Fiesta del alma», p. 260

pp. 32-33 
11.1. Antología, ed. de Cano Gaviria y Lentine

- «Poeta», pp. 91-92

pp. 22-23

· «Tenebrae», pp. 93-95

pp. 35-36

- «Arcanum» pp. 96-98

pp. $40-42$

· «Adonai Adonaï», pp. 99-100

pp. 60-61

• «Melos melancolía», pp. 101-102

pp. 105-106

11.2. Música de lobo. Antología poética (1941-2001), ed. de Pont

- «Canto criaturial», p. 263

pp. 15-16

· «Tenebrae», pp. 264-265

pp. 35-36

· «Terra», pp. 266-267

pp. 37-39

· «Arcanum», pp. 268-269

pp. 40-42

• «Imágenes», pp. 270-272

pp. $45-47$

· «Pasiones», pp. 273-274

pp. 56-57

• «Adonai Adonaï», pp. 275-276

pp. 60-61

- «Lazareto de los sueños», pp. 277-278

pp. 62-63

- «Poemata», p. 280

pp. $77-78$

• «Melinea», p.281

pp. $80-81$

- «Lantamara», p. 282

pp. $84-85$

· «Nihilismo», p. 283

p. 91

• «Viva vox», pp. 284-286

pp. 90-94

• «Saloma», pp. 287-288

pp. 102-103

• «Melos melancolía», pp. 289-290

pp. 105-106 
En este apartado incluimos dos obras recopilatorias que no pueden considerarse como meras antologías. Su centro de interés gravita en torno al soneto como modelo poético, tanto de tinte clásico como territorio elegido para la experimentación. Por ello crean el ciclo poético de los sonetos, que abarca desde 1941 a 1987. Los sonetos se editaron en 1963 y Soneto vivo en1988. A su vez, algunos poemas publicados por primera vez en Los sonetos quedan recogidos en poemarios y en las antologías posteriores. Otros poemas, en cambio, se hallan únicamente en ella. Soneto vivo, por su parte, contiene casi todos los poemas de Los sonetos y añade algunos nuevos y otros que pertenecen a otras obras. De esta manera, resulta una ampliación de la anterior. Aquí detallamos la situación de los poemas en la obra original, de la que fueron tomados, y el número de página de la obra de este ciclo.

Por otra parte, cuando ya estaba impreso el libro Los sonetos, la censura suprimió tres poemas. Estos son «Eros tremendum», «Fuego en las tripas» $\mathrm{y}$ «El oro de mi instinto», que fueron reemplazados por «Pavana», «La Virgen del Aprisco»y «Llagas de adolescencia», menos peligrosos y más acordes con las coordenadas ideológicas del poder.

\section{Los sonetos}

1.1. Poemas que pertenecen a otras obras:

\subsubsection{Versos de pronto}

• «Un verso más», p. 9

- «Para algunas sensibilidades», p. 53 
- «La garganta canta», p. 81

p. 15

- «Soy un pecado», p. 82

p. 17

\subsubsection{La flauta prohibida}

- «Catorce veces que», p. 10

p. 159

- «Domingo de ramos», p. 16

p. 164

- «Ultradestino», p. 17

p. 158

- «El asesino de una flor», p. 18

p. 160

- «Mi rabo», p. 19

p. 161

• «París», p. 20

p. 157

- «Lapis Lazarius I», p. 22

p. 165

- «Nunca es tarde», p. 29

p. 162

- «Un siete en la frente», p. 113

p. 163

1.2. Poemas recogidos con posterioridad en las diversas antologías

1.2.1. Poesía 1945-1969, ed. de Grande

• «Máquina del dolor», p. 11

p. 189

- «Pavana», p. 12

p. 197

- «Destino», p. 13

p. 186

- «La Virgen de Aprisco», p. 14

p. 78

- «Denise», p. 15

p. 185

- «Llagas de adolescencia», p. 21

p. 198

- «La casa muerta», p. 34

p. 68

- «Del derecho internacional», p. 39

p. 71

• «No me sorprende el sueño», p. 41

p. 72

- «A un muerto loco», p. 74

p. 74

- «Satán al aparato», p. 85

p. 173

- «Soneto a Greta Garbo», p. 88

p. 75

- «Soneto para decir callando», p. 96

p. 151

• «El santurrón», p. 99

p. 79

- «Soneto escrito en la taberna», p. 103

p. 81

- «Eros tremendum», censurado

p. 187

- «Fuego en las tripas», censurado

p. 188 


\subsubsection{Metanoia, ed. de Cózar}

- «Dime hombre», p. 9

· «Máquina del dolor», p. 11

pp. 234-235

- «Destino», p. 13

p. 233

- «La casa muerta», p. 34

pp. 130-131

- «Robar el mundo», p. 37

p. 121

- «Del derecho internacional», p. 39

pp. 133-134

- «Muerta pagana», p. 48

p. 134

- «Para algunas sensibilidades», p. 53

pp. 117-118

- «Soy a tu lado», p. 63

p. 135

- «Cabeza de silencio», p. 65

pp. 135-136

- «Dame Dios este verso», p. 67

p. 123

- «A una muerta amada», p. 72

p. 133

- «Satán al aparato», p. 85

p. 222

- «Soneto a Greta Garbo», p. 88

p. 136

- «Inspirado en un retrato de Jec», p. 93

pp. 123-124

- «Eros tremendum», poema censurado

pp. 233-234

\subsubsection{Energeia}

- «Catorce veces que», p. 10

pp. 148-149

- «Domingo de ramos», p. 16

p. $149^{577}$

- «Ultradestino», p. 17

pp. 146-147

- «El asesino de una flor», p. 18

p. 147

- «Mi rabo», p. 19

p. 148

- «Lapis Lazarius I», p. 22

p. 144

- «Lo que siempre digo», p. 26

p. $83^{578}$

- «Nunca es tarde», p. 29,

p. $143^{579}$

577 Ory inserta el poema dentro del ciclo de La flauta prohibida (1954-1967) y, en su interior, dentro de la obra Todo es una gota de fuego. Este poema no aparece publicado en la edición de La flauta prohibida (1979).

${ }^{578}$ Aunque este poema no forma parte de Poemas (1969), Ory lo integra en Negruras (1946-1950). En esta antología su autor amplía sustancialmente este ciclo.

579 Aunque el poema aparece publicado en La flauta prohibida (1979) en el interior de la obra Novena, en Energeia Ory lo inserta en Todo es una gota de fuego. 
- «Tocando estoy la clave de lo mago», p. 35

p. $78^{580}$

- «No duermo nunca», p. 40

pp. $86-87^{581}$

· «Dos sonetos», pp. 44-45

pp. $108-109^{582}$

- «Cuatro sonetos de Prometeo», pp. 46-49

pp. $112-114^{583}$

- «Ecritos de Dios», p. 54

p. $100^{584}$

• «Dice Leopardi», p. 56

pp. $79-80^{585}$

$\cdot$ •«Oración», p. 57

p. $80^{586}$

- «Mal toco», p. 60

p. $81^{587}$

- «Aguanto el mar», p. 61

p. $88^{588}$

• «Con su mano», p. 64

pp. $109-110^{589}$

- «Hice a mis ojos», p. 73

pp. $81-82^{590}$

- «La garganta canta», p. 81

p. 48

- «Soy un pecado», p. 49

p. 49

- «Erzulie (icono criollo)», p. 90

p. $82^{591}$

- «Un siete en la frente», p. 113

p. $150^{592}$

1.2.4. Antología, ed. de Cano Gaviria y Lentine

· «Ultradestino», p. 15

p. 13

- «La casa muerta», p. 32

p. 14

- «Lapis Lazarius I», p. 22

p. $85^{593}$

· «Los ojos y el alma», p. 69

p. $87^{594}$

\section{${ }^{580}$ Ver nota 574.}

581 Aunque no aparece en Poemas (1969), el poema aparece integrado en el ciclo Negruras, en la obra Los lejanos lejanos.

582 Poema que pertenece al ciclo Órgano constante (1951-1953), publicado íntegramente y de manera exclusiva en Energeia.

${ }^{583}$ Ibíd.

584 Ibíd.

585 Ver nota 574.

586 Ibíd.

587 Ibíd.

${ }^{588}$ Ver nota 577.

${ }^{589}$ Ver nota 578.

590 Ver nota 574.

591 lbíd.

592 Ver nota 573.

${ }^{593}$ Los autores de la antología lo recogen de Soneto vivo.

594 Ibíd. 
1.2.5. Música de lobo. Antología poética (1941-2001), ed. de Pont. ${ }^{595}$

- «Máquina del dolor», p. 10

- «Pavana», p. 12

p. 243

- «Destino», p. 13

p. 236

- «La Virgen del Aprisco», p. 14

p. 232

- «Denisse», p. 15

p. 235

- «Domingo de ramos», p. 16

p. 241

· «Lapis Lazarius I», p. 22

p. 234

- «La casa muerta», p. 34

p. 231

- «El hombre de los palomares sucios», p. 43

p. 230

- «Para algunas sensibilidades», p. 53

p. 227

- «Escritos de Dios», p. 54

p. 233

• «Un verso más», p. 55

p. 226

- «Soneto a Greta Garbo», p. 88

p. 229

- «Erzulie (icono criollo)», p. 90

p. 228

- «Un siete en la frente», p. 113

p. 242

- «Eros tremendum», censurado

p. 239

- «Fuego en las tripas», censurado

p. 238

1.3. Poemas que únicamente aparecen publicados en la obra.

- «A mi esposa», p. 23

- «El inmenso semejante», p. 24

· «Azúcar amarilla», p. 25

- «Lapis Lazarius II», p. 27

- «Nada nada», p. 28

- «Lo mano que ata», p. 30

- «Ser luminoso», p. 33

· «Yo soy potro», p. 36

• «Amo el sueño», p. 39

- «La carroña otoñal», p. 42

- «Buscando mi casa», p. 59

$\cdot$ • Pozo calabozo», p. 62

- «Sobre una voz melodiosa», p. 66

595 Todos los poemas se recogen de Soneto vivo. 
- «Sus dedos eran», p. 68

- «Allí me la pegó naturaleza», p. 69

- «Abracadabra», p. 70

- «La quimera del oro», p. 74

- «Divina comedia», p. 75

- «Dormid así», p. 76

- «Se fue a coger», p. 77

• «No sí», p. 78

- «Marina», p. 79

- «La ninfa perdida», p. 80

- «Soneto del fuego», p. 86

- «A Charles Spencer, llamado Charlot», p. 87

• «Soneto a Joan Leslie», p. 89

- «A tu hija», p. 91

- «A Pilar Paz Pasamar», p. 92

- «Respuesta a un soneto de Rafael», p. 94

- «André Frénaud», p. 95

- «A mi madre», p. 97

- «Primer poema para María Asunción», p. 98

- «Conflictos onomásticos», p. 100

- «Sobre un dicho de Empédocles», p. 101

- «El femenino eterno», p. 102

- «Dos glosas de lobo», pp. 103-105

- «Siete sonetos a un niño», pp. 106-110

- «Dos sonetos en una taberna», p. 111.

\section{Soneto vivo}

2.1. Poemas contenidos en Los sonetos.

- «Nada nada», p. 81

- «A mi esposa», p. 82

- «Nunca es tarde», p. 83

- «Lapis Lazarius», p. 85

- «Denise», p. 86 
$\cdot$ «Destino», p. 87

p. 13

- «París», p. 88

p. 20

- «El asesino de una flor», p. 89

p. 18

- «Mi rabo», p. 90

p. 19

- «Catorce veces que», p. 91

p. 10

- «Fuego en las tripas», p. 92

censurado

- «Ultradestino», p. 93

p. 17

- «Eros tremendum», p. 94

censurado

- «Máquina de dolor», p. 95

p. 10

- «Domingo de ramos», p. 96

p. 16

- «Lo que siempre digo», p. 97

p. 26

- «Azúcar amarilla», p. 98

p. 25

- «El inmenso semejante», p. 90

p. 24

- «El oro de mi instinto», p. 100

censurado

- «Un siete en la frente», p. 101

p. 113

- «Pavana», p. 102

p. $12^{596}$

- «Llagas de adolescencia», p. 103

p. $21^{597}$

· «La garganta canta», p. 116

p. 81

- «Soy un pecado», p. 118

p. 82

· «Un verso más», p. 120

p. 51

- «Para algunas sensibilidades», p. 122

p. 53

- «Sobre una voz melodiosa», p. 123

p. 66

- «Inspirado en un retrato de jec», p. 124

p. 93

• «Ser luminoso», p. 125

p. 33

- «La clave de lo mago». p. 126

p. $35^{598}$

- «Del derecho internacional», p. 127

p. 39

- «Muerta pagana», p. 128

p. 50

- «A un muerto loco», p. 129

p. 58

· «Pozo calabozo», p. 130

p. 62

- «Erzulie (ícono creolo)», p. 131

p. 90

• «Oración», p. 132

p. 57

• «Mal toco», p. 133

p. 60

${ }^{596}$ Poema que en Los sonetos sustituyó a «Eros tremendum».

${ }^{597}$ Poema que en Los sonetos sustituyó a «El oro de mi instinto».

${ }^{598}$ En Los sonetos su título es «Tocando estoy la clave de lo mago». 
- «A Greta Garbo», p. 134

p. $88^{599}$

- «El hombre de los palomares sucios», p. 135

p. 43

- «La casa muerta», p. 136

p. 34

- «Hice a unos ojos», p. 137

p. 73

- «La Virgen del Aprisco», p. 138

p. 14

· «El santurrón», p. 139

p. 94

· «Aguanto el mar», p. 140

p. 61

• «Amo el sueño», p. 141

p. 38

- «No duermo nunca», p. 142

p. 40

- «Los ojos y el alma», p. 143

p. 71

- «Abracadabra», p. 144

p. 70

- «La mano que ata», p. 145

p. 30

- «Escritos de Dios», p. 147

p. 54

• «Con su mano», p. 148

p. 64

- «Los dos sonetos», pp. 149-150

pp. $44-45$

• «Dime hombre», p. 151

p. 9

1.1. Poemas pertenecientes a obras anteriores

\subsubsection{Poesía primera}

2.2.1.1. Poemas de adolescencia.

- «En mí», p. 107

p. 180

- «Y», p. 108

p. 181

- «Era como», p. 109

p. 178

· «Ángelus», p. 110

p. 179

- «La tristeza amarilla», p. 111

p. 176

- «Besos en la floresta», p 112

p. 177

- «Todo es puente», p. 114

p. 174

2.2.1.2. La sombra de la alondra

· «Ipoema», p. 113

p. 185

${ }^{599}$ En Los sonetos su título es «Soneto a Greta Garbo». 


\subsubsection{Canciones amargas}

- «Como Chatterton», p. 115

2.2.2. Versos de pronto

- «La garganta canta», p. 116

p. 15

• «Cabía yo en el mundo», p. 117

p. 16

- «Soy un pecado», p. 118

p. 17

- «Como antes», p. 119

p. 21

· «Un verso más», p. 120

p. 16

- «Para algunas sensibilidades», p. 122

p. 15

\subsubsection{Técnica y llanto}

- «Parece ser que el hombre», p. 15

p. $13^{600}$

2.2.4. Lee sin temor

- «Tanático retrato», p. 16

p. 156

\subsubsection{La flauta prohibida}

- «Nunca es tarde», p. 83

p. 162

- «Lapis Lazarius I», p. 85

p. 165

· «París», p. 88

p. 157

- «El asesino de una flor», p. 89

p. 160

- «Mi rabo», p. 90

p. 161

- «Catorce veces que», p. 91

p. 159

- «Ultradestino», p. 93

p. 158

- «Domingo de ramos», p. 96

p. 164

- «Un siete en la frente», p. 101

p. 163

${ }^{600}$ El título original es «Soneto». 
2.3. Poemas no contenidos en Los sonetos que aparecen en las antologías anteriores y posteriores

2.3.2. Poesía 1945-1969, ed. de Grande

- «Soneto soy de cristal», p. 104

p. $199^{601}$

2.3.1. Metanoia, ed Cózar

- «Hijo de la luz», p. 24

pp. $295-296$

- «Soneto en eses», p. 29

pp. 3304-305

2.3.3. Energeia $^{602}$

• «Acéfalo», p. 17

p. 202

- «Soneto frutas», p. 18

p. 203

- «Soneto me viajo», p. 19

pp. 203-204

- «Mi Laura de Noves», p. 20

p. 204

- «Ajo ojo», p. 23

p. 205

- «Palacio del insomnio», p. 24

pp. 205-206

- «Mirándome el pie», p. 25

p. 206

- «Satori», p. 26

p. 207

- «Tambor de sicomoro», p. 27

p. 217

- «El publicano», p. 28

pp. 207-208

- «Combate», p. 33

p. 208

2.3.4. Antología, ed. de Cano Gaviria y Lentine

- «Tambor de sicomoro», p. 27

p. 86

2.3.5. Música de lobo. Antología poética (1941-2001), ed. de Pont

- «Mi Laura de Noves», p. 20

p. 244

- «Soneto en eses», p. 21

p. 246

- «Tambor de sicomoro», p. 27

p. 245

- «Tú y yo delante de la casa muerta», p. 31

p. 247

${ }^{601}$ En la edición de Félix Grande, el título del poema es «Soneto».

602 Todos estos poemas, a excepción de "Tambor de sicomoro», se incluyen en el ciclo de Soneto vivo, que en la fecha de publicación de antología, realizada por el propio Ory, abarca desde 1971 a 1977. En cambio, «Tambor de sicomoro» se inscribe en el ciclo Tambor de sicomoro, fechado entre 1975 y 1977. 
- «Ventrílocua vates», p. 37

p. 248

- «Voz de luz», p. 56

p. 249

- «Gaya ciencia», p. 66

p. 250

- «Ave fénix», p. 73

p. 251 


\section{APÉNDICE VIII. VARIACIONES DE LOS POEMAS ORIGINALES EFECTUADAS EN EL CICLO DE LOS SONETOS}

La escritura oryana se define como una continua reelaboración de los poemas originales. Se trata de una poesía en constante movimiento, dinámica y cambiante, que se halla en permanente proceso de reconstrucción. Cada nueva publicación supone una modificación de la poesía anterior. Esta es, pues, una poesía de la reescritura.

Los sonetos (1963), de algún modo, constituye una reelaboración de la poesía anterior. Los poemas que pertenecen a Versos de pronto sufren modificaciones en las ediciones posteriores. De modo general, en cada edición los poemas van adquiriendo nuevas disposiciones. Los sonetos supuso la primera trasmutación de la poesía oryana, en esta publicación se cambió la forma de algunos de los poemas anteriores. Este mismo proceso de reconstrucción se efectúa en también Los poemas de 1944 (1973), como se ha visto ren el Apéndice I, y en Las patitas de la sombra, obra en la que algunos romances han experimentado sustancialmente cambios sustanciales, tal y como se podido observar en el Apéndice II. Los cambios que aparecen en Los sonetos son confirmados por el autor en Energeia (1978), la única antología sobre su propia poesía que Ory realizó. Obra que, además, supone una nueva reelaboración de la poesía anterior. En ella Ory modifica algunos poemas de su poesía primera y de su etapa postista.

En Soneto vivo (1988) asistimos otra vez al escenario de una nueva transformación. Esta obra modifica los modelos anteriores que se ofrecían en Los sonetos. De esta manera la poesía oryana pierde de vista el modelo original para instaurarse como copia de la copia. Poesía que está sometida a un proceso constante de deconstrucción, que se ofrece como una dinámica reconstrucción. 
Las variaciones efectuadas sobre los viejos poemas operan por simbiosis. Estas se basan, por una parte, en la semejanza del significado, pues las palabras cambiadas deben funcionar en la misma línea significativa contextual. De otro lado, las modificaciones operan también en la similitud fónica. El punto de partida de la sustitución de una palabra por otra es la coincidencia de algunos sonidos, como pueden ser los iniciales o los finales, fonemas que se repiten y otros sonidos coincidentes. Los cambios no alejan en demasía el nuevo poema de la forma anterior, son pequeñas alteraciones que surgen como ínfimas mutaciones orgánicas y señalan, en todo caso, la naturaleza cambiante de una poesía dinámica.

1. Variaciones que aparecen en el ciclo de Los sonetos

\subsection{Versos de pronto}

\subsection{1. «Para algunas sensibilidades»}

Este poema sufre pocos cambios a lo largo del tiempo. Comparado con otros, sus cambios son mínimos. En Los sonetos (p. 53) existen algunos cambios respecto al poema original de Versos de pronto (p. 15). En su nueva forma desaparecen casi todos los signos de puntuación. Prácticamente los únicos cambios sufridos son la supresión del pronombre pronominal «se» del cuarto verso y el punto que cierra el primer soneto y parte la frase que se encavalgababa del primer al segundo soneto. De esta forma aparece en la edición original:

La casa, el vaso y si la siempreviva no se pusiera en flor y si tu cara no se pusiera en flor y si dejara la casa, el vaso[,] y si se mueriera viva

en la tierra, en la casa, en donde liba su raíz sublunar, en donde vara [...]

En Los sonetos existe una ruptura entre el primera y la segunda estrofa, marcada por un punto:

$[\ldots]$ no se pusiera en flor y si dejara 
la casa el vaso y si muriera viva.

En la tierra en la casa en donde liba $[\ldots]$

En Soneto vivo (p.122) se produce algún cambio respecto a las formas anteriores. En ellas los dos tercetos tenían la siguiente disposición:

Que lo recuerdo en medio de la casa tanta sed para vaso tan pequeño $\mathrm{y}$ todo el mar en la pequeña boca.

Ya en el sueño tu cuerpo rompe el asa y no puedo cogerlo por el sueño cuando la mano de mi sed lo toca.

El poema cambia de forma en la última edición. Se trata de algunas modificaciones que afectan al último verso del primer terceto y a los dos primeros del segundo terceto:

$[\ldots]$

tanta sed para vaso tan pequeño

y todo el mar tan grande en poca boca

Ya en mi sueño la ola me traspasa

como un recuerdo en el que pierdo el sueño

cuando la mano de mi sed lo toca.

\subsection{2. «Un verso más»}

Existen cambios en este soneto de Versos de pronto (p. 16). En Los sonetos (p. 55) se modifica mínimamente el primer cuarteto y el segundo terceto. Además se suprimen los signos de exclamación que abren y cierran el primer terceto. El primer cuarteto del soneto original tenía la siguiente forma:

Un verso más[,] Dios mío[,] y otro día y un paso más y un llanto más que cabe que si me ven vivir tan poco grave sepan que es porque vivo todavía. 
En Los sonetos este se modifica, partiendo con un punto la frase al final del segundo verso. Además se cambian algunas palabras en el tercer verso y el cuarto verso.

Un verso más Dios mío y otro día y un paso más y un llanto más que cabe. Pues que al verme vivir tan poco grave digáis que es porque vivo todavía.

También varía el segundo verso del último terceto. En Versos de pronto esta estrofa tenía la siguiente disposición:

Pero cada mañana como todos salgo del sueño donde estoy de codos y un verso más[,] y un día más[,] y un paso.

En Los sonetos cambia la primera palabra del segundo verso:

Pero cada mañana como todos vuelvo del sueño donde estoy de codos: y un verso más y un día más y un paso.

En Soneto vivo (p. 120) se suprimen todos los signos de puntuación, incluidos los de la versión de Los sonetos.

\subsection{3. «La garganta canta»}

Este poema que pertenece Versos de pronto (p. 15) experimenta algunos cambios en la edición de Los sonetos (p. 81). Los cambios sólo afectan al segundo cuarteto. En Versos de pronto este presenta esta disposición:

Vuelo[,] me paro de la carne santa tanto polvo de tierra recrecida se me junta. Me paro y se me anida un pie en el corazón y se adelanta.

En Los sonetos este cuarteto toma otra forma:

Vuelo me paro de la carne santa tanto polvo de tierra sin salida 
busca salida y ando y se me oxida

un pie en el corazón y otro en la planta.

Esta es la versión que se recoge en Energeia (p. 48), la única modificación se reduce a la supresión de los signos de puntuación. En Soneto vivo $(\mathrm{p}, 116)$ el poema aparece con la misma disposición que poseía en Energeia.

\subsection{4. «Soy un pecado»}

Este soneto se publica por primera vez en Versos de pronto (p. 17). En Los sonetos (p. 82) sufre algunas modificaciones. Se sustituye la palabra «venas» del original por «penas» en el segundo verso.

Soy un pecado[,] tengo el alma llena de venas[,] y quisiera un monte oscuro

Soy un pecado tengo el alma llena de penas y quisiera un monte oscuro

El segundo cuarteto de la primera edición:

Soy un pecado más, soy una pena más, soy lo que más odio y más procuro[...] $\mathrm{y}$ en mis ojos de nada y llanto duro apenas [si] la luz circula y frena.

queda sustituido por:

Soy un pecado dentro de una pena y soy lo que más odio y más procuro siento en mis ojos blancos llanto duro donde apenas la luz contiene antena.

Cambia también el primer terceto, este en su versión inicial posee la siguiente forma:

Mi muerte está en mi frente[,] cómo baja[...] ...cómo estuvo en mi pelo... iy qué suave hasta mis ojos va llegando y llega...! 
En Los sonetos queda sustituido el último verso por «hasta mis pies resbala que me anega!». De manera que este terceto queda así:

Mi muerte está en mi frente cómo baja ... cómo estuvo en mi pelo... iy qué suave hasta mis pies rebala que me anega!

En Energeia (pp. 49-50) aparece la versión de Los sonetos sin los signos de puntuación. Del mismo modo aparece en Soneto vivo (p. 118).

\subsection{5. «Cabía yo en el mundo»}

Este poema de Versos de ponto (p. 16) sufre algunas modificaciones en Soneto vivo (p. 117), pues aquí aparece publicada la versión de Energeia (p. 49). Ver Apéndice IV, nota. 544. Los cambios afectan al cuarto verso del primer cuarteto y a los versos tercero y cuarto del segundo:

$\begin{array}{ll}\begin{array}{l}\text { un racimo redondo de alegría } \\ \text { para ti y para mí como un hermano }\end{array} & \text { (v. 3) } \\ \begin{array}{l}\text { un racimo redondo de alegría } \\ \text { para los dos en un momento vano }\end{array} & \text { (v. 3) } \\ \text { zumo fué por tu sangre sangre mía } & \text { (v. 5) } \\ \text { que yo mi sed para tu sed partía } \\ \text { como la partiré para el gusano. }\end{array}$

\subsection{Otros poemas}

\subsection{1. «Sobre una voz melodiosa»}

En este poema las variaciones que ofrece la edición de Soneto vivo (p. 123) respecto a la de Los sonetos (p. 67) son muy sutiles. De hecho, se trata de cambios mínimos. En el primer verso se suprime el primer punto:

Ya sé que es ella[.] Pero ¿tan temprano? 
Ya sé que es ella pero ¿tan temprano?

Otra variación se produce en el último verso del segundo cuarteto:

para mi triste mudo labio enano.

que me abre el día y me despierta en vano

En los versos siguientes sólo hay dos variaciones. Se trata del verso final de las siguientes estrofas. En la tercera queda sustituida la última palabra del verso final del primer terceto «hilo», por la palabra «tilo»:

la madera de un hombre como un hilo? (v. 11)

la madera de un hombre como un tilo?

Y en el último verso de la cuarta estrofa se cambia la palabra «filo» por «hilo».

¡Más que voz! ¡Más que ala! ¡Más que filo! (v. 14)

¡Más que voz! ¡Más que ala! ¡Más que hilo!

\subsection{2. «Ser luminoso»}

En este poema las variaciones sufridas también son mínimas, sólo afectan a los dos últimos versos del segundo cuateto. Si en Los sonetos (p. 33) estos tenían la siguiente disposición:

por los muros ocultos donde yerra mi propio bulto con su propio peso.

en Soneto vivo (p. 125) aparecen con la siguiente forma:

por estos muros donde mi alma erra erre que erre y la sostengo en peso 


\subsection{3. «Del derecho internacional»}

Aquí los cambios todavía son menos perceptibles. En Soneto vivo (p. 127) simplemente se suprime la mayúscula de la palabra «Enmienda» del segundo verso del segundo cuarterto, los dos puntos que cierran el primer verso del último terceto y los signos de admiración que abren y cierran el último verso del poema de la edición de Los sonetos (p. 39). Quedan suprimidos todos los signos de puntuación. Mostramos aquí los cambios:

$$
\begin{aligned}
& \text { pronunciar yo el discurso de la Enmienda } \\
& \text { pronunciar yo el discurso de la enmienda } \\
& \text { [i]y una libra de oro será el mundo[!] } \\
& \text { y una libra de oro será el mundo }
\end{aligned}
$$

2.1.4. «A un muerto loco»

Este poema también sufre cambios mínimos. Solamente varían los versos segundo y tercero de la primera estrofa. Quedan sustituidos los de la edición de Los sonetos (p. 58):

¿O bien braceando en las helíceas heces no sé si con las aves o los peces

por:

\footnotetext{
¿O bien como humo subes y te meces entre nubes con aves o con peces
}

de la edición de Soneto vivo (p. 129).

\subsection{5. «Pozo calabozo»}

En este poema sólo cambian dos palabras y dos versos del poema publicado en Los sonetos (p. 62). En Soneto vivo (p. 130), el último verso del segundo cuarteto sustituye «sus dolientes» por «delicados»: 
con sus dolientes dedos cuando gozo

con delicados dedos cuando gozo

En el último verso del primer terceto, se sustituye la palabra «amigo» por «abrigo»:

y es mi amigo y mi sombra inevitable.

y es mi abrigo y mi sombra inevitable.

Por otra parte, en la última estrofa varían los dos últimos versos:

Ardo y me pierdo en este matrimonio triste que yo lo veo inconfesable, pues quien vela mi sueño es el demonio.

Ardo y me pierdo en este matrimonio del cielo y el infierno miserable ¿llora un ángel con risa de demonio?

2.1.6. «Hice a unos ojos»

En este poema también las variaciones son mínimas, sólo afectan a una palabra y a dos versos de la primera estrofa. En Los poemas (p. 73) la primera estrofa aparece del siguiente modo:

No me mires con ojos de balido de desvalido espino de cigüeña de sin origen de escondido nido de noche que naufraga en una seña.

En Soneto vivo (p. 137) la estrofa queda así:

No me mires con ojos de balido de desvalido esclavo de cigüeña que emigra solitaria y busca nido de noche naufragando en una seña

En Energeia (pp. 81-82) el poema aparecía en su forma definitiva, incorporadas ya estas modificaciones. 


\subsection{7. «Amo el sueño»}

En este poema los cambios realizados en Soneto vivo (p. 141) son más perceptibles. Por un lado cambian totalmente los cuartetos, en Los sonetos (p. 38) los dos cuartetos tenían la siguiente forma:

Si lo dormido nunca duerme y ello es un misterio y el misterio es suyo lo dormido es un sello y un capullo y no hay misterio más pequeño y bello.

Si es el misterio una dormida huella que vive y muere aunque su mundo es vivo el misterio es lo mismo que una estrella que bulle en lo alto de su brillo esquivo.

que cambian por esta otra:

Si el sueño del arroyo es el arrullo y el sueño es dueño del misterio ello tiene en la noche oscura timbre y sello por cuanto el rey del sueño siente orgullo

Se ilumina la mina del ser cuyo tesoro de oro humano es lo más bello que conoce el dormido en un destello lumbre en la sombra brillo de cocuyo

Por otro lado, el poema sufre pequeñas variaciones por la sustitución de algunas palabras o de todo un verso. En las dos últimas estrofas sólo existen pequeños cambios y algunas sustituciones de palabras:

Amo el sueño porque es señal de una más grande seña[,] de la muerte seña es seña de la muerte y de la luna[.]

Amo el misterio por su semejanza al sueño y a la muerte y a la leña que engendra el fuego hermano de la danza[.]

Amo el sueño porque es señal de una más grande seña de la muerte enseña igual que la guadaña de la luna 
Amo el misterio por su semejanza

con el sueño y a la muerte y con la leña

que engendra el fuego hermano de la danza

\subsection{8. «La mano que ata»}

En este poema sólo se modifican tres versos, el último del primer terceto y los dos primeros del segundo. En la edición de Los sonetos (p. 30) los tercetos están dispuestos de la forma siguiente:

No es todo vano no es vano este vino de tu sal viva que mi lengua aprieta mirando al mar que bulle en el amor[.]

Sólo es vana la cosa y el divino espino de la rosa que sujeta la mano que ata el cielo con la flor[.]

En Soneto vivo (p. 145), estos quedan así:

No es todo vano no es vano este vino de tu sal viva que mi lengua aprieta sintiendo la saliva del amor

Y nada menos vano que el espino del divino rosal cuando sujeta la mano que ata el cielo con la flor 
Con anterioridad a la publicación de la obra ya habían aparecido editadas en la revista Papeles de Son armadans los poemarios La flauta prohibida ${ }^{603}$ y El rey de las ruinas $^{604}$, cuyos poemas quedaron integrados en la edición de 1979. En la nueva edición se amplía el número de poemas que forman parte de El rey de las ruinas, exactamente se suman 9 poemas a los 18 poemas de la primera edición.

1. Poemas publicados en la primera edición de La flauta prohibida.

• «Prólogo a un plato de lentejas», pp. 257-258

p. 101

- «Mi clima puesto en himno», pp. 259-260

pp. 103-104

- «Antiguo anticuario», pp. 261-262

pp. 105-106

- «Sacando punta a mis dedos», p. 263

p. 107

• «Amo...», p. 264

p. 116

- «La tierra», p. 264

p. 113

• «Delicado delirium», pp. 266-267

p. 112

· «Examen de poesía», p. 268

p. 115

2. Poemas publicados en la primera edición de El rey de las ruinas.

- «Tu escritura de guante solitario», p. 159

p. 79

- «Saber estar de rodillas», p. 159

p. 80

$\cdot$ - «Recurro a un fuego», p. 160

p. 81

• «Un maestro de Job», p. 160

p. 82

- «Argumento para un gran grito», pp. 161-162

${ }^{603}$ Papeles de Son Armadans, $n^{\circ} 114$, septiembre, 1965, pp. 257-268.

${ }^{604}$ Papeles de Son Armadans, $n^{\circ}$ 164, noviembre, 1969, pp. 158-174.

${ }^{605}$ En la edición posterior el poema lleva por título «Hipocrite lecteur». 
- «Te aconsejo dormir cuando no puedas» ${ }^{606}$, p. 163 p. 85

- «Poema que no pude proseguir por miedo», p. 164 p. 86

· «Estar ungido por las lágrimas», pp. 165-166 pp. 87-88

• «Negro spirituals», p. $167 \quad$ p. 89

• «España mística», p. 168 p. 90

- «El rey de las ruinas», p. $169 \quad$ p. 92

• «Rogativa introito», p. $170 \quad$ p. 93

- «Discurso sobre problema inefable», p. 171 p. 94

- «Mis manos son azadas de oro», p. 172 p. 95

• «Himno a Dios», p. 172 p. 96

- «Lo mismo soy sublime que soy grosero», p. $173 \quad$ p. 97

• «Soneto», p. $174 \quad$ p. 98

3. Variaciones entre los poemas de ambas ediciones.

\subsection{La flauta prohibida}

\subsection{1.«Prólogo a un plato de lentejas»}

Ya se ha comentado el cambio de título de la edición posterior por el de «Hypocrite lecteur». El poema antiguo se parte en dos poemas diferentes. La primera estrofa del poema original se transforma en el poema «Prólogo a un plato de lentejas», situado en la página 101 de la nueva edición. Las estrofras segunda y tercera de poema originario forman ahora, sin separación estrófica alguna, el nuevo poema titulado «Fantasías acerca de mi arte» (p. 102). La primera estrofa del poema originario venía formada por los primeros ocho versos. Y los nueve versos restantes formaban la segunda y tercera estrofas del poema originario.

\subsection{2. «Mi clima puesto en himno»}

Se sustituye la última estrofa del poema originario por otra. En el poema originario, esta estrofa quedaba formada del siguiente modo:

Un auxiliar, me califico loco

también del niño y de la voz del caos

${ }^{606}$ En la edición posterior el título se acorta: «Te aconsejo dormir». 
Un hijo de esta noche y de otra noche que ama la danza y el amor que vive

En el poema posterior la última estrofa queda así:

También del niño y de la voz del caos

Un hijo jovenado de la noche

que ama la danza enorme del amor

Pero también me califico loco

\section{1 .3 «Amo...»}

En este poema se efectúan dos cambios importantes. Se amplía la segunda estrofa, se añaden el tercer y el cuarto versos a los dos primeros que formaban la estrofa en el poema inicial. En la primera versión, la segunda estrofa tenía esta disposición:

Amo los fuegos fatuos

y las vírgenes fatuas

En la edición posterior queda así:
Amo los fuegos fatuos
y las vírgenes fatuas
Amo los abanicos
y los pavos reales

La tercera estrofa también se amplía. La del poema original era la siguiente:
Amo el mal más que la miel
y el viento más que el bien
Amo los saltimbanquis
y los bancos de arena
Amo los abanicos
y los pavos reales

En la edición posterior esta estrofa queda de este modo:

\footnotetext{
Amo lo que se enciende

lo que vuela y se abre

lo que enloquece y crece
} 
lo que se mueve y salta

lo que bebe los vientos

lo que es contacto y música

lo que es vasto y casto

lo que es milagro y peligro

lo que respira y se estira

lo que viaja por antojo

\subsection{El rey de las ruinas}

\subsection{1. «Recurro a un fuego»}

Se añade el verso quinto al poema original, cuya forma es la siguiente:

Recurro a un fuego en que hablo y callo fuego

De allí no salgo y me oigo el alma y cuando

sumo mis ojos de un misterio ciego cuando los sumo y cuando estoy hablando

de un silencio mortal Recurro a un fuego

En la edición final el poema queda así:

Recurro a un fuego en que hablo y callo fuego

De allí no salgo y me oigo el alma y cuando

sumo mis ojos de un misterio ciego

cuando los sumo y cuando estoy hablando

mis ojos oyen y mi boca anega

de un silencio mortal Recurro a un fuego

\subsection{2. «Un maestro de Job»}

Se añaden dos versos y el subtítulo del poema «Mesopotamia» a la versión original. Se trata de los versos undécimo y duodécimo. Si el final del poema en la primera edición era este:

Cuando como invoco el nombre de la diosa Me llegará

en la edición posterior queda así:

Cuando como invoco el nombre de la diosa Así pienso que la gracia de Dios 
me llegará

Me llegará

\subsection{3.«Te aconsejo dormir»}

El título original era «Te aconsejo dormir cuando no puedas». En el séptimo verso hay un cambio que pasa casi inadvertido; en el poema original aparecía la expresión «medianoche», formada por la unión de las dos palabras, y en la versión posterior éstas aparecen separadas. Así

asómate al balcón a medianoche

queda sustituido por:

asómate al balcón a media noche

3.2.4. «Poema que no pude proseguir por miedo»

Cambian los versos sexto y noveno. En la primera edición el poema toma esta disposición:

$$
\begin{aligned}
& {[\ldots]} \\
& \text { Me vio a mí un gran toro } \\
& \text { y le dije: ¡Por Dios! } \\
& \text { Me vio a mí una ventana } \\
& \text { abierta y no me dijo } \\
& \text { ciérrame ciérrame } \\
& {[\ldots]}
\end{aligned}
$$

En ella se producen dos cambios casi insignificantes. En el verso sexto la expresión «¡Por Dios!» queda sustituida por «ipordiós!»y en el noveno «ciérrame ciérrame» queda sustituido por «ciérrameciérrame». De modo que el fragmento queda así en la última edición:

\section{$[\ldots]$}

Me vio a mí un gran toro

y le dije: ¡pordiós!

Me vio a mí una ventana

abierta y no me dijo

ciérrameciérrame 


\section{$[\ldots]$}

\subsection{5. «Negro spirituals»}

En este caso los cambios son parecidos, en el segundo y en el octavo versos se unen las expresiones que en el poema original estaban separadas. El verso segundo aparecía así:

$$
\text { Ay Jesús Ay Jesús }
$$

y se cambia por

$$
\text { AyJesús AyJesús }
$$

El verso octavo, cuya disposición era:

$$
\text { Ay Jesús y María }
$$

se cambia por:

$$
\text { AyJesúsyMaría }
$$

3.2.6. «Discurso sobre problema inefable»

En este poema cambia el tercer verso, fruto de la supresión del punto. Si originariamente el inicio de poema mostraba este aspecto:

La hoz del enfermo maduro y el horror de tejedor de la existencia[.] El frágil puente mordido en las oraciones $[\ldots]$

En la edición posterior toma la siguiente disposición:

La hoz del enfermo maduro y el horror de tejedor de la existencia el frágil puente 
mordido en las oraciones

[...] 


\section{APÉNDICE X. EDICIONES DE MELOS MELANCOLÍA.}

Melos melancolía se publica en 1999 y supone una reconstrucción de poemas publicados en revistas literarias ${ }^{607}$. La obra integra Érase una vez una voz y Nabla. La primera parte está compuesta por 24 , de los que 23 ya fueron publicados. Únicamente «Crepúsculo del batelero» es inédito. La segunda queda formada por 15 poemas. La edición de 2004 añade un poema a Nabla. Este se titula «Conjuros y delirios» ${ }^{608}$ :

Aún tengo un minuto para mi lindo papel

coloca bien la desesperación

en el nido de la línea grotesca

qué poema no se perfecciona

con un poco de vacío silencioso

Estoy al tanto de mi sola gnosis

Bajo las manos versi strani

La voz metanocturna del no clama

su experiencia maníaca

Aldabonazo o chispa que habla bien

Mirad la mano paralítica del no

con su amada batuta

El no que no se empina ni no

se agacha nunca ante el consuelo lelo

Sin ataque se libra su álef

Despeña el alma en la palabra sofá

rodéate de ninfas tan sólo un cuarto de hora

Y si miras el mapa invisible del mundo

descubrirás los elfos de máxima elegancia

Vete de aquí y llévate tu lupa

Ningún ángel bromea hazte amigos supernos

Da las gracias al viento que ulula

y regala tu oído terreno de vacío

Un soplo inmenso consuela el corazón

607 Ana Sofía Pérez Bustamante (2012: 14). La primera parte de la obra, Érase una vez una voz, está formada por poemas que aparecieron en diversas revistas entre 1980 y 1995 , aunque su fecha de escritura queda situada entre 1979 y 1986 . Nabla, segunda parte de la obra, consta de poemas publicados entre 1977 y 1995.

${ }^{608}$ Melos melancolía, Montblanc, Igitur, 2003, pp. 95-99. 
que plañe la belleza estallando en sollozos

Ha terminado el orbe del horizonte solar

Tiempos malignos de cadenas a ultranza

¡Maldito lo que no sea abierto espacio!

Tumba y abismo desespera el alma

enemiga de la negrura

Despierta de tu sueño sordomudo de bípedo

y limpia con esencia de eucalipto la atmósfera

Todo el tiempo metido en tu retrete de pesadillas

En las capas inferiores se ha perdido el respeto

al viento serio y magnífico

Riqueza del espacio en su antiguo gorjear

¿Dónde están los discípulos ardientes del desierto?

Montañas de carroña terrores y terrores

Los sótanos sangrientos llenos de dinero

Y yo que fui tan anochecedor

metiéndome en los coches más negros de las noches

Tan negra es la ventana

No tengo lluvia ya

No tengo santos ni uno

No tengo ni siquiera mechero

Remiendo mis silencios sin fumar

Beso mi máquina de escribir

y riego mi maceta

En fin abro mi lata de conservas

Como en mi casa

Me rasco

Soñaré con camellos duerma o no

Todas las calles son lágrimas

Mirad el cielo qué viejo está

Los pájaros no tienen trabajo

Oh madre tiro mi alma a la basura

De asco escupe la luna sobre nosotros

Un poeta escribe con su sangre la palabra mierda

En el insomnio de basura me malgasto

Cruje mi rostro malparado de silencio

Islas encajes de la vida mi soror ${ }^{609}$

lates aún con tu venda mugrienta

Tirito al contacto de la colcha helada

Subiré a las altas pestañas

${ }^{609}$ Sic. 
en pos de las nubes de mis ojos

Poe el momento no veo más que yermo

Aquí no se revela águila real

Sacaré una virgen del populacho

para decir con ella amén

En vano espero la varita mágica

Meto uñas en la raja de mi hucha

Aunque las ratas me hablan con cariño

monologo inauditos disparates

Quiero que baje un dios y me acaricie el pelo

Preserva de los extremos tu médula

De pronto entra en el cuarto un joven árabe

transporta una sonrisa refrescante

habla español conmigo en secreto

Se sentó al lado de mi cabeza

condueño ${ }^{610}$ de la cama de delirios

Mira fijamente mi llavero tirado

Charcos por todas partes leche emponzoñada

Valle de asco y de fraude mina de miseria

No hay nadie que no esté de luto

Menos mal que se ordenó llorar

Pero ya no quedan lágrimas en las tiendas

Los jefes del mundo bruñen sus coronas

$\mathrm{y}$ tienen tiempo para banquetes

Locos plenus larvarum pirámides de sangre

Han desollado ángeles mamones

Cerdos tras sacerdotes y madres de mil ojos

Fiesta en la casa de la bailarina

Allí está el presidente con el mago de turno

y sus perros alanos entre el séquito

mientras crece la cola de las lágrimas

Diversión y desfile apogeo de masas

Público abastecido de butacas y médicos

Mas bocados de dátil en la angustia

La sonrisa y el beso virutas en el suelo

Promontorios de goces mosto y regaliz

Lavando están el trono del amor

por si vienen sus dulces reyes amarillos

Ningún artista trabaja ya dice el papiro egipcio

Todo se tambalea impera la insolencia

Lo mismo hoy la risa sufre hambruna

Unos trayendo sacos llenos de sangre seca

Rezadores se apartan beata solitudo

${ }^{610}$ Sic. 
Antorchas y trompetas vivaquean los seres Es difícil la marcha avante van algunos

Los menos atesoran conducta en las ruinas

Se espanta un soñador en el frío de la noche Harto quizá de estrellas contempla sus entrañas

El sol de oro borracho ignora este plantío Bajo los indoloros llantos de lluvias sucias perdido olor de origen en el álbum del ser ¿Se entera el universo que hay gente vividora que acuestan en el fango sus huesos aburridos? ¿Y viste tú al atleta paqueteando la noche? Mi cerebro interroga también se dormirá 


\section{APÉNDICE XI. POESÍA VISUAL}

La poesía visual oryana se halla en varias publicaciones:

1. Antologías

1.1. Metanoia (1978, 1990):

- Manu militari, p. 327

- Elle en rêve que des belles robes et de plaisir, p. 328

- Mentón-culo (1972), p. 239

- Pesadilla sexual ${ }^{611}$ (1973), p. 330

$\cdot$...et maintenant (1973), p. 331

- Opération été plein midi(1973), p. 332

- Desnudo en la vía láctea (1976), p. 333

- Los testículos del dios (1976), p.334

2.1. El desenterrador de vivos (2006):

- Leopardo, pp. 16-17

- Trovador, p. 21

- Araña (1973), pp. 48-49

- San Sebastián, p. 52

- Carne y oro, p. 55

- La casa muerta, pp. 56-57

- Naufragio, p. 58

- Homenaje a Novalis, (1982) p. 61

- Apocalipsis, p. 62

- Manu militari, pp. 64-65

- Águila (2004), p. 66

${ }^{611}$ El mismo collage aparece en El desenterrador de vivos con otro título: Araña. 
2. Revistas y otras publicaciones:

2.1. Litoral, no 19-20, Málaga, abril-mayo 1971.

- La no novia

2.2. Voratosca, Papers literaris d'Olot-Misión, $\mathrm{n}^{\mathrm{o}}$ 10, Olot, 1973.

$\cdot$...et maintenant, p. 84

- Opération été plein midi, p. 85

2.3. Operador, $\mathrm{n}^{\circ} 1$, abril 1978.

- Piernas de mujer con cuchillo (1977)

- Mujer con tijeras (1977)

2.4. Carlos Edmundo de Ory. Textos críticos sobre su obra (2001)

- Homenaje a Novalis (1982), p. 252

- La no novia, p. 256

2.5. Caleta, segunda época, $\mathrm{n}^{\circ} 16,2001$.

- Mar mariposas para Ángela (2006), p.311

- Pesadilla sexual (1973), p. 315

- Sin título, p. 316

- Sín título, p. 317

- La espalda (1984), p. 318

- Los testículos de Dios (1976), p. 319

- Desnudo roto, p. 320

- Mentón-culo (1972), p. 321

- Sin título (1962), p. 322

- Sin título, p. 323

- La casa muerta ${ }^{612}$, p. 324

- Horrible tempestad ${ }^{613}$, p. 325

- Manos con árboles, p. 326

- La no novia, p.327

${ }^{612}$ Aparece en esta edición sin título.

613 Titulado en francés, en El desenterrador de vivos aparece titulado como Naufragio. 
Sin título (1977), p. 328 
APÉNDICE XII. COLLAGES

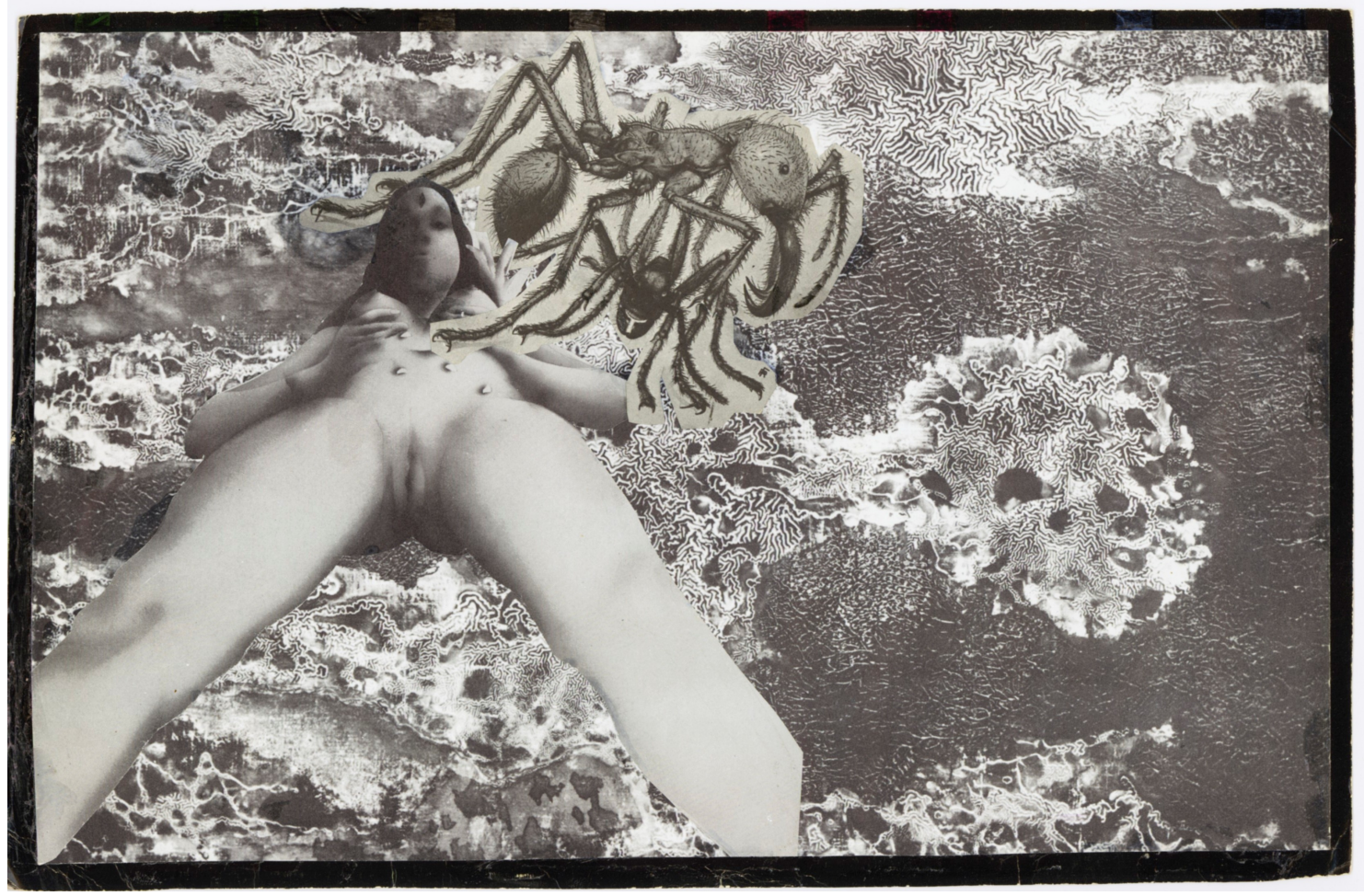




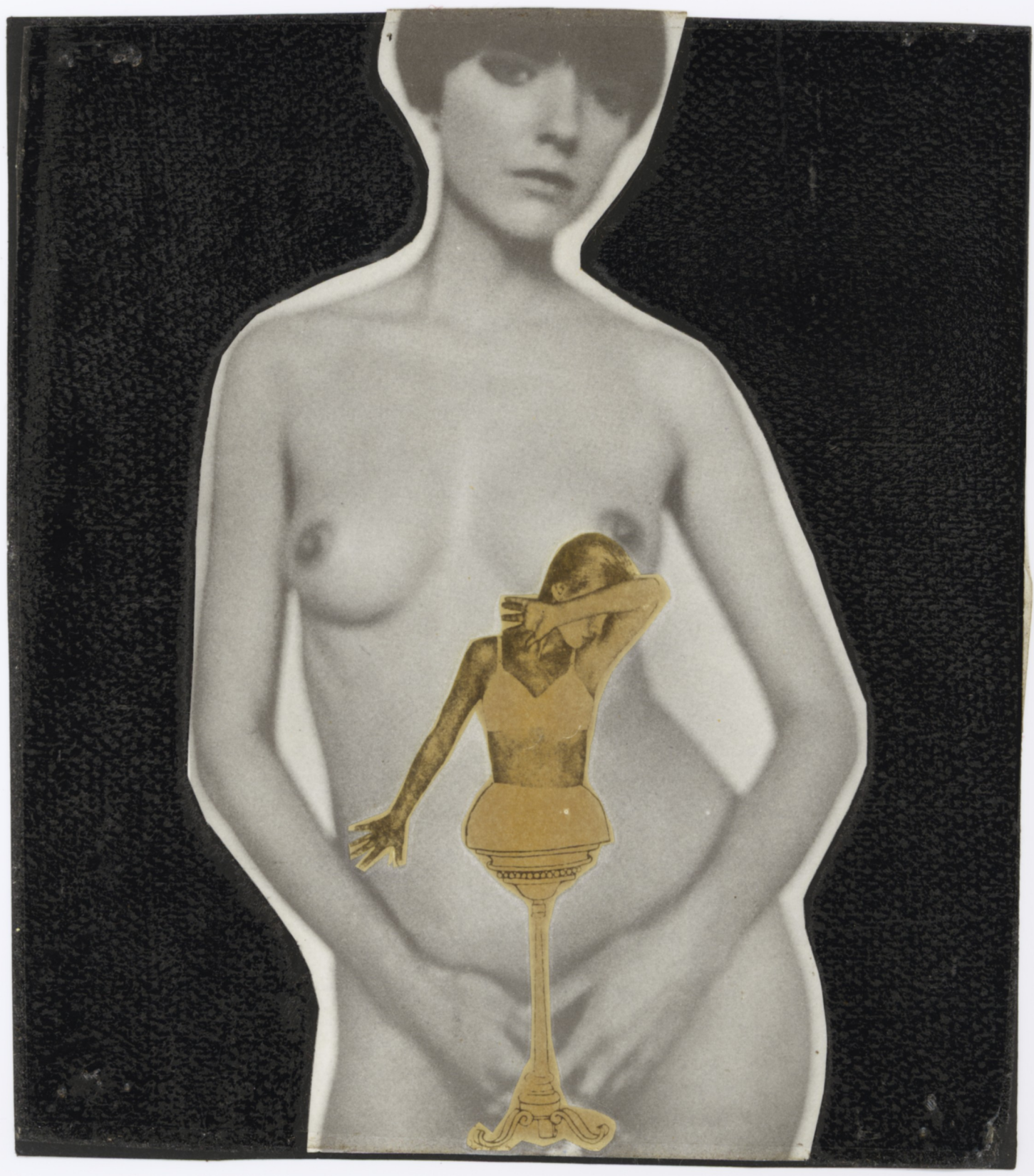

775 


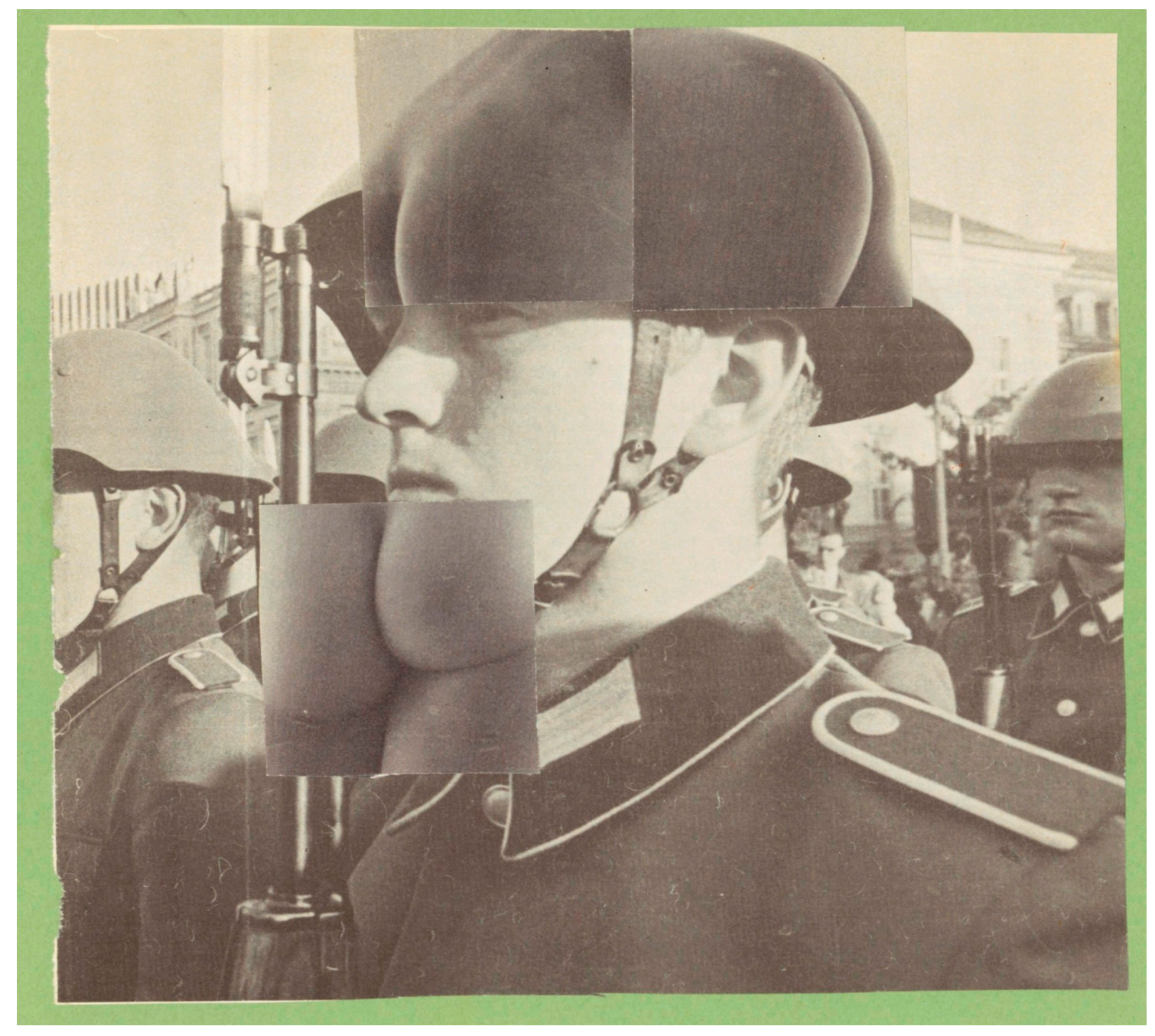




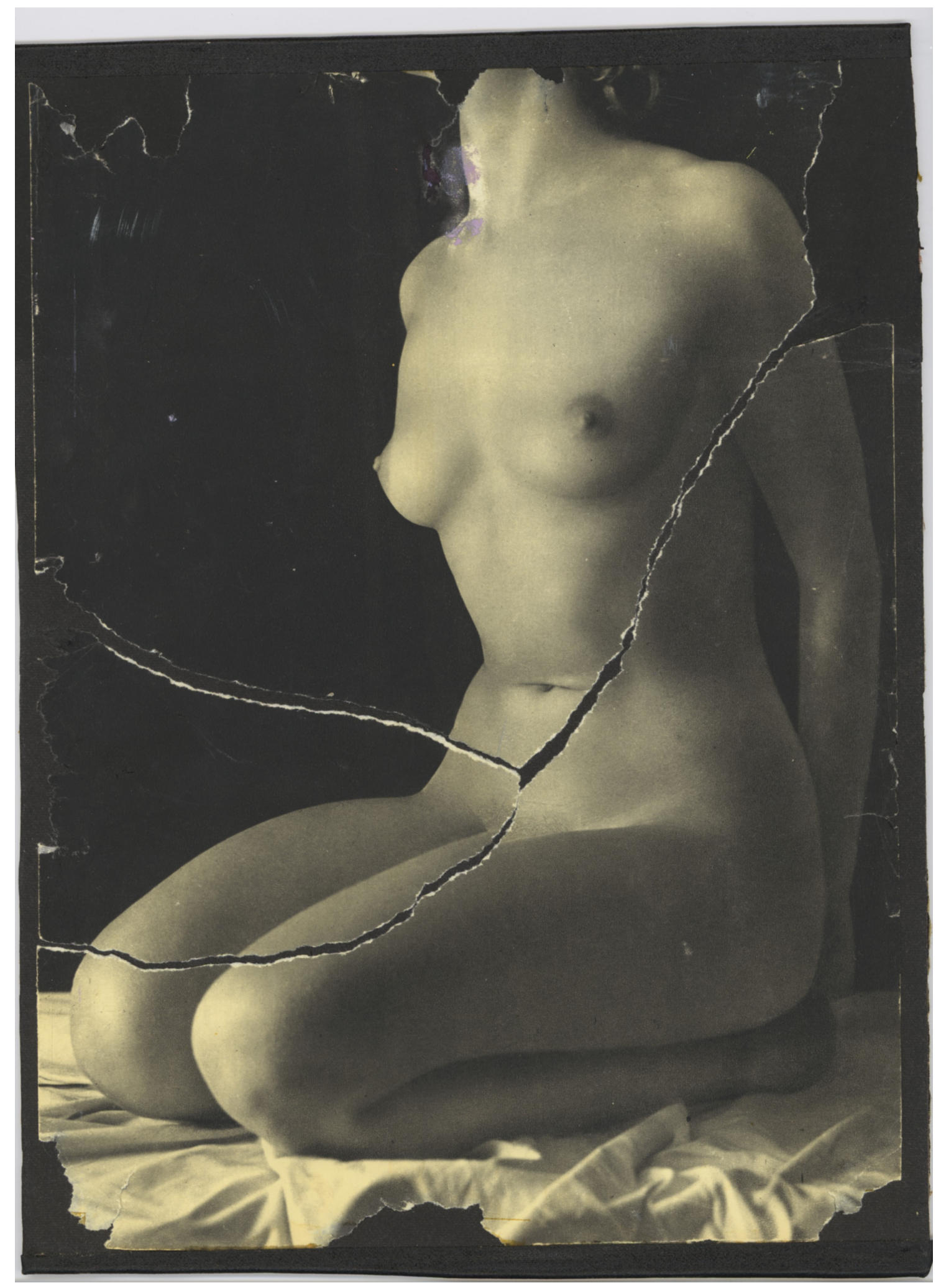




\section{APÉNDICE XIII. TESTIMONIOS DE POETAS DEL SIGLO XX Y DEL SIGLO XXI QUE CERTIFICAN SU PERTENENCIA A LA HERENCIA ORYANA}

Mostramos aquí algunos fragmentos de la correspondencia electrónica mantenida por el autor de la tesis con los poetas estudiados que conforman la herencia oryana. Las respuestas ofrecidas por ellos son el mejor testimonio que puede apoyar las opiniones vertidas en este apartado de la Tesis:

· Jesús Fernández Palacios, 23/09/2015, jftpalace@gmail.com

[...] He leído tu texto referido a nuestras sendas oryanas y he advertido que junto a múltiples aciertos has descuidado diversos pasajes donde aparecen errores y erratas [...] Esto no dificulta, como es lógico, que yo puede decirte que tu texto está bien concebido para la finalidad que persigue [...] Por eso debo agradecerte y felicitarte por el esfuerzo de aproximación y diagnóstico que has realizado al configurar esta legítima genealogía.

·José Ramón Ripoll, 20/09/2015, ripollsalomon@gmail.com

[...] Todo lo que apuntas de mi poesía me parece muy acertado.

· Rafael Adolfo Téllez, 29/09/2015, rtellezflores@gmail.com

Amigo Rafael: lo que dices sobre mi poesía me emociona. Veo que la conoces bien. Te agradezco enormemente lo que dices y más todavía que me relaciones con ese poeta extraordinario que fue Carlos Edmundo de Ory.

Caigo ahora que es verdad lo que dices: "libre, solitaria... rehuye normativas y cánones". De algún modo sigo viviendo en esa cabaña de la que hablas mirando al infinito.

Me llena de orgullo y me hace feliz lo que dices.

·Juan José Téllez, 6/10/2015, jitellezrubio@hotmail.com

Yo conocí a la poesía de Carlos mucho antes que a él, cuando era apenas un adolescente y cayó en mis manos una antología de poetas gaditanos del siglo XX que publicó la Caja de Ahorros de Cádiz. Sus versos me interesaron por su singularidad y por su música. Luego se me fue cruzando en mi camino, bien a partir de la antología Nueva Poesía 1: Cádiz, que él prologó y en la que figuraban Fito, Jesús, José Ramón o Antonio Hernández. Yo llegué tarde a Marejada $[\ldots]$ 
Quizá, de entre mis libros de poemas, el título que más influido se vio por la de Ory fue Bambú, que tenía un deje modernista entre melancólico y rebelde. Tras recibirlo, él me escribió la única carta que recibí de su puño y letra y en la que me decía: "El poeta no escribe más con tiza blanca sobre la pizarra de la escuela poética de temas manidos".

· Uberto Stabile, 3/10/2015, uberetostabile@hotmail.com

Querido Rafael, perdona la demora en contestar [...] Me veo perfectamente reflejado en los contactos que me atribuyes con Ory.

· Amador Palacios, 29/09/2015, amadorpalacios1954@gmail.com

Querido amigo: Muchas gracias por tus palabras; pero no creo que puedas hablar de mí como heredero de la poesía de Ory,. Pues no creo que mi poesía recoja una influencia oryana manifiesta $[\ldots]$

·Ana Sofía Pérez-Bustamante, 26/10/2015, anasofia.pbm@uca.es

Estimado Rafael: me ha gustado muchísimo lo que escribes, y lo suscribo plenamente.

· Mercedes Escolano, 7/10/2015, mercedesescolano@hotmail.com

[...] Ory no es uno de mis poetas preferidos, pero lo leí en la adolescencia y hubo muchos poemas que me emocionaron. En aquella época, yo pensaba que la poesía no tenía que ser necesariamente algo "serio", me interesaba más ese componente lúdico y juguetón, que muchos poetas han olvidado pero que Ory siempre cultivó a lo largo de su obra. En mi libro Felina Calma y oleaje hay influencias de Ory [...] La verdad es que la ironía flota en todo el libro. Yo entonces intentaba dar un ritmo trepidante a muchos poemas rompiendo la sintaxis, concatenando muchos verbos de acción y adjetivos calificativos, eliminando conjunciones y signos de puntuación [...] Hay muchos elementos surrealistas en mi primera etapa poética.

· Guadalupe Grande, 12/10/2015, gauadalupegrande@gmail.com

[...] Todo lo que señalas me parece bien, abrumador en la medida en que mis pretensiones no alcanzan ni al microscopio ni al telescopio la vasta voluntad creadora que tenía Carlos, que además fue un trabajador inagotable y no tuvo en la vida otro destino que la poesía.

\section{·José Manuel García Gil, 20/09/2015, manegar1965@gmail.com}

[...] No hay ningún libro que refleje sobre otros la impronta de Ory y todos beben de su personalidad poética, de sus imágenes desbordantes, del baúl loco y profundo de sus tradiciones, de su ingenuidad, de su espíritu rebelde y no gregario. Me enseñó a usar el lenguaje como un juego en continua creación. Y a entender la poesía como algo que nos debe sacudir sin hacernos mucho daño [...] A intentar huir de lo sabido y de los lugares comunes, también me enseñó. 


\section{- Carmen Camacho, 21/10/2015, carmen@camacho.net}

Es una alegría saber que estás acabando una tesis sobre Carlos Edmundo, me emociona muchísimo. Y es un honor muy grande que contemples mi trabajo como herencia de Ory, pues lo es mucho y me gusta que se me note - creo que los oryanos sin excepción nos sentimos orgullosos de serlo.

\section{$20 / 11 / 2015$, carmen@camacho.net}

Yo escribía ninimás desde antes de conocer la obra de Ory, creo que por un libro de citas célebres que cayó en mis manos cuando yo era niña, me gustaba jugar con ellas. En mi primer año de universidad fotocopié algunas páginas de un libro que tenía frases cortas de las que a mí me gustaban, al estilo -pero mejores- de las que yo empezaba a publicar en fanzines madrileños. Pero me olvidé de anotar en aquellas fotocopias el nombre del autor. Por otro lado, en las insuficientes clases de literatura que se impartían en periodismo, tuve noticia del Postismo. Me interesó mucho, me hice con los manifiestos. Cuando logré averiguar que el autor de los aerolitos era el mismo postista que me había alucinado empezó el lío: la poesía de Carlosedmundo había entrado de lleno en mi vida [...] Ory es una referencia fundamental en mi obra, también en mi postura ante la vida.

\section{· Miguel Ángel García Argüez, 15/10/2015, garcia.arguez@gmail.com}

Ante todo muchas gracias por relacionar de esa manera tan generosa la poesía de servidor con la del maestro Carlos, al que evidentemente he leído con fruición desde adolescente [...] y cuya obra sigo admirando y teniendo como referente. El análisis que haces de los puntos en común no solamente me encanta sino que me llega a ruborizar un poco.

\section{· David Eloy Rodríguez, 20/10/2015, davideloy@yahoo.es}

Me encanta que relaciones mis versos con la poesía del gran Ory, todo un honor para mí. Gracias por señalarlo. Ory es un poeta irradiante, un compañero sabio, un maestro mágico, y agradecido, con la interesante y precisa, tan atenta como generosa, lectura que haces de mi obra y de mi trabajo.

\section{· José María Gómez Valero, 1/11/2015, jgomezvalero@yahoo.es}

Las convergencias que reseñas entre mi poesía y la de Ory me parecen muy adecuadas y precisas, comparto tu mirada y los puntos en que incides, gracias por esas apreciaciones sobre mi trabajo.

\section{·Pablo Acevedo, 20/10/2015, pabloacevedog@hotmail.com}

Sobre mi posible convergencia con Ory, creo que has dado en el clavo: no se da un magisterio estético conscientemente asumido, desde el cariz personalísimo que denotan nuestras respectivas obras, pero sí una manera afín de enfrentarnos a esa necesidad expresiva que subyace al milagro poético: 
exploración de los límites del lenguaje (taumaturgia) y ensanchamiento de la experiencia por la emoción, autenticidad (identidad entre poesía y vida), asedio de soledad y automarginalidad como condiciones preliminares de un misticismo bufo (extrañamiento del yo), mezcla de lo divino y lo profano (según la naturaleza del interés poético) y, sólo más tarde, crítico e intelectual.

\section{· Javier Vela, 20/10/2015, jvela@fundacionory.com}

Te agradezco enormemente la reseña, que comentaré contigo en persona, y te sugiero la lectura de Hotel Origen, que se acaba de publicar en Pre-Textos [...], por la concomitancia de ciertos textos breves con la poesía oryana. Los otros dos aspectos están plenamente justificados y me alegra que un investigador de tu perspectiva se vaya a encargar de ellos.

28/10/2015,jvela@,fundacionory.com

Querido Rafael: leo ahora el archivo y veo que te has acercado sintética pero muy acertadamente a Hotel Origen. Que alegría. Nada entonces que añadir. 